UNIVERSIDADE DE SÃO PAULO

FACULDADE DE FILOSOFIA, LETRAS E CIÊNCIAS HUMANAS DEPARTAMENTO DE HISTÓRIA PROGRAMA DE PÓS-GRADUAÇÃO EM HISTÓRIA SOCIAL

MARINA MARIA DE LIRA ROCHA

"El río nos quedó adentro": Direitos humanos e os debates sobre desaparecimento forçado e genocídio na Justiça de Transição do território rio-platense

\author{
V.1 \\ (VERSÃO CORRIGIDA)
}

São Paulo 
UNIVERSIDADE DE SÃO PAULO

FACULDADE DE FILOSOFIA, LETRAS E CIÊNCIAS HUMANAS

\title{
“El río nos quedó adentro”: Direitos humanos e os debates sobre desaparecimento forçado e genocídio na Justiça de Transição do território rio-platense
}

\author{
Marina Maria de Lira Rocha \\ Tese apresentada à Faculdade de Filosofia, \\ Letras e Ciências Humanas da Universidade \\ de São Paulo como exigência parcial para a \\ obtenção do título de Doutora em História \\ Social. \\ Área de Concentração: História Latino- \\ Americana. \\ Orientador: Prof. Dr. Francisco Carlos \\ Palomanes Martinho
}

(VERSÃO CORRIGIDA)

V.1

São Paulo

2018 


\section{AUTORIZO A REPRODUÇÃO E DIVULGAÇÃO TOTAL OU PARCIAL DESTE TRABALHO, POR QUALQUER MEIO CONVENCIONAL OU ELETRÔNICO, PARA FINS DE ESTUDO E PESQUISA, DESDE QUE CITADA A FONTE.}

Catalogação na Publicação

Serviço de Biblioteca e Documentação

Faculdade de Filosofia, Letras e Ciências Humanas da Universidade de São Paulo

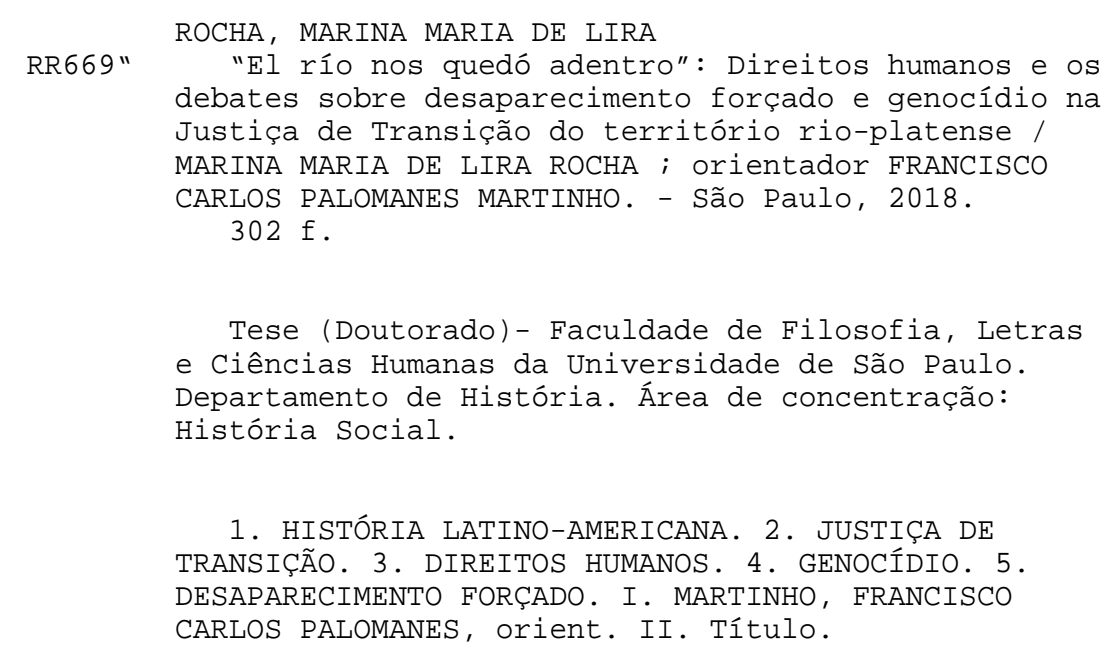

1. HISTÓRIA LATINO-AMERICANA. 2. JUSTIÇA DE TRANSIÇÃO. 3. DIREITOS HUMANOS. 4. GENOCÍDIO. 5. DESAPARECIMENTO FORÇADO. I. MARTINHO, FRANCISCO CARLOS PALOMANES, orient. II. Título. 
ROCHA, Marina Maria de Lira. “El río nos quedó adentro”: Direitos humanos e os debates sobre desaparecimento forçado e genocídio na Justiça de Transição do território rio-platense.

Tese apresentada à Faculdade de Filosofia, Letras e Ciências Humanas da Universidade de São Paulo como exigência parcial para a obtenção do título de Doutora em História Social.

\section{BANCA EXAMINADORA}

Prof. Dr. Francisco Carlos Palomanes Martinho

Instituição: Faculdade de Filosofia, Letras e Ciências Humanas da Universidade de São Paulo (FFLCH-USP)

Profa. Dra. Maria Helena Rolim Capelato

Instituição: Faculdade de Filosofia, Letras e Ciências Humanas da Universidade de São Paulo (FFLCH-USP)

Profa. Dra. Maria Paula Nascimento Araujo

Instituição: Instituto de História da Universidade Federal do Rio de Janeiro (IH-UFRJ)

Profa. Dra. Samantha Viz Quadrat

Instituição: Instituto de Ciências Humanas e Filosofia da Universidade Federal Fluminense (ICHF-UFF)

Profa. Dra. Gabriela Pellegrino Soares

Instituição: Faculdade de Filosofia, Letras e Ciências Humanas da Universidade de São Paulo (FFLCH-USP) 


\section{AGRADECIMENTOS}

Relembrar o percurso desse trabalho, que tardou anos para ser elaborado, passa necessariamente por uma série de pessoas que deram-no vida. Pessoas que sem seus comentários, apresentações, redes, conexões, desabafos, contrassensos, afetos e cuidados talvez esta tese tivesse uma face distinta ou quiçá não conseguiria existir. Por isso, este espaço é (e não poderia deixar de ser) dedicado aos que abriram portas para esta finalização, cada um de sua forma.

Agradeço inicialmente ao meu orientador, professor Francisco Carlos Palomanes Martinho, que me acolheu no espaço da Universidade de São Paulo (USP), um espaço até então desconhecido por mim, e aceitou o desafio que nos coloquei, ora estimulando questões ora limitando minha pretensão de abraçar o mundo e me chamando à realidade. Ao professor também devo a liberdade, que permeou a relação de orientação, sempre pronto a escutar e me deixar ser nas minhas escolhas acadêmicas. Também agradeço aos colegas reunidos pelo professor, em orientações e discussões de textos, que me fizeram entrar em contato com outras formas de pensar e de escrever.

Agradeço à minha banca de qualificação pela "leitura guia" que realizaram daquele texto, indicando-me não apenas leituras, como também caminhos a serem seguidos: às professoras Mariana Martins Villaça (Universidade Federal de São Paulo, UNIFESP) e Gabriela Pellegrino Soares (USP). À professora Gabriela Pellegrino, em especial, menciono sua generosidade em permitir-me acompanhar suas aulas de História da América, cuja dedicação com o ensino e a experiência na área abrilhantaram meu estágio no Programa de Aperfeiçoamento de Ensino, tornando-o um verdadeiro aprendizado sobre educação na disciplina.

Agradeço às professoras Maria Helena Rolim Capelato (USP), Maria Paula Araujo (Universidade Federal do Rio de Janeiro - UFRJ), Samantha Viz Quadrat (Universidade Federal Fluminense - UFF) e Gabriela Pellegrino Soares (USP), o aceite em participarem da leitura do trabalho finalizado, conformando uma banca de avaliação que é inestimável, já que todas são mulheres, acadêmicas, parte de "minha bibliografia" e parte da bibliografia de todos que estudam História e Memória da América Latina.

Reconheço a importância das inúmeras pessoas que trabalham na administração e secretarias da Universidade de São Paulo e tiveram a paciência de explicar-me (algumas vezes, repetidamente) os processos, as burocracias, os papéis produzidos, que me permitiram 
ter acesso ao espaço da Universidade e circular pelos congressos, seminários, encontros, arquivos, bibliotecas e etc.

A circulação, marca desse estudo, não poderia deixar de estar nos agradecimentos. Cada lugar em que passei me proporcionou conhecer gente de imensa importância na troca de pensamentos e experiências.

Encontrar o pessoal do Memoria Abierta (Buenos Aires, Argentina) me possibilitou pensar nos objetivos e questões para a tese. Agradeço especialmente à Evangelina Sanchez, do arquivo documental desta instituição, que me recebeu com a sabedoria sobre o próprio arquivo e me orientou sobre a documentação dele, inclusive me presenteando com publicações do mesmo.

Não poderia deixar de agradecer aos organizadores e participantes (em distintas categorias) dos anuais Seminários Internacionais Políticas de la Memoria, realizados pelo Centro Cultural Haroldo Conti (Buenos Aires, Argentina), dos quais participo desde 2013. Foi nesse espaço que dei meu primeiro passo em direção ao estudo da luta pelos direitos humanos, ouvindo testemunhos e trabalhos, observando a arte produzida sobre a temática e entrando em contato com Madres-Línea Fundadora e Abuelas de la Plaza de Mayo.

No Paraguai, a recepção foi uma das maiores surpresas obtidas e espero tê-la retribuído aqui, em pequena escala. Tenho uma dívida de afeto com o Dr. Martín Almada (conhecido por toda Assunção), devido ao seu trabalho incessante dentro e fora da Fundación Celestina Pérez de Almada e do Museo de las Memorias: Dictadura y Derechos Humanos. Não é exagero falar que este ser humano é uma das almas da relação entre direitos humanos e memórias paraguaias. E, por meio de seu taxista de confiança, que acidentalmente me buscou no aeroporto da cidade, em minha primeira visita ao país, tive o prazer de conhecê-lo.

Agradeço também ao pessoal do Centro de Documentación y Archivo para la Defensa de los Derechos Humanos, que me recebeu e me guiou por dentro do Archivo del Terror, me proporcionando uma experiência única de poder ver os documentos do Sistema Condor. Agradeço ao pesquisador Albert Manke (NS-Dokumentationszentrum München), responsável pela visita alemã ao país para reformulação do Museo de las Memorias, que conheci em um seminário da Fundação Getúlio Vargas (FGV-Rio de Janeiro), por haver me cedido sua documentação pessoal do trabalho técnico realizado, tão preciosa para a concepção desta tese.

Também o acaso me fez entrar em contato com a excelente Eliana Carvidón, bibliotecária da Secretaría de Derechos Humanos para el Pasado Reciente (Uruguai), que me abriu a porta inicial para a documentação da história uruguaia. Não poderia deixar de citar também as equipes do Museo de la Memoria (Montevidéu, Uruguai) e da Hemeroteca da 
Biblioteca Nacional (Montevidéu, Uruguai), principalmente o senhor Elbio Ferrario e a professora Antonia Yañez, pelos comentários e materiais disponibilizados para o estudo.

Agradeço as trocas realizadas com o pessoal da International Association of InterAmerican Studies, essencialmente aos professores da University of California (Santa Barbara, Estados Unidos da América), Francisco Lomelí e María Herrera-Sobeck, que me receberam no grupo de maneira inesquecível. Também ao pessoal da Facultad Latinoamericana de Ciencias Sociales (FLACSO) pelos congressos e encontros sobre direitos humanos na América Latina, principalmente à Ana Bartol Gutiérrez (Universidad de Salamanca) e Mónica Aparicio Guirao (Universitat de Barcelona), pessoas que permanecem intercambiando incessantemente informações sobre memórias na Argentina e Uruguai.

Sou grata pela oportunidade de poder desfrutar, em grande parte da trajetória desse estudo, de uma bolsa concedida pela CAPES, fazendo possível dedicar-me à elaboração dessa pesquisa sem maiores contratempos. É importante colocar que a produção de conhecimento necessita ser reconhecida socialmente como uma atividade legítima e que, portanto, o privilégio obtido por mim (principalmente, no período final desse trabalho, com uma série de incertezas na área de Ciência e Tecnologia) deveria ser expandido e alcançar todos que desejam exercê-la - ou seja, deixar de ser privilégio.

Pessoalmente, também se faz extremamente necessário o agradecimento aos círculos de amizades diversas, que me afagaram esses anos (e muitos outros): Débora Miranda (alma gêmea desde a infância), Maria Pilar Cabanza (amiga e revisora de "portunhol”), Elisa Azzi (amiga de aventuras e desbravamentos), Carine Rocha e Claudia Baquero (amigas dos desabafos e liberação pela música e dança), Aura Hurtado (amiga uspiana), Florencia Martorelli e Lucia Gambetta (meus portos-seguros em Buenos Aires).

Dedico, por fim, um pequeno espaço para agradecer o imenso afeto familiar, que me ajudou a seguir em frente e não apenas nessa escrita: Mãe (Iracilda de Lira Rocha), pai (Rafael Brandão Rocha), irmã (Bárbara de Lira Rocha) e o recém chegado Valentim, que veio ao mundo só para arrancar nossos sorrisos e nos deixar hipnotizados com tanta vida e alegria. 
$\begin{array}{llllll}\text { Clavo } & \text { mi } & \text { remo } & \text { en } & \text { el } & \text { agua } \\ \text { Llevo } & \text { tu } & \text { remo } & \text { en } & \text { el } & \text { mío }\end{array}$

Creo que he visto una luz al otro lado del río

El día le irá pudiendo poco a poco al frío Creo que he visto una luz al otro lado del río

Sobre todo creo que no todo está perdido Tanta lágrima, tanta lágrima

y yo, soy un vaso vacío

Oigo una voz que me llama casi un suspiro Rema, rema, rema. Rema, rema, rema

En esta orilla del mundo lo que no es presa es baldío

Creo que he visto una luz al otro lado del río

Yo muy serio voy remando muy adentro sonrío

Creo que he visto una luz al otro lado del río

Sobre todo creo que no todo está perdido Tanta lágrima, tanta lágrima

y yo, soy un vaso vacío

Oigo una voz que me llama casi un suspiro Rema, rema, rema. Rema, rema, rema

Clavo mi remo en el agua Llevo tu remo en el mío Creo que he visto una luz al otro lado del río 


\section{RESUMO}

ROCHA, Marina Maria de Lira. “El río nos quedó adentro”: Direitos humanos e os debates sobre desaparecimento forçado e genocídio na Justiça de Transição do território rio-platense. 2018. 299 f. Tese (Doutorado em História Social) - Faculdade de Filosofia, Letras e Ciências Humanas. Universidade de São Paulo, São Paulo, 2018.

Esta tese analisa os processos de transições à democracia e os debates referentes à luta pela educação sobre/para os direitos humanos, em três países distintos (Argentina, Paraguai e Uruguai). Utilizando-se de uma metodologia transnacional, na qual o pano de fundo é o fluxo de conhecimento sobre violações cometidas pelos Estados, durante as ditaduras destes países, conectadas pelo Sistema Condor, ela procura delinear a construção de uma identidade conformada pelo território imaginado do Río de la Plata. Esta identidade se baseia nas memórias sobre a violência e nas lutas pela consolidação das memórias das vítimas em um espaço público, sob a pretensão da construção de conhecimento para a não repetição de histórias de catástrofes. Desta forma, as discussões trabalhadas abrangem debates sobre os direitos humanos de níveis locais, regionais e globais, em diferentes contextos. E elas trazem para o debate rio-platense dois conceitos essenciais dentro dos direitos humanos, que marcam a identidade regional: a prática social genocida e o desaparecimento forçado.

Palavras-chave: Sistema Condor. Justiça de Transição. Direitos humanos. Identidade rioplatense. Genocídio. Desaparecimento forçado. 


\begin{abstract}
ROCHA, Marina Maria de Lira. “El río nos quedó adentro": Human rights and the debates on forced disappearance and genocide in the Transitional Justice of the River Plate territory. 2018. 299 f. Tese (Doutorado em História Social) - Faculdade de Filosofia, Letras e Ciências Humanas. Universidade de São Paulo, São Paulo, 2018.

This thesis analyzes the processes of transitions to democracy and the debates concerning the struggle for education about/for human rights in three different countries (Argentina, Paraguay and Uruguay). Using a transnational methodology, in which the background is the movement of knowledge about violations committed by the states, during the dictatorships of these countries, connected by the Condor System, it seeks to delineate the construction of an identity conformed by the imagined territory of the River Plate. This identity is based on memories of violence and struggles to consolidate the victims' memories in a public space, under the pretense of building knowledge for non-repetition of catastrophic stories. In this way, the discussions include human rights debates at local, regional and global levels in different contexts. And they bring to the River Plate debates two essential concepts within human rights that mark the regional identity: genocidal social practice and forced disappearance.
\end{abstract}

Keywords: Condor System. Transitional Justice. Human rights. River Plate's identity. Genocide. Forced disappearance. 


\section{RESUMEN}

ROCHA, Marina Maria de Lira. “El río nos quedó adentro”: Derechos humanos y los debates sobre desaparición forzada y genocidio en la Justicia de Transición del territorio río-platense. 2018. 299 f. Tese (Doutorado em História Social) - Faculdade de Filosofia, Letras e Ciências Humanas. Universidade de São Paulo, São Paulo, 2018.

Esta tesis analiza los procesos de transiciones a la democracia y los debates referentes a la lucha por la educación sobre/para los derechos humanos, en tres países distintos (Argentina, Paraguay y Uruguay). Por medio de la utilización de una metodología transnacional, en la que el telón de fondo es el flujo de conocimiento sobre violaciones cometidas por los Estados, durante las dictaduras de estos países, conectadas por el Sistema Cóndor, la investigación busca delinear la construcción de una identidad conformada por el territorio imaginado del Río de la Plata. Esta identidad se basa en las memorias sobre la violencia y las luchas por la consolidación de las memorias de las víctimas en un espacio público, bajo la pretensión de construcción de conocimiento para la no repetición de historias de catástrofes. De esta forma, las discusiones trabajadas abarcan debates sobre los derechos humanos de niveles locales, regionales y globales, en distintos contextos. Así mismo, tales discusiones proporcionan al debate río-platense dos conceptos esenciales dentro de los derechos humanos, que marcan la identidad regional: la práctica social genocida y la desaparición forzada.

Palabras clave: Sistema Cóndor. Justicia de Transición. Derechos humanos. Identidad rioplatense. Genocidio. Desaparición forzada. 


\section{LISTA DE IMAGENS}

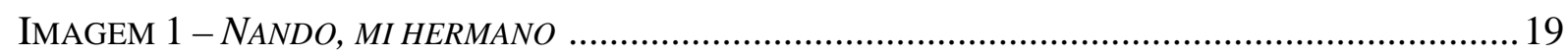

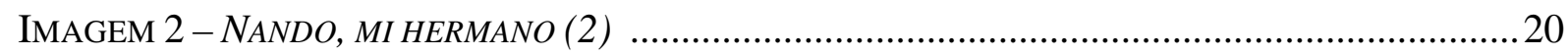

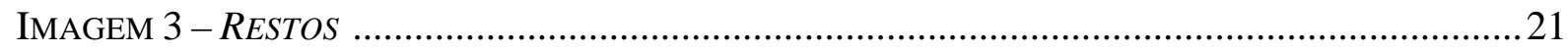

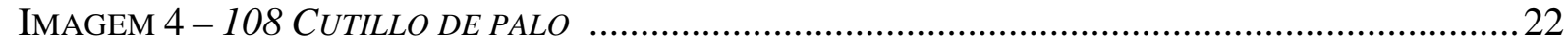

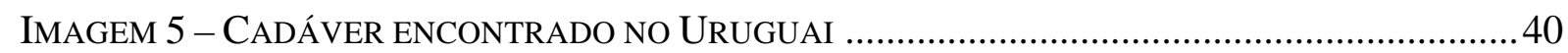

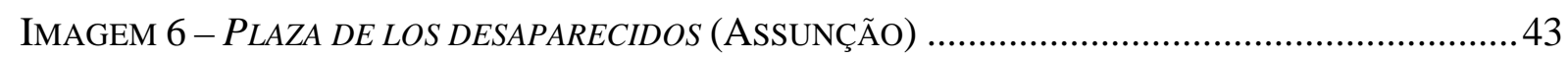

IMAGEM 7 - MEMORIAL DE LOS DETENIDOS-DESAPARECIDOS (MONTEVIDÉU) ............................43

IMAGEM 8 - PARQUE DE LA MEMORIA (BUENOS AIRES) ….............................................. 44

IMAGEM 9 - MOTHER WITH THE DEAD SON DE KATE KOLLWITZ ........................................... 73

IMAGEM 10 - TOPOGRAFIA DO TERROR (BERLIM, ALEMANHA) ............................................. 74

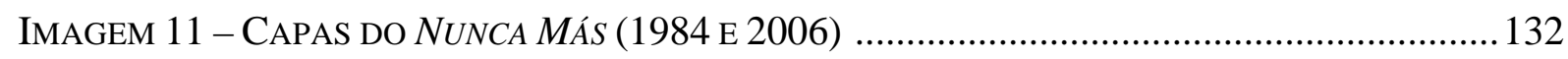

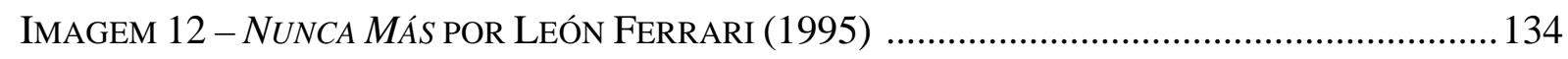

IMAGEM 13 - AUdIENCIA PÚBLICA DA COMISIÓN DE VERDAD Y JUSTICIA ................................ 144

IMAGEM 14 - APRESENTAÇÃO DO PRÉ-INFORME FINAL DA COMPAZ .................................. 154

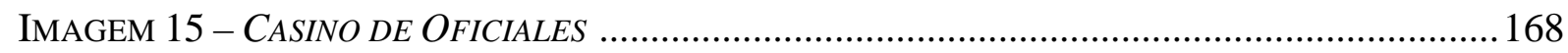

IMAGEM 16 - CAPUCHA (LUGAR DE CONCENTRAÇÃO DOS DETIDOS-DESAPARECIDOS NO CASINO

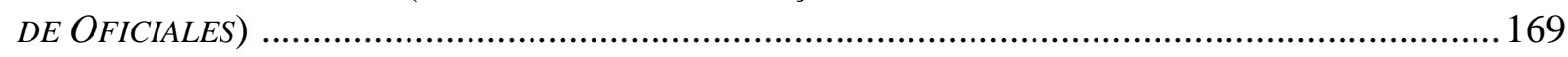

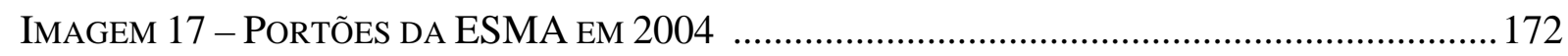

IMAGEM 18 - MAPA DE ATIVIDADES NO ESPACIO PARA LA MEMORIA …................................ 174

IMAGEM 19 - EDIFÍCIO PRINCIPAL DA EX-ESCUELA DE MECÁNICA DE LA ARMADA ................... 175

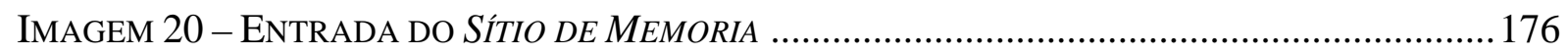

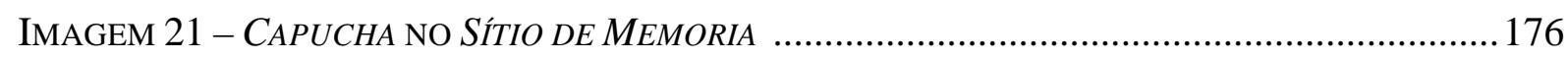

IMAGEM 22 - O JuIZ José Augustín FeRnÁNDEZ EM UMA DAS SALAS DE LA TÉCNICA .......... 181

IMAGEM 23 - VISITA DO COLÉGIO TÉCNICO JAVIER (2003) ............................................. 185 
IMAGEM 24 - MAPA DO MUSEO DE LAS MEMORIAS

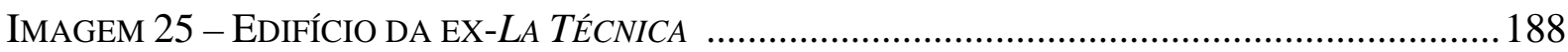

IMAGEM 26 - RECONSTITUIÇÃO INTERNA DAS CELAS DA DNAT …....................................... 188

IMAGEM 27 - SALA DESAPARECIDOS (MUSEO DE LA MEMORIA) ............................................ 190

IMAGEM 28 - QuinTA DE MÁximo SANTOS ABANDONADA (SEM DATA) ................................ 192

IMAGEM 29 - MAPA do CENTRo CULTURAL MUSEO DE LA MEMORIA ....................................... 193

IMAGEM 30 - CASA PRINCIPAL E ENTRADA DO MUSEO DE LA MEMORIA …................................ 193

IMAGEM 31 - EXPOSIÇÃO FOTOGRÁFICA MEMORIA A LA VISTA (FOTOGRAFIAS DE NANCY

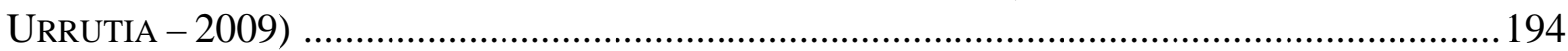

IMAGEM 32 - HALL OF WiTNESS (US HoloCAUST MEMORIAL MUSEUM) ................................. 199

IMAGEM 33 - DACHAU CONCENTRATION CAMP MEMORIAL SITE _.........................................200

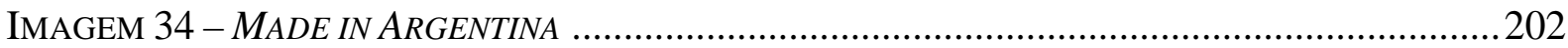

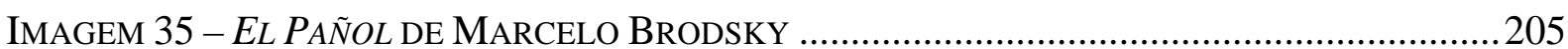

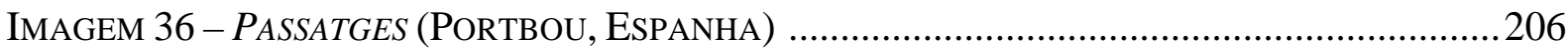

IMAGEM 37 - CELAS DE ISOLAMENTO (NUMBER FOUR EXIBITION) …....................................210

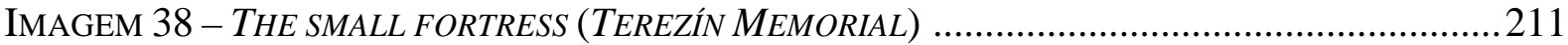

IMAGEM 39 - SALA DE LA MEMORIA (PARQUE POR LA PAZ) ....................................................2 213

IMAGEM 40 - PERWord did not find any entries for your table of contents.M-36 .................214

IMAGEM 41 - NS-DOKUMENTATIONSZEMTRUM DER STADT KÖLN .........................................225

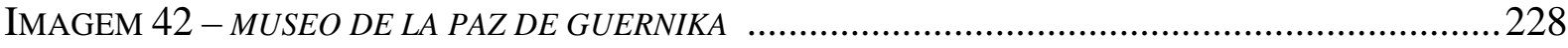

IMAGEM 43 - NO PERMITAMOS LA REIVINDICACIÓN DEL PASADO STRONISTA _............................233

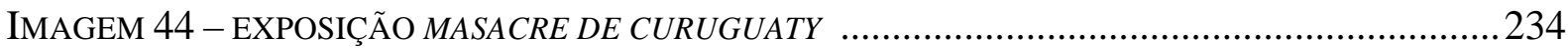

IMAGEM 45 - OBRA DE LEÓN FERRARI EXPOSTA NO EL INFORME ORLETTI - CONEXIÓN

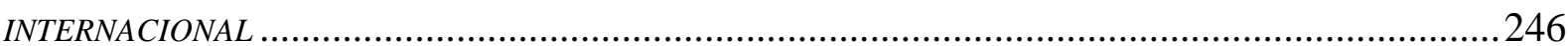

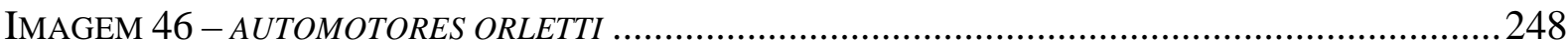

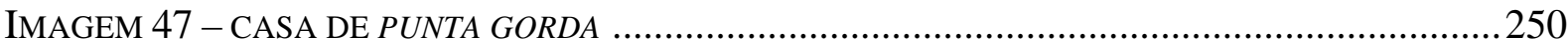


IMAGEM 48 - PROYECTO MARCAS DE LA RESISTENCIA .251

IMAGEM $49-E L$ BRILLO DE TU MIRADA 253 


\section{SUMÁRIO}

INTRODUÇÃO - O RIO É MEMÓRIA ...............................................................................17

CAPÍTULO 1 - O PESO DOS MORTOS: MEMÓRIA, TRAUMA E VIDA ................................48

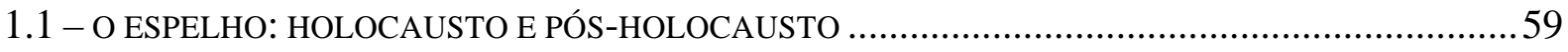

1.2 - OS CONTEXTOS DE TRANSIÇÕES NO TERRITÓRIO IMAGINADO DO RÍO DE LA PLATA ..............76

CAPÍTULO 2 - JUSTIÇA TRANSICIONAL E TRANSNACIONAL ...........................................84

2.1 - O SISTEMA INTERAMERICANO DE DIREITOS HUMANOS E SEU PAPEL NA TRANSIÇÃO DA

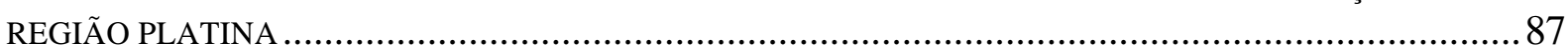

2.2 - A UTILIZAÇÃO DO SISTEMA INTERAMERICANO DE DIREITOS HUMANOS NA ARGENTINA..... 90

2.3 - A UTILIZAÇÃO DO SISTEMA INTERAMERICANO DE DIREITOS HUMANOS NO PARAGUAI..... 104

2.4 - A UTILIZAÇÃO DO SISTEMA INTERAMERICANO DE DIREITOS HUMANOS NO URUGUAI........ 110

2.5 - A UTILIZAÇÃO DO SISTEMA INTERAMERICANO DE DIREITOS HUMANOS EM PERSPECTIVA

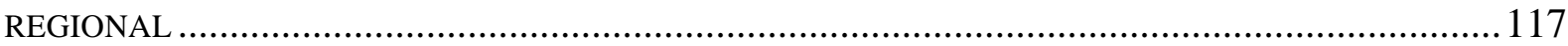

CAPÍTULO 3 - PALAVRAS NOS VENTOS DA COSTA: TESTEMUNHOS E INICIATIVAS

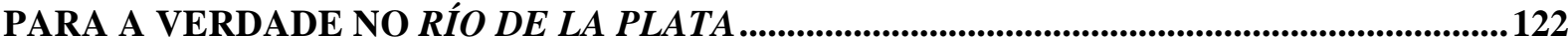

3.1 - TESTEMUNHOS NO ESPAÇO PÚBLICO E A COMISIÓN NACIONAL SOBRE LA DESAPARICIÓN DE

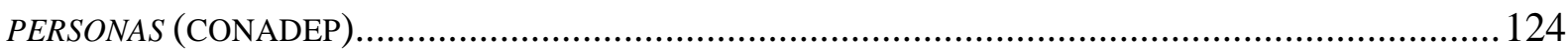

3.2 - TESTEMUNHOS NO ESPAÇO PÚBLICO E A COMISIÓN DE VERDAD Y JUSTICIA (CVJ) ............... 137

3.3 - TESTEMUNHOS NO ESPAÇO PÚBLICO E A COMISIÓN PARA LA PAZ (COMPAZ) ........................ 150

3.4 - OS ESPAÇOS DAS COMISSÕES EM PERSPECTIVA REGIONAL ............................................. 158

CAPÍTULO 4 - NARRATIVAS E TERRITÓRIOS: AS MEMÓRIAS PARA A EDUCAÇÃO

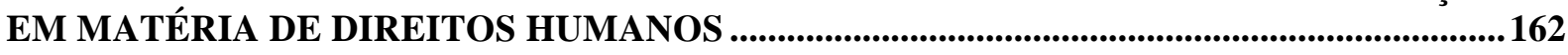

4.1 - A MUDANÇA EPISTEMOLÓGICA: ESPACIO PARA LA MEMORIA, PROMOCIÓN Y DEFENSA DE LOS

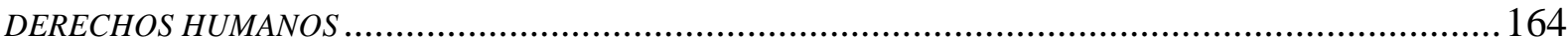

4.2 - A BASTILHA PARAGUAIA E O MUSEO DE LAS MEMORIAS: DICTADURA Y DERECHOS HUMANOS 176

4.3 - SOBRE MEMÓRIAS E RESISTÊNCIAS: CENTRO CULTURAL MUSEO DE LA MEMORIA 188

CAPÍTULO 5 - DOS CAMINHOS AOS TERRITÓRIOS: UMA HISTÓRIA DOS DEBATES PELA MEMÓRIA. 
5.1 - CAMINHOS AO ESPACIO PARA LA MEMORIA: O CASO ARGENTINO COMO EXEMPLAR. 196

5.1.1 - FUTURO MUSEO DE LA MEMORIA: O QUE QUEREMOS? . 197

5.1.2 - DISCUSSÕES DAS VÍTIMAS/SOBREVIVENTES SOBRE A EX-ESMA... 215

5.2 - CAMINHOS AO MUSEO DE LAS MEMORIAS: GLOBALIZAÇÃO E REGIONALIZAÇÃO DO CASO PARAGUAIO 222

5.2.1 - COOPERAÇÃO PARA TRANSFORMAÇÃO. 223

5.2.2 - UM COLETIVO DE LUTADORES E LUTADORAS NA REGIÃO 230

5.3 - CAMINHOS AO MUSEO DE LA MEMORIA: UMA SAÍDA PARA O LOCAL. 238

5.3.1 - O PROJETO DO MUSEO DE LA MEMORIA 239

5.3.2 - AS MARCAS DE RESISTÊNCIAS NA CIDADE E O MUME... 249

5.4 - OS CAMINHOS PERCORRIDOS: DEBATES RIO-PLATENSES 254 


\section{INTRODUÇÃO \\ O RIO É MEMÓRIA}

A pesar de su inmensidad, allí las aguas son muy poco profundas (CONTI, 1998, p. 7).

O Río de la Plata é um patrimônio regional que abarca diversas representações. A representação do lugar de chegada esperançosa na América, do lugar de diversão e tempo livre da população, do lugar histórico e de eventos político-culturais, do lugar de impulso econômico com entrada e saída de mercadorias, do lugar de memórias e experiências. Para países como a Argentina, Uruguai e Paraguai, ele é a excepcionalidade formada por suas histórias contadas individual ou coletivamente, que marcaram delimitações territoriais, independências, integrações, vitórias e derrotas, histórias de vida, perdas e violências (GATTI, 2011a).

Haroldo Conti, o notável escritor argentino, desaparecido em maio de 1976, vítima da repressão ditatorial de seu país natal, descrevia, em seus romances, rios que se manifestavam como a própria vida humana: rios que marcam os homens em seus sustentos, em seus caráteres, em suas lembranças. Homens ribeirinhos que, como as próprias águas que os circundam, são calmos e solitários - com seus "olhos de peixe" são "indiferentes como o rio" -, contudo, inesperadamente, podem insurgir-se, transformando seu curso e destruindo o caminho por onde passam. Afinal, tal como os homens, Conti afirmava que "el río es muy grande. Uno no puede saber todo lo que hace el río" (CONTI, 1998, p. 76).

Mesmo com a imensidão de sentidos que dele emerge, a representação que aqui nos cabe introduzir é aquela que traz as vivências das águas que unem histórias de repressões e de tempos traumáticos, que, por sua vez, vinculam e dissociam experiências e memórias no território demarcado pelo Río de la Plata. Esse rio específico carrega, em seu fluxo, a simbologia dos Terrorismos de Estados, das prisões e torturas, dos desaparecimentos e das "revelações" de violações aos direitos humanos, durante os períodos de ditaduras e pósditaduras nos países limítrofes - Argentina, Paraguai e Uruguai (GATTI, 2011a).

Nas obras de artes visuais sobre memória argentina, produzidas por Marcelo Brodsky (convenientemente denominadas por Andreas Huyssen como Memory Art ${ }^{2}$ ), o Río de la Plata

\footnotetext{
${ }^{1}$ Geograficamente, o Río de La Plata é o estuário que liga os rios Paraná e Uruguay ao oceano. Ele, aqui, ${ }^{2}$ Segundo Huyssen (2001, p. 7-11), o trauma histórico, vivido com a diminuição da esperança sobre a modernização e as memórias da "guerra suja" latino-americana, ressoou, principalmente, na produção de artes visuais, a partir dos anos 1980. Neste sentido, as obras de Marcelo Brodsky interpelam o passado recente e trazem ao público um debate internacional sobre a memória traumática e seu compromisso com os direitos
} 
aparece como pano de fundo para se "trabalhar a memória" da repressão. E o termo utilizado "trabalho da memória", que define suas obras, é aquele proposto por Elizabeth Jelin (2002), no qual se vincula o trabalho - processo de elaboração e transformação ativa de si mesmo e do mundo - à memória, com a finalidade de interpretá-la conscientemente no presente e, desta forma, dar-lhe vida para atuar no mundo social.

No caso de Brodsky, suas obras criam um espaço que reivindica a memória e a história recente, penetrando sua história de vida, a história argentina, a história regional e a história mundial, vinculando-as aos traumas sofridos nesses espectros. Este trabalho de sua "arte da memória", majoritariamente construído através de fotografias, mas não em sua totalidade, passa a ser um lugar de questionamento e conhecimento sobre a repressão nas fronteiras (DE LA VEGA; SERNA; BRAVO, 2001, p. 3).

Neste sentido, trazemos aqui dois exemplos sobre como Brodsky refletiu a perspectiva do rio como memória, que intitulou nossa introdução. No capítulo de Memory Works (2001), dedicado ao seu irmão, Fernando Brodsky, o Río de la Plata é a paisagem de chegada da família Brodsky à Argentina, no qual navegou seu tio-avô Salomón e cuja imagem deste homem de pé em um navio "desafia o futuro", de onde "tudo pode se esperar". Ao lado dessa imagem de futuro, no entanto, o autor realiza uma montagem, colocando outra fotografia produzida em viagem dos dois irmãos Brodsky, ainda crianças, posicionados, em provocação infantil, na frente de uma placa de "proibido permanecer neste lugar". Tristemente, a história pessoal dos Brodsky iria permanecer naquele rio. Fernando, sequestrado em 1979, encontra-se desaparecido desde então e é possível que seu corpo tenha sido jogado naquelas águas, nas quais, quando crianças, "não podiam permanecer".

Imagem 1 - Nando, mi hermano

humanos, associando o discurso da memória às atividades e movimentos por esses direitos. E, por isso, denomina tais obras como parte da "memory art", ou seja, da prática artística sobre memórias, que também produz memórias. 

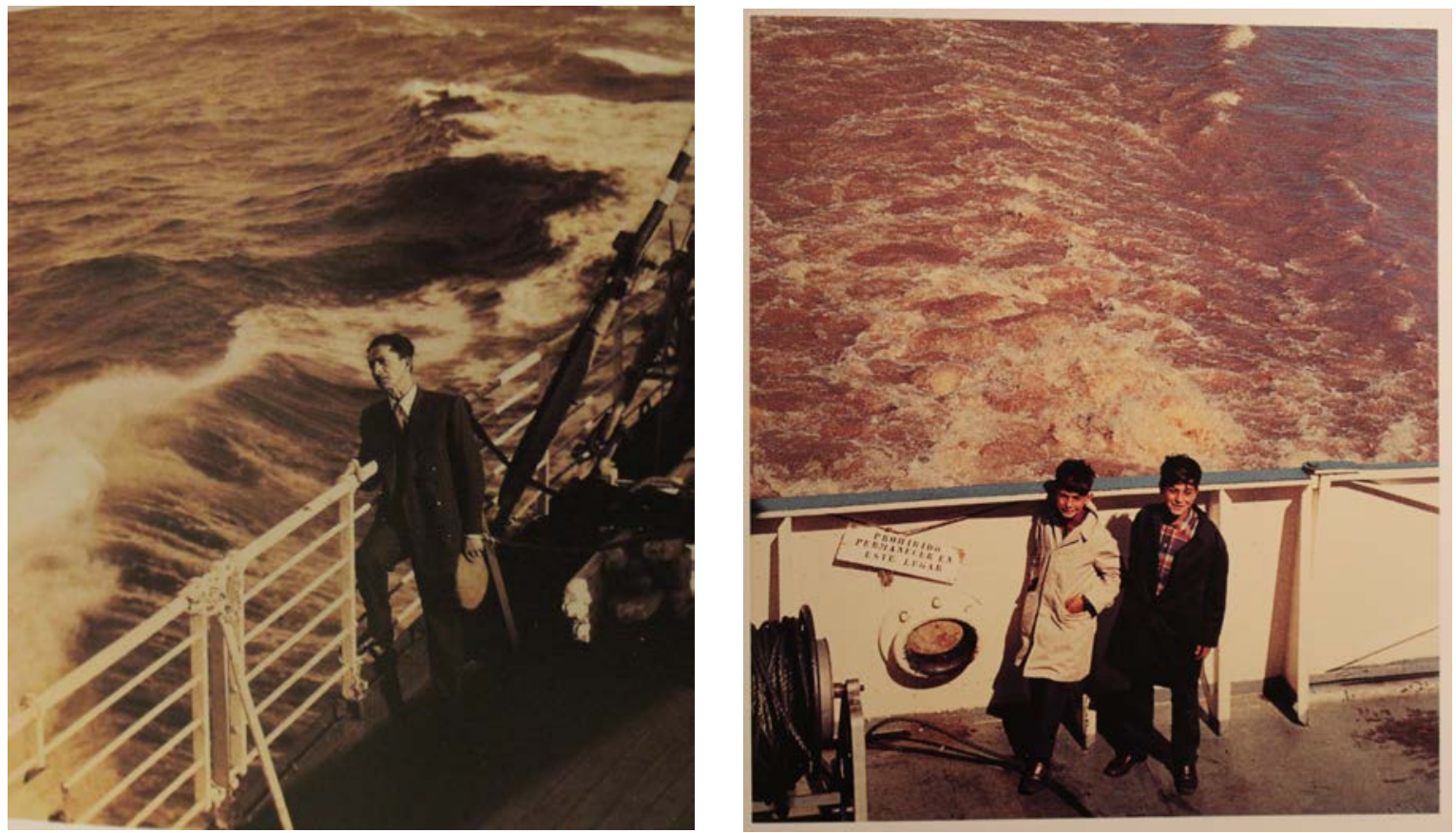

Fonte: BRODSKY, 2001, p. 59.

Finalizando a homenagem ao irmão neste trabalho, composto por fotografias de suas infâncias, imagens do altar montado na residência de sua mãe para rememorar Fernando e pela fotografia do irmão realizada por Victor Basterra ${ }^{3}$, quando ambos estavam detidosdesaparecidos, em Buenos Aires, na Escuela de Mecánica de la Armada (ESMA), Marcelo Brodsky traz uma imagem do mesmo rio de águas turvas com as inscrições "Al río los tiraron, se convirtió en su tumba inexistente" (BRODSKY, 2001, p. 48-61). Nessas representações, o rio nos sugere duas visões: a porta de entrada e de expectativa de um futuro melhor e o destino final de histórias individuais e coletivas, que é "tumba inexistente", criada para silenciar as violências que existiram. É, portanto, lugar de esperança (não só da chegada no início do século XX, mas também esperança de que os desaparecidos do final deste mesmo século estejam lá) e, por isso, lugar de trauma. Um rio que deixa de ser paisagem para ser, ele mesmo, um território de memória para a história do desaparecimento no Cone Sul.

\section{Imagem 2 - Nando, mi hermano (2)}

\footnotetext{
${ }^{3}$ Victor Basterra era trabalhador gráfico e militante do Peronismo de Base (PB), quando foi sequestrado em 1979. Preso por mais de quatro anos, foi obrigado a realizar trabalhos de falsificação de documentos, cujas fotografias de repressores e detidos-desaparecidos eram copiadas e guardadas por ele. Ao receber permissões para sair, Basterra escondia as cópias para levar consigo ao exterior da Escuela de Mecánica de la Armada. Essas fotografias identificaram, posteriormente, muitos repressores que trabalharam naquele Centro Clandestino de Detenção e determinaram o paradeiro de pessoas que passaram por ali - desaparecidas ou ex-detidasdesaparecidas.
} 

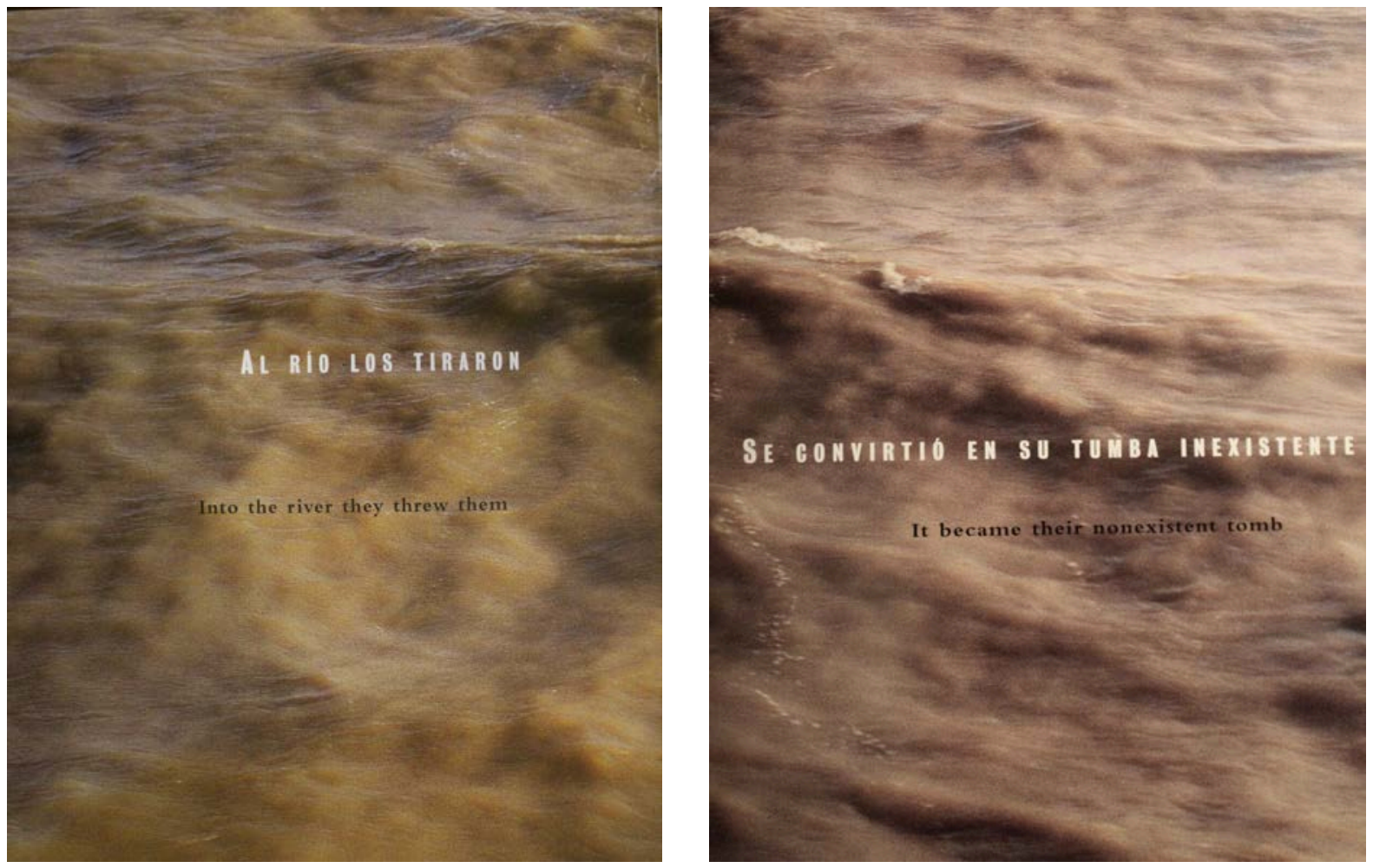

Fonte: BRODSKY, 2001, p. 60-61.

O segundo trabalho que recuperamos do mesmo autor, cujo rio aparece como símbolo da repressão, é aquele que o envolveu na construção do Parque de la Memoria na Costanera Norte de Buenos Aires. Em 18 de julho de 1994, a Asociación Mutual Israelita Argentina (AMIA) sofreu um atentado que explodiu seu edifício e matou 84 pessoas (entre filiados, empregados e transeuntes), marcando profundamente a coletividade judaica e, novamente, a sociedade argentina pela falta de esclarecimento do ocorrido e de responsabilização por ele.

Com os trabalhos de resgate dos corpos no local, os despojos do edifício foram trasladados para a ribeira do Río de la Plata, onde permaneceram esquecidos por algum tempo. Quatro anos depois, organizações de direitos humanos propuseram constituir com aqueles "restos" um parque de esculturas em homenagem às vítimas do Terrorismo de Estado argentino, proposta essa aceita pelos deputados portenhos e nomeada como Parque de la Memoria (BRODSKY, 2001, p. 106-115).

Brodsky, acompanhado de Ana Weinstein, sobrevivente do atentado contra a AMIA, saiu para fotografar os escombros e recuperar algumas fotografias do antigo edifício, em arquivos, constituindo imagens que formariam parte de sua exposição, denominada Nexo. Essa expedição pelos arquivos e os "restos" resultou na descoberta de fragmentos do antigo edifício, além de utensílios que o compunham, e na proposta de constituir uma homenagem também àqueles mortos específicos, nas margens do rio, onde seria o futuro parque. Brodsky 
se envolveu ativamente no projeto e conseguiu em seu trabalho associar o passado ao presente, as violências atuais (da década de 1990) às memórias traumáticas do país, e marcar o território do rio com uma luta cotidiana pelos direitos humanos, expandindo os sentidos de vítimas, ao conectar, através da falta de responsabilização, as violações cometidas na ditadura com as violações permanentes em democracia.

\section{Imagem 3 - Restos}
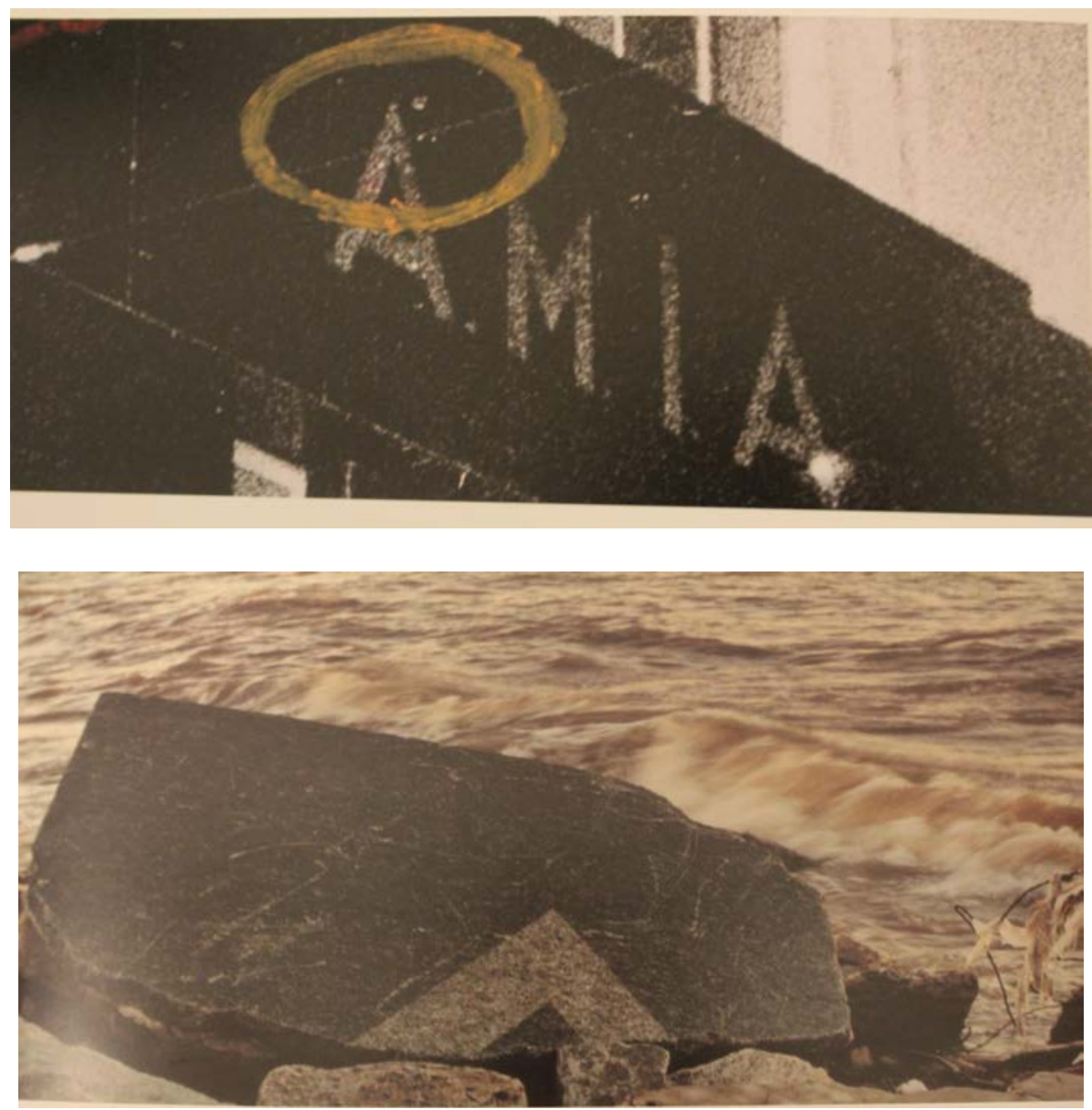

Fonte: BRODSKY, 2001, p. 113-114.

O rio foi temática de abertura para o documentário paraguaio "108 Cuchillo de Palo", dirigido pela cineasta Renate Costa (2010). ${ }^{4}$ Recuperando a imagem de um tio, encontrado morto na sua casa, nos anos oitenta - uma morte fruto indireto da perseguição aos

\footnotetext{
${ }^{4}$ O número 108 é muito simbólico no Paraguai, inclusive sinônimo pejorativo para denominar homossexuais no país, cujo preconceito popular se aprofundou, a partir da ditadura stronista. Em 1959, diante do assassinato do radialista Bernardo Aranda, a polícia de Assunção lançou uma lista de suspeitos pelo crime composta por 108 homens que foram perseguidos e humilhados publicamente devido às orientações sexuais. Esses tipos de listas com "pessoas amorais" passaram a ser práticas da ditadura e eram enviadas aos colégios, igrejas, universidades, bancos e etc., marcando e marginalizando as pessoas listadas.
} 
homossexuais pela ditadura stronista (apesar de não completamente esclarecida pela família da vítima e determinada oficialmente como suicídio) -, Renate abre o filme trazendo o rio como a personagem que guarda a memória da repressão paraguaia. Associando imagens do fluxo das águas a uma narrativa, o documentário interpreta aquelas águas como uma metáfora para o conhecimento sobre a história e a verdade no país. Ao mesmo tempo, ele aponta que, para observar esse "rio de verdade", é necessário virar-se em direção contrária à cidade de Assunção, "dando as costas" para a mesma e, dessa forma, ignorando a construção da memória das vítimas por parte de uma cidade que não enxerga o seu passado. A questão que se abre na argumentação do filme é: como associar, então, uma cidade que não valoriza a crítica ao seu passado ditatorial com uma memória dessas vítimas, que está (mesmo que silenciada) presente em seu cotidiano? O rio, enquanto memória, está ali, em um lugar específico; bastaria modificar a direção do olhar para poder alcançá-lo.

Imagem 4 - 108 Cutillo de Palo

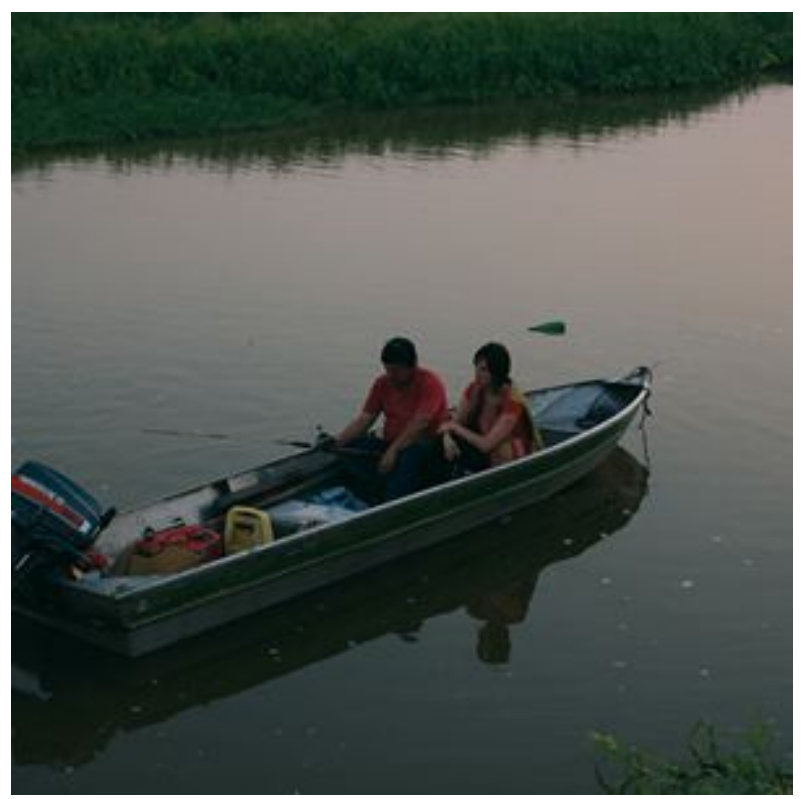

Fonte: 108 CUTILLO DE PALO, 2010.

Ele também foi tema de diversos textos do escritor uruguaio Mario Benedetti ao retratar suas experiências de resistências, durante os anos ditatoriais e pós-ditatoriais, no país, no exílio e no "des-exílio", como ele mesmo afirmava sobre o seu retorno. Em 1979, por exemplo, quando lança seu livro Cotidianas, publica nele o belíssimo poema "Por qué cantamos", onde expressa a vontade de falar, diante de uma região repleta de covas e vergonhas. As respostas ao seu questionamento sobre os motivos para se cantar nessa situação 
estão, de acordo com a poesia, nos mortos, nos sobreviventes, nos seus destinos. Estão, pois, no rio, que ressoa a sorte das vítimas do "cruel que não tem nome" e cujo choro e a raiva não bastam para "vencer a derrota". E o que venceria, então, a derrota? Neste poema, onde cada pergunta tem sua resposta, a resposta do poeta para se vencer a derrota experimentada é cantar a militância pela vida, nesse espaço marcado pelo rio de sofrimentos (BENEDETTI, 1979, p. 102-103).

E muitos outros trabalhos, nos campos artísticos e literários, poderiam ser aqui recuperados para exemplificar como o rio tornou-se lugar simbólico da memória sobre a repressão nos territórios platinos. Contudo, pretende-se apontar apenas que são essas águas e esses sentidos de integração e fluxos que nos ajudarão a pensar os trabalhos da memória sobre as violências de Estados e as quebras dos direitos humanos na Argentina, Paraguai e Uruguai. Desafiada pelo curso do Río de la Plata, a proposta desse estudo é analisar as discussões e conformações, ora confluentes, ora divergentes, das memórias destes três países, que passaram por experiências ditatoriais e se conectaram por essas violências e consequências das mesmas, em um fluxo contínuo, desempenhando papéis protagonistas no passado de violência e no presente de reflexão sobre a mesma.

Este curso das experiências dos trabalhos das memórias traumáticas inicia-se na consideração de que as memórias coletivas, além de campos de disputas, possuem também uma história própria (CERRUTI, 2001, p. 14-25). Elaboradas com o passar do tempo, elas são frutos de imensas discussões, de debates em torno de suas narrativas e de "conversas" com outras experiências nacionais e transnacionais. Perseguir esta complexa elaboração é nosso objetivo.

Poderíamos ter escolhido outros caminhos para seguirmos no espectro dos trabalhos de memória e da história das memórias nessa região. No entanto, a partir da revisão bibliográfica sobre os processos de globalização e seus fluxos culturais ${ }^{5}$ e sobre os hábitos e os sentidos para o consumo e o imaginário de maneira global, que nos conectam uns aos outros e expandem o que Serge Gruzinski chama de uma "consciência-mundo", ou seja, a integração dos homens numa perspectiva mundial - de informações, de sentidos, de mercados e etc. -, trazemos a aplicação dessas ideias para a construção do campo das memórias: memórias constituídas no espaço local, mas que consideram essa "consciência mundo".

Primeiro pelo entendimento de que os direitos humanos, fundamentos dessas memórias, já nascem como uma narrativa transnacional, tanto por seus objetos em si, quanto

\footnotetext{
${ }^{5}$ Cf. GINZBURG, 2004; GRUZINSKI, 2012; SAID, 2011; CANCLINI, 2015; e MARTÍN-BARBERO, 2013.
} 
por suas extensões aos campos das ciências humanas, onde dialogam história, psicologia, direito, educação, literatura e ciência sociais. Por conseguinte, memórias abordando experiências catastróficas, com objetivo de impulsionar os direitos humanos, se fortalecem nesse discurso transnacional. Depois, porque os trabalhos de memória, ao serem pensados, trazem consigo a "consciência-mundo" como parte de discussões sobre projetos e objetivos.

Nesse sentido, os três países mencionados possuem características que ressaltam aos olhos, quando pensamos nas pesquisas sobre memórias. No Cone Sul, ao tratarmos das memórias sobre a história recente, talvez o exemplo mais comum nos estudos acadêmicos seja daqueles que tomam a história argentina como modelo por suas práticas nos tempos ditatorial e transicional. Os países vizinhos, por sua vez, Paraguai e Uruguai, não possuem a mesma tradição acadêmica, o que nos leva ao desafio de trazê-los para este debate.

Entretanto, não queremos apresentá-los de maneira isolada, por entendermos que a região possui a fluidez nas dinâmicas dos modelos repressivos ditatoriais e nos trabalhos de memórias sobre os mesmos. Assim, não há pretensão de se realizar um estudo comparativo, que aborde de maneira isolada as experiências únicas e particulares de cada país, casos de estudo. Pretendemos sim romper os limites das especificidades históricas nacionais (PRADO, 2005, p. 11-33), trazendo-as quando pensamos serem necessárias, e analisando-as em conjunto, ampliando discussões sobre uma temática pouco explorada dessa história - as conexões entre as histórias das memórias no âmbito regional e global.

Sabemos das especificidades destes países em relação às instituições das ditaduras, das repressões e das transições e há uma historiografia sobre a temática comparativa da região, a qual explora especificamente os casos chileno, brasileiro e argentino. ${ }^{6} \mathrm{O}$ que, todavia, nos falta é um diálogo intenso regional (e internacional) sobre os trabalhos da memória, a partir dessas experiências comparadas.

A existência de uma série de acontecimentos e suas circulações justificam a proposta inicial como será possível observar ao longo de todo o trabalho. À guisa de introdução, apontamos algumas justificativas para tal pensamento transnacional ${ }^{7}$, o qual julgamos fundamental na análise escolhida para o Cone Sul.

\footnotetext{
${ }^{6}$ Cf. JELIN, 2002; BAUER, 2014; QUADRAT, 2008, p. 361-395; e NEVES, 2014.

${ }^{7}$ A transnacionalidade engloba interações e conexões entre bens, pessoas, ideias e imaginários, que não possuem fronteiras definidas. Como uma preocupação em relação aos processos de globalização, o conceito de transnacional atua na História como uma metodologia utilizada para perceber as interconexões entre os sujeitos e as sociedades para além de suas fronteiras nacionais.

Informações sobre os debates nas Ciências Humanas relativos às metodologias comparativas e transnacionais, Cf. PURDY, 2012.
} 
Destacamos como primeira conexão que podemos realizar de imediato, neste caso, aquela que ganhou o nome do pássaro chileno comedor de carniça: o Condor. Sabemos que as alianças dos Serviços de Segurança do Uruguai, Paraguai, Bolívia, Chile, Brasil, Argentina e Peru reuniram forças, a partir das décadas de 1960 e 1970, em torno da ideia de perseguir e capturar "terroristas" e inimigos, nos espaços nacionais e internacionais, através do que se consolidou, posteriormente, como Sistema ou Operação Condor. Este Sistema, depois de oficialmente organizado, coordenava a troca de informações, extradições, prisões, e operações, inclusive com treinamentos, incluindo assassinatos dentro e fora da América Latina (DINGES, 2005).

Desde o final da Segunda Guerra Mundial, a noção de Doutrina de Segurança Nacional ${ }^{8}$, em conjunto à ideia de contenção da ideologia comunista, tornou-se o fundamento para a vigilância no território latino-americano e para os auxílios entre as escolas militares estadunidenses e da região, com a finalidade de eliminar esses inimigos comuns, independentemente de suas nacionalidades (BOCCIA PAZ, 1999). A Revolução Cubana e as posteriores conexões com a União das Repúblicas Socialistas Soviéticas (URSS) reforçam o imaginário do perigo comunista no continente. E a migração sem controles nas fronteiras, principalmente de pessoas que escapavam das repressões e refugiavam-se em países vizinhos, propunha a ideia de que a "subversão comunista" penetrava nos países tal como um "inimigo externo", que viria a abalar a suposta ordem nacional.

Os Serviços de Segurança, neste sentido, começam a criar redes de infraestrutura internacional para conter organizações que possuíam propostas políticas divergentes do modelo capitalista da época, principalmente as organizações guerrilheiras, entre elas Montoneros $^{9}$ (Argentina) e Organización Primero de Marzo ${ }^{10}$ (OPM - Paraguai), e a união pela Junta Coordinadora Revolucionaria ${ }^{11}$ (JCR) dos movimentos Tupamaros $^{12}$ (Uruguai), Ejército Revolucionario del Pueblo - $\mathrm{ERP}^{13}$ (Argentina), Ejército de Liberación Nacional $\mathrm{ELN}^{14}$ (Bolívia) e Movimiento de Izquierda Revolucionaria - $\mathrm{MIR}^{15}$ (Chile). Desta forma,

\footnotetext{
${ }^{8}$ A Doutrina de Segurança Nacional é o fundamento teórico de proteção do território contra um inimigo externo, no caso o "perigo comunista", que coloca o país em questão na constante "guerra interna" para conter os avanços deste mesmo inimigo e proteger a "democracia” (PADRÓS, 2005).

${ }^{9}$ Cf. LANUSSE, 2005.

${ }^{10}$ Cf. BOCCIA PAZ, 2006.

${ }^{11}$ De acordo com os comunicados da JCR (1974), a ideia da união era "derrotar definitivamente a la reacción imperialista-capitalista, aniquilar a los ejércitos contrarrevolucionarios, expulsar el imperialismo Yanqui y Europeo del suelo latino-americano (...) y iniciar la construcción del socialismo" (CANJE..., 1974, p. 6-10).

${ }^{12}$ Cf. GATTO, 2004.

${ }^{13}$ Cf. MATTINI, 2007.

${ }^{14} \mathrm{Cf}$. ASOCIACIÓN DE FAMILIARES DE DETENIDOS DESAPARECIDOS Y MÁRTIRES POR LA LIBERACIÓN NACIONAL, 2007.
} 
criou-se, já em 1964, as Conferências dos Exércitos Americanos ${ }^{16}$ (CEA), realizadas anualmente para se discutir a luta antissubversiva e estabelecer maneiras de obter informações regionais sobre estes grupos considerados subversivos. Além disso, são famosos os cursos preparatórios na Escola das Américas, onde aprimoravam-se os métodos repressivos antissubversivos e anticomunistas, observados nas práticas de todos os processos de Terrorismos de Estados na região (BOCCIA PAZ, 2008).

Assim, em um contexto de fomentação da perspectiva anticomunista, baseado em um mundo de Guerra Fria, a vontade política de coordenação transnacional para a repressão no território latino-americano aumenta e passa a se inspirar em distintos "exemplos repressivos", de níveis mundiais, como as técnicas aportadas da Alemanha nazista ou os métodos militares e paramilitares aplicados na região do sudeste asiático pelos Estados Unidos (dos quais alguns responsáveis converteram-se, posteriormente, em participantes ativos no Sistema Condor), ou as técnicas francesas de contra-insurgência, experimentadas na Indochina e Argélia. Com financiamentos ou facilitações de operações e especializações em investigações, torturas, prisões e assassinatos internacionais, delineia-se uma espécie de "multinacional do crime" (GAUDICHAUD, 1994), cuja rede funcionava com fontes de ingressos, patrocinada por grêmios patronais e empresas nacionais e internacionais, além da colaboração de companhias aéreas e serviços postais para a concretização desse fluxo entre fronteiras.

Já é público que, em outubro de 1975, o Chile, através do chefe da Dirección de Inteligencia Nacional, Manuel Contreras, convocou uma reunião de trabalho internacional para a criação de um banco de dados unificado, com um sistema de comunicação ágil para informação sobre membros e organizações consideradas subversivas. Segundo Boccia Paz, não foi casual que o Chile tenha proposto a reunião, pois a ditadura pinochetista enfrentava-se com os reagrupamentos de militantes opositores do sistema ditatorial, no exílio, principalmente membros do MIR. Portanto, o anseio em se desfazer dos reagrupamentos no estrangeiro impulsiona o desejo de um acordo para reprimir em todo o Cone Sul (BOCCIA PAZ, 1999).

Apesar do Sistema Condor não ter inventado uma nova fórmula, já que a cooperação era apoiada, como visto, desde a Segunda Guerra Mundial, pela Central Intelligence Agency (CIA) e pelo Federal Bureau of Investigation (FBI) e já haviam ocorrido, em anos anteriores, sequestros de cidadãos brasileiros, chilenos e argentinos por grupos paramilitares da

\footnotetext{
${ }^{15}$ Cf. SANDOVAL, 1990.

${ }^{16}$ Informações sobre a CEA podem ser consultadas no seguinte endereço eletrônico: <https://www.redcea.com>. Acesso em: 04 jan. 2017.
} 
Argentina e do Brasil e pela polícia paraguaia, ele sistematizou a colaboração entre polícias e Forças Armadas na região. A primeira incursão de assassinato internacional dessa cooperação, por exemplo, foi a morte por atentado a bomba contra o general chileno Carlos Prats, em setembro de 1974, exilado na Argentina. ${ }^{17}$

Podemos destacar também a ação da polícia paraguaia, em maio de 1975, quando membros da JCR foram, da Argentina ao Paraguai, realizar a transferência de dinheiro da guerrilha argentina (ERP) a Santiago (MIR) e planejar uma mudança de sede da Junta Coordinadora. Amílcar Santucho (irmão mais velho de Roberto Santucho - um dos fundadores do ERP) e Jorge Fuentes (MIR), os dois responsáveis pelas atividades supracitadas, foram interceptados pela polícia, antes de chegarem à Assunção, e Santucho foi preso. Fuentes, apesar de conseguir chegar à capital, foi detido no dia seguinte e as prisões de ambos significaram uma das grandes operações para se obter informações sobre a organização (via interrogatórios e torturas) e um marco na colaboração, entendendo que aqueles prisioneiros forneceriam um mapa das atividades da JCR para a repressão regional. Essas informações desencadearam uma enorme investigação e aprisionamento dos membros da JCR, ocupando os serviços de inteligência no Chile e Argentina por mais de um ano (DINGES, 2005).

Neste mesmo ano, também ocorre a denominada "Operação Colombo", que resulta na morte de 119 chilenos, executados ou mortos em torturas no país. A justificativa das mortes foi a argumentação transnacional, em que o exército chileno afirmava haver a intenção do MIR em estabelecer um foco de guerrilha rural em Salta (Argentina) e que, portanto, estes guerrilheiros morreram em enfrentamentos com o exército argentino naquele território, apresentando inclusive seus cadáveres à imprensa, a qual divulgava essa versão dos fatos. Posteriormente, comprovou-se que aqueles homens e mulheres foram assassinados em seu país natal (COMITÉ DE DEFENSA DE LOS DERECHOS DEL PUEBLO, 2005).

E diversos outros casos vão acontecendo, neste período pré e pós-acordo oficial do Sistema Condor, como iremos abordar de maneira diluída, durante os capítulos deste trabalho. No entanto, com o golpe na Argentina, em março de 1976, a cooperação avança rapidamente e o país torna-se um dos principais centros de união nesse Sistema.

O repúdio internacional pelos fuzilamentos do início da ditadura chilena, fez com que a Junta Militar argentina escolhesse uma "linha prudente" de repressão, fundamentada no

\footnotetext{
17 Informações sobre o caso Carlos Prats podem ser consultadas no seguinte endereço eletrônico: <http://www.archivochile.com/Memorial/caidos_mov_popular/P/prats_gonzalez_carlos.pdf>. Acesso em: 06 jan. 2017.
} 
desaparecimento. O método repressivo no país, portanto, baseou-se nos sequestros, detenções clandestinas e desaparecimentos forçados, que já vinham em um crescente desde o início dos anos 1970, todavia que o denominado "Processo de Reorganização Nacional" o instrumentalizou, sistemática e massivamente, para eliminar seus potenciais inimigos (NOVARO; PALERMO, 2003).

O desaparecimento de pessoas permitiu que se estendesse a suspeita/culpa por toda a sociedade, afetando-a pela incerteza sobre as vítimas dessas ações e das práticas de torturas e mortes, sobre as delações efetivamente realizadas e sobre os responsáveis pelas violações aos direitos humanos. Era acompanhado pelo botín de guerra (pilhagem para a guerra), cujo roubo de pertences das vítimas (incluindo seus filhos pequenos ou nascidos em cativeiro) movimentava uma rede econômica clandestina de venda desses objetos roubados e de falsificação de documentos para as crianças desaparecidas. Desta forma, o país foi dividido em zonas de operações, constituiu uma série de Centros Clandestinos de Detenção e Extermínio, lançou campanhas contra o que chamavam de "escravização ideológica marxista" e teve resposta positiva de setores empresariais, que "resolviam seus problemas sindicalistas" com a política repressiva.

A "receita antissubversiva argentina" transformou seu sistema de informação e repressão em modelo para a região, incluindo o país na rota de aperfeiçoamento de oficiais para táticas militares, com cursos realizados na Escuela de Mecánica de la Armada, tal como anteriormente eram enviados oficiais para especializações aos Estados Unidos, ao Chile e ao Brasil. Ela também passa a ser ativa na relação com o Sistema, repassando informações obtidas sob torturas e fazendo inúmeros prisioneiros estrangeiros, que eram entregues fora das fronteiras ou mantidos encarcerados (detidos-desaparecidos) no próprio país.

Desta maneira, centenas de bolivianos, chilenos, uruguaios e paraguaios foram sequestrados em território argentino. Na Bolívia, militares argentinos foram convocados para coordenar ações, que resultaram em cerca de 1500 mortos e desaparecidos, no chamado "Golpe da Coca" de 1980. Também aplicaram suas metodologias em Honduras, Nicarágua, Guatemala e El Salvador (NOVARO; PALERMO, 2003).

No caso paraguaio, país de longa tradição de regimes ditatoriais e de abrigo de militantes anticomunistas e responsáveis por violações aos direitos humanos (incluindo criminosos nazistas ${ }^{18}$ ), existiu, dentro das Forças Armadas, o orgulho de ter sido, tal como considerado por Richard Nixon, o lugar na América Latina "mais consequente na luta

\footnotetext{
${ }^{18}$ Acolheu, particularmente, o médico nazista Joseph Mengele e o chefe da loggia maçônica Licio Gelli.
} 
anticomunista" (GAUDICHAUD, 1994). Consequente, entretanto, no sentido de que, através da unidade entre governo, Forças Armadas e Partido Colorado, pela figura de Alfredo Stroessner, o país era uma espécie de "laboratório das técnicas de repressão" para conter essa ameaça externa do comunismo.

Segundo Pastor Milciades Coronel, chefe do Departamento de Investigaciones de la Policía (DIP), o país necessitava reforçar suas técnicas de repressão, pois era lugar estratégico para os movimentos comunistas ingressarem na região do Cone Sul. E, nessa guerra,

\begin{abstract}
los efectos de estos movimientos, nosotros, los paraguayos sentimos en escala nacional. Pero no ignoramos que la conspiración es de escala internacional. Paraguay por su posición tradicionalmente anticomunista y por su estratégica posición geográfica, es el país objetivo del momento. Instalado aquí el marxismo, las espaldas de nuestros vecinos quedan expuestas (CORONEL apud BOCCIA PAZ, 2008, p. 123).
\end{abstract}

Dessa forma, centralizada em Assunção, a informação era a grande arma da repressão paraguaia, que, por um lado, justificava os enormes investimentos em "inteligências" e métodos de torturas (montando arquivos imensos com informações policiais), e, por outro, cooptava a sociedade para auxiliar na tarefa de desarticular o comunismo, através da delação por suspeita - como afirmou o policial Camilo Almada "se um indivíduo pensa como comunista e atua como comunista é porque ele é comunista" (GUENA, 1996, p. 72). Assim, são mais de 200 fichas encontradas em arquivos sobre os soplones ou pyragues, indivíduos civis que vigiavam e denunciavam estes suspeitos, assinando informes em troca de acessos gratuitos para espetáculos, ingressos para partidas de futebol, passes livres em transporte público ou reconhecimento pelo Partido Colorado (GUENA, 1996).

A partir dessas informações ocorriam as práticas de aprisionamentos constantes talvez o caso mais emblemático seja o de Luis Alfonso Resck, fundador do Partido Democrata Cristão, preso 119 vezes durante a ditadura stronista -, torturas, mortes e falsos julgamentos de prisioneiros. Uma das chaves do entendimento desse processo repressivo, extremamente longo (são 35 anos de stronismo: 1954-1989), é a lealdade ao Partido e ao líder, que combinaram as práticas de repressão anticomunista com a corrupção, o clientelismo e o apoio financeiro externo - fluxos incontáveis de dólares entraram no país para a construção de hidrelétricas e o financiamento da agroexportação de algodão e soja. Desta forma, dois dos maiores grupos afetados pelo sistema repressivo foram os trabalhadores rurais e as populações indígenas, que residiam nas regiões de incursão econômica (BOCCIA PAZ; GONZÁLEZ; PALAU, 2006). 
No início dos anos 1970, por exemplo, a população rural, extremamente empobrecida, inicia uma auto-organização, com auxílio da Igreja Católica, em forma de cooperativas para produção, distribuição e consumo agrário - as Ligas Agrárias Cristãs. Posteriormente, membros da OPM, estudantes paraguaios retornados, que vinham do Chile e Argentina, se juntaram ao movimento, ampliando a experiência de autogestão. $\mathrm{O}$ governo decide acabar com estas Ligas, através de uma forte repressão, principalmente nos territórios de Yhu e Jejuí, superlotando a cárcere Penal de Emboscada com mais de mil presos nessas operações. ${ }^{19}$

Dentro do Sistema Condor, portanto, o Paraguai é responsável pelo intercâmbio de informações sobre suspeitos e prisões de paraguaios no exterior (especialmente na Argentina, onde muitos exilados se dirigiam por motivos econômicos) e de estrangeiros no país. Estes traslados não necessitavam de muita organização e eram realizados, muitas vezes, em carros civis, que cruzavam as fronteiras, portanto clandestinamente (GAUDICHAUD, 1994).

O Uruguai adentra o Sistema Condor também a partir de sua colaboração nas prisões e trocas de informações com os países vizinhos. Desde antes da "bordaberrização" do sistema democrático - termo utilizado por Juan José Artega (2000) para denominar a militarização do poder civil nas instituições democráticas do país, a partir de 1973 -, o Uruguai reprimia o inimigo comunista, através de uma política de aprisionamento de suspeitos, na qual se calcula que, entre os anos 1968 e 1978, foram feitas mais de 55 mil vítimas nas prisões por motivos políticos (BAUMGATNER; MATOS; MAZZEO, 1987).

Quando, em junho de 1973, o presidente eleito Juan María Bordaberry abre espaço político para as Forças Armadas, dissolvendo as Câmaras de Senadores e Representantes e gestando um autogolpe de cunho autoritário, o modelo de Doutrina de Segurança Nacional passa a fundamentar as prisões em massa, que atingiram toda uma classe trabalhadora urbana, sindicalista e estudantil. Dentro dessas prisões, as violações aos direitos humanos eram recorrentes, com o objetivo de obter informações para manter o controle da "situação subversiva" e destruir o "aparato político-militar subversivo", proporcionando a segurança para o desenvolvimento nacional (BAUMGATNER; MATOS; MAZZEO, 1987). Com a renúncia de Bordaberry, em 1976, e a escalada ao poder por parte das Forças Armadas, é institucionalizado o poder autoritário para a conformação de um projeto econômico

\footnotetext{
${ }^{19}$ Em março de 1977, a Confederação Anticomunista Latino-Americana (CAL) se reuniu em Assunção, com presença de responsáveis por torturas e membros de esquadrões da morte, onde se discutiu diversos temas, entre eles a participação de membros da Igreja Católica no "movimento comunista internacional". Logo, ficou estabelecido, naquele momento, o denominado Plan Banzer, cuja finalidade era a erradicação dos religiosos adeptos da Teologia da Libertação, através de execuções de membros de comunidades religiosas, em todo o continente. Cf. ABRAMOVICI, 2005.
} 
neoliberal, pelos Atos Institucionais, que forjavam as ações ilegais por meio de uma legislação apropriada para elas.

Logo, o país é considerado um grande "campo de detenção" do tamanho de seus limites geográficos (BAUMGATNER; MATOS; MAZZEO, 1987). Estas detenções, seguidas pelos desaparecimentos circunstanciais - as negações oficiais de responsabilidades pelas prisões, torturas e roubos -, eram posteriormente legalizadas com trâmites judiciais para que os detidos-desaparecidos se transformassem em prisioneiros por razões de Segurança Nacional. Fugindo desse sistema, o número de exilados no país cresce vertiginosamente, superando 300 mil pessoas.

E, desde o início do Sistema Condor, os uruguaios tiveram uma participação ativa na repressão internacional, principalmente em conjunto com os argentinos, pelo qual o número de desaparecidos no país, de acordo com a primeira investigação oficial (2003), já expressa tal conexão: conforme os relatos, entre 164 uruguaios desaparecidos permanentemente, 127 pessoas foram sequestradas na Argentina e duas no Paraguai.

A complexa rede de repressão uruguaia contava com duas grandes forças: a Dirección Nacional de Información e Inteligencia (DNII), criada em 1947, que tinha a função de polícia política e era vinculada ao Ministério do Interior, perseguindo e controlando a entrada e saída dos suspeitos em suas fronteiras; e o Servicio de Información de Defensa (SID), que centralizava a produção de informação realizada pelas Forças Armadas para manter a segurança contra as infiltrações comunistas, em constante contato com outros países, especialmente Argentina, Bolívia, Brasil e Paraguai. O SID repassava as informações para os demais organismos repressivos, como, por exemplo, o Organismo Coordinador de Operaciones Antisubversivas (OCOA), uma agência de inteligência militar e de atuação clandestina, criada pelo Comando Geral do Exército, em 1974. De caráter ilegal, o OCOA centralizava parte das ações contra a subversão, realizadas por agentes de organismos policiais e militares, e constituía diversos Centros Clandestinos de Detenção em todo o país (RICO, 2008, Tomos 1 e 2).

Fora dele, coordenou atividades em conjunto com as Forças Armadas argentinas, pelos Centros Clandestinos da ESMA e Automotores Orletti. Este último, um dos símbolos da repressão transnacional - durante alguns meses foi o "epicentro do Sistema Condor" (GAUDICHAUD, 1994) -, funcionou entre maio e novembro de 1976, dependente das Forças de Segurança argentinas e uruguaias. Antiga oficina mecânica, em Buenos Aires, o espaço alugado foi utilizado tanto como depósito para os saques de botín de guerra, quanto como 
cárcere clandestino e lugar de interrogatórios dos detidos-desaparecidos de diversas nacionalidades (CONADEP, 2006).

Se em princípio nos parece que o Sistema Condor terminou nos anos 1980, com os regressos às democracias e a suposta suspensão das práticas de torturas e desaparecimentos institucionalizados, muitos autores apontam não haver nenhum elemento de dissolução do mesmo. Ao contrário, a coordenação transnacional repressiva continuou acontecendo, com as reuniões regulares da CEA, que agrupam representantes militares dos governos democráticos, e com um sistema de informações atuando, principalmente, nos territórios colombiano, venezuelano e peruano. Martin Almada aponta, por exemplo, que existem, anualmente, cerca de 14 mil soldados que se aplicam aos cursos de repressão antissubversiva, provenientes da Colômbia, Chile, Peru, Nicarágua, República Dominicana, Equador, Panamá, Honduras, El Salvador, Guatemala, Costa Rica, Paraguai, México, Brasil, Canadá, entre outros. Portanto, a perspectiva da repressão aos "terroristas/subversivos" no território latino-americano segue como uma política com dimensões internacionais (ALMADA, 2009).

Considerando essa visão transnacional da repressão, apenas no período ditatorial do Cone Sul, os números oficiais de vítimas são assombrosos: a estimativa é de cerca de 50 mil assassinatos, 35 mil desaparecidos (incluindo 8 mil crianças desaparecidas ou assassinadas), 400 mil encarceramentos por motivos políticos e 4 milhões de pessoas exiladas. ${ }^{20}$ Essas são as vítimas de um sistema de informação a qualquer custo. Como coloca Márcia Guena (1996, p. 21),

Qualquer método valia: delação, extorsão, vigilância, extrapolação de fronteiras, tortura e morte. $\mathrm{O}$ documento passou a valer mais que o homem. O primeiro era lido e sempre preservado em arquivos; o segundo se extraía informação e ele estava pronto para ser descartado, jogado em algum rio.

Com a perspectiva da informação mais valiosa que o ser humano, esses crimes do Sistema tornaram-se, posteriormente, os elementos aceleradores de processos internacionais, obtendo significados singulares, tanto simbólicos quanto legais (DINGES, 2005). Significados simbólicos, na medida em que representavam, nos diversos campos e práticas, as violações aos direitos humanos internacionais, de maneira internacional, com testemunhos e documentações, encontrados "espalhados" internacionalmente. Significados legais, pois a natureza internacional desses crimes atraiu a atenção de advogados e militantes dos direitos humanos, em diversas partes do globo, e expandiu as jurisdições (nacionais e internacionais) para processar seus responsáveis.

\footnotetext{
${ }^{20}$ Esses números se baseiam em investigações oficiais e são bastante controversos.
} 
A partir da "descoberta" desse Sistema (entre aspas porque sabemos da responsabilidade dos atores político-econômicos e civis no desenvolvimento do projeto na região, portanto, não se "descobre” algo que é público), a legislação internacional de direitos humanos se reelabora para contemplar a penalização das violações cometidas. A prisão de Augusto Pinochet, em 1998, por exemplo, foi resultado da primeira ocorrência de processos de tipo internacional, baseada nos crimes contra a humanidade e contra um país aliado, desde a Segunda Guerra Mundial. O caso iniciou-se quando promotores espanhóis concluíram que a legislação espanhola, combinada aos precedentes internacionais, remetendo-se principalmente ao julgamento de Nuremberg, permitia fundamentar acusações contra violadores de direitos humanos nas ditaduras do Cone Sul, considerando-os contemplados pela legislação de crimes contra a humanidade (DINGES, 2005).

Para testar a teoria, esses promotores apresentaram, primeiramente, uma denúncia contra os membros da Junta Militar argentina por genocídio, referente a dez vítimas espanholas. Posteriormente, agregaram outros casos de violações contra espanhóis, ocorridos no Chile. O juiz Baltasar Garzón, encarregado de julgar a denúncia, aceitou-a, fundamentando-se na jurisdição internacional e permitindo investigações, inclusive com pedidos de liberação documental - algo ainda inédito para a época. Os detalhes sobre o Sistema Condor e a identificação da ação criminosa de Augusto Pinochet levaram o advogado Juan Garcés a escrever uma petição com fins de interrogar o ex-ditador chileno. E, aproveitando a viagem de Pinochet à Inglaterra, Garzón pediu, então, a extradição do mesmo e sua prisão com o argumento de que:

(...) Augusto Pinochet Ugarte, à época chefe das Forças Armadas e do estado chileno, executou atividades criminosas em coordenação com as autoridades militares da Argentina (...), dando ordens para a eliminação física de algumas pessoas, para tortura, sequestro e desaparecimento de outras, do Chile e de diferentes nacionalidades e em vários países, por meio das ações do Serviço Secreto (Dina) e dentro do acima citado "Plano Condor" (GARZÓN apud DINGES, 2005, p. 65).

Foi, portanto, a primeira vez que o Sistema Condor aparece como uma coordenação repressiva continental, em casos judiciais.

Desta mesma forma, ainda no campo legal, o Sistema também fundamentou alguns casos abertos na Justiça argentina, a partir de 1999, nos quais se reconheceu a existência do Sistema e se consideraram culpados penalmente os integrantes das Forças Armadas argentinas e uruguaias, utilizando-se como provas os testemunhos das vítimas e sobreviventes e as documentações do arquivo paraguaio (Archivo del Terror) - fato original no âmbito da justiça 
de transição regional. Em particular, foram condenados 18 imputados por privação ilegal de liberdade e agravantes de 105 vítimas do Sistema (14 cidadãos argentinos, 11 bolivianos, 22 chilenos, 13 paraguaios e 45 uruguaios), com condenações variando entre 8 e 25 anos de prisão (ARGENTINA, 2015). A importância dessa causa para a região está no fato de que "por primera vez en América Latina un tribunal reconoce la existencia del Plan Cóndor como asociación ilícita" e que "si estuvieran vivos Pinochet o Stroessner estarían en esta causa", como declarou, em entrevista, o diretor executivo do Centro de Estudios Legales y Sociales (CELS), Gastón Chiller (CHILLER apud CUÉ, 2016, sem paginação).

Portanto, os crimes, as vítimas e a documentação produzida pelo Sistema Condor foram capazes de romper barreiras históricas dentro dos processos legais de responsabilização, na região e internacionalmente. Contudo, essa não é a única consequência da existência deste Sistema, no que tange às mobilizações conectadas regional e globalmente para a justiça de transição.

Os casos de trabalhos das memórias, em toda região, vão se elaborando, a partir do atrelamento transnacional entre as memórias especificas de diversos regimes repressivos e as memórias regionais desse Sistema. Os novos territórios de memória, em especial no Cone Sul, vão surgindo, com a finalidade de interpretar coletivamente o passado, e explorando as discussões sobre outras memórias de catástrofes, delineando, portanto, um uso daquilo que Tzvetan Todorov (2013) denomina de memórias exemplares. Estas são caracterizadas por elaborar categorias em espaços públicos de forma generalizada, travando analogias com outros passados, sem perder a singularidade dos eventos recordados. Desta forma, "desindividualiza" (ou coletiviza) a realidade vivida em determinados contextos.

Existem muitas críticas, entretanto, que rejeitam a ideia de uma memória exemplar em prol da singularidade e incomparabilidade de eventos históricos - é o contexto de muitas análises sobre o Holocausto, por exemplo, no qual ainda há uma proposta de considerá-lo não apenas singular, contudo também o "mais traumático evento" na história humana (dinâmicas recorrentemente denominadas como hierarquizações dos sofrimentos). Pensando neste sentido singular, talvez nenhum evento humano pudesse ser comparado em debate público e, assim, construiríamos memórias e identidades estanques, sem o diálogo entre os fenômenos traumáticos. A proposta de Todorov (2013) vem em outra direção. Para o autor, trabalhar com a comparação (semelhanças e diferenças) é avançar na compreensão das realidades históricas e das representações delas.

Assim, segundo Todorov (2013), uma memória narrativa em espaço público deve servir não apenas para recordar singularmente o evento lembrado, mas também, para 
reconhecer coletivamente as relações entre essas memórias e outras memórias e histórias e, paralelamente, com os eventos do presente e do futuro. Esta ideia já havia sido proposta por Walter Benjamin (2012, p. 241-252), que colocava, como um dos papéis fundamentais das memórias e da História, o ato de "lançar luz sobre os eventos análogos", com a finalidade de impedir que outras catástrofes viessem a ocorrer ou, ao menos, que nos fizessem capazes de reconhecê-las enquanto catástrofes no presente.

E, se trazemos esse debate sobre a memória exemplar para o campo dos direitos humanos, ele consolida a própria existência da luta por esses direitos em nível mundial. De acordo com Andreas Huyssen (2014, p. 195-213), enquanto movimento social transnacional e fora de uma interpretação puramente legalista, os direitos humanos se auto-alimentam com os trabalhos de memórias, uma vez que estes últimos fundamentam os discursos sobre direitos humanos. Isto quer dizer que ambos os movimentos, interessados nas violações e proteções dos direitos básicos do homem, se baseiam nas histórias, reconhecendo-as enquanto injustiças, que precisam ser discutidas para projetarem-se em direção a um futuro distinto, um futuro melhor.

Logo, sabemos que houve uma violação, porque sabemos o que é violação, a partir de experiências precedentes e das memórias construídas nos espaços públicos sobre elas. E modificamos o embate pelos direitos humanos, de acordo com as analogias dessas memórias e com os desafios que novas experiências de catástrofes nos impõem.

Diversos são os casos de memórias exemplares, que poderiam ser abarcados nas discussões do campo das memórias em âmbito global. Particularmente, para o Cone Sul, fica claro que as experiências sobre o Holocausto impulsionaram muitos dos debates sobre os períodos ditatoriais, como veremos na sequência do texto.

Consideramos aqui três motivos para essa transnacionalização das memórias, que, apesar de parecerem óbvios, devem ser expostos para o entendimento da particularidade do chamado "pós-holocausto" no território latino-americano. O primeiro é a temporalidade das transições à democracia no Cone Sul, que se superpõem aos próprios debates sobre memórias do evento de genocídio praticado pela Alemanha sob o Nacional Socialismo. Essas discussões, dos anos 1980 e 1990, transformaram a perspectiva de análise da história do genocídio, trazendo também as "novas" visões de experiências da região, principalmente no que se refere aos desaparecidos, formando uma espécie de "trama metodológica" entre ambas as experiências. Depois, as propostas que surgem, a partir desses debates, para se recuperar a memória nos espaços públicos, em um contexto pós-Guerra Fria e pós-ditatorial, são inovadoras para a época e pensam em outras questões sobre o passado a serem exploradas no 
presente: os imperialismos e colonialismos, as políticas neoliberais e os sistemas de exclusão social. Ou seja, houve diversas mudanças de perspectivas para se trabalhar as memórias sobre as violações aos direitos humanos. Por fim, a superexposição do evento Holocausto, inclusive com as devidas críticas sobre sua mercantilização e consumo cultural ${ }^{21}$, converteu-o, talvez, no grande estopim para se pensar nas memórias exemplares em nível internacional.

Ao longo do tempo, as discussões vão ganhando novos exemplos de conformações de memórias em espaços públicos e consolidando esses elos transnacionais de memórias exemplares sobre a violência na história, que influenciaram as políticas nacionais, os processos judiciais, os debates sobre as violações, as Comissões de Verdade e as produções artísticas e memoriais sobre a temática do trauma. Como afirma Huyssen (2014, p. 14-15),

Para onde quer que olhemos, as discussões transnacionais tornaram cada vez mais obsoleto o paradigma nacional mais antigo dos estudos sobre a memória, ainda que as respectivas preocupações nacionais ou regionais tenham permanecido poderosamente no centro desses debates transnacionais. Os debates públicos sobre a memória, no Chile, Guatemala, Brasil ou México, seguiram o exemplo dos havidos na Argentina, e o modelo sul-africano de Comissões de Verdade multiplicou-se pelo mundo afora. A guinada transnacional dos estudos sobre a memória influenciou claramente a política nacional, os processos judiciais, as Comissões da Verdade e os debates populares de muitos países, e se articulou de maneira vigorosa na literatura, nas artes plásticas, em filmes e documentários, e até na arquitetura de museus e memoriais.

Para o caso platino, três grandes exemplos são os eventos das conformações da Comisión sobre la Desaparición de Personas (CONADEP-Argentina), que traz à tona as denúncias sobre os crimes ditatoriais e seus métodos repressivos e influencia demais denúncias de vítimas em toda a região; do Archivo del Terror (Paraguai), que modifica a visão sobre a luta pela informação no território, trazendo a possibilidade de acesso a ela e de justiça com provas documentais; e do Espacio para la Memoria y para la Promoción y Defensa de los Derechos Humanos (Argentina), que transforma o grande Centro Clandestino de Detenção e Extermínio, a ESMA, símbolo regional das violações neste período, em um espaço que engloba discussões sobre os direitos humanos e lutas pela verdade. Conformados em décadas diferentes (1980, 1990 e 2000), os citados casos perpassam debates sobre outras

\footnotetext{
${ }^{21}$ A discussão sobre os mercados da memória adentra os debates sobre o patrimônio, que exploraremos a seguir neste trabalho. No entanto, recuperamos aqui a ideia de Néstor Canclini (2015) sobre pensar o consumo na América Latina, a partir dos bens consumidos e seus consumidores, ao invés de desqualificá-lo de imediato em um âmbito moral. Isto quer dizer que, apesar dos modelos globais de consumo, que impõem uma espécie de homogeneização cultural, existe também neles uma via de reconhecimento cultural e de mediação sobre esses bens consumidos, que precisa ser levada em conta nas análises sobre o consumo.
} 
experiências de trabalhos de memória, demonstrando um processo dinâmico de transformações das memórias exemplares por todo o globo.

Voltamos a enfatizar que, através da conexão entre as histórias desses países e os exemplos dentro dos debates sobre memórias, não pretendemos eliminar uma linha de análise historiográfica importantíssima, que aborda as distintas repressões e políticas de memórias em cada território ou outros tipos de abordagens comparativas. Contudo, pretende-se lançar um olhar sobre a perspectiva transnacional, que muitas vezes é deixada à margem dos enfoques sobre história e memória no Cone Sul, preferindo-se a referência aos espaços específicos, desconsiderando a história da memória globalmente.

Neste sentido, tencionamos olhar esse intercâmbio de ideias em suas múltiplas camadas e hierarquias, assumindo formas diferentes em distintos momentos históricos. Tal como propõe Huyssen (2014, p. 11-17), queremos "desembrulhar" as diferenças e semelhanças espaciais e temporais, alcançando um método de comparação sobre a história da memória regional, que possa mover-se em espaços nacionais, regionais e globais, ir e vir em tempos e geografias imaginativas (HUYSSEN, 2014, p. 19-38). E nossa geografia imaginada é o território do Río de la Plata.

Desta forma, optamos por trabalhar com as discussões em três territórios de memórias e verificar as incursões de seus discursos e exemplos no campo das memórias sobre Terrorismos de Estados e sobre as memórias globais de eventos catastróficos: os espaços públicos oficiais e nacionais para denúncias das vítimas de violências estatais, os casos levados ao Sistema Interamericano de Direitos Humanos e alguns patrimônios constituídos nesses trabalhos de memórias. Concebendo os territórios de memórias - ou lugares de memória; lieux de memoire (NORA, 1989, p. 7-24) - como originários da perspectiva de que os trabalhos da memória são pensados, disputados e negociados para fundamentar uma identidade, a partir de datas comemorativas, celebrações públicas, patrimônios (entre eles, o recentemente denominado "lugares de consciência") e etc., os casos escolhidos para este trabalho aparecem com três estâncias de discussões, que dialogam entre si: o local, o regional e o global.

Os dois primeiros territórios a serem trabalhados trazem espaços públicos que dão vozes às violações dos direitos humanos no local e regional, mas que ingressam no âmbito mundial, rompendo paradigmas e criando novas temáticas para as discussões sobre memórias e direitos humanos. Por outro lado, especificamente para os casos dos patrimônios, enquanto artefatos que expressam uma narrativa e identificam um coletivo em seus tempos e sentidos, 
através da exibição em edifícios, museus, memoriais, bibliotecas, arquivos, entre outras instâncias de mediação ${ }^{22}$, seus projetos já se identificam dentro de debates globalizadores.

Nossas escolhas, aqui, se devem mais aos níveis de discussões dentro da constituição de cada espaço, nas três estâncias geográficas que desejamos identificar, e menos à inquestionável importância dos mesmos nacionalmente. Assim, decidimos trabalhar com as formações do Espacio para la Memoria y para la Promoción y Defensa de los Derechos Humanos (Argentina), do Museo de las Memorias: Dictadura y Derechos Humanos (Paraguai), e do Centro Cultural Museo de la Memoria (Uruguai).

Segundo Susan Buck-Morss (2013, p. 75-89), as análises sobre a construção da memória coletiva nacional precisam também abarcar uma dimensão "desnacionalizada" para ser completa. Ou seja, necessitamos, ao trabalhá-las, refletir sobre as influências e experiências precedentes, que foram consideradas no processo de construção da memória coletiva. Posto que, apenas verificando esse conjunto total das constituições dos territórios de memória, entendemos os posicionamentos das memórias abordadas e de suas representações em cada espaço.

Fica claro, contudo, que os debates nessas instâncias nos trazem diversos argumentos, conceitos e práticas advindas de inúmeras dimensões, os quais seríamos incapazes de realizar em um estudo que não fosse dimensionado para toda uma vida na pesquisa acadêmica. Logo, com critérios das leituras documentais, escolhemos dois conceitos/práticas considerados fundamentais nas relações transnacionais para os casos analisados, e que aparecem constantemente nos debates desses territórios: o desaparecimento forçado e o genocídio.

O desaparecimento é uma particularidade rio-platense, que, na interpretação local, é um campo social relacionado às trajetórias individuais, às relações sociais, às representações culturais, às rotinas, às narrativas, às objetivações científicas e às realizações institucionais. Gabriel Gatti (2011b) defende a tese de que, apesar de haver outros momentos históricos marcados pelo desaparecimento forçado, os desaparecidos do período ditatorial no Cone Sul são os responsáveis pela fundamentação da concepção de uma "identidade global do desaparecido". Com a gênese na acepção argentina do desaparecimento forçado, o conceito ganha êxito no âmbito mundial e circula social, cultural, política e juridicamente.

Na história regional, os desaparecidos são consequência do Poder Desaparecedor (CALVEIRO, 2013). Este é caracterizado pelo estado de exceção; pela superposição de práticas legais e ilegais de repressão; pela militarização da sociedade e o policiamento das

\footnotetext{
${ }^{22}$ Cf. POULOT, 2009 e CHOAY, 2006.
} 
Forças Armadas; pela ideia de que basta ser suspeito para ser culpado; pelo esvaziamento do caráter humano nas práticas de tortura; pelo maquinário burocrático dos Centros Clandestinos de Detenção ou das prisões legalizadas; pelo aceite de setores sociais da lógica de desaparecimento; e pela negação ou silêncio diante da violência aplicada nos sujeitos-vítimas desse sistema (CALVEIRO, 2011, p. 112-142).

Desta maneira, houve a decisão política, em toda a região, de não deixar saber os paradeiros de pessoas, de construir a constante ameaça de desaparecimento, de utilizar métodos inumanos para conseguir informações e de não entregar os cadáveres das pessoas assassinadas (como afirmou um coronel do exército argentino, "os cadáveres não se entregam" ${ }^{23}$ ). O desaparecimento forçado (circunstancial ou permanente) nos permite reconhecer a tentativa (arruinada) de se esconder os crimes do Poder Desaparecedor. Arruinada, por um lado, porque os detidos-desaparecidos circunstanciais saíram de seus cativeiros e relataram suas experiências. E, por outro, porque os detidos-desaparecidos permanentes insurgiram desses testemunhos ou de seus esconderijos impostos - o rio, o mar ou as fossas comuns e tumbas Nomen Nescio (SALAMA, 1992).

Entre os anos 1976 e 1979, por exemplo, apareceram diversos cadáveres nas costas uruguaias, provenientes da Argentina - em um total de 24 corpos, divididos em dois grupos: aqueles reconhecidos, que saíram na imprensa do Uruguai, e aqueles não reconhecidos, 14 pessoas que apareceram em Colonia del Sacramento. Todos os cadáveres possuíam sinais de violência, mãos e pés atados por cordas, e alguns apresentavam perfurações de balas.

O governo uruguaio, nesse momento, realizou alguns estudos de marés, nos quais se conclui que, durante o inverno, devido às cheias dos rios Paraná e Uruguay, as correntezas arrastavam vegetais, restos calcários e pedras, desembocando diretamente nas cidades de Buenos Aires e Colonia e separando-se em dois braços; um para o oceano Atlântico e outro que contornaria toda a costa uruguaia. Assim, aquelas correntes arrastaram também os corpos, sugerindo a hipótese de que a quantidade aparecida nas costas do país é muito menor do que o número de corpos, cuja provável submersão nas águas o torna incalculável.

\footnotetext{
${ }^{23}$ De acordo com o relato do pai de Elena Arcer Sahores (Legajo N.4272), desaparecida em La Plata, o coronel do Grupo Operaciones 113, depois de explicar-lhe tecnicamente as operações "brancas" ou "negras", de acordo com o uso ou não dos uniformes das Forças de Segurança, portanto legais ou ilegais, e sob o pedido de que se entregasse o corpo de Elena, lhe contestou "los cadáveres no se entregan" (CONADEP, 2006, p. 244).
} 


\section{Imagem 5 - Cadáver encontrado no Uruguai}

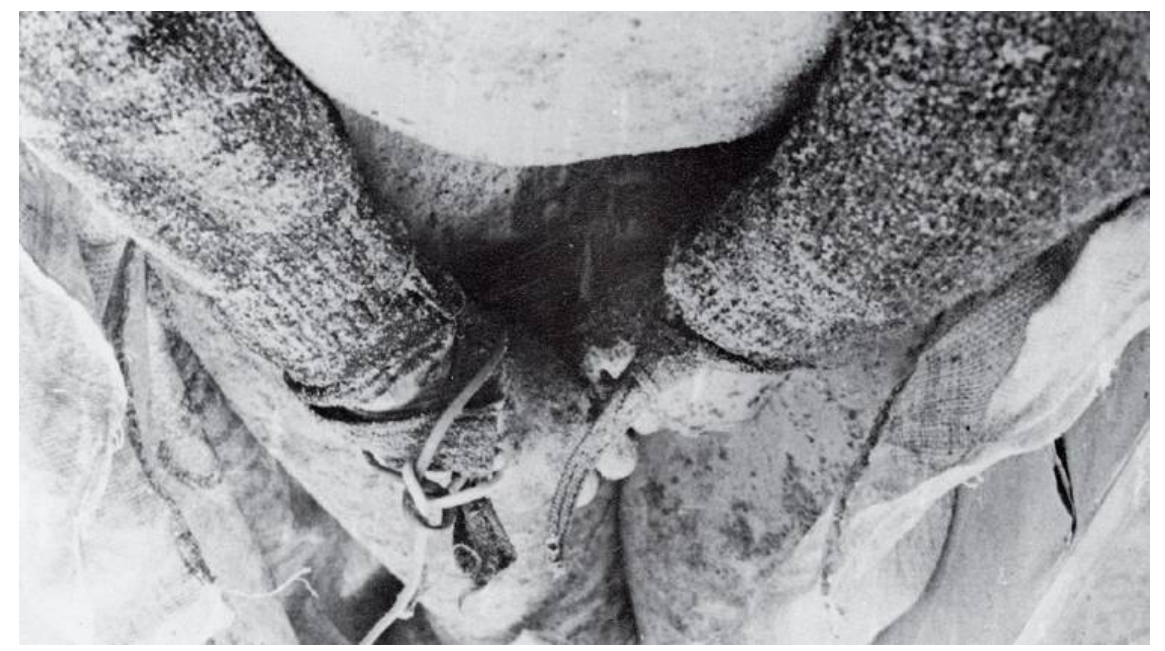

Fonte: ARCHIVO CIDH/OEA. Disponível em: <http://www.infojusnoticias.gov.ar/nacionales/vuelosde-la-muerte-las-fotos-del-horror-3618.html>. Acesso em: 09 jan. 2017.

Por consequência, esses "reaparecimentos" das vítimas acenderam alguns debates públicos sobre os atos praticados pelas Forças Armadas na região. Enquanto temáticas de diversos campos de estudos, essas imagens de sofrimentos de corpos nos fornecem a interpretação de que são provocadoras de compaixão em seus observadores, despertando algum tipo de sensibilidade nos homens (LAQUEUR, 1992, p. 239-275). Assim, quando os corpos das costas uruguaias começaram a aparecer, eles trouxeram consigo questionamentos sociais sobre suas procedências e seus destinos dentro do país. Segundo um documento da Força Aérea brasileira, por exemplo, datado de 1977:

(...) lançar corpos no Rio de la Plata está criando problemas para o Uruguai, como a aparição de cadáveres mutilados nas praias, e fornos crematórios dos hospitais do Estado estão sendo usados para a incineração de subversivos capturados (DINGES, 2005, p. 315).

Esta visão sobre a violência dos corpos aumentou, todavia mais, depois do que se confere como um "destape midiático", ou seja, quando os meios de comunicação começaram a falar dos "reaparecimentos" de corpos, nos períodos pós-ditatoriais. Os cadáveres passam, portanto, a protagonizar, tal como Claudia Feld (2010, p. 25-41) propõe, um "show de horror", que vai relatando as revelações de cemitérios clandestinos e condensando as violências dos regimes, a partir desses corpos nos meios comunicacionais. Este "show" acaba por provocar um sentimento social de injustiça e de desejo pela verdade, que expunha a necessidade de informações sobre a vida dessas vítimas, mais do que a respeito de seus 
destinos finais. Como afirmou Héctor Schmuckler, em ocasião da identificação do corpo de seu filho, encontrado nos anos 1980, “Los muertos, mi muerto, seguirán sin sepultara y no tendrán calma hasta que los silencios duros y los silencios rumorosos no se abran a las palabras" (SCHMUCLER apud SALAMA, 1992, p. 277).

Os desaparecimentos permanentes "descobertos" tornaram-se, pois, base para projetos de investigações de crimes e para a devolução das identidades dessas pessoas, em alguns casos, por exumações e trabalhos de arqueologia, e, em outros, por testemunhos, Comissões de Verdade e pesquisas sobre a temática. Esses mortos tornaram-se evidências e vítimas do Poder Desaparecedor, ganhando, enfim, uma identidade coletiva (os desaparecidos) pelo trauma que experimentaram.

O desaparecido circunstancial, por sua vez, aquele indivíduo preso fora do sistema legal e que, por algum tempo, permaneceu sem que se tivessem informações dele, reaparece com vida, no mesmo cenário de destape. Em contextos diferentes (determinados pelas escolhas pessoais), ele torna-se testemunho daquilo que viveu, como o viveu e com quem o viveu. Logo, seu corpo vivo dá voz aos mortos e estabelece uma visão diferenciada sobre o sistema que o vitimou, deslocando (ou tentando deslocar) o argumento de "necessidade da luta antissubversiva" no caminho de uma visão que os perceba enquanto vítimas do Terrorismo de Estado.

E, assim, o sentido de vítima expande-se. Ao contrário do que imaginamos, desaparecer com alguém não foi apenas uma ação contra a vítima direta. $\mathrm{O}$ desaparecimento proveu também outros sujeitos de uma espécie de punição com a espera por reconhecimentos, respostas e responsabilizações. Ou seja, a identidade dos desaparecidos amplia-se para além do "evento de desaparecer" e engloba outras pessoas, em outros tempos.

Primeiramente, elas são os membros familiares, cujo contexto, no qual as organizações políticas estavam suspendidas, transformou-os na organização social possível para buscar respostas (CATELA, 2001). Posteriormente, a experiência dos familiares vai à esfera pública, ganhando um considerável espaço na agenda dos direitos humanos em toda a região (JELIN, 2010, p. 227-249).

A centralidade dos detidos-desaparecidos é incorporada ao campo das memórias, constituindo-se em símbolo da luta regional e em um problema de todos em nível mundial. Como afirma Ludmila Catela (2001, p. 273), para o caso dos desaparecidos argentinos,

"São 30000 desaparecidos", mas também alguém com nome e sobrenome; são um conjunto sem distinção, mas também uma exposição onde se podem ver e traçar biografias; são fotos sem nome, mas também associadas a histórias individuais. São julgamentos internacionais que só se tornam 
eficazes em sua relação com julgamentos pela verdade para saber o destino de cada desaparecido particular. A lógica dos laços primordiais predomina e pode expressar-se tanto no sentido de "socializar a maternidade" quanto simplesmente por meio de uma individualidade com uma foto carregada pelo próprio corpo da mãe (...) Mais uma vez, é a colocação em jogo da moeda política que serve como câmbio nas fronteiras entre o público e o privado, constantemente redefinidos, e espaço de disputas por excelência entre a família e a nação.

Logo, a representação do detido-desaparecido ganha espaço público como problema coletivo e é a grande coesão dos organismos de direitos humanos. Essa categoria identitária ou campo social, fundamentada no sujeito individual, estabelece seu lugar simbólico no combate pela memória, verdade e justiça. E, assim, transborda aos espaços públicos, em instâncias pedagógicas, canais de comunicação e de identidades, e territórios para se lembrar as experiências do trauma.

Para além das fronteiras da intimidade, a brutalidade do sofrido se transforma progressivamente em ações grupais, que conseguem causar impacto nas memórias coletivas. Assim, a incessante presença dos "familiares" estabeleceu rituais e comemorações cuja reprodução vai depositando marcas indeléveis na paisagem cultural urbana: monumentos, placas, museus (CATELA, 2001, p. 205).

Como sabemos, as homenagens aos desaparecidos nos espaços públicos ganham, cada vez mais, lugar dentro das cidades em todo o mundo, contudo, principalmente, na América Latina. Em Assunção, mesmo com a falta de vontade política dos governos pós-ditatoriais, a Plaza de los Desaparecidos, que se encontra ao lado do Palácio de Governo, carrega a placa rememorativa dos desaparecidos. Existe um projeto, apresentado pelas organizações de direitos humanos paraguaias, de construção de um monumento (um muro com inscrição dos 469 nomes de desaparecidos e fuzilados na ditadura stronista) para lembrar esses sujeitos/vítimas do Estado, que parece não se concretizar. Em Montevidéu, no Parque Carlos Vaz Ferreira, pela iniciativa das Madres y Familiares de Detenidos-Desaparecidos, foi construído, em 2001, um muro de vidro com a inscrição dos 174 nomes de desaparecidos da ditadura, denominado Memorial de los Detenidos-Desaparecidos. Em Buenos Aires, por sua vez, são inúmeros casos de territórios de memórias que trazem a figura dos detidosdesaparecidos. O já citado Parque de la Memoria, por exemplo, possui um monumento em formato de quatro estrelas que contêm os nomes dos desaparecidos no país. 
Imagem 6 - Plaza de los Desaparecidos (Assunção)

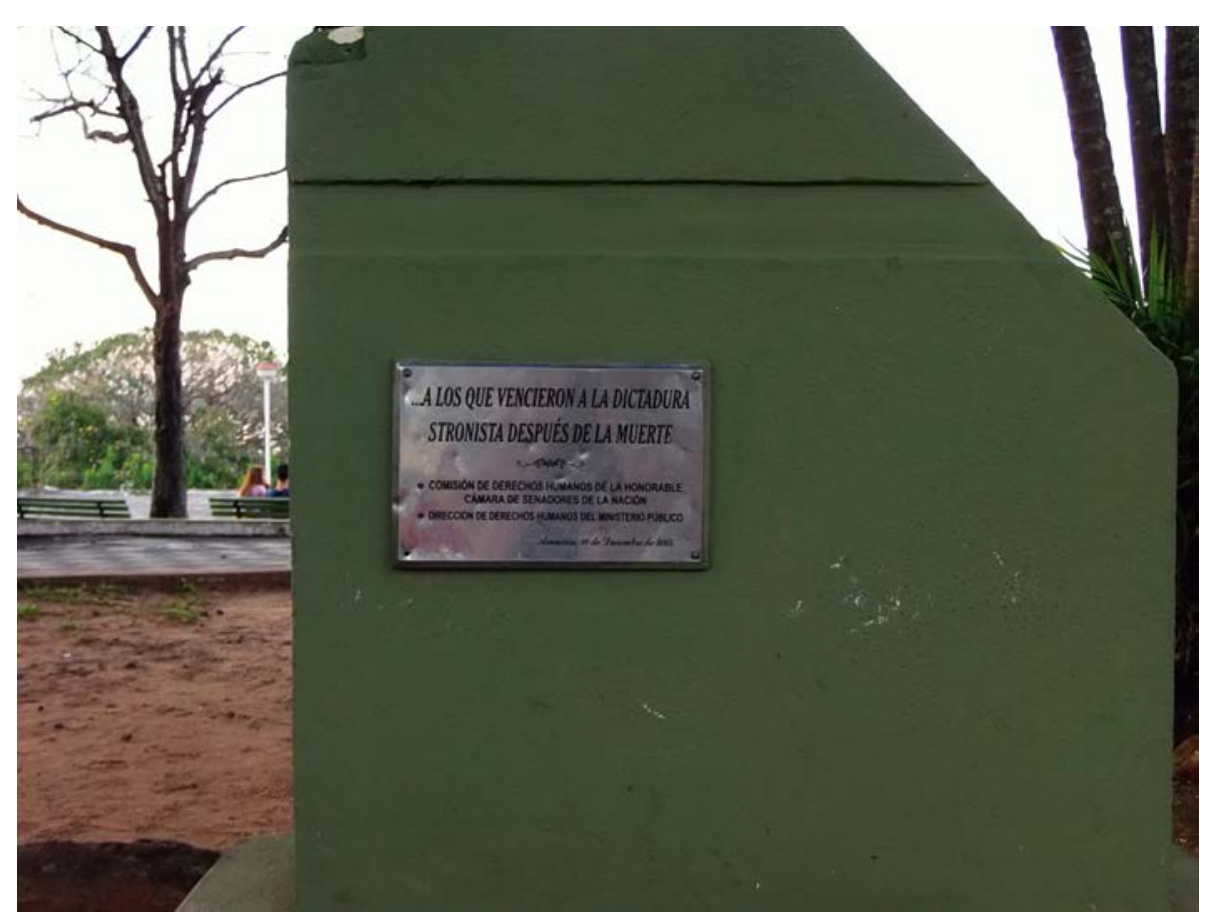

Fonte: Arquivo Pessoal. Fotografia de 2015.

Imagem 7 - Memorial de los Detenidos-Desaparecidos (Montevidéu)

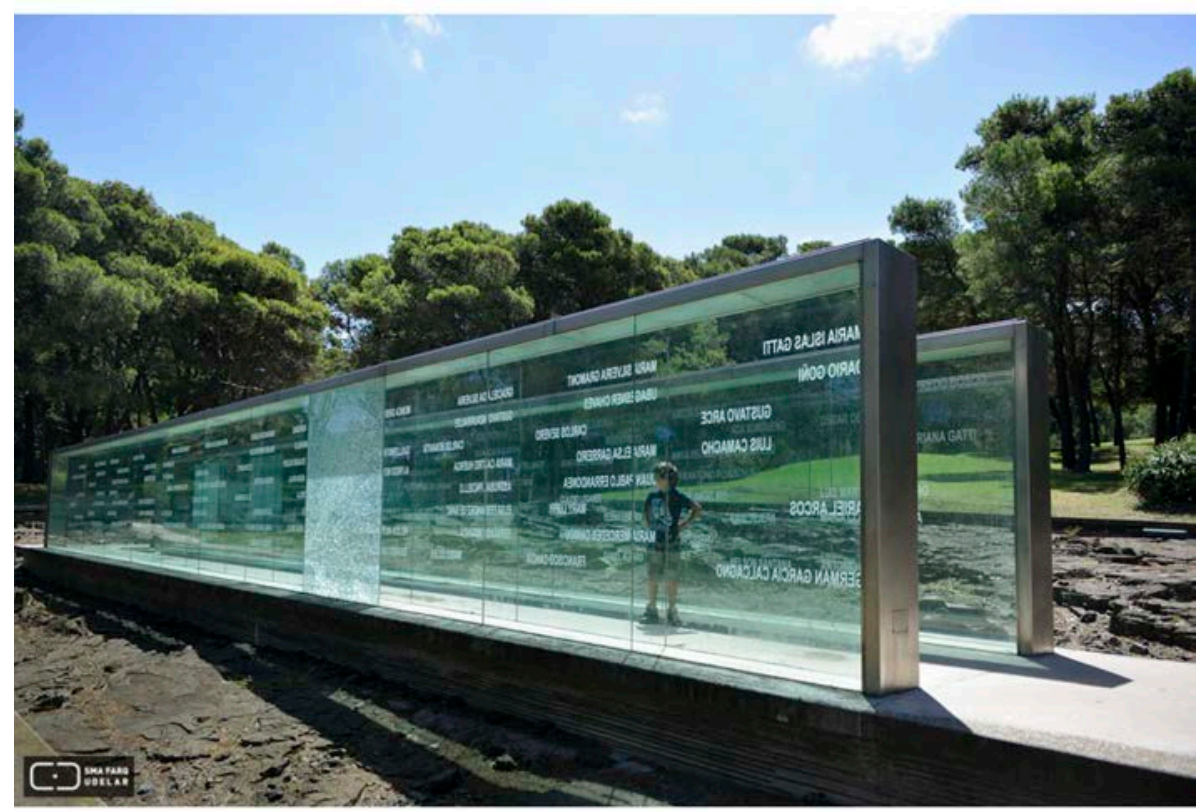

Fonte: ARCHIVO UNIVERSIDAD DE LA REPÚBLICA. Imagem disponível em: $<$ http://concursos.fadu.edu.uy/index.php/concursos/memorial-en-recordacion-a-los-detenidosdesaparecidos >. Acesso em: 10 jan. 2017. 
Imagem 8 - Parque de la Memoria (Buenos Aires)

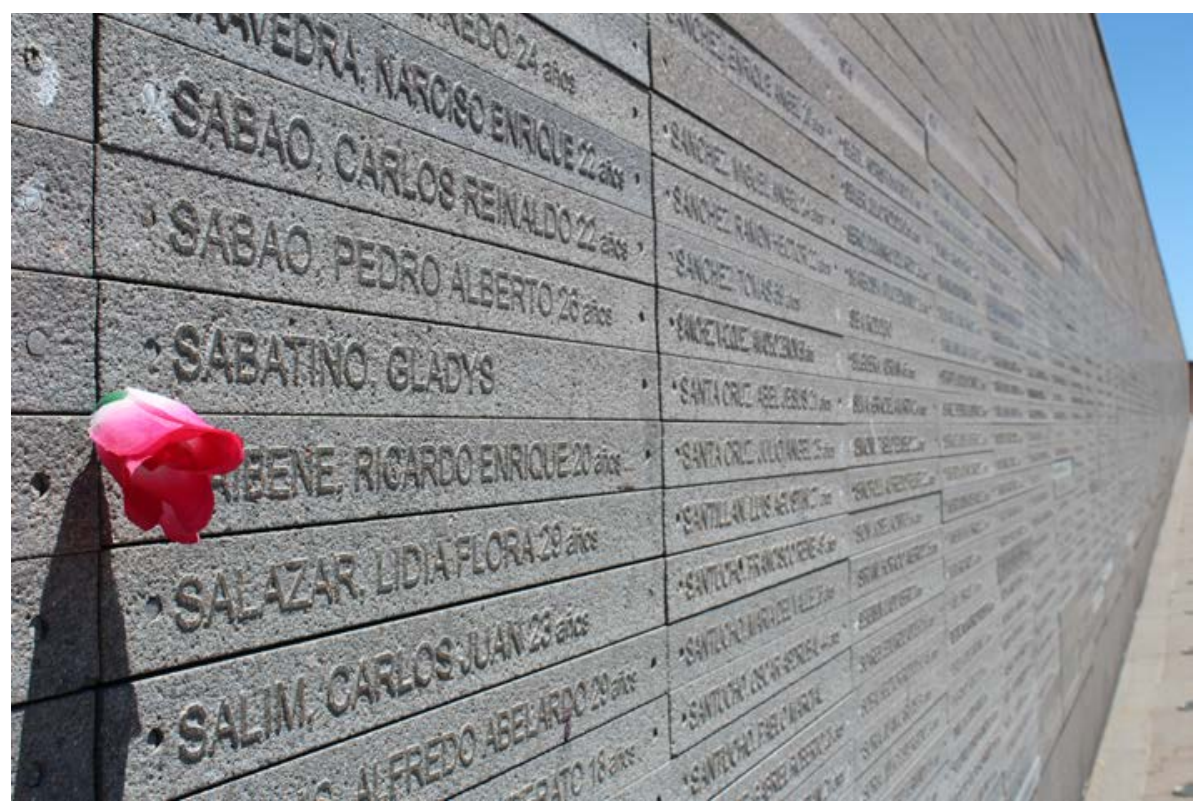

Fonte: Arquivo Pessoal. Fotografia de 2016.

Percebemos que o campo social do detido-desaparecido (permanente ou circunstancial) sintetiza, em um primeiro momento, a representação regional da catástrofe, do controle dos corpos, dos traumas, da dominação, da fabricação de um "indivíduo civilizado" pela eliminação do outro, da necessidade (criada) de lucro, civilização e progresso, da barbárie, da modernidade exacerbada, e dos Centros Clandestinos de Detenção e prisões como "máquinas da civilização". Por abarcar todas essas experiências em corpos, o detidodesaparecido reúne os problemas nacionais, internacionais e regionais das discussões sobre violências de Estados, em todos os tempos (GATTI, 2011a).

Em 1994, enfim, a Organização dos Estados Americanos (OEA) define o sentido jurídico do desaparecido na região, na Convenção sobre o Desaparecimento Forçado de Pessoas. Nesta Convenção, ele se constituiu em privação de liberdade, cometida por agentes do Estado ou pessoas que atuem com sua autorização e apoio, seguida da falta de informação ou negação sobre a mesma privação, impedindo o exercício de recursos legais e de garantias processuais, e tornando-o crime até que o desaparecido reapareça (ORGANIZACIÓN DE LOS ESTADOS AMERICANOS, 1994).

Desta maneira, a definição do desaparecido ganha forma jurídica, não apenas transnacional, como também atemporal. De acordo com Luis Pérez Aguirre (AGUIRRE apud GATTI, 2011a, p. 62), o desaparecido é a pessoa cuja condição humana lhe é negada, e, ao 
negar-lhe ser humana, este "não homem" perde o direito de estar em um lugar e em uma data. E, com essas características da falta de alteridade, ele circula nas sociedades e atravessa fronteiras, sendo até hoje um campo social fundamental para se pensar as políticas repressivas latino-americanas.

El desaparecido es considerado como un no-ser; el Estado de Seguridad Nacional no quiere reconocerle su carácter humano. Más aún, en el esquema del 'enemigo permanente', los desaparecidos no son considerados ni siquiera como delincuentes (que en toda sociedad democrática sigue siendo persona), porque no tienen derecho ni a ser procesados y juzgados, a tener públicamente la condición de 'presos'; a conocer su sentencia. La condición de los desaparecidos es un caso extremo de 'alteridad': ¡la sociedad les quitó toda cualidad humana! ¡Se les niega su condición humana! Se procura suprimirles el último lazo que tenían con la sociedad; se les niega hasta el derecho de estar en un lugar y fecha (AGUIRRE apud GATTI, 2011a, p. $62)$.

O genocídio, por sua vez, aparece como outro grande integrador internacional nessas discussões dos territórios de memória. Apesar de muito criticado enquanto conceito para se pensar no caso latino-americano, principalmente quando se reflete em sua definição jurídica, é ele que reverte muitos argumentos persistentes em favor de uma "paz social" e "reconciliação nacional" com o passado, particularmente nos territórios argentino e paraguaio, como abordaremos nas próximas páginas.

Rompendo com a ideia legal de que o genocídio é o extermínio - mortes, lesões graves, submetimentos intencionais, medidas para impedir o nascimento e traslados à força de grupos nacionais, étnicos, raciais ou religiosos (ORGANIZACIÓN DE LAS NACIONES UNIDAS, 1948), as interpretações em torno do genocídio ganham outras representações simbólicas, que agregam destruições de relações sociais, em uma região na qual a ausência segue presente e o desaparecimento marca uma identidade (FEIERSTEIN, 2012). A consciência de que o genocídio é um crime internacional fundamenta os argumentos, em muitos dos territórios de memória analisados, para obter justiça, que tarda a ser elaborada nos períodos pós-ditatoriais. Portanto, ele é estratégico para impulsionar a luta pelos direitos humanos na região.

Citamos aqui dois exemplos iniciais do uso deste conceito como impulsionador de questões sobre memórias nesses países. Primeiro, nos processos iniciados em 2003, na Argentina, em favor da anulação das chamadas Leyes de Impunidad, e nos processos posteriores a esta mesma anulação, há um número menor de absolvição de considerados responsáveis por violações aos direitos humanos, quando estes processos se baseiam na legislação internacional do genocídio (FEIERSTEIN, 2015). Depois, no caso do Informe da 
Comissão de Verdade paraguaia, que dedica todo um capítulo sobre a repressão no país, cujo alvo eram as populações indígenas, argumentando a necessidade de justiça pelos genocídios (etnocídios) cometidos pelo governo stronista.

Apesar de abordarmos mais profundamente nos capítulos que se seguem, queremos apontar, nesta introdução, que o genocídio vem como forte argumento nas questões judiciais e de reconhecimento das vítimas na região. É o recurso que surge nas dinâmicas dos debates internacionais e que justifica pensar a repressão regional também nessas dinâmicas. Pois, se o desaparecimento sintetiza, em um primeiro momento, a representação da catástrofe e da fabricação de um "indivíduo civilizado" pela eliminação do outro regionalmente, para depois expandir-se ao nível mundial, o genocídio sintetiza a representação transnacional da dinâmica de extermínio de grupos sociais, em distintos contextos, a ser aplicada localmente.

Por fim, este trabalho está dividido em 5 capítulos, adequados tematicamente e que precisam ser lidos enquanto complementares, temporal e espacialmente. Avançaremos indo e vindo em busca de uma estratégia narrativa, que condiga com nossa proposta transnacional. Os capítulos apresentam divisões específicas para análises locais dos debates sobre territórios de memórias, mas procuram trazer essas experiências na conexão entre os modelos de memórias exemplares, as narrativas sobre violências transnacionais e os conceitos e práticas de desaparecimento forçado e genocídio.

No primeiro capítulo, intitulado "O peso dos mortos: memória, trauma e vida", colocamos a experiência platina dentro de uma discussão global. Ele procura introduzir esse momento da história dos direitos humanos e dos debates sobre justiça, em um nível internacional, no qual ingressam as experiências do Cone Sul latino-americano. Neste sentido, reflete sobre os exemplos que potencializam determinados argumentos sobre revisitar o passado no presente.

O segundo capítulo, "Justiça Transicional e Justiça Transnacional”, busca estabelecer as influências internacionais de um organismo oficial de direitos humanos, o Sistema Interamericano de Direitos Humanos (SIDH), nos processos de transição dos países estudados. Analisando casos específicos, verificaremos como estes organismos foram utilizados como meios de denúncias e pressões a fim de estabelecer um debate em torno das memórias sobre o passado.

No terceiro capítulo, "Palavras no vento da costa: Testemunhos e iniciativas para a verdade no Río de la Plata", desenvolvemos a importância desse espaço público nacional de reconhecimento das vítimas de violações cometidas pelo Estado, que não é apenas simbólico, por ser espaço de escuta desses traumas, sendo também espaço material de reparação, onde se 
cria documentação e se persegue uma verdade. Neste sentido, elaboramos as conformações, desenvolvimentos e consequências da Comisión Nacional sobre la Desaparición de Personas (CONADEP-Argentina), da Comisión para la Paz (COMPAZ-Uruguai), e da Comisión de Verdad y Justicia (CVJ-Paraguai), trazendo os aportes de memórias exemplares que esses debates fomentaram.

O quarto capítulo, "Narrativas e Territórios: as memórias para a educação em matéria de direitos humanos", destinamos às análises dos patrimônios sobre traumas, buscando a integração dos discursos pelos conceitos de desaparecimento e genocídio. E, desta forma, ele introduz o capítulo final, "Os caminhos aos territórios", que trata, então, das discussões especificas nas criações desses patrimônios. Busca, portanto, analisar as falas e argumentos que trazem essas experiências nacionais, regionais e internacionais, dentro do campo dos direitos humanos, e que fundamentaram a necessidade de transformação dos espaços (relacionados ou não com as violações regionais) em territórios de memória ou lugares de consciência.

Assim, este estudo apresenta uma perspectiva dos trabalhos das memórias de maneira integrada na região e estabelece um diálogo possível entre elas e os direitos humanos. Se, como afirmam Chauveau e Tétart (1999, p. 7-38), a história do passado recente é um impacto do último século, que desconstruiu pressupostos através da violência e de nossa constante demanda por direitos, este trabalho investe em um universo latino-americano de possibilidades, diante das violações aos direitos humanos atemporais. E, de outra forma, propõe também uma história que leve em conta o desenvolvimento das relações entre memórias e direitos humanos, indo do local ao global e do global ao local. Desta maneira, desenvolve uma história das memórias ao longo do Río de la Plata; rio que tem memória; rio que é memória. 


\title{
CAPÍTULO 1 \\ O PESO DOS MORTOS: MEMÓRIA, TRAUMA E VIDA
}

\begin{abstract}
Nada más cierto para nosotros que esa frase inolvidable: "el peso de las generaciones muertas oprime como a una pesadilla en el cerebro de los vivos". Porque son los muertos de nuestra propia generación quienes nos oprimen (...). ¿Qué hubiera sido de ellos - y de nosotros - si no los hubieron asesinados y estuvieron todavía vivos? ¿Qué hubiera sido del presente si tanto sacrificio, si tanta energía resistente, tanta risa, tanto fervor y tantas ganas, y hasta tanta belleza hubieran estado hoy vivas? ¿Sería igual el mundo? ¿Seriamos los mismos nosotros? Estamos inscriptos en una estrella siniestra cuyo efecto se prolonga en el presente para todos (ROZITCHNER apud FEIERSTEIN, 2014, p. 257).
\end{abstract}

As catástrofes marcam as substâncias material e espiritual de um povo. Retratando a guerra, uma das faces das catástrofes humanas, Walter Benjamin (2012) afirmou que ganhá-la ou perdê-la é algo que penetra profundamente na estrutura existencial dos homens. Enquanto o vencedor a conserva, incorporando-a ao seu patrimônio, através de imagens, monumentos, obras e etc., o vencido deixa de possuí-la e retorna ao mundo silenciado. Um silêncio que não só exprime a pobreza das experiências comunicáveis, como também, denota as forças destruidoras que fragilizaram o corpo humano - um corpo cansado.

O corpo que é o espaço concreto da tarefa revolucionária, pois nele, imprime-se o presente e o passado vividos, os verdadeiros dramas da existência do homem. Nele, estão as inscrições deixadas pelas paixões, vícios e conhecimentos. Uma sabedoria e experiência que merecem ser transmitidas para os demais seres humanos do coletivo.

$\mathrm{Na}$ teoria benjaminiana de transmissão de experiências, para haver sucesso entre o que se narra e o que se é percebido, o narrador e seu ouvinte precisam viver em uma comunidade de vida e de discursos comuns, lugares cujo desenvolvimento da técnica capitalista tende a destruir, distanciando os homens e as gerações. Segundo Benjamin (2012, p. 213-240), a matéria narrada e a atividade de narrar (o gesto e a palavra) precisam permear um fluxo comum, uma história continuada e aberta ao conjunto dos homens em um espaço e tempo.

O indivíduo isolado das tradições e memórias de seu coletivo não percebe essa utilidade da narrativa, que comunica uma história ampla ao ouvinte livre para interpretá-la. Assim, a imagem do passado, que é irrecuperável e ameaçada de desaparecimento em cada presente, através da narrativa, pode ser apropriada e despertada para trazer esperanças ao tempo de agora e ao futuro. 
Uma das formas de narrativas das memórias de coletivos humanos entre e intergerações é institucionalizá-las pelas marcas territoriais e simbólicas nas cidades. No mundo contemporâneo, essas marcas são muitas vezes relacionadas aos eventos considerados catastróficos para a humanidade - as guerras, os extermínios de populações, as práticas de atos desumanos e de violências contra grupos sociais. Contrariamente ao que somos acostumados a pensar, essas marcas não fazem parte de uma existência imediata após as catástrofes, contudo, são frutos de longas reflexões sobre os desastres e os valores a serem erigidos em favor de um futuro com respeito ao outro.

Sob expressões produzidas por sujeitos, movimentos sociais e políticas estatais, que respondem às demandas ou tomam iniciativas voluntárias, essas "marcas do horror" são justificadas pelo "dever de memória" e a construção de um futuro democrático (JELIN, 2013, p. 129-144). Mas, pensando em suas narrativas, o que significam as marcas do passado traumático no presente e como elas são capazes de fundamentar a democracia e a liberdade humana?

De acordo com Luciana Heymann (2007, p. 15-43), o uso das memórias no mundo contemporâneo está intimamente relacionado às lutas identitárias ${ }^{24}$, ao reconhecimento público de grupos considerados vítimas de processos históricos e à reparação em relação aos passados catastróficos. Ao recuperar o passado (pelo processo com critérios conscientes e inconscientes de seleção), uma orientação narrativa é construída como pano de fundo para trazer interrogações do presente sobre este passado - o que denominamos de usos da memória. Esse uso, um direito individual e coletivo, é responsável por nossas convicções e sentimentos sobre a memória narrada (TODOROV, 2013).

Quando os acontecimentos vividos são trágicos, no entanto, é costume associar os usos da memória ao pressuposto de "dever da memória": um dever de testemunhar e recordar as catástrofes vividas para chamar a atenção sobre os eventos e para que eles não se repitam. Este conceito, surgido na França da década de 1950, a partir das narrativas memoriais sobre o Holocausto, propõe uma memória focalizada nas perspectivas das vítimas e assume a postura de obtenção de justiça e reparação. Desta forma, processos fundamentados no dever da memória valorizam os testemunhos, o culto aos mortos, as homenagens, as lembranças e as políticas com efeitos pedagógicos no espaço público (HEYMANN, 2007, p. 15-43).

\footnotetext{
${ }^{24}$ As identidades são aqui pensadas como referências constitutivas de indivíduos ou grupos sociais, com sistemas de representações, reconhecimentos, práticas, tradições e hábitos, que aproximam ou dissociam as pessoas. Não são referências estáticas, no entanto, se transformam de acordo com o tempo e o espaço. E, desta forma, são fundamentadas nas memórias de um passado vivido individual ou coletivamente, nos conjuntos simbólicos do presente e nas projeções de um futuro almejado.

Cf. HOBSBAWM; RANGER, 2005; FERES JR., 2005; GATTI, 2011; e BOSI, 1994.
} 
Elizabeth Jelin (2002) propõe que os atos de memória com funções pedagógicas possuem geralmente dois momentos de construção. Um primeiro momento se refere aos sujeitos ativos, no cenário político, que lutam pela rememoração do passado. Nessa disputa, estes sujeitos pretendem obter o reconhecimento social e a legitimidade para sua memória narrativa. Em um segundo momento, se institui um projeto com a intenção educacional (relacionado geralmente aos direitos humanos), cuja finalidade é transmitir a experiência vivida àqueles que não a viveram ou àqueles que a experimentaram de maneira distinta.

A pedagogia e a educação aos direitos humanos são propostas discutidas desde a Carta das Nações Unidas (1945), que as estabelece enquanto práticas de ensino com o objetivo de situar o respeito pelos direitos humanos. A educação para os direitos humanos (Human Rights Education) é toda a aprendizagem que desenvolve o conhecimento, as capacidades e os valores dos direitos humanos, essenciais para a cidadania em uma sociedade democrática (ORGANIZAÇÃO DAS NAÇÕES UNIDAS, 1945).

Essa educação tem dois escopos essenciais. Aprender sobre os direitos humanos, que significa um processo cognitivo e que inclui a história dos direitos humanos, seus documentos e mecanismos de implementação. E aprender para os direitos humanos, que significa compreender os princípios da igualdade e dignidade humana com o compromisso de respeitar e proteger esses direitos.

Em 1993, durante a Conferência Mundial de Direitos Humanos, afirmou-se a responsabilidade dos Estados pela garantia de uma educação que se destinasse a reforçar o respeito aos direitos humanos e às liberdades fundamentais. Assim, se propôs a adoção de um programa de educação com a temática, visando a compreensão, a tolerância, a paz, as relações amistosas entre nações e a democracia.

A Conferência Mundial sobre Direitos Humanos considera que o ensino, a formação e a informação ao público em matéria de Direitos Humanos são essenciais para a promoção e a obtenção de relações estáveis e harmoniosas entre as comunidades, bem como para o favorecimento da compreensão mútua, da tolerância e da paz (ORGANIZAÇÃO DAS NAÇÕES UNIDAS, 1993, sem paginação).

Em muitos casos desses projetos educacionais, que abordam as memórias traumáticas de uma população no espaço público, a pretensão é fornecer informações para o desenvolvimento dos sujeitos e estabelecer uma reflexão crítica sobre o passado. Desta forma, o dever dessa memória no campo pedagógico está em ampliar a construção de memória narrativa (dentro ou fora das memórias oficiais, dependendo da política estatal sobre seu passado), que possibilite aprender para/sobre os direitos humanos. 
Analisando os casos desses tipos de memórias no Cone Sul americano, Elizabeth Jelin (2013) afirmou que as recentes incorporações na vida social do paradigma dos direitos humanos estão intimamente conectadas às violações das ditaduras militares. Mesmo que a noção de violações na região seja extremamente mais ampla do que as memórias abordadas em público, o processo educativo para os direitos humanos se iniciou com a valorização das memórias dessas vítimas ditatoriais.

De acordo com a autora, essa valorização da narrativa sobre as violações em ditaduras, na temporalidade curta e enquanto exemplo, contempla o dever da memória e a instância pedagógica das memórias traumáticas no espaço público (JELIN, 2013). Entretanto, na longa duração, essas perspectivas deveriam considerar estruturas sociais e econômicas, a universalidade de direitos civis e políticos, econômicos, sociais e culturais, individuais e coletivos, ingressando, assim, nas experiências ditatoriais como parte (mas não totalidade) da agenda dos direitos humanos. Ou seja, usar essas memórias de forma que se perceba seu dever de compartilhar experiências, historicizá-las, e tomá-las como obrigação moral, assegurando ao sujeito o espaço de apropriação, de direito à memória e de intervenção política sobre os marcos da memória coletiva ${ }^{25}$.

Nesse trabalho, as memórias das catástrofes e seus usos simbólicos não aparecerão apenas como documentos a serem analisados, no entanto, também como ferramentas teóricometodológicas, que circulam em espaços e tempos distintos, tornando-se exemplos ou memórias exemplares (TODOROV, 2013). Assim, elas serão percebidas como categorias sociais nas lutas pelos direitos humanos e nos processos de (re)construções em espaços públicos.

Sabemos que o passado, aquele que nos preenche cotidianamente, existe a partir da nossa consciência sobre os acontecimentos que experimentamos. O passado sentido é aquele recordado por nossa memória, que divide o ontem do hoje, e essas memórias, conscientes ou espontâneas, nos revelam rastros do mesmo passado, que vai se confirmando e continuando pelas lembranças dos outros (LOWENTHAL, 1998, p. 63-201).

Nessa dinâmica, as memórias ficam sujeitas aos atos de lembrar, esquecer, revisar, recuperar, transmitir, preservar e alterar. Michael Pollak (1989, p. 3-15) chama a atenção para

\footnotetext{
${ }^{25}$ Andreas Huyssen critica a ideia de memória coletiva, considerando-a memória oficial ou nacional e baseandose nas tendências globalizantes das memórias narrativas. Embora ainda perceba discursos de memórias fundamentados em soberanias nacionais, propõe que o conceito de memória coletiva está fundamentado na concepção antropológica da cultura como homogênea e ignora o fluxo migratório e heterogêneo das lembranças locais, regionais e globais. Aqui, entretanto, utilizamos "memória coletiva" em seu caráter de coletividade, em um determinado espaço e tempo, considerando as disputas e conexões com memórias nacionais, regionais e mundiais (HUYSSEN, 2014, p. 195-213).
} 
essas constantes disputas em torno das memórias e para as negociações delas nos espaços públicos, cujo objetivo de se conformar como projeto político faz com que algumas memórias se "encaixem melhor" no projeto nacional (ou regional e global) em detrimento de outras.

Um dos belíssimos exemplos dentro dos estudos dessas memórias "silenciadas" é o trabalho de Alessandro Portelli (1998, p. 103-130) sobre o massacre de Civitella Val di Chiana, durante a Segunda Guerra Mundial. Nessa recuperação das memórias divididas em torno do evento histórico deste massacre - memórias oficiais da resistência italiana ao fascismo e memórias das vítimas e seus familiares no povoado de Civitella - percebe-se o descompasso do que é lembrado daquilo que é esquecido no espaço público, que acaba por se transformar em ressentimentos e necessidades de criação de espaços próprios para confirmar narrativas na coletividade.

Desta forma, no espaço público, as memórias podem ser abordadas considerando dois objetivos distintos: 1) suprimir o presente, sacralizando as memórias e abordando-as linearmente; ou 2) generalizá-las na esfera pública, como princípios de ação. Estas últimas abordagens, como já apontamos em nossa introdução, são chamadas por Todorov (2013) de memórias exemplares - aquelas que reafirmam o sentido de justiça, através da "desindividualização" dos casos particulares nas narrativas das vítimas de violências. Afirmar a generalização, no entanto, não significa esquecer as diferenças locais e temporais dos eventos históricos, e sim, informar sobre outras catástrofes análogas.

Nosso estudo se debruça sobre essas memórias exemplares, relacionando os acontecimentos entre si, através das comparações e generalizações. Quem fala de generalizações fala em semelhanças e diferenças de experiências históricas, que por suas memórias narrativas, nos dão o alerta ou, como colocou Benjamin (2012, p. 141-171), "nos desperta para o futuro" sobre novas e velhas catástrofes.

No obstante, tenemos que conservar viva la memoria del pasado: no para pedir una reparación por el daño sufrido, sino para estar alerta frente a situaciones nuevas y sin embargo análogas. El racismo, la xenofobia, la exclusión que sufren los otros hoy día no son iguales que hacen cincuenta, cien o doscientos años; precisamente, en nombre de ese pasado no debemos actuar en menor medida sobre el presente. (...) Lejos de seguir siendo prisioneros del pasado, lo habremos puesto al servicio del presente, como la memoria - y el olvido - se han de poner al servicio de la justicia (TODOROV, 2013, p. 61-62).

Trabalhando com modelos exemplares das memórias traumáticas no espaço público, dois conceitos do campo político-jurídico são centrais para as discussões teóricas dos séculos XX e XXI: os crimes contra a humanidade e os genocídios. A figura do crime contra a 
humanidade (ou de lesa humanidade ${ }^{26}$ ) é formulada no Tribunal Militar de Nuremberg (1945) como ferramenta para os julgamentos dos criminosos nazistas, retomando uma expressão jurídica prévia, que implicava lesões sobre o conjunto da humanidade (FEIERSTEIN, 2015). Com a limitação legal para penalizar os crimes acontecidos como crimes de guerra $^{27}$ (a tipologia disponível na época), o tribunal oferece essa saída conceitual, aplicada aos assassinatos, extermínios, escravizações, deportações, perseguições políticas, religiosas ou raciais e outros atos cometidos contra a população, antes ou durante a Segunda Guerra Mundial.

Portanto, a definição de crimes contra a humanidade possui uma avaliação ético-moral por parte de quem julga os responsáveis por esses crimes e choca-se com diversos outros conceitos, como "Crimes de Massa", “Atrocidades" ou "Crimes de Estado". Apenas em 1998, depois de longas discussões em torno dos objetos que caracterizariam os Crimes contra a Humanidade, o Estatuto de Roma (Tribunal Penal Internacional) o define enquanto homicídio; extermínio; escravidão; deportação; prisão ou privação de liberdade física grave; tortura; agressão e escravidão sexual; prostituição forçada; violência sexual; perseguição de grupo ou coletividade por motivos políticos, raciais, nacionais, étnicos, culturais, religiosos ou de gênero; desaparecimento forçado de pessoas; crimes de Apartheid; ou outros atos desumanos, quando cometidos no quadro de ataque, generalizado ou sistemático, contra qualquer população civil (ORGANIZAÇÃO DAS NAÇÕES UNIDAS, 1998).

Contudo, quando se definiu crimes que seriam contra toda a humanidade, perdeu-se uma das grandes discussões sobre o termo, que era a de responsabilidade estatal por estes crimes. Segundo Feierstein (2015, p. 58-59),

Sin poder establecer límites claros a lo atroz o a lo inhumano (porque son calificaciones subjetivas), muchos de los delitos del código penal de cualquier Estado podrían ser catalogados como atroces o como vulnerantes del conjunto de la humanidad sin que por ello justifiquen el requisito de una jurisdiccionalidad internacional o la puesta en cuestión de garantías como la prescripción, la territorialidad o la amnistía. El único argumento genuino y coherente para legitimar tanto la jurisdicción como la transformación de las garantías ha sido el carácter estatal de los crímenes (...) fundamental en la comparación con cualquier otro delito.

\footnotetext{
${ }^{26} \mathrm{O}$ termo "lesa humanidade" se refere à figura jurídica de "lesa majestade", que denotava crimes políticos contra a autoridade soberana.

${ }^{27}$ Estabelecido a partir das Convenções de Genebra (1864, 1906, 1929 e 1949), este ramo do direito internacional regula a condução dos conflitos armados, buscando proteger pessoas que não participam ativamente deles - civis, profissionais de saúde, humanitários, soldados feridos, enfermos, náufragos e prisioneiros de guerra.
} 
Neste sentido, a decisão política de abolir o caráter estatal sobre os crimes contra a humanidade, o eleva à dimensão fundamental da pressão popular para implicar aos Estados suas responsabilidades diante do direito internacional. O mesmo não ocorre com a definição primordial do genocídio.

De acordo com a Convención para la prevención y la sanción del delito de genocidio (1948), o genocídio é um delito internacional, do qual o mundo civilizado pretende liberar-se, através da cooperação entre os Estados. Ele é definido como matança; lesão grave de integridade física ou mental; submissão intencional de um grupo e de suas condições de existência; medidas para impedir o nascimento destes grupos; e transporte pela força de sujeitos de um grupo a outro. Todos esses atos, perpetrados com a intenção de destruir (total ou parcialmente) um grupo nacional, étnico, racial ou religioso, devem ser punidos por uma corte competente do Estado, onde eles ocorreram, ou por uma corte penal internacional. Percebe-se, portanto, a responsabilidade estatal, nacional e global, no combate a este crime.

A definição jurídica, datada de finais dos anos 1940, garantiu a igualdade de lei para diversos grupos de vítimas. Todavia, ela desconsiderou alguns debates precedentes sobre a natureza do crime e o estabeleceu através de tipologias das vítimas, ao invés do tipo de ação cometida contra elas, que muitas vezes pode ser análoga ao homicídio. Rafael Lemki afirmava, em 1947, por exemplo, que o "genocidio es la negación del derecho a la existencia de grupos humanos, en el mismo sentido que homicidio es la negación a un individuo de su derecho a la existencia" (LEMKI apud FEIERSTEIN, 2014, p. 39).

Com a definição jurídica internacional, entretanto, o genocídio passou a ser um crime cometido contra quatro grupos específicos: étnico, nacional, religioso ou racial. Estabeleceu, pois, um direito diferenciado, classificado pelas vítimas, que desconsidera crimes de mesma prática e sistemática realizados contra outros sujeitos.

Logo, as memórias silenciadas de casos marginalizados perante esta Convenção passaram a cobrar a tipificação do genocídio para além da preocupação meramente teóricojurídica, introduzindo a definição de "feitos genocidas" ou "práticas genocidas". No ano de 1997, como visto em nossa introdução, quando variadas organizações de direitos humanos de Madrid apresentaram à Justiça espanhola a causa contra militares argentinos por delitos de terrorismo e genocídio, o juiz Baltazar Garzón qualificou o genocídio contra um grupo nacional diferente das vítimas propostas pela Convenção Internacional.

Daniel Feierstein (2014) propõe que o uso da noção de "prática social genocida" amplia o conceito jurídico, considerando esta prática como um processo realizado por seres humanos contra seres humanos, que requer treinamento, aperfeiçoamento, legitimação e 
consenso social para a construção ou desconstrução de valores, ações políticas e práticas de resistências e confrontações. Segundo Feierstein, a prática social genocida é a destruição das relações sociais de autonomia e cooperação e de identidade de uma sociedade, através do aniquilamento do outro e do uso do terror, em instâncias que também englobam as dimensões políticas e culturais.

Aplicar esse conceito não significaria dizer que os processos históricos das práticas sociais de genocídio sejam os mesmos - seus tempos, espaços e marcos ideológicos são distintos. Contudo, existe um fio condutor dessas práticas, que excede ao singular e se remete à tecnologia, ao poder e à negação do outro pelo extermínio. E essa generalização da experiência genocida constrói relações entre pessoas, entre corpos, entre processos históricos, entre confrontações e expropriações, e nos auxiliam a pensar as memórias dos traumas em uma visão transnacional.

Este conceito proposto relaciona-se, de certa forma, com aquele defendido por Hannah Arendt (1999), de "massacres administrativos". Criticando justamente parte da denominação jurídica do genocídio, que viria para introduzir uma legislação sobre um crime até então "desconhecido" pela humanidade, Arendt coloca sua inadequação de aplicabilidade, uma vez que massacres de povos inteiros já tiveram precedentes na história antes dos anos 1940. Neste sentido, a noção dos massacres administrativos, proposta pela autora, seria capaz de relacionar o extermínio com uma economia automatizada e imperialista, política, econômica e culturalmente.

A perspectiva do massacre, por sua vez, também é criticada por alguns estudiosos que a observam, em seu uso, enquanto fragmentária do uso de genocídio, tornando-o apenas aplicável aos casos de extermínio, e não considerando todas as práticas que correspondem aos processos históricos e sociais do genocídio (outras características da tentativa de eliminação de grupos humanos). O massacre seria utilizado como forma de amenizar práticas de violência, cujas consequências sociais e políticas permanecem nas populações em que são aplicadas, como o deslocamento de populações, a eliminação cultural, o aniquilamento político, entre outras (FEIERSTEIN, 2015).

Isto ocorreria também no uso de outros conceitos como politicídio, limpeza étnica ou Terrorismo de Estado. No último caso, bastante utilizado nos países aqui estudados, a definição é vista como uma característica do Estado de exceção, na qual este incorpora aos seus aparatos coercitivos a dupla função de legalidade e ilegalidade da repressão.

É base, por exemplo, da tese de Enrique Padrós (2005) sobre a construção histórica da ditadura de Segurança Nacional uruguaia, cujo fator repressivo radicalizado foi essencial para 
a imposição de um modelo econômico, pressionado pelo capital internacional e pelas elites nacionais. A necessidade de despolitização, disciplinarização e desmobilização social, para inibir as contradições dentro da "unidade nacional", movimentou um sistema de terror praticado pelo governo com o respaldo de setores dominantes da sociedade.

De acordo com Padrós (2005), se cabe ao Estado a responsabilidade pelo monopólio da violência, também cabe a ele reconhecer os direitos das dinâmicas sociais. Uma vez que se pratica uma intervenção direcionada contra setores que questionam a ordem social, através de medidas legalizadas - como o Estado de Sítio, por exemplo - e métodos clandestinos - dos quais o cidadão está impossibilitado de apelar judicialmente pelas agressões aos seus direitos, liberdades e propriedades -, cria-se um Terrorismo Estatal. Esse terrorismo é mantido com uma "pedagogia do medo" ou uma "cultura do medo", que convencem, pelo discurso oficial, sobre a necessidade dessas violações, ou que reprimem pelas constante ameaça de transformar qualquer pessoa em vítima do sistema.

Esta perspectiva, apesar de abordar particularidades do Estado na prática da violência, possui uma precedência de uso no Cone Sul, que necessita ser esclarecida. Segundo Hugo Vezzeti (2009), o Terrorismo de Estado, inicialmente definido por seus atos de violência (sequestros, torturas, crimes, bombardeios e etc.) praticados desde o Estado, fora utilizado com a finalidade de igualar as violências praticadas por distintas organizações e instituições, fundamentando a Teoria dos Dois Demônios ${ }^{28}$, nas análises do período pós-ditatorial latinoamericano.

Portanto, ao usar essa perspectiva do Terrorismo de Estado, temos em conta uma interpretação crítica do conceito, na qual permanecem as práticas dessa violência pelo Estado com vontade política de destruir identidades e grupos sociais. Por isso, ele é válido para caracterizar as práticas da repressão, mas não substitui a ideia de práticas sociais genocidas (FEIERSTEIN, 2015).

O mesmo ocorre com a ideia, colocada em nossa introdução, de Poder Desaparecedor, proposta por Pilar Calveiro (2013). Modalidade repressiva de poder, típica das ditaduras no Cone Sul americana, ela determina as práticas de violência, com objetivos de extermínio de pessoas e suas representações, através de um processo de burocratização da violência, legal e clandestina, que institucionalizou o terror.

Entre as conceituações desses modelos de crimes contra populações, a prática social genocida ganha espaço na relação entre ciências humanas e técnicas jurídicas e amplia seus

\footnotetext{
${ }^{28}$ História da Teoria dos Dois Demônios, Cf. FRANCO, 2014.
} 
usos para outros tempos históricos como modelos. De acordo com Barbara Harff (2000, p. 4159), com a essência das práticas para a eliminação do outro (física ou simbólica), esse conceito pode ser utilizado em diversos tempos e com distintas finalidades - genocídios pósguerras ou pós-imperialismos; genocídios pós-coloniais; genocídios pós-golpes e pósrevolucionários; ou genocídios com intenções de conquistas. Ao generalizarmos a prática social de genocídio, podemos conceber o risco recorrente deste crime e sua capacidade de fazer um número incalculável de vítimas no território mundial.

Neste sentido, atualmente existem três tipos de usos da Convenção sobre o Genocídio (1948). Uma interpretação normativa dela, que se remete à prática do genocídio, incluindo ou excluindo seus tipos em favor dos princípios universais de igualdade e valor da vida humana - interpretações que estendem os crimes para vítimas aparte das colocadas na Convenção. Uma interpretação restritiva na prática jurídica, que sustenta a literalidade da redação, não excedendo a liberdade de interpretação como ferramenta característica da legalidade. E, por fim, essa interpretação histórico-sociológica do conceito da Convenção, que aponta para a compreensão dos genocídios como estratégias de poder (FEIERSTEIN, 2015).

A partir dessas interpretações do campo científico e da prática jurídica, tenta-se compreender globalmente o significado ético-político do genocídio. E, com essa meta, os movimentos pelos direitos humanos orientam-se na criação do regime internacional de direitos e relacionam-se com a memória narrativa das violações para alcançar finalidades educativas e exemplares.

Como já apontado, Andreas Huyssen (2014, p. 195-213) propõe que o futuro dos direitos humanos depende de sua relação com a memória das violações, afinal somente esta memória é capaz de fornecer os elos entre o passado vivido, que não se deseja repetir, e o presente. Esta relação é constituída a partir do interesse de ambos os movimentos (direitos humanos e memórias) pelas violações e proteções aos direitos básicos do homem, pela história das catástrofes humanas, e pelo reconhecimento (e, em certa medida, a correção) dos erros e injustiças do passado, imaginando um futuro melhor.

Na conexão entre memórias e (in)justiças, Huyssen (2014) aponta o papel da memória como impulsionadora, na esfera pública (no jornalismo, em filmes, nos meios de comunicação, na literatura, nas artes, na educação, nas intervenções urbanas e etc.), de processos contra violações. Considerando que os discursos contemporâneos da memória são construções complexas, geradas por situações políticas específicas do final do século XX fim das ditaduras na América Latina, a queda do muro de Berlim, o colapso da União Soviética, fim do Apartheid na África do Sul e os genocídios em Ruanda e na Bósnia -, os 
sistemas internacionais e legislações vêm se transformando em concepções mais políticas do que jurídicas a favor dos direitos humanos. E, neste sentido, as reinterpretações do conceito jurídico de genocídio vão sendo aplicadas nas políticas favoráveis aos direitos humanos.

O autor afirma que, apesar do conflito entre transnacionalidade dos direitos humanos versus soberania nacional (algo que será abordado adiante), os discursos e práticas da militância pelos direitos humanos apoiam-se em exemplos concretos de violações, que nos treinam a imaginá-las e reconhecê-las nos diversos tempos. Neste sentido, defende que os direitos humanos devem ser vistos como direitos coletivos, que protegem o conjunto da humanidade, ao invés de considerados como direitos individuais (HUYSSEN, 2014).

Ao propor uma história dos direitos humanos e de sua imaginação ${ }^{29}$ enquanto verdade universal, Lynn Hunt (2009) os analisa como frutos da empatia pelo corpo do outro “direitos para o semelhante" - cujo embrião está no século XVIII, com o texto da independência estadunidense ("todos os homens são criados iguais, com direitos inalienáveis à vida, liberdade e felicidade") e dos Direitos do Homem e do Cidadão na Revolução Francesa ("os homens nascem e permanecem livres e iguais em direitos"). No entanto, esses homens semelhantes do início dos direitos humanos, merecedores desses direitos, eram aqueles caracterizados pela organização da vida social e política da época - homens, brancos, livres.

Desta forma, Hunt (2009) afirma que os direitos humanos, por um lado, fracassam pelas permanências de práticas de agressões imperialistas, proteções nacionais, xenofobias, racismos e etc., que se perpetuam mesmo após as suas declarações. Todavia, por outro lado, obtêm sucesso justamente na luta política da coletividade, ganhando terreno nas conquistas pelos direitos políticos, direitos trabalhistas, das mulheres, das minorias, entre outros.

Depois das guerras mundiais, a Declaração Universal expressa esse conjunto de aspirações morais para a comunidade mundial e cristaliza os anos de luta com um processo circular de conhecimento das violações e os sentimentos provocados por elas. "A história dos direitos humanos mostra que os direitos são afinal mais bem definidos pelos sentimentos, convicções e ações de multidões e indivíduos, que exigem respostas correspondentes ao senso íntimo que enfrentam" (HUNT, 2009, p. 215-216).

Percebemos, assim, que os mortos pelas catástrofes humanas têm direito sobre nós a partir do ponto de vista de que somos responsáveis por elaborar as memórias, consciências e sentimentos na luta pelos direitos humanos para a coletividade (HUYSSEN, 2014, p. 195-

\footnotetext{
${ }^{29}$ Imaginação proposta no mesmo sentido que Benedict Anderson (1993) trabalha com a definição do nacionalismo, portanto, como uma comunidade política imaginada.
} 
213). A dignidade das vítimas e seus destinos precisam ser preservados na memória exemplar. Primeiro, porque é objetivo dos responsáveis pelas práticas sociais de genocídio eliminar não apenas os grupos sociais, como também, as recordações de suas existências. Depois, porque a memória das vítimas fundamenta-se no reconhecimento das situações análogas/memórias exemplares, que nos leva a uma educação em matéria de direitos humanos.

\section{1 - O espelho: Holocausto e Pós-Holocausto}

Não há espelho, mas a nossa imagem está aí na nossa frente, refletida em cem rostos pálidos, em cem bonecos sórdidos e miseráveis. Estamos transformados em fantasmas como os que vimos ontem à noite (LEVI, 1988, p. 32).

O Holocausto, enquanto evento histórico, e suas narrativas ampliaram as possibilidades de análises sobre memórias de traumas no século XX. O denominado PósHolocausto, trabalhos de memória que recuperam o evento, apresentando-lhe representações no presente, definiu uma série de atividades no campo das ações políticas, das intervenções urbanas, das transformações linguísticas, dos testemunhos e dos instrumentos judiciais (estes últimos vistos acima).

Nos anos 1980, o Terceiro Reich, o Holocausto e a história da Segunda Guerra Mundial tornaram-se os principais objetos de estudos na Europa e nos Estados Unidos, quando os testemunhos de sobreviventes despontaram como interesses centrais e trouxeram preocupações sobre as teorias, metodologias e seus respectivos limites em relação aos eventos traumáticos (HUYSSEN, 2014, p. 11-17). Uma das grandes questões apontadas, nesses anos, foi a das relações entre narrativas das memórias e as testemunhas que ganharam espaço público para relatar suas experiências.

De acordo com variados testemunhos, as experiências catastróficas não eram experiências com fácil relato ou de simples assimilação dos ouvintes, uma vez que as palavras existentes em nosso vocabulário cotidiano não conseguiriam representar essas experiências tais como foram vividas nos corpos das vítimas.

Assim como nossa fome não é apenas a sensação de quem deixou de almoçar, nossa maneira de termos frio merecia uma denominação específica. Dizemos 'fome', dizemos 'cansaço', 'medo' e 'dor', dizemos 'inverno', mas trata-se de outras coisas. Aquelas são palavras, criadas, usadas por homens livres que viviam, entre alegrias e tristezas, em suas casas. Se os Campos de Extermínio tivessem durado mais tempo, teria nascido uma nova, áspera linguagem, e ela nos faz falta agora para explicar o que significa labutar o dia inteiro no vento, abaixo de zero, vestindo apenas camisa, cuecas, casaco 
e calças de brim e tendo dentro de si fraqueza, fome e a consciência da morte que chega (LEVI, 1988, p. 182).

As ideias de espaço compartilhado e de fluxo comum entre narrador e ouvinte nos possibilitam perceber as dificuldades que existem para aproximar a vítima e seus relatos dos grupos sociais ouvintes, que não sofreram violações ou que, muitas vezes, as legitimaram. A dificuldade de se falar sobre o trauma do Holocausto, por exemplo, aparece nessas vozes de vítimas, que são vítimas porque foram frutos de crimes coletivos - justificados pela necessidade de eliminar seres "irreconciliáveis" com a "civilização pretendida" - e, ao mesmo tempo, porque sofreram a dor da barbárie. Vítimas que possuem a dupla identidade dentro de si: a do mal imposta no passado, que deveria ser eliminado pelo universo concentracionário; e a de vítima do sistema, imposta posteriormente pela sociedade.

Primo Levi (1988) chega a considerar esta identidade imposta como uma "condição espiritual de vítima". Um desequilíbrio que é existencial e que reflete na perda de confiança no mundo. Em seus relatos, ele afirmava:

Ser judeu significa não só trazer consigo uma catástrofe ocorrida no passado e cuja repetição no futuro não pode ser inteiramente excluída, algo a que estou obrigado. Além disso, há o medo. Todas as manhãs, ao me levantar, posso ler a tatuagem de Auschwitz no meu antebraço. Ela penetra nas entranhas mais profundas da minha existência. Chego a ter dúvidas sobre se ela constitui toda a minha existência. Todos os dias, sinto-me como naquele dia em que levei a primeira bofetada do policial. Todos os dias, perco novamente a confiança no mundo (LEVI, 1988, p. 148-149).

Esta condição espiritual de vítima é algo impossível de ser representada sem que haja uma continuidade entre o narrador e o ouvinte. Ser "incomunicável”, entretanto, não significa que não se possa entender os eventos históricos e as consequências sociais deste passado. Muito menos que não se possa ouvir, concedendo espaço legítimo para os testemunhos cumprirem seu dever de memória em comunicar o trauma e possibilitando o retorno dessas vítimas à coletividade da qual foram excluídas (LANG, 2005).

I only know that without this testimony, my life as a writer - or my life, period would not have become what it is: that of a witness who believes he has a moral obligation to try to prevent the enemy from enjoying one last victory by allowing his crime to be erased from human memory (WIESEL, 2006, p.8). ${ }^{30}$

\footnotetext{
${ }^{30}$ Só sei que sem este testemunho, a minha vida como um escritor - ou a minha vida, ponto final - não teria se tornado o que é: o de uma testemunha que acredita que tem a obrigação moral em tentar impedir o inimigo de desfrutar uma última vitória ao permitir que seu crime seja apagado da memória humana (WIESEL, 2006, p. 8, tradução nossa).
} 
Portanto, os testemunhos das vítimas do regime nazista passaram a carregar esse dever da memória de se opor à tentativa (frustrada) de eliminação das pessoas e das provas sobre a existência das práticas sociais de genocídio, principalmente daquelas que determinavam a experiência dos Campos de Concentração (os Lagers). Como a maior parte dessas testemunhas desapareceu fisicamente e muitos dos fatos narrados tiveram suas provas materiais destruídas, a narrativa da experiência dos sobreviventes tornou-se a aversão à "desmemória" - elas foram as memórias resistentes à prática social genocida.

No entanto, nem sempre elas tiveram espaço de legitimidade. Algumas das ações relatadas eram tão cruéis de se ouvir no pós-guerra, que se tornou difícil sua credibilidade social. E, seguindo a máxima de Paul Celan (apud LANG, 2005, p. 79), na qual "There is no witness for the witness" "31, apenas com um espaço legítimo para as narrativas das vítimas, se conseguiu quebrar as "mentiras ou verdades por conveniência", tal como coloca Levi (1988), que foram tornando-se narrativas oficias naqueles anos subsequentes à guerra.

O caso da publicação do livro de memórias de Primo Levi É isto um homem?, em 1947, na Itália, por exemplo, traz essa recepção social das narrativas das vítimas logo após o final da Segunda Guerra Mundial. Com modesta repercussão em suas vendas, apesar das críticas acolhedoras que recebera, Levi considerava a modificação da trajetória do livro, a partir de 1959, quando teve sua primeira edição alemã publicada. Para ele, aquele livro escrito aos descendentes dos judeus italianos mortos nos Campos de Extermínio, naquele momento iria dialogar, enfim, com os opressores e expectadores do nazismo. Havia chegado o momento de obter suas respostas para compreender os alemães.

As cartas enviadas por esses novos leitores do livro, cerca de 40 cartas entre os anos 1961 e 1964, demonstraram, contudo, uma crença de que "quase todos, mas não todos tinham sido surdos, cegos e mudos: uma massa de 'inválidos' em torno de um núcleo de perversos. Quase todos, mas não todos tinham sido covardes" (LEVI, 2016, p. 138). Levi aponta que algumas dessas cartas - uma amostragem não representativa, já que quem comprou o livro sabia do que se tratava - foram respondidas por ele, travando o diálogo desejado, ora ressentido $^{32}$, ora movido pela compreensão, sobre os argumentos de "engano" em relação ao regime nazista e sobre o comprometimento da sociedade alemã para a construção de um futuro melhor.

Suas cartas-respostas colocaram o questionamento sobre o sujeito nazista não fanático, mas oportunista, que deveria responder por uma culpa social (e não individual, espiritual ou

\footnotetext{
${ }^{31}$ Não há nenhuma testemunha para a testemunha (CELAN apud LANG, 2005, p. 79, tradução nossa).

${ }^{32}$ Análises sobre ressentimento, Cf. FERRO, 2007; e BRESCIANI; NAXARA, 2009.
} 
punitiva) pela legitimidade dada ao poder político Nacional Socialista. Perguntou aos seus interlocutores sobre os processos de "desnazificação" que a Alemanha estava se comprometendo a fazer e entendeu o fato de que as novas gerações criassem um mito horrorizado em relação à figura de Hitler, apesar de não compreender uma geração mais velha comprometida com a "falta de culpa" pelo ocorrido.

Descreve, por exemplo, a ampla correspondência que teve com uma de suas leitoras alemãs sobre a educação na Alemanha para a "não repetição", na qual ela defendia um interesse pela história do país, mas, ao mesmo tempo, a posição apolítica do país diante dos fatos e da culpa coletiva. Levi relata o encontro que a mesma leitora teve com Albert Speer ${ }^{33}$ para uma entrevista e a sua surpreendente decepção ao encontrar um homem arrogante diante de sua culpa individual.

Levi, portanto, conclui que a culpa social precisava ser trabalhada para que as vítimas ganhassem voz dentro da sociedade alemã e para que suas histórias fossem finalmente contadas. Não significava, segundo ele, que todos os alemães precisavam ser responsabilizados penalmente, todavia que eles deveriam perceber suas responsabilidades e dar credibilidade às vozes silenciadas.

Quase todos os sobreviventes, oralmente ou em suas memórias escritas, recordam um sonho muitas vezes recorrente nas noites de confinamento, variado nos particulares, mas único na substância: o de terem voltado para casa e contado com paixão e alívio seus sofrimentos passados, dirigindo-se a uma pessoa querida, e de não terem crédito ou mesmo nem serem escutados (LEVI, 2016, p. 7-8).

Como vimos, a prática social genocida pretende exterminar não apenas o homem em seu sentido físico, mas também, exterminar os seus símbolos, a sua cultura, os seus rastros de existência. Desta forma, o sistema não conseguiu se completar. Mesmo destruindo arquivos, colocando abaixo edifícios, câmaras de gás e crematórios e apontando para uma "solução final", o universo concentracionário constituído pelo regime nazista foi um universo aberto socialmente, do qual deixou seus indícios e testemunhas.

\footnotetext{
${ }^{33}$ Albert Speer (1905-1981), o "arquiteto do nazismo", foi o arquiteto oficial do regime, responsável pelas políticas de "reassentamento" dos judeus, além de roubos e vendas de obras de arte, e foi Ministro de Armamento do Terceiro Reich. Ele também auxiliou na consolidação do sistema de trabalho escravo nos Campos de Concentração para aumentar a produção bélica durante a guerra. No julgamento de Nuremberg, foi o único dos julgados que se considerou culpado e foi condenado a 20 anos de prisão. Depois de cumprir sua pena, publicou diversas obras, entre elas Por dentro do Terceito Reich (1970), Spandau: O diário secreto (1976) e Infiltration: How Heinrich Himmler schemed to build an SS industrial empire (1981). Neste sentido, ganhou visibilidade pública pela postura do "bom nazista arrependido", mas carregando a (auto)denominação de ator passivo diante do sistema de terror.
} 
Por um lado, a indústria da morte, conformada por produtores e empresários industriais, que se aproveitaram das condições e necessidades dos Lagers para obter lucro, conectou a vida cotidiana concentracionária à vida cotidiana fora dos Campos de Concentração. Este envolvimento das economias internas e externas ao Campo ampliou as responsabilidades por sua existência e as testemunhas sobre os seus funcionamentos.

Por outro lado, os escombros dessa destruição também falaram sobre o que existiu. As ruínas (materiais que denotam a presença a partir da ausência ${ }^{34}$ ) passaram a conceber um passado que poderia ser imaginado. Produtos dessa modernidade, que pretendeu o esquecimento de determinadas memórias, as ruínas, contraditoriamente, tornam um passado autêntico justamente porque têm escombros, comprovando que esse passado existiu.

No documentário Noite e Neblina (1955), por exemplo, fica evidente a conexão entre as ruínas dos Campos de Concentração e Extermínio nazistas e suas capacidades de comunicar uma memória do passado experimentado, cuja tentativa de apagamento fracassara. Em cenas de "aberturas dos portões das máquinas de extermínio", onde se narram a vida cotidiana e as violências dos Campos, percebe-se que as ruínas são instrumentos interrogativos sobre o passado no presente.

O último minuto do documentário de Alain Resnais traz essas imagens das áreas então ocupadas pelos Campos, em um movimento da câmera de aproximação e distanciamento, cuja voz do narrador nos instiga a pensar na paisagem como despertadora/impulsionadora da memória crítica sobre o passado. E o texto, escrito pelo poeta Jean Cayrol (1911-2005), comenta que

Nove milhões de mortos assombram essa paisagem.

Quem de nós vigia, nesse estranho observatório, para avisar da vinda de novos carrascos?

Será que eles são diferentes de nós?

Em alguma parte, entre nós há kapos com sorte, chefes ressurgidos, informantes, há os que não acreditavam, ou só de vez em quando.

E há nós, que olhamos estas ruínas como se o velho monstro estivesse morto. Sob elas que retomamos a esperança diante da imagem que se afasta. Como se sarássemos da peste concentralizadora. Nós que fingimos que isso pertenceu a um tempo e a um país. E que não olhamos em volta de nós. $\mathrm{E}$ que não ouvimos o grito que não cala (NOITE E NEBLINA, 1955, 32').

É a paisagem arruinada, abandonada e ruidosa. Através dela, o narrador questiona sobre a natureza dos homens responsáveis pela catástrofe específica, sobre a especificidade da catástrofe observada e sobre a observação dessa catástrofe como não específica.

\footnotetext{
${ }^{34}$ Cf. LE GOFF, 1990.
} 
Em um terceiro movimento desse rompimento com o universo concentracionário, temse o sujeito determinante que é o sobrevivente. A existência dos sobreviventes desfez definitivamente com a pretensão do sistema de eliminar esse grupo social, principalmente, ao conseguirem narrar suas experiências. Mesmo que o momento da libertação tenha sido um contexto trágico de destruição e sofrimento, as narrativas dos sobreviventes possibilitaram transmitir a memória do genocídio como exemplar.

Primo Levi aponta constantemente, em seus escritos, a consciência do sofrimento humano, sentido no corpo das vítimas e dos outros homens "perdedores", como o elemento possível para conectar suas narrativas aos ouvintes. Contudo, ele vai além e considera que a configuração mundial, com seus problemas urgentes (desemprego, fome, guerras, exaustão de recursos naturais e etc.), necessita dessas narrativas para percebermos nossas eternas possibilidades em retornar àquele passado, por convivermos com as mesmas violências úteis e inúteis no mundo contemporâneo ${ }^{35}$ (LEVI, 2016).

Portanto, essas marcas de violências movidas pela intolerância, pela vontade de poder, por razões econômicas ou fanatismos religiosos e políticos devem ser percebidas, no espectro das memórias das vítimas de práticas sociais genocidas, enquanto exemplos. E, assim, aceitar a responsabilidade que nós temos no presente de perceber situações análogas às práticas genocidas e multiplicar os espaços de fluxos entre narradores e ouvintes.

Dominick LaCapra (2009) chama a atenção para a importância desse espaço social de escuta, não apenas para a sociedade, que elabora a memória coletiva, contudo também para a vítima que ganha parte na negociação entre suas experiências e aquilo que se pode ouvir socialmente. Testemunhar, segundo LaCapra, na dimensão individual, é elaborar com o coletivo um trauma pessoal para desfazer-se da compulsão à repetição e estabelecer a distância para recomeçar a vida, reintegrando-se socialmente.

Muitas das vítimas sobreviventes, logo após a guerra, sem esse espaço social, passaram a encontrar uma forma de comunicar ao coletivo ("surdo, cego e mudo"), através da escrita. O poeta romeno Paul Celan, por exemplo, que publicou ao longo de sua vida mais de oitocentos poemas, encontrou nesta narrativa a maneira de elaborar seus sofrimentos e culpas por haver sobrevivido ao que quase toda sua família não conseguiu sobreviver.

\footnotetext{
${ }^{35}$ A “violência útil” é caracterizada por Levi (2016) como aquela que serve para o funcionamento econômico e para o objetivo de subjugar uma população. A "violência inútil” é aquela que não tem serventia, que é aplicada por emoções e hierarquias de poder.

No regime nazista, a violência inútil era aquela que se aplicava à população subjugada, quando a fazia ficar desnuda, passar fome, cansaço, frio, quando a humilhava cotidianamente com regras, pelas marcas impressas em seus corpos, na realização de experiências cientificas ou quando utilizava seus cadáveres carbonizados para aterrar trechos e fertilizar a terra. Ou seja, não bastava exterminá-la, desejava-se aplicar emocionalmente a hierarquia de poder com uma violência que era inútil ao sistema de extermínio.
} 
Celan, que já havia saído de Paris fugindo da guerra, em Czernowitz (Ucrânia) escapa novamente, quando Hitler rompe o pacto de não agressão com a União Soviética e invade o território, saqueando-o e executando quase toda população. Nas deportações dos judeus, Celan consegue esconder-se na antiga fábrica de detergentes e cosméticos da cidade, mas tem seus pais levados à Mijailovka (Rússia) - campo que abrigava trabalhadores na construção de uma estrada, onde o pai morre debilitado pela fome e pelo frio e a mãe, baleada em 1942 . Com o fim da guerra, ele descobre que um de seus tios que ficara em Paris, havia sido enviado a Auschwitz e assassinado. Em 1970, Celan terminou com sua vida, atirando-se no Rio Sena, desde a ponte Mirabeau, a mesma na qual já havia dedicado um poema dos anos 1960, cuja a epígrafe dizia “todos os poetas são judeus".

As temáticas dos sentimentos causados pela morte e pelos sofrimentos fazem parte de seus poemas, desde a década de 1950. No interior do livro Amapola e memória (1952), elas são a consistência de seus poemas e, no mais conhecido - Fuga da morte -, Celan escreve

Negra leche del alba la bebemos de tarde
la bebemos al mediodía de mañana la bebemos de noche
bebemos y bebemos
cavamos una fosa en los aires no se yace allí estrecho
Vive un hombre en la casa que juega con las serpientes que escribe
que escribe al oscurecer a Alemania tu pelo de oro Margarete
lo escribe y sale de la casa y brillan las estrellas silba a sus mastines
silba a sus judíos hace cavar una fosa en la tierra
nos ordena tocad a danzar (CELAN, 1999, p. 63).

Outro grande livro, que aparece nos anos 1950, é Noite, escrito por Elie Wiesel (19282016), sobrevivente dos Campos de Concentração de Auschwitz e Buchenwald, ganhador do Nobel da Paz (1986) e idealizador do Museu do Holocausto, em Washington. O escritor romeno escreveu diversos livros de ficção e não-ficção, que trabalham com as experiências vividas por ele nos Lagers.

\section{Em Noite, Wiesel descreve}

Never shall I forget that night, the first night in camp that turned my life into one long night seven times sealed.

Never shall I forget that smoke.

Never shall I forget the small faces of the children whose bodies I saw transformed into smoke under the silent sky.

Never shall I forget those flames that consumed my faith forever.

Never shall I forget the nocturnal silence that deprived me for all eternity of the desire to live.

Never shall I forget those moments that murdered my God and my soul and turned my dreams to ashes.

Never shall I forget those things, even were I condemned to live as long as God Himself. 
Never (WIESEL, 2006, p. 34). ${ }^{36}$

Portanto, tornar-se um testemunho, para muitas vítimas, foi dar sentido à própria sobrevivência. Afinal, muitas delas foram questionadas e colocadas em lacunas de "vítimas incompletas" por sobreviverem ao que muitos não conseguiram sobreviver.

E por três décadas durou o silenciamento social diante dessas falas que vão encontrando pequenos espaços em publicações sobre suas experiências. O cenário se modifica a partir dos anos 1980, na Europa e nos Estados Unidos, devido à ampliação do debate sobre o Holocausto, iniciado com as discussões sobre uma série de TV (Holocausto, 1979) e com os movimentos em torno das comemorações do quadragésimo e quinquagésimo aniversário do final da Segunda Guerra Mundial. Importante lembrar que, em meados daquela década, a mudança no contexto mundial impulsiona as discussões sobre os direitos humanos, no auge do desmoronamento da União Soviética, dos términos dos regimes ditatoriais latinoamericanos, dos genocídios em Bósnia e Ruanda e da guerra do Kosovo.

Em 1985, na União das Repúblicas Socialistas Soviética (URSS), com a ascensão reformista de Mikhail Gorbachev, a solução governamental para a estagnação econômica do território foram as campanhas da perestroika e glasnost, que ganham imensa legitimidade no ocidente pela proposta de reestruturação econômica e política. Fundamentada na liberdade de informação, na introdução do Estado constitucional e democrático e nas legalizações de pequenas empresas privadas em detrimento da concentração das empresas estatais, a política de liberação e descentralização do mercado foi acompanhada por uma separação entre Estado e Partido, o que afetou a unidade da União Soviética e ocasionou uma "corrida pela autoproteção e autossuficiência" das comunidades e territórios que faziam parte dela (HOBSBAWM, 1995). Desta forma, entre os anos 1989 e 1990, o poder comunista abdicou ou deixou de existir na Polônia, Tchecoslováquia, Hungria, Romênia, Bulgária e República Democrática Alemã. Esse processo de "desmoronamento" (com grande difusão simbólica da

\footnotetext{
${ }^{36}$ Nunca me esquecerei daquela noite, a primeira noite no Campo, que fez minha vida uma noite longa e sete vezes aferrolhada. Nunca me esquecerei daquela fumaça.

Nunca me esquecerei dos rostos das crianças cujos corpos eu vi se transformarem em fumaça sob um céu mudo. Nunca me esquecerei daquelas chamas que consumiram minha fé para sempre.

Nunca me esquecerei daquele silêncio noturno que me privou por toda eternidade do desejo de viver.

Nunca me esquecerei daqueles momentos que assassinaram meu Deus, minha alma e meus sonhos, que se tornaram desertos.

Nunca me esquecerei daquilo, mesmo que eu seja condenado a viver tanto tempo quanto o próprio Deus.

Nunca (WIESEL, 2006, p. 34, tradução nossa).
} 
queda do muro de Berlim ${ }^{37}$ ) foi alvo de enorme repercussão em propaganda no mundo ocidental, principalmente no que tangia aos desrespeitos aos direitos humanos.

No caso iugoslavo, de finais dos anos 1980, especificamente, cuja coesão se encontrava na administração centralizada no Partido Comunista, sob a ditadura de Joseph Baz Tito, seu colapso econômico e desigualdades regionais irromperam nas rivalidades étnicas da Federação de Repúblicas Socialistas, composta por Eslovênia, Croácia, Bósnia-Herzegovina, Sérvia, Montenegro e Macedônia. Com o apoio de parte da Liga Comunista, que desejava as reformas e aberturas dos mercados, a Comunidade Econômica Europeia (CEE), principalmente a Alemanha, projeta-se na capitalização desse Leste Europeu, incentivando discursos nacionalistas e de independências e iniciando a ocupação de mercados nos marcos da globalização (PADRÓS, 1999).

A luta entre um governo central unido, baixo hegemonia Sérvia, com a figura fundamental de Slobodan Milosevic, e os movimentos independentes se intensificou, primeiramente, na Eslovênia, Croácia e Macedônia, implodindo em um genocídio étnico, que se estendeu à Bósnia, que resultou em mais de trinta mil mortos. A falta de interesse mundial na dimensão econômica da Bósnia fez com que este conflito durasse três anos e que Sarajevo se tornasse sinônimo de tragédia humana nos anos 1990.

E os conflitos no Leste Europeu adentraram estes anos, enquanto negociava-se a entrada da Polônia, Hungria e República Tcheca na CEE e na Organização do Tratado do Atlântico Norte (OTAN), em troca de que os mesmos fechassem suas fronteiras para as rotas de tráficos de drogas e pessoas na região. Neste sentido, houve um crescimento da corrupção nas fronteiras, o surgimento de exércitos e a fragilização de territórios "desinteressantes" economicamente para a Comunidade Europeia.

Apenas em 1998, as denúncias públicas de genocídios no território de Kosovo ganham espaço midiático internacional, enquanto as ações do Exército de Libertação (ELK) aumentavam e a OTAN intervinha, com um acordo desigual, sem negociação com a Iugoslávia, no qual teria permissão para realizar investigações, vistorias, regulamentações, não pagar impostos ou taxas, realizando suas operações e trazendo a aplicação da guerra de "soma zero". No caso Europeu, o interesse dessa intervenção armada era evitar a "exportação" do caos político, a emigração e o narcotráfico da região, enquanto os Estados Unidos justificavam a existência de uma organização (a OTAN) criada para o contexto da Guerra Fria, mas que, todavia, intervinha nas relações mundiais.

\footnotetext{
${ }^{37}$ Para imagens do muro desde seu período de construção até a queda do mesmo, ver o documentário: THE BERLIM WALL. Edição: Wieland Giebel. Produção: Berlin Story. Berlim: 2013.
} 
No território africano, o início dos anos 1990 também foi marcado pelas discussões sobre os interesses por detrás dos genocídios. Em abril de 1994, o avião do presidente de Ruanda é abatido por um míssil, quando este retornava da Tanzânia, onde assinara o Acordo de Paz que, teoricamente, colocaria fim à guerra civil entre o governo e a Frente Patriótica Ruandesa (FPR). A notícia dessa morte desencadeou o genocídio em Kigali, onde as forças de segurança começaram a identificar pessoas da etnia Tutsis, e, posteriormente, a ação se espalhou por todo o país, no qual grupos Hutus armaram-se para assassinar a etnia inimiga (COUTO, 2013).

Segundo organizações humanitárias, foram mais de um milhão de mortos e quase três milhões de refugiados. O papel internacional neste evento, que tem posteriormente um novo episódio genocida no ano de 2003, é questionado tanto na perspectiva da demora de ações contra o genocídio, por parte das Organizações das Nações Unidas e dos países aliados ao governo ruandês (que já dava sinais de propagação ao ódio, desde 1990), quanto pelo "jogo de oposições" praticado pelos governos europeus durante as manifestações de independência dos anos 1950 - especificamente a Bélgica -, e posteriores alianças econômicas, que beneficiavam determinada etnia de acordo com seus interesses.

O julgamento desses crimes foi realizado em âmbito nacional, causando uma superpopulação carcerária no país, e internacional, reforçando a culpa de Hutus e o ressentimento contra a etnia. Os desdobramentos sociais e políticos na região africana dos Grandes Lagos são desastrosos, com o deslocamento de milhões de pessoas para campos de refugiados, inclusive Hutus fugindo de represálias desde a tomada do poder pela FPR. Muitos Hutus cruzaram as fronteiras com a República Democrática do Congo (anteriormente Zaire), que, aliada à Ruanda e Uganda, financia movimentos de extermínio dentro dos campos militares e de refugiados.

Fato é que o início desse contexto mundial de ebulição das discussões sociais sobre os genocídios foi o lançamento de Holocausto (1979) pela televisão estadunidense. Minissérie de quatro episódios, da emissora NBC, filmada na Áustria e em Berlim ocidental, ela foi sucesso de público nos Estados Unidos e na Europa. Contando a história da família Weiss, judeus alemães, e de um agente da Schutzstaffel (SS - tropa de proteção nazista), Holocausto abordou diversas temáticas, como a criação dos Ghettos judeus e as mortes nas câmaras de gás.

Contudo, a série recebeu diversas críticas, entre elas, a do já citado escritor Ellie Wiesel, que retratava uma exploração do tema (pelo cinema, televisão e teatro) com um senso "vulgar" das experiências das vítimas. Para Wiesel, por exemplo, produções como 
Holocausto ou a peça da Broadway Ghetto foram melodramas simplistas, que tendiam a minimizar a tragédia, perdoá-la e romper com a tradição do universo particular da morte para os judeus, com fins de espetacularizá-las (WIESEL, 1989). Obviamente, existem, de acordo com o autor, produções comprometidas com a memória, tal como alguns livros de memórias, inclusive os de Primo Levi, alguns documentários, como o já citado Noite e Neblina ou Shoá de Claude Lazmann. No entanto, o principal dessas obras era ter a sensibilidade de fazer ouvir aos testemunhos, caso que não ocorreu com a série estadunidense.

É o ingresso, portanto, das primeiras críticas sobre a comercialização do Holocausto, enquanto bem cultural de consumo, a partir das produções audiovisuais, e a descaracterização do evento para a venda. Nos anos seguintes, este debate aumenta e, em meio às comemorações do quadragésimo aniversário do fim da Segunda Guerra Mundial, em 8 de maio de 1985, dois acontecimentos marcam o espaço público sobre esse passado.

O primeiro deles foi a controvérsia gerada pela visita, em início de maio daquele ano, pelo presidente estadunidense Ronald Regan à República Federal da Alemanha (RFA). Declinando convites para visitas em alguns Campos de Concentração, Regan afirmava querer focalizar sua passagem no país nas questões do presente, com um relacionamento amigável com a RFA, ao invés de insistir em seu passado belicoso.

Contudo, quando a agenda oficial foi liberada ao público, havia o planejamento de Regan de visitar o Kolmeshöne Military Cemetary, em Bitburg. No referido cemitério, encontram-se tumbas de cerca de dois mil soldados alemães, sendo 49 das tropas SS. Sob uma enorme pressão política e de grupos judeus, dentro e fora do país, Regan decidiu não alterar os planos da visita ao cemitério, mas incluir uma parada no ex-Campo de Concentração Bergen-Belsen, o que não amenizou os ânimos e provocou, além de repúdio, alguns protestos no momento da visita (WEINRAUB, 1985).

O segundo evento marcante desta comemoração foi o discurso do então presidente da República Federal da Alemanha, Richard von Weizsäcker. Nele, Weizsäcker apontou a necessidade nacional de comemorar a data, enquanto um "dia de liberação" do povo alemão uma liberação da inumanidade e da tirania do Nacional Socialismo. Não se esquecendo do sofrimento de muitas pessoas no pós-guerra, ele enfatizou de que aquele dia era para comemorar o fim de uma "aberração na história alemã" e provocar a memória do povo em prol de uma "reconciliação nacional" com as vítimas.

E, assim, colocou

Today we mourn all the dead of the war and the tyranny. In particular we commemorate the six million Jews who were murdered in German 
concentration camps. We commemorate all nations who suffered in the war, especially the countless citizens of the Soviet Union and Poland who lost their lives. As Germans, we mourn our own compatriots who perished as soldiers, during air raids at home, in captivity or during expulsion. We commemorate the Sinti and Romany gypsies, the homosexuals and the mentally ill who were killed, as well as the people who had to die for their religious or political beliefs. We commemorate the hostages who were executed. We recall the victims of the resistance movements in all the countries occupied by us. As Germans, we pay homage to the victims of the German resistance - among the public, the military, the churches, the workers and trade unions, and the communists. We commemorate those who did not actively resist, but preferred to die instead of violating their consciences (VON WEIZSÄCKER, 1985, p. 2). ${ }^{38}$

Apesar deste discurso ampliar o espectro das vítimas do nazismo, fato até então pouco mencionado, ele deu uma especial atenção à resistência dentro e fora da Alemanha. Desta forma, ambos o discurso tendeu a amenizar os sentimentos de culpa e responsabilidade social dos alemães, a partir da ênfase na dimensão da consciência individual e de um olhar para a "superação" do passado.

No ano seguinte, essas discussões se acalentam, quando o historiador Ernest Nolte escreve um artigo sobre a inabilidade da RFA em deixar o "passado passar", por dois motivos, segundo o autor: o interesse das gerações mais jovens em acusar "seus pais" por um passado de horror e o interesse das vítimas, que teriam privilégios pelo "status de vítimas". O argumento principal de Nolte era a de que a historiografia sobre a Alemanha nazista deveria liberar-se de um pensamento coletivista, modificando suas bases para uma política liberal e democrática, que libertaria também o indivíduo das "estigmatizações" nas memórias.

Isto significaria entender a história da Alemanha nazista admitindo que as técnicas e processos utilizados naquele momento, já eram de uma realidade colocada pela União Soviética. Ou seja, a barbárie adotada, o extermínio, as execuções em massa, a aniquilação do inimigo, as torturas e etc. não estavam fora do universo contextual existente, e a violência foi uma resposta ao medo do "terror vermelho".

No one murder, and specially not a mass murder, can justify another, and we will be lead astray by an attitude that pants only to the one murder and to the

\footnotetext{
${ }^{38}$ Hoje lamentamos todos os mortos da guerra e da tirania. Em particular, celebramos os seis milhões de judeus assassinados nos campos de concentração alemães. Celebramos todas as nações que sofreram na guerra, especialmente os inúmeros cidadãos da União Soviética e da Polônia que perderam a vida. Como alemães, lamentamos nossos próprios compatriotas que morreram como soldados, durante ataques aéreos em casa, em cativeiro ou durante expulsões. Celebramos os ciganos Sinti e Romani, os homossexuais e os doentes mentais que foram mortos, bem como as pessoas que tiveram que morrer por suas crenças religiosas ou políticas. Nós celebramos os reféns que foram executados. Recordamos as vítimas dos movimentos de resistência em todos os países ocupados por nós. Como alemães, prestamos homenagem às vítimas da resistência alemã - entre público, militares, igrejas, trabalhadores, sindicatos e comunistas. Nós celebramos aqueles que não resistiram ativamente, mas preferiram morrer em vez de violarem suas consciências (VON WEIZSÄCKER, 1985, p. 2, tradução nossa).
} 
one mass murder and ignores the other, even though a casual nexus is probable (NOLTE, 1993, sem paginação, grifo do autor). ${ }^{39}$

De modo óbvio, esse texto causou uma enorme repercussão, entre o verão e o outono de 1986, com diversas respostas publicadas sobre a particularidade do Holocausto e as rejeições pelas comparações relativizadas. Jürgen Habermas, por exemplo, contestou o artigo de Nolte, considerando a sua tentativa de "normalização do passado nazista" como uma tendência à apologia e ao desejo de unificar a história alemã em torno de um passado palatável (MADSEN, 2000).

Esse debate - Historikerstreit - não era novidade em proposta de conhecimento, já que, desde a década de 1960, discutia-se a particularidade ou não da história alemã. O historiador Fritz Fischer desenvolveu, em seu livro Germany's Aims in the First World War (1961), a tese do sonho imperialista alemão, que sugere a continuidade de desejos expansionistas, autoritários e agressivos e, portanto, uma Alemanha culpada pelas catástrofes do início do século XX. Essa teoria, conhecida como Sonderweg (o caminho especial), se firmou naqueles anos e recebeu diversas críticas, entre as quais, a ideia de que a violência nazista era reflexo daquela praticada pela URSS.

Percebemos, portanto, que essas comemorações dos anos 1980 foram fundamentos para uma discussão intensa sobre "reconciliação" entre países inimigos na guerra ou entre vítimas e sociedade alemã. No entanto, a reconciliação pretendida era fundamentada ora por um perdão do passado, pouco discutido socialmente até aquele momento, ora por um esquecimento ou um apagamento da memória, que se baseava na responsabilização do outro pelo genocídio local.

No quinquagésimo aniversário do final da Segunda Guerra Mundial (1995), já em meio às discussões sobre outros genocídios, ocorreram diversas tentativas de comemorações, por todo o mundo. Muitas delas estiveram malfadadas por recusas de pedidos de perdão (como no caso de Tóquio para a Coréia do Sul), por discussões sobre datas comemorativas (como no caso alemão sobre a transferência do fim da guerra para o ano de 1989) ou por protestos contra determinadas comemorações (como no caso do Museu Aeroespacial da Smithsonian Institution, que se viu obrigado a cancelar uma exposição sobre Hiroshima para não ofender os veteranos de guerra estadunidenses).

\footnotetext{
${ }^{39}$ Nenhum assassinato e, especialmente nenhum assassinato em massa, pode justificar outro, e nós seremos desviados por uma atitude que suspira apenas por um assassinato e por um assassinato em massa e ignora o outro, mesmo que haja provavelmente um nexo causal (NOLTE, 1993, sem paginação, tradução nossa).
} 
Naqueles anos 1990, a transformação simbólica da cidade de Berlim (unificada) estava a todo vapor, ocasionando variados debates sobre o que se fazer com os espaços de memória, que foram representados com marcas da ex-União Soviética. Um desses exemplos é o "Monumento ao Soldado Desconhecido", na avenida Under der Linden - Neue Wache. Central Memorial of the Federal Republic of Germany to the Victims of War and Dictatorship (DARTON, 1995).

Inaugurado inicialmente em homenagem à Batalha de Waterloo (1822) e aos soldados da guerra contra os franceses, nos anos 1930, o Neue Wache começou a ser utilizado para cerimônias militares, especialmente depois da ascensão de Hitler, que demonstrava seu poderio bélico oficialmente naquele lugar. Com o final da Segunda Guerra e a divisão da cidade, os comunistas restauraram o edifício, e ele passou a ser considerado um símbolo antifascista na Berlim Oriental, dedicado "Às vítimas do fascismo e do militarismo". Nele, acendeu-se uma chama para os dois túmulos que se encontravam no espaço: um soldado e um resistente, desconhecidos.

Em 1993, o chanceler Helmut Kohl (1930-2017) mandou apagar esta chama e substituí-la por uma cópia da estátua da artista expressionista Kàthe Kollwitz, Mother with the dead son (Mãe com o filho morto), produzida no ciclo War (Guerra) de obras em madeira, entre os anos 1922 e 1923. A inscrição também foi modificada, como uma homenagem "Às vítimas da guerra e da tirania". Com essas ações, Kohl foi acusado de "rearrumar" a história do país, confundindo as vítimas do nazismo com seus adeptos e ofendendo aos judeus pela sugestão que a obra de Kollwitz faz à Pietà cristã. 


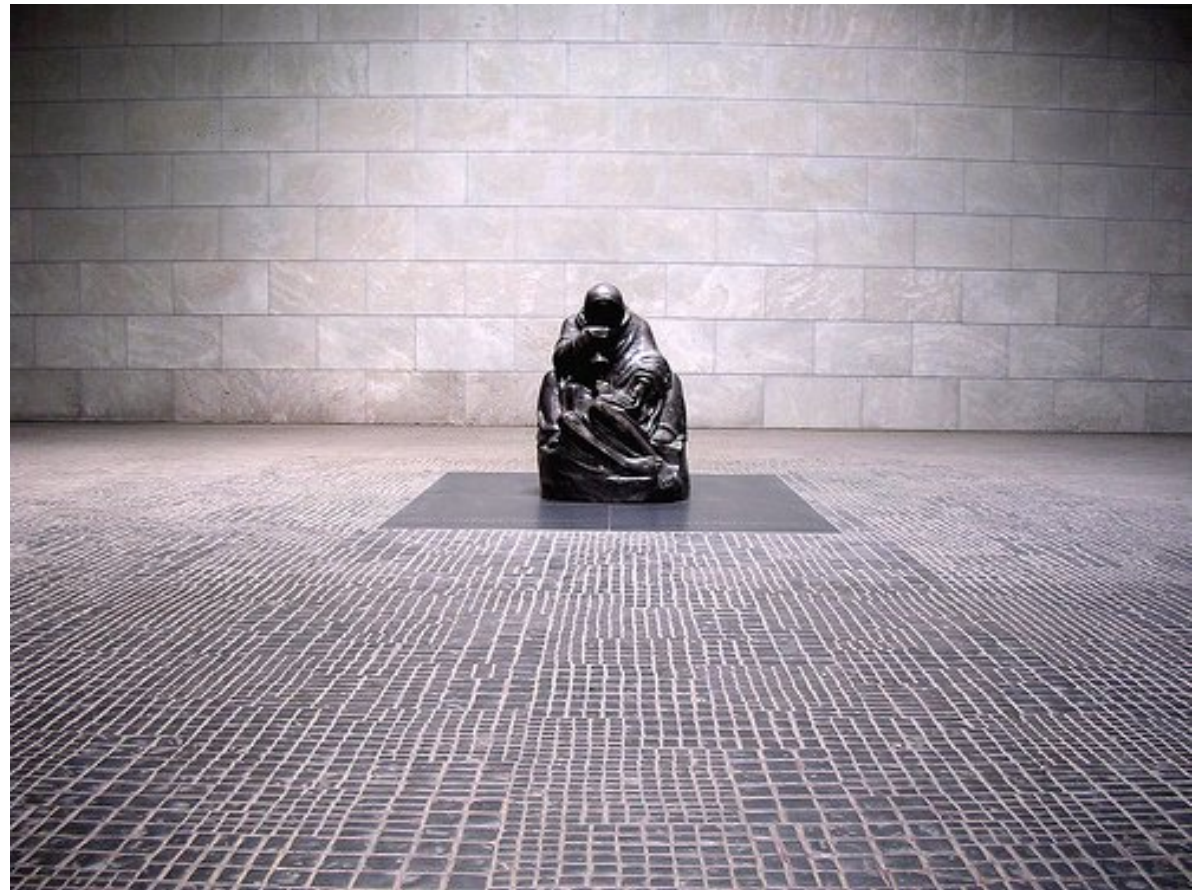

Fonte:

PEACE

PALACE

LIBRARY.

Disponível

em:

$<$ https://www.peacepalacelibrary.nl/2012/05/the-body-counts-civilian-casualties-in-war/new-wachestatue>. Acesso em: 06 mar. 2017.

Também interessante é o caso da discussão sobre o terreno de Prinz Albrecht, que abrigava os palácios nos quais concentravam-se as instituições de poder nazista, entre os anos 1933 e 1945, destruídos depois da guerra. Nos anos 1980, com a pressão popular, a República Federal da Alemanha resolveu recuperar historicamente o lugar, realizando investigações arqueológicas e uma exposição denominada Topografia do Terror. O êxito desta exposição de 1987 fê-la transformar-se em permanente, e que se projetasse um centro de documentação, museu e fundação, inaugurados em 1992, como projeto-chave da reunificação da cidade (VINYES, 2004).

Imagem 10 - Topografia do Terror (Berlim, Alemanha) 


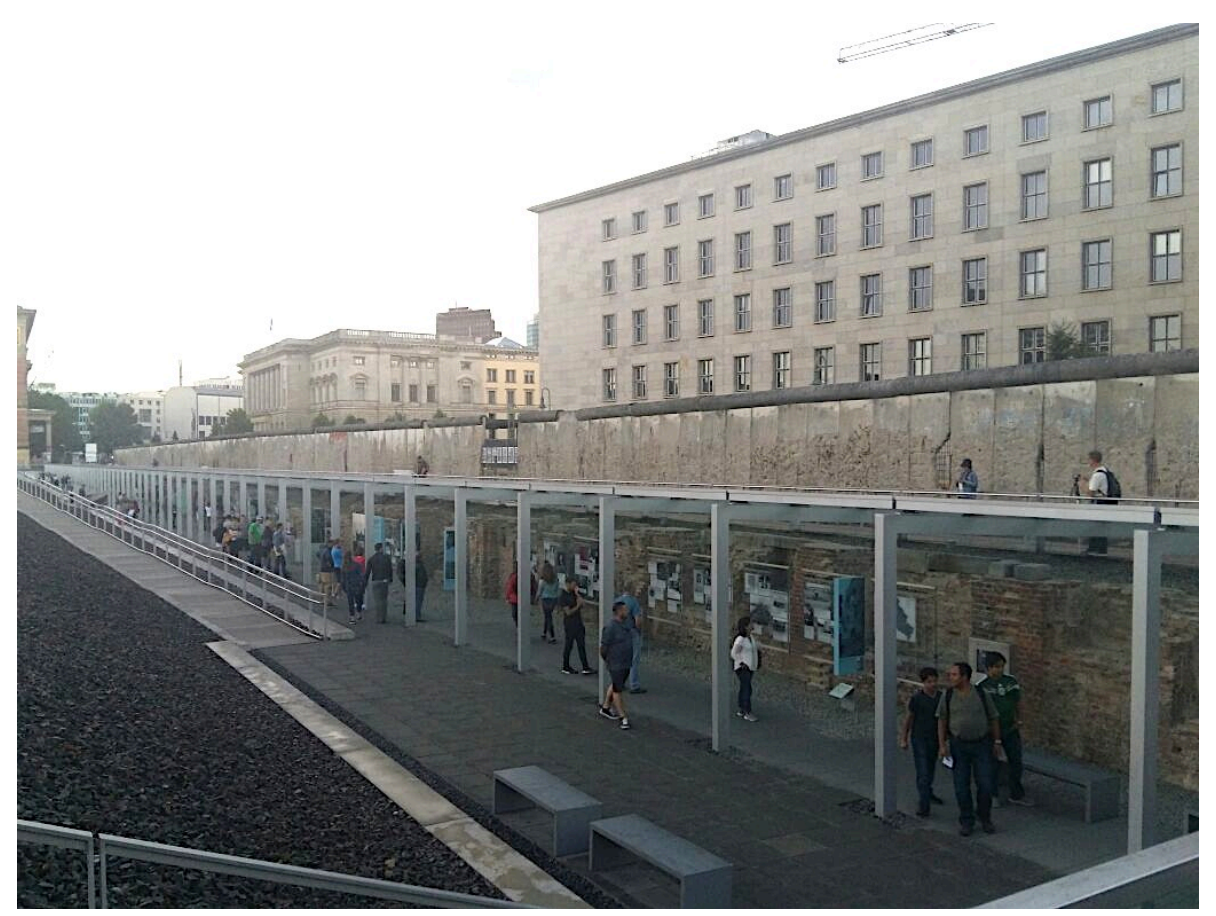

Fonte: Arquivo Pessoal. Fotografia de 2017.

E diversos são os exemplos de debates sobre as transformações nas narrativas sobre o Holocausto dentro e fora da Alemanha. Estas representações se tornaram cada vez mais importantes para a conservação da memória do Holocausto, em nível mundial, pois a geração testemunhal dos sobreviventes segue desaparecendo e as gerações mais novas passam a conhecer a experiência, em segunda e terceira mãos, através dessas memórias narrativas. Desta forma, a experiência do que LaCapra (2009) denomina de "memórias e testemunhos secundários" é determinante para a internacionalização das recordações sobre o Holocausto e para a reconciliação (efetiva) com este passado.

As vítimas morrem, e é bom que assim seja, pois há muito tempo tornaramse redundantes. Felizmente, também desaparecem os carrascos, atingidos pela lei da morte biológica. Mas, em ambos os lados, continuam a nascer novas gerações. Entre uma e outra, todas marcadas pela origem e pelo ambiente, volta a se abrir o velho abismo intransponível. Um belo dia o tempo o fechará. Mas o processo de maturação temporal não deveria ser acelerado por uma reconciliação leviana, irrefletida, fundamentalmente falsa. Ao contrário: como se trata de um abismo moral, ele permanece aberto (LEVI, 1988, p. 18-19)

A partir das últimas décadas, com diversos exemplos de práticas sociais genocidas, que continuam ocorrendo, esse crescimento da (des)comemoração do Holocausto teve papel crucial para transformação das experiências do homem em relação ao seu tempo e espaço. Ele foi acompanhado pela mudança no imaginário geracional, onde as pessoas, que anteriormente acreditavam no futuro e na modernização, passam a investir na difusão do passado e, 
portanto, nas memórias exemplares, realocando os "futuros presentes", de Reinhard Koselleck (2006), em prol da presença do passado no imaginário coletivo (HUYSSEN, 2014, p. 139$153)$.

As diversas narrativas memoriais ressoam, ganham e perdem legitimidades, transformando o Holocausto nesse lugar-comum para se falar de traumas em contextos nem sempre relacionados (HUYSSEN, 2000, p. 9-40). Seu crescimento é justificado pelo processo de globalização da memória, onde o Holocausto é percebido não apenas como uma das bases históricas da Convenção de Genebra sobre o genocídio e sobre as violações aos direitos humanos, mas também, como instrumento de analogia para outros traumas históricos e representações que circulam com as produções artísticas e memoriais.

Para Andreas Huyssen (2014, p. 177-194), a transnacionalização do Holocausto permite sua recordação (mesmo que distinta do evento original), funcionando como metáfora para outras histórias e lembranças traumáticas. E estas éticas e estéticas que circulam, questionam categorias universais de progresso, de ascensão linear da História e de conceitos iluministas, criticando a barbárie do século XX, que nos habituou ao morticínio, ao sacrifício e à guerra (HOBSBAWM, 1997, p. 268-280).

Em contrapartida, o uso dessa memória também pode valorizar uma indústria cultural, a chamada vulgarmente de "hollywoodização do Holocausto". Para este sentido, o Holocausto "metáfora para outras catástrofes" é capaz de universalizar uma representação do que seria o "trauma" e encaixá-la em formas, que seriam mais compreensíveis ao público ou (até mesmo) mais valorizadas economicamente.

Por um lado, essa forma de representação percebe a unificação das experiências dos homens, através de processos éticos e culturais europeus, que não levam em conta a diversidade da humanidade e que caracterizam o sofrimento pelo Holocausto, hierarquizandoos a partir dele. Por outro, ela opera dentro de uma indústria que comercializa a memória, amenizando-a para a venda - o que Canclini denomina com sucesso como a "geopolítica do souvenir", integrando o patrimônio das catástrofes à sua comercialização (CANCLINI, 2014, p. 37-46).

Néstor Canclini (1997, p. 57-85) sugere, no entanto, que a própria dinâmica da indústria cultural pode, em certa forma, ampliar o conhecimento sobre o patrimônio mundial. E, desta forma, essa crítica ao Holocausto como exemplar e sua apropriação econômica não abrandariam o caráter principal, marca da história "após Auschwitz", que é o fato de que o Pós-Holocausto modificou as estruturas políticas e culturais da sociedade, ampliando o conhecimento sobre as violações e relacionando os trabalhos da memória aos direitos 
humanos. A noções de justiças e memórias, advindas dessas discussões, alcançaram demarcar as atrocidades e tentar educar sobre/para os direitos humanos, através dos territórios e (em certa medida) dos próprios "souvenires", que possuem essa capacidade (mesmo que limitada) de fazer circular mundialmente as histórias catastróficas.

Isto significa que a prática social genocida nazista e as memórias e discussões sobre estas práticas lançaram luz aos demais tipos de genocídios, que ocorreram e ocorrem no mundo, impulsionando políticas internacionais favoráveis aos direitos humanos. E, sendo tema profundamente trabalhado, o Holocausto torna-se esse exemplo fundamental.

Mesmo se o Holocausto tem sido mercadorizado interminavelmente, isto não significa que toda e qualquer mercadorização inevitavelmente banaliza-o como evento histórico. Não há nenhum espaço puro fora da cultura da mercadoria, por mais que possamos desejar um tal espaço. Depende muito, portanto, das estratégias específicas de representação e de mercadorização e do contexto no qual elas são representadas (HUYSSEN, 2000, p. 21).

Portanto, o "trauma central do século XX", no sentido daquele que implementou novas questões à vida, serve para transcender seu caráter de norma, que o coloca como problema único. O Holocausto foi único, no sentido específico contextual. Contudo, ao cruzar sua unicidade com outros eventos catastróficos da humanidade, chegamos à possibilidade de generalização de seus problemas, desde as posições subjetivas - o nacionalismo, o preconceito, o sentido de superioridade étnica, a violência inútil e etc. - às objetividades políticas, econômicas e sociais das práticas de genocídios (LACAPRA, 2009). Esses paradigmas precisam ser considerados, quando se defende a justiça contra violações e a educação aos direitos humanos, e, essencialmente, relacionados nos estudos sobre a história das memórias.

\section{2 - Os contextos de transições no território imaginado do Río de la Plata}

Dizemos cadeira, janela ou relógio, palavras que designam meros objetos, e, no entanto, de repente transmitimos algo misterioso e indefinível, algo que é como uma chave, como uma mensagem inefável de uma região profunda do nosso ser. Ou pelo que entendem aqueles aos quais a mensagem secretamente se destina. (...). Porque o homem faz com os objetos o mesmo que a alma realiza com o corpo, impregnando-o de desejos e sentimentos, manifestando-se através das rugas carnais, do brilho dos olhos, dos sorrisos e da comissura dos lábios (SABATO, 2008, p. 17).

Todas essas discussões e eventos de meados dos anos 1980 e dos anos 1990 passam pela América Latina em dois contextos específicos para o Cone Sul: o fim das ditaduras 
militares e o início de uma década marcada pelos discursos e políticas neoliberais como soluções para essas "novas democracias". Nossos três casos de estudos são alguns dos exemplos de como circularam esses debates no território transnacional com suas devidas especificidades.

O caso argentino, de alguma forma, passa a ser o exemplo em nosso espaço imaginado sobre essas políticas de transição, com seu intenso combate às Forças Armadas, depreciadas em nível global. Essa ditadura, "alvo" das críticas internacionais desde finais dos anos 1970, como veremos mais profundamente ao longo desse texto, frutos das denúncias nacionais, que buscavam respostas pelas práticas de repressão, centralizada no desaparecimento, aprofunda os debates sobre a ética e a moral das práticas das ditaduras, em relação à vida humana, no sistema mundo de reconhecimento sobre violações.

Desde início dos anos 1980, enfrentando-se com um contexto político interno complexo, com o retorno intenso das atividades sindicais, com uma grave crise econômica e com o transborde público de suas práticas de Terrorismo de Estado, as Forças Armadas argentinas percebem (novamente) no discurso nacionalista uma possível solução para sua manutenção de seu poder. Desta forma, decidem retomar, pela guerra, as Ilhas Malvinas da Inglaterra, fundamentando-se socialmente através de um discurso sobre soberania nacional e levando em conta uma série de argumentos equivocados, incluindo a crença de um apoio exterior, que nunca viria (LORENZ, 2007).

A guerra das Malvinas - efêmera temporalmente (durou entre 2 de abril à 14 de junho de 1982) -, em 33 dias de combates, marcou o fim da ditadura, adicionando mais 899 mortes no número de vítimas do "Processo de Reorganização Nacional". Além de enfrentarem-se com uma Armada potencialmente mais forte (a Inglaterra decidiu utilizar seu maior operativo militar, desde a Segunda Guerra Mundial), os soldados argentinos tiveram problemas de adaptação no terreno, ocasionados pelo clima, pela escassez de alimentos e pelos maus tratos, tanto por parte dos ingleses, quanto pelos oficiais e suboficiais argentinos, que reproduziam as violências praticadas no continente ${ }^{40}$.

De acordo com Federico Lorenz (2012), essa juventude da guerra protagonizou simbolicamente o final da ditadura. O Serviço Militar, então obrigatório, a transformou em Colimbas (Corre-Limpia-Barre / Corre-Limpa-Varre), que, baseada na disciplina, confirmava a servidão aos "ideais nacionais" e às Forças Armadas. Na guerra, especificamente, esses

\footnotetext{
${ }^{40}$ Sobre violência na Guerra das Malvinas, Cf. FOGWILL, 1983.
} 
jovens representavam as imagens da Pátria e de uma Nação que, segundo os militares, passava constantemente por "momentos de provação".

Com a derrota, por um lado, essa juventude tornou-se socialmente vítima de seus superiores, somando-se às violações dos direitos humanos ocorridas no país.

Nuestros hijos fueron enviados a una lucha que no eligieron, decidida por un gobierno que no eligieron, para la cual no estaban preparados. Había en la Argentina cuarenta mil profesionales preparados por vocación y estudio para una guerra. No é fácil entender por qué se envió a diez mil muchachos de 18 a 20 años que carecían de la preparación necesaria [...] pero allá fueron y se comportaron con gran valor y dignidad (BUSTOS, 1982, p. 13).

Por outro lado, ela levantou o debate sobre o "combate aos ex-combatentes", como propõe Federico Lorenz (2007), que tinha como prerrogativa a "desmalvinização" do discurso militar. A ideia de "desmalvinização", advinda de uma reportagem escrita por Osvaldo Soriano, afirmava que

Quienes no quieren que las Fuerzas Armadas vuelvan al poder, tienes que dedicarse a "desmalvinizar" la vida argentina. Eso es muy importante: desmalvinizar. Porque para los militares las Malvinas será siempre una oportunidad de recordar su existencia, su función y, un día, de rehabilitarse. Intentarán hacer olvidar la "guerra sucia" contra la subversión y harán saber que ellos tuvieron una función evidente y manifiesta que es la defensa de la soberanía nacional (SORIANO apud LORENZ, 2007, sem paginação)

"Desmalvinizar" significava, então, consolidar uma democracia sem a causa nacional, que fundamentava o apoio público às funções da Armada, em seus sentidos de defesa do território argentino a "qualquer custo" contra os "subversivos" internos e os inimigos externos.

Assim, segundo Miguel Bonasso (1985), duas gerações argentinas marcaram o fim do regime: 1) os desaparecidos, exilados e os que tiveram de abandonar suas militâncias para salvarem suas vidas, representados pelas lutas de organizações nacionais e internacionais de direitos humanos; e 2) os "chicos de la guerra", aqueles convocados para a guerra em Malvinas, retornados ou não, que demonstraram a decadência e o autoritarismo da ditadura. Apesar de ambas gerações se separarem temporalmente, elas foram frutos da derrota na defesa de sua própria concepção de liberação nacional - de um lado, a derrota da revolução e, de outro, a derrota da guerra e desse projeto de extermínio.

Perdendo legitimidade diante das inúmeras violações aos direitos humanos e das crises internas, que não foram solucionadas, o Regime Militar, na figura do general Leopoldo Galtieri, renuncia, em junho de 1982, iniciando um processo de redemocratização no país (PRADO; PELlEGRINO, 2014). No entanto, os "hijos del Proceso" - a geração 
(des)informada pelo Terrorismo de Estado - desestruturaram o argumento de completa derrota da política ditatorial. Ou seja, mesmo considerando os dois sujeitos vítimas - os desaparecidos e os "meninos da guerra" -, parte da sociedade argentina continuava a reproduzir discursos de época ditatorial, aceitando a visão dicotômica entre violências extremadas (a Teoria dos Dois Demônios, por exemplo) e a perspectiva da ordem e apaziguamento das lutas sociais, através de uma redemocratização que não questionasse a responsabilidade social pelo Terrorismo de Estado (FELD; FRANCO, 2015).

Alguns autores trabalham com a ideia de que a transição à democracia argentina teve uma espécie de continuidade no imaginário e nos valores sociais, ao revés de um completo repúdio em relação às Forças Armadas. Esse impacto negativo viria, portanto, a partir do informe Nunca Más (1984), que, apesar de cristalizar uma ideia de violências extremadas, foi capaz de trazer à tona os discursos das vítimas do Terrorismo de Estado, e dos juízos aos excomandantes (Juicios de las Juntas, 1985), que trouxe dados para condenar as violações sistemáticas aos direitos humanos no país (FELD; FRANCO, 2015).

Em termos econômicos, depois do início de um período democrático mergulhado em crises, a solução para o cenário argentino (mas também latino-americano) é fundamentada na vitória de um discurso neoliberal, que, em curto prazo, trouxe ingressos financeiros estrangeiros, através das dívidas externas contraídas e da venda de empresas estatais - a indústria argentina foi particularmente arrasada e foram vendidos o sistema de aposentadoria, Aerolineas Argentinas, Gas del Estado, Obras Sanitárias de la Nación, Empresa Nacional de Telecomunicaciones, Ferrocarriles Argentinos, Correo, os sistemas de produção e distribuição de energia elétrica e Yacimientos Petroliferos Fiscales. No entanto, ao (não tão) longo prazo, esse processo econômico gerou profundas crises no interior do país, agravando as desigualdades sociais e a pobreza, ocasionando desemprego e empurrando grande parte da população para a informalidade (ANSALDI, 2003, p. 27-43).

Nesse sentido, o primeiro momento de debates argentinos sobre a ditadura (19761983), em democracia, é marcado pelas vítimas específicas - os desaparecidos, especialmente -, cujo exemplo de violações passa a circular por todo o mundo, na forma de reconhecimento da violência na região imaginada platina, tornando-as centrais para a diferenciação entre os processos de direitos políticos e de liberdades, ditatoriais e democráticos. Em um segundo momento, com todas as experiências que trazem o genocídio como centro dos debates mundiais, com a impunidade dos responsáveis pelo Terrorismo de Estado e com o aprofundamento da pobreza no país, a ideia da "prática social genocida" ingressa nos debates sobre a ditadura, conectando a violência estatal aos modelos econômicos. Ela passa a 
argumentar, também, um processo democrático excludente de populações e que viola os direitos não apenas de liberdades políticas, mas ainda, os direitos civis e humanos, no que tangem à moradia, ao trabalho digno, à vida e etc.

No Uruguai, a ditadura (1973-1984), derrotada no plebiscito de 1980, procura uma saída negociada, mediante o Acordo do Clube Naval (1984), no qual representantes da ditadura, do Partido Colorado, do Frente Amplio e da Unión Cívica (Partido Nacional) decidem reestabelecer a Constituição de 1967 e o sistema de partidos, precedente à 1973. Neste acordo, estabeleceu-se que haveria uma continuidade do Consejo de Seguridad Nacional, do dispositivo de suspensão de garantias individuais (o Estado de Insurrección) e das promoções aos chefes militares. Também se ajustou os juízos militares, em casos de prisões fundamentadas no Estado de Insurrección, impedindo os juízos civis pelos crimes ditatoriais, criando um "recurso de amparo" legal para permitir pessoas ou organizações sociais de apelarem judicialmente às decisões do governo e determinando que o Congresso eleito atuasse como Assembleia Constituinte e colocasse a Carta Fundamental em referendum popular (ANSALDI, 2003, p. 27-43).

As eleições de 1984, contudo, foram marcadas por diversas limitações, através de proscrições de dirigentes políticos e do Partido Comunista, assim como pela permanência de presos políticos nos cárceres uruguaios, até a vitória de Julio María Sanguinetti. Desta forma, a transição à democracia no país foi caracterizada pelo que Waldo Ansaldi (2003) denomina de "partidocracia", que, apesar do ingresso do Frente Amplio no movimento eleitoral, modificando o sistema bipartidário anterior à ditadura, manteve a discussão sobre a transição, em níveis de liberdades e direitos políticos.

Em 1986, o país reconhece como obsoleta a pretensão de punir os crimes cometidos por funcionários militares e policiais, em cumprimento de suas funções e sob ordens superiores, até primeiro de março de 1985, através da Ley de Caducidad de la Pretención Punitiva del Estado. Os processos já abertos, compreendidos dentro da nova lei, deveriam ser suspensos e os casos de denúncias sobre desaparecimentos ou menores sequestrados, investigados pelo Poder Executivo e pela Justiça Militar, tentando deste forma encerrar os debates sobre a ditatura, em um sentido de "pacificação nacional" (URUGUAY, 1986).

Em termos econômicos, o Uruguai foi o único país na década de 1990 que rechaçou, pelo voto popular, as vendas de suas empresas estatais. Isso não significa que ele não tenha sofrido com o enquadramento da democracia interna no sistema econômico internacional, onde as grandes corporações passaram a ditar regras econômicas a serem cumpridas em todo 
o território latino-americano, sofrendo as consequências do mesmo com o empobrecimento de sua população (ANSALDI, 2003).

Desta forma, o país passa limitadamente por uma revisão do período ditatorial e de sua transição, fundamentada nas questões dos modelos econômicos, como feito pelos demais casos de estudo. Mantendo seus debates em uma esfera regional de concepções das violações cometidas, com o sujeito principal sendo o desaparecido (GATTI, 2011), as disputas pelas memórias uruguais sobre seu passado recente seguem sendo pelo rompimento do acordo sobre a Ley de Caducidad e pelo conceito de resistência como central nos debates sobre direitos humanos e memórias.

O Paraguai, país com longos períodos ditatoriais e um sistema político democrático tradicionalmente bipartidário (Partido Colorado e Partido Liberal), tem como momento de derrocamento da ditadura unipessoal de Alfredo Stroessner (1954-1989) a fratura no próprio Partido Colorado, quando se inicia a disputa pelo sucessor da ala stronista. A crise interna no partido fomenta um setor (Alianza Nacional Republicana) defensor da democracia, que fora afastado do governo por Stroessner. Devido a essa fração, aos altos níveis de corrupção, à fragmentação das Forças Armadas, e à deterioração da relação com a Igreja Católica, depois da visita do Papa João Paulo II (em 1988), e com o governo estadunidense sob a presidência de Ronald Reagan pressionando o país com questionamentos direcionados aos direitos humanos, as Forças Armadas lideraram um golpe que pôs fim ao regime stronista e fez do general Andrés Rodríguez presidente interino.

A agenda de liberação tinha quatro pontos: 1) acabar com o Estado de Sítio, vigente ininterruptamente desde 1954; 2) reconhecer os partidos políticos e as liberdades civis e políticas; 3) convocar um colegiado para escrever a Constituição; e 4) legitimar um novo governo com eleições. Reagrupando os interesses políticos do Partido Colorado e das Forças Armadas, este governo chama as primeiras eleições em 1989 (eleições livres, apesar de não liberadas da corrupção), das quais sai vencedor o próprio general Rodríguez pelo Partido Colorado (NICKSON, 2010, p. 265-314).

Logo, o Paraguai segue uma série de eleições, cujas vitórias são dadas ao Partido Colorado, constituindo uma linha política que ingressa nesse cenário econômico dos anos 1990, a partir da abertura para o capital internacional e o ingresso do país no mercado mundial, acendendo suas fronteiras para importação de produtos e para a venda dos poucos produtos produzidos pelo país, principalmente o incremento da agroexportação. Isso faz com que os conflitos pela terra e o empobrecimento da população rural seja um dos maiores problemas sociais do país (VILLAGRA, 2011). 
Nesse sentido, há uma divisão nos debates sobre as violações paraguaias, no que tange às questões do campo e da cidade. Se, por um lado, na cidade, o desaparecimento e as prisões são os símbolos da repressão recuperada pela memória das vítimas, uma clara conexão com o território platino, por outro, no campo, tem-se a noção do genocídio (principalmente referente às populações indígenas afetadas pelas violências ditatoriais e democráticas) como argumento fundamental para se alcançar esse discurso mundial sobre os direitos humanos.

A generalização de uma "consciência" sobre democracias, baseadas na liberdade política e em eleições universais, motivou o argumento das violações aos direitos humanos, no âmbito regional, essencialmente pela figura do desaparecido. No entanto, os anos seguintes pós-ditaduras possuíram uma profunda decadência de redistribuição de riquezas, retrocessos em direitos sociais e ausências ou dificuldades em matérias de penalização das práticas estatais de terror. Segundo Waldo Ansaldi (2003), nos foram oferecidas "democracias pobres", em seu sentido de precariedade de mudanças estruturais e empobrecimento populacional.

Sabemos que, desde a colonização, a governabilidade no território latino-americano é fruto de nossa posição na produção internacional em sistemas de plantações, fazendas e estâncias, de propriedade da terra e de suas relações com o trabalho, de dependência e imperialismo. A situação econômica particular das transições no Cone Sul aprofundou esse empobrecimento, integrando-nos a um sistema de mercado, coordenado por grandes corporações e aumentando nossas dívidas externas e desigualdades internas. Os anos 1980 foram tão negativos para o território que são caracterizados pela Comisión Económica para América Latina y el Caribe (CEPAL) com a expressão de "década perdida" (com exceção do Chile e Colômbia).

A década de 1990, por sua vez, marcada pelos cortes nos gastos públicos, a desregulação dos setores econômicos, especialmente com a destruição de grande parte das conquistas trabalhistas, associadas ao estado de proteção latino-americano, pela depreciação das moedas nacionais, pela abertura dos mercados para competição, abandonando políticas protecionistas, transformou as estruturas sociais dos países. A América Latina torna-se, nesses anos, a região com maior desigualdade do mundo, onde $10 \%$ da população passa a receber a maior fração dos ingressos totais (ANSALDI, 2003, p. 27-43).

Nesse momento, no qual a economia de mercado é dominante, o ímpeto democrático ingressa em um modelo que não atende as necessidades e não resolve os problemas substanciais de sua população. Associada ainda ao clientelismo e à corrupção estrutural (que aumenta nos períodos ditatoriais e nas democracias posteriores), essa consolidação 
democrática é restritiva e afeta a credibilidade na própria democracia - com exceção do Uruguai, que tem um dos índices mais altos de credibilidade no continente. Em uma medição realizada em 2002, pela organização Latinobarómetro ${ }^{41}$, por exemplo, percebeu-se que a demanda de ordem na região em detrimento da liberdade era majoritária em diversos países e que, em alguns deles, como o Brasil e o Paraguai, os índices de aceitação de ditaduras são extremamente altos, apesar do passado recente.

Desta forma, os movimentos pelos direitos humanos no Cone Sul, que conseguiram de maneira irregular, em cada território, manter a demanda por memória sobre o passado recente, buscando verdade e justiça, ingressam nesse novo cenário com um grande desafio: conseguir relacionar memória e direitos humanos para alcançar a "não repetição do passado", sob o mote regional do Nunca Más. Muitas dessas organizações percebem a necessidade de se fazer uma revisão das histórias recentes, conectando-as com as histórias de violações globais e com os modelos econômicos que se beneficiam das violências.

E as estratégias para tal finalidade são diversas, de acordo com seus tempos e espaços. Como veremos a seguir, os debates sobre as violações aos direitos humanos e suas representações no espaço público transitam nos níveis mundial e regional (aqui, especificamente, nas figuras das práticas de desaparecimento forçado e das práticas sociais genocidas) para conseguirem desenvolver as experiências históricas de forma a conectar passado-presente-futuro e a sensibilizar as gerações pelo sofrimento do outro. Portanto, é necessário perceber como essas estratégias se estendem ou se limitam, através da história da memória sobre as violações aos direitos humanos no território imaginado do Río de la Plata.

\footnotetext{
${ }^{41}$ Dados disponíveis em: <http://www.latinobarometro.org/latOnline.jsp>. Acesso em: 20 maio 2018.
} 


\section{CAPÍTULO 2 JUSTIÇA TRANSICIONAL E TRANSNACIONAL}

Que los criminosos de lesa humanidad reciban el castigo que merecen es justicia en todos los sentidos. La justicia que llega tarde no es justicia (GIUBI apud 35 AÑOS DEL STRONISMO, 2011).

Após um período de conflito, violência em massa ou violação sistemática dos direitos humanos, o esforço para a construção da paz é definido como justiça transicional. Esse tipo de justiça é composto por um conjunto inclusivo de estratégias, formulado para enfrentar o passado, permeado de catástrofes, e que possui objetivos de processar perpetradores, revelar a verdade sobre crimes ocorridos, reparar as vítimas destes crimes, reformar instituições e promover uma reconciliação possível (VAN ZYL, 2011, p. 47-72).

Processar violadores dos direitos humanos, apesar de ser um esforço criticado em muitas ocasiões, serve para evitar futuros crimes, consolar as vítimas e criar novas normas, através de um castigo penal. Mesmo que sejam processos custosos e lentos, cuja resposta é parcial, estes julgamentos instalam valores e sanções sobre as violações e reestabelecem uma confiança dos cidadãos no Estado, demonstrando que este procura protegê-los, ao invés de violar seus direitos.

Revelar a verdade se remete à ação ética no presente de lembrar uma problemática do passado, considerada inadequada para os dias atuais - uma responsabilidade moral sobre a reescrita deste passado. A busca pela verdade das catástrofes humanas, por um lado, trabalha com os rastros da memória (seus escritos, ruínas, testemunhos e etc.) e, por outro, ajuda a sensibilizar futuras gerações contra práticas abusivas, divulgando informações sobre crimes e reconhecendo injustiças praticadas.

As reparações às vítimas assumem diferentes formas, que vão desde a ajuda material (compensações, pensões e bolsas) até medidas simbólicas (construções de monumentos, memoriais, comemorações nacionais e etc.), passando pela assistência psicológica e médica às suas vítimas. As políticas de reparação deveriam considerar categorias de vítimas, que não 
rompessem com seus distintos grupos em um mesmo espaço, mas ponderando o contexto socioeconômico da localidade, onde essas reparações ocorrem.

Para confrontar as violações dentro da justiça de transição, também se fazem necessárias modificações nas instituições responsáveis por elas, incluindo a possibilidade de suas dissoluções. Os governos precisam, neste sentido, adotar programas de depuração dos crimes do passado e impossibilitar a perpetuação de violadores em cargos públicos, reestabelecendo a integridade das instituições democráticas.

Por fim, o controverso conceito de reconciliação, muitas vezes atrelado às ideias de "perdão obrigatório", de impunidade e de esquecimento, precisa ser visto sob um prisma da "superação dos ressentimentos sociais", ocasionados pelos conflitos e violências contra a população, pois esses ressentimentos potencializam novas quebras dos direitos humanos como vimos, por exemplo, no caso de Ruanda e a região dos Grandes Lagos africanos. Nesta visão positiva da reconciliação, não se nega o passado de horror tampouco o sofrimento das vítimas, contudo propõe reparações proativas, demonstrando a possibilidade de retorno destas vítimas à participação política e social.

Produzidas em contextos desequilibrados, nos quais perpetradores de violações aos direitos humanos podem ainda conservar um poder social, a justiça transicional busca equilibrar as demandas por memórias, verdades e justiças. Diversas modalidades de justiça de transição foram implementadas, no espaço global e ao longo do tempo, considerando posições histórico-políticas e estruturas de força e poder no interior de cada localidade (ARAUJO, 2012, p. 145-162).

Neste sentido, Ruti G. Teitel (2003, p. 69-94) propôs uma genealogia da justiça de transição, que englobaria três períodos distintos: 1) Uma origem nos anos pós-Segunda Guerra; 2) Sua associação com a "onda de transição democrática" de finais do século XX (período pós-Guerra Fria); e 3) Aquela associada com as condições contemporâneas de conflitos entre normas de direitos humanos e violências. A primeira fase desta justiça é reconhecida no seu símbolo máximo, que é o Julgamento de Nuremberg, e no estabelecimento da criminalização de violações, através de normas internacionais e cooperações entre países. O segundo período é marcado pela utilização desse sistema internacional para se construir uma perspectiva nacional (e inclusive individual) de justiça transicional. E a terceira fase se conecta, então, com os processos de globalização que, por um lado, expandem os exemplos dessas justiças e, por outro, congelam as mesmas como exemplos únicos, desenvolvendo, a partir delas, normas jurídicas e ações políticas contra o "novo inimigo violento", o terrorismo. 
Apesar da generalização das questões abordadas nas diferentes justiças de transição, é claro que este movimento global genealógico passou por negociações internas e transnacionais, determinadas por discursos sobre memórias de violações e direitos humanos. Assim, surgem distintas organizações internacionais atentas aos procedimentos de justiças de transições e aos conflitos locais e regionais, como uma espécie de sistema internacional de vigilância e de recomendações sobre procedimentos em relação aos direitos humanos.

Aos opositores desse sistema internacional, os direitos humanos e as memórias, em nível global, não enxergam origens históricas e políticas locais, focalizando-se em uma perspectiva eurocêntrica e imperialista sobre direitos. Boaventura de Sousa Santos, por exemplo, afirma que os direitos humanos fazem parte de políticas normativas operadas globalmente e que tendem a despojar uma maioria populacional por não agir a favor da luta dos excluídos.

Sousa Santos (2010) considera que o entendimento convencional dos direitos humanos, como universalmente válidos, não percebe contextos e práticas humanas que são diferentes entre si. Defendendo uma perspectiva definida como "epistemologia do sul" (e percebendo o sul como uma metáfora do sofrimento humano causado pelo capitalismo e pelo colonialismo em escala global), ele afirma a necessidade de inteligibilidade recíproca das experiências e de reconhecimento da diversidade mundial. Neste sentido, a "gramática dos direitos humanos", por apresentar-se como a única oposição ao poder e valorizar a punição, não auxiliaria as críticas à visão unilateral das situações e despolitizaria as narrativas de sofrimento (SOUSA SANTOS, 2013).

My argument is that so long as human rights are conceived of as universal human rights they will tend to operate as a globalized localism, a form of globalization from above. To be able to operate as a cosmopolitan, counterhegemonic form of globalization human rights must be reconceptualized as multicultural (SOUSA SANTOS, 2007, p. 11). ${ }^{42}$

Por outro lado, para os defensores da internacionalização dos direitos humanos, citar a genealogia destes, como maneira de desconsiderá-los universais, serve para fundamentar a perpetuação das práticas de violações e não responde aos desafios da modernidade social e econômica, que se tornou global. Esta "concepção positiva” de um sistema internacional exige um nível de abstração no julgamento das quebras aos direitos humanos (de interpretação contextual dos regulamentos) e uma necessidade de lembrar atrocidades, em

\footnotetext{
${ }^{42} \mathrm{O}$ meu argumento é que, desde que os direitos humanos sejam concebidos como direitos humanos universais, tenderão a funcionar como um localismo globalizado, uma forma de globalização a partir do alto. Para poder operar como uma forma cosmopolita e contra-hegemônica de globalização, os direitos humanos devem ser reconceitualizados como multiculturais (SOUSA SANTOS, 2007, p. 11, tradução nossa).
} 
diversos pontos do globo, para mobilizar os homens em favor da luta por esses direitos, através do poder afetivo da memória das catástrofes, que pode ser transnacional (SANTOS, 2007).

Fato é que, a partir da década de 1970, em muitos lugares do mundo, os discursos sobre direitos humanos e memórias marcaram os movimentos sociais com essas perspectivas transnacionais. Orientado na direção à criação de um regime internacional de direitos, o movimento internacional pelos direitos humanos tentou (e segue tentando) lidar com a justiça de transição em diversos países, apoiando-se em exemplos concretos de violações, interpretando-as nos devidos contextos, com a finalidade de construir soluções jurídicas, políticas e morais para interromper a proliferação dos sofrimentos.

Em muitos países, a permanência de indivíduos e de atos ligados aos regimes autoritários ou ditatoriais em instituições democráticas limitou (e limita) as investigações, os julgamentos e as políticas de reparações aos danos causados às vítimas. Como alternativa, organizações de direitos humanos, vítimas e familiares passam a apelar para organizações internacionais e a debater internacionalmente as naturezas política e legal dos Estados procedentes, que, fundamentados na "reconciliação" nacional - no sentido do "perdão obrigatório", do esquecimento, e da impunidade -, não resolvem as violações cometidas internamente (CANTON, 2011, p. 263-290).

Assim, nas últimas décadas, a relação entre direitos internacionais e ações locais de movimentos sociais se desenvolve, confrontando as violações internas pelos organismos internacionais, que, de acordo com Reinhold Görling (2003, p. 195-205), passam a ser uma força social, unindo homens e movimentos em torno das imperfeições de instituições locais e dos anseios pela verdade e pela justiça. Esse denominado "ativismo jurídico transnacional" passou, então, a provocar os sistemas internacionais, a fim de que estes ajam diante das conjunturas nacionais, politizando-as sob outra perspectiva. Através de suas redes, o ativismo jurídico defende causas, ideias e normas, percebendo o direito e as normas internacionais enquanto instrumentos auxiliares para a resolução de conflitos e como estratégias que devem ser utilizadas pelos movimentos sociais nacionais (SANTOS, 2007).

\section{1 - O Sistema Interamericano de Direitos Humanos e seu papel na transição da região platina}

Como um organismo regional das Nações Unidas, a Organização de Estados Americanos (OEA) foi criada com a pretensão de ser uma instituição que pudesse 
desenvolver na região ações cooperativas em domínios cultural, econômico e político. Unidos por esses princípios, em um contexto pós-Segunda Guerra Mundial, países americanos consideraram consolidar diversos tratados e convenções, discutidos desde os anos 1890, e a assinar o Tratado Americano de Soluciones Pacíficas e a Declaración Americana de los Derechos y Deberes del Hombre - primeiro documento internacional sobre a temática dos direitos humanos, seis meses antes da Declaração Universal (ORGANIZAÇÃO DOS ESTADOS AMERICANOS, 1963).

Mediante a assinatura da Carta de la Organización de los Estado Americanos (1948), os Estados membros reafirmaram a adesão ao direito internacional e aos princípios básicos de solidariedade entre os povos: o exercício democrático representativo, as liberdades individuais e a justiça social baseada no respeito aos direitos do homem. A solidariedade na defesa das Américas era tema do Tratado Interamericano de Asistencia Recíproca (1947), que pretendia prevenir e reprimir ameaças e atos de agressão contra qualquer país americano.

A Declaração Americana dos Direitos e Deveres do Homem (1948), por sua vez, procurou estabelecer a dignidade humana, reconhecendo-a nas instituições jurídicas e políticas de cada país (por suas Constituições), com a finalidade de proteger os direitos essenciais dos homens e criar circunstâncias para se "alcançar a felicidade". Logo, determina, entre outros direitos e deveres, o direito à vida, à liberdade, à igualdade, à segurança, à livre opinião e etc.

Juntando esforços a favor dos direitos dos homens e das liberdades democráticas, efetuou-se, em 1959, a conhecida reunião de Ministros de Relações Exteriores dos países membros para discutirem a existência de países não democráticos, incompatíveis com o exercício deste modelo político pretendido para as Américas. Também se debateu a obrigação da OEA em proteger os direitos humanos (onde cita-se especificamente a liberdade de informação e opinião), mediante procedimentos judiciais, já incorporados nas Constituições locais (ORGANIZACIÓN DE LOS ESTADOS AMERICANOS, 1959). Neste sentido, pediuse à Comissão Interamericana de Paz a realização de um estudo sobre os Estados antidemocráticos nas Américas e suas violações aos direitos humanos, realizando um informe e algumas sugestões para solucionar o problema.

Percebendo a necessidade dessa constante vigilância, propôs-se, nesta reunião, a criação da Comissão Interamericana de Direitos Humanos (CIDH). Podemos observar, nesse princípio das atividades que precederam a Comissão Interamericana, uma posição contextualizada em Guerra-Fria, que considerou esforços contra países determinados como antidemocráticos ou contrários às pré-disposições políticas dos membros da OEA. 
Apenas em 1979, entra-se em acordo sobre o Estatuto da CIDH, que teria a função de observar e defender os direitos humanos, servindo como órgão consultivo da OEA, e entendendo os direitos humanos como aqueles definidos pela Convenção Americana sobre Direitos Humanos. Esta Convenção, assinada dez anos antes, rege as normas e regras sobre os direitos humanos, reiterando a Declaração Universal dos Direitos Humanos (1948). Desta forma, reafirmou as condições que permitem a cada pessoa possuir direitos econômicos, sociais e culturais e deveres civis e políticos (ORGANIZACIÓN DE LOS ESTADOS AMERICANOS, 1969).

Ela também instituiu a Corte Interamericana de Direitos Humanos (Corte Interamericana) como um recurso individual, caso haja violação aos direitos e deveres propostos pela Convenção e o esgotamento de procedimentos na Comissão Interamericana. Desta forma, os Estados membros, indivíduos ou a Comissão podem apresentar um caso para a decisão da Corte Interamericana, que possui a competência de interpretá-lo e julgá-lo, a partir da Convenção.

Assim, a CIDH e a Corte Interamericana são dois órgãos que se complementam, sem graus de hierarquia, com a finalidade de manter o compromisso contraído pelos Estados da OEA. À Comissão é atribuída o estímulo de consciência pelos direitos humanos, a formulação de recomendações e compromissos internacionais, estudos e informes para o desempenho de suas funções, a solicitação aos governos de informações sobre direitos humanos, a realização de observações nos Estados membros e etc. (ORGANIZACIÓN DE LOS ESTADOS AMERICANOS, 1979).

A Corte Interamericana se centra majoritariamente em casos onde há impunidade para os responsáveis por violações aos direitos humanos e atua através de quatro procedimentos: 1) garantir os direitos consagrados na Convenção, inspirando a jurisprudência nacional; 2) controlar a Convenção; 3) difundir sentença e informação; e 4) recomendar treinamento das forças de segurança, leis em matéria penal e medidas para julgamento de violadores (CASSEL, 2007, p. 197-207).

Logo, o que se considera o Sistema Interamericano de Direitos Humanos (SIDH) é esse conjunto total formado pelos Estados, que implementam obrigações internacionais; pelos órgãos políticos da OEA, que garantem os pressupostos coletivos do Sistema; pela CIDH e Corte Interamericana; e pelas vítimas e organizações que as mobilizam. O SIDH pretende, nessas relações, conscientizar sobre a situação dos direitos humanos locais e regionais, através de informação, e solucionar casos individuais, atentando para os desacordos com as normas internacionais. Além disso, ele cria um espaço de diálogo entre o Estado e suas vítimas, 
prevendo uma relação de forças mais equivalente (na medida do possível) do que aquelas que acontecem intrafronteiras (DULITZKY, 2007, p. 171-195).

Durante as transições pós-ditatoriais na América Latina, o SIDH procurou acompanhar processos políticos no trato do passado autoritário e delinear o direito à justiça, à verdade e à reparação para aquelas vítimas específicas (ABRAMOVICH, 2009). A CIDH e a Corte Interamericana passaram a ser apeladas pelas vítimas e organizações de direitos humanos como uma estratégia de diálogo e de negociação com os Estados, onde se denuncia práticas e impulsiona agendas nacionais - o que se conhece, no campo do direito, como "Estratégia Bumerangue". Ou seja, se lança uma proposta à nível internacional com o intuito de que as resoluções retornem ao território nacional, modificando relações locais entre Estados e justiças de transição (SANTOS, 2007).

\section{2 - A utilização do Sistema Interamericano de Direitos Humanos na Argentina}

Em mais de três décadas, o caso argentino de justiça de transição apresenta uma experiência relativamente consolidada, a partir da aplicação do direito penal. A condenação de alguns dos máximos responsáveis pelas violações aos direitos humanos tornou-se uma realização sem precedentes no mundo e um ponto de inflexão (um exemplo) nos esforços globais para se obter justiça para as vítimas (FILIPPINI, 2011, p. 19-47).

Desta forma, para o país, o direito internacional ofereceu um esquema moral, uma pressão política e uma reflexão sobre a impunidade, cuja CIDH e a Corte Interamericana tiveram importância, desde a década de 1970, quando recebiam diversas denúncias sobre violações que ocorriam no país. Convidada pelo governo militar argentino para uma observação in loco, a fim de comprovar sua competência em matéria de direitos humanos, a Comissão Interamericana efetuou sua primeira (e única) visita ao país, em setembro de $1979 .{ }^{43}$

Enviando representantes que entrevistaram membros da Junta de Governo, da Corte Suprema, ministros, autoridades civis e militares, ex-presidentes e representantes de diversas instituições - políticas, educacionais, religiosas, culturais, humanitárias, meios de comunicação, profissionais e pesquisadores -, a CIDH recebeu testemunhos sobre as violações cometidas sob a ditadura e intentou esclarecê-las. Ela percorreu as cidades de Buenos Aires, Tucumán e Córdoba, e realizou inspeções em recintos penitenciários,

\footnotetext{
${ }^{43}$ As visitas realizadas pela CIDH, aos longos dos anos, estão disponíveis para consulta no seguinte endereço eletrônico: <http://www.oas.org/es/cidh/actividades/visitas_todas.asp>. Acesso em: 03 nov. 2016.
} 
carcerários e centros militares de detenção (COMISIÓN INTERAMERICANA DE DERECHOS HUMANOS, 1980b, Capítulo II).

O Informe com os resultados desta observação colocou a comunidade internacional a par das violações massivas e sistemáticas e obrigou o governo militar a respondê-las internacionalmente. Segundo o referido Informe, desde 1975, a CIDH recebia inúmeras denúncias sobre prisões irregulares, torturas e desaparecimentos, que afetavam um grupo considerável de pessoas no país e cujas implicações estavam comprometendo a sociedade como um todo ${ }^{44}$. As irregularidades, que violavam os direitos à vida, à liberdade, à segurança e integridade pessoal, à justiça, à liberdade de opinião e expressão, aos direitos políticos e trabalhistas, e à liberdade religiosa, atingiam, de acordo com a CIDH, um número indefinido de vítimas no país (COMISIÓN INTERAMERICANA DE DERECHOS HUMANOS, 1980a).

Dando especial atenção ao "problema dos desaparecidos", a Comissão atenta para seus Informes Anuais, correspondentes aos anos 1976 e 1977, nos quais expressou a preocupação pela negativa do governo argentino sobre a sistemática de prisões com procedimentos inumanos, infringindo a integridade pessoal e a vida das vítimas. A incapacidade do governo em manter a segurança do Estado por meios legais manifestar-se-ia tanto na incerteza sobre a sorte dos desaparecidos, quanto na atitude inapropriada do mesmo Estado diante de órgãos nacionais e internacionais de proteção aos direitos humanos. Desta forma, a CIDH concluiu que

La "desaparición" parece ser un expediente cómodo para evitar la aplicación de las disposiciones legales establecidas en defensa de la libertad individual, de la integridad física, de la dignidad y de la vida misma del hombre. Con este procedimiento se hacen en la práctica nugatorias las normas legales dictadas en estos últimos años en algunos países para evitar las detenciones ilegales y la utilización de apremios físicos y psíquicos contra los detenidos (COMISIÓN INTERAMERICANA DE DERECHOS HUMANOS, 1980a, Capítulo III: El problema de los desaparecidos, sem paginação).

Assim, ela recomendou a realização de uma lista com a relação dos mortos e desaparecidos no país, retratando também informações sobre os últimos. Além disso, solicitou a criação de um registro central de detidos, a derrogação do Estado de Sítio, a libertação de

\footnotetext{
${ }^{44}$ Caso do ex-senador Hipolito Solari Yrigoyen (1976), caso do deputado Mario Abel Amaya (1976), caso de Gustavo Westerkamp (1976), caso do fechamento da oficina distrital Testemunhas de Jeová (1976), caso do sacerdote irlandés Patrick Rice (1977), caso de Enrique Larreta Pierro (1977), caso de Monica María Mignone (1977), caso de Nélida Azucena e seus cinco filhos (1977), caso da sueco-argentina Dagmar Hagelin (1977), caso de Monica Bustus (1977), caso de Jorge San Vicente (1977), caso de Rosa Ana Frigerio (1978), caso de Raúl Héctor Cano (1978), entre outros.
} 
indivíduos indevidamente presos, a investigação dos casos de tortura, a dotação de trato humanitário com os presos e processos legais para estas prisões.

Diante dessas denúncias, realizadas no âmbito internacional (que fora inclusive apoiada no discurso em Roma do Papa João Paulo II, no início dos anos $1980^{45}$ ), o governo militar ignorou as medidas recomendadas e respondeu que não poderia informar o paradeiro dos desaparecidos, uma vez que muitos deles possuíam antecedentes penais ou vinculações "subversivas" desconhecidas oficialmente. É famosa a coletiva de imprensa dada por Rafael Videla, na qual ele afirma que o país não tem nada a esconder e que, justamente por defender a liberdade e a dignidade do homem, eles haviam entrado nesta guerra contra o "terrorismo":

para defender la libertad y la dignidad del hombre, la Argentina tuvo que enfrentar este tremendo problema de una guerra en la que pago precio de sangre (...) eso ocurrió en defensa de los derechos humanos del Pueblo argentino (COLETIVA OFICIAL DE IMPRENSA, 1980, 1’50min). ${ }^{46}$

Desta forma, percebemos a inversão do uso do conceito de direitos humanos, fundamentado em uma liberdade e dignidade humana a serem alcançadas depois da eliminação do sujeito "subversivo" e na não concepção de que a própria prática de eliminação feriria os direitos humanos. Tal como Feres Jr. (2005) propõe, a exclusão do outro pelo não reconhecimento de sua existência e pela cultura do medo faz com que os direitos humanos sejam percebidos, por essa interpretação, como a liberdade no sentido de ser "livre" de uma ameaça.

Quando, em 1982, a Argentina perde a Guerra das Malvinas e o processo de deterioração da legitimidade dos militares se aprofunda, o governo orquestra sua saída do poder, publicando o Documento final de la Junta Militar sobre la guerra contra la subversión y el terrorismo (1983a), onde fundamentava a auto-anistia dos militares. Nele, os militares assumiam a responsabilidade pela "guerra antissubversiva" e desqualificavam as denúncias de desaparecimento, a partir de um apelo ao juízo divino por seus atos e uma continuidade legal de decretos firmados pela ex-presidente Isabel Perón. ${ }^{47}$

Essa regulamentação foi questionada pelos movimentos de direitos humanos e pelo primeiro presidente eleito pós-ditadura, Raúl Alfonsín, que a considerou inconstitucional e enviou ao congresso um conjunto de decretos para proteger os direitos humanos. Entre eles, o

\footnotetext{
${ }^{45}$ Sobre diferentes papéis de grupos que faziam parte da Igreja Católica durante a ditadura argentina, Cf. VERBITSKY, 2010; MIGNONE, 1987; PADRÓS, 2015; e NOVARRO; PALERMO, 2003, entre outros.

${ }^{46}$ Para ter acesso à coletiva de imprensa completa, ver: 〈https://www.youtube.com/watch?v=3AlUCjKOjuc〉. Acesso em: 17 jul. 2016.

${ }^{47}$ Em 5 de fevereiro de 1975, por exemplo, Isabel Perón assinou o decreto 261/75, que permitiu às Forças Armadas intervir e aniquilar os "subversivos" da região de Tucumán, onde atuava a guerrilha do Ejército Revolucionário del Pueblo (ARGENTINA, 1975).
} 
decreto 187/83 que conformou a Comisión Nacional sobre la Desaparición de Personas (CONADEP), a primeira comissão do mundo para investigar os crimes de ditaduras, em especial, a questão dos desaparecidos, abordada no próximo capítulo.

Em 1985, iniciou-se, no país, o primeiro julgamento de crimes contra a humanidade (Juicios de las Juntas) e crimes de guerra (para julgar o caso de Malvinas), desde o julgamento de Nuremberg. Conduzido por uma Corte Civil, composta por seis juízes, foram denunciados 709 casos, com 833 testemunhas, para julgar crimes de sequestros, torturas, desaparecimentos forçados e assassinatos durante a chamada, naquele momento, "guerra suja". 48

A novidade desse juízo estava não apenas na ideia de punição para os responsáveis por um golpe de Estado - fato inédito na História nacional, que sofreu com golpes em 1930, 1955 e 1966 - pelo terrorismo estatal, como também na modalidade utilizada, com audiências orais e públicas. Normalmente, os processos penais eram realizados em audiências escritas, sem a participação direta das partes envolvidas, e as audiências públicas, com depoimentos dos envolvidos nos casos, deu imensa visibilidade às informações e experiências das vítimas, transformando o cenário de disputa política (KAUFMAN, 1987).

Em suas memórias, Raúl Alfonsín (2013) afirmou que o objetivo desses juízos não era condenar todos aqueles que violaram os direitos humanos no país, o que seria um "objetivo inalcançável", e sim, obter um castigo exemplificador. Determinar, pois, que, independentemente do poder de um grupo social, ninguém estava acima da lei.

No entanto, o grande alcance desses juízos foi tornar ainda mais público contexto repressivo ditatorial e "comover" à opinião pública em torno das vítimas do sistema. Logo, em meio às sentenças, o mês de outubro de 1985 é marcado, na cidade de Buenos Aires, pelas ameaças de bombas em escolas e atentados contra a sede do Comando do Exército, automóveis de chefes militares e contra oficiais na ativa, incluindo o caso de ameaça à casa do Ministro do Interior. O governo decide decretar o Estado de Sítio no país, por um período de 60 dias, enfatizando o cumprimento de direitos políticos e individuais no processo eleitoral a ser realizado no mês seguinte, mas ocasionando manifestações de grande porte contra esse decreto, que recordava tempos ditatoriais (PRIETO, 1985).

No final do ano de 1986, o presidente decide assinar a Ley de Caducidad de la Acción Penal, conhecida como Punto Final (ARGENTINA, 1986), pretendendo, através da extinção

\footnotetext{
${ }^{48}$ O Archivo Memoria Abierta disponibiliza para consulta 530 horas de gravações desses juízos, realizadas pela emissora estatal Argentina Televisora Color. Um compilado pode ser visto em: <http://www.memoriaabierta.org.ar/juicioalasjuntas/>. Acesso em: 03 jul. 2016.
} 
de causas não julgadas, limitar temporalmente os processos dos Juicios e, ao mesmo tempo, acelerar aqueles já em andamento. No entanto, a consequência dessa ação foi uma hiperatividade judicial, para se cumprir o prazo, que superou o número de penalizações desejado oficialmente, ocasionando na instituição militar uma espécie de sentimento de estar constantemente em julgamento.

Em princípios do ano seguinte, se instala, portanto, uma crise militar, apoiada por setores da imprensa, demandando o fim dos Juicios de las Juntas. O major Ernesto Barreiro, citado em acusações de crimes de torturas, comunicou sua decisão de não apresentar-se à Justiça e pediu apoio ao tenente coronel Luis Polo que o refugiou no Regimento 14 de Infantería Autotransportada. Pela insubordinação, lhes foram dadas as baixas do serviço militar, o que causou revolta nas bases da instituição (ALFONSÍN, 2013).

O panorama de tensão política se aprofundou, quando o tenente coronel Aldo Rico abandonou seu regimento, em Misiones, para tomar controle da Escuela de Infantería na Capital Federal. E, assim, várias unidades das Forças Armadas foram sendo ocupadas em todo o país, acompanhando as ações do coronel Rico. Apesar da negociação entre governo e esse movimento específico, parte dos militares, desconformes com a decisão de retirarem-se das ocupações, sublevou-se em Salta e Tucumán, sob a liderança do tenente coronel Ángel León. Os denominados Carapintadas demonstraram a insubordinação das Forças Armadas ao governo democrático e pressionaram a ação governamental para reformar o Código de Justiça Militar.

Desta forma, em finais de 1987, Alfonsín assina a lei de Obediencia Debida (1987), anistiando aqueles que executaram tarefas em subordinação aos seus superiores. De acordo com Alfonsín, como ele jamais aceitaria a anistia decretada pela Junta Miliar, seu governo conseguira que os principais responsáveis pelos "atos aberrantes" tivessem sido julgados, logo, apresentou uma solução para a não impunidade no país - com isso, ele critica a atitude posterior do governo Carlos Menem (Partido Justicialista) ao decretar a impunidade: "El indulto, curiosamente, fue decretado por un justicialismo que, siendo oposición, me exigía meter presa a casi toda la oficialidad de las Fuerzas Armadas" (ALFONSÍN, 2013, p. 80).

Contudo, as crises no país não cessaram com essa concessão governamental. Uma série de greves levadas tanto pelos sindicatos, quanto por organizações agropecuárias, tomou conta do cenário nacional. O fim do ano de 1987 e início de 1988 ainda foram marcados por reivindicações e pedidos de anistias para os militares, ocasionando os levantamentos do Exército em Monte Caseros e Villa Martelli. E, em janeiro de 1989, acontece a tomada do quartel de La Tablada. 
O Movimiento Todos por la Patria (MTP), formado por ex-militantes do Ejército Revolucionario del Pueblo (ERP) e influenciado pela Revolução Sandinista, na Nicarágua, ocupou parcialmente as dependências do quartel de La Tablada, buscando uma insurreição popular em favor da revolução. Segundo o MTP, eles tentavam impedir um suposto golpe de Estado, planejado por Carlos Saúl Menem e o coronel Mohamed Alí Seineldín - um dos membros das rebeliões dos Carapintadas (HILB, 2007).

Apesar das polêmicas em torno dos objetivos e da ação do MTP neste momento, fato é que as Forças de Segurança recuperaram as dependências do quartel, com um combate de aproximadamente 30 horas, que resultou em 29 mortes. E, com o término da operação, agentes do Estado incorreram em métodos de repressão com graves violações aos direitos humanos, como torturas, fuzilamentos e desaparecimentos. Isto demonstrou que os métodos de repressão das forças policiais e das Forças Armadas continuariam sendo utilizados em democracia, assim como permaneceriam não reconhecendo os direitos internacionais como pautas dessas instituições.

Sem a responsabilização pelos eventos, em 1992, os pais de Guillermo Maqueda (membro do MTP) apelam à Comissão Interamericana, para que esta intercedesse a favor do filho, condenado à 10 anos de prisão pelo ataque. A CIDH entra com um processo na Corte Interamericana, solicitando que se declarasse a Argentina culpada pela violação dos direitos de Maqueda em ser ouvido por um tribunal imparcial, com presunção de inocência e garantias judiciais, e que esta declarasse sua liberdade imediata, por via do indulto, indenizando-o por danos morais. O Estado entra em acordo, libertando Maqueda em 1994 (CORTE INTERAMERICANA DE DERECHOS HUMANOS, 1995).

Três anos depois diversas vítimas ingressaram com pedido de investigação internacional sobre os feitos realizados em La Tablada, considerando um total de 49 vítimas de crimes de torturas, execuções extrajudiciais e desaparecimentos, além de uso excessivo da força no momento de combate e nas prisões. Nesta causa, a CIDH aceita o argumento dos peticionários sobre a falta do Estado na sua obrigação em investigar o caso, atuando de maneira a evitar a elucidação do mesmo e discriminando os presos com base na sua postura política (COMISIÓN INTERAMERICANA DE DERECHOS HUMANOS, 1997).

Com a finalização antecipada do governo de Alfonsín, Carlos Menem, vencedor das eleições de 1989, decide conceder, enfim, os indultos demandados pelas Forças Armadas aos condenados pelos juízos precedentes. Em outubro de 1989, Menem indultou todos os chefes militares processados e que não foram beneficiados pelas leis de Punto Final e Obediencia Debida (exceto o ex-general Carlos Guillermo Suárez Mason, extraditado para os Estados 
Unidos), todos os membros de grupos guerrilheiros e pessoas acusadas de "subversão" (exceto os condenados por La Tablada), militares uruguaios, participantes das rebeliões militares dos anos 1987 e 1988 e ex-membros da Junta de Comandantes na condução da Guerra das Malvinas. ${ }^{49}$ Em dezembro de 1990, ele indultou um novo grupo de pessoas: exmembros das Juntas de Comandantes condenados nos Juicios de las Juntas e militares condenados por crimes de lesa humanidade, como Jorge Rafael Videla, Emilio Massera e Roberto Viola, o líder dos Montoneros Mario Firmenich ${ }^{50}$, Norma Kennedy e Duilio Brunello (condenados por má gestão de fundos públicos) e Martínez de Hoz (ex-Ministro de Economia, condenado por participação em torturas). ${ }^{51}$

Logo após ao Punto Final, a CIDH começa a receber causas contra o governo argentino, denunciando as leis de impunidade e considerando que estas violavam o direito às garantias judiciais, previstas na Convenção Americana, assinada pela Argentina em 1984. Em 1989, essas denúncias foram ampliadas contra os indultos (COMISIÓN INTERAMERICANA DE DERECHOS HUMANOS, 1993).

A estratégia adotada de defesa do governo argentino contra as acusações na CIDH era a de que tais crimes haviam ocorrido antes da assinatura da referida Convenção pelo país e de que o Estado enfrentou o problema das violações, diferentemente de outros países na América Latina - respondendo-as com "reconciliação nacional" e consolidando a democracia, através do Nunca Más e das indenizações às vítimas e seus familiares.

A CIDH, considerando a falta de recursos internos idôneos para se anular tais medidas na Corte Suprema local, aceitou as denúncias contra as leis de impunidade. Publicou, portanto, um Informe, entendendo que estas tinham caráter de anistia e foram posteriores à assinatura pelo país do compromisso com a Convenção. Desta forma, a Argentina estaria privando o direito à proteção e às garantias judiciais de seus cidadãos, e a CIDH recomendou a compensação dos peticionários ${ }^{52}$ e a elucidação de suas denúncias.

Todavia, as determinações da CIDH contrárias à legislação ficam em suspenso até 1995, quando o cenário nacional se modifica. Neste ano, o ex-capitão de corveta Adolfo Scilingo começou a declarar publicamente sua participação em operativos que, com aviões da Marinha, jogavam desaparecidos em mar aberto ou rios - os "vuelos de la muerte" (VERBITSKY, 1995a). A “crise de consciência” de Scilingo fora iniciada nos anos 1990, a

\footnotetext{
${ }^{49}$ Decretos N.1002; 1003; 1004; 1005 de outubro de 1989.

${ }^{50}$ Cf. CELESIA; WAISBERG, 2010.

${ }^{51}$ Decretos N.2741; 2742; 2743; 2744; 2745; 2746 de dezembro de 1990.

${ }^{52}$ Em 1993, o governo celebrou audiências, com intermediação da Comissão, para uma solução amistosa com os peticionários da causa, a fim de estabelecer indenizações para encerrar casos sobre violações aos direitos humanos.
} 
partir do indulto dado ao ex-general Rafael Videla, que lhe ocasionou o impulso de escreverlhe uma carta rogando para que se falasse a verdade sobre os desaparecidos. Na carta, Scilingo protestava:

Como respuesta ante el tema de los desaparecidos usted dijo: hay subversivos viviendo con nombres cambiados, otros murieron en combate y fueron enterrados como $\mathrm{NN}$ y por último no descarto algún exceso de sus subordinados. ¿Dónde me incluyo? ¿Usted cree que estos traslados realizados semanalmente eran productos de excesos inconsultos? Terminemos con el cinismo. Digamos la verdad. Dé a conocer la lista de los muertos, pese a que en su momento no asumió la responsabilidad de firmar la ejecución de los mismos. La injusticia condena que dice que cumplió fue con la firma de un presidente ordenando en juicio, con la firma del fiscal solicitando condena, con la firma de jueces firmando sentencia. Todos, equivocados o no, dieran la cara y su firma. Nosotros todavía cargamos con la responsabilidad de miles de desaparecidos sin dar la cara (SCILINGO apud VERBITSKY, 1995a, p. 5).

Ele nunca obteve resposta de Videla, assim como nunca obteria resposta de nenhum superior que escrevera solicitando os nomes dos desaparecidos e a descrição das práticas e métodos de eliminação dos "inimigos". Resolveu formular, pois, uma denúncia criminal em um Juizado da Capital, conseguindo, enfim, a comoção dentro das Forças Armadas e a visibilidade para falar publicamente. A partir desse ato, deu uma entrevista ao jornalista Horacio Verbitsky, que lançou o livro com os conteúdos da mesma - traduzido para o português, francês, inglês e italiano - e apareceu na mídia argentina e internacional dando testemunho como o "militar arrependido" do sistema repressivo (VERBITSKY, 1995b).

Para Scilingo, a Escuela de Mecánica de la Armada lhe ordenava atuar à margem da lei e, desta forma, o transformou em delinquente, cúmplice de seus ex-superiores (VERBITSKY, 1995a). Tanto ele quanto aqueles que cumpriram ordens foram convencidos a pensar que os prisioneiros eram "subversivos" em uma "guerra" para salvar o país. Logo, não questionavam a instituição, contudo, automatizavam as atividades repressivas, em um esquema de rotatividade, no qual todos tornavam-se responsáveis por crimes.

Tomando ciência de que havia participado em crimes contra a humanidade, ele declarou sua responsabilidade por dois traslados aéreos para atirar pessoas nas águas do Atlântico: o primeiro voo efetivado com 13 pessoas a bordo de um Skyvan da prefeitura de Buenos Aires e o segundo voo com 17 pessoas, em um Electra da Aviação Naval. Às vítimas, dizia-se que seriam trasladadas a uma cadeia no sul e que deveriam ser vacinadas, recebendo, assim, a primeira dose de anestesia, reforçada no voo, de onde eram atiradas nuas nas águas. Esta operação se realizava às quartas e sábados, na ex-ESMA, e levou em torno de 15 a 20 pessoas à morte por voo durante dois anos. 
Com esse sistema de eliminação, começaram a aparecer os corpos, sem explicação de onde provinham e, por isso, o sistema teve de ser aperfeiçoado. No programa de Mirtha Legrand, Scilingo afirmou que

\begin{abstract}
ese maquiavélico y siniestro aparato fue perfeccionándose porque en el año 1976, cuando se produjo el primer vuelo (...) sobre el Río de la Plata, los primeros desaparecidos cayeron cerca de Uruguay. Esos cuerpos, el gobierno de la época de Uruguay dijo que eran producto de un motín coreano. Después, apareció un cuerpo de una mujer y dijeron que era un cuerpo de... varias historias. Y después, como estaban vestidos, aparecieron monedas argentinas y fueron identificándolos y se fue modificando el sistema (SCILINGO apud PROGRAMA ALMORZANDO CON MIRTHA LEGRAND, 1997, 1'40min).
\end{abstract}

Segundo o juiz Baltasar Garzón, o argumento de subordinação aos superiores para cometer atos inumanos, adotado por Scilingo (e diversos outros responsáveis por crimes contra direitos humanos, cometidos nas ditaduras do Cone $\mathrm{Sul}^{53}$ ), esconde a sensação de impunidade e de poder, que os agentes repressivos possuíam na situação em que se encontravam como algozes. Além disso, tal como proposto por Arendt (1999), analisando o caso do nazismo, ao argumentarem uma culpa individual e de consciência diante de atos inumanos cometidos pessoalmente, e ao se considerarem enquanto subordinados em uma cadeia de comando, os algozes retiram-se de uma culpa penal por haverem cometido crimes hábeis de penas judiciais.

La mentalidad del verdugo siempre tiene sido la misma. Matar por obligación. Matan y torturan por costumbre. Por cumplir órdenes. Son personas que aparentemente son normales pero que se mueven en un círculo muy restrictivo, dónde saben que su poder no se pierde. Dónde no van a tener que enfrentarse en un debate, en un dialogo, en una mirada a sus victimas en igualdad de condiciones. Entonces se cubren. Como los delincuentes que son (GARZÓN apud EL ALMA DE LOS VERDUGOS, 2007).

Desta forma, o argumento de Scilingo, para o caso dos Vuelos, separava a prática do crime de "saber sobre atos desumanos" e cometê-los de acordo com a demanda superior. Para ele, seu trabalho dentro da ESMA era diferente do trabalho dos torturadores - aqueles que realizavam uma tarefa designada especialmente para um sujeito "capaz de fazê-la" por sua perversidade. Os torturadores tinham uma "maldade nata", que ele não possuía. Apesar de

\footnotetext{
${ }^{53}$ Outros casos de "militares arrependidos" foram aparecendo nessa mídia, que abria espaço para tais declarações: o ex-cabo Víctor Ibáñez; o torturador Julio Simón, o capitão Héctor Vergez; e, inclusive, o exalmirante Emilio Massera. Dois anos depois das declarações de Scilingo, por exemplo, Miguel Etchecolatz, segundo Chefe de Polícia de Buenos Aires, na época de ditadura, condenado à 23 anos de prisão nos Juicios e anistiado pela Ley de Obediencia Debida, foi ao programa televisivo Hora Clave, para divulgar seu livro La Otra Campana del Nunca Más, e negou a existência de um sistema repressivo ditatorial, fundamentado no desaparecimento, justificando sua responsabilidade, através da obediência (FELD, 2016, p. 77-101).
} 
assentir que havia presenciado torturas, Scilingo afirmou que nunca as praticou e essa diferença entre assistir e participar era fundamental para diferenciar os sujeitos do sistema repressivo (VERBITSKY, 1995a).

Ante todo, yo quiero aclarar es que no soy un facineroso. No soy un facineroso porque los facinerosos duermen perfectamente todas las noches. Yo, desde que hice el primer vuelo, sino uso lexotanil o alcohol, no duermo. Nosotros ganamos una guerra. De eso no tengo dudas. Yo que hice, le hice total e absolutamente convencido. Pero la guerra terminó y quedaron los hombres, quedaron desaparecidos y quedaron muchas heridas. Yo en ese momento, dadas como están las cosas, quiero decirles a todos los que me están escuchando que yo me siento un asesino (SCILINGO apud PROGRAMA HORA CLAVE, 1995).

Durante essas declarações e diante da comoção pública que elas causaram, Scilingo foi perseguido, lhe ofereceram dinheiro para silenciar-se, o ameaçaram e o prenderam sob acusação de fraude. ${ }^{54}$ Quando solto, depois de dois anos encarcerado, foi sequestrado e agredido. Então, decidiu ir à Espanha e declarar diante de Baltasar Garzón, convencido de que este iria protegê-lo como testemunha (VARSKY, 2011, p. 49-74). No entanto, o juiz entendeu que ele era responsável por delitos de lesa humanidade, e o prendeu ainda em depoimento. Ele foi condenado à 1084 anos de prisão.

As declarações do ex-capitão vieram em um contexto bastante específico no país. Em 1994, Menem havia decidido ascender os capitães de fragata Juan Carlos Rolón e Antonio Pernías para a patente de capitães de navio. Acontece que ambos os candidatos foram oficiais de inteligência da Escuela de Mecánica de la Armada e a imprensa divulga seus antecedentes, dando voz às vítimas e familiares de desaparecidos, que relatavam as participações de Rolón e Pernías em graves violações (VERBITSKY, 1995a, p. 07-10).

Juan Carlos Rolón efetuou tarefas a favor do almirante Emilio Massera e foi investigado pelo sequestro e morte de Mónica Jáuregui. Antonio Pernías havia sido preso, em 1987, por torturar as monjas francesas Alice Domon e Léoni Duquet, além de ser acusado por outras nove prisões ilegais e pelo massacre na Igreja de San Patricio. Ambos foram nomeados em denúncias da CONADEP, mas foram absolvidos pelo Punto Final, no caso de Rolón, e pela Obediencia Devida, que libertou Pernías.

$\mathrm{O}$ presidente Menem alegou, naquele momento, que nunca iria premiar oficiais que estivessem envolvidos em crimes contra a humanidade, contudo, ele já havia assinado as ascensões das patentes. Logo, a solução encontrada foi a de ratificar a decisão, através de uma

\footnotetext{
${ }^{54}$ Dois anos depois, o juiz Osvaldo Miguel Solimine, que o acusou e o condenou com provas ocultadas, foi destituído do cargo e condenado criminalmente por violação de domicílio, abuso de autoridade, prevaricado e associação ilícita (LIBERTARON..., 1997).
} 
seção pública no Senado. Os capitães, indecisos sobre as declarações e abandonados pelas Forças Armadas, que não se pronunciaram sobre os casos, decidiram depor na sessão, realizada em outubro de 1994.

O primeiro depoente foi Antonio Pernías, que apresentou sua trajetória militar até chegar aos trabalhos na ESMA, do qual deixou claro que suas atividades eram parte de um sistema de comando: "yo no fui un voluntario para permanecer en el Grupo de Tareas de la Escuela de Mecánica de la Armada. Me tocó igual que tocó a muchos" (PERNÍAS apud VERBITSKY, 1995a, p.81). Reconheceu que a tortura era uma "arma" para a "guerra sem lei" e admitiu sua relação com o assassinato das monjas, sugerindo que, no caso dos padres, a Polícia Federal também estaria envolvida. No entanto, seu discurso retratou a impossibilidade de tomar outra decisão dentro da instituição, pois havia uma hierarquia a ser obedecida.

Contra esse argumento, o senador Ricardo Lafferriere questionou a compreensão de Pernías sobre ordens superiores, contestando-lhe:

Usted sabe que desde la Segunda Guerra Mundial el concepto de la obediencia ciega y mecánica ha cambiado sustancialmente, que hoy existen reglas básicas de convivencia humana que cualquier hombre, sobre todo aquellos que tienen la posibilidad de dictar normas u órdenes, tiene que tomar como base siempre para poder llevar adelante su misión, y esto implica estas normas básicas de humanidad (LAFFERRIERE apud VERBITSKY, 1995a, p. 85).

O segundo depoente também declarou haver cumprido com deveres na instituição e, por isso, ter participado de grupos de tarefas que estiveram a cargo da "repressão ao terrorismo". Juan Carlos Rolón disse ao senado que tampouco possuía outra opção e que, na época, estava de acordo com as práticas contra "subversivos" para "restituir a vida democrática na Argentina". Alegou ainda que o sistema de repressão, em sua rotatividade de atividades, fazia com que todos soubessem das ações na ESMA.

Antes desses depoimentos transbordarem à opinião pública, havia apenas um precedente de testemunho militar no país e, por isso, esses casos foram extremamente divulgados. O contra-almirante Horacio Mayorga - chefe da operação na base de Trewlew ${ }^{55}$, em 1972 - havia declarado no ano de 1985, que matava-se na instituição. Segundo Mayorga, as Forças Armadas (sensíveis aos sentimentos dos parentes dos desaparecidos, que não participavam da "guerra suja") possuíam a consciência de que a tortura e a morte eram condenáveis. Todavia, eles eram oficiais com deveres a serem cumpridos em favor da Pátria.

\footnotetext{
${ }^{55}$ Em 22 de agosto de 1972, dezesseis guerrilheiros, fugidos da prisão de Rawson e detidos na base aérea Almirante Zar, em Trelew, foram fuzilados por ordens militares. Cf. MARTÍNEZ, 2007.
} 
A discussão no Senado sobre as patentes se prolongou até 1995. Esses episódios concluíram-se com a renúncia do Vice-Ministro de Defesa e de três subsecretários. Além disso, os oficiais perderam os direitos à aposentadoria e o congresso começou a pedir informações sobre os militares que fizessem pedidos de patentes para a Asemblea Permanente de los Derechos Humanos (APDH) e para o Centro de Estudios Legales y Sociales (CELS), além de analisar os documentos da CONADEP (MORALES, 2011, p. 79-110).

Neste período de impunidade, com os debates sobre responsabilidades vindo à tona, os movimentos pelos direitos humanos começaram a mobilizar também estratégias locais para questionar o contexto e apresentar recursos para se conhecer o destino dos desaparecidos. Por um lado, com a reforma constitucional (1994), que estabeleceu a inabilidade de ocupação dos cargos públicos por aqueles que tivessem interrompido a ordem constitucional (um marco no processo de constitucionalismo transicional), as vítimas, os familiares de desaparecidos e os organismos de direitos humanos utilizaram diversos mecanismos para impugnar funcionários públicos que seguiam atuando.

Por outro, moviam-se processos judiciais pela verdade, criando uma estratégia inovadora, que habilitou um novo espaço de recuperação e recopilação de informações. O primeiro desses processos foi apresentado à Câmara Federal, em 1995, por Emilio Mignone, dentro da denominada "Causa ESMA", para obter informações sobre o paradeiro de sua filha e sobre as dependências militares em que fora aprisionada (ROMANIN, 2013b, p. 5-23).

Mignone já havia apresentado, em 1977, a denúncia da prisão no ano anterior de Mónica María Candelaria Mignone, de 24 anos, para a CIDH. Afirmando desconhecer o paradeiro da filha, a causa de sua detenção e se ela encontrava-se viva ou morta, Mignone pediu seu habeas corpus em diversas instituições, que negaram a prisão da mesma. A Comissão Interamericana recomendou ao governo libertar Mónica, informando onde ela se encontrava detida, recomendação esta ignorada pelo Estado argentino (COMISIÓN INTERAMERICANA DE DERECHOS HUMANOS, 1978a). Nos anos 1990, Mignone ganha a causa em instância nacional de justiça para saber o paradeiro da filha desaparecida.

Neste mesmo sentido, Carmen Aguiar Lapacó solicitou saber sobre o paradeiro de sua filha Alejandra Lapacó, na "Causa Club Atlético". Carmen e Alejandra foram detidasdesaparecidas, em março de 1977, e levadas ao Club Atlético, onde foram torturadas física e psicologicamente. Carmen foi liberada e iniciou a busca pela filha, apresentando habeas 
corpus e pedindo sua liberação. No entanto, apenas nos processos dos Juicios de las Juntas foi que tomou conhecimento do destino de Alejandra, vítima dos traslados da morte. ${ }^{56}$

Diferentemente de Mignone, o processo de Lapacó não obteve resultados positivos, devido aos diversos recursos interpostos pelos advogados das Forças Armadas e os conflitos nas instâncias judiciais. Persistindo no argumento de violação aos compromissos e tratados internacionais, a peticionária denunciou à Comissão Interamericana o governo argentino pelo sequestro, privação ilegítima e tormentos de Alejandra, além da impunidade e silêncio sobre este caso. A CIDH aceitou a petição, admitindo que o Estado lhe negara o direito à verdade e à justiça (COMISIÓN INTERAMERICANA DE DERECHOS HUMANOS, 2001).

O resultado dessas negociações trouxe outra dinâmica nacional de justiça, favorecendo o direito à verdade e ao desenvolvimento da modalidade de justiça transicional chamada de Juicios por la Verdad. Como estratégias não penais, os Juicios por la Verdad tratavam de ingressar na justiça apelando por informações, busca de crianças apropriadas e protestos éticos pela verdade (ROMANIN, 2013a). Iniciados em 1998, na cidade de La Plata, estes juízos buscavam saber as circunstâncias, os modos, os lugares, as datas, e as pessoas envolvidas em cada violação. Ao longo do tempo, foram espalhando-se por todo o país Bahía Blanca, Buenos Aires, Mendonza, Rosario, Córdoba, Salta, Misiones, Jujuy e Mar del Plata - e ressignificando a representação social do Terrorismo de Estado, assim como amenizando o sentimento de injustiça dos familiares de desaparecidos e sobreviventes.

Seus peticionários entendiam que, desta forma, poderiam demandar uma verdade simbólica, no que implicava conhecer os feitos repressivos, e uma verdade material para saber sobre o destino final dos desaparecidos. Além disso, conseguiram o apoio social e político, debater a noção de verdade e de vítimas, constituir procedimentos de audiências públicas e abertas à comunidade, e decidir quais testemunhos gostariam de recolher (entre eles, também os de violadores).

Nos anos 2000, congressistas apresentaram, enfim, o pedido de anulação das leis e suas invalidações foram decididas em tribunais e ratificadas pela Corte Suprema, no Caso Simón (2005). Neste caso, a Corte Nacional ditou a sentença que declarou as leis de Punto Final e Obediencia Debida como inconstitucionais e ordenou a prisão preventiva de Julio Héctor Simón, suboficial da Polícia Federal, pelo sequestro de José Poblete, sua esposa Gertrudis Hlaczik e sua filha Claudia Poblete, em 1978 (VALLE, 2006).

56 A entrevista de Carmen Lapacó ao Archivo por la Memoria pode ser encontrada em: <http://www.buenosaires.gob.ar/educacion/programasymemoria/archivos-por-la-memoria/carmen-lapaco>. Acesso em: 09 ago. 2016. 
José (cidadão chileno) e Getrudis militavam na Juventud Peronista e foram sequestrados junto da menina Claudia de poucos meses de idade. Todos foram levados ao Centro de Detenção El Olimpo e desapareceram. Em 2000, Claudia foi reencontrada pelas Abuelas de la Plaza de Mayo e teve sua verdadeira identidade restituída.

A sentença do caso Simón foi fundamentada no compromisso internacional aceito pela Argentina, considerando não apenas o Informe da CIDH de 1992, como também a Sentença da Corte Interamericana no caso Barrio Altos - Peru (CORTE INTERAMERICANA DE DERECHOS HUMANOS, 2001). Em junho de 2000, diante da execução de 15 pessoas e a tentativa frustrada de assassinato de mais 4 indivíduos, em Barrio Altos (1991), por efetivos militares e civis que compunham Esquadrões da Morte, a Corte Interamericana aceitou a denúncia da CIDH contra o Estado peruano por violar o direito à vida e à integridade pessoal dessas vítimas.

Neste caso, a Corte condenou o Estado peruano, em favor das vítimas considerando o argumento de que

El presente caso es fundamentalmente un caso gravísimo y tristísimo de ejecuciones extrajudiciales cometidas por agentes del Gobierno peruano, actuando en forma clandestina e ilegal ... Pero es también sobre ... la imposición deliberada de mecanismos legislativos y judiciales para impedir el conocimiento de los hechos y para impedir la sanción de los responsables. Es por eso que ... se trata no solamente sobre los hechos sangrientos que ocurrieron en Barrios Altos, sino también sobre la actitud del ex Gobierno del Perú de violentar sus obligaciones internacionales (cuyo) único objetivo era la impunidad. (...) Lo que hay que hacer en las próximas semanas, meses, días, es específicamente remover estos obstáculos en la legislación peruana para que efectivamente las víctimas de Barrios Altos tengan acceso a la verdad y a la justicia y tengan recursos para hacer valer sus derechos ante el Estado peruano (CORTE INTERAMERICANA DE DERECHOS HUMANOS, 2001, p. 13-14).

Desta forma, decidiu-se, por unanimidade, reconhecer internacionalmente o Estado peruano como responsável por tais crimes, declarar que a auto-anistia é incompatível com a Convenção Americana, e recomendar a investigação do caso Barrios Altos, determinando suas responsabilidades. Esses argumentos jurídicos internacionais fundamentaram os procedimentos de justiça de transição argentina, retornando às implicações penais, no país.

O tempo transcorrido entre a impunidade e a escolha pela penalização poderia haver favorecido o esquecimento ou a necessidade de se colocar um "ponto final" em etapas passadas para seguir ao futuro. No entanto, a resistência dos movimentos de direitos humanos (internos e externos à Argentina) foi fundamental para reabrir os juízos frente aos crimes do passado recente. Lutou-se pela reabilitação da justiça penal diante desses casos de violações, 
privilegiando a investigação e a responsabilização das mesmas. Assim, aceitou-se as normas do direito internacional e os juízos internos decidiram utilizá-las, considerando as leis nacionais insuficientes para dar conta das responsabilizações pelo passado (VARSKY, 2011, p. 49-74).

\section{3 - A utilização do Sistema Interamericano de Direitos Humanos no Paraguai}

Pouco tempo depois de haver iniciado seus trabalhos no território americano, a Comissão Interamericana começou a receber diversas denúncias relativas às violações de direitos humanos cometidas na República do Paraguai. Essas denúncias foram crescendo e levaram a CIDH a formular seu primeiro Informe sobre o país ainda em 1961. Entre os anos de 1963 e 1965, buscou-se o convite para a realização de uma visita in loco, a fim de averiguar as denúncias sobre o sistema repressivo no país, baseado no Estado de Sítio, na falta de proteção judicial aos direitos humanos, na prática da proscrição política, na falta de liberdade de imprensa e no controle do Partido Colorado, que não permitia a participação política da oposição. Esta visita foi negada diversas vezes e as autoridades paraguaias passaram a não cooperar com os trabalhos da CIDH sobre o país.

Neste sentido, o movimento de denúncias internacionais por paraguaios continuaram, seja na divulgação da imprensa ou pelo próprio sistema, cuja CIDH aceitou distintos casos relativos às prisões ilegais e desaparecimentos forçados, às repressões e prisões de estudantes, camponeses e de etnias indígenas, às prisões por motivos políticos, à falta de processos ou informações sobre essas pessoas (o governo paraguaio lançava diversas listas de presos dificultando a contabilização dos mesmos) e às torturas e mortes em cárceres. Um desses casos, por exemplo, é o da população Aché, que, em 1974, realizou a denúncia de perseguição da etnia, incluindo assassinatos de inúmeras pessoas, vendas de crianças, negativas de atenção médica, maus tratos e torturas, condições inumanas de trabalho e atos para destruir sua cultura (COMISIÓN INTERAMERICANA DE DERECHOS HUMANOS, 1977).

Da família Tupi-guarani, os Aché (Guayakí) são uma população não sedentária, mas com um território de caça delimitado por tradição, na região oriental do país (MUNZEL, 2008, p. 55-105). Durante a ditadura stronista e sua política anti-indígena, as pressões sobre a cultura e territórios indígenas se intensificaram, através do Departamento de Assuntos Indígenas, que regulava códigos de trabalho, estatutos agrários e de terras e a assimilação de comunidades inteiras. Estas eram consideradas "estorvos" para a consolidação do "progresso", pensado como políticas econômicas através, por exemplo, do Tratado de Itaipú 
(1973), do Tratado da Ponte da Amizade (1956 e 1965) ou pela exploração das terras por empresas argentinas, inglesas e estadunidenses (MELIÀ, 2008, p. 135-146).

Desde 1972, começou a se falar no genocídio dos indígenas paraguaios, não apenas pela clara diminuição da população no território (no caso dos Aché, por exemplo, em 1960, contabilizavam-se 6 milhões, 831 mil e 306 pessoas, e este número fora reduzido, em 2008, para mil e seiscentas pessoas), como também pela tentativa de eliminações culturais dessas populações (CLAVERO, 2008, p. 23-42). E essa informação sobre o genocídio no país ainda é muito difícil de ser trabalhada, principalmente porque as violações aos direitos humanos dessas populações seguem acontecendo.

Como resposta às denúncias da CIDH, no ano de 1977, o governo declarou que

(...) la política del Gobierno del Paraguay no es una política de genocidio de los Indígenas Aché, sino una política orientada a promover la asimilación y ofrecer protección dentro de las posibilidades de recursos limitados, habiéndose establecido la 'Colonia Nacional Guayakí' en 1960. Esta conclusión preliminar no excluye la preocupación sobre la posibilidad de abusos por particulares en regiones remotas del territorio del Paraguay (COMISIÓN INTERAMERICANA DE DERECHOS HUMANOS, 1977, sem paginação).

Considerando que as quebras dos direitos humanos dos povos indígenas paraguaios encontravam-se como "abusos por particulares em regiões remotas" do país, o governo ignorou as diversas denúncias que ocorriam sobre a própria Colonia Nacional de Guayakí (departamento de Caazapá), uma reserva formada nos anos 1960. Segundo essas, a colônia com pretensão de "proteção" à população Aché, converteu-se, nos anos 1970, em um campo para "amansar" os indígenas e os integrarem em trabalhos nas áreas rurais. Além disso, realizavam-se na região verdadeiras caças humanas para escravizá-los, prostituí-los ou eliminá-los (MUNZEL, 2008, p. 107-133).

Aceitando não considerar tais feitos como genocídio - um erro que vem sendo revisto pelas investigações paraguaias constantemente -, a CIDH recebeu a denúncia por graves violações aos direitos à vida, à liberdade, à segurança e integridade das pessoas, à proteção familiar, à preservação da saúde e bem-estar, ao direito ao trabalho justo e ao descanso. Recomendou ao governo que adotasse medidas para proteger a etnia e sancionar os responsáveis pelos feitos denunciados. O governo ignorou as demandas, afirmando respeitar os direitos humanos da população Aché.

Outro caso de denúncia também importante no sistema internacional foi o da prisão, em 1975, de aproximadamente 200 pessoas, das quais várias delas permaneciam desaparecidas. Segundo os denunciantes, as residências dessas pessoas foram invadidas, seus 
pertences roubados e elas levadas presas, sendo que algumas com informações e outras sem conhecimentos sobre seus paradeiros. Muitos casos de tortura foram relatados nessas prisões e algumas mulheres foram levadas grávidas. Sem resposta do governo, a CIDH presumiu as denúncias como verdadeiras e recomendou ao Paraguai a liberdade imediata dessas pessoas, investigações necessárias sobre as prisões e suas condições e sanções aos responsáveis por infringirem os direitos internacionais (COMISIÓN INTERAMERICANA DE DERECHOS HUMANOS, 1977).

Diante desses casos, a CIDH resolve, portanto, realizar um Informe sobre as Condições dos Direitos Humanos no país, publicado em 1978. Nele, recomenda o fim do regime de Estado de Sítio, em vigência por mais de 30 anos naquele momento, a legalização das prisões por autoridades competentes e declarações sobre informações dos detidos, a liberdade de pessoas detidas em virtude do Estado de Sítio, a assistência às mulheres grávidas e seus recém-nascidos em cativeiro, a punição e prevenção contra os procedimentos cruéis e inumanos nas prisões e um convite para a Comissão realizar a visita in loco no país (COMISIÓN INTERAMERICANA DE DERECHOS HUMANOS, 1978b) - os pedidos de visita pela Comissão serão inúmeros, durante os anos seguintes, mas apenas atendidos em 1990, já em democracia, quando se realiza a primeira incursão paraguaia da CIDH.

Sobre este Informe, o governo paraguaio comunicou a impossibilidade interna de se realizar tal visita, contudo, assegurou que o país vivia em "clima de liberdade e democracia". Informou que as acusações em matéria de direitos humanos eram falsas, realizadas por "inimigos da nacionalidade paraguaia" e que o governo estava disposto a cooperar com a CIDH e manter os direitos humanos no país, concluindo que

\footnotetext{
En defensa de los derechos humanos amenazados constantemente por los enemigos de nuestra nacionalidad el poder público aplica los preceptos que le facultan a mantener el orden y la legalidad. Me asiste la convicción de su digna presidencia tienen su origen en una errónea información o en la aviesa intención de dañar el nombre de mi Patria (COMISÓN INTERAMERICANA DE DERECHOS HUMANOS, 1978b, Introducción, sem paginação).
}

Desta forma, o argumento regional de que "se viola os direitos humanos em favor dos direitos humanos e da democracia" também se encontra presente, durante todo o período ditatorial deste país. A situação começa a se modificar em início dos anos 1990, quando introduz-se, então, discussões sobre a justiça de transição local.

E, em questões de justiça de transição, a relação do Paraguai com o Sistema Interamericano de Direitos Humanos é marcada pela decisão da Corte Interamericana sobre o caso Velásquez versus Honduras de 1988. Em 1986, a Corte Interamericana recebeu a 
denúncia sobre a prisão violenta do estudante Manfredo Velásquez por elementos da Dirección Nacional de Investigación das Forças Armadas de Honduras. Mesmo depois que várias testemunhas o viram sendo torturado e acusado de suposto delito político, o governo hondurenho seguia afirmando que Velásquez não se encontrava preso.

No entanto, testemunhos e documentos apresentados pela CIDH demonstraram a existência da prática de desaparecimento, amparada pelo poder público de Honduras, entre os anos 1981 e 1984, e da execução e sepultamento clandestino de Velásquez (COMISIÓN INTERAMERICANA DE DERECHOS HUMANOS, 1988). Durante o processo desenrolado pela Corte Interamericana, algumas testemunhas deste caso foram sequestradas e mortas, confirmando a continuidade das práticas de violações aos direitos humanos com a finalidade de "silenciamento" dessas vítimas.

A decisão final da Corte Interamericana sobre o caso foi marcada pela defesa de um processo e castigo contra os delitos aos direitos humanos, que não deveriam limitar-se à reparação econômica. No entanto, pela situação econômica hondurenha, a reparação deveria estender-se dos âmbitos materiais aos imateriais, investigando e julgando os responsáveis, entregando documentações, elaborando espaços para a educação em matéria de direitos humanos e etc.

Como caso base nas argumentações de casos levados à $\mathrm{CIDH}$, a condenação de Honduras fundamentou diversas denúncias sobre o período da ditadura stronista, em época de transição. Em 2004, por exemplo, a CIDH recebeu denúncias feitas pelo International Human Rights Law Group e o Comité de Iglesias para Ayuda de Emergencia (CIPAE) sobre violações dos direitos de liberdade pessoal, integridade, vida e garantias judiciais de Agustín Goiburú (fundador do grupo político MOPOCO, detido na Argentina e levado à Assunção), Carlos Mancuello e os irmãos Rodolfo e Benjamín Villalba (acusados de pertencer ao "grupo terrorista" que realizou um atentado contra Stroessner) ${ }^{57}$.

O Estado paraguaio é acusado, neste caso, de detenção ilegal, tortura e desaparecimento destes indivíduos, entre os anos de 1974 e 1977. Passado o processo à Corte Interamericana, esta seguiu os procedimentos de ouvir testemunhos, recolher documentos nos arquivos paraguaios e chamar peritos sobre a ditadura stronista e a Operação Condor para deporem (CORTE INTERAMERICANA DE DERECHOS HUMANOS, 2006a).

\footnotetext{
${ }^{57}$ Cf. ASERETTO, 2010.
} 
$\mathrm{O}$ argumento de defesa do Estado paraguaio era de que havia aberto, dentro da Defensoría del Pueblo ${ }^{58}$, uma instância para cuidar de indenizações às vítimas da ditadura stronista (PARAGUAY, 1996), que, apesar de demoradas, funcionariam como uma reparação dentro do próprio país.

[...E]s importante señalar que los familiares de las víctimas de la Dictadura del Gral. Stroessner en todo momento -en esta etapa democrática del paíshan tenido disponible el acceso a la justicia, sin que ningún órgano o agente del Estado haya obstruido o interferido a los mismos en su derecho de ejercer las querellas criminales o las correspondientes acciones civiles, de hacer uso de las garantías judiciales y de la protección judicial. En ese sentido, no se ha impedido a los familiares de las víctimas o sus representantes el acceso a la jurisdicción civil ordinaria para el reclamo de indemnización por daños y perjuicios, así como el acceso a otras instancias, como la Defensoría del Pueblo, a los efectos de requerir de manera independiente y autónoma las demandas judiciales e indemnización correspondiente, en virtud de la Ley No. 838/96. [...] Los familiares de las víctimas no han hecho uso de estos recursos judiciales o administrativos para obtener eventualmente una justa indemnización y ello no es imputable al Estado (CORTE INTERAMERICANA DE DERECHOS HUMANOS, 2006a, p. 11-12).

Sabemos que, mesmo sem uma legislação específica que impeça as vítimas paraguaias de ingressarem na Justiça contra agentes do Estado stronista, a permanência de atores envolvidos com o regime dentro dos círculos de poder no país faz com que os processos encaminhados não sigam os trâmites judiciais, sendo majoritariamente negados. Diante disso, a Comissão Interamericana argumentou que não existiria de fato essa pretensão do Estado paraguaio em solucionar os crimes cometidos durante a ditadura. E que suas vítimas continuavam pedindo por informações sobre os casos mencionados e pela justiça.

(...) los supuestos buenos oficios o intenciones del Estado "no existen en la realidad y en su pretensión por hacer creer de la existencia de esfuerzos de su parte por llegar a una solución amistosa no es creíble y carece de toda fuerza y consistencia", y la confesión del Estado de la mayoría de los hechos del presente caso hace cesar la controversia respecto de éstos. Así, consideran pertinente que la Corte declare mediante sentencia la verdad sobre los hechos y las violaciones cometidas contra las presuntas víctimas y sus familiares, así como la consecuente responsabilidad internacional del Estado (CORTE INTERAMERICANA DE DERECHOS HUMANOS, 2006a, p. 13).

\footnotetext{
${ }^{58}$ A Defensoría del Pueblo é uma instituição estatal, criada em 1995, e composta por um defensor parlamentar comissionado que, por cinco anos, possui funções de defesa aos direitos humanos, de canalização de reclamações populares e de proteção aos interesses comunitários. Tem o dever de receber e investigar denúncias de violações aos direitos humanos, emitir censura pública por atos e comportamentos de violações, fazer informes anuais, divulgando a situação do país, denunciar ao Ministério Público essas violações, solicitar habeas corpus, amparo e proteção às vítimas, executar programas para divulgar e promover o conhecimento e práticas aos direitos humanos e sugerir modificação de normas em órgãos públicos (PARAGUAY, 1995).
} 
Considerando os fatos dispostos, a decisão da Corte Interamericana foi bastante ampla. Ela aceitou diversas exigências de reparações às vítimas desta causa, mesmo enfatizando as medidas reparatórias já realizadas pela legislação de indenização e pelos trabalhos da Comisión de la Verdad y Justicia, a serem analisados no próximo capítulo. As reparações demandadas e aceitas foram, entre outras, as de indenização por danos aos familiares, de investigação das responsabilidades na detenção e desaparecimento dos indivíduos, de medidas para localizar e entregar os corpos dos desaparecidos, de pedido de desculpas públicas e oficiais às vítimas do regime, de implementação de material sobre direitos humanos no currículo escolar, de estabelecimento de lugares e datas para comemoração das vítimas e de apoio médico e psicológico aos seus familiares e sobreviventes.

Importante ressaltar aqui duas características impulsionadas, neste caso, que são levantadas por diversas argumentações dos organismos de direitos humanos no país. A primeira é a decisão da Corte em não aceitar o pedido de recomendação de justiça penal, inclusive negando aos peticionários a extradição de Stroessner, que se encontrava no Brasil. Essa argumentação vai contra todo o movimento de derrogação das leis de anistia, inclusive no próprio âmbito do Sistema Interamericano, que encontrava-se em atividade no início dos $\operatorname{anos} 2000$.

Desta forma, a CIDH para o Paraguai enfatizou o direito à verdade e às reparações econômicas e simbólicas, mas negou o direito das vítimas pela justiça penal. Ou seja, apesar do SIDH estar se pronunciando sobre as distintas anistias no Cone Sul americano, no caso paraguaio pronunciou-se contra as penalizações.

A segunda tem a ver com a grande presença do Sistema Condor como linha de argumentação para a responsabilidade do Estado paraguaio. Em um capítulo desta sentença, por exemplo, fundamentado em uma imensa literatura sobre o Sistema ${ }^{59}$, a Corte chama a atenção sobre a repetição dessa "política criminal", cuja "guerra contra a subversão" (hoje "guerra contra o terrorismo ou a delinquência") segue fundamentando crimes dos Estados práticas de torturas, detenções ilegais, sequestros, voos clandestinos, execuções extrajudiciais e desaparecimentos forçados.

Ela cita, inclusive, a resolução do Parlamento Europeu, que condena as ações da CIA em deportações e detenções ilegais com princípios de combater o terrorismo, considerando

\footnotetext{
${ }^{59}$ Cita-se, por exemplo, os estudos de Boccia Paz, de John Dinges, de Martin Almada, de Esteban Cuya, entre outros.
} 
inaceitáveis as práticas dos governos estadunidense e demais países responsáveis por essa “diplomacia”, que inclui práticas de torturas ${ }^{60}$. Assim, o

Cóndor redividus! Sus métodos y prácticas atroces e inhumanas siguen siendo seguidos y aplicados, en contexto distinto, en nuestros días! Cuando aprenderá el ser humano con las lecciones del pasado, con el terrible sufrimiento de las generaciones anteriores? (...) En definitiva, no se combate el terror con el terror, sino dentro del Derecho (CORTE INTERAMERICANA DE DERECHOS HUMANOS, 2006a, p.125-126).

Neste sentido, a Corte responsabilizou a esfera internacional pelas violações aos direitos humanos (que continuam a acontecer), e que necessitam de divulgação para que as populações lutem por seus direitos. Esta característica transnacional da repressão, além de ter sido um dos fundamentos da própria repressão paraguaia, foi também impulsionada pelo "encontro" com o Archivo del Terror (1992), cujos documentos são elementos-chaves na comprovação de um sistema repressivo internacional e da peculiaridade nacional, que modificou a justiça de transição no país.

\section{4 - A utilização do Sistema Interamericano de Direitos Humanos no Uruguai}

Mesmo havendo assinado a Convenção Americana de Direitos Humanos em 1969 e a ratificado em 1985, a justiça de transição uruguaia é caracterizada pelo desinteresse na realização dos preceitos estabelecidos em normas internacionais, devido sua opção de anistia interna, estabelecida pela Ley de Caducidad de la Pretención Punitiva del Estado (MARCHESI, 2012, p. 217-227).

Ainda durante a ditadura, o Sistema Interamericano foi recorrido por organizações de direitos humanos e indivíduos vítimas do Terrorismo de Estado uruguaio, que realizaram denúncias de crimes e violações ocorridas durante a ditadura. Em 1978, por exemplo, a Comissão Interamericana aceitou o caso de Jorge Mazzarovich, preso em outubro de 1974 e liberado pela Justiça Militar "em caráter definitivo" no ano seguinte.

No entanto, a polícia o submeteu ao processo de comparecimento à delegacia semanalmente e, em uma dessas oportunidades, o manteve detido por considerá-lo um "alto dirigente de uma associação ilícita". A denúncia na CIDH consistia que esta nova prisão, confirmada pela Justiça Militar, mantinha Mazzarovich incomunicável e submetido às práticas de tortura. Desta forma, recomendou sua liberação imediata e a investigação da

\footnotetext{
${ }^{60}$ Cf. EUROPEAN PARLIAMENT, 2006.
} 
denúncia pelo país, que não lhe respondeu sobre o caso (COMISIÓN INTERAMERICANA DE DERECHOS HUMANOS, 1978e).

Esses tipos de denúncias, realizadas desde a declaração do Estado de Guerra Interna (1972), levaram a CIDH a produzir um Informe sobre a Situação dos Direitos Humanos no Uruguai, publicado em 1978. Segundo ela, as denúncias, feitas por parentes de detidos, cidadãos e organizações, domiciliados no país e no exterior, aumentavam e chegavam a estabelecer um número variado entre 3 a 8 mil presos políticos naquele momento; cerca de 60 mil pessoas que haveriam passado pelas cárceres por motivos políticos e ideológicos, muitos desses sem informações dadas aos parentes ou com base legal da prisão fundamentada no Código Penal Militar; 25 mortos em prisões por consequência das torturas; e inúmeros casos de descrições de aplicação desses métodos nas cárceres uruguaias (COMISIÓN INTERAMERICANA DE DERECHOS HUMANOS, 1978c).

Assim, a CIDH recomendou a investigação das violações aos direitos à vida, à liberdade, à segurança e integridade das pessoas, à liberdade de opinião e expressão, o direito à justiça e ao processo regular e ao direito de participação política. Solicitou medidas apropriadas do governo em cooperar com a Comissão, reprimindo o abuso contra as pessoas detidas e libertando aquelas presas indevidamente. Pediu ainda o convite para a realização de uma visita in loco da mesma.

O governo uruguaio, entretanto, respondeu que as pessoas detidas e mencionadas nos casos denunciados à CIDH estavam presas com o fundamento do Estado de Guerra ou pelas "medidas de segurança"; que o número de internação de civis nos hospitais militares era resultado de enfrentamentos com as autoridades; e que as mortes de alguns deles não foram consequência de aplicação de torturas físicas - "en ningún establecimiento de detención, arresto o reclusión se ejercitan torturas o prácticas vejatorias de ninguna clase" (COMISIÓN INTERAMERICANA DE DERECHOS HUMANOS, 1978c, sem paginação). Neste sentido, negou o pedido de visita da Comissão Interamericana no país, confirmando uma "solução interna" para os problemas de alguns dos "excessos" - abusos individuais dentro da instituição.

Desta forma, a CIDH segue, ao longo dos anos ditatoriais, recebendo denúncias e solicitando ao país uma solução para as violações aos direitos humanos que ocorriam. Em 1984, por exemplo, denunciou-se à Comissão Interamericana a detenção do médico cirurgião Vladimir Roslik, falecido em prisão devido às aplicações de torturas (COMISIÓN INTERAMERICANA DE DERECHOS HUMANOS, 1984). 
Roslik havia sido preso junto a nove pessoas, em San Javier, onde foi comunicado a sua esposa sobre seu falecimento por uma parada cardíaca. A autópsia realizada pelos médicos das Forças Armadas foi contestada pela autópsia realizada à pedido da família, que constatou sinais de violência no corpo, de asfixia e águas nos pulmões, características provenientes da prática de tortura conhecida como "submarino".

No mês seguinte de sua morte, o coronel Federico Ledesma fez uma conferência de imprensa sobre o caso de Roslik, confirmando o processo de dois oficiais do Exército responsáveis por homicídio e irregularidades no serviço. Não houve, entretanto, demais informações sobre as sentenças dos mesmos e, temendo pela vida de outros detidos, a CIDH pediu informações adicionais ao governo e declarou a violação do direito à vida, à liberdade, segurança e integridade pessoal, à inviolabilidade de domicílio e prisão arbitrária, solicitando sanções aos responsáveis. Contudo, mesmo com a visibilidade internacional ${ }^{61}$ dada ao caso, o governo uruguaio decidiu não responder ao pedido, afirmando já haver realizado procedimentos internos para resolvê-lo.

Com o fim da ditadura e a declaração da Ley de Caducidad, as denúncias pelo Sistema Interamericano de Direitos Humanos ganham novas perspectivas. Mesmo considerando a tendência do Estado uruguaio em não responder aos Informes e recomendações da Comissão, fundamentando-se na consolidação de uma justiça de transição pelo argumento de "reconciliação" - no sentido de "perdão obrigatório" e impunidade -, entre junho de 1987 e abril de 1989, a CIDH recebeu oito denúncias de uruguaios, uma delas contendo nove peticionários contra o Estado.

Estas vítimas denunciavam os efeitos jurídicos da Lei N.15848/86 como uma violação aos direitos estabelecidos pela Convenção Americana, principalmente os de proteção e garantias de processos judiciais em casos de violações aos direitos humanos. Ponderando que o Poder Executivo confiou à Justiça Militar as investigações sobre estes crimes, os denunciantes colocaram em dúvida a imparcialidade dessas Forças nos procedimentos de investigação e afirmaram a privação de seus direitos de recorrer aos tribunais civis. A CIDH concebeu que a Ley de Caducidad encobria questões graves de violações e interpretou-a enquanto incompatível com a Convenção, recomendando ao governo a compensação pelas violações e medidas para esclarecê-las (COMISIÓN INTERAMERICANA DE DERECHOS HUMANOS, 1992).

\footnotetext{
${ }^{61}$ Cf. GUIGOU, 2009.
} 
Nestes casos, a Corte Suprema do país declarou a constitucionalidade da lei, aprovada em referendum nacional, e o governo manifestou seu exercício soberano sobre as medidas legislativas uruguaias, que "não violariam a Convenção ou nenhuma outra norma internacional". Afirmou que os denunciantes possuiriam outras vias de reparações, como indenizações ou pedidos de investigações internas.

Neste sentido, a posição governamental em relação à Ley de Caducidad foi a de argumentar sempre um erro da Comissão Interamericana em não ponderar o contexto “jurídico-político democrático" do país e a legitimidade interna da referida lei ${ }^{62}$. O Estado uruguaio considera que as leis de anistia devem ser vistas como parte de um programa de "pacificação nacional” e que as mesmas não limitam as investigações de violações e as indenizações, apenas eximem estes processos de serem levados à justiça penal.

Em 1989, um grupo de cidadãos e familiares de detidos-desaparecidos conformaram uma Comissão Nacional Pró-Referendum contra a Ley de Caducidad de la Pretensión Punitiva del Estado, obtendo assinaturas de mais de $25 \%$ do eleitorado para interpor o recurso de referendum sobre a causa. Neste, realizado em abril daquele ano, a cidadania uruguaia confirmou a lei. O Poder Executivo, através do presidente Julio María Sanguinetti, declarou, portanto, a anistia àqueles envolvidos na "confrontação da violência política", cujo processo, em algum momento, "pode ter englobado uma situação limite e discutível", que seria investigada. E concluiu que

es una discusión cerrada, que esta es una discusión perimida y que - luego de todo lo que hemos discutido y hecho - lo peor que podemos hacer es seguir dando vueltas en torno a una discusión que ya está terminada de un modo concluyente (SANGUINETTI apud SANGUINETTI ..., 1989, sem paginação).

Por outro lado, para as vítimas do sistema, a lei "tristemente confirmada pelo voto popular" passa a ser sinônimo de impunidade, sob discurso de uma "paz" impraticável diante da possibilidade de repetição das mesmas violações. Segundo Mario Benedetti,

(...) la historia del ser humano no es más que la historia de sus utopías. La humanidad sólo ha avanzado cuando ha corrido el riesgo de perseguir lo imposible, y es gracias a esos visionarios que la frontera de lo posible se fue ensanchando.

(...) La Comisión Nacional pro Referéndum nunca pidió venganza sino justicia, y sobre todo, conocimiento de la verdad. "La ignorancia no es inocencia sino pecado", decía el poeta Robert Browning. El resultado del referéndum impide el ejercicio de la justicia, pero no la búsqueda de la

\footnotetext{
${ }^{62}$ Existem inúmeras discussões sobre a relação entre número de exilados do país e o resultado da legitimidade interna dessa lei.
} 
verdad. Así que no se hagan demasiadas ilusiones: la seguiremos buscando. Con denuedo y con fe (BENEDETTI, 1989, sem paginação).

Quatro anos depois do Informe da CIDH sobre a Ley de Caducidad, movimentos de direitos humanos iniciam as Marchas de Silencio, a fim de pressionar o direito à verdade no país. Para estes movimentos, era necessário reconfigurar o conceito oficial de pacificação e reconciliação e iniciar uma campanha pela justiça e verdade. Fundamentando-se no cumprimento do artigo quatro da própria lei, no qual o Poder Executivo ficaria obrigado a recolher denúncias relativas às pessoas detidas-desaparecidas e esclarecê-las, as Marchas de Silencio saem às ruas todos os anos com essa demanda.

Apenas em 2000, o presidente Jorge Batle (Partido Colorado) negocia a exigência, compondo a Comisión para la Paz, com a finalidade de investigar o destino dos desaparecidos e as denúncias de violações aos direitos humanos, tema este do próximo capítulo. Nos termos da justiça penal, a CIDH e suas recomendações sobre a lei de anistia no país foram recuperadas em algumas decisões da Suprema Corte de Justiça uruguaia.

Em 2009, por exemplo, (no mesmo ano em que se votou novamente pela anulação da lei e perdeu-a), a Justiça sentenciou Gregorio Alvarez - Chefe do Exército (1978-1979) e expresidente do país (1981-1985) - por desaparecimento de 37 pessoas, entre os anos de 1977 e 1978, e Juan Carlos Larcebeau - capitão de navio - por traslados clandestinos da Argentina ao país e a coautoria na morte de 29 pessoas. Ambos foram condenados por homicídio agravado, no âmbito do Sistema Condor, e delito continuado de desaparecimento, com penas de 25 e 20 anos de prisão, respectivamente. Esta sentença afirmou que

Toda violación de un derecho humano genera al Estado la obligación de proveer y garantizar un recurso efectivo. Esta obligación ha sido reiterada por los Principios y directrices básicos sobre el derecho de las víctimas de violaciones manifiestas de las normas internacionales de derechos humanos $\mathrm{y}$ de violaciones graves del derecho internacional humanitario a interponer recursos y obtener reparaciones. La obligación de juzgar y sancionar a los autores de graves violaciones a los derechos humanos, como expresión del deber de garantía, tiene su asidero jurídico en tratados e instrumentos internacionales de derechos humanos (URUGUAY, 2009b, sem paginação).

No mesmo ano, Blanca Sabalsagaray Curutchet formulou a denúncia para investigação das circunstâncias e dos responsáveis pela morte de sua irmã Nibia Sabalsagaray, em junho de 1974, nas dependências militares uruguaias, dada oficialmente como morte por suicídio. Com o Poder Executivo afirmando a integração do caso Sabalsagaray na Ley de Caducidad, a peticionária solicitou a declaração de 
inconstitucionalidade da mesma, em vias de exceção para este caso, por entender que ela transgrediria a Constituição da República e os tratados internacionais.

Em 1975, a CIDH já havia intervindo no caso, considerando a morte de Nibia por enforcamento duvidosa, ainda mais pela negativa do governo em autorizar nova autópsia, solicitada pelos familiares. Desta forma, transmitiu ao Estado uruguaio informações adicionais para que o mesmo cumprisse com as investigações, considerando que a vítima sofreu homicídio. Contudo, obteve a resposta oficial de que "não se havia comprovado nada ilícito" no caso (COMISIÓN INTERAMERICANA, 1978d).

Durante as investigações, ficou comprovado que o caso de Nibia havia sido um homicídio em interrogatório, onde se exerceu violência física contra a vítima, que não possuía nenhuma participação direta na "luta subversiva". Desta forma, foram acusados dois militares pelo "dolo eventual" - quando há intenção do agente em obter algum resultado, mas outro resultado consequente de sua conduta também é aceitável, no caso, a morte para obter informações.

Toca-se novamente, portanto, na temática da vida humana, naquele momento, ser menos importante que a informação (GUENA, 1996). Para conseguir os resultados na "guerra contra a subversão" regional, as condutas dos agentes repressivos não eram questionadas, pois haveria um objetivo maior.

Em 2011, em decisão inédita, a Corte Suprema do país, entendendo a cooperação com a Corte Penal Internacional em matéria de luta contra o genocídio, os crimes de guerra e de lesa humanidade, considerou improcedente a lei de anistia para o caso Sabalsagaray. De acordo com esta sentença,

La presente ley, no podrán declararse extinguidos por indulto, amnistía, gracia, ni por ningún otro instituto de clemencia soberana o similar, que en los hechos impida el juzgamiento de los sospechosos o el efectivo cumplimiento de la pena por los condenados (URUGUAY, 2009b, sem paginação).

Outro caso marcante de luta por investigações a nível internacional é o de Juan Gelman, iniciado em janeiro de 2010. Neste mês, a CIDH apresentou a demanda na Corte Interamericana contra o Estado uruguaio referente à denúncia de desaparecimento forçado de María Claudia García Iruretagoyena de Gelman, em finais de 1976, detida grávida na cidade de Buenos Aires. Presumindo seu posterior traslado ao Uruguai e sem saber as circunstâncias de seu desaparecimento, María Claudia deu à luz a uma menina em dependências militares, que foi entregue para adoção (CORTE INTERAMERICANA DE DERECHOS HUMANOS, 2011). 
Descobriu-se, posteriormente, que ela foi detida junto a Marcelo Gelman, por comandos militares uruguaios e argentinos, e levada ao Centro de Detenção Clandestino Automotores Orletti. O corpo de Marcelo foi descoberto, em 1989, pelo Equipo Argentino de Antropología Forense (EAAF), que investigou as condições de sua morte e determinou que Marcelo havia sido executado em 1976. María Claudia foi levada à Montevidéu, ficou detida na sede do Servicio de Información de Defensa (SID) e teve sua filha no Hospital Militar. A criança - María Macarena - foi retirada de mãe e entregue à família do policial Ángel Tauriño, assim como descoberto nos anos 2000.

Considerando o Sistema Condor, a CIDH acusou o Estado uruguaio de impunidade (baixo argumento da Ley de Caducidad) em relação ao desaparecimento forçado de María Claudia, pela supressão de identidade de sua filha e pelo sofrimento causado à família. O Estado reiterou a responsabilidade no caso, declarando esse reconhecimento através do Informe da Comisión para la Paz e da lei de "Actuación Ilegítima del Estado entre el 13 de junio de 1968 y el 28 de febrero de 1985" (URUGUAY, 2009a).

A lei em questão pretende reconhecer as vítimas, promovendo ações materiais ou simbólicas de "reparação moral com o fim de restabelecer a dignidade das vítimas e a responsabilidade do mesmo" (Estado). Desta forma, anseia a identificação de lugares públicos, onde se produziram violações aos direitos humanos, a definição do destino memorial de edifícios que fizeram parte do sistema repressivo, a expedição de um documento às vítimas do Terrorismo de Estado, no qual se credite suas condições (detidos por motivos ideológicos, desaparecidos, falecidos, nascidos em cativeiro e etc.), e o estabelecimento de datas comemorativas para o país rememorar os eventos traumáticos de sua história.

Contudo, para a CIDH, esse reconhecimento da Lei N. 18596/2009 é parcial, pois, mesmo admitindo violações aos direitos humanos, em crimes de natureza continuada, como o desaparecimento de pessoas, o governo considera essas mesmas violações limitadas na investigação das responsabilidades, levando em conta o tempo no qual foram cometidas e sua integração na Ley de Caducidad. Ou seja, se o crime é continuado, não deveria haver limitação temporal que justificasse a falta de um processo judicial.

A Corte Interamericana sentenciou, pois, as leis de anistia como inadmissíveis em casos de crimes contra a humanidade, tornando-se "obstáculos" para alguns Estados investigarem e sancionarem seus responsáveis, e incompatíveis com as normas da Convenção Americana. $\mathrm{O}$ fato da Ley de Caducidad ter sido aprovada em regime democrático e ratificada pela cidadania, segundo a Corte, não a fazem legítima diante do direito internacional (CORTE INTERAMERICANA DE DERECHOS HUMANOS, 2011). 
De acordo com esta sentença, a existência de um verdadeiro regime democrático está em suas instituições formais que, particularmente em casos de violações aos direitos humanos, possam protegê-los, o que não acontece no Estado uruguaio, especialmente no caso da família Gelman. Assim, concluiu que

El Estado debe garantizar que la Ley de Caducidad de la Pretensión Punitiva del Estado, al carecer de efectos por su incompatibilidad con la Convención Americana y la Convención Interamericana sobre Desaparición Forzada de Personas, en cuanto puede impedir u obstaculizar la investigación y eventual sanción de los responsables de graves violaciones de derechos humanos, no vuelva a representar un obstáculo para la investigación de los hechos materia de autos y para la identificación y, si procede, sanción de los responsables de los mismos (CORTE INTERAMERICANA DE DERECHOS HUMANOS, 2011, sem paginação).

Considerando essas posições, no ano de 2011, a Câmara de Representantes aprovou uma lei que reestabelecia a pretensão punitiva do Estado para os delitos do Terrorismo de Estado, cometidos até $1^{\circ}$ de março de 1985 , sem computar tempo de prescrição ou caducidade entre 22 de dezembro de 1986, quando se assinou a Ley de Caducidad, e a vigência desta nova norma. Estes delitos seriam considerados crimes de lesa humanidade e, de acordo com os tratados internacionais, deveriam ser investigados e devidamente punidos (URUGUAY, 2011).

Com esta nova lei, quarenta casos foram abertos contra violadores no país. No entanto, dois anos depois, a Corte Suprema decide considerá-la inconstitucional em seus artigos 2 e 3, por infringir o direito adquirido (de caducidade da pretensão punitiva) e por condenação retroativa (URUGUAY, 2013). Desta forma, a decisão colocou a legislação interna como fundamentalmente mais importante do que as normas internacionais sobre os direitos humanos, estendendo essa discussão ao tempo presente, apesar do intento de encerrá-la.

\section{5 - A utilização do Sistema Interamericano de Direitos Humanos em perspectiva regional}

Percebemos que a Comissão Interamericana possuiu (e possui) um papel de intermediação do diálogo entre vítimas de violações aos direitos humanos e seus perpetradores na forma dos Estados. Desta maneira, apesar de nem sempre atendida, para os casos de violações aos direitos humanos cometidos em ditaduras no Río de la Plata, ela propõe medidas a serem adotadas pelos países, com finalidades de reparação, prevenção de futuras violações, investigação, punição de responsáveis e proteção às vítimas (BASCH et al., 2010). 
Durante as ditaduras no Cone Sul, o SIDH foi como um "porta-voz" das vítimas que não encontravam recursos internos para serem escutadas em seus sofrimentos individuais e coletivos. Muitas das denúncias realizadas nos três países estudados indicavam essa explanação internacional sobre as violações nas figuras dos desaparecidos, dos presos por motivos políticos, das práticas de tortura nas prisões desse sistema de repressão, das consequentes mortes por essas práticas e dos genocídios étnicos - claras quebras dos acordos internacionais.

Como colocado por Teitel (2003), dentro da "genealogia da justiça de transição", o SIDH entraria no que a autora denomina de segunda fase, na qual é associada às "ondas de transições democráticas". Neste período, a utilização do sistema internacional serve, em uma dimensão individual, para se (re)construir verdade e justiça nacionalmente.

Se no caso argentino, o Estado negava, diante dessa vigilância internacional, a própria existência de seu principal método repressivo - o desaparecimento - desqualificando o sujeito vítima, no caso paraguaio e uruguaio, essa desqualificação se dirigia aos presos (legal ou clandestinamente), tratando-os de "inimigos subversivos", portanto, merecedores das detenções.

Aos torturados, não. Estes eram justificados pelo excesso individual em uma solução interna e coletiva para a "guerra contra a subversão" de toda a região. E como solução/problema interno, estes casos resolver-se-iam também internamente. Assim, em todos os casos mencionados, os Estados acusados utilizam-se desse argumento para justificar as denúncias comprovadas.

Neste sentido, há uma inversão do argumento da própria Comissão Interamericana, na qual os governos acusados de violações pretendiam ser os próprios defensores dos direitos humanos. Considerando que aqueles indivíduos combatidos nas "guerras internas" eram violadores das liberdades dos demais indivíduos e destruidores da "verdadeira democracia", os Estados em questão entendiam-se como patronos dos direitos humanos em prol dos "verdadeiros nacionais". Desta forma, a integração da repressão é percebida também pelos discursos utilizados.

Essa ideia fundamentada na inversão dos valores dos direitos humanos é alavancada em discursos para o ouvinte externo ao país, o público internacional, já que as práticas internas eram as de desrespeito aos direitos humanos, realizadas conscientemente pelas Forças Armadas e policiais, com um determinado consenso social sobre as mesmas (a máxima do "basta ser suspeito para ser culpado"). Uma consciência denotada, inclusive, nas atitudes de negar as visitas in loco da Comissão Interamericana, o que demonstra saber sobre suas 
irregularidades, ou nos resultados de investigações da mesma e suas consequentes respostas oficiais.

Durante o período de transição, entretanto, o papel do SIDH se modifica, elaborando não apenas as denúncias sobre um passado violador, como também aprofundando o espaço de resistência contra a insubordinação das Forças Armadas e de Segurança às instituições e práticas democráticas, contra os sujeitos que praticaram o Terrorismo de Estado e contra as políticas de esquecimento e impunidade, que sugeriam uma "pacificação" nacional imposta.

No caso argentino, a permanência de atitudes dentro das Forças Armadas, que levaram às legislações limitadoras de punição e, posteriormente, decretaram a liberdade de violadores, fez com que a $\mathrm{CIDH}$ fosse meio de diálogo entre o contexto nacional e os anseios pela verdade sobre os desaparecidos e pelo cumprimento das normas internacionais. Neste sentido, quando nos anos 2000, soluciona-se o caso Simón, a partir do argumento do compromisso internacional e de outras determinações advindas da própria Comissão Interamericana, percebe-se claramente este impulso das discussões sobre a impunidade no âmbito internacional, retornando ao território de origem e reformulando uma cultura nacional de justiça transicional, a partir da instituição judicial e aplicação penal de responsabilidades - a "Estratégia Bumerang".

No Uruguai, a CIDH pouco conseguiu interferir na dinâmica nacional, devido ao posicionamento do Estado em estabilizar essa justiça transicional a partir da anistia, mesmo que esta tenha sido inúmeras vezes considerada incompatível com a Convenção Americana. Entretanto, o apelo ao Sistema Interamericano não foi (e não é) em vão. A visibilidade que se dá a uma "paz impossível”, sem verdade e justiça, questiona as instituições do país em casos específicos (dentro de suas possibilidades) que, de acordo com a interpretação daquele que julga, torna possível uma argumentação favorável pela exceção à lei. Por outro lado, ele também coloca em movimento as organizações de direitos humanos, dando-lhe legitimidade de pauta em nível nacional e internacional.

Em 2016, por exemplo, quando autoridades judiciais na Itália entraram com um processo de investigação e julgamento pelo desaparecimento de 23 cidadãos italianos que viviam no Cone Sul, entre os anos 1973 e 1978, viu-se a real possibilidade de condenação de 14 acusados uruguaios, entre eles o ex-Oficial da Marinha Jorge Tróccoli. Tróccoli que, em outras oportunidades, havia declarado publicamente torturas e assassinatos no período ditatorial, vive no território italiano e declarou-se inocente perante este juizado. Em ampla comoção, familiares uruguaios foram à Itália para o julgamento, esperando a condenação de Tróccoli, impossível no país de origem, onde, para o infortúnio dos mesmos, viram todos os 
acusados - com exceção de Juan Carlos Blanco ${ }^{63}$ - serem absolvidos por crimes contra a humanidade (DECEPCIÓN ..., 2017).

Novamente, percebemos a importância da integração regional e do aprofundamento sobre o Sistema Condor, que nos possibilita colocar em visibilidade pública as vítimas dos terrorismos de Estados. A partir dele, se é capaz de mobilizar internacionalmente os juízos e as verdades, fazendo que as vítimas nacionais sejam, tal como colocaram Catela (2001) e Gatti (2011) sobre os desaparecidos, "problemas de todos".

Por fim, no Paraguai, o Sistema Interamericano foi considerado como uma possibilidade de denúncia sobre o silenciamento durante a transição do próprio país, no que tange aos crimes da ditadura stronista. E, neste sentido, é interessante perceber que a Corte Interamericana rompe com seu próprio argumento de anistia incompatível com a Convenção Americana e determina que as responsabilidades no país (que não possui anistia) não deveriam ser levadas à justiça penal.

No entanto, a justiça de transição paraguaia, segundo o SIDH, ganha um conceito de reparação, que une a verdade a uma justiça simbólica, colocando ênfase na reparação imaterial de suas vítimas. Como vimos, um debate profundamente fundamentado no caso hondurenho (1988) sobre como a situação econômica do país, que limita as reparações financeiras das vítimas, deve converter-se em uma reparação imaterial - com significados de educação em matéria de direitos humanos.

Outro ponto de grande importância, que aparece nesta luta pela justiça transicional paraguaia, é a denúncia de um sistema internacional de repressão, através do Sistema Condor, que fundamenta as solicitações de justiça penal fora do próprio país, o que também ocorre no Uruguai. Isto porque, internamente, as questões não se movem nas instituições nacionais, devido à permanência institucional dos atores responsáveis por violações aos direitos humanos.

Neste sentido, a Argentina havia pedido, por exemplo, a extradição de Alfredo Stroessner, que vivia exilado no Brasil, desde 1989, para responder por crimes do Sistema Condor, realizados no país. Contudo, é conhecida a negativa por parte do Brasil em extraditálo. Stroessner seria réu em um juízo oral com 105 vítimas, que condenou, em 2016, 15 exmilitares por associação ilícita para desaparecimento forçado, entre eles, o ditador argentino

\footnotetext{
${ }^{63}$ Juan Carlos Blanco já se encontrava preso pelas mortes de Zelmar Michelinni e Héctor Gutiérrez Ruiz (condenado em 2006 na causa que também condenou Juan María Bordaberry) e pelo desaparecimento forçado e homicídio agravado de Elena Quinteros, em 2010. Cf. POR LA MUERTE..., 2010.
} 
Reinaldo Bignone e o oficial uruguaio Manuel Juan Cordero, culpados pela participação no sequestro e desaparecimento do filho e da nora de Juan Gelman (TRIBUNAL ..., 2016).

Assim, percebemos que a CIDH impulsiona o diálogo entre a sociedade e o Estado em relação aos direitos humanos, dando visibilidade pública, todavia contando com a vontade política de seus atores internos. De um lado, os Estados, dentro do contexto nacional, necessitam se posicionar quanto às responsabilidades e às consequências de seus atos. Por outro, as vítimas, familiares e organizações de direitos humanos, responsáveis pelas denúncias, precisam ver no SIDH um instrumento de luta, uma maneira de conectar os direitos humanos às resistências internas.

$\mathrm{E}$ os dois conceitos/práticas essenciais, que, dentro de um modelo de repressão internacional, aparecem como justificativas para as diversas estratégias do SIDH, são o desaparecimento forçado (que justifica grande parte dos casos) e o genocídio.

No caso do genocídio, apontado no SIDH, a partir de denúncias das vítimas da população Aché, não foi aceito como argumento pela CIDH para a penalização do Paraguai. No entanto, ele levantou discussões sobre o extermínio das populações indígenas, que são fomentadas por organizações de direitos humanos e estudiosos sobre a temática, buscando uma via para se conseguir a responsabilização pelo genocídio em época da ditadura stronista e a continuidade dessa prática.

A particularidade rio-platense do desaparecimento, por sua vez, é a grande argumentação aceita no SIDH, primeiro por ser considerado um crime sem temporalidade, e depois, por ser a conexão visível de práticas repressivas, em todos os territórios dos Estados membros da OEA, independentemente de seus contextos políticos, tal como nos apontou Gatti (2011). Neste sentido, ele fundamenta não apenas a responsabilização dos Estados pelos crimes cometidos, como também a necessidade de transformação das instituições internas, responsáveis por investigações e punições destes crimes.

Apesar de todas as críticas sobre valores e políticas normativas de direitos humanos feitas globalmente (SOUSA SANTOS, 2007, 2013), tem-se nessas experiências um caminho. Um caminho, primeiro, de chegar ao espaço de fala para denunciar publicamente violências internas e buscar soluções e reponsabilidades. Portanto, um espaço público legítimo para as vítimas elaborarem seus traumas e constituírem testemunhos secundários, como coloca La Capra (2009). E, depois, um caminho de oposição às políticas de esquecimento e impunidade das violações, através de compromissos realizados internacionalmente, e com a ideia de que as resoluções internacionais possam retornar às instituições nacionais, alterando-as de alguma maneira. 


\section{CAPÍTULO 3}

\section{PALAVRAS NOS VENTOS DA COSTA: TESTEMUNHOS E INICIATIVAS PARA A VERDADE NO RÍO DE LA PLATA}

La memoria estalla hasta vencer a los pueblos que la aplastan
y que no la dejan ser libre como el viento (GIECO, 2001, sem paginação).

Outro elemento da justiça de transição, que ocorreu como experiência de diversos países e em distintos tempos, é a elaboração de espaços públicos, nos quais os testemunhos das vítimas de catástrofes podem ser escutados. Apesar de muitas vezes parecer que a determinação de falar publicamente por parte de uma testemunha de catástrofe humana é categórica, seja com a finalidade de sobrepor-se à passividade que lhe é designada socialmente ou para retornar às práticas das quais fora marginalizada, como vimos em páginas anteriores, nem sempre a vítima encontra um lugar social legítimo para seu testemunho ou interlocutores dispostos a escutá-la. Portanto, todo espaço destinado aos testemunhos traumáticos precisa ser considerado como fruto de lutas, conquistas e negociações, como um território de memória.

Também já abordamos que, em muitos relatos de sobreviventes de práticas sociais genocidas, é possível perceber uma espécie de "convivência" (interna e nem sempre pacífica) entre seus sentimentos de isolamento e incompreensão com a sociedade. Neste sentido, geralmente, a simples possibilidade da narrativa torna-se a garantia para a (re)existência social dessas pessoas que elaboram suas memórias particulares para uma abordagem pública, de discursos transformados para o coletivo, com a possibilidade de cristalizarem-se ou não em políticas de memórias, memórias coletivas e afetividades sociais (CYTRYNOWICZ, 2013, p. 123-139).

Logo, uma vez obtido um lugar social de fala para a testemunha, este espaço é capaz de transformar a relação entre a vítima e a sociedade e entre a sociedade e suas memórias dos passados de violências. No primeiro caso, a testemunha consegue elaborar suas angústias, podendo expressá-las na dimensão individual, encontrando um interlocutor que pode não estar em um contexto equivalente de sofrimentos, tal como Benjamin (2012) previa, contudo, que está disposto (ou é obrigado) a escutá-la enquanto portadora de relatos legítimos. No segundo caso, ela socializa a dor, elaborando-a coletivamente e tornando as memórias individuais (primárias) em memórias dos outros e de todos (secundárias), que passam a ter, então, também o "dever de memória” (LACAPRA, 2009). Ou seja, através da sensibilização coletiva 
em relação à experiência e à emoção do outro, os ouvintes tornam-se responsáveis por compreender e transmitir os relatos das vítimas e transformam-se na voz média delas, no sentido de mediação, testemunhas indiretas da memória do trauma.

Jesús Martín-Barbero (2013) coloca a mediação como uma forma de comunicação que cria vínculos societários entre os sujeitos, através dos sentidos nos âmbitos culturais e políticos. Estes sentidos pressupõem associações que caminham entre diferenças e solidariedades, resistências, dissidências e comunhões, transformando experiências e memórias relatadas em formas de vínculos entre os cidadãos (inclusive formulando o sentimento de pertencimento a uma comunidade).

Se pensarmos em termos dessa voz média para os casos das ditaduras no Cone Sul, é extremamente importante discorrermos sobre os espaços públicos para a elaboração dessa mediação, que são criados por políticas estatais, comumente impulsionadas por mobilizações de organizações de direitos humanos em busca da criação desses laços entre testemunhas e ouvintes. Neste capítulo, tratamos de um desses territórios de memórias e lugares legítimos para a elaboração de vozes médias sobre as experiências ${ }^{64}$, com os casos das iniciativas para as verdades pós-ditatoriais em espaços públicos. ${ }^{65}$

\footnotetext{
${ }^{64}$ Existem diversas experiências de Comissões de Verdade, em níveis globais e ao longo do tempo histórico. Cf. ARAUJO; PINTO, 2017 e SOUSA SANTOS et al., 2010.

${ }^{65}$ Recuperando a noção dos espelhos como exemplos de experiências de sucesso a serem observados, durante as construções de justiças transicionais, um dos grandes reflexos mundiais deste tipo de mediação, é o caso da África do Sul e da Comissão de Verdade e Reconciliação (CVR). Este caso específico trouxe um espaço de fala mediada, de maneira exemplar, principalmente por seu objetivo final de reconciliação e da possibilidade de uma "transição pacífica" do regime de Apartheid.

Constituída em 1995, com o acordo que levou ao governo a Unidade Nacional, na figura de Nelson Mandela, a CVR pretendia, com a verdade, apaziguar o ódio (compreensível) de ativistas antiapartheid contra seus algozes, responder as demandas pelos testemunhos de crimes contra a humanidade e unir esforços para anistiar violadores de direitos humanos, a partir de um discurso de base moral para a "nova" África do Sul (GROSSMAN, 2000, p. 7-24). Logo, ela utilizou-se de um método de recolhimento de testemunhos que apontavam a verdade sobre a violência de ambos os lados. Assim, nesse espaço social criado, as testemunhas nomeavam os danos e os crimes cometidos (até 2003, foram cerca de 22 mil testemunhos recolhidos), e a estes denunciados thes eram aplicados o perdão e a anistia.

De acordo com Verne Harris (2014), apesar da consideração de utilizar-se o modelo alemão para elaborar políticas de memórias com essa produção da CVR, não foi possível no país a unificação desses relatos e suas elaborações simbólicas nos espaços públicos. Segundo Harris, os usos dessas memórias produzidas pela CVR acabaram por corroborar uma narrativa linear da história do Apartheid, focalizada nas grandes perspectivas (por exemplo, na luta contra o Apartheid ou na criação de instituições de direitos humanos), desmobilizando a noção de justiça para a população em seu cotidiano.

Apesar das críticas sobre seus procedimentos, principalmente relativos ao "perdão", associado a uma moralização inclusive religiosa, e as produções realizadas com o conteúdo dessa Comissão de Verdade, a CVR sul-africana tornou-se um exemplo mundial de criação de um espaço público para testemunhos, talvez justamente por essas particularidades citadas. A fórmula da "transição pacífica" de um regime violento, como o Apartheid é entendido muitas vezes, para uma vitória da reconciliação entre os cidadãos do país, é, contudo, bastante questionável em níveis de acordos internacionais sobre direitos humanos e em relação ao real impacto sobre a população, vítima dessas violações.
} 
Propomos aqui abordar três exemplos das estratégias de Comissões nos contextos argentino, paraguaio e uruguaio. Enfatizando o espaço público (de variados níveis) para os testemunhos, no sentido de se alcançar um objetivo maior de justiça de transição, pretende-se perceber as memórias relatadas, a circulação desses testemunhos, seus laços sociais de afetividade e as produções e debates advindos desses trabalhos (as vozes médias), em espaços e tempos distintos. Enfim, perceber as influências e os fluxos de causas/consequências das mesmas no território local, regional e global.

\section{1 - Testemunhos no espaço público e a Comisión Nacional sobre la Desaparición de Personas (CONADEP)}

Na Argentina, as denúncias dos organismos de direitos humanos sobre as violações praticadas pelo Estado iniciaram-se antes do fim da ditadura, como nos casos apresentados internacionalmente, elaborados no capítulo anterior. Contudo, a produção de conhecimento sobre as vítimas e suas respostas sociais não atingiram um estado público nacionalmente pleno até os comícios das eleições de 1983 (CRENZEL, 2008).

Em abril deste ano, as Forças Armadas haviam lançado o "Documento final de la Junta Militar sobre la guerra contra la subversión y el terrorismo", que teve efeitos jurídicos e fundamentou a Lei N. 22.924 de "Pacificación Nacional", como vimos, auto-anistiando as Forças Armadas (ARGENTINA, 1983b). A resposta foi imediata. Organismos de direitos humanos e a opinião pública rechaçaram a lei e voltaram-se ao pedido de constituição de uma comissão bicameral para investigar o Terrorismo de Estado, a ser conformada por um futuro governo civil e que apelasse à participação da sociedade.

Esse tema centralizou os debates eleitorais daquele ano. $\mathrm{O}$ candidato à presidência pelo peronismo, Ítalo Luder ${ }^{66}$, afirmava a irreversibilidade da lei assinada, enquanto Raúl Alfonsín expressou sua inconstitucionalidade e defendeu um julgamento pelas violações aos direitos humanos, baseado em três categorias de autores: os que davam ordens, os que atuavam além delas por questões de crueldade e os que atuavam fundamentados nelas. $\mathrm{O}$ último candidato, como sabemos, vencedor das eleições, ao assumir a presidência, em dezembro de 1983, enviou ao congresso um conjunto de leis para proteger os direitos humanos e assinou os decretos 157 e 158 .

\footnotetext{
${ }^{66}$ Político e advogado que assumiu a presidência durante uma série de licenças tiradas pela presidente Isabel Perón (1974-1976) por motivos de saúde.
} 
Nos referidos decretos, definiu-se a restauração da vida democrática através de uma justiça, promovida pela investigação pública e perseguição penal aos responsáveis por formas violentas de ação política - os militantes de organizações guerrilheiras: Mario Eduardo Firmenich, Fernando Vaca Narvaja, Ricardo Armando Obregón Cano, Rodolfo Gabriel Galimberti, Roberto Cirilo Perdía, Héctor Pedro Pardo e Enrique Heraldo Gorrianrán de Merlo (ARGENTINA, 1983c). Por outro lado, pela violência de Estado, delitos de homicídio, privação ilegal da liberdade, aplicação de torturas e sequestros de crianças, condenava-se o Conselho Supremo das Forças Armadas e seus integrantes: Jorge Rafael Videla, Orlando R. Agosti, Emilio A. Massera, Roberto E. Viola, Omar D. R. Graffigna, Armando J. Lambruschini, Leopoldo F. Galtieri, Basilio Lami Dozo e Jorge I. Anaya (ARGENTINA, 1983d).

Dois dias depois, Alfonsín assinou outro decreto que conformava uma Comissão Nacional para esclarecer os feitos relacionados ao desaparecimento de pessoas (Comisión Nacional sobre la Desaparición de Personas - CONADEP). Esta Comissão tinha funções de receber denúncias e provas de delitos para a remissão à Justiça; averiguar o paradeiro das pessoas desaparecidas; localizar as crianças retiradas da tutela dos pais; denunciar qualquer tentativa de ocultamento ou destruição de provas relacionadas aos feitos que se investigavam; e emitir um informe final (ARGENTINA, 1983e).

Nesse sentido, o executivo convocou para integrá-la membros destacados de organismos de direitos humanos e figuras públicas que não foram afetadas diretamente pelos desaparecimentos. Os convites feitos e aceitos conformaram uma mesa de trabalho com o advogado e ex-reitor da Universidad de Buenos Aires Ricardo Colombres, o médico Rene Favaloro, o decano da Faculdade de Engenharia Hilario Fernandez Long, o bispo da Igreja Metodista Argentina Carlos Gattinoni, o matemático e filósofo Gregorio Klimovsky, o rabino e fundador do Movimiento Judío por los Derechos Humanos Marshal Meyer, o Monsenhor Jaime de Nevares, o filósofo Eduardo Rabossi, a jornalista Magdalena Ruiz Guiñazú, e, como presidente da Comissão, o escritor Ernesto Sabato. ${ }^{67}$ Posteriormente, foram indicados, como representantes do Congresso, os deputados do Partido Radical Santiago Marcelino López, Hugo Diógenes Piucill e Horacio Hugo Huarte.

Mesmo com a resistência da organização das Madres de la Plaza de Mayo, que defendiam uma ação parlamentária e faculdades coercitivas para obrigar os militares a darem

\footnotetext{
${ }^{67}$ A escolha de Sabato foi polêmica, pois o escritor, durante a ditadura, havia elogiado Jorge Rafael Videla e foi um dos entusiastas do nacionalismo na Copa do Mundo de 1978 e na Guerra das Malvinas. Cf. SKREPETZ, 2012 .
} 
seus depoimentos (CRENZEL, 2008) - o que levaria posteriormente à própria divisão da organização -, em 22 de dezembro de 1983, a CONADEP começou a funcionar. Ela centrarse-ia nos depoimentos dos familiares de desaparecidos, dos sobreviventes de Centros Clandestinos de Detenção e das testemunhas involuntárias, tais como moradores de zonas próximas aos Centros Clandestinos, testemunhas oculares de sequestros e assassinatos, médicos, enfermeiros e empregados de cemitérios com fossas clandestinas. ${ }^{68}$

A Comissão trabalhou com testemunhos anteriormente publicados pelos organismos nacionais e internacionais de direitos humanos e com preenchimento de formulários e entrevistas pelas testemunhas que, muitas vezes, já traziam seus depoimentos por escrito. Adriana Calvo, por exemplo, ex-detida-desaparecida e testemunha na CONADEP, em entrevista para televisão, confirmou levar consigo seu testemunho escrito por sentir-se demasiado ansiosa em falar publicamente. Seu marido Miguel Calvo, por sua vez, a acompanhou até a Comissão, mas afirmava haver esquecido o que lhe ocorreu e, portanto, não saber o que declarar, no momento dos chamados públicos para testemunhos. Contudo, segundo Adriana, eles esperaram por mais de uma hora para a realização do depoimento e, durante essa espera, houve um desbloqueio de seu cônjuge que lhe pediu uma folha de papel e começou a escrever mais de noventa nomes de pessoas que estavam presas junto a ele (DEL SILENCIO..., 2004).

As mesas de recebimento desses depoimentos foram divididas por ordens de trabalho e, posteriormente, por Centros Clandestinos de Detenção, onde cada especialista tomava declarações que se referenciavam às experiências vividas. A Comissão se instalou em Buenos Aires, mas viajava ao interior do país e ao exterior para tomar depoimentos das vítimas e fazer inspeções em Centros Clandestinos, procurando provas materiais de sua existência.

Se, a princípio, a Comissão suscitou uma série de críticas relativas ao seu funcionamento, a situação começou a se modificar, quando alguns dos participantes que tomavam esses depoimentos renunciaram por não suportar (de maneira emocional) a tarefa de escutá-los $^{69}$. Sem gente para o trabalho, os movimentos de direitos humanos se colocaram à disposição para colaborar - Asamblea Permanente por los Derecho Humanos, Movimiento Ecuménico por los Derechos Humanos, Liga Argentina por los Derechos del Hombre e Familiares de Detenidos y Desaparecidos por Razones Políticas (CRENZEL, 2008).

Em outra instância, a CONADEP lançou uma enorme campanha televisiva e radial para fazer saber seu funcionamento e agregar testemunhos. A fim de divulgar sua produção,

\footnotetext{
${ }^{68}$ Sobre testemunhas involuntárias, Cf. LEVÍN, 2005.

${ }^{69}$ Ver testemunhos em DEL SILENCIO..., 2004.
} 
por exemplo, foi realizado um programa televisivo, sob título de Nunca Más, exibido pelo Canal 13 (emissora estatal) em julho de $1984 .^{70}$

Antes de sua exibição, o governo assistiu ao programa e não concordou em passá-lo ao público, com medo de que seu conteúdo gerasse conflitos com as Forças Armadas e, acima de tudo, repulsa dos telespectadores. No entanto, Ernesto Sabato ameaçou renunciar à Comissão, caso este não fosse televisionado. Neste impasse, Alfonsín decidiu liberá-lo com a condição de que houvesse uma introdução, feita pelo, então, Ministro do Interior Antonio Tróccoli, onde enfocar-se-ia na importância da CONADEP e na visão dela em encarar a violência sob uma perspectiva que não retratava a "história completa".

O programa mostrou depoimentos sobre os desaparecidos, confrontou explicações ditatoriais sobre o Terrorismo de Estado e abordou o sensacionalismo da imprensa nos casos de aberturas de tumbas anônimas para identificar restos humanos. ${ }^{71}$ Sucesso de audiência, com 1.640.000 telespectadores, o programa foi capaz de modificar o cenário político, ocasionando a demissão do chefe do Exército, e de legitimar a Comissão, com exceção das Madres de la Plaza de Mayo e suas críticas sobre o silêncio de nomes dos responsáveis pelos crimes contra a humanidade e sobre a condição dada aos desaparecidos pelo programa como "opositores da ditadura", apagando suas militâncias políticas e suas lutas pela igualdade social.

Podemos afirmar que o teor do conteúdo escolhido e produzido pela Comissão, enquanto política de memória provida pelo Estado e com o apoio da maioria das organizações de direitos humanos, na década de 1980, era o desaparecido. Este foi definido, naquele contexto, como o indivíduo do qual fora tirada a presença na sociedade pela força, em contraposição aos sujeitos que conseguiram escapar dos cativeiros ou foram liberados deles, considerados como sobreviventes. Logo, a história a ser contada na CONADEP era a do desaparecido permanente (CONADEP, 2006).

Por um lado, as especificidades da história do país resultaram nessa escolha. Afirmava Ernesto Sabato, no prólogo do informe final da Comissão, que os desaparecidos eram uma “(...) Palabra - jtriste privilegio argentino! - que hoy se escribe en castellano en toda la prensa del mundo" (CONADEP, 2006, p. 13). Isto queria dizer que só o Estado argentino igualou a decisão do extermínio e sua prática clandestina ao desaparecimento de pessoas. Assim, mesmo que as discussões sobre violência política e estatal rompessem a fronteira do

\footnotetext{
${ }^{70}$ Sobre o programa, Cf. FELD, 2007.

O programa Nunca Más (1984) está disponível em : <https://www.youtube.com/watch?v=HuuQ4WLQs2I>. Acesso em: 10 dez. 2017.

${ }^{71}$ Sobre a postura da imprensa nos anos 1980, Cf. FELD, 2010. p. 25-42.
} 
contexto da ditadura ${ }^{72}$, é a figura do desaparecido permanente, como fruto de uma política de extermínio levada pelo Estado, que apelou às lembranças de quase toda a população do período pós-ditatorial.

Por outro lado, o desaparecimento quebrou a relação da morte como fim natural no país, desestruturando-o culturalmente. A morte, dentro da perspectiva da cultura ocidental, possui âmbitos temporal, espacial e imaginário - ela é um tempo no ciclo da vida que implica em espaços e rituais de despedidas. Quando há um desaparecido, a morte fica presa às incertezas e esse sentimento se aprofunda, no momento em que o responsável por ela tem a decisão de ocultar seus atos e lugares de tortura, degradação e assassinato, além dos corpos (CATELA, 2001). Portanto, o desaparecimento precisava ser respondido para a restituição dessa cultura relativa à morte no país.

Durante a constituição da CONADEP, acreditava-se ainda que muitos desaparecidos estariam vivos. Acreditava-se, não apenas pelo desejo de ver os desaparecidos retornados à sociabilidade, contudo também, porque nenhum sobrevivente havia declarado, naquele momento, testemunhar a morte dos desaparecidos e não se podia entender os motivos pelos quais algumas pessoas sequestradas pelo sistema de terror ainda estavam vivas (CALVEIRO, 2013). No entanto, essa esperança foi diminuindo ao longo dos trabalhos da Comissão, já que, sob denúncias concretas, não se encontrou vivo nenhum desaparecido. Como relatou Graciela Fernández:

(...) Tenían familiares que habían recibido por intermedio de anónimos lo que fueron datos muy precisos de donde sus hijos estaban. Unos en el Chaco. Un caso en el Chaco, otro caso en el sur. En un corte en el sur. Y un otro caso en Uruguay. Cuando yo vi eso, me di cuenta de que la estrategia de los Servicios de Inteligencia iba a ser, si aceptaba, tener a la Comisión corriendo por el país en busca de los desaparecidos (FERNÁNDEZ apud DEL SILENCIO..., 2004, Primeira Parte).

Assim, em janeiro de 1984, a Comissão mudou sua estratégia de investigação e passou a trabalhar com a ideia de que os desaparecidos estavam mortos. Essa ideia foi muito controversa, primeiro pela impossibilidade de imaginar o país com uma política de extermínio - igualando-se ao genocídio - deste tipo (é conhecida a frase de uma integrante das Madres aos deputados, em reuniões para a conformação da CONADEP, que afirmou "Nosotras no

\footnotetext{
${ }^{72}$ A violência argentina é abordada como temática histórica e tradição política, desde o século XIX, no qual era praticada a partir de uma atividade normalizadora e regularizadora, alcançando o imaginário popular. Neste sentido, passa por todos os golpes militares no século XX, pelas práticas do peronismo de 1940, 1950 e 1970 e pelas organizações políticas que levantaram a luta armada como forma de militância, nas décadas de 1960 e 1970. Cf. NOVARO; PALERMO, 2003 e ROCHA, 2015.
} 
podemos concebir que se haya asesinado a treinta mil personas, porque si así fuese estaríamos en un país de locos").

Além disso, essa postura de considerar os desaparecidos como mortos eximiu o governo de procurar por desaparecidos que poderiam ainda estar vivos em cativeiros (CRENZEL, 2008, p. 63-68), o que ocasionou muitas discussões sobre possíveis mortes para silenciamento, no período imediato pós-ditadura. No entanto, decidiu-se oficialmente considerá-los mortos e, assim, impedir judicialmente a saída do país de pessoas relacionadas aos desaparecimentos e às apropriações de crianças, por crimes de sequestro e homicídio.

Logo, delinearam-se fronteiras epistêmicas sobre o desaparecimento. Ao colocar os desaparecidos como vítimas centrais da investigação, realizada pela Comissão, definiu-se elaborá-los enquanto "vítimas inocentes", não explorando sua identidade, apenas qualificando-os por suas atividades profissionais. Ao fazer esta análise seletiva, apagou-se uma relação entre captores e detidos, tal como uma análise dos perpetradores do Terrorismo de Estado. Por fim, a cifra que chega pela CONADEP em relação ao número de desaparecidos (8960 casos) era incerta. ${ }^{73}$

Todavia, a posição do Estado, entre 1983 e 1985, foi assumir o discurso da chamada Teoria dos Dois Demônios. Apesar das diversas discussões atuais sobre os usos, as cristalizações e a historicidade dessa percepção sobre "violências enfrentadas", a Teoria dos Dois Demônios é vista como um conjunto de representações coletivas, com grande circulação nos anos 1970 e 1980, no qual as violências e seus "métodos ilegítimos" eram explicados pela oposição de forças políticas no país (FRANCO, 2014).

No caso do Nunca Más, apesar de pontuar uma diferença nos enfrentamentos violentos, essa representação se apresentava já no Prólogo do resumo das investigações.

(...) a los delitos de los terroristas, las Fuerzas Armadas respondieron con un terrorismo infinitamente peor que el combatido, porque desde el 24 de marzo de 1976 contaron cone 1 poderio y la impunidad del estado absoluto, secuestrando, torturando y asesinando a miles de seres humanos (CONADEP, 2006, p. 11).

Portanto, na interpretação oficial, as "verdadeiras vítimas" estariam à margem dessa guerra irracional e, por isso, as militâncias e os sentidos políticos dos depoimentos apresentados não estavam presentes no texto.

(...) el Nunca Más implantaba y extendía el conocimiento de los crímenes, constituía una figura purificada de víctima. En verdad, quien mejor encajaba en ese papel era el desaparecido (es decir asesinado), recordado y recuperado

\footnotetext{
${ }^{73} \mathrm{Em}$ 2006, foram registrados oficialmente 13 mil casos e as organizações direitos humanos falam de 30 mil desaparecidos.
} 
por su familia, sobre todo si entraba en la categoría de los inocentes de toda militancia. (...) Lo importante es que esa extensa apelación a la solidaridad de los sentimientos (que no excluían algún interés morboso) y la traducción en términos de dramas familiares contribuía a oscurecer una mirada más abierta a la historia (VEZZETTI, 2003, p. 119-120).

Ressaltamos ainda dois pontos interessantes para esta análise, abordados pela investigação da CONADEP. O primeiro é a crítica à impunidade realizada nos meandros do texto do informe final, tanto no que tange à premissa de não punição, tomada por parte dos violadores de direitos humanos, que os fizeram realizar tais violações sem culpa, quanto no caso dos "sistemas repressivos", cuja estrutura englobava, além de funcionários públicos, outros setores sociais, como por exemplo, membros da Igreja Católica. De alguma forma, fala-se, então, de responsabilidades sociais pela prática do desaparecimento (CONADEP, 2006, p. 250-268), algo que, como vimos, era pauta de discussão presente nesses anos 1980, em nível mundial, e, especificamente, nos debates sobre as violações do regime nazista.

O caso do padre Christian Von Wernich, o sacerdote católico responsável pela capela da Polícia de Buenos Aires, é emblemático. Mencionado em diversos testemunhos da CONADEP por visitar Centros Clandestinos de Detenção e participar de violações aos direitos humanos nos mesmos, Von Wernich acabou por ser condenado à prisão perpétua, em 2007, como coautor de delitos de homicídio agravado e privação ilegal de liberdade (PODER JUDICIAL DE LA NACIÓN, 2007). No testemunho de Luis Velasco à CONADEP, por exemplo, algumas de suas ações são expostas.

Una vez escuché cuando Christian Von Wernich le contestaba a un detenido que pedía no morir que "la vida de los hombres depende de Dios y de tu colaboración". En una oportunidad se dirigió a mí tocándome los pelos del pecho y diciendo sonriente "te quemaron los pelitos" ... También lo escuché defender y justificar las torturas reconociendo que a veces las había presenciado. Cuando se refería a algún operativo, decía: "Cuando hicimos tal operativo..." (CONADEP, 2006, p.263-264).

Percebemos, neste relato, tanto a participação do padre nesse sistema de violações e na cultura do medo para a obtenção de informações, quando diz que a vida de Velasco dependia de sua colaboração, quanto a sua responsabilidade, quando utiliza-se da terceira pessoa do plural para relatar os operativos das Forças Armadas.

Outra questão colocada pela CONADEP é a colaboração dos Sistemas de Segurança além das fronteiras. Os depoimentos que abordaram essa "reciprocidade dos sequestros" entre países demonstraram a transgressão dos direitos internacionais, primeiramente e mais óbvio em matéria dos direitos humanos; com prisões clandestinas e desaparecimentos ou mortes de 
cidadãos estrangeiros no país e de argentinos no estrangeiro - o "aparato repressivo multinacional" (CONADEP, 2006, p. 268-276).

Sobre o caso do sistema de intercâmbio de prisioneiros e informações paraguaio, por exemplo, o depoimento de Osiris Irineo Ayala, detido em 1976 por oficiais e civis e levado ao Regimiento de Infantería de Monte 29, em Formosa (Argentina), esclarece que

En una de esas oportunidades estuve con un grupo de gente y un guardia hablando en idioma guaraní dice: "Hay uno que no es paraguayo, dígale al Capitán Espada que nosotros no queremos llevar gente que no sea paraguaya".

Es de destacar que, en el lugar que se refiere el Sr. Ayala, sólo quedó él de las catorce personas que se encontraban detenidas (CONADEP, 2006, p. 269).

No entanto, o aparato repressivo multinacional" falava sobre um desrespeito ao asilo político, que fora concedido às vítimas estrangeiras, e sobre o princípio de soberania nacional, transgredido, quando se permitiu que funcionários estrangeiros ingressassem no país para realizar ações ilegais (CONADEP, 2006, p. 268-276). O caso do agente estadunidense Michael Towley ${ }^{74}$ é um dos exemplos citados no informe, onde suas declarações de atuação em nome da Dirección de Inteligencia Nacional chilena, como os assassinatos de Orlando Letelier (em território estadunidense), de Carlos Prats (em território argentino) e do General Juan José Torres (na Bolívia), o transformaram em testemunha protegida nos Estados Unidos e, portanto, impossível de ser trasladado para julgamentos nos países em que cometeu tais crimes.

Estas evidencias deben merecer de la autoridad constitucional argentina el mayor celo revisor, con el afán impostergable de garantizar el ejercicio pleno de la soberanía de la Nación en el control exhaustivo sobre las eventuales violaciones ilegítimas de personal de nuestro país con funcionarios extranjeros (CONADEP, 2006, p. 276).

Depois das investigações, a CONADEP dividiu-se para escrever o informe e entregálo ao governo. Silveira e Salvador encarregaram-se da tarefa de escrever sobre a Comissão; Colombres, suas recomendações; Fernández Long explicaria o sistema de computação empregado; Piucill descreveria o desaparecimento de conscritos; Aragón, o de sindicalistas; Mansur, o de advogados; De Nevares escreveria sobre o papel da Igreja; López, sobre o papel doutrinário da repressão; Klimovsky, o lado antissemita dela; Carlos Zamorano, sobre a repressão internacional; Ruiz Guiñazú descreveria a apropriação de crianças; Enrique Fernández Meijide, sobre os métodos de tortura; Graciela Meijide coordenaria os escritos

\footnotetext{
${ }^{74}$ Sobre as atividades de Towley no aparato repressivo, Cf. MUÑOZ, 2010, Capítulo "O avanço global de Pinochet.
} 
sobre os Centros Clandestinos de Detenção; e Sabato redigiria o prólogo (CRENZEL, 2008, p. 94).

Nove meses depois (em 20 de setembro de 1984), a Comissão entregou o informe ao presidente Raúl Alfonsín, em cerimônia pública e televisionada ${ }^{75}$, com mais de 50.000 páginas, e um resumo para publicação, intitulado Nunca Más. Setenta mil pessoas se reuniram na Plaza de Mayo, em Buenos Aires, para assistir ao ato e exigir o julgamento dos responsáveis pelo Terrorismo de Estado. Um dia depois, o presidente entregou o resumo do informe para sua publicação pelo Editorial Universitaria de Buenos Aires (EUDEBA).

A capa do livro, na qual pode-se ler a consigna do Nunca Más "pichada" em um fundo vermelho, foi produzida pelo design gráfico Pablo Barragán. Sua primeira edição, com 40.000 exemplares, saiu em novembro de 1984 e se esgotou em dois dias. Até março do ano seguinte, além de se editar exemplares em braile, foram vendidos 190.000 exemplares do informe, incluindo uma edição publicada pela Círculo de Lectores e a primeira lançada no exterior pela editora espanhola Seix Barral em conjunto com EUDEBA. ${ }^{76}$

Imagem 11 - Capas do Nunca Más (1984 e 2006)
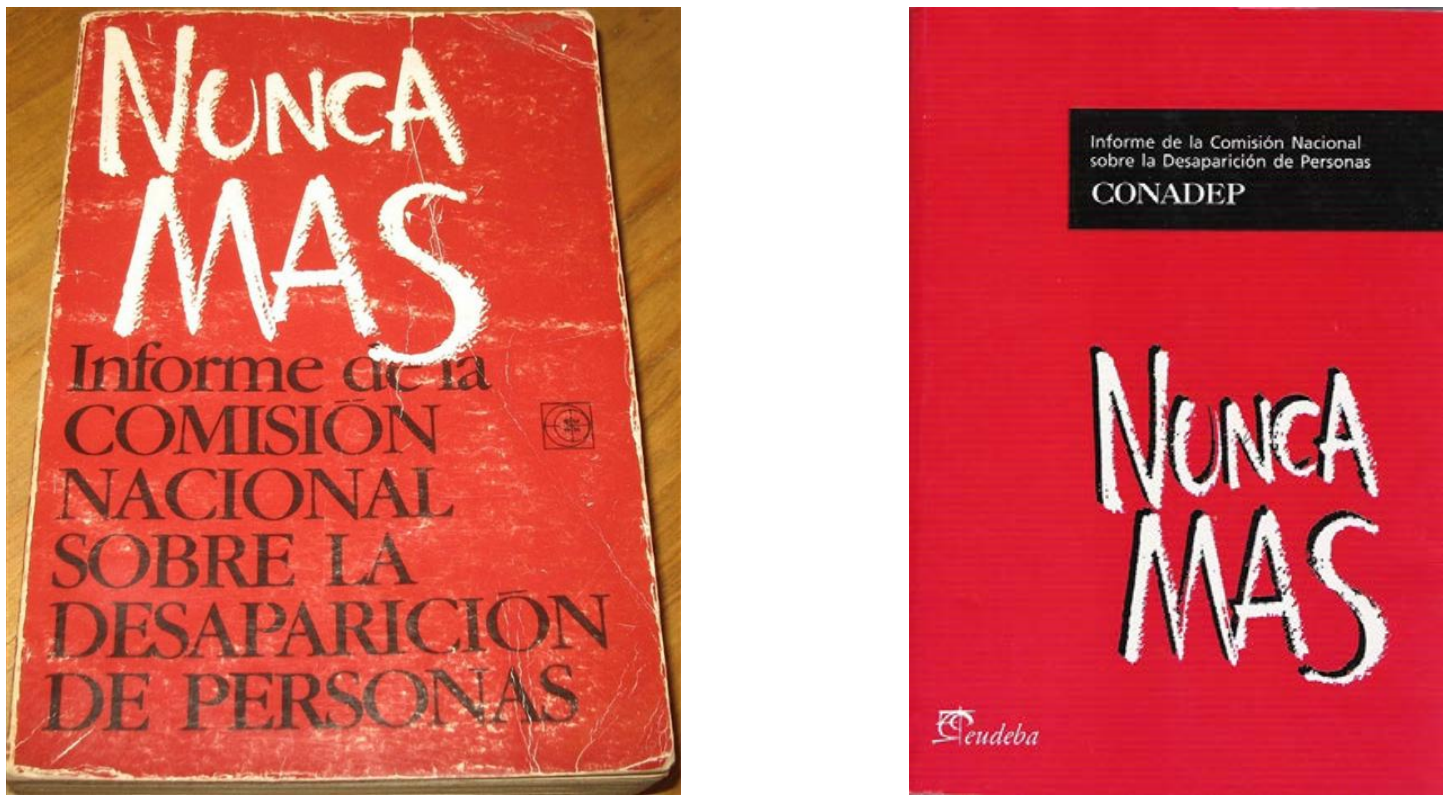

Fonte: Arquivo Pessoal. Fotografias de 2017.

\footnotetext{
75 A entrega está disponível para consulta no endereço eletrônico: <https://www.youtube.com/watch?v=eHn4wYeWuuY>. Acesso em: 01 fev. 2017.

${ }^{76}$ De acordo com Emilio Crenzel (2008, p. 131-132 e nota 226), os preços do informe e anexos não foram guardados pela editora, mas havia uma preocupação com o alto preço, pois, segundo uma carta enviada a EUDEBA, eles custariam $\$ 750$ e $\$ 1500$, respectivamente, em um salário mínimo de $\$ 16000$.
} 
O público daquele livro era diverso, de militantes dos direitos humanos à sociedade em geral. Os livros, além de vendidos, foram também distribuídos em muitas bibliotecas e, posteriormente, tornaram-se leitura obrigatória nas escolas. ${ }^{77}$

Em uma entrevista, realizada na década de 1980, com 30 leitores, apenas quatro deles declararam haver lido o Nunca Más por completo. Os demais revelaram não realizar toda a leitura, devido ao conteúdo traumático do mesmo. A maioria dos entrevistados afirmaram que seu conteúdo era legítimo, apesar de considerarem a ausência de aspectos políticos e da abordagem da violência guerrilheira, nos anos 1970, afirmando novamente a visão das violências enfrentadas. Também apontaram o desconhecimento prévio à publicação sobre a política de extermínio estatal da ditadura - retirando-se da responsabilidade pelo acontecido e a necessidade de punição dos responsáveis pelos crimes contra os direitos humanos (CRENZEL, 2008, p. 132-133).

Importante ressaltar que, meses depois do resultado da CONADEP, os Juicios de las Juntas iniciaram-se, mobilizados por uma considerável parcela social. Como já colocado, a meta era responsabilizar a Junta Militar pelo aparato de poder ilegítimo, e as sentenças condenaram os comandantes que exerceram a repressão, atribuindo-lhes responsabilidades e penas diferentes. Nestes casos, o Nunca Más foi um dos instrumentos de prova.

Ele foi também impulsionador de diversas atividades no campo cultural em relação às memórias do passado recente. Filmes e livros ficcionais ou de memórias foram produzidos, focalizando nessas vítimas do informe - desaparecidos, crianças apropriadas, exilados e mortos. ${ }^{78} \mathrm{O}$ próprio Nunca Más fora traduzido em diversas línguas e publicado em países como o Brasil, Itália, Grã-Bretanha e Estados Unidos.

Sua circulação foi intensa até os anos de 1986 e 1987, quando o governo de Alfonsín considerou o projeto de Punto Final e assinou a lei de Obediencia Debida (1987). O ambiente de esquecimento oficial tendeu a se aprofundar com a presidência de Carlos Menem, como abordado anteriormente, e, nesse sentido, a publicação de novos exemplares do Nunca Más passou a ser financiada pelas organizações de direitos humanos, com pequenas tiragens, combatendo o contexto desfavorável para a memória das vítimas da ditadura argentina (CRENZEL, 2008, p. 147-153).

\footnotetext{
${ }^{77}$ Para seu uso nas escolas, foi lançado, em 2006, um manual de utilização do Nunca Más para professores, intitulado "Haciendo Memoria en el País de Nunca Más". Cf. DUSSEL; FINOCCHIO; GOJMAN, 2006.

${ }^{78}$ Alguns desses filmes foram Hay unos tipos abajo (1985), La Historia oficial (1985), El exílio de Gardel (1986), La Noche de los Lápices (1986), A los compañeros la libertad (1987), e Made in Argentina (1987). Para uma seleção de filmes produzidos no país sobre a temática, ver: <http://www.memoriaabierta.org.ar/ladictaduraenelcine>. Acesso em: 10 abr. 2017.
} 
Apenas em 1995, o país revive as grandes publicações do livro. Nesse ano, por trás dos debates sobre as declarações de Adolfo Scilingo, voltou-se à política de reimpressão do Nunca Más, que agregou na lista de desaparecidos mais 545 pessoas, frutos de novas denúncias. Nesse mesmo ano, o jornal Página/12 distribuiu 75.000 exemplares aos seus leitores, com a preocupação de prolongar a linha editorial do jornal e "transmitir esse passado às novas gerações". Nos exemplares, o texto é ilustrado com colagens do artista León Ferrari, que associavam o período ditatorial argentino ao regime nazista (CRENZEL, 2008, p. 156162).

Imagem 12 - Nunca Más por León Ferrari (1995)
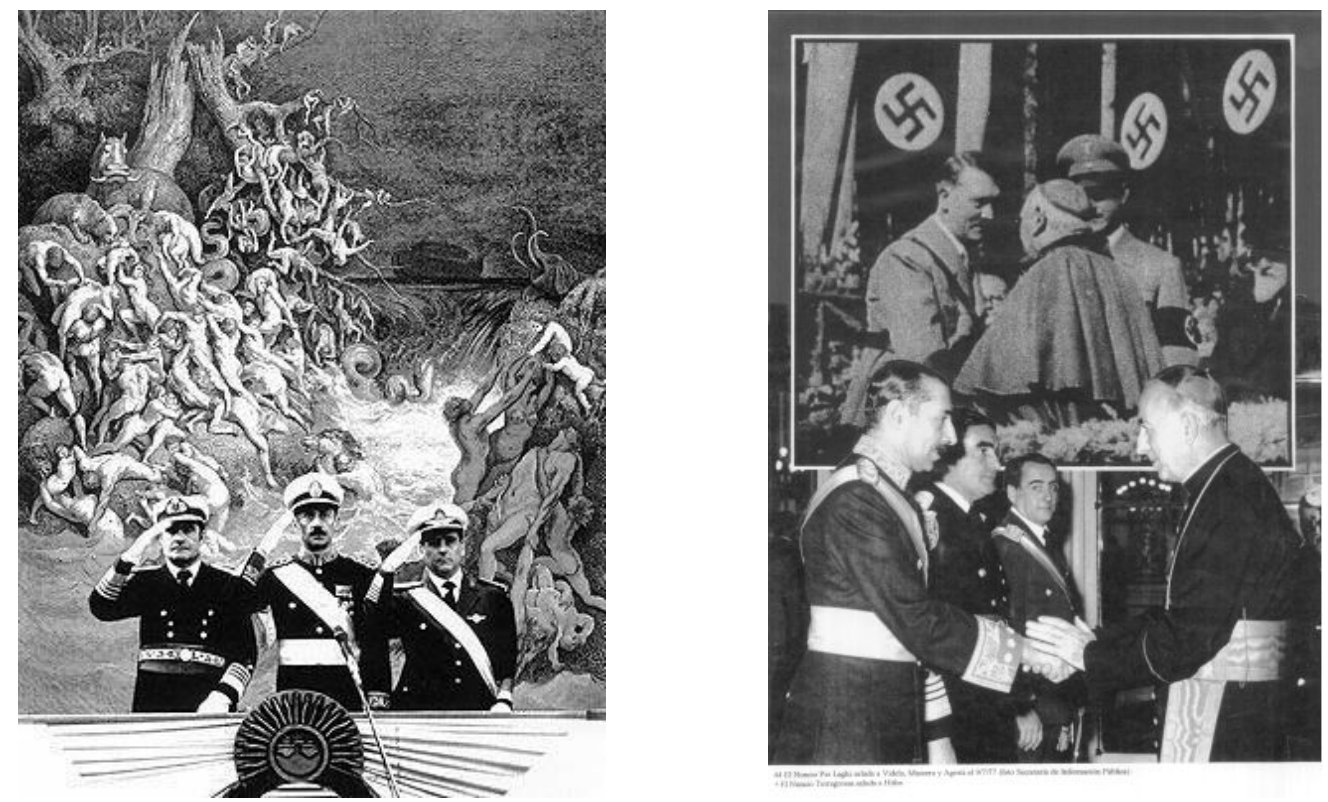

Fonte: ARCHIVO DE LEÓN FERRARI. Disponível em <http://propuesta77.blogspot.com.br/2014/03/Leonferrari.html>. Acesso em: 13 nov. 2017.

Nesse momento de impunidade, vê-se claramente o desenvolvimento do argumento, do qual a obra de León Ferrari é um dos exemplos, onde se aproximam as consequências dessa ditadura específica do país aos crimes contra a humanidade nazistas. Em diversos trabalhos artísticos e discursos individuais ou coletivos, essa articulação pareceu ser fundamental para "se explicar" publicamente a luta contra o esquecimento e pela punição de responsáveis pelas práticas sociais genocidas.

No ano seguinte, em rememoração aos vinte anos do golpe, EUDEBA reeditou o livro que fora vendido em conjunto com o filme Malajunta, do diretor Eduardo Aliverti. Como forma de complementação do discurso do Nunca Más, o documentário em questão procurava retratar os argumentos explicativos da Junta Militar, contrapondo-as aos depoimentos sobre os 
desaparecidos e as provas apresentadas pela CONADEP. Por fim, criticava o contexto de esquecimento que o país vivia e o silenciamento social em torno dessa história (MALAJUNTA, 1996).

Em 2006, no trigésimo aniversário do golpe, EUDEBA volta a publicar, além de 55.000 exemplares em conjunto com o Página/12, na versão do jornal, uma nova edição do Nunca Más, desta vez, com uma introdução assinada pela Secretaría de Derechos Humanos de la Nación, sob a presidência de Néstor Kirchner (2003-2007, Partido Justicialista). Devemos lembrar que governo kirchnerista iniciou a política de confronto com as Forças Armadas, ganhando legitimidade em relação aos organismos de direitos humanos e elaborando uma série de políticas de memória para recuperar o passado, até então, esquecido oficialmente.

A nova introdução, intitulada "Edición del $30^{\circ}$ aniversario del Golpe de Estado", agrega novos valores ao sentido do golpe. Colocando as exigências de verdade, justiça e memória do país e atendendo às reivindicações das Madres de la Plaza de Mayo ao assumir o número de 30.000 desaparecidos e dar cunho político ao processo, a Secretaría de Derechos Humanos deixa clara a posição ditatorial de instituir um novo modelo econômico neoliberal e que, por detrás dessa política, desencadear a estratégia de Terrorismo de Estado. É, pois, a vinculação oficial deste processo ao conceito de prática social genocida.

Actualmente tenemos por delante la inmensa tarea de revertir una situación de impunidad y de injusticia social, lo que supone vencer la hostilidad de poderosos sectores que con su complicidad de ayer y de hoy con el terrorismo de Estado y las políticas neoliberales la hicieron posible. Por ello, al mismo tiempo nos interpelan los grandes desafíos de continuar haciendo de la Argentina, frente a esas fuertes resistencias, no sólo un país más democrático y menos autoritario, sino también más igualitario y más equitativo.

El NUNCA MÁS del Estado y de la sociedad argentina debe dirigirse tanto a los crímenes del terrorismo de Estado - la desaparición forzada, la apropiación de niños, los asesinatos y la tortura - como a las injusticias sociales que son una afrenta a la dignidad humana (CONADEP, 2006, p. 89).

Em 2012, com a quarta reimpressão da oitava edição do Nunca Más, surgiu a polêmica em torno desta introdução. A ex-participante da CONADEP Magdalena Ruiz acusou, através de uma coluna no caderno Opinión do jornal La Nación, que a referida Secretaria, ao incorporar sua introdução, teria retirado a assinatura do prólogo no informe, produzido por Sabato. O falecido autor, para a jornalista, fora, portanto, "roubado", desapropriado de sua memória consolidada no informe final da CONADEP (GUIÑAZU, 2012). 
Em clima de disputa ${ }^{79}$, o filho de Sabato, Mario Sabato, promoveu uma petição à editora EUDEBA, assinada por diversos sujeitos dos meios acadêmicos e culturais argentinos, solicitando a autoria explícita de seu pai no prólogo, nas publicações do Nunca Más. A editora respondeu que nenhuma edição do livro havia levado a assinatura em seu prólogo, portanto a solicitação de Sabato filho não possuía fundamento (LYNCH; ROFFO, 2012 e LYNCH, 2012).

De acordo com Emilio Crenzel (2008, p. 93-98), o informe da CONADEP tinha o caráter coletivo e convidava aos organismos de direitos humanos a participarem com recomendações para o texto final. Desta forma, havia sido combinado que nenhum dos textos seria assinado, independentemente de quem o escrevera. Logo, é importante perceber que esses debates giram em torno de um não esquecimento do processo histórico sobre a produção do Nunca Más. Afinal, fica evidente que, depois de quase trinta anos, não apenas o texto se modificara, com novos enxertes, como também seus leitores (mediadores) se tornaram outros.

Esses "leitores recentes" não possuem o laço político e cultural com o livro, no sentido da violência compartilhada, pois não têm lembranças próprias do Terrorismo de Estado - não são testemunhas primárias. Assim, passam a conceber a relação com a leitura destes testemunhos, a partir de outros espaços de socialização, como as escolas, bibliotecas ou meios de comunicação. Desta forma, a disputa pela memória do Nunca Más torna-se uma disputa por seu valor afetivo na sociedade - sobre quem possui a "verdade" na apropriação daqueles depoimentos.

Apesar das discussões sobre a legitimidade de seus textos e enxertos posteriores, é incontestável a importância que a CONEDEP possui nesses sentidos de memória de catástrofes, nos níveis locais, regionais e globais. Na introdução de seu estudo sobre os processos políticos e ressignificações sociais do livro para o país, Emilio Crenzel (2008) aponta marcas desse significado social em atitudes coletivas e pessoais, como, por exemplo, a escalada, em 2004, que um professor de educação física realiza no monte de Aconcagua (Mendoza), levando consigo a bandeira argentina e uma placa reproduzindo a capa do Nunca Más, com a finalidade de chamar atenção para a luta pela dignidade humana e pela memória coletiva.

\footnotetext{
${ }^{79}$ Não se pode esquecer que o contexto dessa produção veio em meio às discussões sobre a Ley de Medios, proposta pelo governo de Cristina Kirchner (2007-2015, Partido Justicialista). Neste sentido, a análise de Ruiz Guiñazu ganha uma grande repercussão social, com a presidente das Madres de la Plaza de Mayo, Hebe de Bonfani, defendendo a nova introdução e qualificando o antigo como "una mierda", que pretendia justificar o Terrorismo de Estado como um jogo de violências contrapostas (GALAK, 2006).
} 
Como forma de transmitir às novas gerações um sentido para esse passado de Terrorismo de Estado, o Nunca Más tornou-se o símbolo nacional que auxiliou nessa construção da identidade do desaparecido e impulsionou as memórias no país. E justamente por essa identidade e pelas dimensões do sistema de desaparecimento, abordados desde então, ele se tornou um modelo exemplar regional e mundial, como resultado de um extenso processo de escuta das vítimas, de seus posteriores julgamentos de responsáveis por crimes e de apresentar uma maneira para estabelecer a justiça transicional exemplar.

\section{2 - Testemunhos no espaço público e a Comisión de Verdad y Justicia (CVJ)}

No Paraguai, o processo de estabelecimento do espaço público destinado à verdade foi diferente. Em 2002, um grupo composto pelas organizações de direitos humanos no país Comité de Iglesias para Ayudas de Emergencia (CIPAE), Coordinadora de DD.HH. del Paraguay (CODEHUPY), Coordinadora de Luchadores y Luchadoras (CODELUCHA), Sindicato de Periodistas del Paraguay (SPP), Fundación Celestina Pérez de Almada (FCPA), Mujeres por la Democracia, Grupo Memoria, Central Nacional de Trabajadores (CNT), Central Unitaria de Trabajadores Auténtica (CUT-A) e Servicio de Paz y Justicia (SERPAJPY) - lançou uma campanha do "Año de la Memoria", comemorando os dez anos do encontro com a documentação do Archivo del Terror (1992), e conformou a Mesa Memoria Histórica, a fim de debater os arquivos da repressão, pressionar os poderes políticos para a instituição de um museu de memória das vítimas da ditadura e para a criação de uma Comissão de Verdade (CÁCERES, 2012).

Sabemos que as eleições que se seguiram à ditadura stronista continuaram dando vitórias ao Partido Colorado (1993, 1998, 1999, devido à renúncia de Raúl Cubas, e 2003), pouco modificando as estruturas sociais para o recebimento dessas memórias das vítimas em espaço público, afinal continuava no poder uma linha política relacionada ao stronismo. Com um país submerso em crises econômicas e sociais, ao longo desses anos, as eleições de 2003 alteram essas estruturas, marcando uma reformulação da política do Partido Colorado, a fim de conseguir manter a governabilidade. Neste sentido, Nicanor Duarte Frutos, vencedor dessas eleições, convoca setores políticos para integrar uma mesa de negociação - "Mesa Patriótica" -, pretendendo renovar o poder judicial e militar, abrir espaço para o Partido Liberal na agenda de demandas políticas, traçar políticas de investimentos sociais e afastar-se do setor stronista do Partido Colorado (PAREDES, 2014). 
Desta forma, Frutos atendeu a demanda da Mesa Memoria Histórica e assinou a lei de criação da Comisión de Verdad y Justicia (CVJ), ainda em 2003. A CVJ tinha os objetivos de investigar as violações aos direitos humanos, cometidas pelos agentes estatais ou paraestatais, desde 1954 até a promulgação da lei, nos delitos de desaparecimento forçado, execuções extrajudiciais, torturas ou lesões graves, exílios e outras violações. A Comissão deveria resguardar a memória e o testemunho das vítimas determinando seus paradeiros, identificando os responsáveis, preservando provas, contribuindo para a verdade oficial, recomendando reformas institucionais, legais e educativas e elaborando propostas de reparações, além de um informe com seus resultados (PARAGUAY, 2003).

Apesar de não possuir o caráter jurisdicional, a CVJ propunha analisar as responsabilidades de indivíduos e instituições do Estado, que contribuíram para crimes contra os direitos humanos, juntar provas para entregá-las ao Poder Judicial e recomendar a adoção de medidas para evitar que tais feitos se repetissem. Com um prazo de trinta dias para iniciar seus trabalhos, ela foi presidida pelo monsenhor Mario Medina Salinas, indicado pelas vítimas, e composta por membros de reconhecida trajetória ética e legitimidade social: Juan Manuel Benítez Florentín, Mario Sandoval, Yudith Rolón Jacquet, Miguel Angel Aquino, Carlos Luis Casabianca, Carlos Portillo, Heriberto Alegre Ortiz, e Víctor Jacinto Flecha. Estes, auxiliados por técnicos e pesquisadores, começaram as entrevistas e o recolhimento de informações.

Sob a meta de alcançar um grande número de vítimas diretas e indiretas do regime, a CVJ lançou campanhas nas rádios, televisões, boletins impressos e digitais, como, por exemplo, a campanha para recolhimento de testemunhos - "2000 testimonios para la história" (2000..., 2007) - ou a campanha para se obter informações relativas às escavações para se encontrar desaparecidos - "Órama ña ñe'evo, Rompamos el silencio" (LANZAN..., 2006). Desta forma, ela concretizou diversas audiências públicas e entrevistas diárias com as vítimas e outras testemunhas, que respondiam questionários de mais de duas horas de duração, na Capital e em outras quatro sedes pelo país (Misiones, Caaguazú, Alto Paraná e Cordillera). Ela também visitou lugares de repressão, como Centros Clandestinos de Detenção ou delegacias policiais, recopilou materiais e documentos, em níveis nacional e internacional, e implementou as audiências coletivas nesses espaços de trabalho, sob o lema Quien olvida, repite.

Mesmo tendo sido conformada quatorze anos depois do fim da ditadura no país, a CVJ pode ser considerada o segundo grande momento em que saíram, em cena pública, os testemunhos sobre violações aos direitos humanos de maneira massiva (o primeiro foi o 
encontro com os arquivos ${ }^{80}$ ). Nesse sentido, ela é uma vitória contra o esquecimento oficial da história de violência no país, trazendo uma lista extensa de crimes cometidos pelos agentes estatais e paraestatais.

El trabajo de toma de testimonios y las investigaciones permitió a la comisión trabajar especialmente sobre los casos de tortura en prisiones y fuera de ellas. Las ejecuciones extrajudiciales y la desaparición forzosa de personas. Además de investigar sobre la represión a la prensa, la violación a las mujeres y a los niños, la apropiación indebida de tierras por agentes estatales y paraestatales y la violación de los derechos de los pueblos indígenas (DOCUMENTAL COMISIÓN DE VERDAD Y JUSTICIA, 2008, sem paginação).

Ao final de seus trabalhos, previstos para dezoito meses corridos, contudo, finalizados apenas em 2008 pela escassez de recursos (que foi resolvida com pedidos de auxílio internacional), a CVJ entregou um informe oficial com todas as investigações, com os testemunhos de 9923 vítimas e propostas de reparações para as mesmas. O Informe Final. Anive Haguã Oiko ("que nunca mais se repita") foi publicado em meio digital e impresso e é conformado por oito tomos: 1) Síntese e Caracterização do Regime; 2) Principais Violações dos Direitos Humanos; 3) As Violações de Alguns Grupos em Citação de Vulnerabilidade e Risco; 4) Terras Ilícitas; 5) As Sequelas das Violações aos Direitos Humanos. A Experiência das Vítimas; 6) As Responsabilidades nas Violações de Direitos Humanos; 7) Alguns Casos Paradigmáticos; e 8) Documentos Suplementares e Lista de Vítimas (COMISIÓN DE VERDAD Y JUSTICIA, 2008, Tomo I: Sístesis y caracterización del régimen).

Interessante perceber que, durante a elaboração deste trabalho, a CVJ dedicou um momento de sua investigação ao que denominou de "grupos vulneráveis": aqueles indivíduos que já são vítimas sociais (pelo preconceito e pelos sistemas político e econômico) e que, portanto, sofreram duplamente com a repressão stronista. Essa discussão, contextualizada nos anos 2000, já traz a caracterização da vitória do modelo neoliberal na América Latina (dos anos 1990) e suas devidas críticas de aplicação com o empobrecimento popular, em favor de uma elite econômica. Fato é que essa dupla repressão - identitária e de oposição ao modelo econômico -, no Paraguai, forma o conceito de "vítimas vulneráveis", composto pelos trabalhadores rurais, mulheres, homossexuais, crianças e indígenas.

Detenho-me, neste momento, em dois desses grupos, porque são parte dessa peculiaridade da história paraguaia. Primeiro, os trabalhadores rurais e, depois, as populações indígenas.

\footnotetext{
${ }^{80}$ Cf. Capítulo 4: "Narrativas e territórios".
} 
Entre os anos 1976 e 1980, houve uma forte repressão aos trabalhadores do campo, baixo à acusação de suposto levantamento armado nas áreas do Chaco - região ocidental do país (Departamentos de Boquerón, Alto Paraguay e Presidente Hayes). Esta repressão foi realizada por ocupações militares em comunidades inteiras, nas quais a violência era aplicada indiscriminadamente (COMISIÓN DE VERDAD Y JUSTICIA, 2008, Tomo I: Sístesis y caracterización del régimen).

No início da década de 1960, como já colocado ${ }^{81}$, as Ligas Agrárias Cristãs associaram-se aos trabalhadores, principalmente da região de Misiones, propondo solidariedade e cooperação para melhorar as condições de vida no campo. Com o apoio do Movimiento Sindicalista Paraguayo (MSP), essas ligas foram expandindo-se pelo território de Neembucú e tornando-se mais organizadas, criando, por exemplo, escolas (Escuelas Campesinas) ou armazéns de consumo, que eliminavam "intermediários" locais da venda dos produtos complementares às produções (ASERETTO, 2001). A partir dos anos 1970, as perseguições a essas organizações foram aumentando e abrangendo prisões, mortes e desaparecimentos em todo o setor rural.

\begin{abstract}
De ahí que las Ligas Agrarias, de inspiración cristiana y practicantes de una suerte de comunitarismo primitivo, se convirtieron en enemigas declaradas para la dictadura. Además de practicar una forma de organización social que no se basaba en el lucro capitalista, tales cooperativas se convirtieron en un botín apetecido porque eran tierras valiosas en sí mismas o cercanas a cuencas hídricas de gran potencial, por lo que sus dueños, que habían pagado cuotas de la propiedad de la tierra, fueron simplemente expulsados por jefes militares y policiales sin poder recuperar su patrimonio hasta el día de hoy (COMISIÓN DE VERDAD Y JUSTICIA, 2008, Tomo VI: Las responsabilidades en las violaciones a los derechos humanos, p. 52).
\end{abstract}

A particularidade local, já citada neste trabalho, é o caso da repressão aos povos indígenas. Durante a ditadura de Stroessner, houve uma recorrente negação à autodeterminação destes povos, à propriedade (esta violada enquanto política econômica de governo, que desalojava as comunidades de suas terras), à identidade, à vida, à liberdade e integridade pessoal das populações indígenas (COMISIÓN DE VERDAD Y JUSTICIA, 2008, Tomo III: Las violaciones de derechos de algunos grupos en situación de vulnerabilidad).

O regime stronista atacou comunidades inteiras com execuções, práticas análogas à escravidão, esterilização forçada e violações sexuais de crianças e mulheres. Além dessas práticas de crimes, mais nítidas aos olhos de qualquer observador, existem também os

\footnotetext{
${ }^{81}$ Cf. Introdução: "O Rio é memória".
} 
testemunhos que relataram à CVJ práticas de discriminação, expressadas pela assimilação forçada religiosa ou política.

Dividindo o trabalho de investigação em oito casos, a partir das comunidades étnicas ${ }^{82}$ - Aché, Maskoy, Toba Qon, Paî Tevyterâ, Avá-Guarani, Ayoreo, Enxet (Kelyenmagategma e Yakye Axa) e Mby’a Guarani -, a CVJ divulgou diversos relatos de membros dessas comunidades sobre violações coletivas e individuais ocorridas no período ditatorial e, posteriormente, em democracia. O testemunho de Emiliano Vera, Avá-Guarani do Alto Paraná, por exemplo, explicita uma diversidade de crimes cometidos, ao longo dos anos, contra sua comunidade: expropriação e exploração de terras e de mão-de-obra por empresas estrangeiras, sob o aval do governo paraguaio, a falta de assistência social e o desrespeito cultural às tradições de seu povo, às diferenças e, inclusive, ao sofrimento que lhes impuseram.

Sabemos todo lo que ha sucedido con la historia de los indígenas, es una historia abierta para las autoridades que quieran conocer el camino que hemos recorrido en este Paraguay, en el que existen distintos pueblos indígenas. (...) mucho ya hemos llorado, porque debimos dejar nuestro territorio, los arroyos, el monte, las familias, todo va desapareciendo, de manos de los brasileños, menonitas, coreanos, todos extranjeros a los cuales el gobierno les abre las manos mientras a los indígenas no los toman en cuenta. Nadie los atiende, ni en educación, como en salud, respecto a lo cual le dicen a los indígenas que usen su medicina natural, pero la pregunta sería, de donde conseguimos medicamentos naturales si hoy nuestra zona es totalmente ocupada por la soja. Además, como ya se dijo, hace más de 35 años que esa empresa tan rica llamada Itaipu, que se apropió de la tierra y la alambró expulsando a los indígenas, viene diciendo de los indígenas que son haraganes, que no quieren trabajar, que son ladrones, alcohólicos, que tienen todos los males. (...) Ahora llegó el tempo de detener todo esto, de que los indígenas se pongan de pié y con una sola palabra, porque los blancos si es por ello, seguirán haciéndolos sufrir (COMISIÓN DE VERDAD Y JUSTICIA, 2008, Tomo III: Las violaciones de derechos de algunos grupos en situación de vulnerabilidade, p. 220-221).

Interessante observar aqui a conexão (e, portanto, a responsabilização) que tal testemunho realiza entre os interesses econômicos por trás das violações aos direitos humanos das comunidades indígenas. É sabida a contenda que houve, nos anos 1960, sobre a região de Sete Quedas, entre o governo paraguaio e brasileiro, em relação à produção energética, onde acusava-se o último de manter interesses imperialistas sobre a região paraguaia. Em 1966, com a Ata das Cataratas, na qual acordou-se o desenvolvimento de estudos em conjunto para a construção de uma usina binacional e a retirada de tropas brasileiras da região, os reflexos

\footnotetext{
${ }^{82}$ De acordo com o censo de 2012, são registradas oficialmente 19 etnias indígenas no país. Cf. PARAGUAY, 2012.
} 
desses avanços na dinâmica econômica dos países em questão ocasionaram vítimas, principalmente a comunidade Avá-Guarani, que residia nas áreas. A pressão do Estado e da empresa Itaipu para a construção da hidrelétrica fez com que os indígenas (que não possuíam muitas opções, já que suas terras estavam sendo invadidas e inundadas) perdessem cerca de 1500 hectares e fossem transferidos para uma reserva, determinada pela mesma empresa. Mesmo com as inúmeras reivindicações por extensões territoriais, o mapa que demarcou a região entregou apenas 231 hectares aos Avá-Guaranis. Assim, o enriquecimento das elites nacionais foi resultado da exclusão dessas comunidades, transformando completamente, pela imposição, a organização e vida dessas pessoas. ${ }^{83}$

Em diversos relatos do relatório final, ainda, há uma clara crítica ao Instituto Nacional del Indigena (INDI), acusado de ser incapaz de efetivar os direitos das vítimas, já que, apesar de apresentarem casos judiciais, principalmente sobre apropriações de suas terras, inclusive com condenações na Corte Interamericana - casos Yakye Axa e Sawhoyamaxa ${ }^{84}-$, os trâmites no Estado nacional são intermináveis. Além disso, o INDI não se encarrega de demandar ao Estado a atenção aos serviços públicos de saúde, educação, água potável, proteção ao meio ambiente, segurança e justiça nas comunidades indígenas, das quais é responsável em fazer a mediação entre as demandas dessas populações e o governo.

Esse contexto de ausência estatal reflete diretamente na permanência das violações aos direitos à vida e à propriedade desses povos que ainda sofrem pela perda de patrimônios culturais, como a língua, religião e cultivos tradicionais. Portanto, de acordo com a CVJ, a prática de eliminação das comunidades indígenas necessita ser revista, no âmbito nacional e internacional (COMISIÓN DE VERDAD Y JUSTICIA, 2008, Tomo I: Sístesis y caracterización del régimen).

E, neste sentido, surge o caso paradigmático do povo Aché Guayakí e a longa discussão sobre o reconhecimento estatal da prática de genocídio contra seus integrantes. Os Achés (Aché Sureños, Aché del Nacunday, Aché Wa ou del Yñaro, Aché septentrionales ou

\footnotetext{
${ }^{83}$ Cf. DEPRÁ, 2006 e COLMÁN, 2016.

Sobre o papel do Brasil na América Latina e as relações de identidade latino-americana, ver: CAPELATO, 2000, p. 286-316.

${ }^{84} \mathrm{O}$ caso Yakye Axa, iniciado em 2003, contra o Estado paraguaio se refere às violações nesta comunidade, de aproximadamente 90 famílias. Sua sentença obriga o Estado a identificar o território tradicional da comunidade, subministrar bens e serviços básicos de subsistência, criar um fundo para recuperar terras e desenvolvê-las, e reconhecer a responsabilidade pelos crimes contra essas pessoas (CORTE INTERAMERICANA DE DERECHOS HUMANOS, 2005).

$\mathrm{O}$ caso Sawhoyamaxa se refere à divisão das terras dessa comunidade, que foram vendidas para companhias privadas, violando os direitos de propriedade, os direitos da criança, à proteção judicial e o direito à vida. A Corte Interamericana decidiu que o Estado deveria entregar as terras tradicionais, pagar indenizações por danos imateriais e oferecer atenção de saúde às vítimas (CORTE INTERAMERICANA DE DERECHOS HUMANOS, 2006b).
} 
Gatu, Ache'de Ybytirusu), distribuídos pelos departamentos de Caaguazú, Alto Paraná, Itapúa, Caazapá, Guairá e Canindeyú, sofreram com diversos crimes contra os direitos humanos. Objetos de sistemática perseguição por parte dos "paraguaios ocidentais", eles foram vítimas de assassinatos, violações sexuais, roubos e vendas de crianças, mortes por contaminação de doenças e destruição cultural - especialmente quando foram obrigados, em determinadas regiões, a passar de agricultores, caçadores, coletores e pescadores ao trabalho rural por jornadas ${ }^{85}$-, execuções extrajudiciais, detenções ilegais e escravizações. A partir dos anos 1959, em cooperação com o Ministério de Defesa, os indígenas Aché Guayakí começaram a ser usados também como "cães de caça" para perseguir grupos políticos, que atuavam com guerrilhas nos montes das regiões onde habitavam. Assim, uma das vítimas testemunhou para a $\mathrm{CVJ}$ :

Fui sacada del monte junto con Margarita Mbywangi. Una família paraguaya me compró por 5000 guaraníes cuando tenía aproximadamente 5 años. Mi mamá me contó que mis abuelos salieron a buscar mandiocas en la chacra de los paraguayos, fueron sorprendidos por los dueños, quienes le persiguieron hasta el monte, disparando arma de fuego, en esa ocasión murieron dos personas, mi papá y una mujer embarazada. Los demás Aché corrieron, momento que fue aprovechado por los paraguayos para apoderarse de tres niños, entre ellos estaba yo. Recuerdo que fui llevada en una carreta y entregada a una família de apelido Colmán de la zona de Yvyrarrovana. Guillermo Colmán, Benita Rotela. Fuí reconocida como hija legítima, pero nunca fuí tratada como tal. Fuí a la escuela hasta el cuarto grado, dejé el estúdio porque la señora se enfermó y tenía que cuidarla. Me maltrataba, "nde india" me decía, me pegaba y me derramaba su orín para humillarme. Mis hermanas adoptivas me pegaban con el palo de la escoba por cualquier motivo. Viví con esta família hasta mi juventude. No tarde en darme cuenta que no pertenecía a esa familia (COMISIÓN DE VERDAD Y JUSTICIA, 2008, Tomo III: Las violaciones de derechos de algunos grupos en situación de vulnerabilidade, p. 190).

Este relato suscita uma série de questionamentos em torno da situação dos Achés. Primeiro, a clara posição de desvalorização de suas vidas, enquanto seres humanos, usando-os como escravos para trabalhos em casas de família (inclusive integrados como objetos em um sistema de mercado pela venda) ou cassando-os e abatendo-os.

Depois, nesse mesmo testemunho, vemos a pontuação do caso de Margarita Mbywangi como exemplar para a luta desses povos. Em 1966, Margarita tinha quatro anos de idade e foi sequestrada e vendida para trabalhar em casas de fazendeiros. Ao completar 16 anos, logrou escapar para a Ciudad del Leste, onde continuou trabalhando como doméstica, e,

\footnotetext{
${ }^{85}$ A empresa argentina Carlos Casado S.A., que atua desde 1883 nas terras da região do Chaco, em extração de tanino, produção agrícola, de laticínios e de gado, é uma das principais acusadas de cometer violações desses tipos, desde os anos 1930. Atualmente, a empresa tem como sócios majoritários o grupo espanhol San José e também uma sociedade com outra empresa argentina, a Cresud.
} 
quatro anos depois, com a ajuda de um padre, reencontrou seu povo. Como sua readaptação fora bastante complicada, levando-a ao alcoolismo, Margarita dedicou-se à reintegração comunitária com uma profissão dedicada ao povo (de parteira) e reaprendendo sua língua.

Por sua história de vida, tornou-se a primeira mulher cacique do Paraguai e foi convidada pelo presidente Fernando Lugo (2008-2012) a ser Ministra de Questões Indígenas do país, em 2008. No entanto, não se adequando no processo político, renunciou ao cargo e passou a dedicar-se às lutas do povo Aché, essencialmente pela demarcação de terras. Mbywangi é porta-voz de sua comunidade e declara a importância do reconhecimento da história de seu povo e da continuação de luta por seus direitos - "duele recordar el pasado. Duele recordar a mi Pueblo. Espero que un día eso termine (...) que devuelvan a nuestros muertos. Pero que también miren a los vivos" (35 AÑOS DE STRONISMO, 2011, Programa 4: Grupos Vulnerables).

Essas condutas contra a comunidade levaram a diversos debates, dentro e fora do país, sobre a possibilidade deles corresponderem ao genocídio, definido pela Convenção para a Prevenção e o Castigo contra o Delito de Genocídio e pelo Estatuto da Corte Penal Internacional (1998). Citando uma série de autores que, desde os anos 1970, denunciam a intenção de se destruir, total ou parcialmente, essa comunidade, entre eles Bartolomeu Meliá, Luicci Miraglia, Mark Münzel e Philippe Piragi Eded, a CVJ afirmou, em seu relatório, que, apesar de não conseguir comprovar o elemento subjetivo da intenção de extermínio dos Achés, houve uma sistematização e generalização dessas violações contra a população. Logo, se está diante de um crime de "lesa humanidade", no grau de perseguição fundamentada pela etnia. 


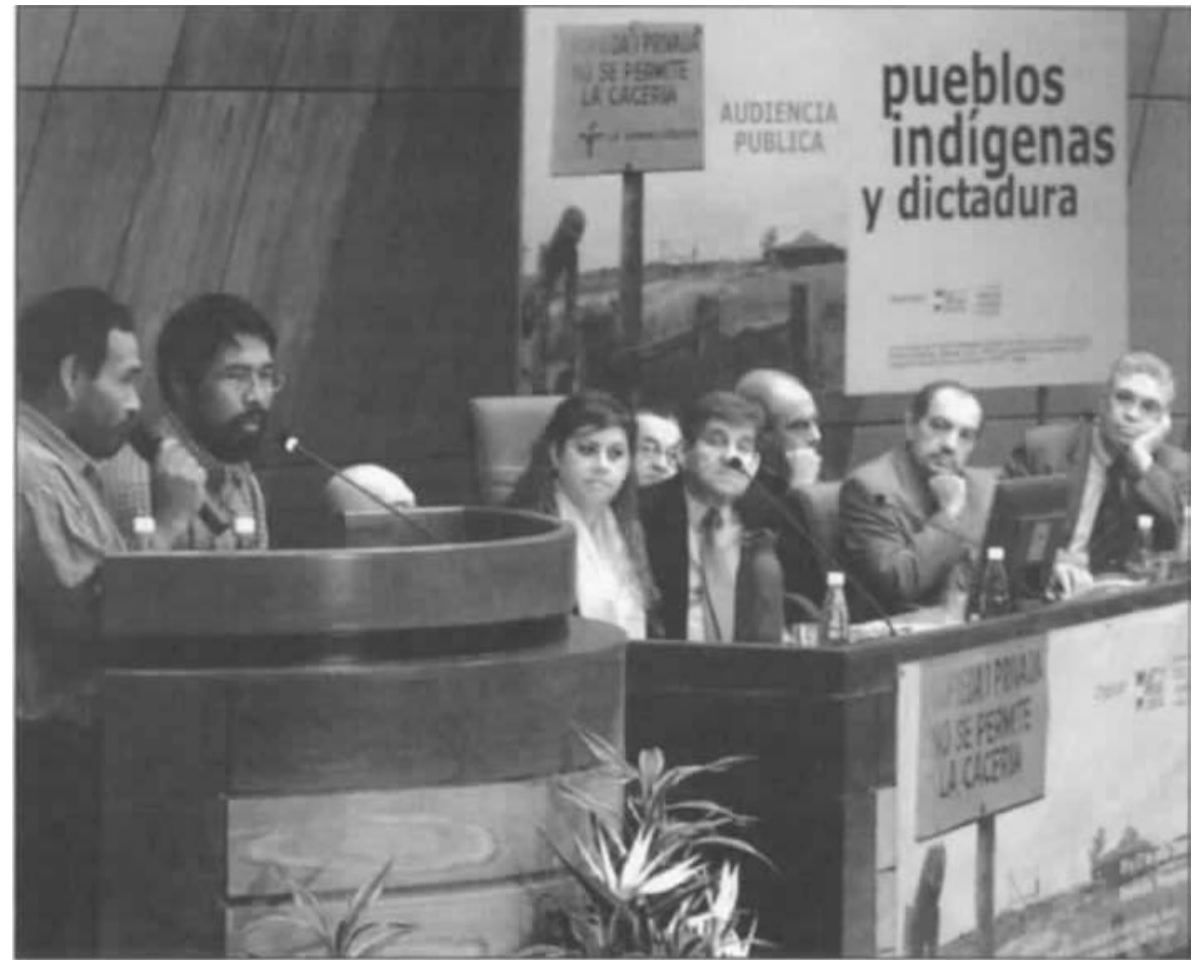

Fonte: Archivo del fotógrafo Luis Vera. In: CLAVERO et al., 2008, p. 261.

Desta forma, a Comissão, muitas vezes, se utiliza do termo etnocídio para designar estes crimes, ao invés de caracterizá-los como genocídio, apesar de não desconsiderar este último por completo. Este pode ter sido o caminho encontrado para a falta da designação de genocídio da população Aché por parte da CIDH, como vimos no capítulo anterior. Pois, com o etnocídio, a CVJ retoma o debate sobre a questão do extermínio, realinhando o descarte desse crime de aniquilamento em vias do direito internacional. Isso nos levaria a outro tipo de discussão (que não nos cabe aqui) que se enquadra no pensamento sobre os motivos de não se considerar internacionalmente o genocídio da população indígena em termos jurídicos, mesmo que as demais ciências humanas já estejam falando sobre a temática, em diversos tempos históricos.

O debate sobre os "grupos vulneráveis" não limitou a Comissão em produzir abordagens das vítimas consideradas regionais. Ela também trabalhou com os detidosdesaparecidos (circunstanciais e permanentes) e mortos por motivos políticos, incluindo militantes do mundo rural, e estabelecendo as prisões ilegais no Paraguai, as torturas, os Centros Clandestinos de Detenções no país, os desaparecimentos forçados e as execuções extrajudiciais, desde 1959. Indicando a modificação na maneira de operar das Forças de Segurança paraguaias após o Sistema Condor, percebe-se o aumento vertiginoso das práticas 
de torturas e aprisionamentos ilegais, a partir do ano de 1975, com diversos casos transnacionais relatados no informe final da CVJ.

Um deles, por exemplo, foi a detenção de argentinos, uruguaios, chilenos e paraguaios na operação policial, levantada para solucionar o atentado que matou o ex-ditador nicaraguense Anastasio Somoza Debayle, que vivia no país desde 1979 - posteriormente, membros do ex-Ejército Revolucionario del Pueblo argentino foram responsabilizados por essa ação. Em início dos anos 1980, diversas casas na Capital foram invadidas, sem procedimentos legais, buscando os possíveis responsáveis pelo assassinato de Somoza Debayle e as fronteiras do país foram fechadas para a entrada e saída de estrangeiros e nacionais.

La operación consistía en allanar casa por casa, ya sean éstas particulares o instituciones públicas, sin autorización judicial. Según el [entonces] Ministro del Interior [Sabino Augusto Montanaro], la revisión tuvo como objetivo detectar a personas que no están con la documentación legal, en especial extranjeros y buscar armas de guerra (COMISIÓN DE VERDAD Y JUSTICIA, 2008, Tomo II: Las principales violaciones a los derechos humanos, p. 241).

Nesses procedimentos, Hugo Alfredo Irurzun Curghi, um dos comandos do ERP, foi detido e executado pela polícia que, na figura de Pastor Coronel, alegou que este havia falecido em enfrentamento. O corpo de Irurzun foi encontrado, apenas em 2007, nas escavações no cemitério El Este, em Assunção, com a colaboração do Equipo Argentino de Antropología Forense.

O governo argentino, naquele momento, apoiou as ações do governo paraguaio, mesmo com as numerosas denúncias de maus-tratos de cidadão argentinos pela polícia paraguaia, manifestando não "tolerar o terrorismo". O governo paraguaio também suspendeu suas relações com a Junta de Governo da Reconstrucción Nacional de Nicaragua, por considerar que a Frente Sandinista de Liberación Nacional estava envolvida no atentado, violando, portanto, o respeito à sua soberania.

Ao encerrar este capítulo de violações aos direitos humanos durante a ditadura, a Comissão realizou uma comparação demográfica de desaparecidos permanentes e executados no país com as mesmas práticas repressivas na Argentina, Chile, Brasil e Uruguai. Assim, chega ao número de uma vítima a cada 6.313 habitantes, enquanto os demais países teriam: Argentina - uma vítima a cada 3.270 habitantes; Chile - uma vítima a cada 5.610 habitantes; Uruguai - uma vítima a cada 23.270 habitantes; e Brasil - uma vítima a cada 243.183 habitantes. Mais do que dar uma ideia da gravidade da situação dos desaparecidos e das 
execuções no país, a CVJ pretendia, com os números, medir a quantidade desses tipos de vítimas no contexto das ditaduras do Cone Sul (COMISIÓN DE VERDAD Y JUSTICIA, 2008, Tomo II: Las principales violaciones a los derechos humanos).

Para os diversos crimes da ditadura stronista, a Comissão realizou um total de 178 recomendações e propostas de reparação das vítimas, com medidas referentes às buscas de pessoas desaparecidas, crianças sequestradas e cadáveres escondidos; às sanções judiciais ou administrativas dos responsáveis por violações; à educação aos direitos humanos e o reestabelecimento desses direitos; entre outras. Ressaltamos a preocupação do informe em precisar a necessidade de espaços de memória no país, eliminando lugares públicos nomeados com responsáveis de crimes, estabelecendo datas comemorativas às vítimas, promovendo programas de reinserção à vida política e social, fazendo políticas públicas para o regresso dos exilados, garantindo a participação de comunidades indígenas nas decisões sobre políticas que as afetem, devolvendo bens, inclusive terras ilegalmente tituladas e etc. (COMISIÓN DE VERDAD Y JUSTICIA, 2008, Conclusiones y Recomendaciones del Informe Final de la Comisión de Verdad y Justicia del Paraguay).

Uma das grandes contribuições do Informe Final. Anive Haguã Oiko é ampliar o conceito de vítimas das ditaduras, sinalizando diferentes grupos sociais, afetados de diversas maneiras pelos sistemas. Considerando todas as vítimas como "luchadores y luchadoras" de causas sociais, claramente resolvendo a problemática sobre as vítimas passivas de alguns informes anteriores, como no caso argentino do Nunca Más, esse informe ganha o espaço público enquanto base para diversas discussões em torno da legalidade, da democracia e da reparação no país.

A própria Comissão apresentou aos organismos judiciais dez denúncias de violações aos direitos humanos, a fim de que fossem considerados crimes imprescritíveis, diante do Código Penal nacional, por serem crimes contra a humanidade. No entanto, os trâmites judiciais internos são extremamente lentos, fazendo com que algumas vítimas passassem a recorrer à justiça no país vizinho, a Argentina, como estratégia para a penalização de responsáveis - desta forma, entraram naquela justiça com causas criminais, em 2013, José Martin Almada, Yudith Rolón, Hernán Rolón, Virgílio Barreiro, Casabianca Rodríguez e Margarita Mbywangi (PRESENTAN..., 2013).

A tentativa de mudança política do país, em 2008, despertou uma esperança relâmpago nas organizações de direitos humanos, sobre as políticas públicas em relação às memórias desse passado. Fernando Lugo (eleito pela coalizão Alianza Patriótica para el Cambio, que destituiu pela primeira vez o Partido Colorado do poder, no pós-ditadura) criou 
um organismo do Estado, a Dirección de Verdad, Justicia y Reparación ${ }^{86}$, para se trabalhar com temas pendentes dos direitos humanos, atualizar constantemente o informe da CVJ, buscar desaparecidos e valorizar lugares históricos.

Em 2011, seu governo também criou a TV Pública Paraguay, que transmitiu a série documental, intitulada 35 años del Stronismo, abordando diversas violações da ditadura com o intuito de divulgar o conteúdo do informe. Cada episódio da série (quatro no total) era uma homenagem aos "luchadores e luchadoras" paraguaios e teve aproximadamente cinquenta minutos de duração, divididos em três blocos: o primeiro, que desenvolvia uma temática específica - os 35 anos do stronismo, o Archivo del Terror, os desaparecidos, e os grupos vulneráveis; o segundo, que fazia um recorrido nos testemunhos das vítimas, encontrados no Museo Virtual "Memória y Verdad sobre el Stronismo" ${ }^{\text {; }}$; e o terceiro, que encerrava o programa, com análises sobre as consequências do governo ditatorial e das violações aos direitos humanos (35 AÑOS DE STRONISMO, 2011).

Trazendo temas locais e regionais, como o crescimento do autoritarismo na sociedade, a conformação de políticas clientelistas e corruptas, as violações aos direitos básicos da humanidade, a importância dos arquivos para a consciência social, os diferentes trabalhos de luta pelos direitos humanos, o espectro enorme de vítimas (diretas e indiretas) de um sistema totalitário, e também de um sistema atual que se pretende democrático, esses programas trouxeram questões sobre como responder socialmente às informações dadas, sobre como romper com a "herança" de violência, e sobre como integrar as lutas pelos direitos humanos de maneira universal.

A própria série se encerra com uma grande reflexão sobre os dias atuais e o desprezo (em discurso e em ações) pelos direitos humanos. Grande parte de uma geração que não consegue conceber direitos básicos ao outro, porque não reconhece nele um ser merecedor. E, neste sentido, o programa abriu espaço para os depoimentos sobre traumas, violências e experiências de lutas cotidianas por reparação e justiça, considerando-as valores coletivos, indo contra a correnteza do individualismo.

De forma bela, por exemplo, Derlis Villalba, filho de desaparecido, socializa sua dor e reflete sobre esses argumentos, em sociedades marcadas pela permanência de atores e práticas de períodos autoritários.

\footnotetext{
${ }^{86}$ A Dirección General de Verdad, Justicia y Reparación é um programa governamental de proteção aos direitos humanos, vinculada, porém autônoma, da Defensoría del Pueblo, que deveria continuar o trabalho da CVJ, conservando documentações, concebendo infraestrutura para investigações e descobertas dos paradeiros dos desaparecidos e trabalhando com reparações simbólicas às vítimas (PARAGUAY, 2009).

${ }^{87} \mathrm{O}$ endereço eletrônico do museu virtual Memoria y Verdad sobre el Stronismo é <www.meves.org.py>. Acesso em: 09 ago. 2015.
} 
Todos los gobiernos totalitarios, todas las dictaduras militares no garantizaron mejores condiciones de vida al pueblo. Al revés, garantizaron privilegios enormes a los sectores involucrados con el poder. No podemos decir que con regímenes totalitarios vamos garantizar mejores condiciones de vida, en materia de salud, educación e etc. Los regímenes totalitarios reprimen la participación de las personas y, sin participación de las personas en las decisiones del país, no es posible un mejoramiento en la calidad de vida de todos (35 AÑOS DE STRONISMO, 2011, Programa 4: Grupos Vulnerables).

Esse espaço de contato entre a sociedade e as narrativas das vítimas, formulando diversos pensamentyos críticos em relação ao passado recente, entretanto, retrocede em 2012, quando Fernando Lugo sofre o golpe político, que o retira da presidência. Ao indicar Emilio Camacho como interventor do Instituto de Desarrollo Rural de la Tierra (INDERT), designando-lhe o papel de realizar a reforma agrária no país e resolver a situação irregular das terras, o governo passou a ser combatido por setores agrários paraguaios, terminando no Masacre de Curuguaty.

Como resposta à ocupação nas terras de Marina Cué, o massacre foi resultado da violência utilizada para se solucionar uma disputa judicial entre a empresa Campos Morumbi S.A. e o INDERT. As terras em questão haviam sido entregues oficialmente ao Instituto para que o mesmo realizasse a redistribuição delas, contudo, com o pedido de desalojamento dos assentados, um fiscal da justiça preparou a desocupação, utilizando-se cerca de 320 oficiais das forças policiais e exigindo papéis que comprovassem a propriedade das terras. Não obtendo resposta, a polícia abriu fogo contra os trabalhadores rurais e provocou a morte de dezesseis pessoas (PARAGUAY: TRAS..., 2013).

As irregularidades das investigações deste caso foram inúmeras - imagens que desapareceram, fotografias que mostravam corpos em posições modificadas, provas incorporadas indevidamente e sinais de execuções de pessoas. A reação política ao episódio foi o juízo do presidente Fernando Lugo e um processo (relâmpago) que o destituiu do cargo - medida essa repudiada pelo Mercosul e pela Unasul, que a consideraram um golpe de Estado. Posteriormente, uma lista de acusados por homicídio doloso agravado colocou diversos trabalhadores rurais na prisão, como responsáveis pelo massacre. O título de propriedade, exigido pelos policiais, até hoje não apareceu, o processo judicial foi suspenso e várias críticas são feitas àquela repressão policial não esclarecida.

Nesse contexto, a população saiu às ruas, realizando diversas manifestações contra o golpe. Essas demandas criaram o "Micrófono Abierto" na Televisión Pública Paraguay, programa onde se opinava sobre a situação política, através de um microfone aberto colocado 
em vias públicas. Segundo Sergio Marcos, diretor do canal na época, "El Micrófono Abierto surgió en un momento muy sensible, donde hubo un cambio de gobierno y eso se utilizó como un espacio de catharsis" (MICRÓFONO..., 2013). Esses atos colocaram em marcha novos mecanismos de justiça transicional, como uma Comissão Investigadora do Masacre de Curuguaty e a plataforma de denúncias nas redes sociais, intitulada "Paraguay resiste al golpe $^{, 88}$.

Neste sentido, o país que ampliou a noção de vítimas e de crimes com seu informe da Comissão de Verdade, vive na constante denúncia de desrespeito aos seus direitos políticos e sociais. Apesar da CVJ haver auxiliado na criação de um espaço para denúncias das vítimas, a falta de interesse político em realizar as recomendações da mesma traz a recorrência de violações contra povos indígenas, contra trabalhadores rurais, contra mulheres e luchadores sociais.

\section{3 - Testemunhos no espaço público e a Comisión para la Paz (COMPAZ)}

No Uruguai, o acordo social em torno da Ley de Caducidad de la Pretención Punitiva del Estado também influenciou a conformação do espaço relativo à Comissão de Verdade do país. Quando aprovada, como vimos no capítulo anterior, a Ley de Caducidad angariou uma série de questionamentos por parte dos movimentos de direitos humanos, nacionais e internacionais, que exigiam, por um lado, sua derrogação e, por outro, a investigação sobre os desaparecidos no país.

Em nove de agosto de 2000, o presidente Jorge Batlle (Partido Colorado) atendeu uma parte dessas demandas e criou a Comisión para la Paz (COMPAZ), com a finalidade de determinar a situação específica dos detidos-desaparecidos e dos menores sequestrados durante o regime militar - as duas categorias não contempladas nos crimes anistiados pela Ley de Caducidad. Esta Comissão teria o prazo de 120 dias para receber, analisar, classificar e recopilar informações sobre desaparecimentos permanentes, através de documentos e recolhimento de testemunhos, em confidencialidade das fontes, e elaborar um informe com suas conclusões, como medida reparatória (URUGUAY, 2000).

Assim, foram chamados pela Presidência para compor a Comissão, em um ato não público, o presidente honorário da Convención Nacional de Trabajadores, José Artigas Délia Correa, o professor de Economia José Claudio Williman Ramirez, o professor de Direito

\footnotetext{
${ }^{88}$ A plataforma pode ser visitada no seguinte endereço eletrônico: 〈http://paraguayresiste.com>. Acesso em: 11 nov. 2015.
} 
Gonzalo D. Fernández, o conselheiro de direitos humanos da Organização das Nações Unidas, Luis Perez Aguirre, o advogado Carlos Ramela Regules e o Monsenhor Nicolás Domingo Fanizzi.

Funcionando no Edificio Independencia, a Comissão contou com o auxílio de uma única funcionária administrativa, Maria Soledad Braga, e seus trabalhos de recolhimento de informação, através de documentos, já elaborados pelas organizações de direitos humanos, e de testemunhos, eram repassados à Presidência da República que, por sua vez, informava aos órgãos de comunicação e aos familiares de detidos-desaparecidos. Assim, tratou de recopilar as informações já existentes pelos aportes documentais da Asociación de Familiares de Detenidos-Desaparecidos, do Servicio de Paz y Justicia e do Instituto de Estudios Legales y Sociales del Uruguay, além de testemunhos de membros de partidos políticos, funcionários públicos, integrantes das Forças Armadas e policiais (quando estavam de acordo em testemunhar), familiares e cidadãos em geral, do país e do exterior, principalmente argentinos, que quiseram colaborar nessa tarefa. Em âmbito internacional, recebeu cooperação da Secretaria de Direitos Humanos argentina, da Equipo Argentino de Antropología Forense, da Câmara Nacional de Apelações Criminais argentina, das Abuelas de la Plaza de Mayo, da Fundación Comisión Católica Argentina de Migraciones, do Ministério do Interior chileno e do Ministério de Relações Exteriores paraguaio (COMISIÓN PARA LA PAZ, 2003).

De acordo com a COMPAZ, seus trabalhos foram dificultados por alguns aspectos da própria criação da Comissão. Primeiro, o longo tempo transcorrido entre os atos cometidos e a instalação da investigação (alguns casos com quase trinta anos de diferença temporal), acarretou na morte de alguns protagonistas e na dificuldade de reconstrução dos mesmos episódios pelos testemunhos entrevistados. Depois, a retração de alguns entrevistados em seus depoimentos levou a Comissão a decidir não gravar ou tomar atas das entrevistas, apenas notas de dados e detalhes significativos - solução um tanto quanto questionável para ser tomada por uma Comissão com intuito de estabelecer a verdade. E, por fim, a fragmentação das informações sobre os desaparecidos foi um grande obstáculo, por contar apenas com os testemunhos das vítimas dessas histórias, cujos elementos-chaves, muitas vezes, estavam nos depoimentos de policiais e militares, não dispostos a dar entrevistas.

Desta forma limitada, as denúncias foram agrupadas em quatro modalidades: 1) pessoas desaparecidas no país; 2) cidadãos uruguaios desaparecidos na Argentina; 3) filhos de pessoas detidas sequestrados; e 4) corpos aparecidos nas costas uruguaias. Como conteúdo, portanto, a COMPAZ priorizou três categorias de repressão que foram os desaparecidos, os 
filhos sequestrados e os mortos. E, dentro dessas condições, recebeu 38 denúncias, sendo seis de cidadãos argentinos, cujas mortes em cativeiro foram confirmadas em 26 casos.

Atenta-se aqui para a questão dos corpos desses desparecidos. Algumas dessas denúncias têm esses corpos (mortos ou vivos) circulando na região, perpassando localidades no Brasil, Bolívia, Paraguai, Chile e, principalmente, na Argentina. Em muitos casos, foram confirmadas passagens de uruguaios por Centros Clandestinos neste último país, antes de desaparecerem. E, em outros casos, cidadãos estrangeiros que foram desaparecidos no Uruguai ou cujos corpos apareceram em suas costas.

Um desses exemplos é o aparecimento de um corpo nas águas do Río de la Plata, em Montevidéu, no ano de $1976 .{ }^{89}$ O corpo de María Rosa Mora, argentina, militante da Juventud Trabajadora Peronista e detida-desaparecida possivelmente na ex-ESMA, foi encontrado por um barco pesqueiro na costa uruguaia. Sua autópsia revelou uma morte por submersão e a possibilidade de haver sido prisioneira, devido às manchas nos dedos correspondentes à retirada de impressões digitais. O corpo de María Rosa foi enterrado como NN no Cementerio del Norte, Montevidéu, e não pôde ser recuperado pela COMPAZ por já haver sido cremado, de acordo com as normas do Servicio Fúnebre y Necrópolis de la Intendencia de Montevideo.

A Comissão levantou a possibilidade de que os corpos de pessoas desaparecidas poderiam haver sido enterrados nas dependências das Forças Armadas e que, no final do ano de 1984, algumas dessas pessoas tivessem sido cremadas (em fornos de fabricação informal) e suas cinzas jogadas no rio. Contudo, em 2005, as Forças Armadas entregaram um informe sobre os casos relatados pela Comissão, que contradiz essas informações. Sob a solicitação do presidente Tabaré Vázquez (2005-2010), as Forças Armadas redigiram um documento, no qual se responsabilizavam pelo desaparecimento de Arpino Vega e Chavez Sosa, reconheciam dois voos desde Buenos Aires para trazer prisioneiros ao país, responsabilizavam-se pela aplicação de tortura nas cárceres, e suas consequentes mortes, e determinavam um paradeiro diferente para estes desaparecidos listados pela COMPAZ, enterrados em quartéis (URUGUAY: HISTÓRICO..., 2005).

O informe de 2005 foi bastante criticado pelas organizações de direitos humanos, considerando que as mesmas Forças não se responsabilizaram por desaparecimentos ocorridos na Argentina, em 1977, tampouco deram conhecimento sobre o verdadeiro número de

\footnotetext{
${ }^{89}$ Para informações sobre corpos identificados e não identificados das costas uruguaias, ver informações na Secretaria de Direitos Humanos do governo uruguaio, disponíveis em: <http://sdh.gub.uy/inicio/institucional/equipos/centro_de_documentacion_y_comunicacion/documentos_equipo_ historia>. Acesso em: 23 jul. 2015.
} 
desaparecidos no país, ponderando apenas o pequeno número dado pela Comissão (MADRES Y FAMILIARES DE DETENIDOS-DESAPARECIDOS, 2005).

Sabemos que esta Comissão, centralizada no espaço nacional e com limitações jurídicas para investigação, enfocou-se nos desaparecidos, mortos e crianças sequestradas, não adentrando na principal modalidade repressiva do país: a detenção de pessoas de maneira extraoficial (o desaparecimento circunstancial) e o exílio político. O sistema de exclusão dos ditos subversivos, como visto, era majoritariamente sua reclusão e, dentro da cárcere, a aplicação de penas rigorosas, arbitrariedades e torturas (PADRÓS, 2008, p. 164-167). Este sistema fez com que o número de exilados do país corresponda à $14 \%$ de sua população (SCHELOTTO, 2015).

Mesmo recordando a responsabilidade do Estado em habilitar a violência, o sequestro e a morte de pessoas, a COMPAZ enquadrou o espaço de fala das vítimas, a partir de pressupostos que não consideram a totalidade das violações locais, tampouco suas especificidades históricas. Neste sentido, o informe contendo 85 páginas é incompleto e inferior em resultados, se comparado às demais investigações realizadas em âmbito regional, anteriores a ele, que poderiam ser consideradas exemplos. 
Imagem 14 - Apresentação do pré-Informe Final da COMPAZ

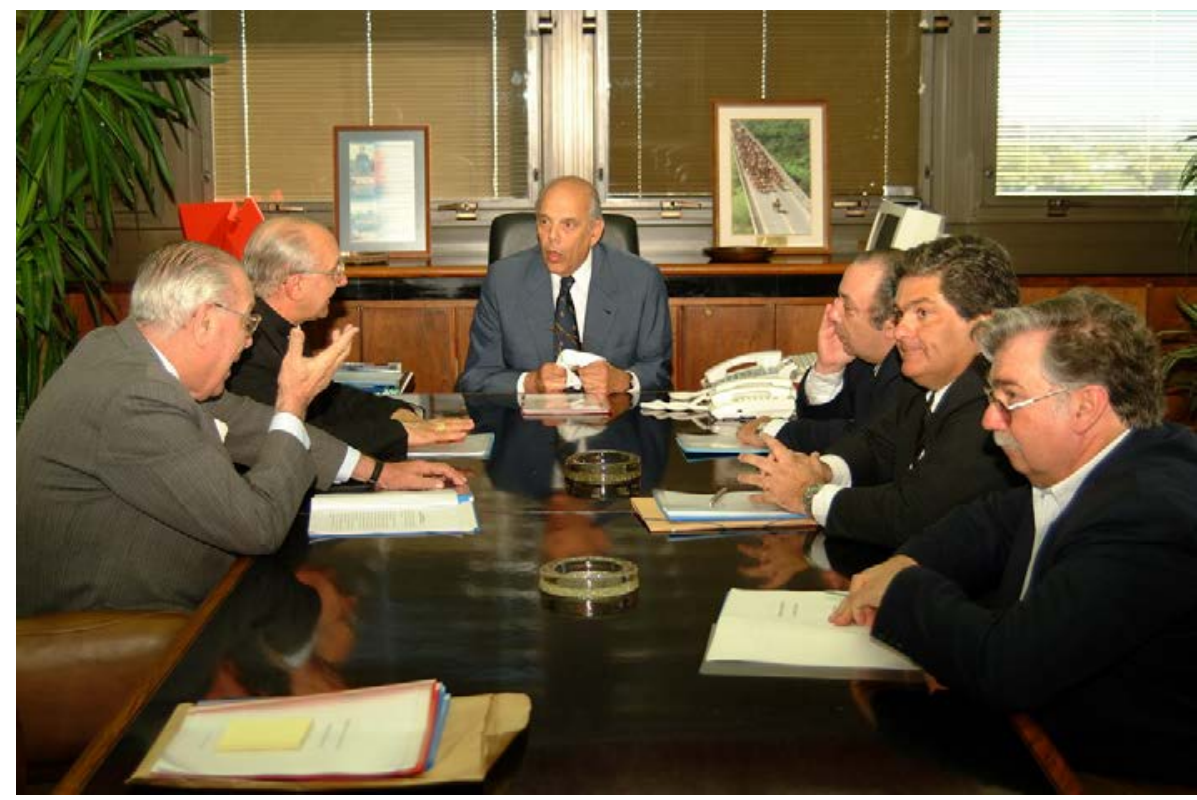

Fonte: ARCHIVO DE LA PRESIDENCIA DE LA REPÚBLICA ORIENTAL DEL URUGUAY. Disponível em: <http://archivo.presidencia.gub.uy/fotos/banco/2002/octubre/octubre2002.htm>. Acesso em: 16 jul. 2015.

A situação desse espaço de fala, entretanto, se modifica com as eleições do primeiro governo de coalizão centro-esquerda (Frente Amplio), cujo candidato Tabaré Vázquez ganha as eleições de 2004. Já no ano seguinte, a Presidência da República realiza um convênio com a Universidad de la República (UDELAR), no qual constituem uma equipe antropológica e outra histórica para desenvolverem pesquisas sobre os detidos-desaparecidos.

Desta forma, estas pesquisas foram realizadas em três etapas: 1) investigações históricas e arqueológicas sobre detidos-desaparecidos, entregues em 2007; 2) complementações dessas pesquisas, entregues em 2010; e 3) resultados de localizações de corpos de desaparecidos, revisões dos arquivos e difusão dessa informações, entregues em 2011 à presidência de José Mujica (2010-2015, Frente Amplio). Os eixos dessas investigações focalizaram-se nas análises de documentos e testemunhos sobre o período ditatorial, o desaparecimento forçado, os delitos de lesa humanidade, incluindo prisões ilegais e o exílio por motivos políticos, e o contexto repressivo, associando-o aos demais contextos de países do sul da América Latina.

Nesse sentido, as novas investigações chamaram a atenção para violações diversas de vítimas no país com sentidos políticos, que crescem entre os anos 1975 e 1977, momento de grande atividade do Sistema Condor na região. Assinala, ainda, que a justificativa para a 
existência desse sistema, fundamentada em diversas documentações do país e do exterior, na repressão à Junta Coordinadora Revolucionaria, não se aplicaria ao território uruguaio, uma vez que, com a colaboração das forças repressivas argentinas, chilenas e paraguaias, as vítimas desse Sistema foram majoritariamente membros do Partido por la Victoria del Pueblo (PVP), que não fazia parte da JCR. No caso dos Tupamaros, estes sim, parte da JCR, as Forças Armadas uruguaias haviam proclamado sua vitória na "luta antissubversiva" contra o movimento, ainda no ano de 1972, portanto, desvalidando tal justificativa (UNIVERSIDAD DE LA REPÚBLICA, 2008, Tomo I).

Logo, os membros do Organismo de Coordinación de Operaciones Antisubversivas (OCOA) são constantemente citados nos informes, como responsáveis diretos das práticas de variadas violações para a obtenção de informações sobre os sujeitos nacionais e estrangeiros a serem vitimados. A conjuntura repressiva regional, com este órgão, que não era encontrado em nenhum organograma estatal, ganha o caráter clandestino nas chamadas operações das Forças Armadas, em distintos territórios, com a finalidade de combate ao inimigo (UNIVERSIDAD DE LA REPÚBLICA, 2008, Tomo III).

Por outro lado, a comissão de investigação arqueológica dedicou-se ao encontro dos restos humanos e suas identificações, através das escavações no Batallón 13 (Montevidéu), Batallón 14 (Toledo), Chacra del Camino Piedritas (Pando), Cantera de ANCAP (Montevidéu), Centro Clandestino La Casona (Montevidéu), Chacra en Pajas Blancas (Montevidéu), Departamento Maldonado (aeroporto e cemitério), Parador Tejes (Canelones) e Brigada de Artillería Antiaerea N.1 (Canelones). Desta forma, além de recuperarem a identidade de alguns desaparecidos e seus lugares de ocultamento, também trabalharam com os processos posteriores que pretendiam perpetuar tais desaparecimentos permanentes, escondendo os cadáveres.

É o caso, por exemplo, da chamada Operación Zanahoria, ocorrida entre os anos 1984 e 1985, que implicou em responsabilidade do próprio (futuro) presidente, na época, Juan María Sanguinetti (Partido Colorado). ${ }^{90}$ Diversos testemunhos - inclusive de militares, cujos nomes de alguns são tarjados para a consulta e não identificação pública dos mesmos afirmavam que, nos anos prévios ao retorno democrático uruguaio, houve a exumação de corpos no batalhões N.13 e N.14 e o ocultamento dos mesmos em outras áreas.

9. Testimonio directo

Ex-soldado asegura haber sido testigo (entre 1984 y 1985, sin poder precisar más) de actividades de búsqueda, con maquinaria, de restos humanos, para su posterior exhumación en Batallón N.13. El testigo asegura: "Llegué a la

\footnotetext{
${ }^{90}$ Sobre o caso, há um filme intitulado Zanahoria - Detrás de la verdad (2014).
} 
máquina bulldozer” [que conducía un soldado, al que preguntó]: “¿y?, salen las zanahorias... me dice allá adelante apareció hoy otros..." (GRUPO DE INVESTIGACIONES DE ANTROPOLOGÍA FORENSE, 2012, p. 67).

Apesar da percepção de terras remexidas na região indicada, todavia não houve a comprovação de que tal operação tenha realmente existido. Em 2014, com a renúncia do coordenador do grupo de antropologia forense, José Lopez Mazz, o Grupo de Investigación en Antropología Forense (GIAF) tomou novas etapas de investigações, desconsiderando a existência da operação em questão, devido às informações desencontradas (LA OPERACIÓN..., 2014).

Os resultados desses trabalhos com a dupla de equipes são as constantes atualizações dos informes que seguem até hoje, com novos acordos entre UDELAR e o Estado, e com conclusões de investigações e documentos, que vão sendo organizados em informes e publicações impressas. As produções são apresentadas, periodicamente, em tomos para a Presidência da República, que vai atualizando as informações para o domínio público.

Com a autorização do Estado, por exemplo, a equipe de historiadores, coordenada pelo professor Álvaro Rico (2008), elaborou uma imensa investigação sobre outras dimensões do Terrorismo de Estado, até então não abordadas pela memória oficial. Pesquisou-se sobre assassinatos políticos, presos políticos, vigilância na sociedade civil, repressão ao movimento estudantis e sindicais, controle ao exílio, transformações de institucionalidade estatal e organismos de inteligência e Justiça Militar.

A Universidad de la República financiou a publicação e difusão desta produção, em três volumes, intitulada Investigación Histórica sobre la Dictadura y el Terrorismo de Estado en el Uruguay (1973-1985). Com três tomos (1- Os assassinatos e desaparecimentos, "sequestrados que nunca foram liberados"; 2- Sistema de violência e vigilância; 3Institucionalidade da repressão em sindicatos e partidos políticos), a obra pretende ser um reconhecimento por verdade e justiça no país que há décadas luta contra a impunidade.

Podemos perceber que esse trabalho constante, movido principalmente pelas organizações de direitos humanos e a UDELAR, vai abrindo "brechas" nas interpretações da anistia uruguaia. Por exemplo, a constituição de uma nova perspectiva em torno da Ley de Caducidad, que não agrega os civis que cometeram crimes contra a humanidade ou os delitos empreendidos fora do país na anulação da pretensão punitiva de responsáveis por crimes cometidos em ditadura. E, desta forma, foi possível condenar na Justiça Penal alguns violadores dos direitos humanos, como o ex-presidente Juan María Bordaberry. 
Em 2006, a Suprema Corte aceitou as denúncias de mais de 3 mil pessoas contra Bordaberry. Ele foi acusado de tomar medidas que infringiram os direitos dos cidadãos; pela detenção de José Arpino Vega, morto no Centro de Detenção Fuerza Aérea Boiso Lanza, em 1974; pela morte em tortura de Eduardo Pérez Silveira no Grupo de Artillería N.1, em 1974; pelo desaparecimento de Luiz Eduardo González, em 1974; pela prisão e desaparecimento de Eduardo Bleier Horovitz, em Punta Gorda, 1975; pelo desaparecimento de Juan Manuel Brieba, em 1975; pela morte de Fernando Miranda Pérez, cujo corpo fora descoberto nas escavações do Batallón N.13; pela morte em tortura de Carlos Arévalo, em 1975; pelo desaparecimento de Julio Gerardo e Ortemín Montes de Oca, em 1975; pela morte de Horacio Gelós Bonilla; e pela morte de Chavez Sosa em tortura, cujas cinzas foram jogadas no Río de la Plata. Assim, condenou-se Bordaberry por delitos contra a Constituição, nove delitos de desaparecimento forçado e dois de homicídio agravado (URUGUAY, 2010).

Outro ponto importante de mobilização dessas investigações é a associação entre Universidade e a memória oficial. Segundo a apresentação do então reitor da UDELAR, escrita para a obra publicada de Álvaro Rico (2008),

Es un honor afirmar que entre esos protagonistas se cuentan no pocos
universitarios y, en particular, el equipo de investigadores de la Universidad
de la República a los que debemos esa obra. Su labor ejemplifica
vívidamente lo que significa cumplir con lo que la legislación vigente define
como los "fines de la Universidad", entre los que figuran "contribuir al
estudio de los problemas de interés general y propender a su comprensión
pública; defender los valores morales y los principios de justicia, libertad,
bienestar, los derechos de la persona humana y la forma democrático-
republicana de gobierno" (AROCENA apud RICO, 2008, Tomo I, p. 9).

Se, por um lado, o ativismo da Universidad de la República em torno aos direitos humanos possibilita a revisão da narrativa sobre o período de repressão, contribuindo para o papel social da instituição, por outro, faz-se uma ligação entre memória oficial e legitimidade científica. Esse possível sentido de imparcialidade para a narrativa deve ser questionado, uma vez que compreendemos que ela não compete às disputas em torno da memória.

Fato é que as novas proposições revisaram possibilidades legislativas, transformando, de alguma maneira, o contexto de silenciamento e impunidade no país. Quando se publica a Lei N.18.596 de 2009, por exemplo, na qual o Estado se responsabiliza pela "quebra do estado de direito que impediu o exercício de direitos fundamentais às pessoas, em violação dos direitos humanos" (URUGUAY, 2009a, sem paginação), puderam ser, enfim, reconhecidas publicamente as práticas sistemáticas de tortura, desaparecimento, prisão sem intervenção judicial, homicídios e aniquilação, em nome de uma doutrina de Segurança 
Nacional (GARRETÓN; GONZÁLEZ; LAUZÁN, 2011). E, essa nova perspectiva só foi possível pelas constantes disputas em torno da justiça de transição uruguaia, que seguem em movimento.

\section{4 - Os espaços das Comissões em perspectiva regional}

As Comissões com iniciativas para a verdade constituíram-se em um dos principais modelos estatais de produção de um espaço para se saber as experiências das vítimas sobre os processos de ditaduras no Cone Sul. Indo além de suas associações entre investigações e processos judiciais, o que muitas vezes não são possíveis pelas leis de anistia ou pelo permanecimento de determinados sujeitos no espaço de poder, seus informes propõem estratégias narrativas e explicações sobre o passado recente, que reafirmam um tipo de “reconciliação nacional”, através da justiça de transição e de identidade das vítimas em cada país.

Nesse sentido, fica evidente o exemplo do modelo do Nunca Más argentino, escolhido como uma das estratégias de divulgação da narrativa do trauma, que se constituiu em memória coletiva nacional, estendendo-se para o espaço regional e global, cujo sujeito central é o desaparecido. A partir dessa figura, outros processos de construção de espaços para se negociar a memória foram instituídos no Cone Sul com resultados diferentes.

Vimos, no caso da Comisión Nacional sobre la Desaparición de Personas e do Nunca Más, uma intensa participação das organizações de direitos humanos e da sociedade, que tomaram para si a responsabilidade em difundir as descobertas, participar politicamente contra o esquecimento e condenar publicamente os perpetradores da violência de Estado. Essa sociedade, que negava o conhecimento dos crimes cometidos, enfrentou-se com a tarefa de escutar os testemunhos de traumas e lhes deu uma legitimidade, a partir desta Comissão.

Segundo Emilio Crenzel (2008, p. 145-146 e nota 254), a experiência e o modelo do Nunca Más circularam nas redes transnacionais de direitos humanos e foram considerados como uma alternativa exemplar para elaborar e expor publicamente as violências perpetradas por ditaduras. Na América Latina, influenciaram Comissões de Verdade oficiais, como a chilena, salvadorenha, guatemalteca e peruana. Contudo, também entusiasmaram informes "Nunca Mais" de grupos da sociedade civil, como no Brasil, Guatemala, Uruguai, cujo Nunca Más fora escrito pelo Servicio Paz y Justicia (1989), e no Paraguai, que teve seu Nunca Más escrito pelo Comité de Iglesia para Ayudas de Emergencia (1990). 
No entanto, este modelo não permaneceu estático no tempo histórico. Ele foi se adequando às interpretações contextuais do país e ganhando novas estratégias para recuperálo, enquanto objeto político. É o caso, por exemplo, do apagamento das questões de responsabilidade social, que o informe trazia e que os Juicios de la Juntas não priorizaram, conformando uma perspectiva fundamentada na Teoria dos Dois Demônios.

Outro caso é, quando na década de 1990, ele torna-se um instrumento de resistência contra a impunidade, retomando inclusive associações com o Holocausto nas novas publicações do informe, para mobilizar teorias internacionais, que pudessem modificar os impactos da falta de justiça. Desta forma, vimos o crescimento dessas associações com o Holocausto como exemplar nas representações simbólicas, que acompanhavam as reedições do Nunca Más.

Ou ainda, quando ganha o tom político, nas comemorações dos 30 anos do golpe, podendo, enfim, associar o processo ditatorial aos modelos econômicos impostos para a América Latina, relacionando, portanto, o extermínio às dinâmicas econômicas. Logo, foi-se tomando forma a ideia de prática social genocida nas interpretações do informe.

No Paraguai, vimos que as demandas dos organismos de direitos humanos e das vítimas de violações também tiveram um papel determinante para a conformação da Comisión de Verdad y Justicia. E, neste sentido, os trabalhos da Comissão e seu informe produzido têm um tom, de acordo com as variadas violações ocorridas no país e suas especificidades.

Atentamos, no texto, para a noção de genocídio que a CVJ se utiliza como forma de orientar a visão dos crimes cometidos pela ditadura, principalmente quando as temáticas se relacionam com as questões da distribuição de terras e das comunidades indígenas. E, tendo estendido suas investigações aos anos que se seguiram à ditadura, ela deixa clara sua visão da perpetuação de violações aos direitos humanos no país contra essas populações.

Também com a perspectiva da relação entre modelos econômicos e sistemas repressivos, a CVJ coloca o país nesse sistema internacional de crime, apontando as responsabilidades das elites locais e internacionais pelas violações aos direitos humanos dos paraguaios. E, por outro lado, também determina a responsabilidade das Forças de Segurança paraguaias na repressão regional.

Percebemos a importância que o modelo paraguaio dá ao Sistema Condor como uma estrutura organizada de repressão regional e, portanto, de responsabilidade pelo passado recente. Estendendo esta responsabilidade, seu informe implica em detalhar ações ocorridas no país, dentro do sistema, e fora dele, principalmente com suas ligações aos regimes brasileiro e argentino. 
A conjuntura de (quase) ingovernabilidade local torna esse espaço de fala ainda mais importante dentro do "caldeirão de disputas políticas" pela memória sobre o Partido Colorado e sua ala stronista, que possuem fortes representações na cultura política do país. Desta forma, o espaço criado pela Comissão é um espaço de ruptura na conformação de sua justiça transicional e deve ser visto como um modelo exemplar dentro da luta regional pelos direitos humanos, mesmo que suas recomendações esbarrem nas dificuldades políticas para empreendê-las.

Para o caso uruguaio, com a Ley de Caducidad intensamente discutida e reafirmada pela população, os organismos de direitos humanos tiveram de revisar suas estratégias para alcançar essa demanda do espaço público em relação à fala das vítimas. Desta forma, a própria lei passou a fundamentar a necessidade de um processo de conformação da verdade oficial, a partir de suas saídas normativas: investigar os desaparecimentos, os crimes em outros territórios e os sequestros de crianças. E, então, sua conexão com a Argentina, a partir do Sistema Condor, torna-se completamente visível.

Com a COMPAZ e seu sentido de "pacificação nacional", a participação pública foi menor, o regime de recolhimento de depoimentos não levou em conta a especificidade da repressão no país e os trabalhos foram considerados, pelos organismos de direitos humanos, uma reparação insuficiente. Contudo, a partir dela, novas demandas foram sendo criadas, e o Estado passa a atendê-las, assinando um acordo com a Universidade, que amplia as informações e as embasa cientificamente, podendo, enfim, destacar outras formas de violações aos direitos humanos do período ditatorial no país.

Devemos pensar que, além das especificidades históricas dos espaços estudados, a conformação dessas Comissões também está distanciada pelo tempo. Essa diferença influencia não apenas o modo de produção e de divulgação dos informes, como também os atores participantes e seus públicos. Isto quer dizer que, na Argentina, por haver conformado outro tipo de transição, os atores e leitores dos anos 1980 estavam envolvidos emocionalmente com aquele passado. Mas, ao longo do tempo, o informe vai sendo revisitado por novos leitores, em outros contextos, conformando novas críticas e transformando aquela informação.

No Paraguai, os tempos da CVJ se mesclam entre passado e presente e, portanto, os sentidos das vítimas se ampliam, tornando-os sempre luchadores nas discussões ativas pelos direitos humanos. Fica claro que as violações no país são recorrentes e, justamente por isso, a ideia de luta é mais enfatizada do que a ideia de vítima passiva. 
E, no Uruguai, décadas após a transição, o tempo determina a necessidade de recuperação dos sentidos das violações. Isto porque as novas gerações se transformaram dentro de uma normalidade de anistia, cujos depoimentos passam a ser possíveis em um espaço específico, limitado pelo governo e pela Universidade. Portanto, a luta dos organismos de direitos humanos tem sido conseguir penetrar nesse contexto de esquecimento, que fundamenta essencialmente uma identidade democrática do país.

Contudo, há um ponto de cruzamento entre esses tempos, que se encontra na ideia de reconciliação e de desejo por um futuro sem violações, trazida por essas Comissões em seus informes. Isso se dá, por exemplo, nos casos da relação entre os trabalhos das comissões com a produção de provas para responsabilizar as violações, fundamentadas nos acordos internacionais. Nestes casos, sob a perspectiva da luta pelos direitos humanos, mesmo que as Comissões não tenham o valor penal, o que acontece com a grande maioria delas, o desejo dos movimentos é ultrapassar o "valor da verdade" e demandar uma reconciliação social que passe pela responsabilização.

De acordo com Sikking e Walling (2008), os mecanismos de justiça de transição não são escolhas únicas (ou verdade ou justiça) e nem possuem sequências e combinações exatas. Eles vão se mesclando e criando possibilidades dentro dos sistemas democráticos de cada país. E, no caso latino-americano, quase dois terços de seus países utilizaram-se de Comissões, embora alguns deles tenham outorgado leis de anistia. Segundo as autoras, essas legislações não impedem que se siga o que denominam de uma "cascata de justiça", onde, apesar de variáveis, se tende a responsabilizar aqueles que atentaram contra os direitos humanos em regimes passados.

E, neste sentido, as Comissões tiveram uma capacidade de modificar os cenários locais aqui estudados, colocando a responsabilidade do Estado pelas violações aos direitos humanos, tornando pública uma identidade das vítimas dos Terrorismos de Estado, e tentando promover uma espécie de reparação. Elas também ampliaram o conhecimento global sobre as violências ocorridas nesses países e suas medidas de justiça de transição para superar o passado recente, e, portanto, possibilitaram uma vitória possível sobre a pretensão de silenciar as vozes de suas vítimas. 


\title{
CAPÍTULO 4
}

\section{NARRATIVAS E TERRITÓRIOS: AS MEMÓRIAS PARA A EDUCAÇÃO EM MATÉRIA DE DIREITOS HUMANOS}

\author{
En Agua Prieta, desierto de Arizona, \\ Vive el pez dorado. \\ Tiene una memoria que dura tres segundos. \\ Vive solo en el presente. \\ Nada sin parar. \\ Reinventa todo a cada instante, \\ pero no llega a ninguna parte, \\ porque su camino es siempre otro. \\ (...) \\ La historia que guarda el pez dorado \\ Es como la nuestra, dura apenas tres segundos. \\ Nuestros dolores se repiten \\ Y aparecen nuevos cada vez (ESPINOSA, 2013, sem paginação).
}

Ingressamos, a partir deste capítulo, em nossos últimos objetos de análise, que são os territórios de memória, constituídos por instituições, que almejam a educação em matéria de direitos humanos. Recuperando a problemática benjaminiana das narrativas e atravessando a recordação, através dela, veremos aqui alguns espaços destinados a representar o passado, de maneira crítica, nas cidades de Buenos Aires, Assunção e Montevidéu.

As marcas de memórias do passado nas cidades contemporâneas permitem o contato entre as gerações e as suas experiências, demarcando socialmente uma determinada interpretação nos espaços públicos. Quando vinculadas às histórias de catástrofes, essas marcas urbanas geralmente transmitem o trauma, recordando suas vítimas, denunciando o horror e constituindo-se em uma instância pedagógica para não repetição (CATELA, 2001).

Cada uma dessas instâncias pedagógicas (placas, monumentos, manifestações, leis, arquivos, museus, julgamentos e etc.) é um território conquistado, cujos potenciais para o ensino passam por escolhas estéticas e políticas, de representações e de fatos, entre a exemplificação ou o mito. A partir dessas escolhas, elas gerem sensibilidades sociais em torno de um tema e articulam os interesses individuais e coletivos, na representação.

Quando se pensa em representações de catástrofes, não se esquece da polêmica frase de Adorno sobre o ato de barbárie que é se escrever um "poema" após Auschwitz. Recebida injustamente como rejeição à poesia, Adorno propôs que a beleza na constituição artística é uma injúria à memória dos mortos, em sua compreensão de que a cultura serve a um sistema ideológico opressivo, e a beleza suaviza as lembranças catastróficas para o consumo (GAGNEBIN, 2013, p. 89-111). 
Pensando uma indústria cultural ainda de meados do século $\mathrm{XX}$ - o que veio se aprimorando tecnicamente, a partir de então -, Adorno expõe essa criação de cultura, que também absorve produções artísticas insubordinadas, criando modelos e fórmulas para alimentar o valor de troca dessas produções. Informações e diversões capazes de preencher o "tempo livre" dos homens (tempo livre do trabalho, que nada tem a ver com a liberdade), que acabam por conferir um maior controle dos produtos consumidos, anulando a liberdade humana frente às escolhas culturais (ADORNO; HORKHEIMER, 1985 e ADORNO, 2002).

Em algum sentido, é a mesma ideia que propõe Walter Benjamin (2012) de que não existe um documento da cultura que não seja também documento da barbárie. Segundo Benjamin, essa produção cultural e suas obras finais demonstram uma espécie de hierarquia da produção ${ }^{91}$, dentro de um modelo capitalista, que aponta para catástrofes como regras, justificadas em nome do progresso. De uma forma distinta de Adorno, no entanto, ele propôs a possibilidade de um enfretamento dessa posição ideológica das produções culturais, nas próprias produções culturais, objetivando o "estado de exceção" - a exceção à barbárie.

O que se coloca em pauta, portanto, é o papel da cultura no sistema capitalista que, assimilada por ele, reflete suas ideologias. E, por outro lado, a necessidade de romper com essa cadeia produtiva, através de uma postura estética política, onde o sofrimento humano possa estar ligado à transformação, à mobilização dos homens diante do horror (BENJAMIN, 2012).

Criar em arte - como também em pensamento - "após Auschwitz" significa não só rememorar os mortos e lutar contra o esquecimento, uma tarefa por certo imprescindível, mas comum à toda tradição desde a poesia épica, mas também acolher, no próprio movimento de rememoração, essa presença do sofrimento sem palavras, nem conceitos que desarticula a vontade de coerência e de sentido de nossos empreendimentos artísticos e reflexivos (GAGNEBIN, 2013, p. 104).

Assim, existiriam duas exigências que se dirigem à "arte depois de Auschwitz": 1) lutar contra o esquecimento e pela rememoração; e 2) não transformá-la em produto cultural a ser consumido - digerido, assimilado e integrado. Essas exigências ultrapassam o campo das artes e também se fazem necessárias, quando pensamos nos trabalhos da memória, nas suas dimensões acadêmicas, patrimoniais e educativas. Como afirmou Benjamin, em um mundo que nos empurra ao futuro (ao progresso permeado de catástrofes), apenas a apropriação crítica das recordações nos desperta desse "inimigo que não cessa de vencer" (BENJAMIN, 2012, p. 241-252).

\footnotetext{
${ }^{91}$ Os trabalhos de Edward Said (2011), entre outros autores, são exemplos dessa conexão entre produção cultural e interesses de expansão capitalista.
} 
No caso específico dos patrimônios, no mundo contemporâneo, as críticas à indústria cultural se unem aos processos de globalização, que ameaçariam bens históricos, arquitetônicos, ambientais e culturais "originais" (ou a "aura" benjaminiana) por sua mercantilização e consumo, através da nova indústria do turismo. Além disso, elas tratam de uma massificação dos bens patrimoniais e tradições populares integradas, então, a essa economia mundial.

Em contraponto, temos no patrimônio um objeto para se pensar, não apenas a identidade nacional e essa homogeneização econômica voltada à cultura, contudo, também outras temáticas, que se relacionam à luta material e simbólica entre grupos políticos, sociais e étnicos. Isto quer dizer que temos caminhos que nos levam aos debates sobre os patrimônios inseridos nesse contexto mundial hierárquico, em suas formas de consumo, democratização e ensino (CANCLINI, 1997, p. 57-85).

Ao trabalhar a memória da catástrofes, no âmbito patrimonial, percebemos que, enquanto frutos de projetos político-ideológicos, muitos patrimônios têm como objetivo a reconciliação social. A ideia de reconciliar tende a eliminar os elementos antagônicos do passado e do presente, assimilando-os em discursos únicos. Desta forma, dificulta nossa tarefa de conceber o patrimônio das catástrofes com suas estratégias, seus enfrentamentos, opressões e tiranias (VINYES, 2014, p. 12-27).

Nesse sentido, propusemos trazer aqui algumas dessas discussões estratégicas, que se enfrentam, na pequena amostragem de territórios de memória selecionados - Espacio para la Memoria, Promoción y Defensa de los Derechos Humanos, Museo de las Memorias: Dictadura y Derechos Humanos, e Museo de la Memoria. Inicialmente, faremos uma introdução ao tema, abordando as instituições em si, para então, adentrar, no próximo capítulo, o universo dos debates que ocorreram anteriormente as suas conformações.

\section{1 - A mudança epistemológica: Espacio para la Memoria, Promoción y Defensa de los Derechos Humanos (Buenos Aires)}

Os anos 1990 argentinos foram apontados, na história da memória do país, como anos de tentativas de silenciamento e esquecimento das práticas sociais genocidas da ditadura. Apesar dessa postura, como vimos, esse período em nada se caracteriza como um "limbo" para os debates sobre direitos humanos, já que diversas ações acerca das memórias do Terrorismo de Estado foram impulsionadas por organismos civis, com o objetivo de acalentar 
debates "enterrados" oficialmente, sob o argumento de encerramento da história do passado recente.

É, a partir desse posicionamento oficial, que os debates sobre o Terrorismo de Estado argentino ganham dois grandes aportes epistemológicos na luta pela memória (a verdade) e pela responsabilização (a justiça): o genocídio e o modelo neoliberal das políticas econômicas. Pensamentos não excludentes entre si, ao revés, extremamente conectados, essas duas interpretações ligadas à ditadura argentina impulsionam as lutas pelos direitos humanos no espaço público.

O genocídio ou o Estado Genocida, que encontramos em muitas falas, é caracterizado pela situação nacional da aplicação do Terrorismo de Estado (a combinação letal entre terror e Estado), que possibilitou o extermínio de uma geração no país e sua figura máxima, já vista nesse trabalho, o desaparecido. A cultura repressora argentina, outorgada ainda mais pelas leis de anistia, se evidenciaria em sua comparação ao fascismo e ao nazismo europeus, assim como na luta pela justiça, mais impelida com o argumento do direito internacional e suas interpretações locais e regionais para essas mortes (GRANDE, 2006, p. 46-47).

Para romper as narrativas de memórias totalizadoras e de discursos únicos (e certamente levando em conta o contexto de falência do Estado, devido às aplicações das políticas econômicas neoliberais no país ${ }^{92}$ ), o genocídio vem estreitamente ligado ao seu propósito de imposições políticas que acarretaram na exclusão social, na pobreza, no imperialismo cultural e econômico e na completa impunidade desse modelo. Logo, a dimensão do enfrentamento e da resistência ganha justificativas na dignidade humana, no sistema democrático, nos direitos humanos e na reformulação de um projeto nacional.

Assim, o grande elemento da repressão regional passa a ser um dos centros dessas discussões que é o Sistema Condor. Sendo caracterizado como essa "multinacional da morte", ele adentra o cenário, conjecturando sobre a responsabilidade internacional nas políticas do passado e do presente.

Desde Hiroshima y Nagasaki, hasta Vietnam y hasta Irak, símbolos del Terrorismo de Estado mundial se impone en estos momentos, existe una larga historia que la memoria debe recuperar.

La Guerra de Baja Intensidad (GBI) llegó para quedarse y la militarización avanza a cada día, con tropas y bases estadunidenses por toda América, conjuntamente con los planes económicos de apoderamiento de nuestros territorios y recursos.

La guerra que el presidente George W. Bush declaró al mundo, supera en la extensión de su mirada a "las fronteras seguras" que Adolf Hitler trazó, está empantanada tanto en Irak, como en Afganistán.

\footnotetext{
${ }^{92}$ Cf. ANSALDI, 2007.
} 
Su avance latinoamericano por varias vías, algunas abiertas y otras más ocultas, también está determinado por el escenario de resistencia que nuestro continente está mostrando al mundo. La lucha por los derechos humanos y de los pueblos nos dignifica, frente a la degradación de los poderosos, que como los gobiernos europeos, se prestan para que hoy en pleno siglo XXI, se lleve adelante una criminal Operación Cóndor mundial, que tendrá otro nombre y será más sofisticada (CALONI, 2006, p. 74).

Nessa argumentação insurgente, os anos de luta contra o esquecimento do horror regional deveriam ser exemplares para a memória mundial e para a história do tempo presente global. Afinal, enquanto os responsáveis pela tragédia latino-americana (internacionais e nacionais; os Estados Unidos e as elites globais e locais) exibissem a continuação de práticas de ocupações, de detidos-desaparecidos, de torturas, afirmando-se defensores dos direitos humanos e verdadeiros combatentes em um mundo ameaçado pelo "terrorismo" - discurso permanente -, os organismos de direitos humanos na América Latina dariam exemplos de que outro mundo e outras lutas são possíveis.

Neste sentido, em 2002, algumas organizações de direitos humanos argentinas Abuelas de la Plaza de Mayo, Asemblea Permanente por los Derechos Humanos, Buena Memoria Asociación Civil, Centro de Estudios Legales y Sociales, Familiares de Desaparecidos y Detenidos por Razones Politicas, Fundación Memoria Histórica y Social Argentina, Liga Argentina por los Derechos del Hombre, Madres de la Plaza de Mayo Línea Fundadora, Movimiento Ecuménico por los Derechos Humanos, Servicio de Paz y Justicia, Hijos por la Identidad y la Justicia, contra el Olvido y el Silencio, e Hermanos de Desaparecidos por la Verdad y la Justicia - se unem em torno de um projeto de transformação do espaço urbano de Buenos Aires, que pudesse diversificar as narrativas de memória, trazendo a perspectiva das vítimas do Terrorismo de Estado para o cenário público da cidade.

Em um acordo com o governo de Buenos Aires, o Instituto Espacio para la Memoria (IEM) é criado, em caráter autárquico economicamente e autônomo politicamente. Sua missão era resguardar e transmitir a memória dos atos do Terrorismo de Estado, até a recuperação do Estado de Direito, aprofundando os temas da democracia e dos direitos humanos e valorizando a vida, a liberdade e a dignidade. A ideia era criar redes de informações e acervos documentais que pudessem auxiliar na tarefa de recuperar a memória, principalmente em lugares na cidade onde funcionaram Centros Clandestinos de Detenção, e de realizar atividades e eventos com os valores dos direitos humanos e a reafirmação do Nunca Más (LEGISLATURA DE LA CIUDAD AUTÓNOMA DE BUENOS AIRES, 2002). 
$\mathrm{Na}$ visão de transformar a memória urbana, algumas atividades eram consideradas primordiais para se iniciar a concretização do projeto. Primeiro, as pesquisas, inclusive criando-se arquivos com coleções privadas e de organismos nacionais e internacionais de direitos humanos, que promoveriam o conhecimento desse passado para as futuras gerações. Depois, a recuperação dos ex-Centros Clandestinos de Detenção, que deveriam carregar uma marca de memória - seja transformando-os em museus ou colocando-se placas rememorativas. Por fim, promover vínculos entre os lugares e a sociedade, com atividades que pudessem mobilizar a opinião pública, em torno da luta pelos direitos humanos palestras, denúncias, exposições, visitas, intercâmbios de materiais e etc.

Essas atividades eram consideradas pelo IEM como formas de resistência ao apagamento da memória, contudo, também uma maneira de construir uma sociedade mais justa. Em seu documento de criação, afirmava-se

La Argentina actual es un país devastado por años de políticas neoliberales que lo sumieron en la pobreza y la fragmentación social y que arrasaron los derechos económicos y sociales de grandes sectores de la población. La necesidad de avanzar hacía un país diferente, sustentado en la justicia y la solidaridad, nos obliga a ejercitar a la memoria, apropiándonos críticamente del pasado para alumbrar el presente hacía la construcción del futuro (INSTITUTO ESPACIO PARA LA MEMORIA, 2005, sem paginação).

Assim, a justificativa era de que a Argentina, como parte de uma estratégia global, implementou o regime repressivo, reconhecido pelas práticas autoritárias e cujo saldo são as inúmeras vítimas. Esse regime tinha a finalidade de instituir um modelo econômico, fundamentado na dívida externa, na dominação e na disciplinarização social - a reorganização das formas de poder interno e das relações sociais, atendendo à imposição externa. Este mesmo modelo, indiferente em relação aos crimes do Terrorismo de Estado, se reiteraria, naquele contexto, na impunidade, na pobreza e na exclusão social. Portanto, construir a memória do passado, com novas narrativas, seria um ato político, que libertar-se-ia dos discursos únicos, liberaria a sociedade para recordar e recuperaria valores dos direitos à vida digna, à educação, à saúde e ao acesso à justiça.

E diversos são os exemplos nas mais variadas falas do/pelo IEM, que trazem essas conexão entre passado e presente. Durante seu lançamento, por exemplo, o ganhador do prêmio Nobel da Paz (1980) Adolfo Pérez Esquivel pontuava

Los pueblos que olvidan y no quieren mirar su camino, son pueblos llamados a desaparecer. La memoria no es para quedarnos en el pasado, nos debe iluminar el presente porque es a través del presente donde podemos generar nuevas condiciones de vida. Tenemos claro que debemos continuar la resistencia, las luchas sociales, para construir una sociedad más justa, 
humana y fraterna, donde la democracia sea realmente derecho y igualdad para todos (INSTITUTO ESPACIO PARA LA MEMORIA, 2006, p. 98-99).

Pretendendo, pois, a recuperação dessa memória crítica, uma das maiores lutas do IEM era recuperar a Escuela de Mecánica de la Armada (ESMA) e transformá-la em um museu. A referida escola foi construída para educar oficias da Marinha em assuntos de manutenção de embarcações, no marco do plano estratégico do século XIX para a defesa do território nacional. Nas primeiras décadas do século XX, ela ganha imensa importância na educação militar, com grandes quadros de alunos, ocasionando a necessidade de expansão de suas instalações, o que ocorreu em 1924, com a cessão do terreno na Zona Norte de Buenos Aires para a construção dos edifícios que, hoje, são conhecidos como a ex-ESMA (NEVES, 2014).

Em meados de 1970, com o enfraquecimento político do peronismo no governo e os inúmeros decretos de Isabel Perón conferindo às Forças Armadas amplos poderes para a perseguição de "subversivos", o chefe da Marinha, Emilio Massera, em conjunto com o diretor da Escola Ruben Jacinto Chamorro, iniciou o acondicionamento de uma das construções da Escola - o Casino de Oficiales - para manter prisioneiros naquelas dependências. Com o golpe de 1976 e o modelo de repressão realizado nos Centros Clandestinos de Detenção (são mais de 500 lugares em todo o país), a ESMA torna-se o maior Centro Clandestino argentino e exemplo da repressão no território regional.

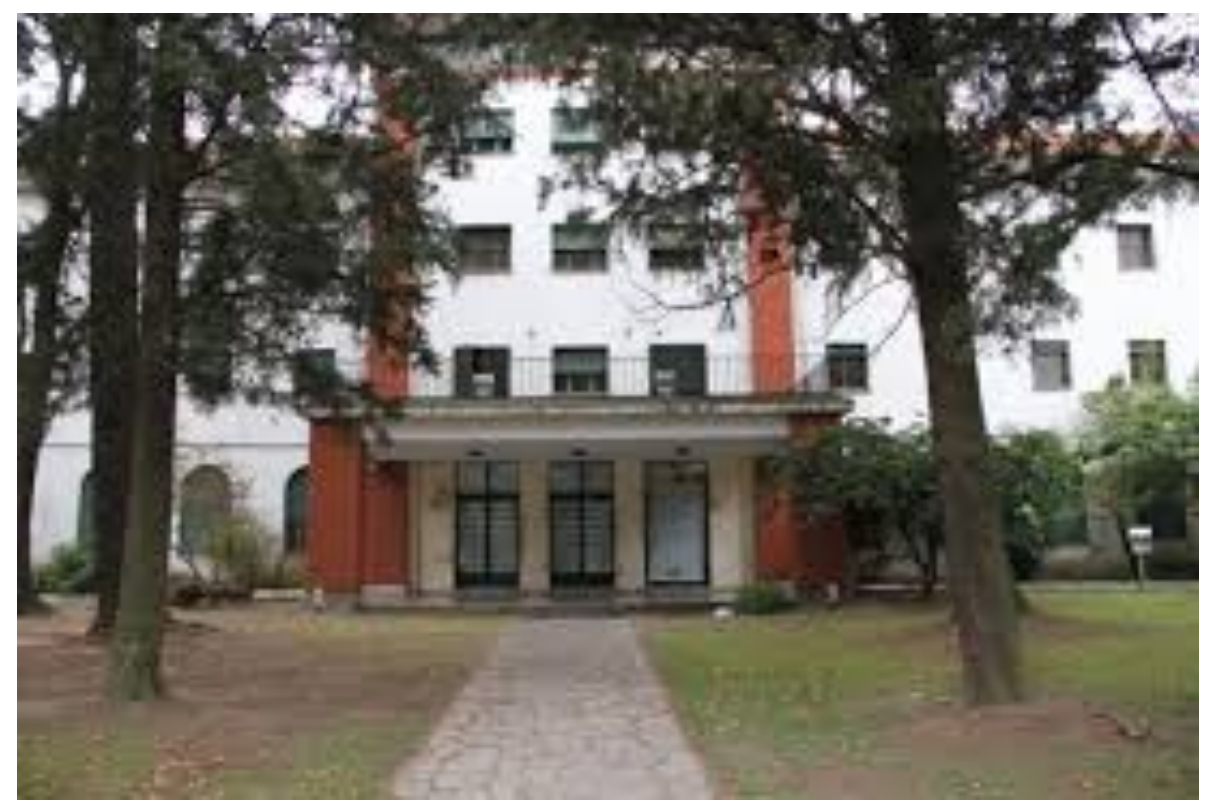


Fonte: ESPACIO PARA LA MEMORIA Y PARA LA PROMOCIÓN Y DEFENSA DE LOS DERECHOS HUMANOS. Folleto de Divulgación. Buenos Aires: Espacio para la Memoria, 20--.

Imagem 16 - Capucha

(Lugar destinado à concentração dos detidos-desaparecidos no Casino de Oficiales)

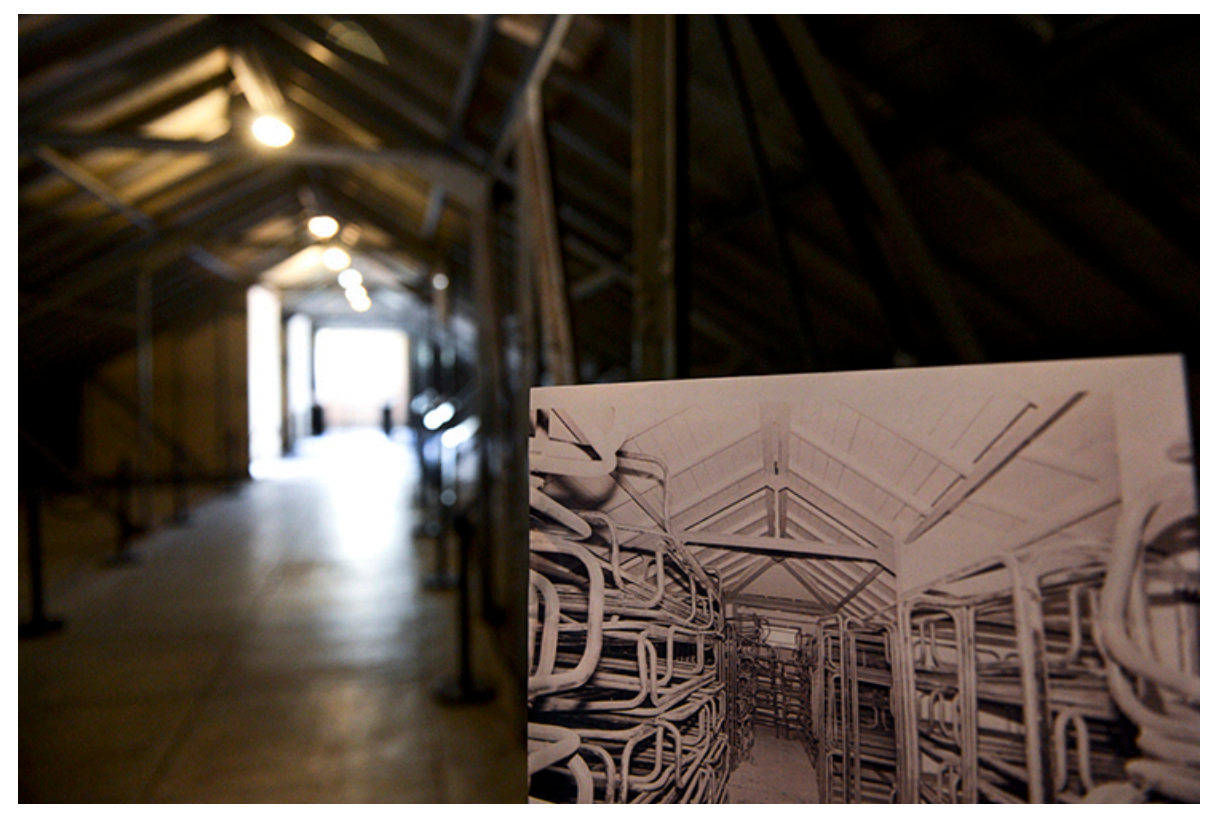

Fonte: ARCHIVO DE LEO VACA. Disponível em: <http://www.infojusnoticias.gov.ar/especiales/laesma-en-13-fotos-del-horror-a-la-memoria-56.html>. Acesso em: 05 jul. 2017.

A Escola, na qual estima-se haver passado cinco mil pessoas e cujo número de sobreviventes acerca-se ao de 200, teve um papel central no sistema repressivo, através de seu Grupo de Tarefas, ligado ao Serviço de Inteligência Naval. As violações com sequestros, roubos, mortes, torturas e uma maternidade clandestina, se realizavam em rotatividade, o que tornava todos os oficias responsáveis por tarefas repressivas naquele espaço. O Centro Clandestino da ESMA funcionou até 1983, ano também da saída das Forças Armadas do Poder Executivo.

Nos anos pós-ditadura, a continuação da ocupação dos edifícios pela Marinha afrontava os organismos de direitos humanos, que reivindicavam a transformação da Escola em um lugar de memória para a cidade. Em 1998, toma-se oficialmente a primeira decisão em relação ao lugar, quando o presidente Carlos Menem (1989-1999) transfere as instalações da Escola para a base naval de Belgrano.

Que en virtud de lo expuesto, resulta entonces apropiado, trasladar las instalaciones de la ESCUELA DE MECANICA DE LA ARMADA de la Ciudad de BUENOS AIRES, a la BASE NAVAL DE PUERTO BELGRANO, Provincia de Buenos Aires.

(...) Que el cambio de instalaciones sobredimensionadas, antiguas y desactualizadas, con alto costo de mantenimiento y baja eficacia educativa 
por construcciones más aptas y modernas, generará importantes ahorros de operación y funcionamiento.

Que el traslado de la ESCUELA DE MECANICA DE LA ARMADA tiene un valor simbólico innegable, sustentado en el atan por dejar atrás las antinomias y asumir las lecciones de la historia reciente, expresando plenamente la voluntad de conciliación de los argentinos.

Que destinar al uso público los terrenos que actualmente ocupa dicha instalación militar y erigir en dicho aspecto libre un símbolo de la unión nacional como único propósito, representa un compromiso ético de convivencia democratica y respeto a la ley (ARGENTINA, 1998, sem paginação).

De acordo com o decreto, o terreno seria destinado ao uso público que valorizasse a "união nacional", assumindo as lições do passado recente e olhando para o futuro de reconciliação. Neste sentido, o intuito era demolir os edifícios e construir um parque e monumento públicos, como símbolos desse "presente apaziguado" em relação ao passado.

A decisão provocou revolta nos organismos de direitos humanos, sobreviventes e familiares de mortos e desaparecidos. Logo no mês seguinte à publicação do decreto, um grupo de pessoas consegue uma liminar judicial para ingressar na ESMA, pela primeira vez depois da CONADEP, a fim de realizar uma inspeção sobre as possíveis demolições pretendidas. Diversos familiares e membros de organizações de direitos humanos ficaram à espera dos resultados, na porta de entrada da Escola, onde encontraram-se com sujeitos visivelmente pálidos e horrorizados ao atravessarem os portões, depois da visita (REVIVIR..., 1998, p. 2-3).

A resistência à demolição, então, ganhou força e o prefeito de Buenos Aires, Fernando de la Rúa (1996-1999), entra na Justiça solicitando a nulidade do decreto, sob alegação de que o terreno era propriedade do município. A ação chegou à Câmara de Apelações e teve decisão favorável para a cidade, recomendando que todo o complexo da ESMA fosse declarado monumento histórico, integrante do patrimônio cultural da nação (NEVES, 2014).

No ano seguinte, os deputados de Buenos Aires pediram a declaração da ESMA como Monumento Histórico Nacional, no projeto de lei aprovado, que designava a criação de um museu de memória. Segundo o deputado Daniel Bravo (2000):

Por esas paredes y por ese edificio de la Escuela de Mecánica de la Armada pasaron entre 5.000 y 6.000 personas; no sabemos cuál fue el paradero de muchas de ellas. Fue uno de los más importantes, entre los 340 centros de exterminio que hubo en la República Argentina durante la dictadura.

El libro "Nunca Más", editado por la Editorial Eudeba, refleja las características que tuvo ese centro de detención. El histórico juicio a la Juntas Militares recogió cada uno de los testimonios absolutamente desgarradores de los sobrevivientes que pasaron por la Escuela de Mecánica de la Armada, que forman parte de la historia de nuestro país. 
Ese predio y esas paredes forman parte de la historia de nuestro país, que no debe ser olvidada y debe ser recordada, como lo que fue, por cada una de las generaciones que nos van a seguir: el peor campo de exterminio de personas de la República Argentina, llevado adelante por una dictadura que tuvo un plan sistemático de secuestro, desaparición, y absolutamente organizado de detención de personas en los distintos centros clandestinos que existían en la Argentina (BRAVO apud LEGISLATURA AUTONÓMA DE LA CIUDAD DE BUENOS AIRES, 2000a, sem paginação).

Por outro lado, a legislatura da cidade apresenta outro projeto de lei para revogação da cessão do uso do terreno pela Marinha, fundamentando-se na ideia de que a mesma subverteu o uso do espaço para o ensino e o utilizou como campo de extermínio. A lei 329/2000 foi aprovada e determinou o uso do terreno e edifícios para a instituição do museu de memória (LESGILATURA DE LA CIUDAD AUTÓNOMA DE BUENOS AIRES, 2000b).

Fernando de la Rúa, tentando amenizar os ânimos de setores militares que pretendiam acabar com o processo de reintegração, sob o argumento de que estariam cedendo a ESMA para "propagar a ideologia da guerrilha", apresenta um projeto de tornar a ESMA parte da Escuela del Estado Mayor. Ao mesmo tempo, a Marinha renomeia a Escola como Escuela de Oficiales de la Armada (ESSA), a fim de desconectá-la com o passado da instituição. No entanto, as mobilizações são inúmeras em favor da entrega do espaço.

Nas comemorações dos 25 anos do golpe, por exemplo, houve uma campanha gráfica promovida pelas organizações que formariam o futuro IEM, na qual imprimiram-se panfletos com os rostos de Emilio Massera, Rafael Videla, Leopoldo Galtieri, Alfredo Astiz e Martínez de Hoz como símbolos do Terrorismo de Estado. As cinco mil reproduções das fotos foram espalhadas em vias públicas com a frase "el golpe no nos afectó la memoria. Terrorismo de Estado Nunca Más". A campanha se complementava com propagandas nas rádios, revistas e televisões, onde ainda colocavam a famosa frase do governador da província, no período ditatorial, Ibérico Saint Jean: "Primero mataremos a todos los subversivos, luego mataremos a sus colaboradores, luego mataremos a sus simpatizantes, luego mataremos a quienes permanezcan indiferentes y por último mataremos a los indecisos" (GINZBERG, 2001).

Em março de 2004, a situação da luta pela memória se modifica. O então presidente Néstor Kirchner realiza a primeira comemoração oficial do Estado argentino em relação ao seu golpe, com um ato de repúdio à ditadura, iniciado na ex-ESMA, que, por sua vez, teve suas grades decoradas com as fotos dos desaparecidos. Estava celebrando-se também o acordo entre o Estado Nacional e a cidade para a transformação da ex-ESMA em um museu de memória para recuperar, resguardar e transmitir a memória do Terrorismo de Estado (ARGENTINA, 2004). 
A assinatura do acordo sobre o Espacio para la Memoria y para la Promoción y Defensa de los Derechos Humanos foi realizada no próprio edifício da ex-ESMA e acompanhada por milhares de pessoas que esperavam nos portões de entrada.

\section{Imagem 17 - Portões da ESMA em 2004}

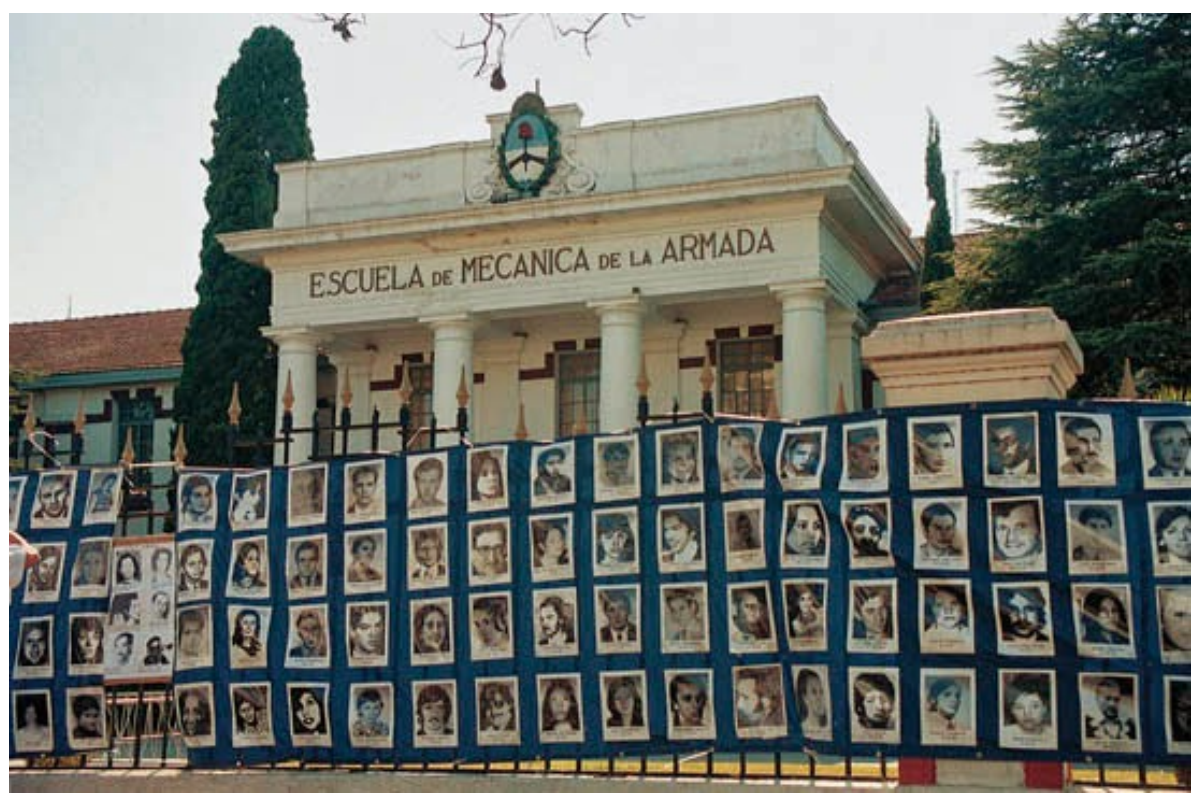

Fonte: BRODSKY, 2005, p. 54-55.

Como ato simbólico, o então presidente retirou das paredes do Colégio Militar de la Nación e do Casino de Oficiales, os retratos dos ex-ditadores Rafael Videla e Reynaldo Bignone, inaugurando placas com as inscrições "Nunca Más golpe y Terrorismo de Estado. Por siempre respecto a la Constitución Nacional, verdad y justicia". Em um discurso de quase 30 minutos, do qual esperava-se a anulação dos indultos, Kirchner não atendeu às expectativas, porém, foi crítico às políticas ditatoriais, recordando a cumplicidade social no golpe, além das consequências econômicas que o projeto ditatorial trouxe ao país. Afirmou que seu governo viria romper com a leitura do passado de violência como atos de excessos individuais, tratando-o como um plano criminal. E pediu perdão em nome do Estado (BAUER, 2014 e GINZBERG, 2004).

Os edifícios da ex-ESMA foram sendo entregues de forma gradual, culminando, então, na comemoração dos 30 anos do golpe. Como um marco social, essas comemorações, acompanhadas por mais de 100 mil pessoas, tiveram como principal bandeira a justiça, cuja multidão que caminhou o percurso entre o Congresso Nacional e a Plaza de Mayo, exemplificava com o mote "como a los nazis les va a pasar, a donde vayan los iremos 
buscar".

E a visita nas dependências da ex-ESMA, neste dia 24 de março de 2006, com a presença de quase 70 representantes de países diferentes, foi marcada pela declaração de Eduardo Luis Duhalde, então Secretário de Direitos Humanos, que enfatizava a punição aos "genocidas", a anulação dos indultos e a restituição de identidades.

¿Cómo se construye una maquinaria de matar de este nivel? ¿Cómo ciudadanos que uno creía normales constituyeron esa maquinaria? ¿Cómo se pudo torturar a chicos de 14 años de incipiente militancia y arrojarlos al mar? ¿Cómo se pudo arrojar al mar a las madres de Plaza de Mayo que buscaban sus hijos? (DUHALDE apud BAUER, 2014, p. 258).

Em novembro de 2007, se concluiu a entrega total dos edifícios e, no ano seguinte, foi instalada a primeira instituição que os ocuparia, o Archivo Nacional de la Memoria. A partir de então, abre-se o Espacio para la Memoria à visitação do público, integrando, em diferentes datas, diversas atividades e organismos de direitos humanos nos prédios desocupados Espacio Cultural Nuestros Hijos (Madres de la Plaza de Mayo - abril de 2008); Centro Cultural de la Memoria Haroldo Conti (maio de 2008); Tecnicatura Popular de Música (2011); Polo Audiovisual Educ.ar (2011); Casa de la Militancia (H.I.J.O.S. - 2011); Tecnicatura en Periodismo Deportivo (2013); Casa por la Identidad (Abuelas de la Plaza de Mayo - 2013); Memoria Abierta (2013); Museo de las Malvinas y Islas del Atlántico Sur (2014); e Museo Sitio de la Memoria (2015). 


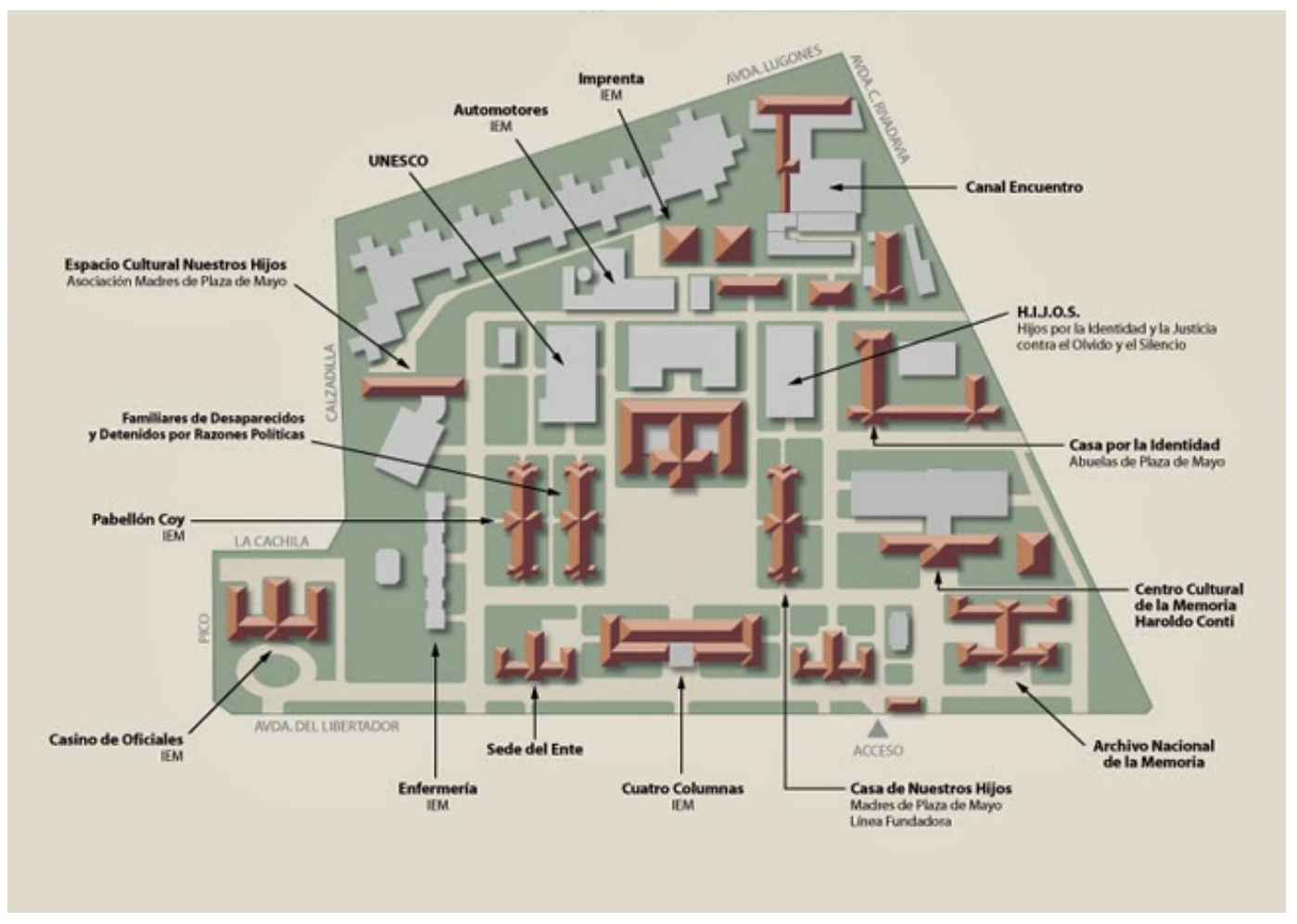

Fonte: ESPACIO PARA LA MEMORIA Y PARA LA PROMOCIÓN Y DEFENSA DE LOS

DERECHOS HUMANOS. Folleto de Divulgación. Buenos Aires: Espacio para la Memoria, 20--.

O Espacio para la Memoria determina-se como um lugar de intercâmbio cultural e de debate sobre o Terrorismo de Estado e a experiência genocida, refletindo sobre o passado recente, a partir da homenagem às vítimas. Como um conjunto integrado de distintas políticas, institucionais e sociais, de níveis regional e nacional, ele desenvolve a preservação da memória e a promoção e defesa dos direitos humanos em distintas perspectivas. ${ }^{93}$

Imagem 19 - Edifício Principal ex-Escuela de Mecánica de la Armada

\footnotetext{
${ }^{93}$ Cf. ESPACIO MEMORIA Y DERECHOS HUMANOS. Disponível em: <http://www.espaciomemoria.ar >. Acesso em: 03 fev. 2017.
} 


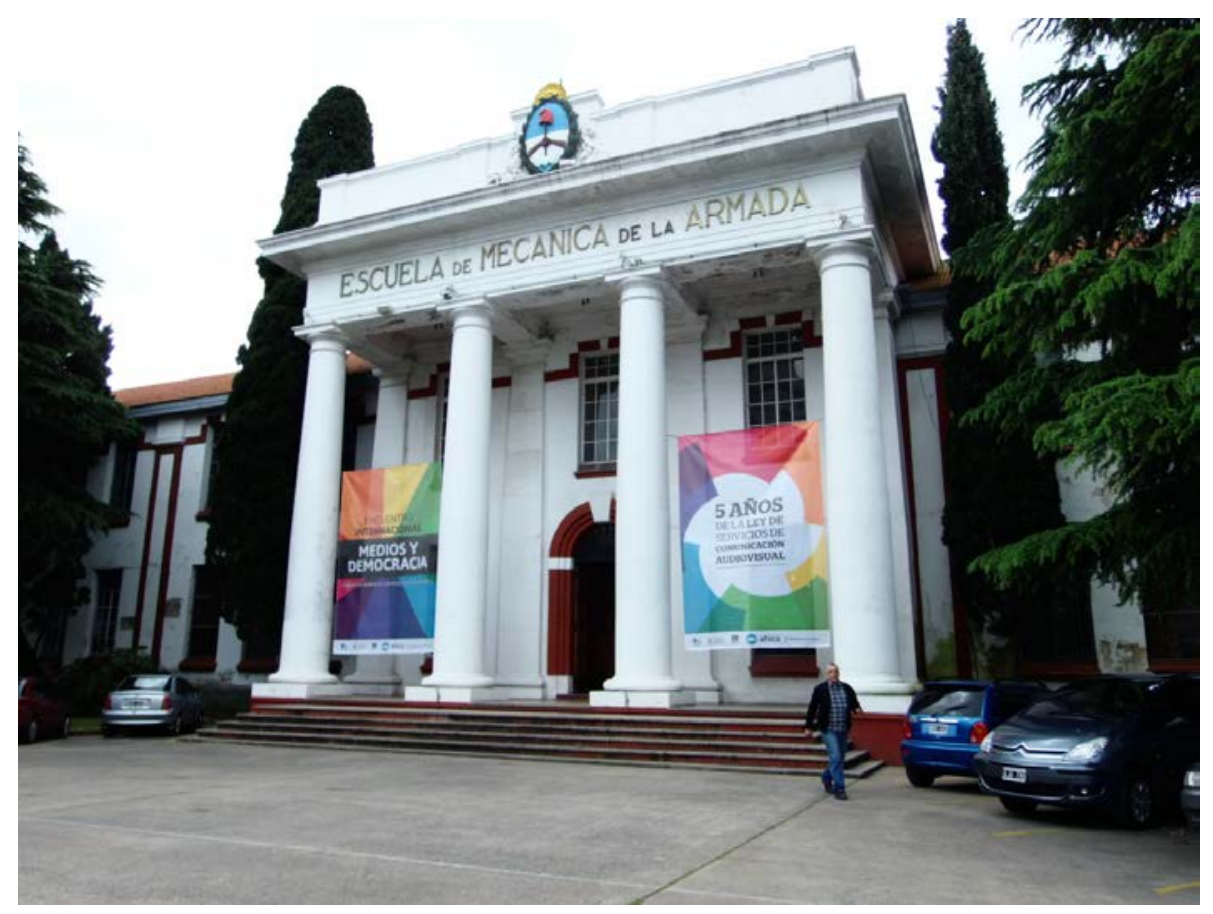

Fonte: Arquivo Pessoal. Fotografia de 2014.

Neste sentido, os trabalhos de recuperação do Casino de Oficiales terminaram em 2015, e ele foi aberto à visitação sob a denominação de Sitio de Memoria. Demanda histórica dos organismos de direitos humanos, o espaço foi conservado para se conhecer seu funcionamento, enquanto se percorre seus três andares: Capucha, Capuchita e Sótano (LA PRESIDENTA..., 2015). A ideia do Sitio de Memoria é mantê-lo em sua estrutura, indicando seus lugares, contextos e violações aos direitos humanos, através das chamadas Estações painéis de vidro com informações - e valorizando as vítimas daqueles espaços com testemunhos de sobreviventes, documentações, fotografias e objetos de detidos-desaparecidos (algumas reproduções dos mesmos, já que alguns originais se encontram em poder da justiça). 
Imagem 20 - Entrada do Sitio de Memoria

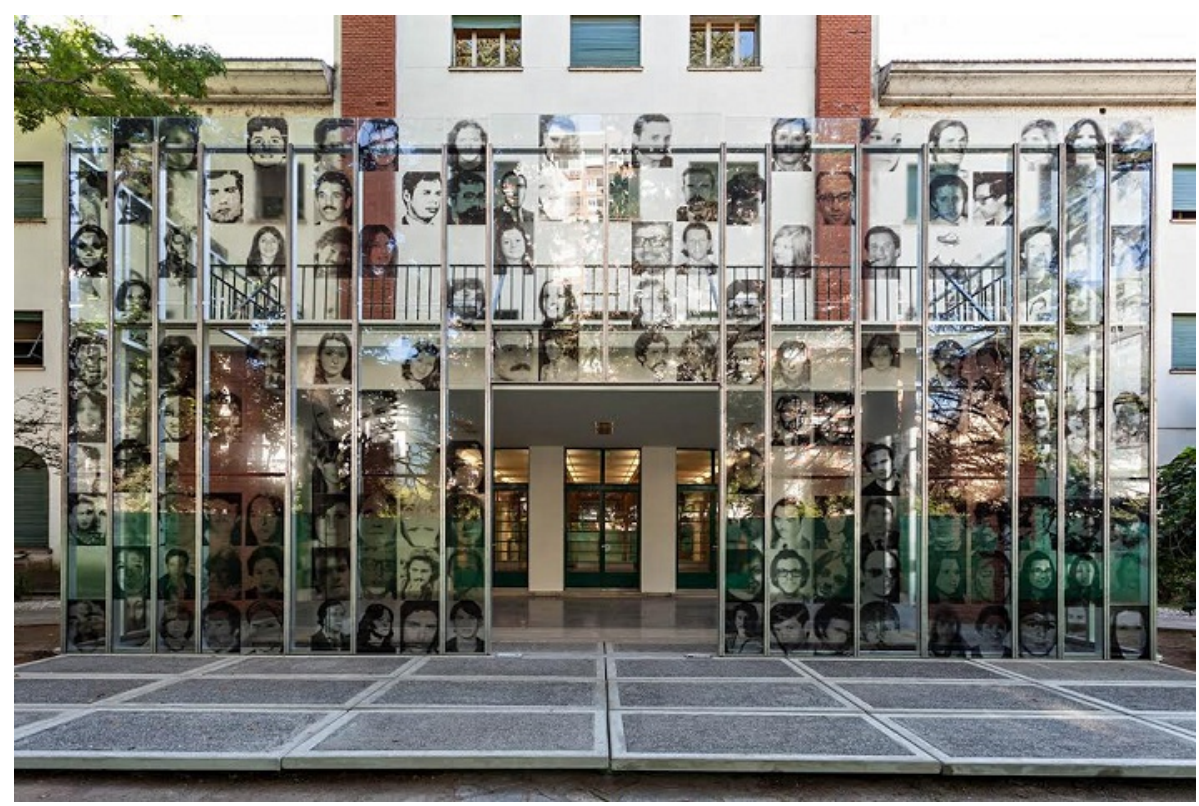

Fonte: ARCHIVO EDUC.AR. Disponível em: <https://www.educ.ar/noticias/126477/la-presidentainauguro-el-sitio-de-memoria-en-la-ex-esma $>$. Acesso em: 04 fev. 2017.

Imagem 21- Capucha no Sitio de Memoria

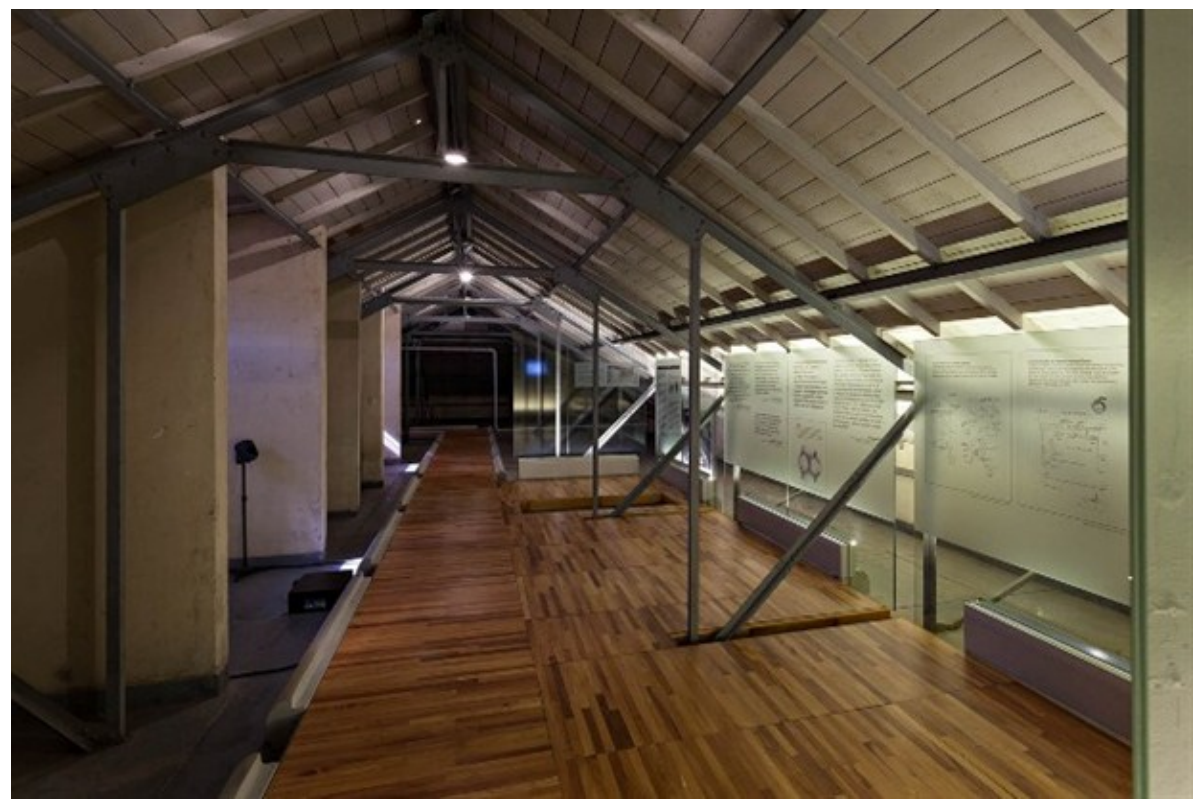

Fonte: ARCHIVO DEL GOBIERNO DE ARGENTINA. Disponível em: <https://www.argentina.gob.ar/derechoshumanos/sitio-de-memoria-esma.aspx>. Acesso em: 04 fev. 2017.

4.2 - A Bastilha paraguaia e o Museo de las Memorias: Dictadura y Derechos Humanos 
Inaugurado em 2002, o Museo de las Memorias: Dictadura y Derechos Humanos é abrigado na antiga casa de uma família assuncenha, no centro da capital, que fora alugada pelo governo stronista para funcionar como a Dirección de Asuntos Técnicos (DNAT ou La Técnica). Organismo criado em 1956, com assessoramento do governo estadunidense, La Técnica se enquadrava no sistema repressivo como uma instância policial para a coação de atividades ditas comunistas, que, ao longo do tempo, foi ganhando forma centralizadora no aparato repressivo. Este último não possuía um organismo reunidor dos trabalhos, como ocorreu em diversos outros países em ditaduras, e, por isso, apoiava-se nas atividades da DNAT para obter informações, através das detenções de suspeitos e aplicações de torturas.

Atuando em todo o território nacional, mas com sede em Assunção, a DNAT tinha o suporte logístico provindo do Partido Colorado, encabeçado pela Presidência de Stroessner e do Grupo Acción Anticomunista (GAA - milicianos civis ligados ao Partido). Focalizada na delação, no controle e na perseguição dos ditos subversivos, trabalhava coordenadamente com a inteligência das Forças Armadas e do Departamento de Investigações da Polícia. Em uma primeira etapa, sob comando de Antonio Campos Alum e dependente do Chefe de Polícia Ramón Duarte Vera e do Ministro do Interior Edgar L. Insfrán, a DNAT, além de atuar nas informações e prisões, também aprofundava no treinamento da "burocracia de repressão" (COMISIÓN DE VERDAD Y JUSTICIA, 2008, Tomo VI: Las responsabilidades en las violaciones a los derechos humanos).

Campos Alum, homem de confiança de Alfredo Stroessner, atuou por várias décadas nesse organismo e foi o representante paraguaio no Sistema Condor. Colaborador na Liga Mundial Anticomunista, ele possuía fortes laços com a Escola das Américas e auxiliou na seleção do Paraguai - junto ao Brasil, Guatemala, Bolívia e Colômbia - para realizar um dos primeiros programas de treinamento policial, com o coronel estadunidense Robert K. Thierry, veterano da Guerra da Coreia. Desta forma, em 1956, Thierry foi ao país e assessorou a criação da DNAT e a formação de policiais, através do "Programa de Administração Pública" e o "Curso de Informação Especial” para a capacitação dos agentes.

As detenções ilegais no país passaram a ser realizadas, então, em lugares públicos e oficiais, sendo La Técnica um dos lugares mais conhecidos socialmente, junto ao lugar de Investigações na Dirección de Vigilancias y Delitos e à Tercera Comissaría da polícia na capital - edifício em frente à La Técnica. Estes espaços de repressão foram responsáveis por torturas, mortes, desaparecimentos e lesões físicas e psicológicas de diversas vítimas, ao longo da ditadura stronista. 
Em finais dos anos sessenta, entretanto, a DNAT perde sua centralidade no sistema repressivo para a Polícia de Investigações, sob a direção de Pastor Coronel, que permanece no cargo até o assassinato de ex-ditador Somoza Debayle, já citado em capítulo anterior. Nesse momento, os departamentos de inteligência, temendo que o país fosse usado como um "corredor de passagem" para as guerrilhas do Uruguai, Brasil e Argentina, se unem mais estritamente aos trabalhos das Forças Armadas para acentuar a repressão regional. Então, a DNAT torna-se um instrumento para obtenção de informações transnacionais.

Apenas nos anos 1980, com o decrescente poder ditatorial, as Forças Armadas se retiram dessas operações que passam às mãos da GAA e dos pyragués (os delatores, que realizavam informes sobre suspeitos). Mesmo com o fim da ditadura, a DNAT continuou a funcionar até o ano de 1992.

Este ano em questão é marcado pela "descoberta" do conhecido Archivo del Terror, composto por diversos arquivos repressivos, e cujo início de sua busca deu-se por dois pedidos judiciais do educador Martin Almada para obter seus expedientes policiais no país (MARTIN..., 1992, p. 72).

Almada é um dos inúmeros paraguaios que, militantes do Partido Colorado, tonaramse alvos de perseguição do regime de Stroessner. Como ele mesmo afirma em suas memórias, transmutou do coloradismo à "subversão".

Era mi condición de colorado la que me hacía oponerme a todas las desviaciones que Stroessner había cometido con la doctrina del Partido. Entre ellas, el vitaliciado, el culto de la personalidad, el inmovilismo político, la entrega de nuestra soberanía y nuestra economía, la colonización cultural y educacional (ALMADA, 1988, p. 98).

Vendo-se sob uma burocracia, na qual professores como ele precisavam apresentar recomendações das seções coloradas ao Ministério de Educação, a fim de conseguirem trabalhos, com salários baixos, ocasionando dívidas e diversas ações contra a classe, Almada se filia à Federação de Educadores Paraguaios (FEP). Em 1972, decide ir à Buenos Aires para seguir os estudos em pedagogia, onde, pela Universidad de La Plata, escreve a tese "Paraguay: Educación y dependencia", na qual analisa o sistema educativo stronista fundamentando-se na perspectiva de beneficiamento da classe dominante do país e pela penetração cultural brasileira e estadunidense, que tornavam o Paraguai terreno de dependência estrangeira.

Em seu retorno, continuou o trabalho no Instituto Juan Bautista Alberdi, em San Lorenzo, e começou a ser acusado de subversão. As provas contra ele variavam entre bilhetes enviados ao Ministério de Educação, a sua tese de doutorado e relatos de atividades por 
denunciantes, colegas do Instituto. Assim, em 1974, ele foi preso e enviado à Tercera Comisaría - o "sepulcro dos vivos" - enquanto o Instituto em que trabalhava era depredado.

$\mathrm{Na}$ cárcere, Almada foi vítima de inúmeras torturas e encontrou-se com diversos detidos-desaparecidos de outros países. Desta forma, se inteirou da circulação de informações arrancadas dos presos políticos, durante os "interrogatórios", e das experiências transnacionais nessas trocas de informações e presos.

Encontrou-se, por exemplo, com Gladys Meilinger de Sanneman, médica que havia sido presa na Argentina, no mesmo dia do golpe no país. Proprietária do Sanatorio de La Candelaria, em Posadas (Argentina), Sanneman se foi do Paraguai 17 anos antes de ser presa, por seu posicionamento antistronista e pelas ameaças que sofria por não outorgar certificados de mortes forjados para corpos de indivíduos que claramente haviam sido assassinados em torturas.

Em 20 de dezembro de 1974, comunicam a Martin Almada o falecimento de sua esposa, Celestina Pérez de Almada. A polícia, que tentou convencer-lhe de que Celestina havia se suicidado, foi contrariada pelo depoimento da mãe de Martin, cujo testemunho afirmou o infarto da mulher perante as torturas psicológicas que sofria cotidianamente, desde a prisão do marido.

Todas las noches la llamaban por teléfono, para comunicarle en detalle el proceso de tu tortura. Las llamadas venían directamente de la sala de tormentos; se le hacía reconocer tu voz, tus gritos desesperados... Le decían por ejemplo, que te habían cortado los dedos, sacado los ojos, arrancado los testículos, etc. El 5 de diciembre de 1974, a las doce de la noche, la llamaron para comunicarle tu fallecimiento y para solicitarle que pasara a retirar tu cadáver a la oficina de Pastor Coronel. Tal noticia le provocó un fuerte impacto al corazón (ALMADA, 1988, p. 137-138).

Depois de mil dias preso e uma greve de fome, com a intervenção do Comité de Iglesias e da Anistia Internacional, Almada foi libertado. No entanto, continuava sendo acusado de abandono de emprego, de provocar os estudantes contra sua sucessora no Instituto, de criar intranquilidade na cidade de San Lorenzo e de confundir a opinião pública com seus "comentários indevidos" sobre sua prisão. Assim, durante dois meses pós-liberdade, ele precisou se apresentar todos os dias na delegacia para prestar depoimentos sobre seus pensamentos políticos e possíveis conexões com o comunismo, até decidir ir ao exílio no Panamá.

Em 1989, Almada retorna ao país e começa a sua luta pela verdade sobre a ditadura, no interior do mesmo - já que seus anos de exílio foram marcados pelas denúncias no exterior das violações aos direitos humanos por parte do regime stronista. Cinco anos depois, portanto, 
ele entra com o pedido na justiça de habeas data, exercendo seu direito constitucional de ver seu prontuário policial, e com a causa acusando Campos Alum, Felipe Neri Saldivar e Juan Arturo Hellman por homicídio, sequestro e lesão corporal contra sua pessoa e a de sua esposa falecida.

O início de dezembro de 1992 é marcado pelo embate público entre a polícia, que negava o conhecimento sobre o paradeiro da documentação ou declarava sua destruição, e os testemunhos que afirmavam a existência da mesma, escondida por indivíduos que permaneciam nesses organismos repressivos. Especificamente sobre a documentação de Almada, o então Chefe de Polícia, Germán Franco Vargas, tentava explicar publicamente que os expedientes, assim como os arquivos completos daquela dependência, haviam desaparecido, durante os dias posteriores ao golpe contra Stroessner. A polícia começou a trasladar secretamente alguns arquivos e a enterrá-los, tentando escondê-los o mais rápido possível (BOCCIA PAZ; GONZÁLEZ; PALAU, 2006).

Contudo, eram inúmeros os depoimentos que afirmavam a existência dos mesmos e as práticas para esconder a documentação. Luis Ocampos Alonso, dirigente do Partido Revolucionário Febrerista, por exemplo, declarou em entrevista que:

(...) durante varios interrogatorios, los responsables por ese organismo represivo (La Técnica), Antonio Campos Alum y el comisario Saldivar (quienes siguen hoy al frente de esa dependencia), hacían preguntas sobre personas que habían estado detenidas o estaban detenidas en Investigaciones, al tiempo que revisaban carpetas con fichas e datos de los presos políticos. Esos papeles se guardaban en un armario ubicado en la sala de Campos Alum.

Esos dos torturadores de La Técnica que hoy siguen tan campantes en esa dependencia del Ministerio del Interior tenían acceso a los archivos de los detenidos por razones políticas; y ciertamente conocen el destino de los mismos, e incluso es posible que parte de los documentos se encuentren aún en esa dependencia (LA POLICÍA..., 1992, p. 29).

Esta tensão entre a polícia e a sociedade se complementou com a tensão interna do próprio Partido Colorado que buscava seu próximo candidato para as eleições à presidência de 1993. A disputa entre Luis María Argaña, o possível sucessor de Stroessner dentro do Partido, e Juan Carlos Wasmosy - vencedor das eleições nacionais, depois de fraudar as eleições internas -, resulta na informação, em sigilo, de que havia documentação na dependência policial da cidade de Lambaré. Almada aciona a Red Privada de Comunicación (RPC) que montou guarda nos portões do lugar, até a chegada da Justiça. Em 22 de dezembro, uma delegação judicial, encabeçada pelo juiz José Augustín Fernández (conhecido como o "juiz em verde", devido sua pouca idade e recente experiência como juiz), solicita a abertura das salas da delegacia, trancafiadas por cadeados (é famosa a frase de Fernández, 
televisionada, em que diz "soy la ley, abra esa puerta"), e encontra-se com a documentação (CORTE SUPREMA DE LA JUSTICIA; MUSEO DE LA JUSTICIA, 2011).

Una pila de documentos que contén una acabada información acerca de los presos políticos pertenecientes a oposición a Stroessner y prisioneros de otros estamentos ciudadanos, estaban guardados en una pieza, en el segundo piso del Departamento de Producción de la Policía de la Capital, situado en la calle 12 de Julio en Lambaré, y el juez José Augustín Fernández ordenó que la puerta sea forzada.

En ese mismo lugar intervenido se encontró la famosa "lista negra", que tiene entre 200 y 250 paginas, con datos pormenorizados de presos y perseguidos políticos. Supuestamente, de acuerdo con las explicaciones escuchadas durante el procedimiento, el listado había sido traído de los archivos de Investigaciones hacía apenas tres o cuatro días. En el patio en donde se encuentra el edificio policial, asimismo, existe la presunción que existirían otros documentos enterrados, y que igualmente contendrían informaciones "clasificadas" de modo ordenado de que la represión cobraba sus víctimas (A LA LUZ..., 1992, p. 72).

Sem controle de quem entrava ou saía do local, nesse dia, resolveu-se que a documentação seria trasladada ao Palácio de Justiça por medidas de proteção. No dia seguinte, por ordem do Poder Executivo, o edifício da DNAT é fechado e encontram-se mais documentos em três salas. O então Ministro do Interior, Hugo Estigarribia, que presidiu o ato de encerramento de La Técnica, anunciava à imprensa o desconhecimento da documentação existente, o que foi dado como falso, ao se constatar que muitos dos documentos do Departamento estavam dirigidos a ele (HALLAN..., 1992, p. 11).

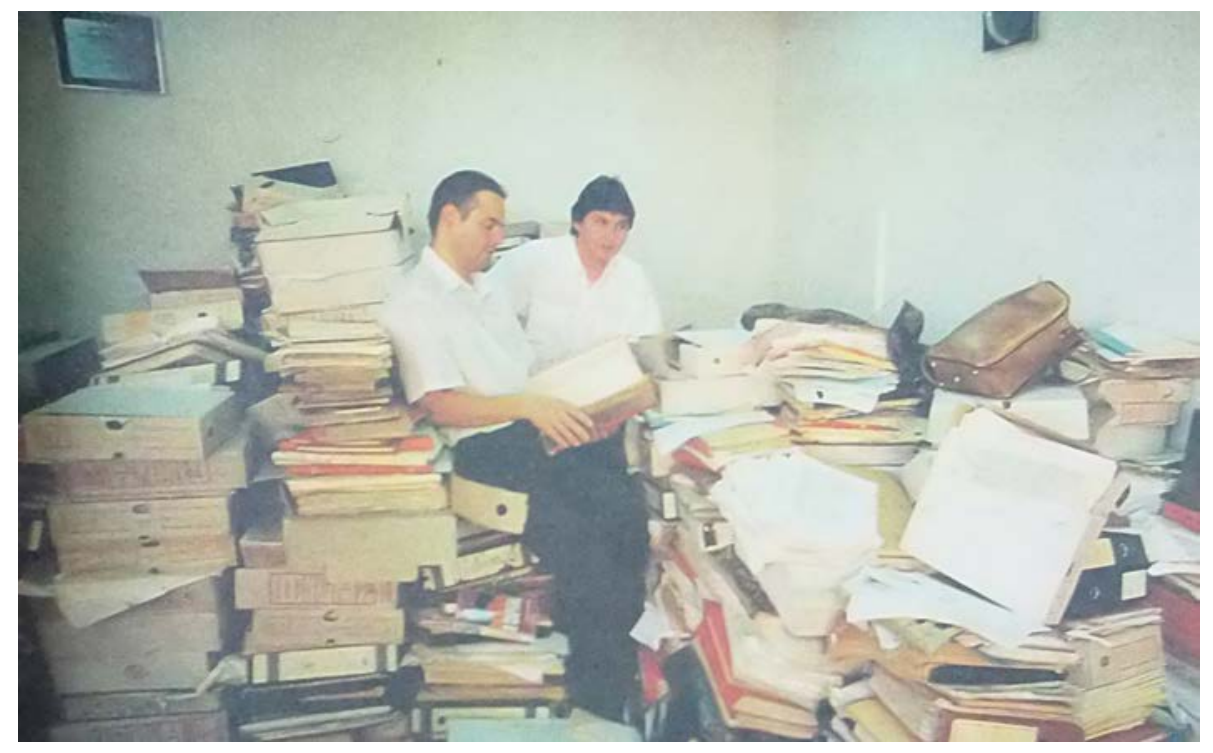

Fonte: Capa ABC Color de 23 de dezembro de 1992. 
E diversos foram os casos de responsáveis por violações, que todavia estavam em seus cargos públicos, anunciando não saberem dos arquivos e tampouco das atrocidades cometidas pela ditadura, que os arquivos colocaram luz. O comissário Santiago Flores Torres, chefe do Departamento de Investigações, deu uma comitiva de imprensa, na qual, presente em uniforme de gala, afirmou que "no sabía que los archivos estaban aquí. Tomaré medidas contra los subalternos que me mintieron" (BOCCIA PAZ; GONZÁLEZ; PALAU, 2006, p.46).

Acontece que aqueles dias foram tomados com informações sobre as "descobertas" das documentações e dos elementos que elas continham. Primeiro, porque o Paraguai foi um dos poucos países na América do Sul onde sabemos que os arquivos das polícias foram conservados significativamente. No caso argentino, por exemplo, o Chefe do Exército deu a ordem, em novembro de 1983, para se incinerar os registros, ato desfeito apenas em 1999, quando a Corte Suprema decidiu pela proibição da queima de arquivos, referentes ao período ditatorial. Neste sentido, as declarações de responsáveis por violações eram a de que não se podia comprovar muitas das denúncias realizadas, já que não se possuía a documentação adequada (BOCCIA PAZ et al., 2008).

A particularidade do resguardo da documentação paraguaia se deu devido à decisão política de não destruí-la, posteriormente ao golpe que destituiu Stroessner, já que há no país a longa tradição de impunidade (existe uma palavra Guaraní para designar essa falta de consequência que é popularmente utilizada: Operaî). E porque os responsáveis pela transição permaneceram no poder, incluindo os chefes de polícia que abrigavam os arquivos e pretendiam seguir utilizando-os (GUENA, 1996).

Depois, essas informações circularam massivamente, pois foi um achado não casual, foi um encontro com as violações e suas vítimas. Toda a trama burocrática, com folhas manuscritas, fotos, expedientes, cadernos e agendas, correspondências pessoais, informes, gravações, materiais de prisões, inventários e ordens judiciais estavam lá. E, para além do território nacional, seus conteúdos transcendiam a repressão interna e conectavam os países vizinhos na rede de crimes.

Assim, foi um "chacoalhar" da opinião pública, que confrontou a unilateralidade dos discursos sobre a ditadura com documentos. Representativamente, como colocou Martin Almada, naqueles dias, ocorreu a "queda da bastilha paraguaia", com intensas repercussões públicas e uma vitória para as vítimas e seus familiares. 
O renomado escritor Roa Bastos, alguns anos depois, descreveu essa mobilização como uma espécie de "alucinação coletiva", onde o "encontro" poderia fundamentar a democracia e a responsabilização dos criminosos.

\begin{abstract}
Es conocida, memorable, fantasmagórica, la historia de ese descubrimiento que en un primer momento pudo parecer un fenómeno de alucinación colectiva. Superaba todos los limites de lo posible, de lo razonable real. Era algo que no podía ocurrir en los marcos del tenebroso poder totalitario, aún después de decapitado a cañonazos por parte de las fuerzas que le habían sido aparentemente adictas hasta la víspera. Algo que no había ocurrido siquiera en el bunker de Hitler, donde sólo quedó su cadáver, el de su amante y los de algunos voluntariosos suicidas (ROA BASTOS, 2006, p. 29).
\end{abstract}

Iniciaram-se, portanto, inúmeros discursos sobre responsabilização daqueles envolvidos no Terrorismo de Estado por suas violações aos direitos humanos, fundamentados nos depoimentos que iam insurgindo, a partir do encontro com a documentação e nas próprias provas que ela trazia. Assim, começaram os processos contra o Chefe de Investigações Flores Torres, contra Antonio Campos Alum, contra o comissário Felipe Neri Salvadi, contra Alfredo Stroessner, contra o Chefe de Inteligência do Exército Benito Guanes Serrano e contra o Chefe de Serviço Especial de La Técnica, Arturo Helmann, por privações de liberdade, abusos de autoridade, torturas e homicídios.

Temendo o desaparecimento da documentação, o Centro de Documentación y Estudios (CDE) se ofereceu para ordenar o arquivo e classificá-lo. Funcionários do Poder Judicial e voluntários do Comité de Iglesias fizeram essas tarefas, sob direção de Rosa Palau, resultando no Centro de Documentación y Archivo para la Defensa de los Derechos Humanos, que se encontra aberto para consulta pública e se tornou a chave-mestra (a grande representação) desse processo de transição paraguaia.

Me parece increíble que sea justamente en nuestro país, con su débil democracia y la continuidad en el poder del partido que sostuvo a Stroessner, el único de la región que ha puesto a disposición de la sociedad los archivos de una dictadura. El Archivo es la diferencia positiva del Paraguay para que haya la vigencia de los derechos humanos (BARREIRO, 2006, p. 13).

E, desde aquele momento, começam os debates sobre transformar La Técnica em um museu de memória, principalmente para mostrar a documentação e construir socialmente a ideia do Nunca Más, da não repetição. O argumento principal era o de que a população paraguaia precisava sair do esquecimento e entender a ditadura stronista enquanto uma história de "horror". Eram, nitidamente, expressões pouco críticas em relação à transição da ditadura e, neste sentido, por exemplo, tem-se declarações como a do deputado colorado 
Sandino Gil Oporto, "Todo ese inmenso material encontrado debe ser exhibido para que la gente conozca que tuvieron que pasar muchos compatriotas durante la sanguinaria dictadura stronista" ou a do deputado febrerista Ricardo Lugo Rodríguez (vítima do regime), na qual dizia “Esta es la historia más negra, quizás, en los últimos cuarenta años y los paraguayos no debemos olvidarla para que nunca más se repita" (LA TÉCNICA..., 1992, p. 27).

Ao longo do tempo, esse argumento vai se arrefecendo, principalmente depois das longas discussões da já abordada Comissão de Verdade paraguaia, e tornando-se mais crítico em relação à transição do país. Segundo Line Barreiro (2006), a tradição ao autoritarismo precisa ser rompida, em uma forma que mostre as violações aos direitos humanos conectadas aos projetos políticos e que consiga modificar, então, uma mentalidade autoritária, historicamente construída.

Muchas veces hemos creído que el Paraguay era un país amnésico. No es cierto. La sociedad paraguaya recuerda y una gran parte de ella equipara el bienestar y seguridad a las dictaduras. Eso viene de muy atrás. Las dictaduras del siglo XIX fueron desplazadas por la guerra que trajo la Tríplice Alianza. Dijeron que era contra el tirano y no contra el pueblo. Pero no quedó casi nadie con vida. Lo que vino fue peor para la gente, a pesar de la fundación de partidos, sindicatos y periódicos. (...)

No es amnesia de lo que padecemos, sino que una parte de la población considera que la conducción autoritaria del país es mejor. Y esa parte de la población supo hacer cultura. (...) Es por eso que puede crecer un movimiento que considera a los crímenes de lesa humanidad del stronismo, como meras sombras de un buen gobierno (BARREIRO, 2006, p. 20-21).

Invertendo o argumento de amnésia da população, portanto, Barreiro expõe a necessidade de construção de uma nova cultura no país, que se fundamente na democracia e na obtenção de direitos fundamentais dos homens. Um bem-estar da população que esteja associado aos períodos democráticos, e não aos períodos ditatoriais.

E, neste sentido, a Fundación Celestina Pérez de Almada faz a proposta do Museo de las Memorias. A Fundação, criada por Martin Almada, nos anos 1990, tem como proposta promover a educação com projetos voltados aos direitos humanos e à cultura de paz no país. Assim, pretende fomentar a educação ambiental e promover os direitos humanos e a cidadania paraguaia, através do resgate da memória histórica, da pesquisa no campo dos direitos humanos e de formações em distintas áreas. ${ }^{94}$

O projeto do museu começa, portanto, com um caráter de realizar atividades educativas dentro do espaço da ex-La Técnica, apresentando-o publicamente, com visitas de escolas e organismos internacionais, e expor, especialmente, a documentação do Archivo del

\footnotetext{
${ }^{94}$ Cf. FUNDACIÓN CELESTINA PÉREZ DE ALMADA. Disponível em: <http://www.fcpa.org.py >. Acesso em: 05 fev. 2017.
} 
Terror. Com um início bastante precário, ele vai se transformando ao longo de sua existência e acumulando novos materiais para a exposição doados à Fundação, e que compõem as salas: Memória Oficial da Ditadura de Stroessner, o Culto à Personalidade, Coleção de Livros e Revistas e Memória das Vítimas.

Imagem 23 - Visita do Colégio Técnico Javier (2003)

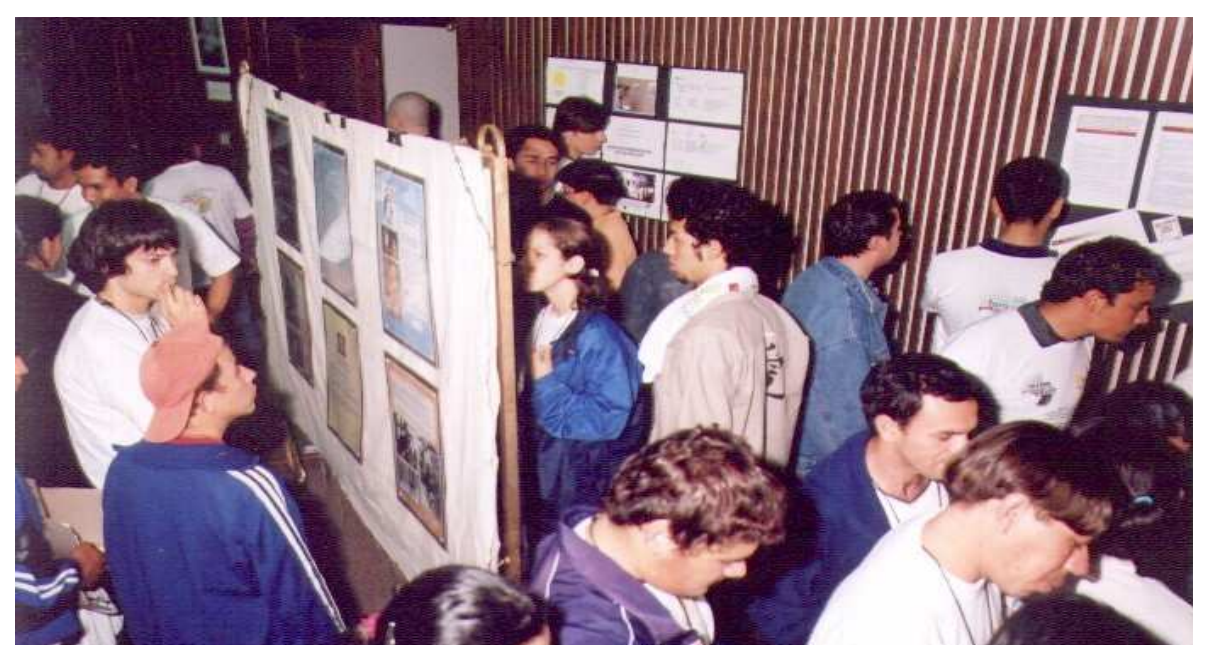

Fonte: FUNDACIÓN CELESTINA PÉREZ DE ALMADA. Disponível em: <http://www.fcpa.org.py>. Acesso em: 05 fev. 2017.

No ano de 2007, o Museo de las Memorias: Dictadura y Derechos Humanos tem a sua reviravolta e traça novas trajetórias, a partir de experiências trazidas por especialistas alemães para o Paraguai, que iremos abordar detalhadamente no próximo capítulo. Cumprindo 30 anos dos desaparecimentos dentro do Sistema Condor, ele reabre suas portas com uma cerimônia no novo auditório "Justicia y dignidad", parte do projeto de modificação da instituição. Segundo Federico Tatter, filho do tenente paraguaio de mesmo nome, exilado e desaparecido na Argentina, a proposta era extremamente válida como um posicionamento na luta pelos direitos humanos, em um país que tende a estar sempre no seu limite ao retrocesso.

El Movimiento por los Derechos Humanos en Paraguay no ha sido constante ni está en la agenda como ocurre en otros países. En el caso de Paraguay, siempre al borde del retroceso, por lo que debemos reinstalar la temática y abordar la recordación sobre un grupo de paraguayos y de otras nacionalidades que han desaparecido en 1977; haciendo mención al Operativo Cóndor. De los 20 que recordamos, 16 son paraguayos-argentinos que han desaparecido en la Argentina, de los cuales varios son trasladados al Paraguay, de la misma forma, dos argentinos y dos uruguayos son detenidos en el Paraguay y desaparecidos en el intercambio (TATTER apud TORRES, 2007, sem paginação). 
Neste sentido, o Museu se insere na dinâmica de repressão internacional e começa a abrigar novas exposições contando a sua história, a dos antecedentes ao Terrorismo de Estado, a da ditadura stronista, a da organização de terror, a das operações e sequestros, a das torturas e repressões nacional e internacional, a dos interrogatórios, a do exílio e das vítimas, com documentos, fotografias, objetos pessoais, imagens e nomes. Se reconhece como um espaço educativo, tal como estabelecido enquanto reparação pela Comissão de Verdade, e um ambiente que valoriza a Constituição Nacional e os tratados internacionais em respeito aos direitos humanos (MUSEO DE LAS MEMORIAS, 2007).

As exposições, extremamente documentadas, vão passando por diversas temáticas no interior do edifício e suas salas, até culminar em seu pátio interno, onde há uma homenagem às vítimas. Essa homenagem é realizada em uma cela da prisão da DNAT reconstruída que representa o sofrimento desses indivíduos. Lembramos aqui que, apesar da longa discussão sobre os povos indígenas e a repressão dos trabalhadores no campo, não há menção específica sobre a temática no Museu, talvez por considerar o espaço urbano, onde ele está proposto, ou pela própria maneira de realizar a reformulação do Museu, como veremos a seguir.

Uma exceção foi, quando em abril de 2012, realizou-se uma cerimônia, no Museo de las Memorias, de entrega dos restos de Damiana Kryygi, menina do povo Aché, sequestrada e levada à Argentina, em finais do século XIX. Depois de sua morte, seus restos foram divididos entre os Museus de Etnologia de La Plata e Berlim para estudos. Entregue oficialmente pelos governos da Alemanha e da Argentina, ela fora restituída à sua comunidade com um ato no Museu, que lembrou o sofrimento dessa população (REPATRIAN..., 2012). 


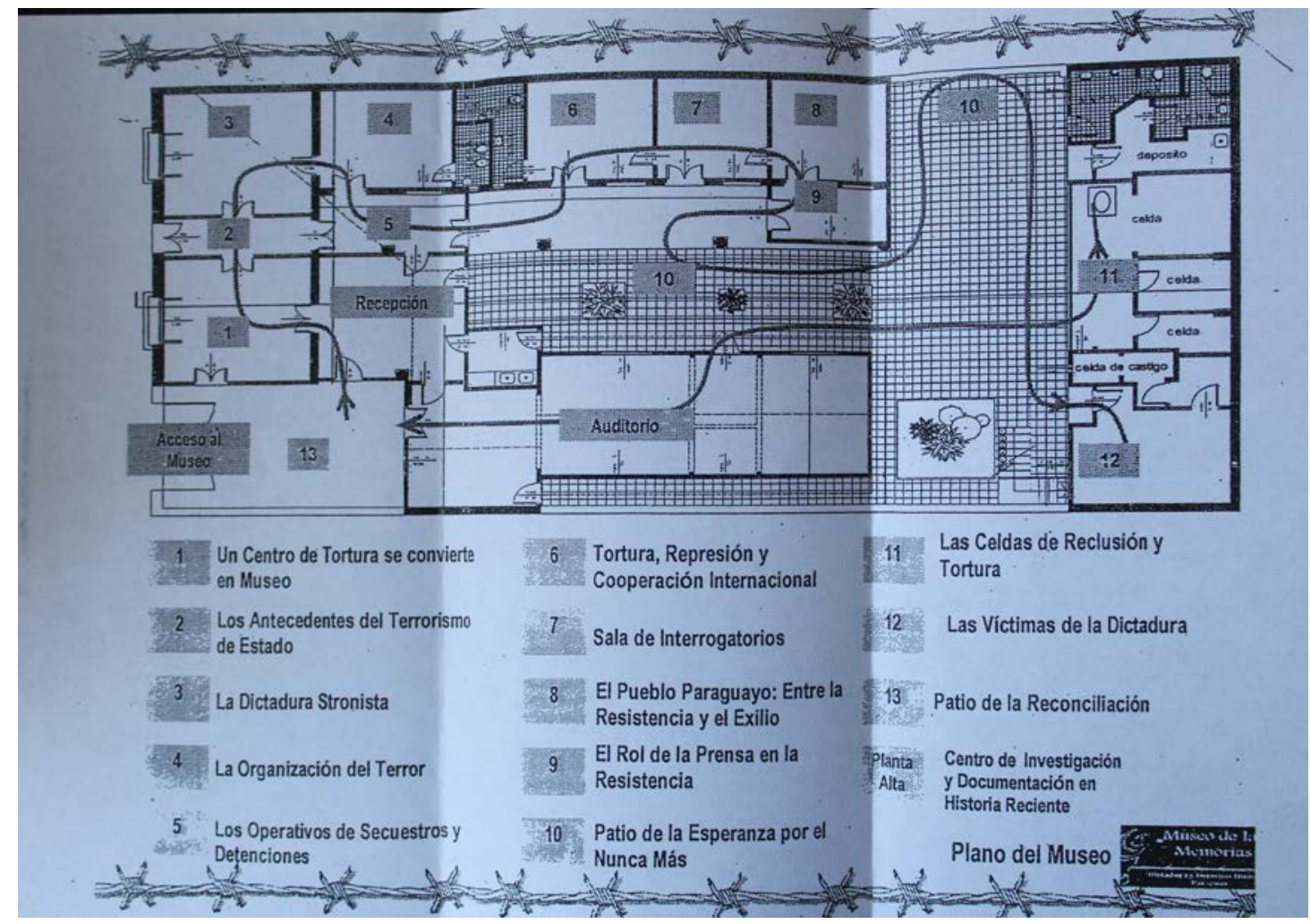

Fonte: MUSEO DE LAS MEMORIAS. Folleto de Información. Asunción: Celestina Pérez de Almada, 2007.

Portanto, este Museu pretende fazer um recorrido sobre a história recente do país e da América Latina, em sua conexão de planos repressivos, objetivando compreender a situação atual e a "origem de nossa pobreza". Se determina como uma oportunidade de repensar o passado e valorizar a luta "heroica" para defender os valores à vida, os direitos fundamentais e das comunidades, a partir da Constituição Nacional e dos acordos internacionais em respeito aos direitos humanos (MUSEO DE LAS MEMORIAS, 2007). 


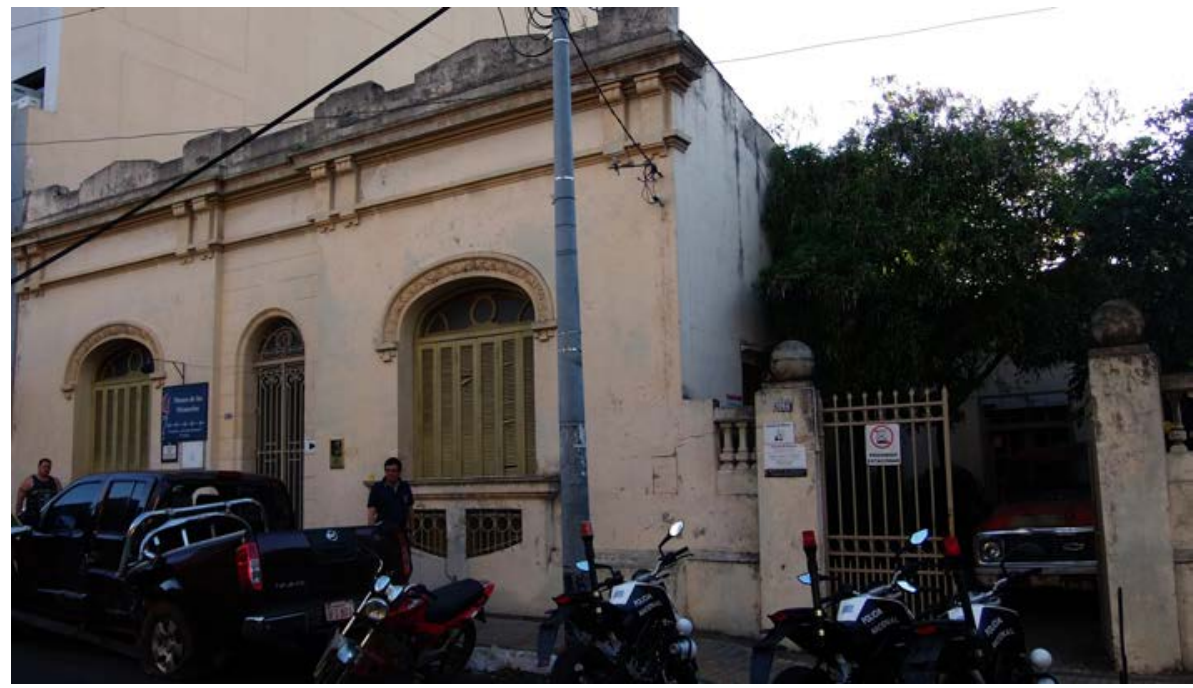

Fonte: Arquivo pessoal. Fotografia de 2015.

Imagem 26 - Reconstituição interna das celas da DNAT

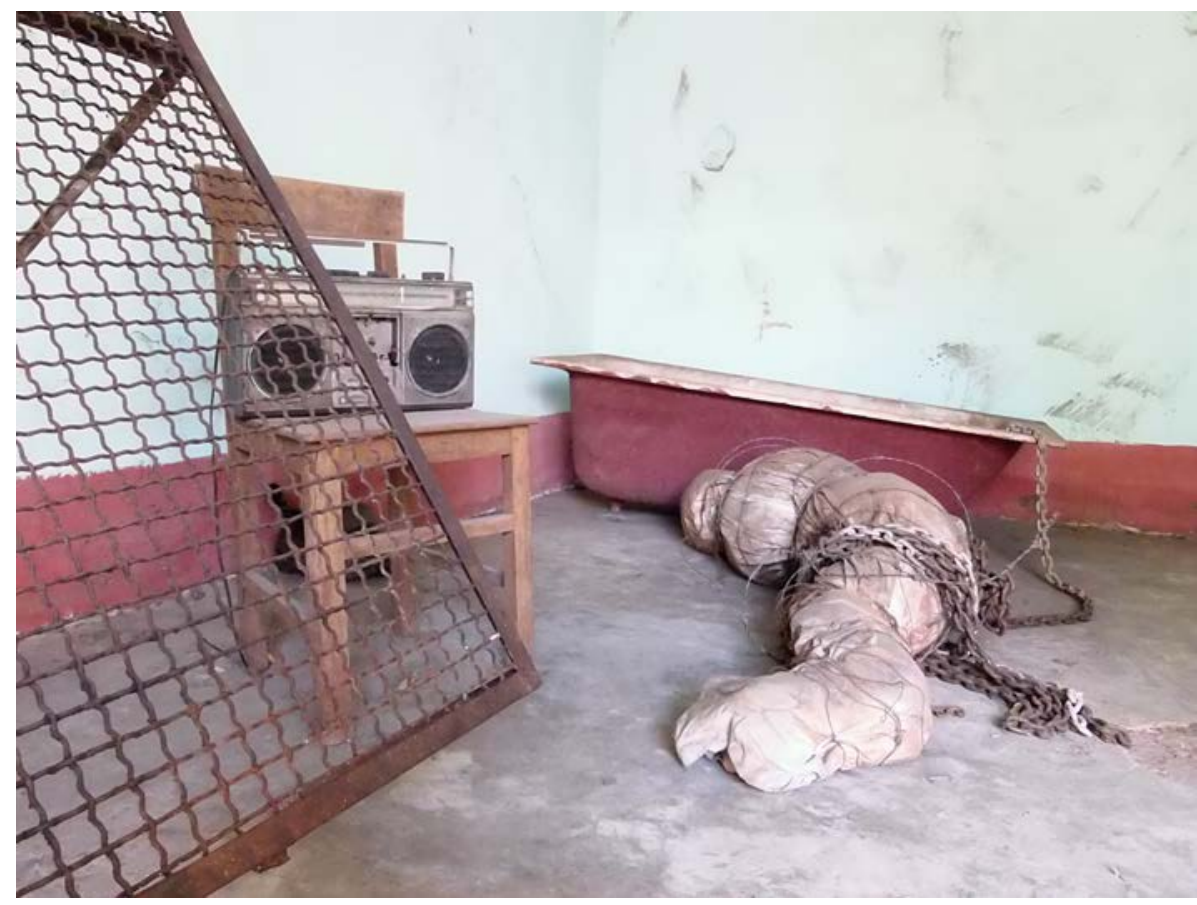

Fonte: Arquivo pessoal. Fotografia de 2015.

\section{3 - Sobre memórias e resistências: Centro Cultural Museo de la Memoria}

Criado em 2006 e aberto ao público no ano seguinte, o Centro Cultural Museo de la Memoria (MUME) é uma instituição interligada à Intendencia de Montevideo, que se dedica à construção da memória sobre o Terrorismo de Estado e sobre a luta dos uruguaios contra a 
ditadura. Com o objetivo de aportar conhecimento para as novas gerações, relativo à história recente do país, e fortalecendo os laços de identidade, ele trabalha com os "conceitos culturais" de liberdade, democracia e justiça social (MUSEO DE LA MEMORIA, 20--).

A proposta de um Centro Cultural amplia as áreas de exposição do Museu, passando o mesmo a oferecer atividades educativas e eventos artísticos, que simbolizem, então, a crítica e a reflexão sobre os genocídios e os Terrorismos de Estados, como expressões da barbárie promovida em prol da "civilização" e com sentidos do Nunca Más. ${ }^{95}$ Desta forma, a justificativa do espaço de consciência traz dois fundamentos básicos: as resistências e a identidade uruguaia.

De acordo com Denise Rollemberg (2016), as resistências, enquanto conceito, possuem uma flexibilidade conectada ao grau de sucesso das ações de restrições e violências dos regimes com ambições totalitárias. Elas articulam a sociedade e os riscos que a mesma tem de tornar-se vítima de determinados Estados com as formas de se contrapor aos sistemas e suas ideias.

No caso uruguaio, esse conceito é usado essencialmente para organizações e indivíduos que combateram a implementação ditatorial no país, em suas diversas maneiras: aqueles lutaram contra a censura, contra as prisões, contra as torturas, contra as mortes e desaparecimentos. No entanto, também se interliga ao momento pós-ditatorial, no qual se resiste ao esquecimento e ao apagamento da memória, a partir da anistia.

Essa ideia vê-se claramente na sala "auge" do Museu, onde se expõem as placas com as fotos dos desaparecidos uruguaios, utilizadas na primeira Marcha contra el Olvido. Muito comemorada, a sala é o símbolo máximo do MUME e traz a luta cotidiana pela justiça e pela verdade sobre aquelas vítimas, cuja batalha dos organismos de direitos humanos e dos familiares é um marco na sociedade uruguaia, trazendo a figura dos desaparecidos e dos mortos e as possibilidades de interpretações no âmbito da lei de anistia, como vimos em capítulos anteriores.

\footnotetext{
${ }^{95}$ Cf. MUSEO DE LA MEMORIA (MUME). Disponível em: <http://mume.montevideo.gub.uy/museo/centrocultural-museo-de-la-memoria>. Acesso em: 20 mar. 2017.
} 

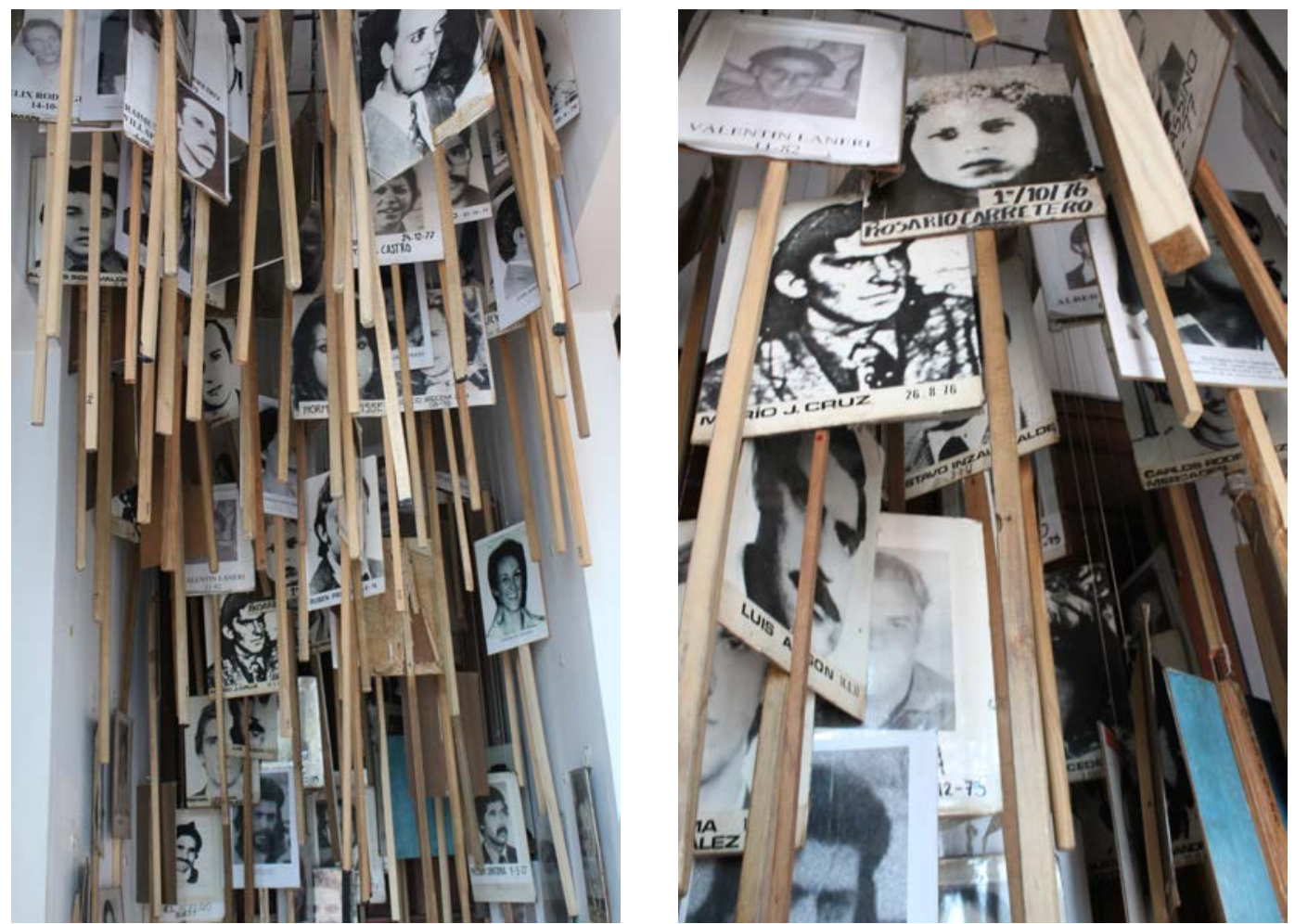

Fonte: Arquivo pessoal. Fotografias de 2016.

Rollemberg (2016), ao trabalhar a construção da memória sobre as resistências na França e Itália, nos lembra que o conceito de resistência foi um esforço iniciado nos anos pósguerra, nos momentos de reconstrução europeia, que teve papel fundamental nas interpretações para apaziguar os sentimentos despertados pelo "conhecimento" das barbáries cometidas durante a Segunda Guerra Mundial. Uma forma de se construir uma identificação, na qual os derrotados poderiam considerar-se ativos nessa "história sombria", recuperando um mito de luta pela liberdade. Posteriormente, já na década de 1970, esse mito de resistência passa a ser enfrentado, a partir das ideias de colaboração e de responsabilidades sociais.

Fato é que, da mesma forma recordadas no MUME, as resistências baseiam a construção de uma identidade no país, que possa trazer os sujeitos como ativos diante do Sistema Repressivo ditatorial. Nessa construção identitária, imprime-se o desejo democrático e de justiça social, opondo-se ao Terrorismo de Estado e interligando-se a outros eventos históricos, que hoje são recordados, a partir do espectro do Nunca Más.

En diversas partes del mundo y ante situaciones diversas pero similares en su esencia, los pueblos instituyen espacios simbólicos de la memoria. Lo hizo el Pueblo judío respecto al holocausto. Lo ha hecho el Pueblo japonés respecto a las explosiones atómicas de Hiroshima y Nagasaki. Se está haciendo en América Latina respecto a las dictaduras que aplicaron 
sistemáticamente el Terrorismo de Estado. ¿Cuál es el fundamento de esta actitud de los pueblos que han sufrido situaciones traumáticas y disolventes de su identidad? ¿Es la revancha? No, el fundamento es que Nunca Más vuelvan a ocurrir esos hechos (MUSEO DE LA MEMORIA, 20--, sem paginação).

Diferentemente dos demais espaços trabalhados, o MUME foi constituído em um edifício que não possui uma conexão direta com o Sistema Repressivo ditatorial uruguaio dos anos 1970. Contudo, relembra a história de ditaduras no país, remetendo-se ao século XIX.

Instituído na Casa-Quinta do general Máximo Santos, o edifício foi projetado e construído entre 1881 e 1886 e era o lugar de descanso do mesmo, quando se tornou presidente da República. Naqueles anos, o Uruguai vivia em processo de modernização, financiado pelas classes altas rurais e pelas famílias tradicionais, identificadas por seus patrimônios, com um projeto autoritário para estabilizar a situação política e econômica do país, advinda da Guerra del Ovino (1860-1868) e da Guerra da Tríplice Alianza (1865-1870). Neste sentido, baseava-se nas relações de dependência pessoal com a figura do caudillo e na fidelidade ao sistema da sociedade patriarcal (ARTEAGA, 2000).

O general Santos, portanto, exerce a presidência de 1882 a 1886, e seus anos de governo são caracterizados pela exibição de luxo e suntuosidade, na qual a casa de repouso em questão, é o símbolo máximo dessa extravagância. Com o término da presidência, Santos torna-se senador, até apresentar sua renúncia, em 1887, e embarcar para a Europa. Ao retornar para o Uruguai, foi impedido de entrar no país e desterrado sob o argumento de que sua vida corria perigo. Passou, então, a viver em Buenos Aires, onde morreu aos 47 anos.

A conhecida Quinta de Máximo Santos possuía em seu exterior um espaço destinado à criação de aves exóticas, um pequeno zoológico com pumas e jaguares, uma gruta artificial, um "túnel do amor" e um castelo dedicado à filha do general. No interior da casa principal, contava-se com salões de festas e reuniões, pinturas de época, tetos trabalhados, um pátio decorado com estátuas e fontes e um jardim de inverno com vitrais. Uma escada de ferro levava ao subsolo, onde havia calabouços para manter os presos políticos.

Desde 1893, a casa foi vendida a diversos novos proprietários, ocasionando retiradas e desaparecimentos de colunas, estátuas, molduras e etc. Em 1943, a Intendencia de Montevideo compra o lugar, e ele tornou-se sede de alguns museus até ser completamente abandonado. Há relatos de vizinhos afirmando que, durante o período ditatorial, a casa foi roubada e destruída, não restando sequer a estrebaria ou as carruagens guardadas no terreno da casa (ALMORZANDO..., 2014). 
Imagem 28 - Quinta de Máximo Santos abandonada (sem data)

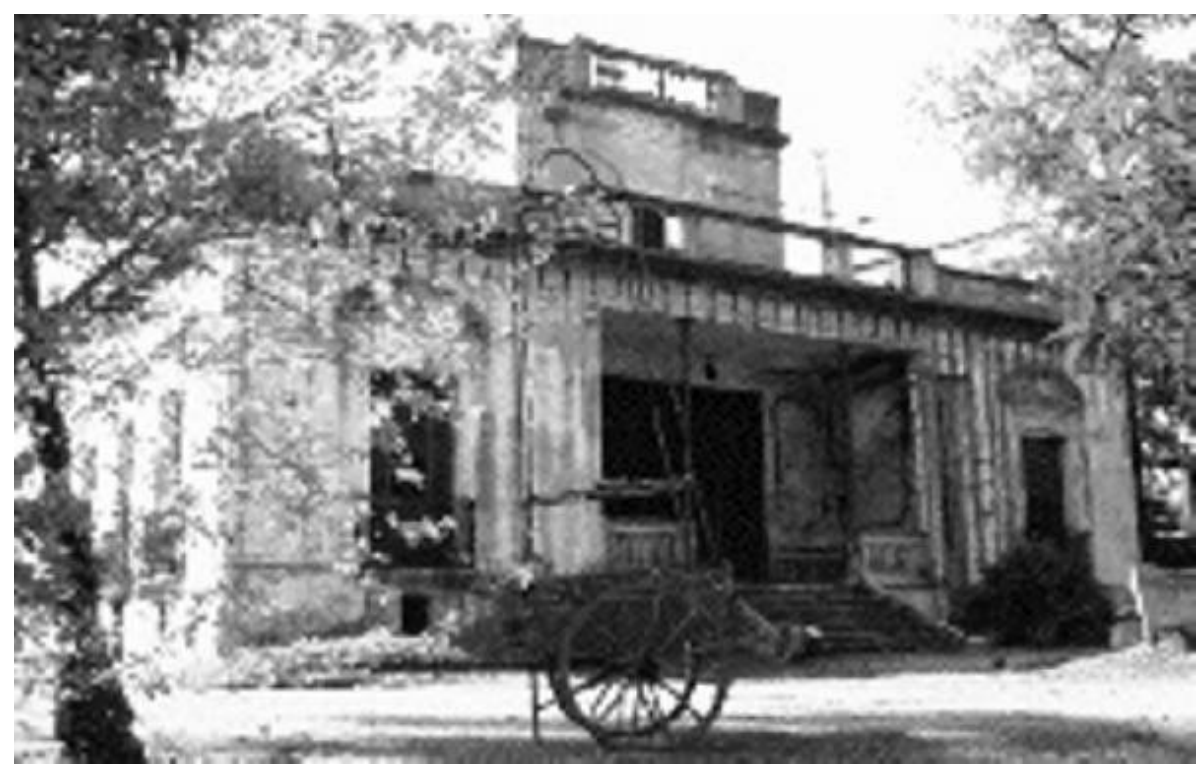

Fonte: ALMORZANDo CON MÁXIMO SANTOS. El País, Montevideo, 7 de octubre de 2014. Disponível em: <http://viajes.elpais.com.uy/2014/10/07/almorzando-con-maximo-santos〉. Acesso em: 03 fev. 2017.

Em 1996, inicia-se o projeto de restauração da Quinta para tornar-se um Centro Cultural da Intendencia, com o convênio de empresas privadas. Durante os quase dez anos de remodelação até se criar o MUME, a casa abrigou um grupo de teatro independente que a utilizava para ensaios e depósito, e foi parte do Departamento de Descentralización que guardava ali caminhões e a utilizava com funções de reuniões administrativas.

Depois de um acordo entre organizações de direitos humanos do país e a Intendencia de Montevideo, a casa torna-se o Museo de la Memoria. Neste sentido, além das exposições e atividades temporárias, a exposição permanente trabalha temas como a instituição da ditadura, as cárceres, o exílio, a resistência, os desaparecidos e a abertura democrática. $\mathrm{O}$ antigo subsolo, onde permaneciam os presos do governo de Máximo Santos, é sala para exposições itinerantes que, ao longo do tempo, abordaram diversas temáticas de violações aos direitos humanos. E a parte externa da Quinta traz mostras artísticas, além de abrigar um edifício com uma biblioteca e arquivo com a documentação pessoal do deputado assassinado na Argentina, Zelmar Michelini. 
Imagem 29 - Mapa do Museo de la Memoria

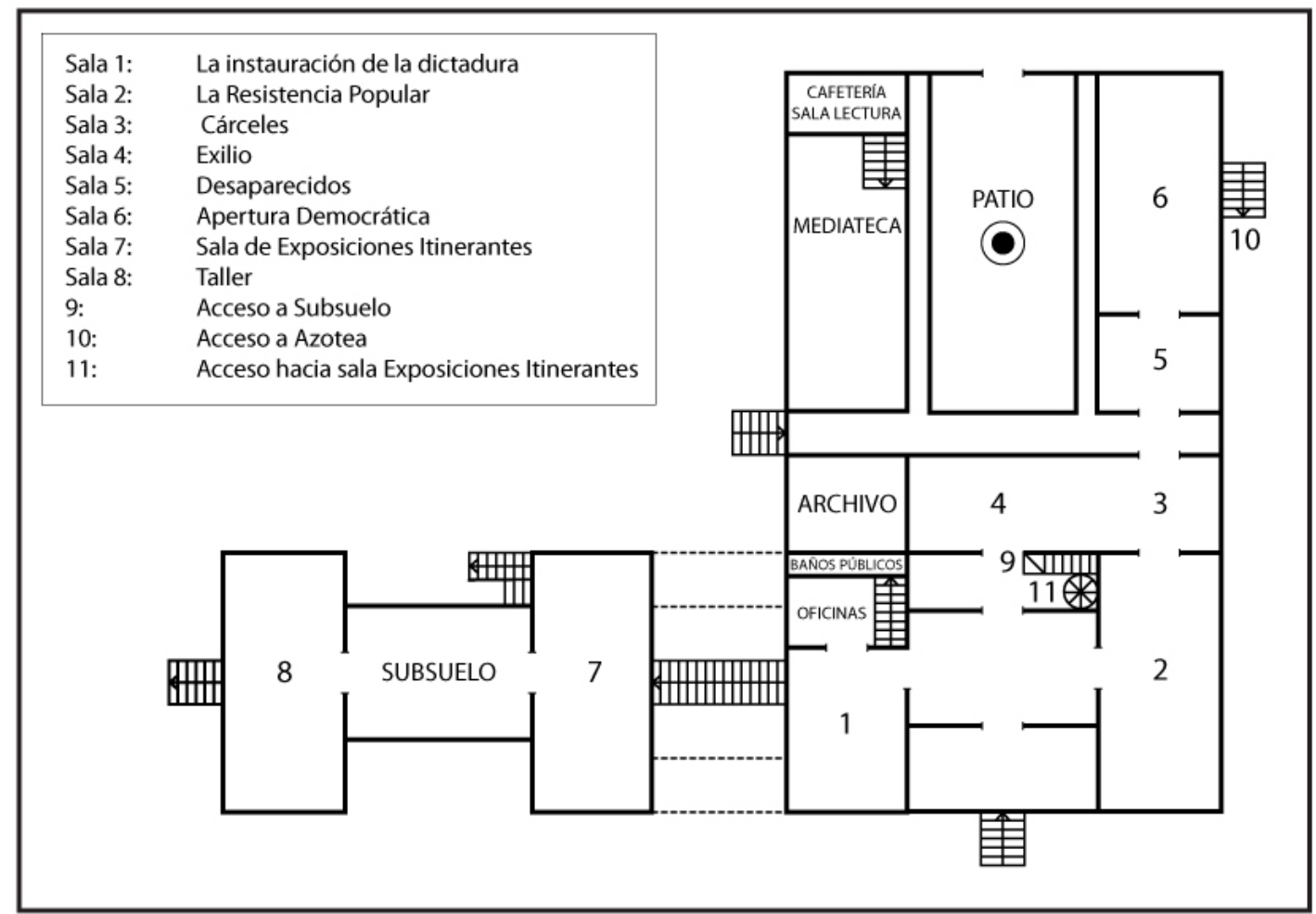

Fonte: MUSEO DE LA MEMORIA. Folleto de divulgación. Montevideo: MUME, 20--.

Imagem 30 - Casa principal e entrada do Centro Cultural Museo de la Memoria

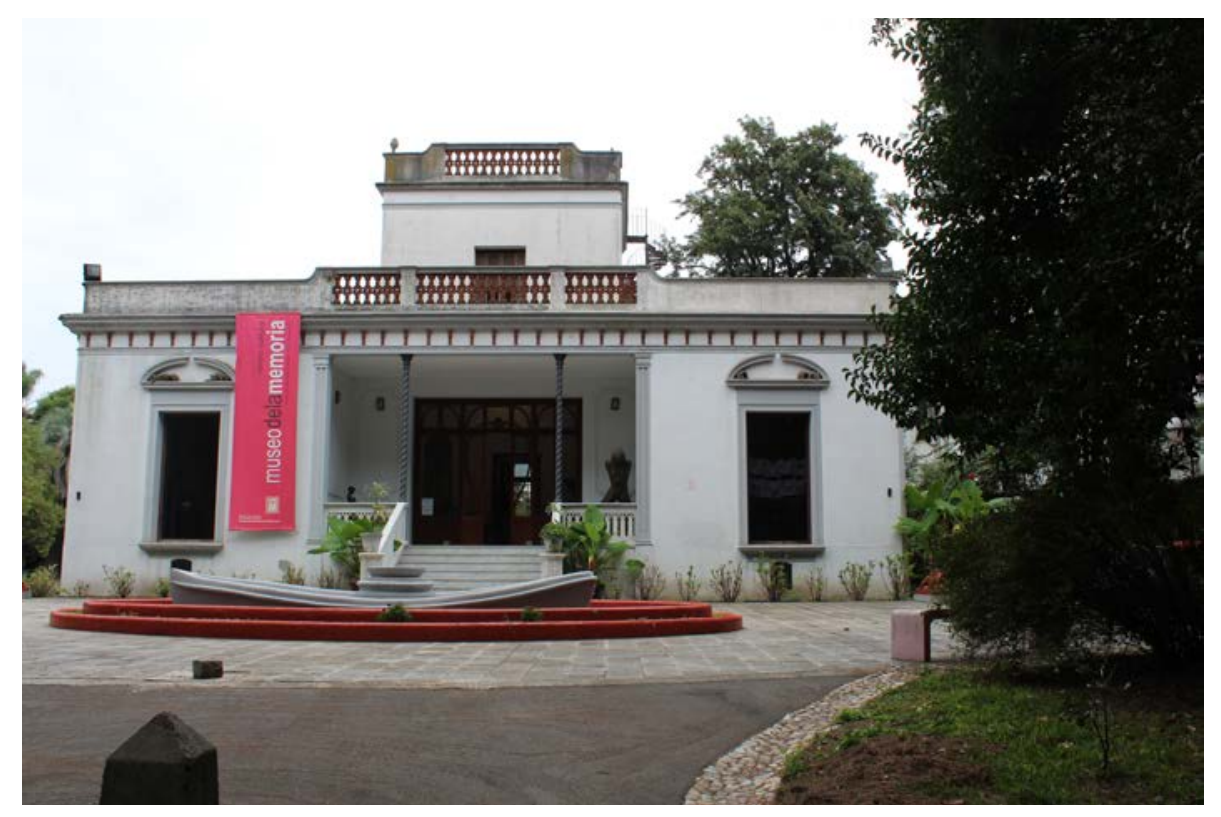

Fonte: Arquivo pessoal. Fotografia de 2016. 
Imagem 31 - Exposição Fotográfica Memoria a la vista (Fotografias de Nancy Urrutia - 2009)
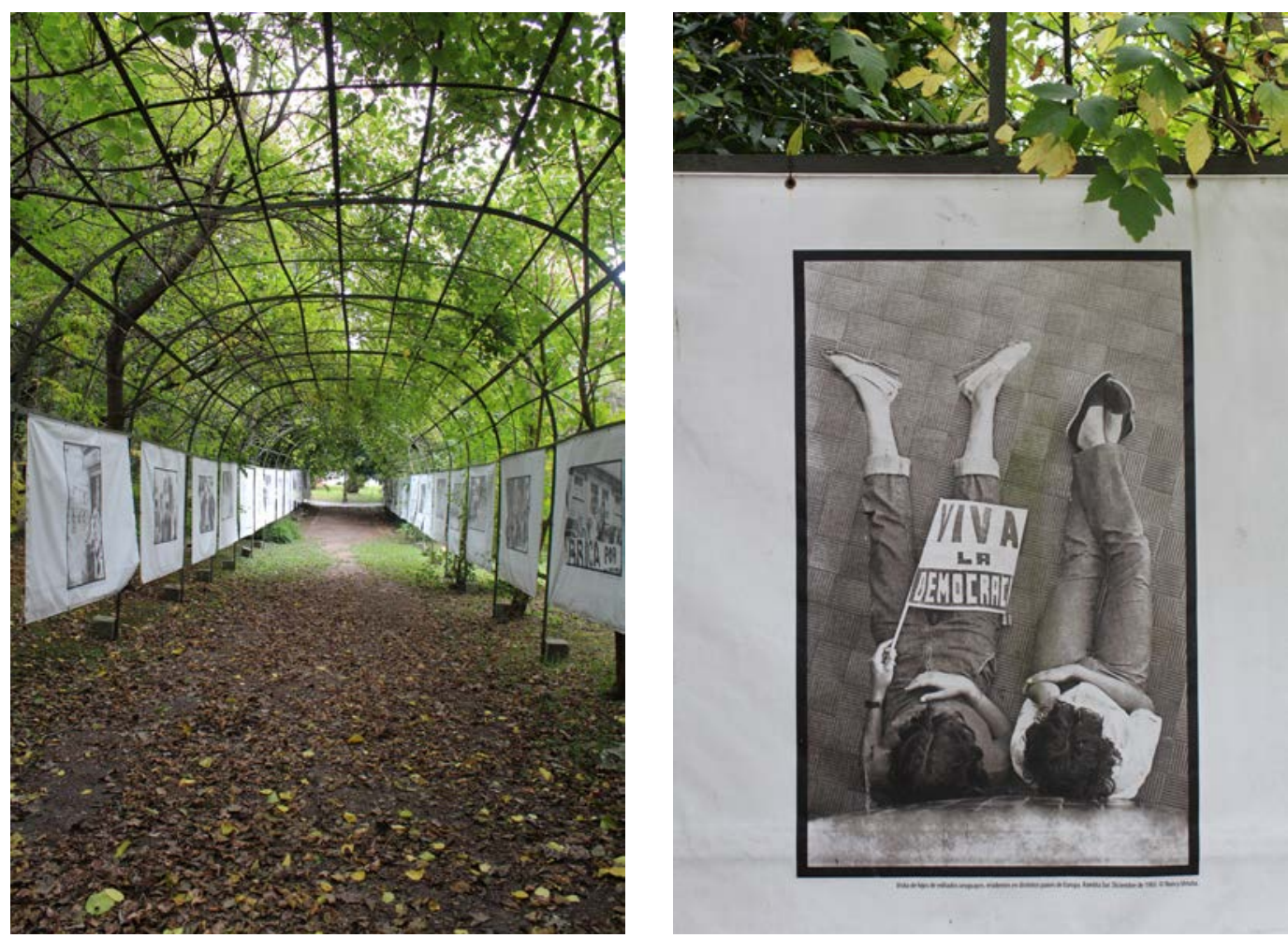

Fonte: Arquivo pessoal. Fotografias de 2016.

O Museo de la Memoria entende-se como uma reparação das violações cometidas pelo Estado terrorista. Enfatizando ser o lugar da resistência a este modelo de governo, o MUME afirma que todas as suas atividades serão contrárias à mentalidade que fundamentou a ditadura, entre elas, a falta de respeito às diversidades e às normas sociais. E, desta forma, lembrar que a população uruguaia resistiu de muitas maneiras, pacíficas e violentas, dentro e fora da lei para derrubar esse projeto poítico e, por isso, foi castigada. Todas as formas de resistir foram castigadas: "fueron todos culpables de luchar contra la implantación de la dictadura" (MUSEO DE LA MEMORIA, 20--, sem paginação). 


\section{CAPÍTULO 5 \\ DOS CAMINHOS AOS TERRITÓRIOS: UMA HISTÓRIA DOS DEBATES PELA MEMÓRIA}

(...) porque los muertos no tienen divisa, son la divisa (ROSENCOF apud VIGLIONI, 2014, sem paginação).

Nesse capítulo final, pretendemos analisar algumas discussões sobre os territórios de memórias, abordados anteriormente. Trazer os debates que antecederam as constituições dos espaços consolidados para as recordações de vítimas é tratar das elaborações dessas instituições pedagógicas, que abordam a não repetição das catástrofes humanas e pretendem transformar as memórias coletivas presentes, constituindo uma identidade em favor dos direitos humanos nos espaços nacionais e internacionais.

Lembrando que trabalhamos com instâncias pedagógicas específicas, em momentos específicos, deseja-se, mais do que fechar um ciclo em torno da consciência para um patrimônio ético, tal como proposto por Ricard Vinyes ${ }^{96}$, abrir espaço para as questões sobre os territórios de memória que estamos construindo. Sabemos que os patrimônios inscrevem-se entre a memória e a história, invocando determinados valores, capazes de estimular as dimensões identitárias individuais e coletivas. Mas esses valores e as representações dos mesmos estão inscritos em um contexto e são, de certa forma, dinâmicos (POULOT, 2009). ${ }^{97}$

No entanto, antes de se inscreverem em um território, esses patrimônios são debatidos, enquanto propostas, das quais algumas saem vitoriosas e outras são marginalizadas. Os debates sobre o patrimônio que refere-se às catástrofes humanas, perpassam não apenas respostas para os contextos locais, contudo também, trazem retornos exteriores a eles, com discussões e exemplos significativos sobre violências estatais, educação em matéria de direitos humanos, vítimas de violações, reparações e lugares onde estas violações ocorreram por todo o mundo.

Desta forma, seguindo o propósito do texto, analisaremos esses debates sobre o patrimônio do Río de la Plata, observando o trânsito entre o local e o global e as experiências intercambiadas nesse fluxo. Não esquecendo-nos da hierarquia que habita a construção cultural e do patrimônio mundial, em uma dinâmica transnacional, o foco será ver como os

\footnotetext{
${ }^{96} \mathrm{O}$ patrimônio ético seria aquele patrimônio que aborda, dentro dele, questões sobre sua conformação e debates sobre problemas de representações, transmitindo-as para seus observadores e públicos. Cf. VINYES, 2014.

${ }^{97}$ Vimos, por exemplo, no primeiro capítulo desse trabalho, como foram sendo (re)formuladas, ao longo do tempo, algumas marcas do passado na cidade de Berlim, que recuperam a representação da violência nazista. Cf. capítulo 1 desta tese.
} 
exemplos considerados exitosos, ao se trabalhar com memórias de catástrofes, são apropriados para se pensar o caso dos desaparecidos e do genocídio nos espaços urbanos de Buenos Aires, Montevidéu e Assunção. Quais são as questões levantadas, ao tratar do desenvolvimento da consciência sobre catástrofes no mundo, que aportam um fundamento para os territórios de memória rioplatenses.

\section{1 - Caminhos ao Espacio para la Memoria: O caso argentino como exemplar}

Inúmeras foram as produções documentais relativas às discussões sobre a conformação do Espacio para la Memoria y para la Promoción y Defensa de los Derechos Humanos. Isto porque, quando, em março de 2004, se assina o acordo para a formação do Instituto Espacio para la Memoria, amplia-se um espaço público para que os organismos de direitos humanos comecem a pensar, concretamente, em um território para suas memórias inscreverem-se no presente.

Desta forma, a escolha aqui foi trabalhar com documentos produzidos pela organização Memoria Abierta, que é uma aliança entre organizações argentinas de direitos humanos - Asamblea Permanente por los Derechos Humanos; Buena Memoria Asociación Civil; Centro de Estudios Legales y Sociales; Comisión de Homenaje a las Víctimas de Vesubio y Protobanco; Comisión por la Memoria, la Verdad y la Justicia de Zona Norte; Familiares de Desaparecidos y Detenidos por Razones Políticas; Fundación Memoria Histórica y Social Argentina; e Madres de la Plaza de Mayo - Línea Fundadora. Apesar de algumas dessas organizações posicionarem-se também individualmente em relação ao espaço conquistado da ex-Escuela de Mecánica de la Armada (ex-ESMA) ${ }^{98}$, sugerimos que a percepção deste coletivo pode sintetizar, na medida do possível, os argumentos desses debates.

O coletivo, criado nos anos 1990, tem como objetivo promover a memória sobre as violações ocorridas no passado recente e valorizar as ações resistentes e lutas pela verdade e justiça. Sua missão é implementar políticas públicas para promover memórias de grupos sociais, ampliar o acesso ao patrimônio da memória, aumentar o arquivo oral sobre a ditadura, aportar ferramentas para causas judiciais e promover aprendizagem e intercâmbios de projetos em arquivos, museus e documentações sobre violações aos direitos humanos. ${ }^{99}$

\footnotetext{
${ }^{98}$ Cf. BRODSKY, 2005. p. 215-225.

${ }^{99}$ Cf. MEMORIA ABIERTA. Disponível em: <http://www.memoriaabierta.org.ar〉. Acesso em: 8 fev.2017.
} 
Abordaremos duas documentações desse coletivo: uma série de debates realizados entre 1999 e 2007; e um conjunto de depoimentos gravados a partir de 2001, que expressam opiniões pessoais dos entrevistados (vítimas ou familiares de vítimas do Terrorismo de Estado argentino). As séries de debates, intituladas "Organización Institucional y contenidos para el futuro museo de la memoria" (1999) e "El museo que queremos" (2004 e 2007), são transcrições de palestras de especialistas e comentários do público que as assistiu. Os depoimentos, por sua vez, são entrevistas gravadas que abordam desejos pessoais sobre o território de memória da ex-ESMA, cujas vítimas falam sobre experiências e anseios dentro do futuro Museo de la Memoria.

\subsection{1 - Futuro Museo de la Memoria: O que queremos?}

Em 1999, Memoria Abierta inicia seus debates, buscando discutir com organizações de direitos humanos, especialistas e demais interessados na construção dessa memória, os fundamentos para a criação de um futuro museu. A incursão pelo tema, naquele ano, foi justificada pela apresentação do projeto de construção do já citado Monumento a las Víctimas del Terrorismo de Estado (1997), que impulsionou a antiga aspiração de se criar um museu da memória no país (MEMORIA ABIERTA, 2000).

Esses primeiros debates teriam a função de se caminhar em direção ao museu que se queria naquele contexto: um museu que cumprisse com a função de preservar documentos e fazê-los acessíveis, de desenvolver a investigação interdisciplinar e de promover ações educativas e exibições que se conectassem ao presente, enriquecendo a cultura democrática.

O primeiro debate destas jornadas introduziu o tema sobre os objetivos de se construir um museu de memória no país e como transformar essa demanda pelo museu - algo proveniente de um setor diretamente afetado pela ditadura - em uma necessidade social. $\mathrm{O}$ palestrante que abriu tal debate foi Américo Castilla, artista argentino e professor na Universidad de La Plata, que, entre os anos 1992 e 2003, dirigiu a Fundación Antorchas (1985-2006), financiando diversos projetos no âmbito da cultura nacional e internacional.

Sua fala direcionou-se a pensar o museu enquanto um lugar de transmissão, apoiado em recursos para se comunicar eficazmente. Neste sentido, três elementos seriam, para ele, fundamentais na reflexão sobre um museu de sucesso: a entidade dramática, a capacidade de comunicar-se com os visitantes e a presença daquilo que ele chamou de "poesia". Para o palestrante, não haveria possibilidades de criar-se um museu de memória com a antiga "prioridade científica" que era dada aos museus de fundamentação identitária. 
Pepe (Pérez Gollán), que dirige el Museo Etnográfico, está acostumbrado a ver en museos que no se adecuan a los tiempos, cómo está exhibido un cacharro y abajo dice: "Cultura Condorhuasi", "Cultura Candelaria", "Cultura de La Aguada", y el espectador está ahí y difícilmente signifique algo, es más, pareciera que el museo le da un significado erudito a esto, pero que el receptor de este mensaje también debe ser un erudito, un receptor calificado para que se dé la comunicación (CASTILLA apud MEMORIA ABIERTA, 2000, p. 7).

Esses museus com significados eruditos ("Museus-Gabinetes de Curiosidades") atribuem o privilégio da exposição à atividade científica e auxiliam uma cristalização de dogmas históricos. No entanto, eles se esquecem de explicitar seu conteúdo simbólico, o que, segundo Castilla, distancia o veículo de transmissão de seu visitante. Neste caso, por exemplo, o palestrante cita a exposição de Paul Klee, no Museu de Belas Artes, em Buenos Aires, que acontecia simultaneamente ao debate e que tratou de conformar-se em um recorrido à distância das gravuras do artista, menores que 30 centímetros. Para ele, essas gravuras foram feitas para uma observação próxima, possibilitando inclusive seu manuseio, e, naquela forma de exposição, escolhida pelo Museu de Belas Artes, as obras perderam tal sentido.

De acordo com Castilla, o expectador contemporâneo já não se conforma com esses recursos narrativos. Ele requer diversas outras funções informativas, inclusive contraditórias da narrativa do museu. Essas novas narrativas é o que ele chama de poesia: quando o visitante consegue vincular uma imagem/conhecimento ao seu sentido, deslocando seu corpo com sons, texturas e movimentos. Assim, exemplifica:

De lo que he visto en el Museo del Holocausto, quizás lo tengo como más memorable, es que un escalón estaba separado del otro de una manera por encima del habitual, y era una chapa fuerte y había un pasamanos que también era de metal y eso era una situación de frialdad, desproporción, ajenidad, donde era obvio que uno estaba en un sitio en el que había un efecto muy dramático y eso era más importante que cualquier leyenda o cualquier imagen que pudiera competir a eso (CASTILLA apud MEMORIA ABIERTA, 2000, p. 8). 


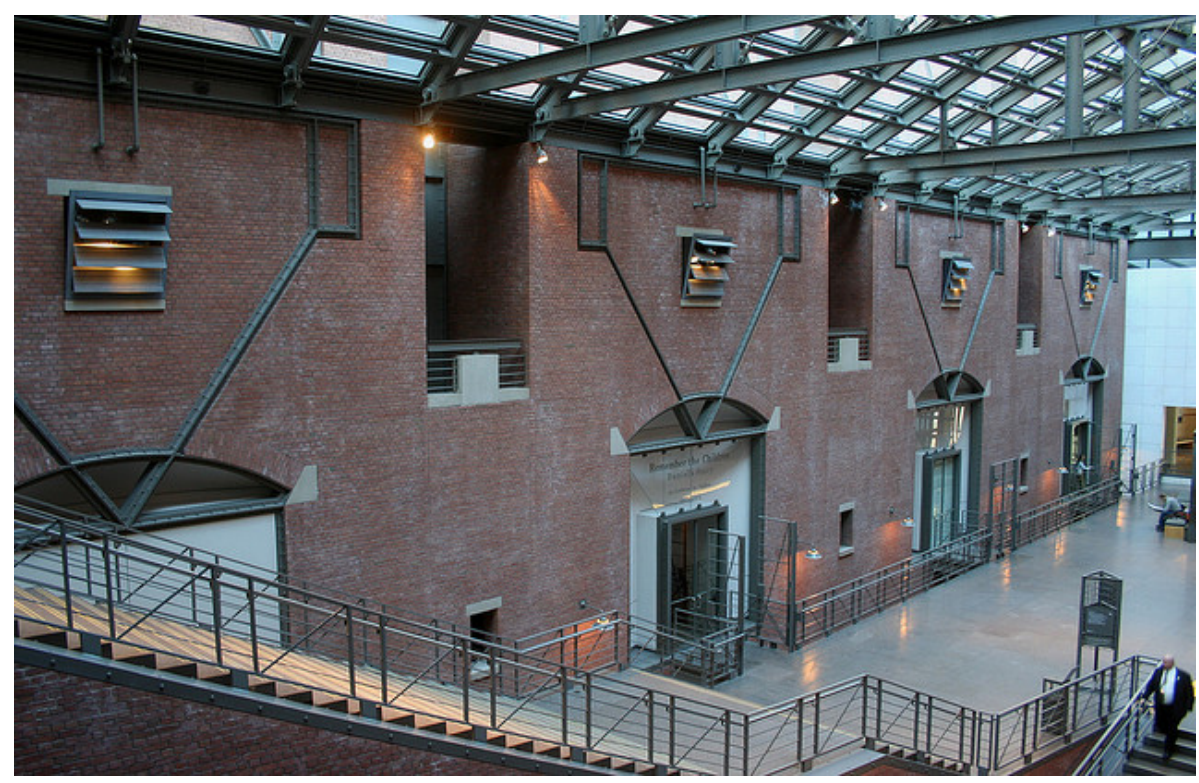

Fonte: HOLOCAUST MEMORIAL MUSEUM. Disponível em: 〈https://collections.ushmm.org >. Acesso em: 07 jul. 2017.

A dinâmica apresentada dos sentimentos e emoções é explorada por Américo Castilla como fundamental para se construir um museu exitoso sobre as catástrofes humanas. A dramaticidade seria o "idioma dos novos museus" para "conversar" abertamente com o visitante. Porque não interessa a leitura do museu sozinha; o que interessa é a coletivização da narrativa, possível apenas por essa chave da emoção.

En una conversación que tuve con Bergman, que fue el diseñador de la exposición del Museo de Holocausto, le pregunté cuál había sido su propósito, qué quiso significar con su mensaje, y él me dijo que lo que él quiso provocar fue la conversación entre generaciones. Este es un tipo de museo que busca que vayan al menos dos generaciones acompañadas y lo que quiso provocar es un diálogo que de otra manera no se hubiera provocado y una transmisión de un evento histórico que de otra manera no se hubiera provocado. Yo le puedo dar fe de que ese objetivo se cumple (CASTILLA apud MEMORIA ABIERTA, 2000, p. 8-9).

José Perez Gollán, o segundo palestrante da mesa, concordou com a visão de um discurso de museu que se afastasse do "Gabinete de Curiosidades" e que se tornasse um lugar de investigação, conservação e difusão, com alternativas sobre como informar. Perez Gollán (1937-2014) era historiador e arqueólogo, foi diretor do Museo Etnográfico, entre os anos de 1987 e 2005, e diretor do Museo Histórico Nacional, de 2005 a 2013.

Em sua experiência, trazia consigo sempre questões como "que museu queremos?" e “que memória queremos?" para a constituição de um projeto de exposições. Percebendo que um futuro museu da memória não poderia abarcar todas as memórias do país, Gollán sugere a 
necessidade de se falar de um projeto gerido coletivamente e que englobasse investigações sobre o modo de trabalhar, sobre como transmitir conhecimento e sobre os níveis de interpretação daquilo que seria comunicado. E, para ele, este projeto deveria romper com o argumento de "coisas sinistras" e falar sobre o cotidiano, recuperando a ideia de "poesia/emoção dentro do museu".

De esos museos de la memoria hay muchos ejemplos. (...) Uno es el museo de un campo de concentración cerca de Múnich, que tiene la particularidad de no ser siniestro. Porque cuando uno llega ahí se conmueve frente a esta cosa de la vida cotidiana. Se entra por una puerta donde dice "El trabajo os hará libres", y uno empieza a tener estas sensaciones cada vez más terribles; y simplemente por la inscripción en un pequeño portón, no hay necesidad de ver cosas truculentas ni nada por el estilo. Creo que esto es de lo que hablaba Américo, de una poesía negra, pero es el deslumbramiento frente a una realidad absolutamente cotidiana (GOLLÁN apud MEMORIA ABIERTA, 2000, p. 13).

Imagem 33 - Dachau Concentration Camp Memorial Site

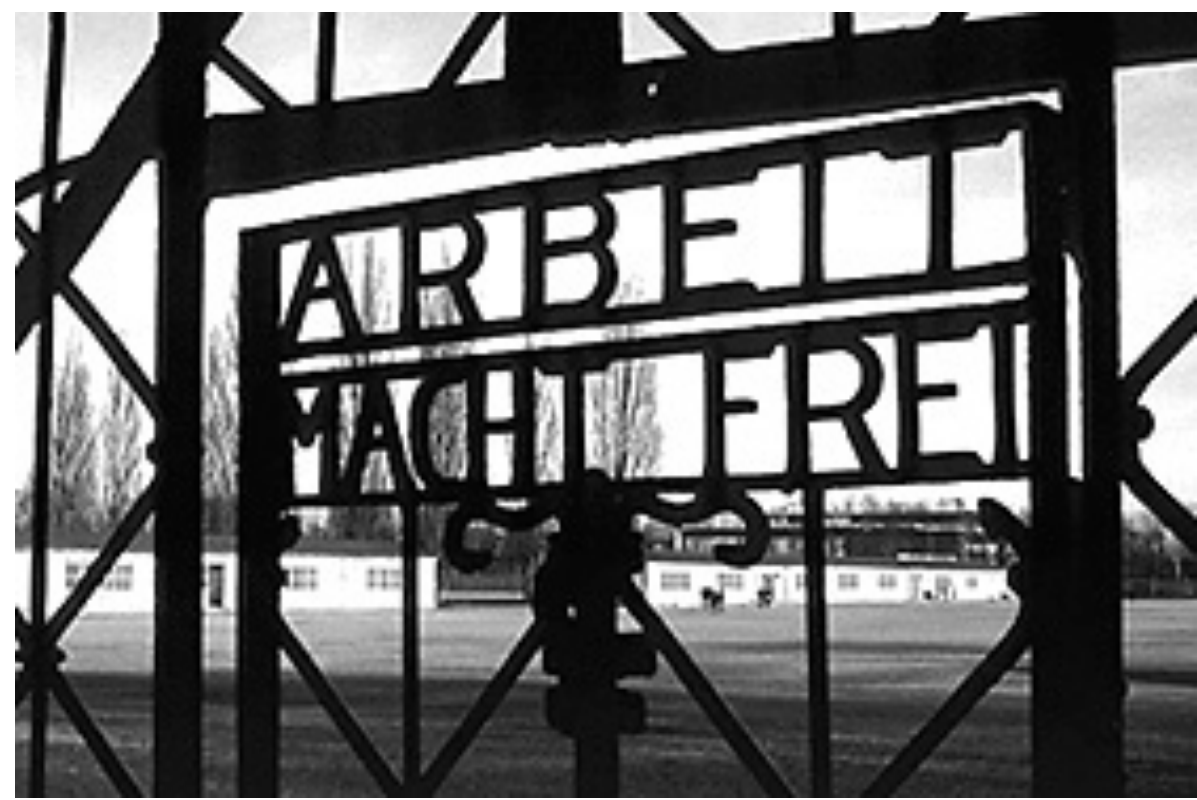

Fonte: DACHAU CONCENTRATION CAMP MEMORIAL SITE. Disponível em: <https://www.kzgedenkstaette-dachau.de/>. Acesso em: 18 jul. 2017.

Gollán conclui que o maior desafio do futuro museu da memória era pensar como mostrar algo que muitos argentinos ainda não estavam dispostos a ver. E, desta forma, afirma que o discurso deste museu precisaria se conectar com o visitante, através das emoções do cotidiano das vítimas.

Héctor Schmuckler, por sua vez, sociólogo e semiólogo, cujo filho, Pablo Schmuckler, foi detido-desaparecido em 1977, aprofundou-se na ideia dessa sociedade "indisposta ao 
passado" e nas ações que poderiam converter a demanda do museu em uma necessidade social para a educação em matéria de direitos humanos. Para Schmuckler, a resposta para essa questão estava em construir um patrimônio da memória fundamentado no Nunca Más.

Primeiro, porque o Nunca Más argentino serviu (e segue servindo) exemplarmente a outras memórias nacionais e internacionais. Depois, porque existiram outras experiências de Nunca Más, que aconteceram em muitos lugares do mundo, mas que trazem esse conteúdo central da "não repetição" de catástrofes, conectadas aos traumas históricos específicos. Portanto, o Nunca Más centralizaria emoções locais e externas.

Citando Benjamin, ele sugere que as histórias do horror repetem-se, em diferentes tempos e espaços - "cada catástrofe da humanidade se repete" (SCHMUCKLER apud MEMORIA ABIERTA, 2000, p. 16). E, de derrota em derrota, os genocídios são os maiores desses exemplos. Logo, o museu da memória do passado recente argentino deveria estar ligado a essa ideia de Nunca Más mundial e da particular não repetição dos genocídios.

O debate suscitado pelas três falas foi, fundamentalmente, sobre qual patrimônio um museu da memória deveria se basear. Dentre as respostas diversas - testemunhos orais, arquivos de organizações de direitos humanos, documentações cotidianas, manuscritos, objetos dos desaparecidos e etc. -, Gollán chamou a atenção para a produção artística que traz a possibilidade de conexão entre a emoção individual à exposição do museu, sem cair na "narrativa do sinistro".

Lembrou o caso, por exemplo, da obra Made in Argentina, de Ignacio Colombres e Hugo Pereyra, apresentada em 1971, que ganhou o Prêmio de Honra do Segundo Salão de Artes Plásticas, em Buenos Aires. A obra consistia em uma caixa de acrílico, contendo uma figura humana de ponta-cabeça, ligada aos fios que acendiam lâmpadas, simbolizando a picana elétrica - a tortura por choques elétricos. Sua inscrição afirmava que aquilo era um “instrumento de horror para a exploração e o colonialismo". Ela foi censurada pelo governo ditatorial, mas os artistas receberam a premiação e doaram o valor da mesma para os presos políticos da época (CENSURA..., 1973). De acordo com Gollán, esse material artístico produzido tem um ponto de vista da vítima, incluindo pensá-la dentro de um contexto social e das formas de repressão vinculadas ao sistema econômico. 


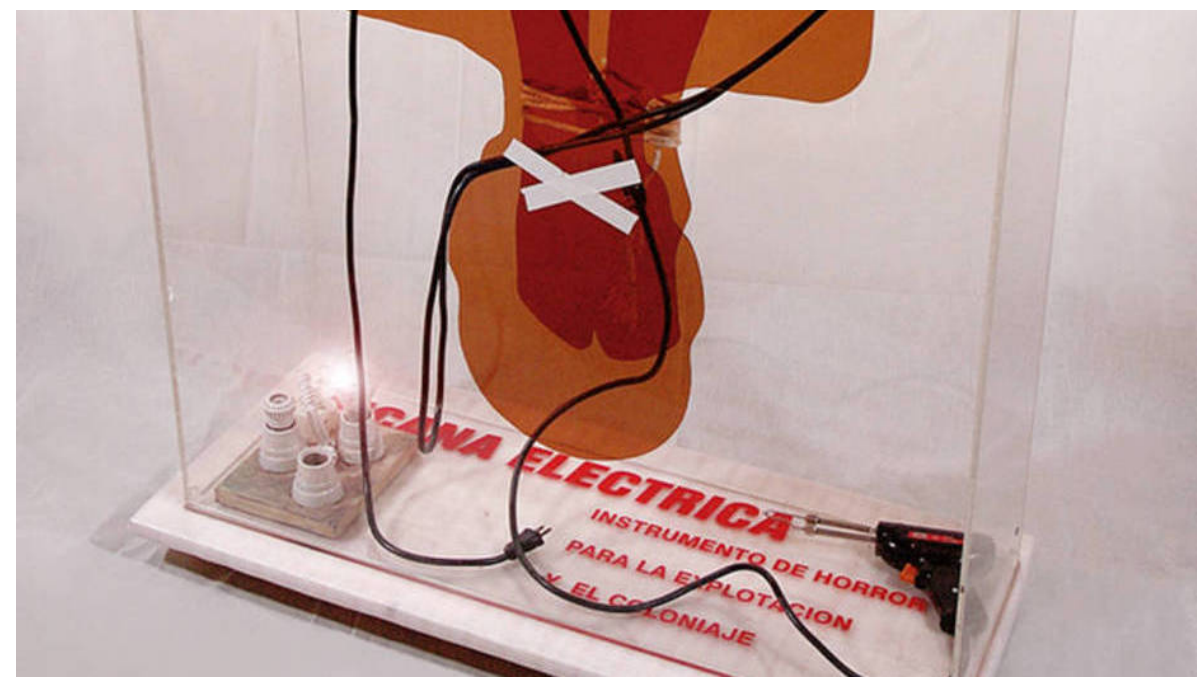

Fonte: MADE IN ARGENTINA. Disponível em: <http://www.teaydeportea.edu.ar/archivos/prohibenlas-obras-made-in-argentina-y-celda>. Acesso em: 03 jul. 2017.

Interessante perceber todo esse debate sobre representações e narrativas, a partir de dois pontos determinantes: o sistema de repressão, dentro de uma máquina econômica, com dinâmicas mundiais; e os modelos de representações, que pudessem escapar do "horror em si" e simbolizar toda essa dinâmica que vitimou a sociedade, em um sentido de construção da não repetição. Ambas as discussões, como vimos, estavam presentes no contexto dos anos 1990, com as repercussões públicas sobre genocídios, em outras partes do mundo, e com os debates e soluções encontrados para territórios de memória, referentes, especialmente, ao período nazista alemão.

A tentativa de escapar do esquecimento argentino passou, portanto, pela necessidade de conectar o público às demandas das organizações de direitos humanos, em todo o globo. E, neste sentido, a escolha foi a de trabalhar com emoções, ao invés de contar uma história linear, e com a memória exemplar, seja pelo sentido do Nunca Más ou pelo sentido do genocídio.

Essa emoção buscada seria também fruto de uma ampliação da noção de vítimas no país. Se pensamos na ideia proposta por Ellie Wiesel (1989), quando criticou a comercialização do sofrimento judeu, apontando a necessidade de se escutar socialmente as vítimas e não usá-las como valor de troca no mercado cultural, a proposta argentina era, a partir da própria crítica ao uso político e econômico de sua vítima principal (os detidosdesaparecidos), expandir o sentido de vítimas para a maioria da população, que, de alguma 
forma, fora afetada pela ditadura. Discussão essa que se aprofunda, ao longo dos anos 2000, como veremos mais adiante.

A segunda mesa de debate segue com os argumentos sobre representações. O sociólogo Horacio González ${ }^{100}$ abre sua exposição, inspirando-se no então recente filme Garage Olimpo para delinear observações sobre a memória no país. Lançado em 1999, o filme conta a história de María, personagem fictício de uma ativista política que foi sequestrada pelas Forças Armadas argentinas e levada ao Centro Clandestino de Detenção Garage Olimpo. Ele explora a relação entre vítima e repressor, retratando torturas físicas e psicológicas no Centro Clandestino (GARAGE..., 1999).

Recuperando o filme, González faz uma crítica às amenizações nas representações sobre os traumas. Para ele, normalmente os "retratos" dessas histórias das vítimas possuem uma ideia de "prudência, receio ou pudor", elegendo símbolos e representações "apaziguados" para serem mostrados como sofrimentos passados. Segundo o palestrante, o diálogo construído para o apaziguamento nega a memória a ser transmitida para as gerações futuras e traz uma "solução prudente" para temas disputados socialmente.

Lembra, por exemplo, os casos de museus que pretendem construir identidades nacionais, apagando as disputas em torno da própria identidade construída.

\begin{abstract}
Así son las naciones y lo que aquí está en juego es esa misma idea del mundo moderno, y esa idea sin duda está en juego en el debate de los museos, de los muertos, de la memoria como creo se pueda ver que está en juego en esa película, que se puede decir que no tiene la menor importancia para el cine pero tiene una gran importancia para este debate (GONZÁLEZ apud MEMORIA ABIERTA, 2000, p. 33).
\end{abstract}

Para Horacio González, era um erro supor que a memória deveria servir ao "mundo moderno" e abrandar as relações entre identidades dentro de uma nação. Se a memória é intermitente, ela deveria ser representada com seus dilemas políticos, porque cada grupo que tenha sido sujeitado a um grande sofrimento, tem o direito de responder a esse problema. Portanto, o museu da memória seria a "réplica", no sentido de resposta. Seria a crítica aos museus de inspirações comunitárias que formam identidades. Seria um gesto político de representação, estética e artística.

León Rozitchner (1924-2011), filósofo e professor das Universidades de Buenos Aires e Rosário, introduziu nessa reflexão o genocídio. De acordo com Rozitchner, a construção de memórias dentro de um "museu resposta" deveria passar pela prática genocida, com a

\footnotetext{
${ }^{100}$ Integrante do Espacio Carta Abierta (2008); grupo de intelectuais argentinos atuante que critica, através de cartas públicas, os conflitos nacionais e latino-americanos. Cf. ESPACIO CARTA ABIERTA. Disponível em: <http://www.cartaabierta.org.ar>. Acesso em: 19 jan. 2017.
} 
finalidade de se combater a impunidade. Por um lado, porque a impunidade alimentaria um sistema, que se aproveita da vida dos demais, perpetuando as violações. Por outro, porque a impunidade possui sua memória (a desmemória) que apaga as vítimas, e suas demandas das vítimas, e é reproduzida por setores sociais que se aproveitaram (e se aproveitam) do terror: os executores e seus cúmplices (Forças Armadas e sujeitos ou instituições dos campos político, cultural e econômico).

A memória da impunidade se enfrenta com memórias resistentes, mas consegue perpetuar-se ao longo dos tempos e em diferentes espaços. A perspectiva do genocídio quebraria, então, esse discurso por focalizar o problema do extermínio nos projetos políticoeconômicos do país e do mundo, em diversos tempos.

Los ecos de cada asesinato resuenan en las galerías subterráneas de la intimidad, destruyen nuestra inocencia porque su sonido siniestro grita una verdad sorda y persistente de la que ya nadie escapa. La violencia cotidiana de nuestra violencia política, social y económica prolonga los estragos de un terror más antiguo y anterior que quedó impune pero no menos activo y vigente en la sociedad argentina (ROZITCHNER apud MEMORIA ABIERTA, 2000, p. 39).

Neste sentido, o museu pensado, abordando a memória do genocídio, seria um museu da resistência à impunidade e à perpetuação da violência - ideia que pode ser conectada à proposta do museu do Nunca Más. Um lugar no qual se reflita a persistência do terror na sociedade e a enfrente, trazendo memórias marginalizadas para o espaço público e as injustiças contra os povos.

Pensando sobre o genocídio e o prolongamento histórico das catástrofes humanas, o debate deste dia foi marcado por ideias sobre o que se abordar em um museu de memória para romper com esses paradigmas. $\mathrm{E}$ os caminhos propostos foram diversos.

Um deles seria tratar, por exemplo, do Terrorismo de Estado e, desta forma, abordá-lo nos Centros Clandestinos de Detenção, representando o horror de maneira simbólica. O comentário abaixo sugere abrir a ex-ESMA, com quatro velas na entrada, e deixar que ela se mostre ao público, a partir dos sentimentos provocados pela própria visitação.

No necesitamos poner como el Museo Histórico Nacional el sable de San Martín o la cama donde durmió o lo que sea. Yo creo que hay cosas que existen, que están y que se muestran la etapa que vivimos. Para mí, la ESMA con cuatro velas en la entrada, la gente sabe que esa es la historia del terror, eso es la idea que yo me hago. Cuando hablan del museo, de las cosas que vamos a poner yo no me hago la idea de poner más que el lugar que es la muestra del horror y que va a marcar toda la historia para las generaciones que entren ahí y que no van a necesitar que haya libros. Están las librerías que venden todos los libros del terror, no que necesariamente estén en ese ámbito (MEMORIA ABIERTA, 2000, p. 42). 
Em contraposição, tem-se opiniões que propuseram um diálogo claro com o público, colocando o tema do extermínio em todos os veículos de comunicação, de maneira explícita e dinâmica. A opinião abaixo, por exemplo, sugere constituir um arquivo, realizar filmes, expor objetos das vítimas e etc. como estratégias para trazer a temática do genocídio para o presente.

Nuestra idea de museo parte de que tiene que ser un museo que muestre bien las cosas, también es que tiene que tener archivo, un archivo de films y de vídeos. Nuestra idea también es hacer una escuela superior donde se dicte como carreras de derechos humanos, es decir la idea es que sea una cosa muy amplia, porque el cine es muy importante pero aquí van a estar los objetos que alguien dijo el otro día las personas son las que dan vida a los objetos, pero las personas se mueren y los objetos quedan. Entonces, va a haber objetos como mencionaba el otro día, todas las cosas que tenemos en familiares hechas por los presos en la cárcel en la época de la dictadura, el museo es una manera de mostrar como lo es el cine, la literatura, como es el arte, los monumentos (MEMORIA ABIERTA, 2000, p. 45).

Horacio González complementa esse pensamento, trazendo o caso da exposição " $E l$ pañol", que retratou o lugar na ex-ESMA, no qual se guardavam objetos roubados das vítimas, através de artefatos que não eram fiéis ao contexto. Contudo, o autor da obra, o já citado fotógrafo Marcelo Brodsky, reconstituiu metaforicamente o espaço, em um ambiente alheio a ele, através de objetos, cheiros e sons. 


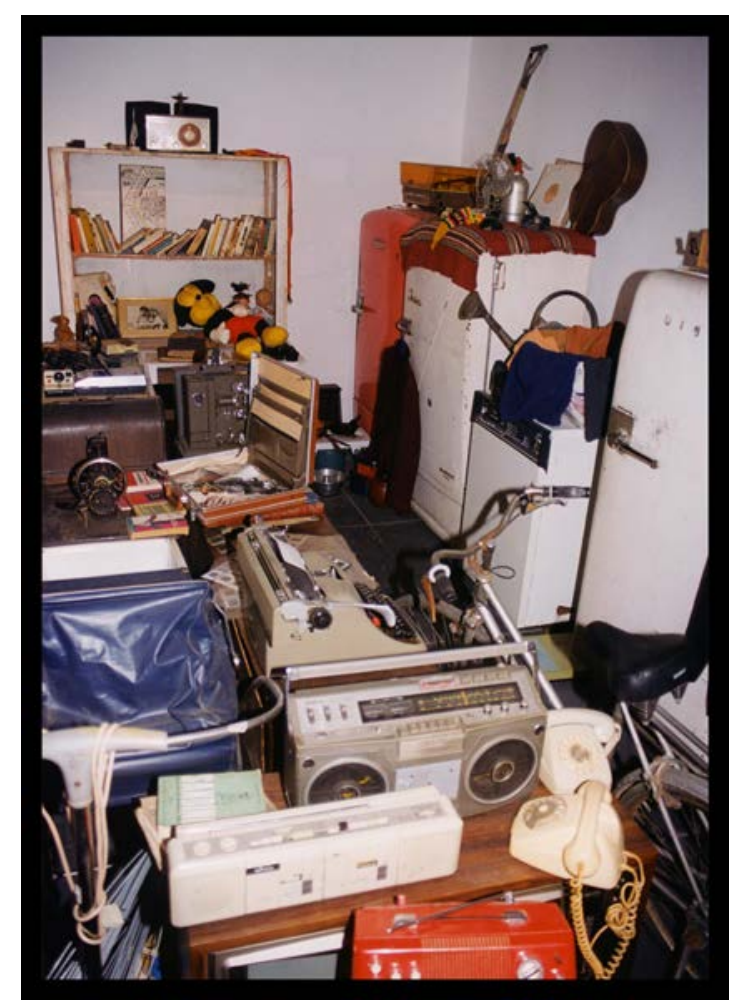

Fonte: BRODSKY, 2001, p. 80.

A instalação, em questão, esteve no Centro Cultural Recoleta, em 1999, na mostracolóquio La desaparición. Arte y política. Segundo Brodsky,

La reconstrucción no pudo hacerse con los objetos originales, sino con otros similares, de la misma época de los apropiados por los represores. No hay gran diferencia entre este pañol y el que estaba en la ESMA. Los mismos objetos, el mismo olor desinfectante, el mismo sonido de las cadenas arrastradas por el suelo $\mathrm{y}$ de helicópteros levantando vuelo. La reconstrucción, hecha sobre la base de testimonios de sobrevivientes, reproduce ese depósito de objetos de escaso valor que habían quedado "disponibles" tras el asesinato de sus propietarios (BROSDKY, 2001, p. 81).

Outro exemplo de representações citado foi o do monumento a Walter Benjamin, em Portbou (Espanha), inaugurado em 1994. Realizado pelo escultor israelita Dani Karavan, o monumento traz a metáfora dos "desaparecidos na Europa" e ganhou o título de "Passagens", homenageando não apenas a obra do autor, mas também seu trânsito tentando chegar ao exílio. Portbou, cuja estação de trem faz a ligação França-Espanha, foi o destino final de Benjamin que pretendia escapar do nazismo por Portugal aos Estados Unidos. Contudo, ao não conseguir o visto francês, Benjamin cometeu suicídio e foi enterrado na cidade. 


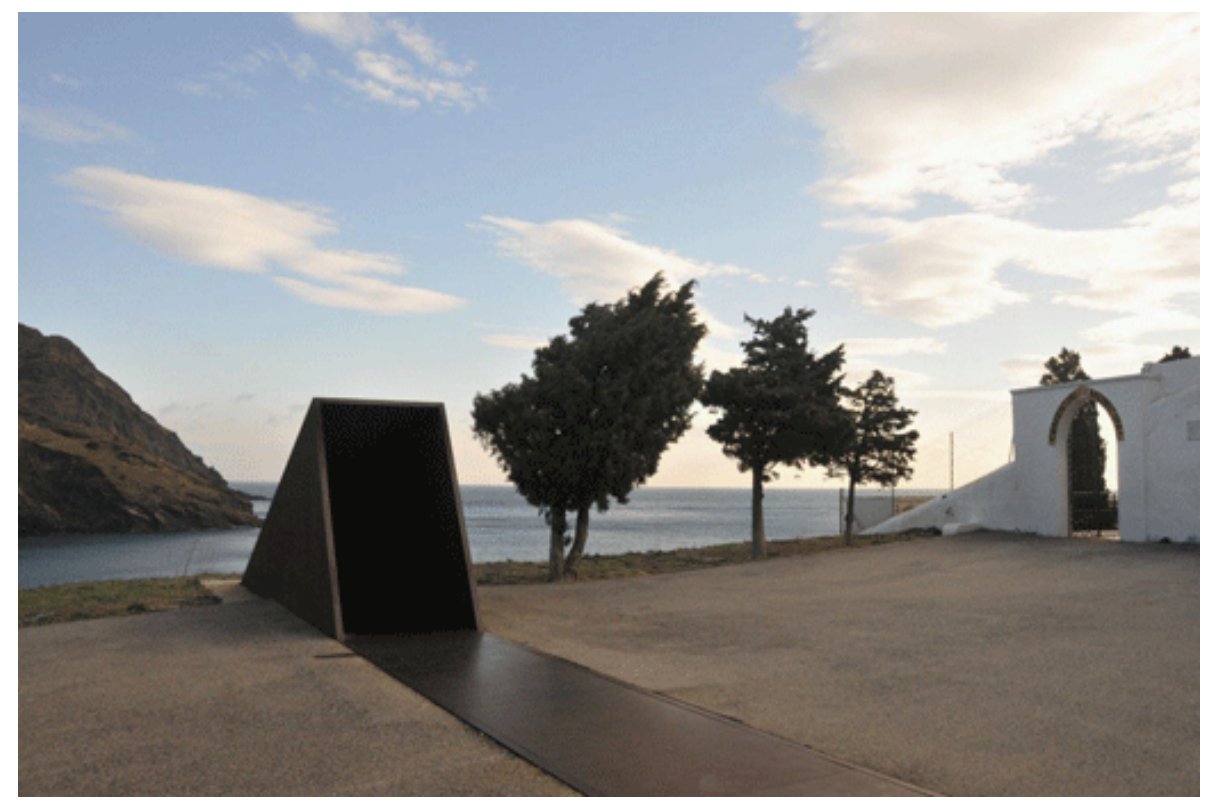

Fonte: WALTER BENJAMIN PORTBOU. Disponível em: <http://walterbenjaminportbou.cat>. Acesso em: 19 jul. 2017.

O monumento em questão traz essa homenagem aos desaparecidos ${ }^{101}$ na Segunda Guerra Mundial, trabalhando com representações em obras de arte e documentos visuais, textuais e sonoros, específicos da época, além do próprio memorial, um trabalho arquitetônico com imensa complexidade de túneis e escadas, que levam às três salas principais. A ideia era abarcar a experiência do visitante em caminhar nessas passagens, sem um percurso único, recuperando nele os sentimentos de exilio e solidariedade.

Assim voltou-se a enfatizar, no debate das Jornadas, a representação dos desaparecidos e do genocídio, a partir do sentido de Nunca Más, da "não repetição" da violência e extermínio estatais. E, desta forma, a ideia da narrativa deste museu deveria percorrer também outros povos e outras culturas, que vivenciaram o genocídio e exploraram a ideia da memória para não repetição.

(...) en ese sentido es una especie de respuesta que estamos dando a una situación de genocidio con la expresión que acuño este pueblo que es el nunca más. En ese sentido, como es un museo, se me está ocurriendo ahora habría que ver como otros pueblos abordaron el nunca más, o cómo lo llamaron ellos no solamente en esa época contemporánea sino en otros siglos pasados y en otras culturas (MEMORIA ABIERTA, 2000, p. 43).

\footnotetext{
${ }^{101}$ Apesar de não tratarmos com profundidade nesse texto, apontamos que Gabriel Gatti (2011b) questiona o uso do termo desaparecido para tratar das vítimas da Segunda Guerra Mundial, mesmo considerando a transnacionalização do conceito. Para o autor, os desaparecidos são frutos de uma política de repressão específica, que se utiliza do método de desaparecer com alguém para encobrir crimes.
} 
A fala do historiador Enrique Vázquez, no último debate dessas Jornadas, é exemplificadora da ideia central de um museu do Nunca Más. Para Vázquez, dever-se-ia recuperar o Nunca Más no museu da Argentina, a partir de uma visão política do processo de sua patrimonialização. Afirmando que, se este museu fosse conformado na década de 1980, ele teria a perspectiva do horror, porque se necessitava elaborar o sofrimento, mas, em finais dos anos 1990, a necessidade era a de debater politicamente o Nunca Más. Ou seja, relacionar a luta política da "não petição" aos modelos de memória e projetos para o país.

\begin{abstract}
Esto es fundamental porque si se pierde de vista esta variable, no se entiende por qué pasó lo que pasó del 76 al 83. Es como que había algunos que eran malos y había otros que para algunos eran también malos y para otros gente buenísima y maravillosa y que se pelearon porque pensaban distinto. Pero ese pensar distinto tiene que ver con la historia previa de la que de algún modo tenemos que dar cuenta. Si no, es como explicar la Shoah sin el racismo. Sacar el racismo de la Shoah significaría pensar que Hitler estaba loco, y que había un montón de tipos que entraron en una especie de histeria colectiva y se agarraron con algunos que no tenían nada que ver con nada. Sacarle a la Shoah al racismo es como sacarle al terrorismo de estado su necesidad (VÁZQUEZ apud MEMORIA ABIERTA, 2000, p. 62).
\end{abstract}

Neste sentido, o palestrante acreditava que o consenso social argentino deveria vir da exploração da militância, desde os anos 1970. Cita, por exemplo, o caso de Rodolfo Walsh como uma metáfora para interpretar o Terrorismo de Estado argentino - um jornalista militante, vindo dos anos 50/60, que faz oposição à ditadura, elaborando a Carta Abierta a la Junta Militar, e é assassinado pelo Grupo de Tarefas da Marinha.

Walsh, no momento de seu desaparecimento (1977), era escritor renomado, tendo escrito a primeira obra de não-ficção jornalística do país, Operación Masacre. Integrante das Fuerzas Armadas Peronistas e dos Montoneros, em março daquele ano, denunciou, em carta aberta (distribuída no mesmo dia em que fora assassinado), a censura à imprensa; a perseguição de intelectuais; os assassinatos em massa; os desaparecimentos; os presos sem julgamentos; as torturas; os corpos jogados nas costas ou enterrados em cemitérios clandestinos, como parte da política de eliminação aos opositores do modelo econômico, implementado pelas Forças Armadas (WALSH, 2014). Seu entorno afetivo também fora afetado pela dinâmica do terror de Estado, com familiares e amigos detidos-desaparecidos.

E esse sentido político da vida deveria ser tratado no futuro museu da memória. Afinal, a memória serviria, de acordo com Vázquez, para recuperar a confiança de uma população em modelos alternativos àqueles que lhes eram impostos, desde a ditadura militar.

Desta forma, o debate da mesa rondou sobre a possibilidade de se criar uma sensibilidade em torno do que foi o Terrorismo de Estado em conexão às lutas políticas. 
Como esse monopólio do exercício da violência transformou o Estado em genocida e quais seriam as responsabilidades sociais pelo acontecido.

(...) esta sociedad se hizo la sorda. El Pueblo argentino es un Pueblo
heterogéneo y mientras unos morían otros miraban para el otro lado, y esto
no quiere decir que ese Pueblo sea responsable. No quiero usar la palabra
culpables, los culpables son los culpables, son los que tendrían que estar
presos. Pero aquí hubo condiciones que hicieron posibles esto; no me gusta
pensar la sociedad como enteramente víctimas, tampoco como culpables. En
ese sentido el despliegue del horror tuvo un efecto anestésico, en el sentido
de "qué malos que eran, yo no me enteré, qué horror!". O sea, era un
escenario donde había malos que hacían cosas horribles, pero donde se era
un espectador inocente. Esta inocencia del espectador, para mí todavía no ha
sido horadada. Hay aquí y allá algunos síntomas, el arte ha hecho mucho, me
acuerdo siempre de la película "un muro de silencio" que termina cuando la
chica le dice: pero mamá nadie sabía todo eso, y la madre le dice: todos
sabían. Entonces ahí retomo lo que decíamos antes, este museo debe plantear
- aunque las generaciones vayan pasando - el problema no concreto e
individual de "vos que hacías" de cómo la sociedad admite, y celebra
(MEMORIA ABIERTA, 2000, p. 69-70).

Os debates de finais dos anos 1990 se seguem com os realizados entre 2004 e 2007.

Em outra conjuntura política, com a possibilidade de juízos penais, com o projeto de criação do Archivo de la Memoria, com escavações de ex-Centros Clandestinos de Detenção e com o acordo firmado para se expropriar a ex-ESMA e criar o Espacio para la memoria, os debates dentro e fora dos organismos de direitos humanos se multiplicaram. Essas novas discussões possuíam objetivos de debater o espaço a ser recuperado na ex-ESMA, como um instrumento para o conhecimento sobre o passado e o ensino sobre/para os direitos humanos.

Desta forma, em junho de 2007, já nos processos de recuperação gradual do espaço, foram convidados, para as discussões sobre "o museu que queremos", seis representantes de Museus de Consciência, que falaram exemplarmente sobre seus trabalhos: Beverly Robertson do National Civil Rights Museum (Estados Unidos); Darryl Petersen do Constitution Hill (África do Sul); Jan Munk do Terezín Memorial (República Tcheca); María Laura Marescalchi do Fondazione Scuola di Pace di Monte Sole (Itália); Margarita Romero do Parque por la Paz Villa Grimaldi (Chile); e Victor Shmyrov do Perm-36 Gulag Museum (Rússia) (MEMORIA ABIERTA, 2007). As falas desses indivíduos se encaminharam no sentido de apresentações dos territórios de memória, suas tarefas cotidianas e algumas considerações a serem levadas para se pensar o museu na Argentina. Trazemos aqui alguns pontos desses debates transnacionais.

Darryl Petersen, diretor do Constitution Hill, em Johanesburgo, apresentou a construção do museu no prédio do antigo forte, onde eram encarcerados prisioneiros políticos 
e de guerra (com divisão entre homens e mulheres e entre negros e brancos), e onde foram cometidas diversas atrocidades relativas às leis do Apartheid. O lugar tem como objetivo promover os direitos humanos e o patrimônio, contudo, apresenta uma proposta para ir além da demonstração do horror e promover ideias sobre como superá-lo.

Logo, ele desenvolve exposições permanentes e temporárias e programas educativos que trabalham com o museu e toda a comunidade que o envolve. Fica bastante evidente para o caso, que a fundamentação é que, além de contar essa história sobre o Apartheid (e lembramos aqui a crítica realizada por Verne Harris (2014) sobre a forma que se constituiu a memória no país, a partir das grandes narrativas baseadas neste modelo), o Constitucion Hill também investe nas atividades educativas para os direitos humanos, tentando romper com o desrespeito às diversidades.

Assim, sugere que o museu na ex-ESMA deveria considerar essa proposta de superação do horror, através da aprendizagem. Petersen afirma que:

(...) espero que elijan utilizar el sitio para generar un espacio de derechos humanos en que el estén incluidas las organizaciones que hablan de todos los derechos humanos: de las mujeres, de los niños, de los homosexuales, de las lesbianas, etc. Porque, como ya dije, el horror sólo puede ser modificado si uno aprende del horror. Que el sitio no sea sólo para los jóvenes o algunas organizaciones, sino que toda la sociedad esté representada en términos generales. Eso, para mí, es lo que va a hacer de la ESMA un lugar donde podamos enfrentar el horror del pasado (PETERSEN apud MEMORIA ABIERTA, 2007, p. 21).

Imagem 37 - Celas de isolamento (Number four exibition)

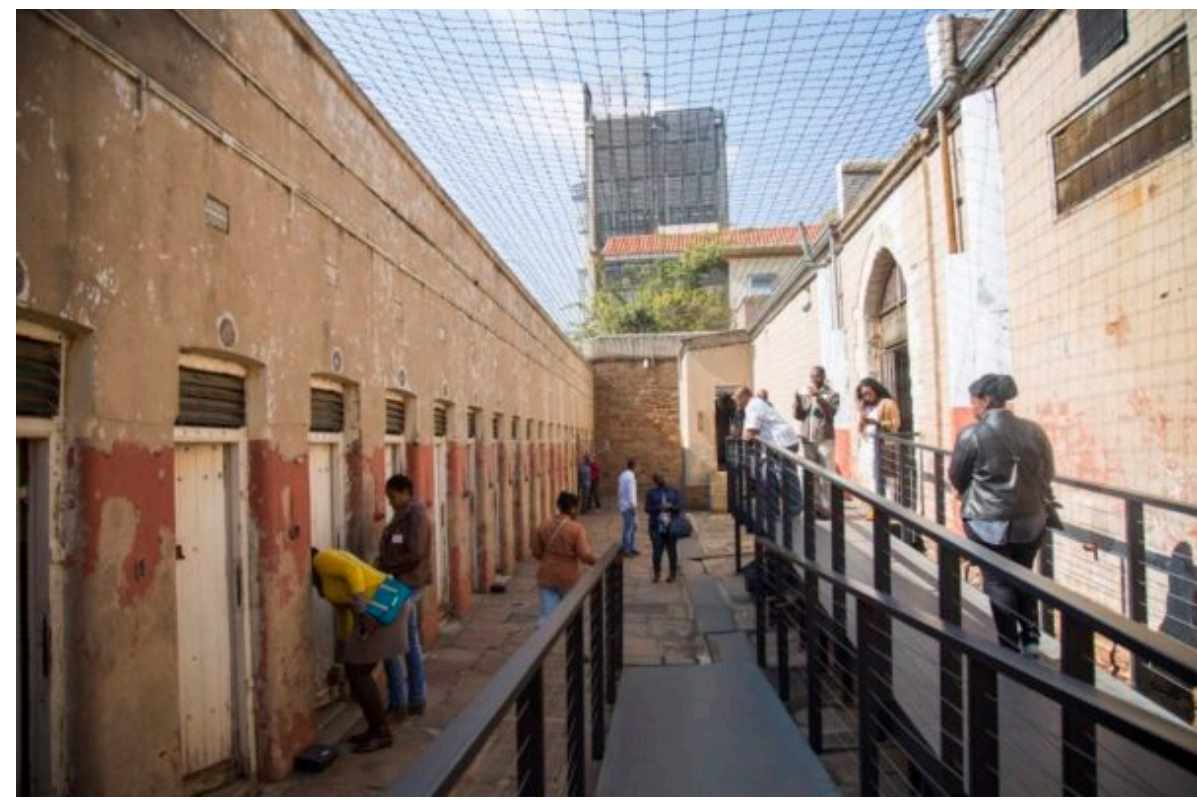

Fonte: CONSTITUTION HILL. Disponível em: <https://www.constitutionhill.org.za>. Acesso em: 6 jul. 2017. 
Jan Munk, diretor do Terezín Memorial, por sua vez, apresentou o memorial que se encontra no antigo Ghetto judeu, criado pelos nazistas em 1941. O memorial engloba, também, a prisão da Gestapo (construída em 1940) para presos políticos e o Campo de Concentração, em um povoado próximo, sendo, portanto, conformado por um conjunto de patrimônios que abordam a história traumática. Sua prioridade é manter os espaços como funcionavam, durante a guerra.

Segundo Munk, tal como na Argentina, esse debate sobre o que se fazer com o espaço, símbolo das violações, foi longo e difícil, pois o governo tchecoslovaco tentou impedir sua constituição, instituindo ali um Museu da Polícia e modificando o lugar com este propósito. Nos anos 1990, houve maiores devastações, devido à ocupação de parte do local pelo exército. E, neste sentido, recuperar este símbolo se tornou a principal ação do memorial, que trabalhou, também como guia para sua recuperação e narrativa, com a participação dos sobreviventes.

Assim, o palestrante enfatizou a necessidade de recordar a história dos judeus na cidade, através de explicações para as novas gerações. E Munk concluiu:

Ya lo dije varias veces, ESMA es un lugar que habla fuertemente, pero es un lugar que también necesita una explicación sobre lo que pasó ahí, necesita el contexto y eso se puede hacer únicamente a través de un museo o exposición. Y luego, recién, podemos aprovecharlo no solamente para el público sino también para la parte más importante del público que son los chicos y jóvenes quienes deberían saber qué pasó y qué no deberíamos olvidar (MUNK apud MEMORIA ABIERTA, 2007, p. 22).

Imagem 38 - The small fortress (Terezín Memorial) 


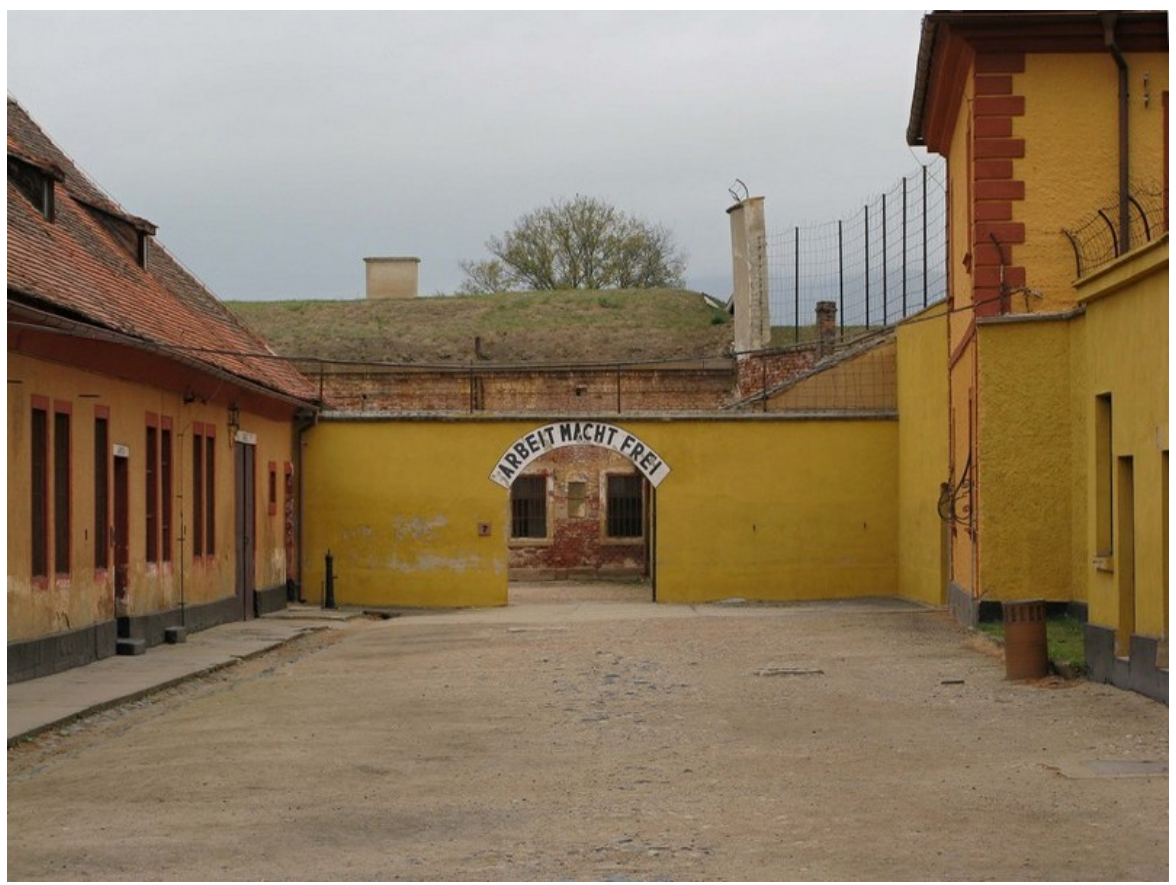

Fonte: TEREZÍN MEMORIAL. Disponível em: < http://www.pamatnik-terezin.cz>. Acesso em: 13 jul. 2017.

Margarita Romero, então vice-presidente da Corporación Parque por la Paz Villa Grimaldi, falou sobre o antigo bairro italiano, tomado pelos militares chilenos, em 1973, onde se instalou a Brigada de Inteligência das Forças Armadas. No ano seguinte, o lugar passou a pertencer à Dirección de Inteligencia Nacional (DINA) e a funcionar como Centro Clandestino de Detenção, por onde passaram cerca de 4500 detidos-desaparecidos.

Em 1984, os militares venderam o lugar a uma empresa construtora, que o deixou em ruínas. Oito anos depois, apresentou-se a proposta de expropriação do terreno e o Estado confiscou o espaço. A partir de então, iniciaram-se diversas discussões sobre seu destino, nas quais decidiu-se a não reconstrução ou reconstituição dos edifícios, considerando que essa reconstituição seria trazer ao público um ambiente de sofrimentos para as vítimas. Logo, a propostas foi constituir um parque, valorizando o respeito aos direitos humanos e a paz.

Reconstruir lo que ahí había significaba, para muchos familiares y personas que participaban en este movimiento, reconstruir el horror, el dolor, algo que había hecho sufrir no sólo las víctimas y familiares sino a toda sociedad. En cambio, construir un parque por la paz en ese sitio que había quedado en ruinas se construía como parte de un proceso que buscaba avanzar hacía a la reflexión y hacia un trabajo de construcción de una cultura de respecto a los derechos humanos para que "nunca más" volviera a ocurrir lo que ahí había sucedido (ROMERO apud MEMORIA ABIERTA, 2007, p. 9). 
Vê-se que não houve, conforme a proposição do governo argentino dos anos 1990, a destruição dos edifícios no espaço, uma vez que estes já se encontravam demolidos. A discussão, aqui, era sobre reconstrução e passava, portanto, por erigir simbolicamente o horror da ditadura, conformando o lugar das "coisas sinistras", tal como apontado por Américo Castilla.

De acordo com Romero, durante o processo de construção desse parque, muitos familiares e ex-detidos-desaparecidos foram ao terreno, e se recuperaram testemunhos e objetos naquelas ruínas. Estas passaram, então, a ser a base da transformação da representação do lugar, ao mesmo tempo em que comprovavam sua existência pela ausência, como já referido nesse trabalho.

O parque funciona como local público e possui um trabalho educativo com visitas guiadas. Ele também se constituiu com uma "sala de memória", através da exposição em pequenas vitrines, elaboradas pelos familiares, de objetos pessoais de desaparecidos que permitem (re)conhecê-los. Uma vez mais, traz-se, portanto, o cotidiano como forma de narrativa e estratégia de comunicação com o público visitante.

\section{Imagem 39 - Sala de la Memoria (Parque por la Paz)}

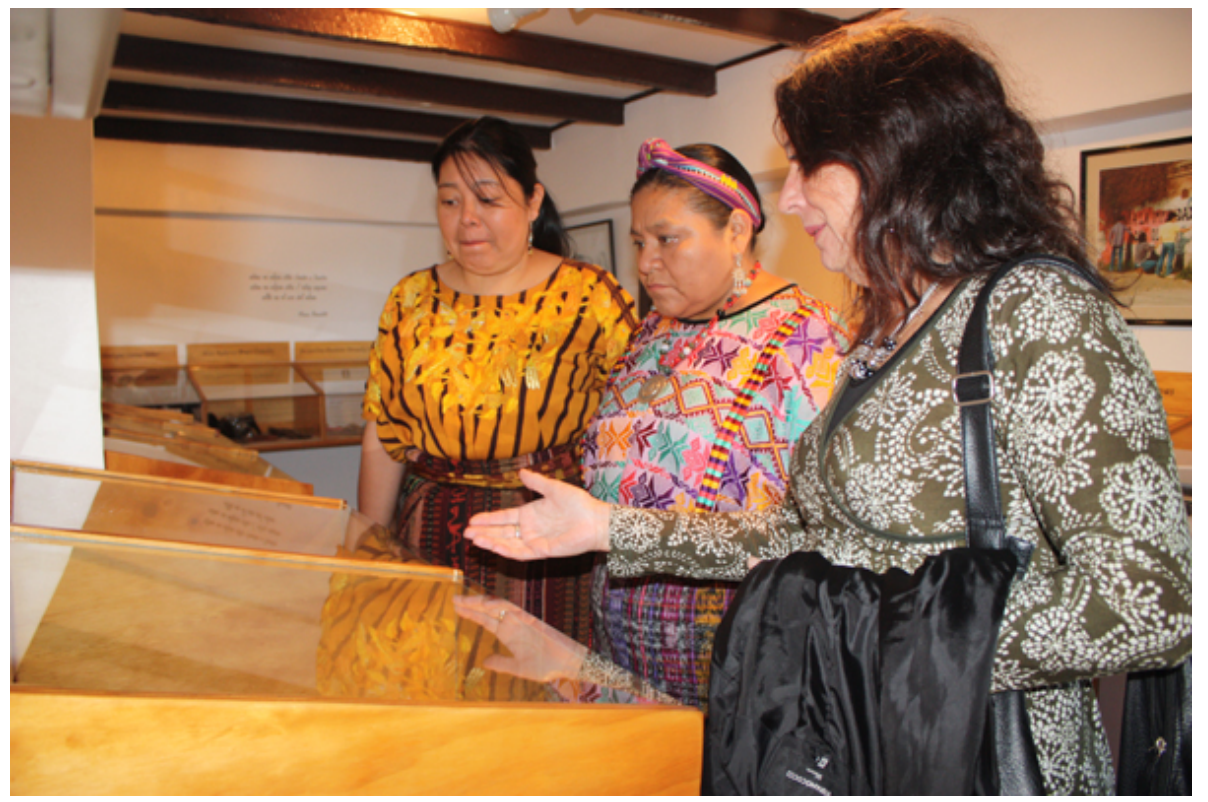

Fonte: PARQUE POR LA PAZ. Disponível em: <http://villagrimaldi.cl>. Acesso em: 20 jul. 2017.

Em 2002, construiu-se no espaço o Teatro por la Vida, utilizado em diversas atividades, principalmente na comemoração de datas significativas na luta pelos direitos humanos. E, naquela época, havia o projeto de construção de um Museo Villa Grimaldi - 
Espacio para la Memoria y Educación de los Derechos Humanos, com a reconstituição de uma cela (Casas Chile) e a elaboração de um arquivo oral, que funcionam desde 2011.

Por fim, trazemos o exemplo de Victor Shmyrov, diretor do Perm-36, em Kuchino, que apresentou o espaço constituído no único Campo de Concentração do Gulag, cuja conservação fora possível. Devido às funções de produção e de acordo com as necessidades de obras do sistema comunista, os Campos de Concentração para trabalhadores eram considerados "fundamentais" economicamente e funcionavam intermitentemente nas localidades, onde se necessitava de mão-de-obra ${ }^{102}$.

O museu, iniciativa de um grupo que buscou financiamento independente, tem o objetivo de reconstrução, restauração e conservação do espaço. Quando os resultados do projeto começaram a parecer, o governo regional decidiu ajudar na restauração e ceder o uso da propriedade (do Estado Nacional). Contudo, com o passar do tempo, o Estado ofereceu ao grupo as opções da compra das terras ou da cessão do museu ao governo, e a organização decidiu tornar-se uma estatal para se manter-se. Ali, constituíram-se exposições permanentes e itinerantes que circulam por todo o país, e atividades pedagógicas, incluindo um espaço sociopolítico para conferências.

Imagem 40 - Perm-36

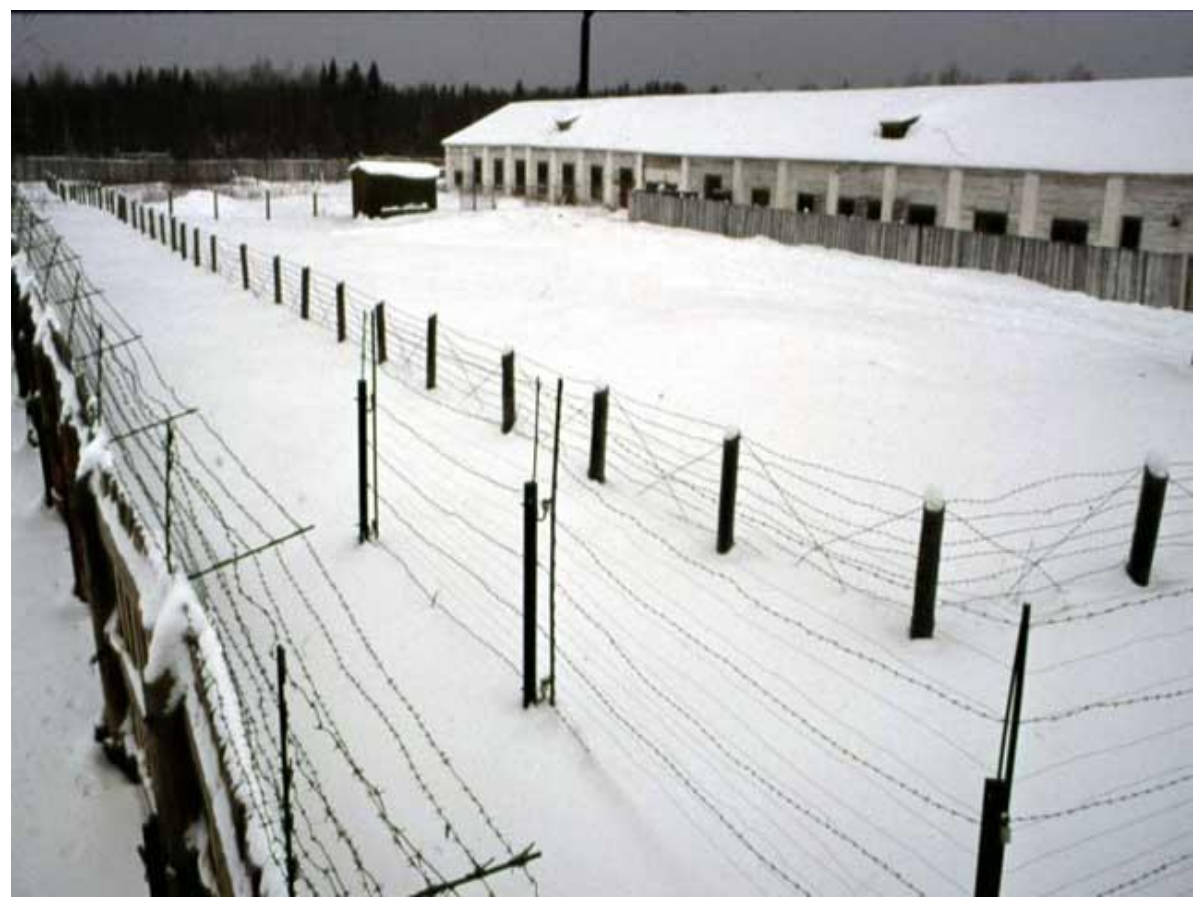

Fonte: WORLD MONUMENTS FOUND. Disponível em: 〈https://www.wmf.org>. Acesso em: 04 jul. 2017.

${ }^{102}$ Cf. APPLEBAUM, 2009. 
De acordo com Shmyrov, é muito difícil encontrar alguma família russa que não tenha, ao menos um de seus membros, vivido em Campos do Gulag. Portanto, as pessoas no país se acostumaram a eles e o viam como um fenômeno natural. O objetivo do museu, neste sentido, é modificar essa mentalidade social, relacionando as temáticas do passado com o presente, de forma que se reflita sobre o Nunca Más.

Shmyrov cita, como exemplo, as consequências das eleições dos anos 2000, nas quais saiu vitorioso Vladimir Putin, ex-presidente interino, primeiro ministro de Boris Iéltsin (1999) e ex-agente do Serviço Secreto da União Soviética (KGB). Para o palestrante, o desconhecimento das histórias dos campos e as críticas a elas são uma das causas do pensamento autoritário da sociedade russa atual. Aponta que, talvez, se as pessoas conhecessem esta história, os resultados das decisões políticas poderiam ser diferentes - o que sabemos que volta a se repetir nas eleições seguintes.

Portanto, todos esses exemplos trazidos nas discussões, a partir dos anos 2004, colocam a ênfase nas representações para o conhecimento entre gerações sobre as vítimas dessas experiências de catástrofes. Indo além do espaço público para o testemunho das vítimas, a ideia, nesse momento, era trabalhar a memória, em distintas formas, que pudessem despertar a compaixão, a reflexão sobre os extermínios, as responsabilidades por eles e possibilidades no campo político de resoluções pacíficas para os conflitos. As vítimas e seus familiares de diferentes territórios, não se reconhecendo em memórias oficiais de "reconciliação" ou de esquecimento, demandam recuperar, nesses espaços, as memórias resistentes, transformando-os em lugares de reflexão sobre as violações. E, assim, conectam a luta de diversos movimentos sociais com as práticas políticas dos mais variados Estados.

\subsection{2 - Discussões das vítimas/sobreviventes sobre a ex-ESMA}

Os depoimentos escolhidos no arquivo oral do Memoria Abierta foram marcados pelo contexto de devolução gradual dos edifícios da ex-ESMA e das discussões sobre a anulação das leis de impunidade no país. Eles abordam concretamente discussões sobre o futuro museu de memória, naquele território de memória, e trazem opiniões que, ao afirmarem a importância de preservá-lo, variam sobre o que se realizar nele. Aqui, não se pretende abordar todo o conteúdo das entrevistas, tampouco todas as entrevistas do arquivo, contudo, analisar as temáticas que tocam no Centro Clandestino específico e as propostas e posições individuais para a utilização do espaço na constituição da memória coletiva do país. 
A primeira entrevista trabalhada é a de Ricardo Coquet. Conhecido como Neco, carpinteiro e diagramador, ex-militante da Juventud Universitaria Peronista (JUP), Coquet foi sequestrado quando tinha 24 anos, em Buenos Aires (março de 1977). A caminho da ESMA, toma a pastilha de cianureto, designada aos militantes para cometer suicídio nos processos de sequestros das forças repressivas, porém, sobrevive a esta tentativa. Segundo o mesmo, ter sobrevivido o fez acreditar que sua missão era manter-se vivo e testemunhar e, nesse sentido, se considera uma testemunha, ao invés de "sobrevivente", como designam algumas organizações ao se referirem àqueles que saíram dos Centros Clandestinos com vida (COQUET apud ARCHIVO ORAL MEMORIA ABIERTA, 2006a).

Posicionando-se desta forma, percebemos como Coquet se insere na luta pela memória, a partir de uma posição ativa, tanto quando foi vitimado no passado ou quando recupera a liberdade e reinsere-se socialmente. Recuperando LaCapra (2009), essa dinâmica pessoal das vítimas, sobre a ação de testemunhar, é de enorme importância para se elaborar os sentimentos individuais para o coletivo e transformar este último em um testemunho secundário das histórias de catástrofes.

Como prisioneiro ilegal, Ricardo Coquet foi submetido a diversos tipos de trabalhos forçados, majoritariamente na oficina de diagramação, assegurando a relação entre sua sobrevivência e o trabalho que lhe fora imposto: "Nosotros pasamos a sobrevivir cuando ellos, según las capacidades o lo que les faltaba, nos bajaban a laburar" (COQUET apud YO SOBREVIVÍ A LA DICTADURA, 2017, sem paginação). Logo, foi obrigado a confeccionar cartazes para as pessoas que eram chupadas/sequestradas ${ }^{103}$ e, posteriormente, a diagramar o Informe Cero, revista produzida sob orientação de Emilio Massera, para difundir a propaganda na Europa de que a ditadura respeitava os direitos humanos. Com essa tarefa, ele saía às ruas com dinheiro para comprar papel de impressão, e testemunhou a "infraestrutura" de venda dos saques, nos momentos dos desaparecimentos. Também foi testemunha de alguns voos da morte, vendo companheiros de cativeiro sendo levados para os traslados da morte.

Liberado em dezembro de 1978 - com a vigilância dos telefonemas semanais, prática recorrente na liberação dos sequestrados -, Coquet relata em entrevista o sentimento de vigilância constante que perdurou nele também em democracia, tal como Primo Levi (1988) apontava sobre a eterna vitimização da vítima, sua condição “espiritual de vítima”. Desta forma, ele faz uma dura crítica sobre o papel da justiça na desnaturalização da violência dos

\footnotetext{
${ }^{103}$ A bandeira com a inscrição "Montoneros", por exemplo, que simulou a responsabilidade no sequestro das monjas francesas Alice Domon e Léonnie Duquet, foi feita por Coquet. Cf. MEGACAUSA ESMA, 2009.
} 
militares, cujos resquícios das práticas, que geram medo, permanecem na sociedade argentina atual.

Grado animal muy burdo. Muy asesino (...) Eso me pasa aún ahora. Ver a un tipo asesino. Lo que pasó con López, por ejemplo. Y las situaciones que pasaron. Ver a Etchecolatz en juicio y decir que no siente o que está bien lo que hizo. Ver cero grados de arrepentimiento. Tomar naturalmente (...) Su naturaleza es esa, una naturaleza asesina y prejudicial para toda la sociedad. Personas que pueden elegir quien puede vivir y quien no puede vivir (...) Está grave la cosa, ¿no? (COQUET apud ARCHIVO ORAL MEMORIA ABIERTA, 2006a, $1^{a}$ parte).

O caso citado é o de Jorge Julio López e se refere ao desaparecimento do mesmo, depois de testemunhar contra Miguel Etchecolatz, na causa em que era querelante contra 62 militares e policiais. Etchecolatz foi condenado à prisão perpétua, em setembro de 2006, e logo depois, López desapareceu em La Plata. ${ }^{104}$

Desta forma, Ricardo reconhece a importância das políticas públicas para a memória e a educação aos direitos humanos. Apesar de haverem sido iniciadas imediatamente à transição, elas foram interrompidas, durante anos, por políticas governamentais, demonstrando que a luta pela justiça não pode cessar. Assim, mesmo com o longo passo dado pelo governo Kirchner, no caminho da memória, para ele, não existem garantias de que essas políticas permaneçam indefinidamente. ${ }^{105}$

Lo que hizo Kirchner en la ESMA me parece fundacional y muy importante. Porque de decir a hacerlo y hacer 'Vamos a resolver este tema en Argentina'. Significó muchísimo, miles de muertes, y vamos a resolver eso en el marco de la justicia (...) la justicia es respectar la consciencia colectiva, para mí, ¿no? Es eso justicia (...) y no pasa otra cosa en ningún país del mundo (...) Yo creo que lo que hizo Kirchner es fundacional porque abre el camino para juzgar y resolver realmente el tema (...) Siento que hay un gran contenido, que la ESMA es enorme, que hacer de la ESMA un museo de la memoria es re-importante. Pero más importante es caminar tranquilo en la calle (...) Además hay que tener huevos para hacer eso siendo presidente y enfrentar a los poderes. Y marcar esa línea con claridad. Mira lo que fue Alfonsín y mira lo que es Kirchner, ¿no? Alfonsín es un enano (...) Pero hay que hacer las cosas. Después de lo que pasó con López, lo de Kirchner es un enunciado: lamentablemente retrocedimos (COQUET apud ARCHIVO ORAL MEMORIA ABIERTA, 2006a, $4^{\mathrm{a}}$ parte).

\footnotetext{
${ }^{104}$ O testemunho de Julio López está disponível na internet. Cf. LÓPEZ, Julio. Testimonio. Buenos Aires, 18 sept. 2006. Disponível em: <https://www.youtube.com/watch?hl=es419\&gl=CO\&feature=player_embedded\&v=FO0cEaSZCVQ>. Acesso em: 20 fev. 2017.

${ }^{105} \mathrm{Na}$ entrevista ao Memoria Abierta, Ricardo Coquet coloca a possibilidade de vitória por Mauricio Macri nas eleições de 2007 para o governo da cidade de Buenos Aires e o possível retrocesso nas políticas de memória e justiça, apesar dos discursos do mesmo afirmando o contrário. Contexto que, no ano de 2015, tornou-se real com sua vitória para a presidência argentina.
} 
Sobre a restituição do espaço da ex-ESMA, mais definidamente, Coquet reafirma sua importância simbólica na cidade e da recuperação de sua memória, principalmente pelo fato de que, nessa disputa, as Forças Armadas perderam esse espaço tão significativo para as vítimas do Terrorismo de Estado. E, no auge dos debates sobre o que se fazer com ela, opina:

Yo se fuera ..., haría del lugar un lugar emblemático de (digamos de) lo que no puede pasar en un país democrático. Pero me parece que tiene que ser un lugar muy claro. Me molesta que las distintas agrupaciones de derechos humanos, como que siento que cada uno quiere poner quiosquito (sin faltar el respecto). Pero siento que es eso. Que tienen que mostrar lo que pasó muy claramente y nada más. Mi propuesta es dejar el Casino Oficial de la ESMA, reproducir lo que pasaba ahí. (...) No vas a poner muñecos de personas torturadas en la ESMA. Pero se puede, por ejemplo, dejar el lugar como está (...) Todo lo demás, yo demolería y haría un gran parque (COQUET apud ARCHIVO ORAL MEMORIA ABIERTA, 2006a, $4^{\mathrm{a}}$ parte).

Seu depoimento nos levanta três tipos de questões abordadas nessa fase da discussão sobre a constituição do museu. Primeiro, a importância do local na construção da memória no país, como símbolo do Terrorismo de Estado, e na justiça, como espaço de prova das violações. Como este ato de rememorar as vítimas da ESMA era essencial para se pensar sobre violências estatais, que não deveriam ter mais lugar em democracia.

Mostra também a disputa pela memória a ser tornada como oficial, encabeçada pelas diversas organizações de direitos humanos. O que seu depoimento chama de "pequenos quiosques", a serem constituídos pelas organizações, são os espaços disputados por elas para ingressar na memória oficial de um Estado que estabelece as "verdadeiras vítimas". São disputas por quem pode falar e contar essa história.

Por fim, aborda o seu desejo, enquanto testemunha, de manter o Casino Oficial aberto e reproduzindo - não de maneira explícita, com "bonecos de pessoas torturadas" - o ambiente da prisão e tortura. Deixando-o como está ou como era, constituindo, assim, uma proposta de representação do espaço reconstituído, porém, os demais edifícios deveriam ser demolidos para se criar um parque em memória às vítimas. Afinal, manter a estrutura da ex-Escuela de Mecánica era permitir as memórias militares na cidade.

Essa reconstituição do horror dentro da ex-ESMA também foi tema colocado por Alejandro Héctor Vasallo. Alejandro Vasallo foi sequestrado junto com sua mãe, Ada Nelly de Valentín e seu irmão Julio César (de nove anos de idade), em 29 de maio de 1977, quando tinha 14 anos. Todos foram levados à ESMA, onde Alejandro permaneceu durante três semanas detido-desaparecido.

Mi mamá gritando que nos iban a matar. Esa fue la parte más dolorosa para mí. Supuestamente, yo pensaba que iba a pasar esto, pasó el tiempo, no 
podría precisarlo, pero no fue muy largo. Bajamos en un lugar donde corría aire. Nos introducen en un lugar sin subir a ningún lado, al mismo nivel donde nos bajamos. Había gritos, era todo una locura. Lo que tenía era el oído, no veía absolutamente nada. Había muchísima gente.

Se escuchaba una risa en el infierno. Las risas sí me quedaron muy gravadas. Mientras estuve ahí, nunca supe que era la ESMA. Más adelante, después de salir, el primero que me lo dice es mi papá (VASALLO apud MEGACAUSA ESMA, 2009, caso 294).

Tendo esse reconhecimento tardio do Centro Clandestino, Alejandro refletiu em seu depoimento ao Memoria Abierta sobre a necessidade de "deixá-lo como era" para que as pessoas tomassem conhecimento sobre as experiências de passar por aquele território. Sua opinião, no entanto, é enfática em relação à demonstração dos procedimentos utilizados pelo sistema do Terrorismo de Estado, como forma de transmitir essas experiências.

Yo creo que tiene que ser un lugar digamos (...) lo que pasa es que ese lugar ha sido cambiado, ha sido vaciado, obvio. Está la estructura, están las paredes, están las puertas y encima cambiadas de cómo fue en esa época. Un edificio solo no hace nada, no dice nada. La ESMA es un simbol. Miras una foto, la fachada. Pero si eso quieres convertirle en un Museo de la Memoria tiene que ser algo interactivo. Para mí, ¿no? Es mi modesta opinión. No he intercambiado opiniones con nadie (...) Tiene que ser algo donde entre un chico y, esa picana o algo que escuchó, la vea. Para mí, la tiene que ver la picana. Tiene que estar ahí y tiene que decir "picana utilizada..." (VASALLO apud ARCHIVO ORAL MEMORIA ABIERTA, 2006b, $1^{\text {a }}$ parte).

Vasallo defende, portanto, a exposição de materiais nesse museu, que faça um recorrido sobre torturas e práticas de extermínio. "O terror tem que se mostrar", afirma ele. Um argumento bastante similar ao proposto por Horacio González, nos anos 1990, no qual propunha retirar das narrativas sobre o horror a "prudência" nas abordagens, em prol de uma educação em matéria de direitos humanos.

E Vasallo continua seu argumento dizendo que as vítimas de outros lugares de repressão têm o direito de realizar sua homenagem, da forma que considerarem mais apropriada - placas, comemorações, museus e etc. Contudo, na ex-ESMA, enquanto símbolo da repressão argentina, a reconstituição era de extrema importância, inclusive desfazendo-se das mudanças, realizadas em 1979, para a visita da Comissão Interamericana de Direitos Humanos. Afinal, "la ESMA tiene un antes y tiene un después también. Tiene una historia" (VASALLO apud ARCHIVO ORAL MEMORIA ABIERTA, 2006b, $1^{\mathrm{a}}$ parte).

Por outro lado, houve depoimentos que encaminharam-se a uma proposta, fundamentada na dinâmica e na crítica sobre a história de violência no país. Alfredo Ayala, 
por exemplo, elabora essa ideia, trazendo a necessidade de incorporar atividades reflexivas ao recente espaço conquistado.

Conhecido como Mantecol, Ayala trabalhava nas atividades dos bairros empobrecidos da Zona Norte de Buenos Aires, com o Movimiento Nacional Villero Peronista, quando foi sequestrado em setembro de 1977. Ayala, levado à ESMA, foi colocado para trabalhar no grupo denominado Perrada - detidos-desaparecidos obrigados a trabalharem na reforma do Casino de Oficiales para a visita da CIDH - e também fez parte do grupo que reformou as casas na ilha El Silencio ${ }^{106}$ (em Tigre) para a recepção de quase 40 detidos-desaparecidos, escondidos na mesma visita.

Segundo Ayala, até 1995, ele preferira manter distância dos organismos de direitos humanos, pois tinha certa desconfiança das atividades realizadas neles e das disputas pela verdade que ocorriam politicamente. Sentia-se estagnado diante de uma justiça e de uma reparação que tardavam muito para acontecer, ao longo daqueles anos.

Hacer un juicio como si fuera una guerra, ¿viste? Dos bandos. Y el bando perdedor es ajuiciado... Acá se destruyó una generación. Miles de casos que se pasan hoy es producto de eso (...) Nos hemos preparado el espacio para decir las cosas como fueron y donde buscar la justicia y por donde pasa la restauración. Y la fabricación de ese espacio tardó mucho tempo, porque hubo que perder mucho miedo. Hubo que perder muchas situaciones (...) Y también paralizó mucho la etapa de Menem. ¿Entiendes? Menem, yo y muchos compañeros lo tomamos como continuidad de lo que fue el golpe. En alguna medida, no? (...) Bueno, creo que después de Menem, si actuaron (AYALA apud ARCHIVO ORAL MEMORIA ABIERTA, 2006c, $5^{\mathrm{a}}$ parte).

Para ele, a ex-ESMA, enquanto museu, precisaria se tornar um espaço "porta-voz" dos sobreviventes (posicionando-se neste lugar de fala, então, diferentemente de Coquet); um lugar de difusão do que aconteceu com todos. Então, por um lado, trazer as vítimas, os desaparecidos circunstanciais, que não possuíam espaço legitimo para testemunhar, até aquele momento, e, por outro, trazer aqueles que morreram ou permanecem desaparecidos, frutos daquele Centro Clandestino. Para o restante do espaço, ele sugere um curioso funcionamento, no qual o museu de memória conviveria junto às novas gerações militares.

Para mí, lo primero que quería yo, cuando me enteré de la ESMA es que sea... que el Casino este tal cual como esta. Se haga la maqueta, todo que se diga y que tenga mucha difusión de lo que pasó ahí. Mucha difusión. Que participen muchos de los compañeros sobrevivientes, que no tienen esa participación. ¿Que tenga las pertenencias de los compañeros que estuvieron

\footnotetext{
${ }^{106}$ A história dessa ilha como Centro de Detenção está intimamente ligada com as relações entre a Igreja e a ditadura. O lugar foi vendido pelo arcebispo de Buenos Aires, em 1979, com documentos falsos, para abrigar os detidos-desaparecidos durante a visita de inspeção da CIDH. Possuía duas casas - a Casa Grande e a Capucha (lugar de tortura) - que, depois da visita, foram utilizadas como lugar para realização de trabalhos escravos com os prisioneiros. Em 1980, ela foi vendida a particulares. Cf. VERBITISKY, 2005.
} 
ahí, viste? Que es un... Cosas de compañeros. Fotos... ¿Entiendes? Que los compañeros estén instalados ahí. Bien, esto, por un lado. Y el resto que sea un testigo. El resto... Que sigan estando las escuelas. Que los militares estén ahí. Que sea un grano en el culo eso (...) Que los hijos de los gorilas sigan yendo a la escuela, viendo que ahí se torturaba. Que por ahí desaparecieron y que ahí hubo familias y que ahí hubo chicos como ellos que desaparecieron y no saben dónde mierda están (AYALA apud ARCHIVO ORAL MEMORIA ABIERTA, 2006c, $6^{\mathrm{a}}$ parte).

No entanto, Ayala também agrega a necessidade de se fazer algo produtivo socialmente no espaço, com a finalidade de dar-lhe uma representação de atividades sociais transformadoras, através de espaços dedicados aos ofícios econômicos, ensinamentos práticos e artísticos. Neste sentido, coloca

Yo colaboro en todo lo que pueda. El otro día caminaba, porque recuperaron un par de galpones ahí, se recuperó. Encima, no entiendo eso. O sea, era un... los milicos están devolviendo lo que a ellos no les encantan. Ahora la ESMA está partida por el medio... En el medio están ellos. Eso es una cosa jodida. Pero bueno. En esos galpones que son inmensos, yo haría incubadoras de empresas y daría posibilidades a muchos que son emprendedores a que empiecen a laburar y hacer cosas. $\mathrm{Y}$ empiecen a producir y vender sus productos, por un lado. Y pondría un instituto de artes y de oficios. Y haría talleres prácticos (AYALA apud ARCHIVO ORAL MEMORIA ABIERTA, $2006 \mathrm{c}, 6^{\mathrm{a}}$ parte).

Fazer algo produtivo, porque, segundo ele, são vinte e quatro edifícios em uma zona valorizada da cidade. E o bom uso desse espaço é determinante para sua existência, justificando sua sobrevivência, temporalmente. Portanto, propõe utilizá-lo como lugar para recuperar a memória, através do museu dentro da Capucha, continuar com algumas atividades militares para a convivência e aprendizagem das Forças sobre questões de direitos humanos, e transformá-lo também em lugar de produção na cidade de Buenos Aires.

¿Cuantos museos se pueden hacer en 17 hectáreas y 24 edificios? ¿Dos? ¡Ya está! ¿Y el resto? ¿Qué se va hacer? Ojalá que sean útiles para todos. ¿Cuantos organismos de derechos humanos pueden ubicarse en la Escuela de Mecánica? Por ejemplo, si es para ubicar a los organismos. ¿Cuatro mil? No sabes lo que son esos edificios. Yo que estuve adentro... iEs impresionante! Con uno te alcanzan todos los organismos. Te puedo decir. Te quedan 33 más (AYALA apud ARCHIVO ORAL MEMORIA ABIERTA, 2006c, $6^{\mathrm{a}}$ parte).

A entrevista de Leonardo Martínez concorda com esses argumentos de variedades de funções dos edifícios da ex-ESMA. O Bichi, ex-militante do mesmo Movimiento Villero Peronista, foi sequestrado em setembro de 1977, na Estação Beccar, província de Buenos Aires, e levado à Escuela de Mecánica. Posteriormente, foi colocado no grupo de trabalho 
Perrada, junto à Ayala, e, em 1979, começou a trabalhar em empresas construtoras, realizando trabalhos na ilha El Silencio.

Liberado em julho do ano seguinte, Martínez considera-se uma testemunha que fala pelos mortos - "no tengo cultura, pero tengo vida" (MARTÍNEZ apud ARCHIVO ORAL MEMORIA ABIERTA, 2006d, $1^{\text {a }}$ parte). Criticando os organismos de direitos humanos que, segundo ele, têm se preocupado em demasia com os processos políticos, principalmente no que tange à discussão sobre quem tem o espaço para construir a memória sobre os desaparecidos, ele afirma que a dinâmica política atual deveria se centrar na transformação social, não esquecendo-se das inúmeras vítimas feitas por um sistema repressivo conectado às políticas econômicas que perpetuam em democracia.

Como yo te digo (...) yo cuando empecé a militar, empecé a militar con un interés sociopolítico. De mejorar la condición humana. La condición de vida de mi gente. De la gente que conozco, de la gente de abajo, la gente laburante, la gente que realmente necesita. Cuando empecé a militar, empecé con esa idea. Y sigo con esa idea. Y he perdido algunos trabajos por seguir esa idea. Porque no me gusta que se lo abuse de los demás. Cuando empecé de vuelta con la política, en 84 , las cosas que se hacían en la política no tenían nada que ver con lo que hacíamos nosotros cuando éramos jóvenes. (...) Entonces, todo lo que sea (...) se nasce con la gente que realmente pasó por eso, con los familiares de la gente que pasó por eso, yo estoy de acuerdo. Pero, si se hace con un contexto más bien político, por decir "con esto traigo voto", "con esto me compro a los familiares", "me compro a los hijos de los detenidos", no estoy de acuerdo (MARTÍNEZ apud ARCHIVO ORAL MEMORIA ABIERTA, 2006d, $1^{\text {a }}$ parte).

Mesmo criticando esse uso político dos detidos-desaparecidos, ele elabora em seu depoimento a importância da memória para o futuro do país. Apesar de não haver comparecido ao ato que devolveu a ex-ESMA para o Estado ("en respecto a las víctimas del lugar"), Martínez concorda com a necessidade de se trabalhar a memória sobre os Centros Clandestinos de Detenção, comparando sua dinâmica com os Campos de Concentração nazistas.

El hecho de llevar compañeros y hacerlos desaparecer en los vuelos de la muerte. A los judíos, ¿que los hacían? Los hacían jabón. Los metían adentro de una cámara y metían gas. Usaban a la gente misma de los presos para hacer cosas que ellos no querían hacer. Y, bueno, un poco con nosotros pasó lo mismo (...) Comparando las cosas, la pasamos (MARTÍNEZ apud ARCHIVO ORAL MEMORIA ABIERTA, 2006d, $1^{\mathrm{a}}$ parte).

De alguma forma, ao fazer essa conexão, Martínez aborda a experiência de recuperação da memória dos Campos de Concentração como uma experiência exemplar para a constituição do museu de memória na Argentina. Cita, de maneira positiva, não apenas os 
museus construídos, como também, os filmes que relatam o extermínio judeu, uma vez que conseguiram abordar publicamente o genocídio.

$\mathrm{E}$, de forma interessante, ele conclui dizendo que, se antes os políticos não se importavam com os desaparecidos, fazendo menção, então, ao período de apagamento da memória e da falta de justiça no país, agora eles eram usados (“somos usados”, incluindo-se como desaparecido circunstancial) para fazer política. Portanto, recuperar a memória das vítimas para o dia de amanhã é essencial, mas não é possível saber como a memória do genocídio argentino irá ser usada politicamente no futuro.

\section{2 - Caminhos ao Museo de las Memorias: Globalização e regionalização do caso paraguaio}

Para o caso paraguaio, trabalharemos duas documentações específicas relacionadas às discussões sobre o Museo de las Memorias: dictadura y derechos humanos - uma dedicada à reelaboração do projeto do Museu, no ano de 2007, com a visita da comissão alemã, que avaliou o espaço e sugeriu modificações, e outra, que é a produção de informativos da Mesa Memoria Histórica, referente à educação em matéria de direitos humanos e o espaço do Museu nesse projeto.

A primeira documentação pode ser considerada uma documentação diversa, composta de relatórios de instituições, como o Proyecto Desaparecidos Paraguay ou o MERCOSUL, que realizaram reuniões durante a estadia da comissão alemã em visita ao Paraguai. Por outro lado, temos o informe produzido pelo pesquisador responsável da mesma visita de cooperação técnica, realizada pelo Senior Experten Service (SES), entre os dias 3 e 31 de maio de 2007, e que versa sobre uma perspectiva institucional em relação ao Museu.

A segunda documentação é composta de revistas/boletins da Mesa Memoria Histórica $^{107}$, publicados entre os anos 2012 e 2014, anos estes marcados pela complexidade política do país. ${ }^{108}$ Estimados como meios de comunicação entre Memoria Histórica e as vítimas/lutadores e lutadoras contra a ditadura stronista, que viviam em distintos lugares do país, a Revista Memorias/Hoy e o Boletín Oñondivepa (“Todos Juntos”) buscaram difundir atividades e lutas naqueles anos, cuja tentativa de unificar os movimentos em torno dos

\footnotetext{
${ }^{107}$ A organização Mesa Memoria Histórica é um coletivo composto pelo SERPAJ-PY, Museo de las Memorias, CODEHUPY, CODELUCHA, Fundación Celestina Pérez de Almada, Sindicato de Periodistas del Paraguay, CUT Auténtica, Central Nacional de Trabajadores, Mujeres por la Democracia, e CIPAE.

${ }^{108}$ As revistas foram publicadas anualmente, sendo três exemplares. Os boletins não possuem datas de publicação, contudo, sua dedução é facilitada pelo contexto reproduzido nos textos, podendo considerá-los publicações da mesma época.
} 
direitos humanos se tornou lema da organização, e o Museo de la Memorias palco para essas discussões.

\subsection{1 - Cooperação para a transformação}

Como vimos, o Museo de las Memorias teve uma longa história de luta pelo patrimônio situado em seu prédio. Até 2006, o museu trabalhou, desde uma dimensão pessoal, com exposições provisórias, através de uma coleção de jornais, relatos de testemunhas, fotografias e documentos do Archivo del Terror. Em março de 2007, no entanto, esse cenário se modificou.

O então presidente alemão Horst Köhler ${ }^{109}$ visitou o museu em uma viagem que realizou ao país para estabelecer relações comerciais. A visita, guiada por algumas personalidades dos movimentos pelos direitos humanos, entre elas Martin Almada, seguiu-se de uma reunião, na qual vítimas do regime stronista deram seus depoimentos, como, por exemplo, Idalina Tatter (EL PRESIDENTE..., 2007).

Idalina era esposa de Federico Jorge Tatter, já citado tenente de fragata, nascido na colônia de Nueva Germania (Departamento de San Pedro, Paraguai) e exilado na Argentina pelas atividades políticas contrárias à ditadura de Stroessner, em 1963. Tatter foi sequestrado em Buenos Aires, no ano de 1976, e continua desaparecido. Sua mulher é uma das peticionárias da ação movida pela Coalición contra la Impunidad, em Nuremberg, contra o Major Peirano, e denunciadora da relação entre a Embaixada Alemã e os militares na Argentina. $^{110}$

\footnotetext{
${ }^{109}$ Köhler, meses depois, naquele mesmo ano, realizaria o evento para marcar o final das indenizações para trabalhadores forçados em Campos de Concentração - projeto da Fundação "Remembrance, Responsability and the Future" -, onde mais de um milhão e meio de vítimas deste crime do nazismo receberam, ao menos, reconhecimento público como vítimas do Nacional Socialismo. Em seu discurso, afirmou, entre outros aspectos desse marco na memória, uma ampliação do espectro das vítimas, agregando a caracterização econômica do sistema de terror: "Yet, the fate of the forced laborers represented one of the most revealing chapters in the history of Nazi terror. During its rule over Europe the people in the occupied countries were not only terrorized for ideological and racist motives but also massively exploited in economic terms, not least by being dragged away from their homes and made to work as forced and slave laborers".

"No entanto, o destino dos trabalhadores forçados representava um dos capítulos mais reveladores da história do terror nazista. Durante o seu domínio sobre a Europa, as pessoas nos países ocupados não só foram aterrorizadas por motivos ideológicos e racistas, mas também, exploradas em termos econômicos, principalmente, sendo arrastadas para longe de suas casas e forçadas a trabalhar como escravos". Cf. KÖHLER, 2007, sem paginação, tradução nossa.

${ }^{110}$ Conjuntamente a outros familiares alemães, a Coalición pediu à Justiça argentina para receber o testemunho do "Mayor Peiote" - Carlos Antonio Españadero, ex-oficial da Secretaría de Inteligencia del Estado, que passava informações sobre os cidadãos alemães detidos-desaparecidos no país. Em 1999, Españadero foi identificado como responsável pelo sequestro de Rubén Santiago Bauer e Susana Beatriz Pegoraro, grávida, cuja filha nasceu na maternidade clandestina da ESMA. No mesmo ano, o "Mayor Peiote" declarou, em entrevistas, que tinha a função de contato com os familiares de desaparecidos alemães para repassar informações sobre o
} 
Em seu testemunho, na visita do presidente alemão, Idalina Tatter enfatizou a relação e a responsabilidade alemã com as ditaduras argentina e paraguaia. Ela afirmou que, ao contatar a Embaixada Alemã sobre o desaparecimento do marido, nunca obteve resposta nem declarações que buscassem esclarecer o ocorrido. Em 1997, ela recebeu informações de grupos de direitos humanos, que continham fotografias de seu esposo acompanhado por policiais paraguaios, confirmando, então, ter sido ele vítima do Sistema Condor (MERCOSUR, 2015).

Köhler, durante a visita, decide, portanto, apoiar o desenvolvimento do Museu, enviando peritos da Senior Experten Service (SES) - fundação da indústria alemã dedicada à cooperação internacional. Desta forma, o patrimônio em questão passa a ter sua primeira conexão direta com o setor privado para desenvolver suas novas atividades propostas.

No ano seguinte, foi enviado o historiador Albert Manke, que por seu trabalho no Nationalsozialismus Dokumentationszentrum der Stadt Köln (NS-Dok), em Colônia (Alemanha), foi indicado para realizar investigações e sugestões em função de melhorias na estrutura do Museu paraguaio. Este Centro de Documentação é fruto da intensa reivindicação social nos anos 1980, para se identificar alguns lugares de terror nazista na cidade alemã. O edifício EL-DE, na Appelhofplatz, no qual funcionava a prisão temporária da Gestapo, era um dos poucos edifícios históricos não destruídos na cidade, cuja postura governamental aplicava uma espécie de "desnazificação incompleta", devido à política cultural da RFA que valorizava em seus patrimônios, a oposição ao inimigo comunista da Guerra Fria, ao invés de repensar a história do Nacional Socialismo na região (MANKE, 2014, p. 101-142).

Contudo, no início dos anos 1980, o professor Kurt Holl e o fotógrafo Gernot Huber entraram clandestinamente neste edifício e divulgaram imagens de seu interior, incluindo quase 1800 inscrições de prisioneiros nas paredes, datadas entre os anos 1943 e 1945, e escritas em alemão, russo, ucraniano, francês, polaco e holandês. Em 1985, formou-se uma iniciativa para criar o Centro de Documentação, cujo funcionamento começou dois anos depois. O museu em si foi aberto ao público, em 1997, depois da exposição "Colônia no Nacional-Socialismo", transformando o NS-Dok em um dos mais importantes museus na Europa sobre o nazismo.

envolvimento destes em ações “terroristas”. Em 2012, descobriu-se que ele era o chefe de Situación General del Batallón 601 com especialização nas guerrilhas do Ejército Revolucionário del Pueblo, inclusive formulando ações de agentes infiltrados no movimento. Dois anos depois, com 84 anos de idade, ele foi condenado à prisão perpétua domiciliar pelo desaparecimento do soldado José Rodríguez Diéguez. Cf. DESAPARECIDOS. Disponível em: <http://www.desaparecidos.org/arg/victimas/t/tatter/>. Acesso em: 04 jan. 2017. 
Imagem 41 - NS-Dokumentationszentrum der Stadt Köln

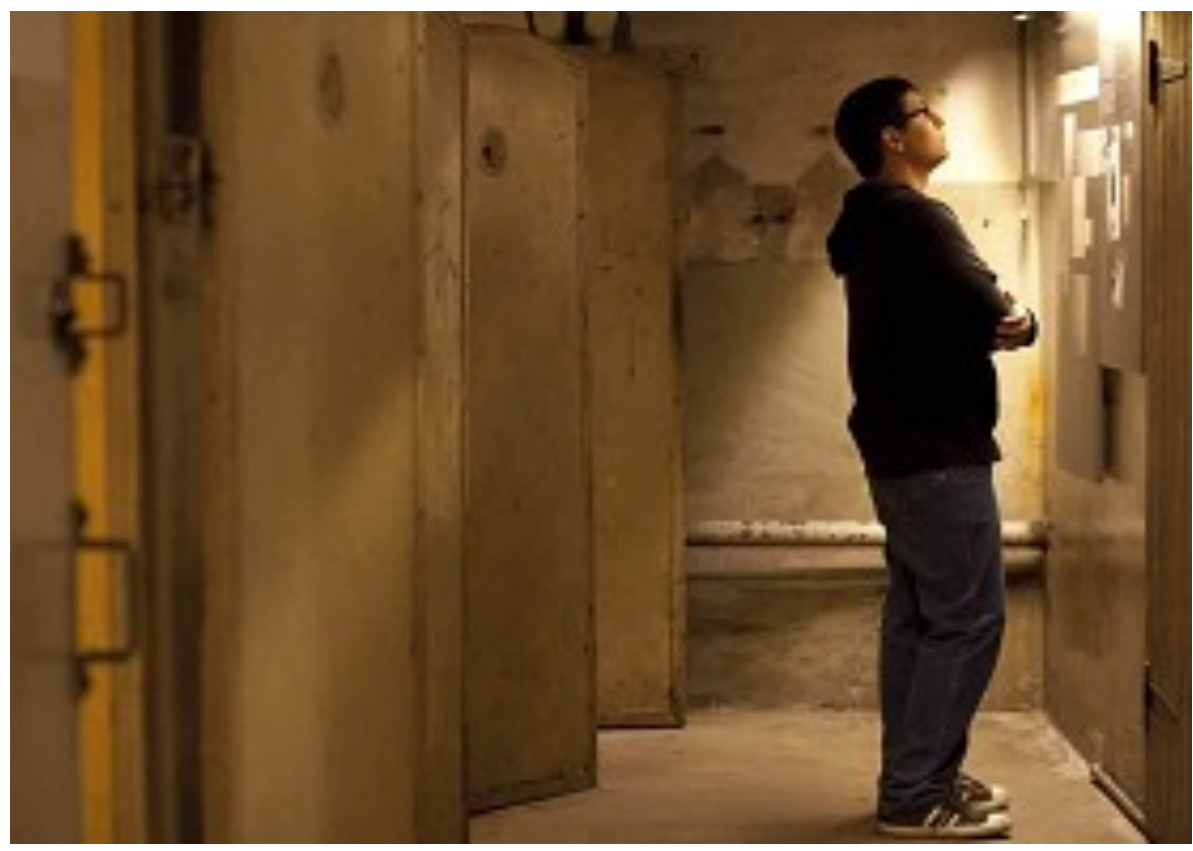

Fonte: MUSEEN KOELN. Disponível em <https://museenkoeln.de/ns-dokumentationszentrum>. Acesso em: 25 out. 2017.

Manke, ao iniciar suas visitas na ex-La Técnica, chegou à conclusão de que a instituição alemã era similar ao edifício em Assunção, por suas atividades históricas comuns de violações: os dois foram instituições repressivas de governos ditatoriais e apresentavam características de prisões violentas com elementos (rastros) que recuperavam os testemunhos e as experiências naqueles ambientes. Portanto, o NS-Dok apresentava um exemplo metodológico para se trabalhar com o espaço paraguaio.

Por estar instalada en el antiguo edificio de la Policía Secreta de Estado (Gestapo), donde ejerce además función de museo, esta institución ofrece condiciones y metodologías muy parecidas a las que se están instalando en el Museo de la Memorias. Además, este museo fue condecorado con el European Museum Award y otros méritos, ya que cuenta con la experiencia profesional y didáctica más moderna del mundo (SENIOR EXPERTEN SERVICE, 2007, p. 1).

Orientando-se pelo modelo aplicado em Colônia, principalmente no que se refere à instituição de um arquivo para a consulta pública e a constituição de um museu, recuperandose as celas da DNAT, o especialista propôs reconstruir o espaço com móveis, mapas e equipamentos da polícia - advindos de outros lugares de repressão no país, já que, com o fechamento da DNAT, houve a retirada de seus pertences pelo poder público. Essa forma de representação do espaço repressivo foi uma escolha de se reproduzir o ambiente e o cotidiano do edifício. 
A missão avaliou as instalações do Museu e suas coleções, considerando-as precárias em relação aos demais museus de memórias no mundo. Segundo a avaliação, as instalações do Museo de las Memorias necessitavam tanto de arreglos na infraestrutura básica - redes pluviais, tetos, muros, portão de entrada, proteção, climatização e alarmes de incêndio -, quanto de compras de equipamentos técnicos e primários que eram inexistentes computadores, sistema de telefonia, aparatos para digitalização de documentos, gravadores, câmaras de vídeo, televisão, microfones e cadeiras para o auditório, além de materiais de informação destinados aos visitantes (SENIOR EXPERTEN SERVICE, 2007).

A comissão alemã também definiu critérios museológicos, desenhando uma proposta para melhorar as instalações, capacitando a equipe da Fundación Celestina Pérez de Almada e elaborando um documento de recomendações para apresentar às autoridades nacionais e internacionais envolvidas com este trabalho. A proposta desenhada para o espaço relacionava a exposição do museu a um Centro de Documentação, vinculado com o conteúdo do Centro de Documentación y Archivo para la Defensa de los Derechos Humanos (Archivo del Terror). Desta forma, pretendia viabilizar a documentação existente, também no Museu, com um sistema de consulta integrado, e complementá-la com a produção de um arquivo oral e audiovisual, que recebesse constantemente testemunhos sobre a memória e a história de $L a$ Técnica.

A conexão entre o Archivo del Terror e o Museu é clara, tanto no sentido de construção das demandas para que o Museu existisse, quanto na elaboração de seu conteúdo expositivo e compositor. Manke afirmava

El Museo de las Memorias por la importancia de su contenido y la historia de su edificio es único en Latinoamérica. Es de destacar que se pudo hacer la combinación única de los documentos del Terror, compuestos por fuentes originales recuperadas por el Dr. Martín Almada el 22 de diciembre de 1992, que forman hoy el Archivo del Terror, con el lugar original del Terror que era la sede de la Dirección Nacional de Asuntos Técnicos (Técnica). Con el trabajo cívico incansable de la Fundación Celestina Pérez de Almada y las organizaciones integrantes de la Mesa de Memoria Histórica este edificio y estas fuentes se convirtieron en el Museo de las Memorias (SENIOR EXPERTEN SERVICE, 2007, p. 8).

Com base nos critérios museológicos e arquivísticos do NS-Dok, portanto, o espaço do Museu fora dividido, no novo projeto, de acordo com um sistema "didático e lógico", conformando uma exposição permanente. Esta explicaria, cronologicamente, o surgimento da ditadura stronista, o personalismo de Stroessner, a organização da repressão em espaços nacionais e internacionais e as estratégias de enfrentamentos, resistências e exílios. 
Recuperando os sentidos múltiplos de resistências para a conformação identitária nacional, como colocado por Rollemberg (2016), o Museo de las Memorias passa a enfatizar, em sua narrativa, as vítimas urbanas, conectadas no sentido de manifestações diversas contra o regime stronista. Desta forma, se pensa o Patio de la Memoria, uma área exterior à casa principal, onde propôs-se reivindicar a memória das vítimas (vítimas oficiais em uma contabilização, na qual, há grandes dificuldades de se incorporar a área rural), através de um monumento e uma placa com os nomes dos presos, torturados e desaparecidos - esta última ainda não concretizada.

Neste mesmo pátio, encontram-se as celas, onde se mantinham os presos, esperando por seus interrogatórios. Com a finalidade de demonstrar a violência propagada naquele espaço, decidiu-se a reconstrução das mesmas, realizada com a pesquisa em material audiovisual gravado no momento de encerramento da ex-La Técnica, em 1992, e com os objetos trazidos de outras instituições policiais. Assim, a representação se tornou explicita, relacionada ao cotidiano da prisão e às práticas de tortura.

Ainda na visita alemã, programou-se uma capacitação dos trabalhadores do Museu, realizando-se oficinas, nas quais se empregou as didáticas de comparação, micro e macro história e métodos de exposição e conservação de objetos, documentos e materiais. Interessante destacar que a comparação central, nessas oficinas, fora realizada não apenas com o Centro de Documentação alemão, contudo também, com o Museo de la Paz de Guernika, Espanha.

Em funcionamento desde 1998, este Museu aborda a temática da história de GernikaLumo e do bombardeio da cidade, durante a Guerra Civil espanhola, em um edifício que abrigava os Juizados, Correios e Telégrafos, na Plaza de los Fueros. Entre 1999 e 2002, realiza-se obras de adequação do edifício, com a elaboração de um novo projeto museológico, que trata da paz, convertendo-o também em um Centro de Documentação sobre o bombardeio, a guerra civil e o exílio da região Vasca.

Es, por tanto, a partir del año 2003 cuando el museo reabre sus puertas ( 8 de enero de 2003) renovando su perfil y ampliando sus posibilidades, convirtiéndose en una institución acorde con las necesidades del mundo de hoy. Un espacio que ha crecido para transformarse en un museo atractivo y dinámico, un museo para sentir y vivir, un escenario en el que la historia, de la mano de la emotividad y de la empatía nos ensancha el camino de la reconciliación, un lugar para pensar que a la paz podemos darle forma entre todos (MUSEO DE LA PAZ DE GUERNIKA, 20--, sem paginação). 


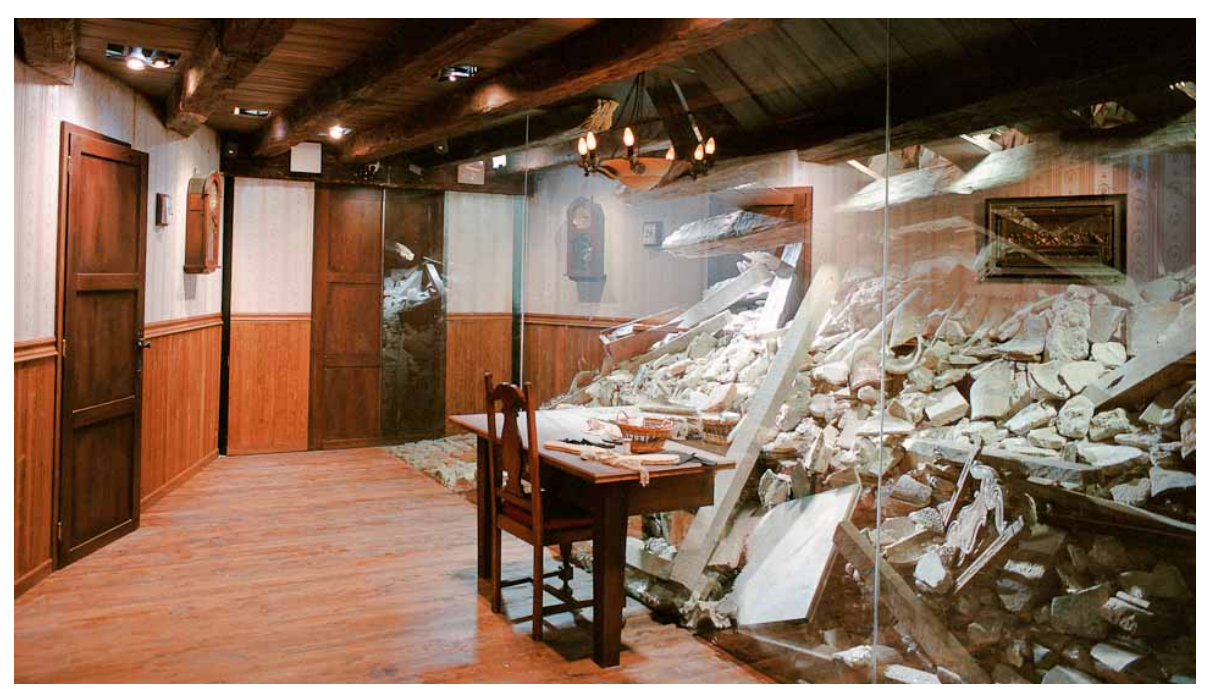

Fonte: MUSEO DE LA PAZ DE GUERNIKA. Disponível em: 〈http://www.museodelapaz.org/es>. Acesso em: 17 jul. 2017.

Logo, vê-se que os debates trazidos pelas duas instituições exemplos para a reestruturação do Museo de la Memorias são a reconstituição dos espaços, de acordo com seu funcionamento, e a constituição de um Centro de Documentação, que possa complementar a narrativa deste museu. As recomendações, pois, para o Museu paraguaio, em relação à concretização da nova proposta, foram: 1) o aumento de sua equipe com funções multidisciplinares (museologia, restauração, conservação, administração e arquivologia); 2) a busca de recursos financeiros em programas nacionais, latino-americanos e internacionais; e 3) a sua incorporação no sistema turístico nacional e no sistema de educação, principalmente em prol do desenvolvimento da disciplina "El autoritarismo en la Historia Reciente del Paraguay".

Para a questão turística que, como vimos, possui uma intensa crítica, principalmente no que tange aos territórios de memória relacionados às catástrofes, a ideia era a de reconhecimento público, pelos visitantes, sobre a história recente paraguaia e aquele território de memoria especifico. Além disso, o debate também incluía os problemas de financiamento, já que o Museu nunca possuiu um orçamento fixo ou apoio estatal permanente, dependendo, enfim, das políticas de cada governo.

No entanto, é a educação em matéria dos direitos humanos o principal argumento da existência desse Museu. Observamos aqui que, durante os dias 16, 17 e 18 de maio de 2007, realizou-se na cidade de Assunção, a XIII Reunião da Comissão Regional Coordenadora de Educação Básica do MERCOSUL e Estados Associados, com a presença das delegações argentina, paraguaia, uruguaia e brasileira. Nesta reunião, houve a apresentação do informe sobre materiais didáticos de direitos humanos e de um plano de trabalho sobre a temática, a 
ser realizado entre os anos 2006 e 2010 (MERCOSUR, 2006-2010). De acordo com a ata desta reunião,

El MERCOSUR manifiesta una firme voluntad de promoción y protección de los derechos humanos, y de profundización y consolidación de la democracia. En ese contexto, se inscribe la necesidad de impulsar todas las acciones que permitan la transmisión del pasado regional reciente a las nuevas generaciones. Por este motivo, se recomienda incluir en la presentación del material didáctico en elaboración, una referencia donde se explicite su pertinencia a las características del tiempo histórico de la región (MERCOSUR, 2007, p. 3).

Assim, buscando o financimento da OEA, a ideia era debater um projeto regional, onde trabalhar-se-ia, no âmbito educativo, conceitos como a democracia e a cidadania, recuperando a trajetória histórica das violações aos direitos humanos na América Latina. ${ }^{111}$ Definiu-se, portanto, a construção de uma biblioteca comum, o desenho de uma página web e um programa de capacitação dos profissionais para trabalharem com essa demanda. E, neste sentido, a delegação paraguaia apresenta sua discussão sobre a tentativa de vincular, no programa nacional educativo, uma disciplina sobre direitos humanos e o autoritarismo na história recente paraguaia.

No ano seguinte (2008), a Comisión de Verdad y Justicia, junto ao Ministério de Educação e Cultura lança o material básico para a disciplina ${ }^{112}$ e inicia as capacitações de docentes para a aplicação da mesma. Desta forma, o Museu ingressa no cenário educacional como referência e "inspiração para o conhecimento sobre o passado do país" e para a construção de um futuro pautado no respeito aos direitos humanos e na paz global.

Con este Museo se ha establecido un espacio histórico motivador de Cultura de Paz, representativo de todos los sectores históricos involucrados en la defensa y la promoción de los Derechos Humanos consagrados en la Constitución Nacional y en la Declaración Universal de los Derechos Humanos. Este proceso permanente se está manifestando a la vez en la incorporación de la Historia Reciente en la educación escolar y universitaria y debe extenderse a la instrucción de la Policía y las Fuerzas Armadas para fortalecer la conciencia cívica del Pueblo Paraguayo y cimentar una democracia que sabe defenderse. Este proceso en Alemania después de la Segunda Guerra Mundial fue penoso y largo, pero conseguimos construir una Cultura de Paz duradera y democrática.

El Museo de las Memorias sirve y servirá de referencia cierta y permanente de los efectos de la violencia en los procesos que determinan cambios radicales negativos en las sociedades. Servirá además de fuente de inspiración para el conocimiento, la defensa y el trabajo en favor de los

\footnotetext{
${ }^{111}$ Cf. MEMORIA EN EL MERCOSUR. Disponível em: 〈http://www.memoriaenelmercosur.educ.ar〉. Acesso em: 24 jul. 2017.

${ }^{112}$ Cf. COMISIÓN DE VERDAD Y JUSTICIA. El autoritarismo en la História Reciente del Paraguay. Disponível em: <http://www.cipae.org.py/V2/biblioteca/CVJAutoritarismo.pdf>. Acesso em: 14 jul. 2017.
} 
Derechos Humanos y la construcción de una sociedad cívica, democrática y consciente de su pasado, construyendo un presente que permita un futuro en Paz (SENIOR EXPERTEN SERVICE, 2007, p. 8).

\subsection{2 - Um coletivo de lutadores e lutadoras na região}

Os conturbados anos entre 2012 e 2014, marcados pelo golpe contra o presidente Fenando Lugo e a ascensão da ala liberal de Federico Franco, foram delineados por um enfrentamento entre as organizações de direitos humanos e o poder político. ${ }^{113}$ As manifestações, em torno das lutas pela reparação às vítimas da ditadura e pela manutenção daquilo já obtido politicamente, cresceram e ganharam espaços públicos, através de atos políticos, discussões acadêmicas e publicações periódicas.

Duas dessas publicações serão aqui analisadas no âmbito do coletivo Mesa Memoria Histórica, já tratado por seu protagonismo na luta pela CVJ, tanto por sua importância na história dos direitos humanos paraguaios, quanto por sua agrupação na luta por esses direitos, rompendo possíveis diferenças entre as organizações que a compõem. Esse conjunto, no contexto de crise política, pretendeu uma maior coesão para diferenciar-se das opiniões favoráveis ao (novo) golpe de Estado e das possíveis regressões ou impedimentos que o mesmo continha em sua proposta para as memórias e os direitos humanos no país.

Para Memoria Histórica, a grande união entre organizações e vítimas se deu em fevereiro de 2013, quando diferentes membros desses grupos foram à Rua Chile, entre os edifícios da ex-La Técnica e da Comisaría Tercera, para comemorarem os 24 anos da queda do regime stronista. $\mathrm{O}$ ato era uma ressignificação do contexto passado no presente, pois muitos dos presentes recordavam o fato de que grande parte do novo governo liberal de Franco fora ativo na ditadura paraguaia e possuía uma opinião positiva sobre seu governo e suas agendas nos campos econômicos e culturais (LÓPEZ, 2013).

Desta forma, na comemoração, daquele ano, do fim do regime, recuperou-se o sentido político das demandas das vítimas, a partir de dois movimentos: as reivindicações no espaço simbólico da cidade de Assunção e a necessidade de se trabalhar a memória para desconstruir a possibilidade de retorno do stronismo, enquanto projeto político, e o discurso pós-golpe (novo) de felicidade social e dignidade humana, durante o período ditatorial de Stroessner.

La sucesión de detalles, situaciones, nombres, escenas y revelaciones de datos desconocidos de la represión, permitieron resinificar las luchas de memorias desde la posición del coraje y desde el rompimiento explícito y deliberado del silencio, no como revictimizante denuncia del horror, sino

\footnotetext{
${ }^{113}$ Cf. Capítulo 3: "Palavras nos ventos da costa".
} 
como proyección política ante las nuevas generaciones que también asistieron a la recordación (LÓPEZ, 2013, p. 5).

Já se dava uma grande campanha dos organismos de direitos humanos contra a reivindicação do ditador e de uma "época melhor" da ditadura, cujos discursos recorrentes na sociedade paraguaia e inflados dentro do próprio governo ganhavam espaço público, principalmente na oratória do então senador (2008-2012) e neto do ditador, Alfredo "Goli" Stroessner. A campanha "No permitamos la reivindicación del pasado stronista" inicia-se, quando a família Stroessner tenta trazer, em 2012, os restos mortais do ditador ao Paraguai, com cortejos e comemorações programadas.

As comemorações e homenagens eram meios recorrentes da ditadura stronista para arraigar uma cultura autoritária de adoração à figura do ditador. Para se comemorar o aniversário de Stroessner ( 3 de novembro), por exemplo, realizava-se uma longa cerimônia com autoridades nacionais e partidárias, fazia-se uma grande festa popular no bairro construído por Stroessner, que levava seu nome, e festejava-se sua vida em inaugurações de obras e publicações, que o homenageavam. A "fecha feliz" permanece no imaginário popular, que segue sendo comemorada, com frequência irregular e apesar dos repúdios de uma significativa parcela social (VERA, 2002, p. 149-194).

Stroessner neto, empresário nos ramos do gado e imobiliário, venceu as eleições para o Senado, em 2008, pelo Partido Colorado, com o lema do avô "paz y progresso". Mesmo admitindo "excessos" no que tange aos direitos humanos, Goli afirmava o "trabalho excepcional" do avô no país: "Si borramos todo lo que construyó el general Stroessner, vamos a volver a la edad de piedra en Paraguay" ('GOLI' STROESSNER..., 2013, sem paginação).

No permitamos la reivindicación del pasado stronista reconhecia o direito de repatriação de qualquer paraguaio falecido no exterior, contudo, considerava inaceitável o propósito de render cortejo ao responsável por gravíssimas violações aos direitos humanos. Segundo Martin Almada,

La justicia no es venganza y no puede haber perdón mientras haya injusticia. Con la caída de Stroessner no cambió la naturaleza corrupta del Estado, aún que haya cambiado el régimen político. Stroessner fue un prófugo de la justicia, que se llevó más de 5 mil millones de dólares y sigue siendo el presidente honorario del Partido Colorado. Los familiares, cómplices y encubridores pretenden traer los restos de Stroessner para ofender nuevamente a las víctimas. Por eso esta movilización de la sociedad civil para decirle a todos: ¡Torturas nunca más!, ¡Stroessner nunca más! (ALMADA apud LA CIUDADANÍA..., 2013, p. 20). 
Neste sentido, o ato em comemoração aos 24 anos do fim do stronismo recupera a necessidade de manter a memória viva, nos espaços públicos, as memórias resistentes ao passado, imaginado positivo, que permanece na sociedade (e que ganha força com o golpe contra Lugo). Para os componentes de No permitamos, os lugares de memória no país precisavam ser salvaguardados e resgatados do esquecimento para ativar a lembrança das vítimas do regime e as consequências do mesmo na sociedade. Assim, defenderam a sinalização dos lugares de repressão e as práticas de atividades que pudessem deixar a "memória viva" - mostras fotográficas, imagens da ditadura, sinalização de tumbas NN e fossas comuns, e exibição de testemunhos escritos ou orais (LA SOCIEDAD..., 2013, p. 17).

Com o mesmo intuito, a Mesa Memoria História divulga seu apoio ao projeto de implementação da Red de Sitios Históricos y de Consciencia de la República del Paraguay. Essa rede teria a função de impulsionar ações de preservação de lugares históricos na luta contra as violações aos direitos humanos e recuperar os Centros de Detenções como lugares de memória.

O informe final da CVJ já havia apontado uma lista com 60 Centros de Detenção, em todo o país, que fora ampliada, ao longo do tempo, para mais de duzentos Centros, funcionando no período ditatorial. No entanto, até aquele momento, a Red de Sitios Históricos conseguira demarcar apenas oito desses lugares: 1) Ex-Departamento de Investigaciones de la Policía de la Capital; 2) Ex-Campo de Concentración de Emboscada; 3) Ex-Campo de Concentración de Abraham Cué (Misiones); 4) Casa Paraguaya (Corrientes, Argentina); 5) Instituto Técnico Superior en Derechos Humanos "Silvano Ortellado Flores" (Misiones); 6) Comunidad San Isidro del Jejuí; 7) Comisaría Tercera Metropolitana; 8) Ex-Departamento de Asuntos Técnicos. ${ }^{114}$

Em meados de 2013, a situação se agravava com a possibilidade de nomeação de 'Goli' Stroessner como embaixador paraguaio nas Nações Unidas, campanha levantada pelo então presidente Horacio Cartes e o chanceler Horacio Loizaga. No mês de novembro, Memoria Histórica, em conjunto com a Coordinadora de Derechos Humanos del Paraguay (CODEHUPY), Mesa Nacional de Derechos Humanos, Decidamos e SERPAJ-PY, chama uma manifestação para recordar os lutadores e lutadoras contra a ditadura. E, através de uma mostra fotográfica, com imagens dos desaparecidos do país, repudiam o retorno do stronismo nos discursos políticos daquele momento (REPUDIAN..., 2013).

\footnotetext{
${ }^{114}$ Cf. MERCOSUR. Sistema de Informação sobre Institucionalidade em Direitos Humanos. Disponível em: <http://sisur.ippdh.mercosur.int/si/web/pt/ficha/institucion/365>. Acesso em: 03 ago. 2017.
} 
Desta forma, vemos que as discussões sobre a não repetição paraguaia passam pelo debate sobre a memória das vítimas, em espaço público, com o expoente máximo do desaparecido, essa figura regional capaz de integrar a luta pelos direitos humanos, mesmo não sendo a configurando a totalidade das vítimas nos diferentes modelos repressivos.

Imagem 43 - No permitamos la reivindicación del pasado stronista

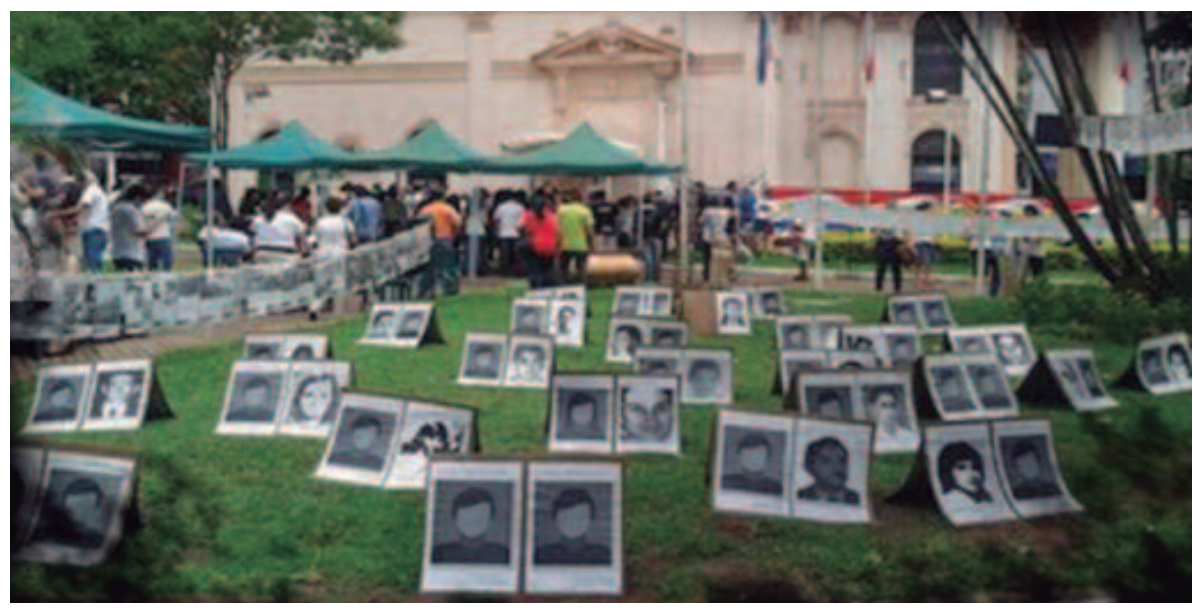

Fonte: Revista Memorias/Hoy, marzo 2014, capa.

Importante lembrar também que, naqueles anos, se comemoravam 20 anos do encontro com o Archivo del Terror. Memoria Histórica relembra o fato, tratando da importância da imprensa e da Justiça na proteção, traslado e difusão do conteúdo dos arquivos encontrados, que impulsionou a luta pela memória no país e a constituição do Museo de las Memorias. Logo, faz um apelo à opinião pública, e a esses organismos em especial, para que se mobilizem em torno do contexto desfavorável em que se vivia.

Conectando o passado ao presente, realizaram-se, nas celas da ex-La Técnica (o espaço chave do Museu), uma cerimônia ecumênica e uma exposição em homenagem às vítimas do recente massacre de Marina Cué. ${ }^{115}$ A exposição fotográfica no Museo de las Memorias resgatava a conexão entre as repressões do governo ditatorial e as do governo democrático, trazendo, de certa forma, nesse argumento, as vítimas de áreas rurais.

\section{Imagem 44 - Exposição Masacre de Curuguaty}

\footnotetext{
${ }^{115}$ Cf. Capítulo 3: "Palavras nos ventos da costa".
} 


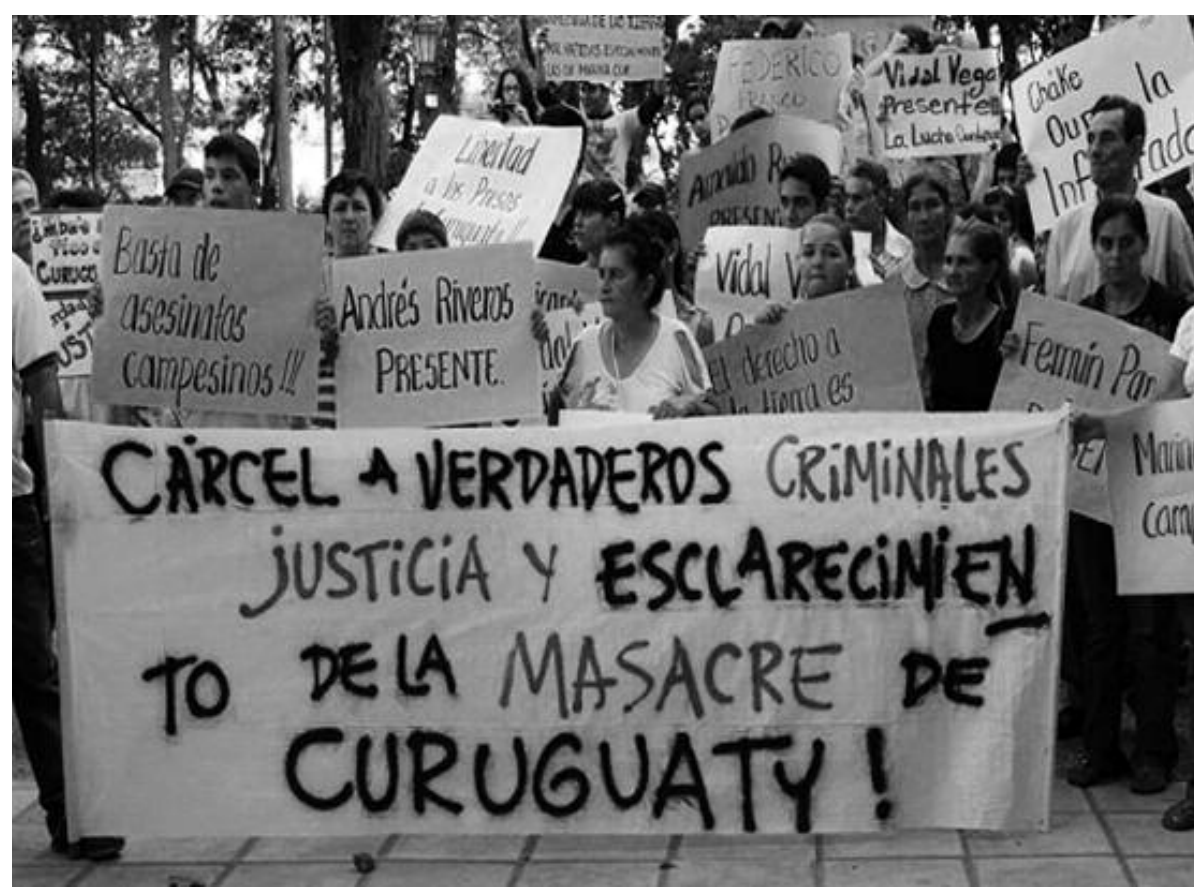

Fonte: Revista Memorias/Hoy, feb. 2013, p. 30.

Com essa conexão, reacende-se a discussão sobre se pensar o sistema repressivo e as memórias resistentes, a partir de uma dinâmica regional. Atentamos, por exemplo, para a comemoração de dez anos da criação da Mesa Memoria Histórica (2002-2012), onde dois discursos pautam a regionalização dos trabalhos das memórias e a ideia de memória exemplar.

Em um seminário realizado pela Universidade Católica, em Assunção, a componente convidada, membro de Madres de la Plaza de Mayo - Línea Fundadora, Nora Cortiñas, compara as experiências argentina e paraguaia, no que tange aos arquivos das ditaduras, colocando o pioneirismo paraguaio na descoberta e no acesso à documentação das repressões. Neste sentido, propõe uma inversão da visão na qual a Argentina é o modelo exemplar nos trabalhos de memória e sugere um "atraso" do mesmo país quanto aos seus documentos. E, por outro lado, alenta o uso judicial dessa documentação paraguaia, a ser utilizada de maneira intra e extra fronteiriça, para se obter justiça nos casos de violações aos direitos humanos (LA JUSTICIA..., 2013, p. 6-7).

Também é interessante o argumento do jornalista Juan Bautista Rivarola, em que aponta uma responsabilidade regional pela situação judicial paraguaia. Segundo Rivarola, o fato do Brasil não haver intervindo favoravelmente nos pedidos de extradição contra 
Stroessner ${ }^{116}$, que incluía também seu filho Gustavo Stroessner, resulta na impunidade de uma ideologia que favorece o rompimento dos direitos humanos.

(...) los autores intelectuales de la represión, los sostenedores ideológicos de la represión, no fueron condenados, no fueron procesados, empezando por Alfredo Stroessner, que a los pocos días después del golpe se fue al Brasil, tuvo el asilo político del Brasil y murió en el 2006 asilado en el Brasil con un gobierno progresista, no hubo ni intento de la justicia paraguaya, a pesar de que hubo un par de pedidos de extradición para traerlo y someterlo a la justicia, pero no fueron muy serios, tampoco el Brasil tenía ninguna intención en traerlo por cuestiones de la geopolítica del Brasil (LOS DERECHOS..., 2013, p.9).

Diante da situação nacional, Memoria Histórica apostou, então, em três frentes urgentes para a luta pelos direitos humanos: a obrigatoriedade da disciplina "El autoritarismo en la Historia Reciente del Paraguay", o direito ao atendimento médico das vítimas e a defesa por novas eleições para Defensor del Pueblo. Com este intuito, realizou encontros regionais internos para discussões (em Paraguarí, Cordillera, San Pedro, Concepción, Alto Paraná, Caaguazú e Misiones), que culminariam no grande Encontro Nacional (Oñondivepa - "Todos Juntos"), realizado no Museo de las Memorias (MESA MEMORIA HISTÓRICA, 20--).

Segundo Memoria Histórica, não se pretendia criar uma nova organização, mas sim, estabelecer uma conexão a níveis nacional, regional e local, com uma rede de organizações composta por vários pólos (apokytã - nós), unidos entre si (joaju - união) para atingir seus objetivos (pira'i ha pira guasú - quando lançados à água, alcançam seus objetivos). Desde novembro de 2012, as organizações vinham denunciando o descaso por parte das instituições do Estado em relação à saúde, educação e políticas de defesa da população para o cumprimento de seus direitos. E, portanto, a Mesa Memória Histórica passa a denunciar o desinteresse nacional em tratar de sua memória sobre o stronismo.

Lo que estamos viendo entonces es el poco interés de parte de las autoridades nacionales, la poca importancia que les dan a cuestiones fundamentales para nosotros, como la reparación integral a las víctimas de la dictadura (LOS DERECHOS..., 2013, p. 2).

No caso da obrigatoriedade da disciplina, luta iniciada, como vimos, com a publicação do Informe da CVJ, sua aplicação optativa não parecia ser suficiente para a organização. Segundo Memoria Histórica, as novas gerações precisavam pensar criticamente sobre a história do stronismo e seus atos de barbárie. Dionísio Gauto, ex-sacerdote e membro de

\footnotetext{
${ }^{116}$ Em 2001, a Argentina pede a extradição do ditador para o julgamento de crimes relacionados à Operação Condor e, em 2003, a justiça paraguaia pede o mesmo no julgamento de crimes contra Federico Tatter, Ignacio Samaniego e Oscar Rojas, desaparecidos em território argentino, entre os anos 1976 e 1978. Cf. A ARGENTINA..., 2001.
} 
Memória Histórica, chama a atenção, por exemplo, para as consequências desse desconhecimento sobre a história do país, que impulsiona pensamentos autoritários na sociedade e uma democracia vazia.

Los jóvenes menores de treinta años no conocen esa historia y por eso son muchos los que prefieren la dictadura a la democracia. Sin embargo, no pueden comparar una dictadura, que no conocen ni conocieron, con una democracia que es más de nombre que realidad (GAUTO apud OVIEDO, 2014, p. 6).

De acordo com as orientações pedagógicas, datadas do ano de 2007 e realizadas pelo Ministério de Educação e Cultura, a disciplina optativa deveria ser oferecida aos alunos do terceiro curso do Ensino Médio, abordando os contextos nacionais e internacionais para o golpe de Stroessner, sua ditadura pessoal e a repressão aos movimentos sociais no país. Neste sentido, os alunos deveriam ser capazes de observar a realidade de modo global, visitar lugares de memória e museus históricos, entrevistar historiadores e vítimas, ler o Informe Final da CVJ, fazer trabalhos em grupos, consultar dados no Archivo del Terror, problematizar conceitos-chaves para a interpretação da história do país, consultar bibliografias, participar de projetos e ações comunitárias e elaborar suas próprias recomendações (MINISTERIO DE EDUCACIÓN Y CULTURA, 2007).

Ao torná-la obrigatória, propunha-se que a educação e essa disciplina, em especial, teriam o sentido de disponibilizar aos jovens instrumentos para construírem suas próprias opiniões sobre um passado que não viveram. "Afinal, como poderiam ter opinião sobre o que é viver em ditadura, se não sabem o que é um governo ditatorial?" (OVIEDO, 2014, p. 6, tradução nossa).

E o argumento de conhecimento do passado se estende para alguns comunicadores e dirigentes políticos, que, todavia, pareciam ignorar o desrespeito paraguaio sobre instrumentos jurídicos, no sistema interamericano e internacional de direitos humanos. "Na ditadura, meter-se em política significava ser comunista e inimigo. Na atualidade, para alguns setores sociais, essa premissa seguiria vigente" (GAUTO, 20--, p. 12, tradução nossa).

Em relação à luta pela saúde, Memoria Histórica apontou a necessidade de atenção especial aos casos, uma vez que as vítimas estariam sofrendo de problemas físicos e psicológicos, decorrentes das sequelas de suas prisões, e o Procurador da República tardaria em emitir certificados médicos necessários para os pedidos de assistência à saúde. Existiam, naquele momento, denúncias de 16 mil pedidos de atenção acumulados na Defensoría del Pueblo, com uma atuação negligente do defensor Manuel María Páez Monges (OVIEDO, 2014). 
O advogado Páez Monges foi o primeiro defensor eleito em 2001 e reeleito em 2004. Apesar das duras críticas realizadas contra sua gestão, pelas irregularidades de seu trabalho, por vínculos com a ditadura stronista e resoluções favoráveis aos repressores do regime, por desaparecimento de dinheiro da instituição, por apoio ao golpe contra Fernando Lugo e pela permanência indevida no cargo (PÁEZ..., 2014), ele se conservou como Defensor del Pueblo, até novembro de 2016, quando assumiu Miguel Ángel Godoy Servin.

Desta forma, a Defensoría del Pueblo é vista pela Mesa Memoria Histórica como o "não-lugar" dos direitos humanos, onde, além de não haver pronunciamento sobre eles, também se distorceriam percepções sobre estes direitos. Primeiro, porque ela não cumpre com seus deveres de defender os direitos humanos. Depois, porque ela haveria se "agarrado" à Lei N.838/96 de indenização às vítimas da ditadura ${ }^{117}$, desconsiderando as demais reparações necessárias, como o caso da educação e da saúde (MESA MEMORIA HISTÓRICA, 20--, p. $5-6)$.

Memoria Histórica, portanto, recupera a discussão da CVJ, concebendo as vítimas da ditadura stronista como lutadoras nas causas sociais do país. Pois, além de haverem sofrido injustiças e atos desumanos durante a ditadura, essas pessoas tomaram consciência de sua dignidade e direitos, ao longo do tempo, e lutam para que eles sejam reconhecidos e respeitados em democracia. Desta forma, ser um lutador é uma maneira de identificar-se como resistente, um dos braços da interpretação sobre resistências.

\section{3 - Caminhos ao Museo de la Memoria: Uma saída para o local}

A marca da transição uruguaia também se fez presente nos trabalhos de memória do país. O difícil percurso para se chegar às constituições de lugares de memória e consciência teve de passar por muita negociação política, iniciada a partir do governo de Tabaré Vázquez, no âmbito nacional, e do intendente municipal de Montevidéu, Ricardo Ehrlich (Frente Amplio, 2005-2010).

Importante observar que nessas eleições municipais, realizadas em maio de 2005, o Partido Colorado, perdedor das eleições nacionais de outubro do ano anterior, com $8 \%$ dos votos para a presidência, angaria o segundo lugar com a candidatura de Pedro Bordaberry, filho do ex-presidente Juan María Bordaberry. Bordaberry filho, que é uma figura bastante

\footnotetext{
${ }^{117} \mathrm{O}$ artigo primeiro da lei determina a indenização para pessoas de qualquer nacionalidade, que durante o sistema ditatorial sofreram violações aos direitos humanos, à vida, à integridade pessoal ou liberdade por parte de funcionários ou agentes do Estado. CF. PARAGUAY, 1996.
} 
controversa na política uruguaia, iria no ano posterior travar uma batalha pública com Rafael Michelini, filho de Zelmar Michelini, em torno da abertura de uma causa contra seu pai pelo assassinato de Zelmar.

Considerado um dos primeiros assassinatos à nível do Sistema Condor, Zelmar Michelini, jornalista e um dos fundadores do Frente Amplio, foi sequestrado em Buenos Aires, em 1976, no hotel onde se hospedava com dois de seus filhos. Três dias depois, seu corpo foi encontrado dentro de um carro junto aos corpos do ex-deputado do Partido Nacional (Uruguai) Héctor Gutiérrez Ruiz, e dos membros dos Tupamaros, Rosario del Carmen Barredo e William Whitelaw.

Em outubro de 2006, Pedro Bordaberry foi ao programa Zona Urbana do Canal 10 de televisão revelar que tinha gravações do senador Rafael Michelini, confirmando sua convicção individual de que o ex-presidente não teria participação direta no crime cometido contra Zelmar. E, portanto, a causa aberta contra Bordaberry pai era inválida. Incitado pelo apresentador, Rafael vai ao mesmo programa para responder as acusações e inicia-se um ríspido debate entre os dois, no qual Bordaberry acusa Michelini de querer lucrar com a morte do pai e mentir sobre os fatos ocorridos. Por outro lado, Michelini acusou Bordaberry de se utilizar dos mesmos mecanismos da ditadura para defender o pai (gravações de conversas privadas entre os dois) e da necessidade de instituição, no país, de uma justiça penal, que condenasse o "ditador que pensa ser intocável” (MICHELINI..., 2006, p. 3).

Durante o programa, os microfones tiveram de ser cortados diversas vezes e a briga continuou depois dele, na porta do estúdio da televisão, onde os partidários de ambos os lados se insultavam. Nos dias seguintes, os meios de comunicação divulgavam a peleja e as opiniões de leitores e de diversas personalidades sobre a temática. No ano seguinte (2007), Bordaberry volta a ser notícia, ao criar uma ala no Partido Colorado, denominada Vamos Uruguay, cujo discurso se encaixaria em uma dinâmica econômica desenvolvimentista, enfatizando a "luta contra a delinquência", através da mudança de leis sobre a maioridade penal.

Nesse clima, emergem as discussões sobre memória na cidade de Montevidéu e a necessidade de se criar espaços que dialoguem criticamente com o passado recente do país. Desta forma, iremos analisar aqui dois projetos, dos quais o Museo de la Memoria faz parte, e que, através de seus desenvolvimentos e de entrevistas com os responsáveis, pretendem trabalhar essa memória urbana.

\subsection{1 - O projeto do Museo de la Memoria}


Em 2005, foi apresentado o projeto para constituição de um museu que trabalhasse com o passado recente uruguaio, ao Departamento de Cultura da Intendência de Montevideo. Este primeiro projeto inicia os preparativos e convocatórias às organizações de direitos humanos e demais organizações sociais para a criação do Museo de la Memoria (MUME). Atenderam ao chamado, conformando, então, a Comisión Pró-Museo de la Memoria: as Madres y Familiares de Uruguayos Detenidos-Desaparecidos, a Comisión de Familiares de Asesinados Políticos, o Crysol - Asociación de ex-Presos Políticos; a organização Memoria de la Resistencia (1973-1985), a Facultad de Humanidades y Ciencias de la Educación da UDELAR; o Taller Vivencias de ex-Presas Politicas; a Asociación de Funcionarios de la Universidad del Trabajo del Uruguay; a Comisión de Derechos Humanos del Plenario Intersindical de Trabajadores-Convención Nacional de Trabajadores; e o Departamento de Cultura y de Planificación de la Intendencia Municipal de Montevideo (FERRARIO, 2010).

Esta Comissão formulou a ideia de criar um espaço na cidade de Montevidéu para a promoção dos direitos humanos e civis e para rememorar a luta pela liberdade, democracia e justiça social, durante a ditadura, entendendo-os como conceitos culturais, que precisam estar em permanente construção e consolidação. Seria este espaço, não apenas um museu para expor as informações sobre o passado recente, mas também, um Centro Cultural, onde se desenvolveriam atividades educacionais e artísticas, em conjunto com a proposta museológica do espaço. Assim, o Centro Cultural responderia

(...) a la necesidad urgente de simbolizar la historia del golpe de Estado en el país, para que nunca más se vuelva a repetir. En tiempos de incertidumbre surge una gran certeza, que la memoria es un arma poderosa para la identidad de nuestros pueblos, y que orienta la lucha para construir una sociedad mejor, con justicia social, democracia, libertad y solidaridad. El Centro Cultural Museo de la Memoria se concibe como una institución cultural donde desarrollar seminarios, mesas redondas, performances, obras de teatro, conciertos de música, actividades educativas, exposiciones y otras actividades que promuevan el sentido crítico y la reflexión (FERRARIO, 2010, p. 2).

Atentamos aqui para a ideia inicial desse debate (que passa a ser fundamental): de que a memória do passado uruguaio serviria para conformar o Nunca Más e as resistências à ditadura, enquanto bases de uma identidade nacional, que se desejava construir. A partir de instrumentos de reflexões críticas sobre a história da ditadura, as organizações que pensavam nesse Centro Cultural pretendiam que ele se tornasse um espaço educativo, em prol do desenvolvimento da identidade, motivada em práticas de justiça social, democracia, liberdade e solidariedade. 
Interessante, portanto, é perceber os valores que a identidade nacional, na narrativa da Comisión Pró-Museo de la Memoria, carrega. Estes valores do presente vão se conectando com o conceito de resistências à ditadura, dando um sentido central para o futuro Museu, que tomaria as práticas de oposição ao governo ditatorial uruguaio como linha argumentativa em exposições e programas educativos.

A primeira proposta, então, era a construção desse Centro Cultural, na ex-fábrica têxtil Camponar (Centro Comunal N.16, Montevidéu), um dos palcos da greve geral de 1973. Em 18 de julho de 1973, a fábrica recebeu um telegrama, ordenando que se despedissem os trabalhadores envolvidos nesta greve, pois o governo havia decretado que a prática de greves era ilegal no país. Neste sentido, durante a ditadura, foram despedidos cerca de sessenta trabalhadores da fábrica e, logo, ela seria considerada um território de memória, que se remete à resistência. ${ }^{118}$

No entanto, quando se iniciam os trabalhos de recuperação do prédio da fábrica Camponar, o Departamento de Planejamento da Intendencia de Montevideo apresenta uma proposta de alocar o museu na ex-Quinta Santos, afinal, esta já havia sido restaurada para abrigar um centro cultural na cidade. Elbio Ferrario, um dos porta-vozes da Comisión PróMuseo e futuro coordenador do Museo de la Memoria, se interessou pelo espaço por se tratar da quinta do ditador Máximo Santos, conhecido por ter sido uma expressão do militarismo uruguaio e por sua postura autoritária (MUSEO DE LA MEMORIA, 20--b).

Segundo Ferrario, utilizar a casa do ex-ditador era ressignificá-la no espaço urbano, transformando um símbolo de violações em um espaço para se discutir os direitos humanos. Tal como feito em antigos Centros de Detenção, no Chile ou na Argentina, ele argumenta que a ex-Quinta de Máximo Santos - onde também houve prisioneiros encarcerados, no século XIX - faria parte dessa memória sobre "Centros de Detenção", que estavam sendo ressignificados em distintos lugares, no Cone Sul, através da memória sobre o passado recente. E, vai além, conectando o projeto da ex-Quinta aos modelos de museus dedicados ao Holocausto, na Europa, que trabalham a memória em lugares-palcos de violações aos direitos humanos.

Assim, a ideia era transformar o sentido da casa para a história do país, realizando exposições com mostras dinâmicas, ou seja, que transitariam pelo país e cambiariam, ao longo do tempo, repensando-se sobre suas formas e conteúdos. No entanto, sempre ressaltando os ideais de luta pela liberdade, pela democracia, e pela justiça social.

\footnotetext{
${ }^{118}$ Atualmente, a ex-fábrica Camponar funciona como um centro cultural e esportivo, no qual se desenvolvem, principalmente, as artes circenses. Cf. CONNIO, 2014.
} 
Usamos el nombre de museo, pero en realidad es un centro cultural. El museo muchas veces se vincula más con una exposición permanente. El museo es museo en tanto recoge objetos y los mantienen, los va a recuperar y va a armar el archivo. Pero no es una exposición permanente porque una exposición permanente tiene mucho que ver con un punto final (EL MUSEO..., 2008, sem paginação).

Esta dinâmica das mostras foi imaginada por seus elaboradores, primeiro porque o museu se nutriria, principalmente, de doações de ex-detidos-desaparecidos ou de seus familiares, portanto, estaria sempre aberto a receber novos materiais a serem incorporados. A proposta que, por um lado, pretendia criar um laço afetivo entre o museu e a comunidade, por outro, dificultava a aquisição desses objetos, justamente pelo afeto que muitas pessoas possuíam com suas doações.

Depois, a dinâmica era vista pela ideia de o Centro Cultural produzir conhecimento e arquivo sobre o passado e os direitos humanos. Por exemplo, já nos primeiros meses de seu funcionamento, a Comisión Pró-Museo de la Memoria realizou um acordo com a TV Ciudad, televisão aberta da Intendencia de Montevideo, para a gravação de dez entrevistas com vítimas da ditadura ou seus familiares, no marco de um projeto intitulado Registro de Testimonios, que iria, posteriormente, tornar-se um projeto contínuo do Museu (GONZÁLEZ, 2014, p. 80-101).

A proposta para as instalações era fazer concursos abertos de bases criativas, a partir de distintos segmentos temáticos: resistências, cárceres, exílios, desaparecidos, instauração da ditadura e desafios para os direitos humanos. Essa ampliação da participação, na construção do conteúdo do Centro Cultural, prevendo o interesse de cidadãos, investigadores, educadores e artistas, traria, além da participação social, a perspectiva de expressões diversas sobre o passado recente (MUSEO DE LA MEMORIA, 2007) - Ferrario inclusive cita a sua pretensão em trazer para dentro do Museu alguns testemunhos ou objetos de militares e policiais que participaram das Forças de Segurança, e que estivessem dispostos a doá-los (EL MUSEO..., 2008).

A missão proposta pelo projeto do MUME, portanto, era promover a paz, os direitos humanos e a memória das lutas populares. E, desde então, surge a concepção de construção da identidade nacional, como justificativa para o Museu, que deveria valorizar a recuperação da memória do passado recente, contudo, enfatizando a luta contra o Terrorismo de Estado e a ditadura.

Este centro será un espacio dedicado a la recuperación de la memoria sobre el horror del terrorismo de Estado y los esfuerzos del pueblo uruguayo en su lucha contra la dictadura, de modo de aportar conocimiento a las nuevas 
generaciones sobre la historia reciente de nuestro país para fortalecer los elementos constitutivos de la identidad nacional. A partir de él podrán integrarse con la mayor amplitud otros proyectos y actividades que atiendan al desarrollo integral del ser humano en su dimensión personal y social (MUSEO DE LA MEMORIA, 2007, p. 2).

Em 10 de dezembro de 2007, o MUME é inaugurado, com diversas atividades artísticas - grupos de dança, música e teatro -, concluindo essa etapa de criação do Centro Cultural. Posteriormente, a Comisión Pró-Museo de la Memoria tornou-se a Asociación de Amigas y Amigos del MUME, cuja a finalidade é aportar conteúdos ao Museu e servir de interlocutora entre este e a sociedade (FERRARIO, 2010).

Desta forma, nos primeiros meses de funcionamento (abril de 2008), o MUME organizou um encontro com Museus de Memória do Mercosul, no qual participaram diversos representantes de instituições, dedicadas à temática: Museo de Arte y Memoria de La Plata (Argentina), Parque por la Paz Villa Grimaldi (Chile), Museo de las Memorias (Paraguay), Casa Museo Giuseppe di Vittorio (Itália), Centro de Información para la Memoria Colectiva (Perú), Memorial Democrático (Cataluña-Espanha), Instituto Espacio para la Memoria (Argentina), entre outros.

Segundo a organização do encontro, o Mercosul estava em um contexto de elaboração da "memória do horror", que assolou toda a região, e da memória da luta dos povos pela liberdade, democracia e justiça - como vemos, termos esses recorrentes na justificativa para a construção do referido Museu. Já havíamos percebido, no caso paraguaio, que o Mercosul estava, naqueles anos, desenvolvendo projetos educativos em matéria de direitos humanos e realizando acordos para se pensar alguns territórios de memória sobre o passado recente latino-americano.

Assim, o Encontro, organizado pelo MUME, se inseria em uma dessas políticas regionais, e pretendia debater as experiências em curso, intercambiando ideias para promover os direitos humanos e a cultura de paz na região.

En ese contexto surgen los Museos de la Memoria como Instituciones cuyo fundamento y objetivo es trabajar en la recuperación y construcción de la memoria mencionada, rescatando y preservando los archivos de represión y generando nuevos archivos de testimonios. Asimismo, son instituciones que promueven en forma activa los derechos humanos y civiles, y la cultura de paz, construyendo espacio de intercambio social y ámbitos de generación de conocimiento, no sólo histórico, sino también sociológicos y pedagógicos. Los museos de la Memoria de América del Sur se encuentran en proceso de fundación y construcción, con desarrollos particulares y diversos. El encuentro de Museos de la Memoria del Mercosur tiene el objetivo realizar un intercambio de experiencias sobre la formación de los museos, 
socializando aciertos, dificultades, concepciones y caminos (MERCOSUR, 2008, sem paginação).

De acordo com os organizadores desse evento, o contexto de criação dos museus de memória relacionados às violações aos direitos humanos latino-americanos é caracterizado como um momento regional, cuja efervescência se dava pelas experiências intercambiadas entre essas novas instituições e pelo desejo coletivo da não repetição dessa história de repressão integrada (da educação em matéria de direitos humanos, do Nunca Más). Neste sentido, as memórias dos Terrorismos de Estados do Cone Sul ganham um espaço público para serem recordadas, nas especificidades de cada país, mas, especialmente, na dimensão das experiências regionais, abordando a temática do Sistema Condor, apreciada na figura do desaparecido.

Como exemplo dessa elaboração, apresentamos uma das primeiras exposições realizadas no Centro Cultural, que traz a noção regional para o debate na área educativa do Museu. A exposição El informe Orletti - Conexión Internacional foi uma proposta do jornalista Enrique Rodríguez Larreta Martínez e teve espaço no Centro Cultural Recoleta (Buenos Aires) e no Museo de la Memoria (Montevidéu), em 2009. Enrique Martínez, uruguaio, vivia em Buenos Aires desde 1973, quando foi liberado da prisão no Uruguai por ser dirigente estudantil. Em 30 de junho de 1976, volta a ser preso, desta vez pelo Exército argentino, e é levado ao Centro Clandestino Automotores Orletti (LARRETA PIERA, 1977).

Seu pai, Enrique Rodríguez Larreta Fiero, alertado de seu desaparecimento, vai à Buenos Aires intentar o recurso de habeas corpus, que lhe é negado pela Corte Suprema, afirmando que havia "seis mil pedidos do mesmo procedimento no momento" e era impossível considerá-lo naquela situação. Ele resolve, então, denunciar o desaparecimento do filho nos periódicos La Nación, Crónica, Última Hora, La Opinión, El Cronista Comercial e The Buenos Aires Herald, em Buenos Aires, e no El País, El Día, e La Mañana, em Montevidéu.

Em 14 de julho de 1976, Larreta Fiero é preso e conduzido ao mesmo Centro Clandestino, onde estava seu filho. Neste, foi vítima de torturas e pôde reconhecer indivíduos das Forças de Segurança uruguaias, que trabalhavam em conjunto com argentinos, assim como diversas pessoas mantidas presas naquele país por serem opositoras do regime ditatorial no Uruguai, entre elas Larreta Martínez. ${ }^{119}$ Em seu testemunho, conta que lhe perguntavam

${ }^{119}$ Cf. JUICIO DE LAS JUNTAS, 1985, arquivo 2539. 
constantemente sobre sua participação e a de seu filho no Partido por la Victoria del Pueblo, em um quarto destinado às torturas, adornado com um retrato de Adolf Hitler.

Mientras se me tortura se me formulan preguntas sobre las actividades políticas de mi hijo y sobre mi participación en el Partido por la Victoria del Pueblo, al que según ellos pertenecía mi hijo. Es en ese cuarto donde puedo ver, en un momento en que por la copiosa transpiración se corre algo la venda, que en la pared hay un retrato de regular tamaño de Adolfo Hitler (LARRETA PIERA, 1977, sem paginação).

No final de julho de 1976, ele foi conduzido clandestinamente ao país de origem, junto a um grupo de pessoas na mesma situação. Mantidos presos em Montevidéu, lhes ofereceram penas de 15 a 20 anos de prisão, caso confirmassem a participação em um grupo guerrilheiro, cuja pretensão era invadir o país por Río Negro, e que fora surpreendido por tropas uruguaias. Mesmo ameaçados de morte, a maioria desses presos negou-se a assinar a declaração, elaborada pela conhecida figura do major Jose Nino Gavazzo, que dizia estar buscando "uma saída" para justificar a presença dos sequestrados no país.

Al día siguiente, en horas de la noche, volvió a presentarse el Mayor Gavazzo, quien dijo venir acompañado por dos soldados armados con ametralladoras a quienes, si continuábamos sin firmar, daría orden de abrir fuego. Nos hizo notar que los soldados le obedecían ciegamente y que nadie estaba enterado de nuestro paradero, de modo que le bastaría hacer lavar la sangre y cubrir los impactos en las paredes para que nadie supiera lo que había ocurrido y cuál había sido nuestro fin. A pesar de las amenazas, continuamos negándonos a firmar lo que se nos exigía. A esa altura de los hechos, yo-y creo que también las demás personas que estaban conmigocomenzamos a advertir que algún hecho exterior estaba urgiendo al Mayor Gavazzo a encontrar una salida a nuestro caso. Era claro que el grupo de secuestrados, siempre esposados con los ojos vendados, sentados y celosamente controlados, no era la causa de su urgencia y de la improvisación con que actuaba (LARRETA PIERA, 1977, sem paginação).

A "negociação" seguia e era realizada sem vendas nos olhos e com cada um dos sequestrados (22 ao total), o que permitiu o reconhecimento das pessoas envolvidas. Larreta Fiero afirmou tentar explicar, naquele momento, ao major Gavazzo, que não possuía antecedentes criminais e que, apesar de contrário à política econômica e aos métodos utilizados pelas Forças Armadas para implementá-la, não fazia parte de nenhum grupo político que "atentasse contra as instituições".

A solução para a situação foi prender 14 pessoas "envolvidas em grupos políticos", que seriam colocadas com armas, em uma "reunião e surpreendidas pelo Exército"; os demais seriam presos em hotéis de Montevidéu com documentos falsos e "provas" de haverem colaborado na campanha para desprestigiar, internacionalmente, os governos uruguaio e 
argentino. Portanto, eles seriam processados por "assistência à associação subversiva", com direito a defensores militares, ao invés de advogados civis. Dias depois, a imprensa lança o comunicado oficial sobre essas ações das Forças Armadas e se inicia a "formalização" das prisões.

Em liberdade, Larreta Fiero vai ao exílio e inicia uma empreitada de denúncias com descrições das condições de seu sequestro, das violações aos direitos humanos e das responsabilidades das autoridades uruguaias e argentinas nestes casos. Conformando o Informe Orletti, no qual detalha suas experiências e das demais pessoas detidas-desaparecidas que pôde identificar, Fierro o apresenta na sede da Anistia Internacional, em Londres, e passa a denunciar as ditaduras nos Estados Unidos, Europa e América Latina. E, nesse sentido, afirmava que

Ante la consciencia del mundo civilizado hago responsables a las autoridades militares uruguayas de todos los daños que puedan infligir desde hoy, en represalia por mi actitud, asumida individualmente, sin consejos o presión de nadie, a mi hijo, a mi nuera, cualquiera de los detenidos junto con ellos o a los miembros de mi familia (LARRETA PIERA, 1977, sem paginação).

Esse material é a base da exposição que Larreta Martínez apresenta para refletir a "globalização da tortura e o traslado ilegal de prisioneiros" nas fronteiras. Logo na entrada desta exposição, lia-se a descrição de que aquela história de afeto - um pai em busca de seu filho sequestrado - tem fundamento em uma crise social e cultural de um mundo atravessado pela violência. E que, apesar dessa narrativa ter um "final feliz", muitas outras foram tragédias. Por isso, se tornaria necessário um trabalho de liberação dessas memórias de horror, silenciadas pelos contextos de impunidade e visibilidade de indivíduos, ligados aos responsáveis por esse modelo econômico-repressivo (EXPOSICIÓN INFORME LARRETA, 2009).

Para conformar a narrativa de El informe Orletti - Conexión Internacional, não apenas a documentação do referido informe era exibida, como também compunha a exposição uma série de trabalhos no campo das artes, que complementavam sua narração. Neste sentido, foram convidados os artistas argentinos Enrique Banfi e León Ferrari e os uruguaios Ernesto Vila, Juan Ángel Urruzola, Octavio Podestá e Pincho Casanova para conformarem uma sala intitulada "Arte e Memória", de livre criação. No caso de Ferrari, por exemplo, ele apresentou 
sua série de colagens para o Nunca Más, onde associa a ditadura argentina ao nazismo, já vista em capítulo anterior. ${ }^{120}$

Imagem 45 - Obra de León Ferrari exposta no El informe Orletti - Conexión Internacional

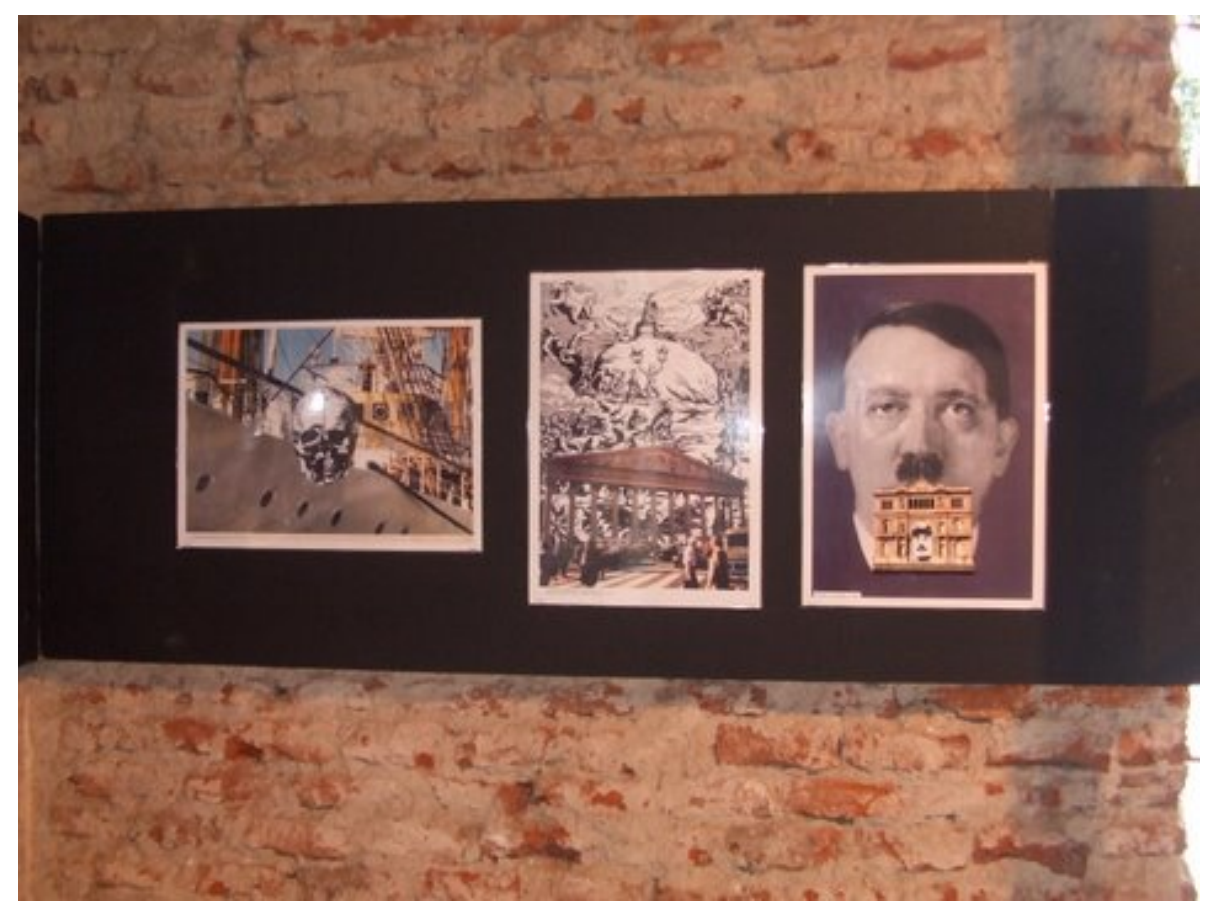

Fonte: EXPOSICIÓN INFORME LARRETA. Disponível em: 〈http://elinforme.larreta.org>. Acesso em: 10 jul. 2017.

Também fazia parte da exposição, a projeção de um vídeo, intitulado "La instalación: Una representación del lugar físico", com imagens capturadas no ex-Centro Clandestino Automotores Orletti, durante uma visita que Larreta Martínez fez ao seu lugar de tortura. ${ }^{121}$ Considerado "lugar histórico", em 2009, pelo governo de Buenos Aires, o vídeo da exposição observava o Centro Clandestino, aberto para primeiras investigações, como um lugar que fora abandonado até então. Desta forma, o vídeo narrava a representação da "miséria daquele lugar, fruto da conexão internacional de violências" e o abandono da memória sobre a mesma conexão (LARRETA MARTÍNEZ, 2009).

\footnotetext{
${ }^{120}$ Cf. Capítulo 3: "Testemunhos no vento da costa".

${ }^{121} \mathrm{O}$ vídeo pode ser visto no endereço eletrônico da exposição. Cf. EXPOSICIÓN INFORME LARRETA. Disponível em: <http://elinforme.larreta.org>. Acesso em: 10 jul. 2017.
} 


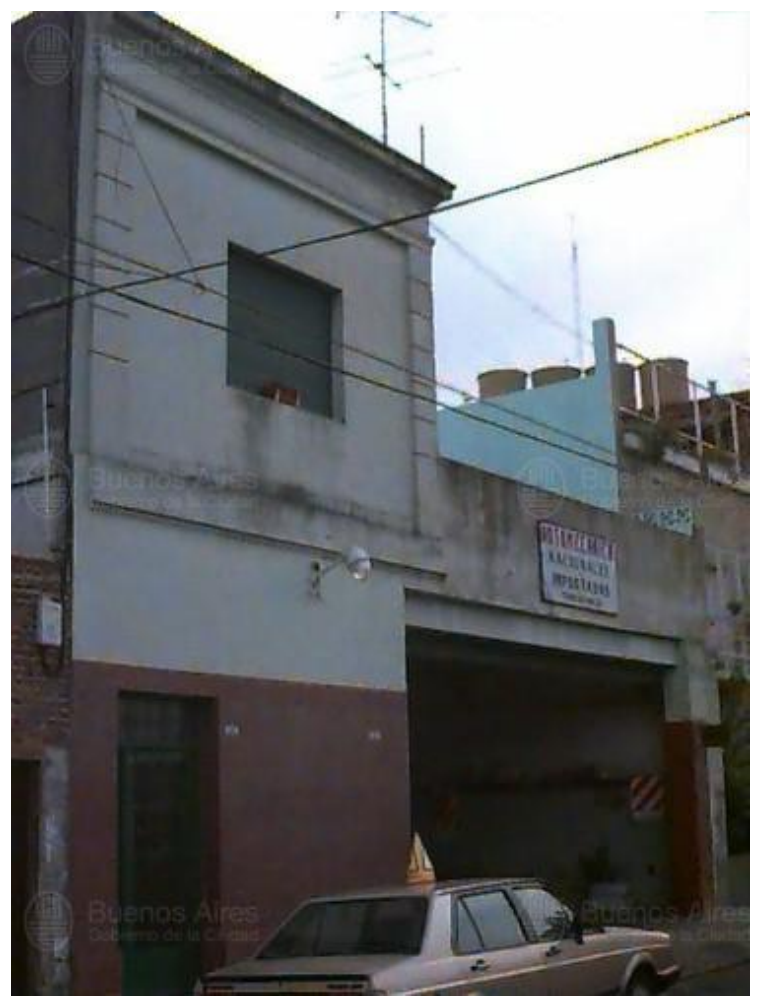

Fonte: GOBIERNO DE BUENOS AIRES. Automotores Orletti. Disponível em: <http://www.buenosaires.gob.ar/MbdUp/contenido/automotores-orletti>. Acesso em: 09 ago. 2017.

Logo, esta exposição foi pensada como um “despertador” das memórias no país. Refletindo o poder da narrativa sobre essas vítimas das "atividades internacionais de intolerância”, ela foi considerada uma representação da busca (de documentos, de pessoas, da verdade), em uma dimensão global, com seus desaparecidos de diversos tempos e espaços. Mas, também representava o Nunca Más, a não repetição relativa, mais especificamente, a esta violência regional (ROSENCOF, 2009).

\subsection{2 - As marcas de resistências na cidade e o MUME}

Também em 2005, um grupo heterogêneo de pessoas - familiares de desaparecidos, vítimas do Terrorismo de Estado uruguaio e demais cidadãos interessados nessa história do país - resolveu trabalhar a memória do passado recente e a resistência à ditadura, criando a Asociación Memoria de la Resistencia (1973-1985). Esta associação civil começou a pensar em um projeto, no âmbito da arquitetura, para interferir nos espaços públicos, a princípio na cidade de Montevidéu, a fim de marcar lugares, onde ocorreram expressões de resistências. 
Para a Asociación Memoria de la Resistencia, as memórias da resistência são parte de um projeto global, que valorizaria as lutas populares contra os abusos de poder e as violações cometidas pelos Estados (YAÑEZ, 2012). Assim, pensando nessa resistência diversa ou nas resistências, a Associação entra em um acordo com a Universidad de la República e cria o projeto de um sistema territorial, no qual seriam marcados lugares, onde se desenrolaram ações de "resistências populares".

Depois de diversos debates, o projeto Marcas de la Resistencia propôs marcar quinze lugares representativos, na cidade de Montevidéu: Ex-Federación de Obreros de la Industria del Vidrio, Avenida 18 de Julio e Río Negro, CX 30: La Radio, Sindicato de la Construcción, Cinemateca Uruguaya, Teatro El Galpón, quarteirão da Universidad de la República, Obelisco de los Constituyentes, Iglesia Tierra Santa, Ombú de Ramón Anador, Estádio Luis Franzini, Casa de Punta Gorda, Fábrica de Neumáticos FUNSA, Sindicato dos Metalúrgicos, e apartamento de Mariano Soler (PROGRAMA DE DISEÑO..., 2006).

Hay lugares significativos, de todos, de algunos, pero siempre para todos. Todos los lugares desde donde se construyó la resistencia son parte de la "memoria de la resistencia". Los lugares o símbolos son referentes de distinta magnitud para el conjunto de la sociedad. Pueden ser lugaressímbolos que desde su significancia como resistencia a la dictadura o reconstrucción de la democracia son, inclusivos de toda la sociedad y referentes a escala de la ciudad y todo el país (tales como: el Obelisco, la Plaza Libertad, o la Universidad), o que puedan tener significado o ser identificados con algunos grupos o protagonistas (organizaciones civiles, culturales, sindicales, religiosas, estudiantiles...) (PROGRAMA DE DISEÑO..., 2006, sem paginação).

Alguns lugares eleitos para fazer parte do projeto inicial foram espaços usados pelos movimentos políticos e sociais para reuniões, atos políticos ou culturais, ou ainda, lugares marcados por greves de trabalhadores. Interessante observar a presença, nessa primeira lista, da Casa de Punta Gorda, na Praia dos Ingleses, que havia sido adquirida pelo Movimiento de Liberación Nacional Tupamaros, no início da década de 1970, contudo, tomada por um operativo militar, em 1974, que a transformou em Centro Clandestino de Detenção, conhecido como Infierno Chico. Neste Centro, foram assassinadas e fuziladas algumas vítimas uruguaias, incluindo aquelas trazidas do Centro Clandestino Automotores Orletti, em Buenos Aires (RODRÍGUEZ, 2011).

Portanto, é o único lugar, neste momento, que sugere a resistência conectada às cárceres do país, talvez por Infierno Chico ter sido, anteriormente à sua história de Centro Clandestino, um lugar de encontro dos movimento Tupamaros. Assim, de certa forma, o 
projeto escapa das discussões mundiais sobre transformar espaços de violações aos direitos humanos em lugares-chaves para se trabalhar a memória da repressão no país.

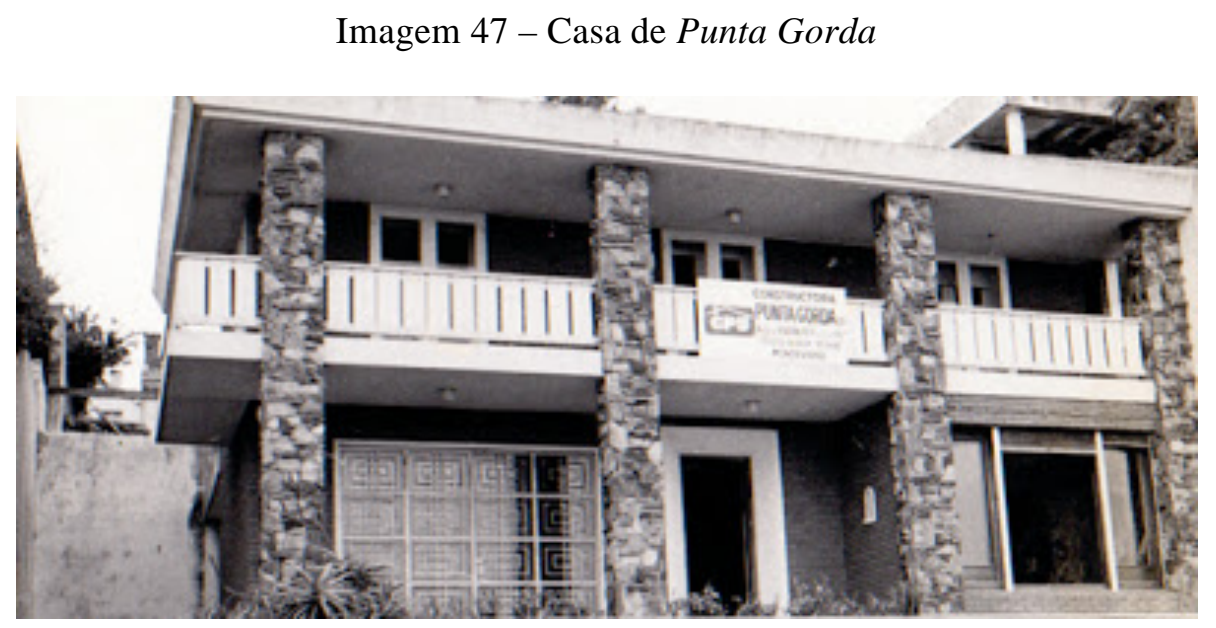

Fonte: CRYSOL. Disponível em: 〈http://crysol.blogspot.com.br/2011/12/la-casa-del-infierno.html>. Acesso em: 08 jul. 2017.

Pretendendo trazer a resistência e tomando a "cidade como um suporte", portanto, a ideia era colocar marcas (placas indicativas), que pudessem habilitar um sistema de comunicação sobre a história do lugar indicado, ligando a cidade às pessoas que transitam nela. A partir dessa rede inicial de territórios de memória, a pretensão era sensibilizar outras organizações, em todo o país, a marcarem também seus espaços de resistência e "preencherem" os espaços vazios de memória por todo o país.

El sistema opera como soporte o medio material de las huellas de la memoria, para vivirlas como marcas del pasado que construyen nuestro presente y futuro, y son parte del proceso de formación de una identidad nacional (...) para generar un proceso de construcción permanente de recuperación de la memoria y lograr así incorporar al mismo el conjunto de la sociedad (PROGRAMA DE DISEÑO..., 2006, sem paginação).

"Preencher os espaços vazios" significava reconstruir uma memória da resistência e desconstruir a desmemória coletiva, demonstrando que, no Uruguai, apesar da tentativa de se esquecer a ditadura, houve luta contra ela e contra seu apagamento histórico (YAÑEZ, 2013). Logo, além das placas, indicando a história do lugar, projetou-se também instalar pequenos assentos para que as pessoas se acomodassem e refletissem sobre o território de memória específico. Pretendia-se, com essas marcas-lugares, "conter o caminhar das pessoas", convidá-las a deter-se naquele espaço.

Allí se instalarán las marcas-lugar que generen un espacio para el encuentro. Serán un lugar-símbolo para detenerse, para estar, para dar lugar a la memoria. Serán también un lugar-dato que identifica el sitio de la resistencia 
actuando como dato-fragmento que en forma sistemática compone el todo y nos dignifica.

Las marcas urbanas ¿Vuelven presente las ausencias? ¿Señalan, denuncian, recuerdan? ¿Qué sentimiento no hemos compartido aun recordando la sede de un sindicato, con dirigentes presos, trabajando en la clandestinidad, convertido en una comisaría? Y cuál es el relato de la emoción contenida ante una sala teatral vulnerada, ajena, cuando todavía sentíamos los ecos explosivos: ¡Cuidado comendador, cuidado comendador! (YAÑEZ, 2012, sem paginação).

\section{Imagem 48 - Proyecto Marcas de la Resistencia}

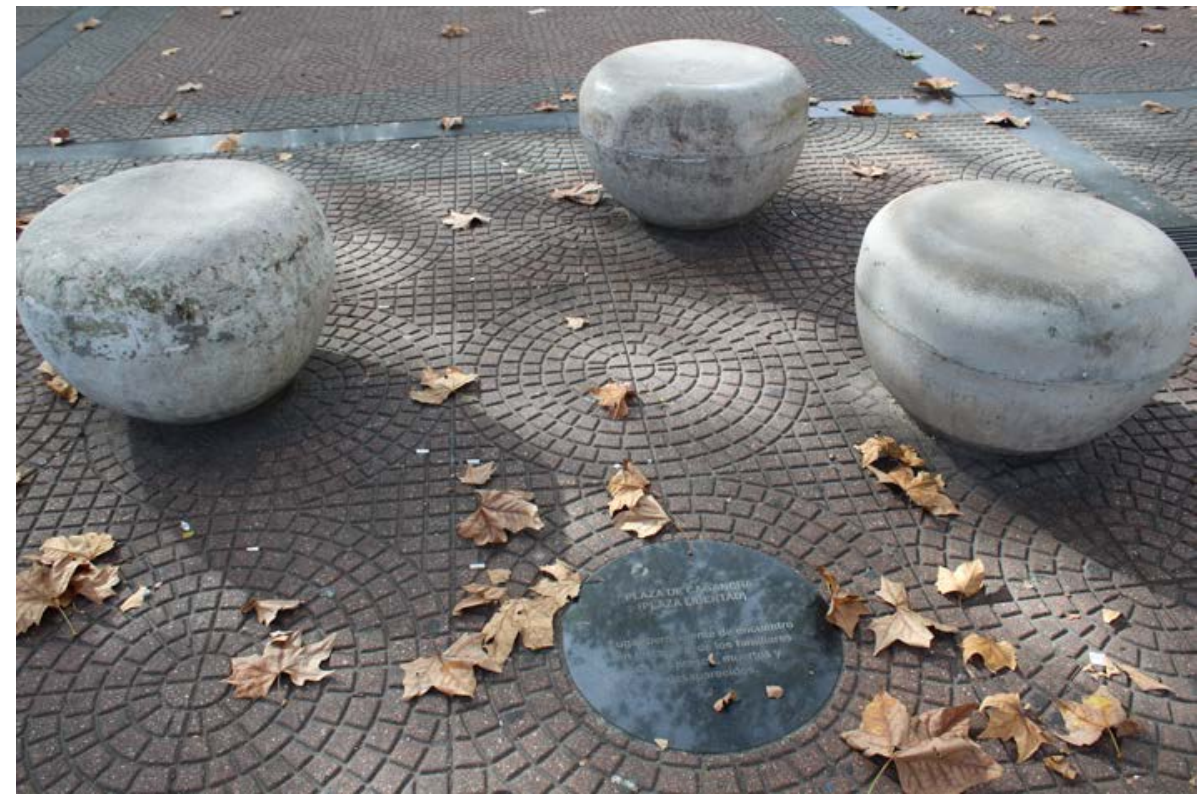

Fonte: Arquivo Pessoal. Fotografia de 2017.

Para Antonia Yáñez (2013), ex-detida-desaparecida, presidente da Asociación Memoria de la Resistencia e membro do Museo de las Memorias, colocar essas marcar era uma forma de conectar, emocionalmente, o espaço ao indivíduo e a cidade às memorias coletivas - uma solução para a questão da poesia, proposta por Américo Castilla (apud MEMORIA ABIERTA, 2000), nos debates argentinos. E, interpelando a resistência na cidade, essas marcas incorporariam o valor da democracia e da luta política, na identidade uruguaia - como vemos, discurso fundamental para a cultura política do país.

Com o projeto realizado, entre os anos 2006 e 2010, desenrola-se uma série de negociações com os partidos políticos para votá-lo na Junta Departamental de Montevidéu. A discussão entre partidos e a Associação modificou dois pontos dentro das disposições iniciais do projeto.

Um primeiro se refere à transformação da ideia de "marcas de resistência" para “monumentos na cidade" e como "marcas de memória" (YAÑEZ, 2012). Essa compreensão 
abrangeria uma "monumentalidade, que agrupa muitas atitudes e ações humanas na conquista pela liberdade" e resolveria a obrigação do Estado em cumprir com a Lei N.1859/2009 que recomendava reparações simbólicas para as vítimas da ditadura. ${ }^{122}$

Por outro lado, teve-se de negociar também outros lugares simbólicos de resistências, que agrupavam as demais posições políticas ou partidos negociadores. Desta forma, aprovouse a integração dos espaços da Asociación de Bancarios del Uruguay (AEBU), o Palacio Lapido, o ex-local de Monte Carlo TV, a Plaza Cagancha (Plaza Libertad), o Diario Acción, a ex-casa do General Líber Seregni (Frente Amplio), o ex-Cine Cordón, a Unión Nacional de Trabajadores y Ramas Afines, a FUCVAM Cooperativa Mesa 2, a ex-casa de Almícar Vasconcellos (Partido Colorado), o Puerto de Montevideo, o Semanario Jaque, o Penal de Punta Rieles, o Edificio de los Conventuales, o Batallón de Infantería N.13, o Servicio de Materiales y Armamiento, a Dirección Nacional de Información e Inteligencia, e a ex-Carcel de Mujeres de Cabildo.

Na comemoração dos 40 anos do golpe, começaram, enfim, os trabalhos de instalação dessas marcas, no conjunto do que se chamou de Recorrido de la Memoria (CAPELLI, 2013). A ideia da comemoração era fazer um passeio por diferentes pontos de Montevidéu, durante o mês de junho de 2013, para mostrar à sociedade onde estariam essas Marcas de la Resistencia a serem inauguradas. ${ }^{123}$

Nesta comemoração, o MUME tornou-se parte do Recorrido de la Memoria, promovendo visitações em seu espaço e duas exposições itinerantes que marcariam a cidade com intervenções artísticas. A primeira, realizada no ex-Servicio de Inteligencia de Defensa (SID), atual sede da Institución Nacional de los Derechos Humanos, foi intitulada como El brillo de tu mirada e formulada pelos artistas argentinos Cristina Piffer e Hugo Vidal e pelo uruguaio Clemente Padín.

O edifício da ex-SID, como vimos, um dos símbolos do Sistema Condor, na cidade de Montevidéu - nele, nasceu Macarena Gelman e estiveram presos os irmãos argentinos Victoria e Anatole Julien -, teve parte de sua estrutura coberta com reflexos de espelhos, levados e colocados pela população, que o iluminavam. A intervenção fazia, assim, uma analogia à necessidade de recuperação da memória da história de horror uruguaia. A mesma

\footnotetext{
${ }^{122}$ Cf. Capítulo 2: "Justiça Transicional e Transnacional".

${ }^{123}$ Em setembro daquele ano, a primeira marca é estreada no Estádio Luis Franzini, lugar onde ocorreu a primeira grande manifestação em favor da abertura democrática (em 25 de setembro de 1983), organizada pela Asociación Social y Cultural de Estudiantes de Enseñanza Pública. E, ao longo do ano, inauguraram-se placas na ex-sede da Federación de Obreros de la Industria del Vidrio (onde iniciou-se a greve geral de 27 de junho de 1973), no Obelisco a los Constituyentes (onde houve outra manifestação pela restituição democrática, em 27 de setembro de 1983), na AEBU, e no Palacio Lapido (onde funcionou o diario El Popular, publicação do Partido Comunista, enclausurado em 29 de novembro de 1973).
} 
proposta já havia sido realizada, na ex-Escuela de Mecánica de la Armada, com auxílio de Daniel Sanjurjo. E, segundo Piffer, durante essas intervenções,

Se van acumulando situaciones, testimonios, la gente se acerca, se producen situaciones de diálogos, invitamos a escribir. Es una experiencia que nos dará distintas sorpresas, particulares de cada lugar (...) Se pide a las personas que traigan espejos e intentamos hacer reflejos sobre fachadas oscurecidas por la historia, ensombrecidas por quienes actuaron allí. 'El brillo de tu mirada' es un trabajo poético por el que tratamos de rescatar el brillo de aquellos que sufrieron la represión (PIFFER apud RODRÍGUEZ, 2013, sem paginação).

Imagem 49 - El brillo de tu mirada

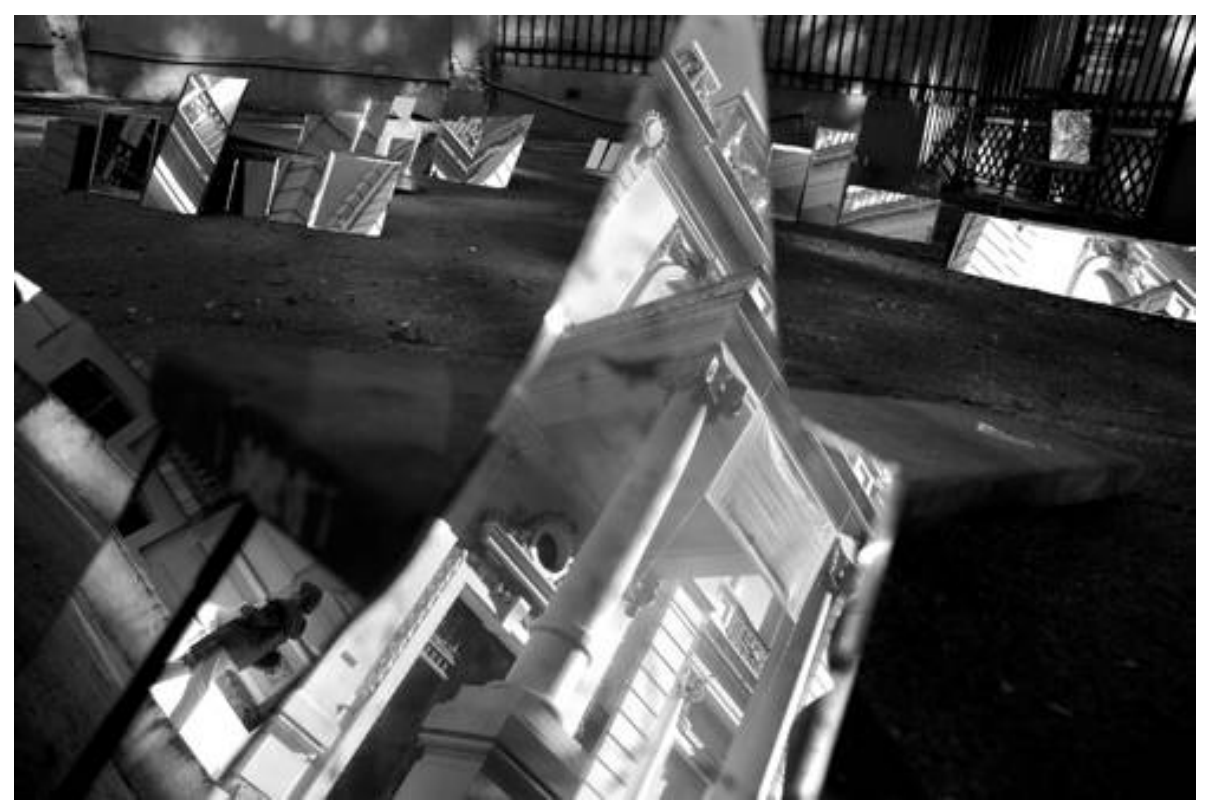

Fonte: ARCHIVO DE PABLO NOGUEIRA. Disponível em: <http://revista.escaner.cl/node/6940>. Acesso em: 27 jun. 2017.

A segunda integração do MUME, no referido Recorrido de la Memoria, foi através da promoção da mostra fotográfica $40^{\circ}$ aniversario del Golpe de Estado y la Huelga General, junto ao Centro de Fotografia de Montevideo. As imagens exibidas nessa mostra fazem parte do arquivo pessoal do fotógrafo Aurelio González e de um arquivo encontrado nos anos 2000, no edifício do diário El Popular, que, como vimos, foi marcado pelo projeto Marcas de la Resistencia. A ideia da mostra era "transmitir a cidadania" com imagens que fazem parte do imaginário popular sobre a greve geral de 1973 e sobre a resistência uruguaia em suas mobilizações contra a ditadura. Essa exposição, posteriormente, foi realizada em outros lugares na cidade de Montevidéu e pelo país, conformando-se em um símbolo para a construção do imaginário sobre essa greve. 
Portanto, com o projeto Marcas de la Resistencia, o Museo de la Memoria iniciou uma atuação para além de suas limitações espaciais e se inseriu, mais profundamente, na dinâmica de constituir uma identidade fundamentada na resistência ditatorial. O projeto segue em andamento, rompendo o silêncio em torno dessas memórias, e expandindo-se para diversas localidades no país.

\section{4 - Os caminhos percorridos: Debates rio-platenses}

Nos perguntamos aqui quais foram os debates e as temáticas trazidas, nesses intercâmbios de ideias e exposições para a conformação dos territórios de memórias, nas cidades de Buenos Aires, Montevidéu e Assunção. Dentro dessas discussões, percebemos alguns pensamentos em torno das instituições a serem criadas e seus objetivos, com dimensões nacionais e internacionais.

Ao observarmos o longo debate suscitado para a criação do Espacio para la Memoria y Promoción y Defensa de los Derechos Humanos, notamos temas transversais que foram se adaptando, de acordo com o cenário político e o contexto social do país. Através de palestras e dos depoimentos recolhidos por Memoria Abierta, verificamos um questionamento sobre os territórios de memória, casos transnacionais e propostas para um lugar dedicado à transmissão e transformação da memória coletiva argentina.

As jornadas "Organización institucional y contenidos del futuro museo de la memoria" trouxeram questões iniciais em torno dos objetivos para se constituir um território de memória, nos finais dos anos 1990. Em um contexto, cuja luta dos organismos de direitos humanos ainda era buscar a solução para a impunidade e abrir espaços para as vozes silenciadas, fica evidente que os debates entre memória e sua consolidação em um espaço público passam pelo entendimento sobre a resolução de reparações penais e simbólicas às vítimas.

Uma das propostas levantadas nas Jornadas foi a de se construir um museu pela noção do Nunca Más (ou o tomando como ponto de partida para se contar uma história da memória), na medida em que se considerou o Nunca Más um modelo de memória exemplar que se expandiu globalmente, em outras experiências e tempos. Para o museu do Nunca Más a proposta seria, então, contextualizá-lo, enquanto evento específico, e também trazê-lo como mote de uma memória narrativa que tem como objetivo final a educação para a não repetição das catástrofes. 
Outra proposta, nesse final dos anos 1990, foi a construção de um museu que abordasse o genocídio, enquanto fio condutor da narrativa, e com um projeto que rompesse com o "sinistro do horror", conectando-o, pois, a outras dimensões, cuja prática genocida se torna responsável, enquanto causas e consequências para as sociedades. Assim, o tema aparece nas discussões, questionando a legitimidade de um modelo sistemático de violência para implementar políticas econômicas.

Admite-se a responsabilidade social, que já havia sido trazida desde Primo Levi (2016), quando fala sobre um "universo concentracionário aberto", e desconstrói-se o argumento de "desconhecimento coletivo" da violência estatal, que, na Argentina, foi delineado nos anos 1980. Por outro lado, trazer o genocídio para o debate, significava também explorar a dimensão das ações desumanas por parte de setores econômicos que apoiaram o sistema de extermínio em prol do lucro.

Com a proposta de tratar o Terrorismo de Estado do país como parte de uma prática social genocida, inúmeros exemplos de territórios de memória aparecem nas argumentações para se trabalhar a memória do país. O que "se fazer ou não se fazer" dão às falas, não apenas imagens de lugares exitosos na construção de memórias, em todo o mundo, como também, ideias para transmissões das memórias traumáticas ao público.

Em ambos os casos propostos, museu do Nunca Más ou do genocídio, vê-se a recuperação da memória das vítimas argentinas, enfatizando o campo do desaparecimento, com fins de criar-se uma memória exemplar, tal como colocado por Tzvetan Todorov (2013). Isto significaria trazer a memória individual (ou de um grupo social específico) ao público, analisando causas e consequências, no passado e no presente, e estabelecendo uma associação entre situações análogas das experiências argentinas. E, como vimos, o próprio projeto do Espacio para la Memoria torna-se, ele mesmo, um exemplo para se pensar e trabalhar as memórias regionais.

Neste sentido, estes modelos de trabalhos da memória exemplar apareceram, naqueles debates, com o objetivo de encontrar uma solução à necessidade de sensibilização do outro frente às lutas pelos direitos humanos. Esta sensibilização se daria através de exposições das memórias silenciadas e das emoções provocadas pelos sentidos humanos, a "poesia" que traduz os elementos do horror, tal como propôs Américo Castilla (apud MEMORIA ABIERTA, 2000).

Portanto, o fio condutor desse debate é a necessidade de sensibilizar a sociedade em prol da verdade e da justiça para as vítimas, no cenário argentino. A memória narrativa proposta, trabalhada com afetividades e políticas em espaço público, precisava trazer uma 
resposta ao contexto que silenciava este setor social. Porque era a vítima, em sentido de todos os afetados pela ditadura, quem deveria estar representada no território de memória. E, assim, a resistência, tanto na perspectiva das memórias, quanto sobre as políticas de direitos humanos, ganha esse espaço de fala.

As discussões sobre "El Museo que queremos" vêm em outro contexto do país, que se pode dizer vitorioso, depois de anos de percalços jurídicos, que impossibilitaram o avanço concreto na exposição das memórias das vítimas em espaço público. Retomando a temática da responsabilidade social pelo Terrorismo de Estado, essas discussões trouxeram, não apenas o questionamento sobre legitimidades, mas também, a postura de determinados atores que seguiriam observando acriticamente o modelo ditatorial e, portanto, continuariam aplicando sistemas de poder, que rompem com os direitos humanos.

Essa "nova entrada" na discussão sobre responsabilidades estende a visão de violações ao presente e trabalha com um território de memória, que pretende transformar a memória coletiva para auxiliar na transformação da própria sociedade. É evidente que o contexto latino-americano, a partir do início dos anos 2000, demonstra a falência de um Estado neoliberal que aprofundou as desigualdades dentro do território, e que também repercutiu nessa discussão.

Neste sentido, os debates sobre o futuro museu são penetrados pelas representações do horror no patrimônio e a missão educativa do mesmo. Isso significa que, este território de memória, deveria ser uma resposta social ao genocídio argentino do passado e à pobreza do presente, que é fruto da continuação de um projeto político-econômico para a região latinoamericana. Com essa dimensão crítica sobre o passado e o presente, o futuro museu seria retirado do sistema de comercialização cultural das memórias ou do "turismo do horror" e emancipado de uso cultual da memória desse passado recente.

Também vimos nesses debates, exemplos de transformações de espaços, em outros países, que ativaram memórias silenciadas socialmente, com a finalidade educativa para a tomada de consciência. Assim, o ponto crucial desses exemplos trazidos ao público foi mostrar as diferentes dinâmicas de reconstrução, restauração ou apropriação de representações, cujas ruínas metafóricas (BENJAMIN, 2014), tiveram seu dever de memória pela criação de uma narrativa fundamentada na transformação social e na resistência aos modelos precedentes.

Os depoimentos individuais, por fim, nos despontaram outras perspectivas sobre o território em questão. As entrevistas, realizadas em um contexto de atendimento das demandas de organizações de direitos humanos para políticas de memórias em níveis estatais, 
elaboraram sugestões das próprias vítimas para o espaço da ex-ESMA. Apesar de entendermos as divergências presentes - defesa de destruição dos edifícios, da construção de uma produção econômica e cultural dentro deles ou da representação simbólica do terror -, elas possuem uma linha condutora comum, que é a de representação do detido-desaparecido (circunstancial ou permanente) naquele ex-Centro Clandestino, símbolo da repressão no país.

Utilizando-se, principalmente, dos lugares de memória exemplares alemães, aqueles depoimentos falaram-nos sobre a globalidade de projetos de memórias em espaço público. No entanto, também abordaram a especificidade do espaço da ex-ESMA, através de seus detidosdesaparecidos. Uma das falas mais marcantes, neste sentido, é a de que o detido-desaparecido é problema de todos, ou seja, o projeto de museu deveria estar voltado para o conhecimento social desse problema, a partir das narrativas das vítimas.

O caso paraguaio também traz intensamente essa dimensão do uso das memórias do âmbito global como exemplos para se realizar no país. A visita técnica executada pela Comissão alemã, que modificou as estruturas do Museo de las Memorias, fez relações comparativas bastante óbvias entre o nazismo e a ditadura paraguaia.

Primeiro, a comparação das funções dos edifícios da ex-La Técnica e do NS-Dok justificou a utilização dos mesmos como territórios de memória, propondo uma reconstituição com estruturas bastante similares. Neste sentido, retirou-se algumas discussões específicas do país, como a repressão aos trabalhadores rurais ou o genocídio das populações indígenas, propondo uma narrativa fundamentada nas vítimas, essencialmente detidos-desaparecidos políticos.

A recuperação das celas, como o monumento principal do Museu (uma recuperação que é mais do que uma restauração, é uma reprodução do ambiente), é uma nítida referência ao NS-Dok, em Colônia, e sua própria recuperação das celas e inscrições na prisão temporária nazista. Portanto, a relação entre ambas instituições, definida pelas funções das mesmas, em épocas de violações, demarcou um trabalho sobre as memórias das cárceres específicas, ao invés de memórias sobre as vítimas da ditadura paraguaia, amplamente debatidas, desde a Comisión de Verdad y Justicia.

Depois, como "exemplo metodológico", intenta-se configurar junto ao Museo de las Memorias um arquivo que, além da documentação integrada com o Archivo del Terror, pudesse produzir uma documentação oral com os testemunhos das vítimas, tal como o NSDok. Contudo, a relação entre Arquivo e Museu, no caso paraguaio, dá-se em uma dimensão intrínseca, uma vez que as existências de ambos se rementem à mesma demanda judicial pelo “encontro" com os documentos paraguaios, nos anos 1990. Ao contrário do que ocorre na 
Alemanha, onde o arquivo é construção posterior à "descoberta" do território de memória, o arquivo no Paraguai é a luz lançada sobre essa memória.

Fato é que a visita técnica alemã possibilitou que a perspectiva local e regional sobre a ditadura paraguaia se expandisse para uma visão global de catástrofes humanas. Percebendo a necessidade mundial de se criar espaços para representar uma cultura de paz, a visão internacional dos direitos humanos ingressa na narrativa do território, a partir desse ano de 2007.

Logo, uma dimensão bastante discutida é a dupla função destes tipos de patrimônio sensíveis, em suas características de serem parte de circuitos turísticos, ao mesmo tempo que são lugares de educação. Se, por um lado, a negatividade sobre a indústria cultural e a reprodução define algumas análises sobre territórios de memórias, no caso paraguaio, influenciado, então, pela dimensão europeia sobre o turismo, ela torna-se uma das formas de sobrevivência do próprio território que não possui auxílio financeiro estatal. Por outro lado, as funções primordiais de constituição de uma cultura democrática e de intenção educativa em matéria de direitos humanos permanecem, através da máxima da "não repetição" e pelas numerosas campanhas pela educação, levantadas pelo Museu e demais organizações.

Por fim, percebemos que a marca fundamental da memória sobre a ditadura paraguaia é a sua integração no Sistema Condor, possivelmente pela história da memória, fundamentada no encontro com os arquivos e no que eles representam nas lutas pelos direitos humanos. Podemos ver, por exemplo, a conexão que se realiza com a luta argentina, vendo-a como exemplo nas questões judiciais, inclusive acessando a sua justiça para obter justiça local. Ou, nos discursos sobre a responsabilização do Brasil pelos empecilhos colocados à justiça para se trasladar Stroessner. Portanto, essa marca da regionalidade se encontra nas memórias do passado e nas responsabilizações por ele.

A dimensão regional e global também pode ser observada no caso uruguaio. A luta contra a desmemória uruguaia, marcada pela constante reafirmação de um projeto político de "reconciliação nacional", rompe com o silêncio social, a partir de quatro elementos fundamentais, que se complementam: 1) a ascensão de um governo que dialoga, timidamente, com as organizações de direitos humanos; 2) a irrupção de discussões em torno das comemorações aos 40 anos do golpe; 3) a associação ativa por parte da Universidad de la República para realizações de projetos; e 4) a permanente pressão dos organismos de direitos humanos para afirmar sua narrativa em espaço público.

No caso do Museo de la Memoria, percebemos discussões que, a partir do universo global de instituições de memória, principalmente em diálogo com a América Latina, trazem 
para o local, a necessidade de abrir um espaço, onde se possa inserir o passado recente na história do país. Neste sentido, faz-se intercâmbios com as experiências argentina, chilena, paraguaia e etc., além da abordagem dos casos da memória do Holocausto, na Europa, tentando justificar a necessidade daquele espaço também no Uruguai.

O elemento considerado determinante na justificativa para acompanhar esse processo global de trabalhos da memória (e talvez particular dessa discussão) é a construção de uma identidade nacional que, ao invés de perpassar a reconciliação acrítica sobre a história, seja conformada justamente na luta contra as violações no país e pela democracia. A constituição de um museu que fale sobre identidade foi um argumento rechaçado pelo debate argentino, considerando esses espaços pedagógicos sobre identidade nacional delimitadores da diversidade humana.

No entanto, esse elemento de identidade, no Uruguai, justifica, não apenas a necessidade de se falar em uma violação interna dos direitos humanos, mas incorporá-la em um contexto mundial de violações, para que, através da crítica ao processo, se possa conformar uma sociedade que entenda seus direitos e promova a justiça social. Logo, a exposição citada, por exemplo, é o modelo de narrativa sobre a conexão entre as repressões extrafronteiras.

Utilizando-se de diversos instrumentos para elaboração dessa narrativa ao público, ela pôde abranger as formas de repressão e os conflitos (individuais e continuados) por (re)conhecimento sobre os detidos-desaparecidos. No entanto, a dinâmica individual se rompe, quando, a partir dos elementos expostos, traz-se a reflexão sobre os direitos humanos, os Centros Clandestinos de Detenção, o Sistema Condor, os traslados ilegais para a repressão e etc. Enfim, todas essas trajetórias e problemas embutidos na narrativa sobre as demais vítimas das violências estatais, para além dos desaparecidos em si.

A mesma ideia de identidade está presente no projeto Marcas de la Resistencia, que, como vimos, engloba o MUME. Contudo, este projeto visa, especialmente, permitir a observação e pensamento sobre as resistências, na cidade de Montevidéu. Resistências que, ao mesmo tempo em que são fluidas e frutos de negociações, fazem parte de um delineamento mundial sobre memórias - e que também aparece no contexto argentino, referenciando-se à resistência contra a impunidade, e no contexto paraguaio, com a escolha da denominação de luchadores e luchadoras contra a ditadura e pela democracia.

Apesar da resistência à reconciliação nacional, fundamentada no esquecimento, estar presente nos debates dos três países de análise, para o caso uruguaio, ela aparece de maneira enfática, através da proposta de constituição de uma identidade nacional. Enquanto na 
Argentina e no Paraguai procura-se combater sistemas político-econômicos, baseados no esquecimento, no Uruguai a luta contra o esquecimento parece ser a de cristalizar a identidade nacional pelo conceito de "ser resistente".

Existe a possibilidade de percebermos este mesmo conceito de maneira positiva, como uma estratégia dos organismos de direitos humanos para abrir espaços públicos destinados à falar sobre violações cometidas no país. Neste sentido, essa ideia pode haver reconquistado um espaço público perdido, em nome de uma determinada reconciliação nacional. Ou, por outro lado, perceber a falta de flexibilidade das resistências, com um modelo de engessamento pela identidade, que apaga as disputas, as diversidades e as responsabilidades. 


\title{
CONCLUSÃO
}

\section{A IDENTIDADE DO RIO E SUAS CONFLUÊNCIAS}

\begin{abstract}
Sí, la vida es eso, por muy atrás o muy delante que se mire, y aún sobre el ciego presente. Una terca llama en el barbacuá de los huesos, esa necesidad de andar un poco más de lo posible, de resistir hasta el fin, de cruzar una raya, un límite, de durar todavía, más allá de toda desesperanza y resignación (ROA BASTOS, 1960, p. 114).
\end{abstract}

Quando Augusto Roa Bastos lança o seu primeiro romance Hijo de Hombre, que se complementaria, posteriormente, com Yo, el Supremo (1974) e El fiscal (1993), a ditadura stronista já havia sido instituída no Paraguai, país de nascimento do autor. Defendendo uma "literatura militante da realidade humana", iniciada com sua poesia, Roa Bastos ingressa nessa empreitada de escrever sobre o homem comum, marginalizado e ignorado pela sociedade, reconhecendo suas sabedorias, suas tradições e suas memórias como parte central da identidade de um país.

Neste sentido, o autor descreve, no romance específico, uma narrativa complexa que envolve uma série de personagens corriqueiros, em duas localidades rurais paraguaias, com saltos temporais que vão desde o início do século XX até a Guerra do Chaco contra a Bolívia (1932-1935). As temáticas dos enredos das histórias, entretanto, permeiam a mentalidade desse interior paraguaio e seguem como problemáticas na estrutura social do país: a pobreza, a (des)esperança, o sofrimento com as guerras e violências, o autoritarismo de um governo central, a dependência de uma política clientelista, o respeito amedrontado pelos "poderosos da região". Tendo ele mesmo sido fruto de exílios forçados durante sua vida (fugiu da ditadura paraguaia, depois seguiu para a França, escapando do contexto ditatorial argentino), o autor retrata os êxodos dessas populações, desejosas de um futuro melhor, que surgem na narrativa como a válvula de escape, produzida pela crítica ao cotidiano do meio rural, ou pelas expulsões, fundamentadas nas produções econômicas do país.

Interessante é perceber que sua literatura faz inúmeras referências sobre a influência do exterior no Paraguai (ora retratado como o "Supremo" - esse personagem paraguaio autoritário, que comanda a ordem social na localidade, beneficiando-se política e economicamente do trabalho dos demais - ora através da mentalidade de uma população influenciada pelo que poderíamos chamar de "imperialismo cultural" (SAID, 2011), desde a colonização que subjugou a população indígena e que perdura na realidade do país, até esse novo/velho imperialismo estadunidense e de países vizinhos de seu território). Um curioso exemplo é a história da passagem do cometa Harley, em 1910, que entrelaça diversas histórias 
no livro e cuja espera por esse "ser exterior desconhecido" ocasiona, em uns, a esperança de um recomeço para a construção de um país melhor (e, em muitos sentidos, esse sujeito externo é considerado potencial "civilizador" da sociedade), enquanto, em outros, ele traz o medo da destruição, ou mais uma destruição sob a referência da própria história paraguaia.

No entanto, é o homem comum quem ganha voz nessa narrativa. Aquele que fala Guarani relata suas experiências e vivências de dor e rebeldia nos diversos contextos. E, desta forma, o personagem Macario (um dos exemplos dessa cultura do interior paraguaio) compara a humanidade ao rio, um rio que expressa os sentimentos e as características humanas: ele tem barrancos e costas e nasce e desemboca em outros rios (ou em outros homens com outras experiências). E, ainda, retrata rios considerados ruins, "maus", aqueles que terminam em pântanos, comparando-os com os sujeitos que reproduzem as lógicas da violência e da dominação (ROA BASTOS, 1960, p. 11-46).

Essa tese pretendeu trazer esta identidade do homem, fundamentada no rio, mais especificamente no espaço imaginado do Río de La Plata e suas confluências ${ }^{124}$. Com águas fluidas, que cruzam com outras águas, abordamos as construções de memórias de uma região, que foram se conectando, ganhando e perdendo forças, em cada contexto local e global, formando, então, um princípio da história da memória regional que baseia a identidade rioplatense.

É claro que a identidade desse rio é muito maior do que fora possível realizar com este estudo. O que conseguimos aqui foi observar um pequeno afluente, se podemos fazer este tipo de metáfora. Um braço que, ao escolher o diálogo sobre as memórias de violência, conectadas pelo Sistema Condor e pelas ditaduras na Argentina, no Paraguai e no Uruguai, deixou à parte diversas outras histórias desse rio. Um braço, entretanto, que cresce e se torna visível, com o passar do tempo e com a possibilidade de consolidação de uma memória coletiva, baseada nas vítimas, intentando romper com os pensamentos autoritários em cada um desses países.

Desta forma, o diálogo aqui construído pretendeu abordar a história da memória com três elementos (ou níveis) de conexão entre o espaço imaginado: a luta pelos direitos humanos, os espaços públicos criados por essa luta e os conceitos utilizados por ela. No que tange à luta pelos direitos humanos e suas transformações, ao longo do tempo, intentamos conectar pensamentos globais que, a partir de finais dos anos 1940, vão integrando os debates locais sobre direitos universais para a humanidade - o direito à vida, os direitos políticos $\mathrm{e}$

\footnotetext{
${ }^{124} \mathrm{Na}$ Geografia, a confluência é o encontro dos cursos de águas.
} 
civis, o direito à dignidade, ao ser livre e a ter pensamentos livres. Assim, nosso braço do rio desemboca no mar.

Mas seu fluxo não tem direção única; essas águas têm movimentos recíprocos. Isto significa, por um lado, que os direitos universais não são estáticos, pois, a própria luta, fundamentada nas memórias de violações e nas interpretações dadas a elas, em todo o mundo, modifica estruturas mentais, políticas, legais e culturais sobre esses direitos. E, desta maneira, eles precisam ser vistos, já que os contextos presentes (inclusive de permanência de violações contra os homens) nos apontam questões de aprimoramento e adequação de acordos internacionais e de práticas contundentes na luta pelos direitos humanos.

Caso não fosse dessa forma, a crítica sobre a estrutura desses direitos e sua formação, fundada na não abrangência da diversidade humana, estaria correta (SOUSA SANTOS, 2007). É fato, como vimos nas páginas anteriores, que eles (os direitos humanos enquanto discursos) foram (e continuam sendo) utilizados também para praticar violações - violências contra a liberdade, a democracia, a vida e etc., que não são vistas como "apropriadas" por um mundo permeado de hierarquias. E isto deve ser pontuado, quando se elabora um estudo sobre os direitos humanos, porque os discursos são apropriados por pessoas em estruturas e contextos sociais, econômicos e políticos.

Por outro lado, ao pensarmos na dinâmica dos direitos humanos, o fluxo local se encaminha também para as discussões globais. Logo, diversos autores apontam a necessidade de repensar esses direitos, em cada contexto, para que suas práticas se tornem efetivamente universais. Lynn Hunt (2009), por exemplo, nos sugere a necessidade da eterna vigilância de direitos adquiridos por lutas cotidianas, em diversas localidades, que estão sempre em perigo de serem retirados. E, por isso, enfatiza a dinâmica da militância e de seus pensamentos.

Assim, como vimos, os anos 1980 em diante são marcantes nos debates globais sobre violações e novas estratégias para representá-las no espaço público e em favor dos direitos humanos. As memórias sobre o Holocausto acenderam uma chama sobre a necessidade de construir espaços para se falar sobre as vítimas e legitimar suas experiências. O fim da União Soviética trouxe debates sobre a alternativa socialista e suas práticas, assim como também fomentou um (falso) discurso de que o capitalismo seria a "alternativa única" para o modelo democrático. Os diversos genocídios fizeram repensar os imperialismos, dominações e suas formas, dentro do modelo capitalista, que possibilitaram massacres e eliminações de inúmeros povos. As saídas das ditaduras no Cone Sul ampliaram as críticas sobre a conexão entre o poder político e econômico e os métodos de repressão, incluindo métodos ainda (naquele momento) não abordados por acordos internacionais, como o caso do desaparecimento 
forçado, uma prática cotidiana da repressão latino-americana. As guerras (de fato ou ideológicas) alimentaram ódios entre nações e entre nacionais, que impossibilitaram a autodeterminação dos povos e suas escolhas livres para modelos de governabilidade.

$\mathrm{E}$, desta maneira, os direitos humanos vão se conectando às memórias, tornando-os propostas de ações no cotidiano, que se auto-alimentam (HUYSSEN, 2014). Primeiro, pela ideia de que os direitos humanos se constituem como auto-evidentes (HUNT, 2009); autoevidentes no sentido de que sabemos o que são violações aos direitos humanos, porque tivemos experiências precedentes recordadas no espaço público. Depois, porque as memórias sobre as violações justificam-se em favor de uma educação em matéria de direitos humanos, concebendo a ideia de não repetição, regionalmente imaginada e mundialmente conhecida como Nunca Más.

Adentramos, então, no segundo nível de discussão desse trabalho, que foi caracterizado pelos espaços públicos de nossos casos de estudo (Argentina, Paraguai e Uruguai), dedicados às construções de memórias. Determinados aqui como territórios de memória (NORA, 1989 e CATELA, 2001), pretendemos em cada exemplo trabalhado trazer algumas dinâmicas (sabemos que limitadas e parciais) de construção e consolidação desses espaços, assim como algumas interpretações sociais dadas a eles e as consequências nos cenários nacional e internacional.

Os primeiros exemplos analisados foram os casos movidos dentro do Sistema Interamericano de Direitos Humanos (SIDH), considerando-o como uma estratégia utilizada, desde as ditaduras, para se falar e denunciar violações do contexto regional. Com um papel de “mediadoras" entre as demandas das vítimas e um Estado responsável por violar os direitos humanos, a Comissão Interamericana de Direitos Humanos e a Corte Interamericana de Direitos Humanos intermediaram conflitos e propuseram medidas para solucioná-los, quando consideraram que não havia métodos internos que pretendiam resolvê-los.

Nos contextos ditatoriais, mais especificamente, o SIDH foi palco de denúncias, que não encontravam lugares nos países de origem, fazendo com que o mundo conhecesse as práticas repressivas regionais vigentes - seus desaparecidos, seus presos por motivos políticos, as torturas nas prisões, as mortes e os genocídios étnicos. A negativa dessas práticas pelos Estados era recorrente, apontando alguns "excessos" a serem "corrigidos internamente" e adotando um discurso de defesa dos direitos humanos e da democracia, quando se lutava contra o inimigo comum do continente: o sujeito amplamente designado como comunista.

Essa inversão dos valores dos direitos humanos é fundamentada em uma ideologia apoiada (de modo geral) internacionalmente até os anos 1980. A partir de então, e com o 
período de transição à democracia, esse "discurso invertido" é suspendido - suspendido no sentido de que ele é retomado de distintas formas, em contextos específicos, até os dias atuais - e o SIDH passa a ser o cenário que agrega denúncias do passado violador, intentando reparações, às resistências diante de um possível esquecimento social do mesmo, adotado em nome das políticas de "reconciliação nacional".

Com os distintos exemplos trabalhados, podemos perceber que o SIDH impulsiona o diálogo entre a sociedade e o Estado, mesmo que não haja a vontade política de abrir espaços para as demandas das vítimas. Primeiro, porque os Estados passam a ser "vigiados" internacionalmente e necessitam se posicionar por suas violações. Depois, porque os responsáveis pelas denúncias, em dimensões internacionais, ganham um instrumento de luta nessa posição desigual entre violadores e vítimas e, de certa forma, um espaço legítimo para serem ouvidos (LACAPRA, 2009).

Os segundos exemplos analisados, nesse trabalho, de disputas e constituições de memórias em espaços púbicos foram as Comissões de Verdade, nos seus distintos contextos de conformações e produções. Percebemos as diferentes estratégias de constituições de espaços de legitimidade para as narrativas das vítimas e como elas foram trabalhadas socialmente com as divulgações de seus informes.

Desta forma, observamos o modelo exemplar argentino e seu mote Nunca Más, expandindo-se nacional, regional e globalmente. Com uma dinâmica intensa, incluindo discussões que vão para além de seu tempo de produção, a sociedade argentina que, em um primeiro momento, teve de enfrentar os debates sobre a repressão específica do país, ao longo do tempo foi agregando discussões sobre regimes autoritários em todo o mundo e ampliando o discurso pela defesa dos direitos humanos.

Também apontamos a diferença do modelo paraguaio que, com uma estrutura criada em debates inseridos no contexto neoliberal da América Latina, já produziu argumentos de ampliações das vítimas e das violações, considerando tanto as especificidades do país (nos casos do interior rural e das comunidades indígenas), quanto sua inserção na hierarquia da economia mundial (nos casos sobre o Sistema Condor e de dinâmicas de apropriações de terras por parte de estrangeiros). Com experiências de governos adversos às políticas sobre direitos humanos, o espaço da Comissão tornou-se um espaço de resistência na conjuntura de justiça transicional e tornou-se (ou dever-se-ia tornar) um exemplo de combate nas lutas pelos direitos humanos.

Para o caso uruguaio, a forma de se romper com a justiça transicional, fundamentada na Ley de Caducidad, a partir da Comissão, esteve na revisão das estratégias de luta e na 
confluência entre os interesses dos movimentos de direitos humanos, dentro da Universidad de la República, com o governo nacional, a partir do governo da Frente Amplia. Por um lado, discutiu-se a possibilidade de investigar crimes possíveis dentro de uma legislação de anistia (o desaparecimento forçado e as mortes, cujos responsáveis são civis). Por outro, estendeu-se essa investigação (no espaço acadêmico) para outros campos, incluindo crimes de outras naturezas e ocorridos no território regional. Portanto, de alguma maneira, a luta dos organismos de direitos humanos conseguiu ingressar no cenário de esquecimento pretendido oficialmente pelo sentido de "pacificação nacional", e construiu um conhecimento sobre a verdade das vítimas e a possibilidade de reparações.

Concluímos, desta forma, que as Comissões de Verdade conseguiram, em suas distintas formas, responsabilizar os Estados pelas violações aos direitos humanos, dando voz às vítimas e concebendo, em si mesmas, uma maneira de repará-las. Também colocamos como fundamental essa produção de conhecimento, com o aval do Estado (ou apesar de), para trabalhar a memória coletiva sobre os passados recentes e divulgar e reconhecer as suas próprias práticas de violações - o que não significa o impedimento de que as violações aos direitos humanos continuem ocorrendo (JELIN, 2013).

Por fim, trabalhamos com os espaços públicos dedicados à educação para/sobre os direitos humanos, em três cidades de nossos casos estudados: Buenos Aires, Assunção e Montevidéu. Objetivamos discorrer, mais especificamente, sobre seus debates de criações, ideias e exposições, que abarcassem esse intercâmbio sobre a relação entre memória e direitos humanos, fundamentando atividades dentro desses espaços.

Desta forma, estabelecemos conexões e disjunções de objetivos e posições de abordagem entre o Espacio para la Memoria y Promoción y Defensa de los Derechos Humanos (Argentina), o Museo de las Memorias: Dictadura y Derechos Humanos (Paraguai) e o Museo de la Memoria (Uruguai). Em todos os três exemplos, fomos capazes de perceber um diálogo local, que se utilizou das dinâmicas regionais para fundamentar suas criações, e o uso de outros espaços em níveis mundiais como modelos de memórias exemplares (TODOROV, 2013) para a conformação de projetos internos.

$\mathrm{Na}$ relação da dupla memória-direitos humanos, observamos o crescimento da afirmação sobre a necessidade de se estabelecer políticas locais de memória, que anseiem pela não repetição de violações, através do conhecimento. Um conhecimento de violações especificas de cada local que, no entanto, fazem sentido pelas violações e contextos regionais. E estes, por sua vez, abarcam o conhecimento sobre as violações e exemplos de territórios de memória em nível global. 
Neste sentido, fica claro o ingresso na válida crítica sobre a apropriação das representações do horror ou a criação mercadológica (principalmente, dentro de uma relativamente nova indústria do turismo), que percebe, no público desses territórios de memória, potenciais consumidores dessas "histórias da barbárie" (HUYSSEN, 2014). No entanto, os casos de constituições de Museus e Centros Culturais de memórias traumáticas e suas representações das vítimas e das práticas de violações aos direitos humanos têm potenciais e objetivos maiores, cuja pretensão é a educação em si e o conhecimento sobre as histórias de violências humanas. Todos os casos estudados trazem a ideia principal de "romper" com o passado; poder mostrá-lo para "lançar luz" sobre catástrofes, tal como proposto por Walter Benjamin (2012).

Assim, majoritariamente as discussões sobre esses territórios rio-platenses passam pelo ato de "como mostrar" o passado recente para que a sociedade possa reconhecer as violações no presente e se engajar em uma luta por um futuro melhor. Essas representações do horror encontraram mediações diversas, que levaram em conta as experiências de "sucesso" precedentes. E o caso exemplar, em nível mundial, é a abordagem dos patrimônios relativos ao Holocausto e a Segunda Guerra Mundial, que aparecem nos debates como experiências a serem observadas, justamente pela mobilização em número de pessoas que visitam estes tipos de territórios de memória.

Para escapar da crítica sobre a amenização dos sofrimentos nos espaços públicos, a fim de garantir um papel mercadológico dos mesmos, pensamos na proposta de Néstor Canclini (2015), que aponta uma saída para a análise do tipo de consumo que está proposto nessa indústria cultural e do turismo, por um lado, e, por outro, a circulação possível desse conhecimento, através do próprio consumo mundial. Este último ponto foi a ênfase do trabalho, que pôde perceber, de certa forma, como o modelo exemplar alemão e estadunidense sobre as temáticas das vítimas do nazismo (obviamente, dentro de uma hierarquia cultural, que não pode ser deixada à parte) circulam no imaginário transnacionalmente.

Com essa circulação, percebemos que todos os nossos casos de estudo utilizaram os modelos de memórias exemplares em seus debates; ora para enfatizar a crítica do consumo, ora para observar suas produções de âmbito cultural. E, nesse sentido, eles se preocuparam em enfatizar uma dinâmica educativa, que pudesse, além da exposição da história local, refletir junto à comunidade sobre a violência, como um todo, e os direitos humanos com exposições, palestras, visitas guiadas e etc., dentro ou fora (como especialmente no caso uruguaio) daquele espaço público criado. 
Desta forma, ingressamos em nosso último nível de análise, que percorreu o caminho dos conceitos utilizados nessa luta pelos direitos humanos na região. Os dois conceitos aqui considerados como mais evidentes são as práticas de desaparecimento forçado e o genocídio.

Observamos que o desaparecimento forçado (GATTI, 2011), considerado na sua amplitude entre o desaparecido circunstancial (aquele sujeito do qual o Estado omitiu seu direito de "estar em um lugar e em um tempo") e o desaparecido permanente (o campo capaz de englobar as representações, as lutas, as vítimas, os familiares e etc. dessas violações do Cone Sul), tem sua origem nesse território rio-platense e se expande, enquanto violação para o mundo, a partir dele. Ele foi e segue sendo o integrador das lutas na região, o que, por um lado, dá força ao argumento de observar essas ditaduras como um projeto político, econômico e cultural regional, e, por outro, desintegra as especificidades das repressões em cada localidade.

Em um âmbito positivo, vimos os debates nos respectivos territórios de memória sobre a integração (pelo Sistema Condor) de todo o Río de la Plata, construindo as pontes entre violações e interpretações dessas violações, em contextos específicos. Assim, analisamos a importância de recuperar o Sistema para legitimar argumentos, tanto no contexto internacional, a partir do SIDH ou da circulação das produções das Comissões de Verdade e, nesse sentido, a Argentina torna-se o modelo exemplar -, quanto para consolidar políticas locais de memória com a produção de investigações internas, com as estratégias de contornar leis de anistia, com as constituições de Museus e Centros Culturais que pretendem criar laços entre a sociedade e as vítimas do Condor. Desta forma, podemos dizer que há uma mentalidade relativamente consolidada (ou seja, trabalhada na memória, desde as próprias ditaduras em questão) de que a violação específica, no contexto do Cone Sul, é o desaparecimento forçado.

Em um âmbito negativo, por sua vez, essa visão pode ser tomada por interpretações hierarquizantes de sofrimentos. Isso significa que, se temos um "sujeito vítima único", os números dessas violações, em cada espaço local, determinam a "gravidade" do poder autoritário e de suas práticas repressivas. E, essa fala, que fortalece discursos antidemocráticos, se encontra com relativa normalidade no espaço regional e precisa ser analisada de maneira crítica, como o intentamos fazer aqui.

Uma das formas de romper esse tipo de perspectiva está no próprio modelo que considera a integração regional. O impulso dado pela revisão das memórias e das histórias rio-platenses, enfatizando o conjunto de circulações de vítimas e de informações, durante os períodos ditatoriais, consegue conectar as repressões e tornar todos os Estados responsáveis 
pelas violações, nesse contexto. Essas revisões circulam nos demais territórios e enfatizam a afirmação de que um “desaparecido é problema de todos” (GATTI, 2011 e CATELA, 2001).

Outra forma de romper com o discurso de hierarquias de sofrimentos é perceber que esse tipo de violação tem a característica de ser atemporal em dois sentidos. Primeiro, dentro dos acordos internacionais, nos quais são considerados crimes vigentes até que a pessoa desaparecida reapareça e possa se responder oficialmente sobre seus paradeiros, destinos e responsabilizações (ORGANIZACIÓN DE LOS ESTADOS AMERICANOS, 1994). Em segundo lugar, o sentido atemporal de que estes crimes são práticas que ocorrem em todos os tempos, mesmo que suas características tenham sido estabelecidas, a partir das ditaduras dos anos 1970 e seus modelos repressivos, resolvendo o "problema dos mortos" pelos regimes ditatoriais.

Outro conceito fundamental percebido nesses debates é o genocídio, que aponta para polêmicas dentro dos discursos sobre direitos humanos. Considerado, nos acordos internacionais (ORGANIZACIÓN DE LAS NACIONES UNIDAS, 1948), como extermínios de quatro grupos populacionais específicos (religioso, nacional, étnico e racial), o conceito de genocídio vem sendo repensado dentro das ciências humanas, desde sua instituição em finais dos anos 1940, de modo a englobar os diversos tipos de extermínios, que se dão em nome de "projetos civilizatórios", do "progresso", de uma máquina político-econômica (ARENDT, 1999; HARF, 2000 e FEIERSTEIN, 2014).

Além dessa expansão dos tipos de vítimas, ainda se questiona sobre a necessidade de perceber o extermínio não apenas como matança, como acontece frequentemente nas decisões jurídicas, contudo também, como eliminação do outro em âmbitos políticos e culturais. Ou seja, ampliar a noção da própria prática que acarreta na eliminação, inclusive da existência pela cultura e memória de uma população. Dessa forma, diversos autores enfatizam a prática em si, aplicada em sociedades de contextos diversos e com propósitos diversos - o que acompanhamos nesse texto como práticas sociais genocidas, recuperando o termo de Daniel Feierstein (2014).

A utilização desse conceito aumenta uma base de interpretação que consegue englobar diferentes crimes contra a humanidade (etnocídio, politicídio, massacre e etc.), utilizados para incorporar crimes e vítimas não enquadrados no sistema judicial internacional, pela fragmentação deles. A ideia, então, é uni-los, através da análise da pretensão de eliminação do outro e da responsabilidade por essas práticas, que é uma responsabilidade nacional e internacional. 
Mesmo que ainda não especialmente utilizado pelo caso uruguaio, vemos essa discussão imersa nos territórios paraguaio e argentino. No caso do Paraguai, a indeterminação da CIDH em considerar o extermínio das populações indígenas como genocídio, fundamentando-se na impossibilidade de comprovar a intenção estatal na eliminação do outro, transformou os discursos de memória sobre os direitos humanos, vistos, principalmente, na Comisión de Verdad y Justicia, colocando-os dentro da fragmentação pelo crime de etnocídio. É claro que diversas organizações e indivíduos questionam esse posicionamento, tentando recuperar o genocídio para caracterizar a relação memória-direitos humanos e ampliar a perspectiva de violações e de responsabilidades.

No caso argentino, a partir dos anos 1990, com a luta contra a desmemória e pela justiça, o genocídio passa a ser um conceito integrador dos discursos sobre direitos humanos. Primeiro, porque reconhece uma intenção e, portanto, a responsabilidade estatal na eliminação do outro para aplicar um modelo político-econômico no país. Depois, porque consegue conectar o país com as discussões mundiais sobre direitos humanos, a partir do modelo de memória exemplar da Alemanha nazista. Assim, fala-se em responsabilidade e punição aos "genocidas", atrelando o conceito de desaparecimento forçado ao próprio genocídio.

Podemos perceber que a utilização desse conceito cresce, no cenário argentino, a partir da crítica aos modelos neoliberais aplicados no país, desde meados dos anos 1990, como soluções econômicas que aprofundam a pobreza e a desigualdade social. Isso significa que há um posicionamento crítico sobre as políticas econômicas e suas consequências dos anos 2000 capaz de relacionar o passado ao presente (esse início de aplicação neoliberal em tempos ditatoriais ao momento de crise aprofundada dos anos 1990 e 2000) e dimensionar o extermínio aos interesses de grupos sociais, nacionais e internacionais, em uma dinâmica capitalista e imperialista, que pretende eliminar posições de diversidades políticas.

É interessante vermos que, desta forma, o marco das consequências dos anos 1990 afeta a concepção latino-americana sobre direitos humanos. As violações consideradas como eliminação do outro, principais argumentos nas memórias sobre as ditaduras, que ainda estão presentes nas sociedades em geral (e devem estar), passam também a integrar-se com o discurso sobre o direito à vida digna e ao não atendimento das necessidades básicas humanas pelo Estado (JELIN, 2013). E esse tipo de violação entra na relação memória e direitos humanos como forma de argumentar que o Estado segue sendo responsável pela morte e pela violação dos direitos de sua população.

Terminamos esse texto, apontando novamente que os discursos sobre os direitos humanos são dinâmicos e, portanto, aqui os vimos em seus contextos e fluxos específicos que 
vão de perspectivas locais a globais, mas que são limitados pelas escolhas dessa tese. Enfatizamos, no entanto, a importância de percebê-los, dentro das ciências humanas e de pesquisas que pretendem romper padrões de pensamentos sociais estabelecidos, nas perspectivas não estáticas de interpretações sobre a realidade das violações, que se transformam, se desintegram, se ampliam, em cada momento histórico.

Se, como afirmou Roa Bastos (1960, p. 114), a vida é ir um pouco além do limite e resistir até o fim, esses debates pretenderam dar uma visão inicial e distinta sobre a possibilidade de uma integração transnacional dos direitos humanos, necessária para se pensar a identidade rio-platense que nos une pela luta de um futuro melhor. Uma identidade que, apesar de fundamentada em muitas memórias de violência, está sempre em movimento para transformar seu próprio curso da história. Pois, apropriando-se desse imaginário das águas, nós somos como um rio, podendo nos desembocar em pântanos, reproduzindo práticas de violência e dominação, ou nos mares, que nos libertam delas. 


\section{REFERÊNCIAS}

\section{Documentos de análise}

\section{Argentina}

ARCHIVO MEMORIA ABIERTA. Juicios de las Juntas. Argentina: Argentina Televisora Color, 1985. Disponível em: <http://www.memoriaabierta.org.ar/juicioalasjuntas/>. Acesso em: 03 jul. 2016.

ARCHIVO MEMORIA ABIERTA. Entrevista con Carmen Lapacó. Disponível em: $<$ http://www.buenosaires.gob.ar/educacion/programasymemoria/archivos-por-lamemoria/carmen-lapaco>. Acesso em: 09 ago. 2016.

ARCHIVO ORAL MEMORIA ABIERTA. Testimonio de Ricardo Coquet. Entrevistador: Daniel Paradeda. Tigre, Buenos Aires, Argentina. 2006a. 3hs51min. Archivo Memoria Abierta - Archivo Oral.

ARCHIVO ORAL MEMORIA ABIERTA. Testimonio de Alejandro Héctor Vasallo. Entrevistador: Daniel Paradeda. Buenos Aires, Argentina. 2006. 2hr40min. Archivo Memoria Abierta - Archivo Oral.

ARCHIVO ORAL MEMORIA ABIERTA. Testimonio de Alfredo Ayala. Entrevistador: Daniel Paradeda. Buenos Aires, Argentina. 2006c. 5hs50min. Archivo Memoria Abierta Archivo Oral.

ARCHIVO ORAL MEMORIA ABIERTA. Testimonio de Leonardo Martínez. Entrevistador: Daniel Paradeda. Buenos Aires, Argentina. 2006d. 4hs01min. Archivo Memoria Abierta - Archivo Oral.

ARGENTINA. Decreto N.261 (1975). Argentina: Presidencia de la Nación, 5 feb. 1975. Disponível em: <http://www.desaparecidos.org/nuncamas/web/document/decreto_261_75.htm>. Acesso em: 05 jul. 2016.

ARGENTINA. Documento final de la Junta Militar sobre la guerra contra la subversión y el terrorismo (1983). Argentina: Fuerzas Armadas, abr. 1983a. Disponível em; <http://www.memoriaabierta.org.ar/materiales/documento_final_junta.php>. Acesso em: 05 jul. 2016.

ARGENTINA. Ley N.22924 (1983). Argentina: Presidencia de la Nación, 22 sept. 1983b.

ARGENTINA. Decreto 157 (1983). Argentina: Presidencia de la Nación, 13 dic. 1983c.

ARGENTINA. Decreto 158 (1983). Argentina: Presidencia de la Nación, 13 dic. 1983d.

ARGENTINA. Decreto N.187 (1983). Argentina: Presidencia de la Nación, 15 dic. 1983e. Disponível em: 〈http://www.derechos.org/ddhh/arg/ley/conadep.txt〉. Acesso em: 16 jun. 2015. 
ARGENTINA. Ley N.23492 (1986). Argentina: Presidencia de la Nación, 24 dic. 1986. Disponível em: <http://servicios.infoleg.gob.ar/infolegInternet/anexos/2000024999/21864/norma.htm>. Acesso em: 17 jul. 2016.

ARGENTINA. Ley N.23521 (1987). Argentina: Presidencia de la Nación, 4 jun. 1987. Disponível em: <http://servicios.infoleg.gob.ar/infolegInternet/anexos/2000024999/21746/norma.htm>. Acesso em: 17 jul. 2016.

ARGENTINA. Decreto N.8. Trasladase a la Base Naval de Puerto Belgrano (1998). Argentina: 6 enero 1998.2 Disponível <http://servicios.infoleg.gob.ar/infolegInternet/anexos/45000-49999/48329/norma.htm>. Acesso em: 9 fev. 2017.

ARGENTINA. Acuerdo entre el Estado Nacional y la Ciudad Autónoma de Buenos Aires sobre a creación del Espacio para la Memoria y para la Promoción y Defensa de los Derechos Humanos (2004). In: BRODSKY, Marcelo (Coord.). Memoria en construcción: el debate sobre la ESMA. Buenos Aires: la marca editora, 2005. p. 226-227.

ARGENTINA. Informe de la Procuraduría de Crímenes contra la Humanidad. La judicialización de la Operación Cóndor. Buenos Aires: Ministerio Público Fiscal, 2015.

COLETIVA OFICIAL DE IMPRENSA COM JORGE RAFAEL VIDELA (1980). Disponível em: <https://www.youtube.com/watch?v=3AlUCjKOjuc>. Acesso em: 17 jul. 2016.

COMISIÓN INTERAMERICA DE DERECHOS HUMANOS. Resolución N.21. Caso Mónica Mignone (1978). OEA, 18 nov. 1978.

COMISIÓN INTERAMERICANA DE DERECHOS HUMANOS. Informe de País: Argentina (1980). OEA, 11 abr. 1980a.

COMISIÓN INTERAMERICANA DE DERECHOS HUMANOS. Informe Anual de 1979. 1980 (1980). OEA, 2 oct. 1980 b.

COMISIÓN INTERAMERICANA DE DERECHOS HUMANOS. Informe N.28. Informe Anual de la CIDH (1992-1993). OEA, 12 marzo 1993.

COMISIÓN INTERAMERICANA DE DERECHOS HUMANOS. Informe N.55. Caso Juan Carlos Abella (1995). OEA, 18 nov. 1997.

COMISIÓN INTERAMERICANA DE DERECHOS HUMANOS. Informe N.21. Informe Anual de la Comisión Interamericana de Derechos Humanos (2000). OEA, 16 abr. 2001.

CONADEP. Nunca Más: Informe de la Comisión Nacional sobre la Desaparición de personas. Buenos Aires: Eudeba, 2006.

CORTE INTERAMERICANA DE DERECHOS HUMANOS. Caso Maqueda versus Argentina: Resolución (1995). OEA, 17 enero 1995. 
ESPACIO PARA LA MEMORIA Y PARA LA PROMOCIÓN Y DEFENSA DE LOS DERECHOS HUMANOS. Folleto de Divulgación. Buenos Aires: Espacio para la Memoria, 20--.

INSTITUTO ESPACIO PARA LA MEMORIA. Documento Fundacional del Instituto Espacio para la Memoria (2005). Buenos Aires: IEM, 20 sept. 2005.

Lanzamiento del Instituto Espacio para la Memoria. In: INSTITUTO ESPACIO PARA LA MEMORIA (Coord.). Un espacio para la memoria. Buenos Aires: IEM, 2006. p. 97-99.

LEGISLATURA DE LA CIUDAD AUTÓNOMA DE BUENOS AIRES. Acta de la 12 Seción Ordinaria (2000). Buenos Aires: Legislatura, 1 jun. 2000a.

LEGISLATURA DE LA CIUDAD AUTÓNOMA DE BUENOS AIRES. Ley 329 Revocase la cesión del predio de Avenida del Libertador. ESMA (2000). Buenos Aires: Legislatura, 14 jun. 2000b. Disponível em: <http://www.ciudadyderechos.org.ar/ddhh/derechosbasicos_l.php?id=7\&id2=239\&id3=5313 $>$. Acesso em: 04 fev. 2017.

LEGISLATURA DE LA CIUDAD AUTÓNOMA DE BUENOS AIRES. Ley N.961. Creación del Instituto Espacio para la Memoria (2002). Buenos Aires: 5 dic. 2002.

LÓPEZ, Julio. Testimonio. Buenos Aires, 18 sept. 2006. Disponível em: <https://www.youtube.com/watch?hl=es-

419\&gl=CO\&feature=player_embedded\&v=FO0cEaSZCVQ>. Acesso em: 20 fev. 2017.

MEGACAUSA ESMA. Testimonios B (“Causa Monjas Francesas" o "Causa Iglesia Santa Cruz"), Buenos Aires, 2009. Disponível em: $<$ http://www.espaciomemoria.ar/megacausa_juicio.php?ju_ID=109\&cabezal=megacausa\&bar ra=megacausa\&titulo=megacausa $>$. Acesso em: 15 fev. 2017.

MEGACAUSA ESMA. Caso 294: testimonio de Alejandro Héctor Vasallo. Buenos Aires, $2009 . \quad$ Disponível em: <http://www.espaciomemoria.ar/megacausa_juicio.php?ju_ID=113\&cabezal=megacausa\&bar ra=megacausa \&titulo=megacausa $>$. Acesso em: 16 fev. 2017.

MEMORIA ABIERTA. Organización institucional y contenidos del futuro Museo de la Memoria. Buenos Aires: Colección Memoria Abierta, 2000.

MEMORIA ABIERTA. Coloquio El museo que queremos: La transmisión de la memoria a través de los sitios. Buenos Aires: Arquivo Memoria Abierta, 26 jun. 2007.

PODER JUDICIAL DE LA NACIÓN. Fallo N.13516 (2007). La Plata: Tribunal Oral Federal N.1, nov. 2007. Disponível em: <http://www.cij.gov.ar/nota-846-Lesa-humanidad--CasacionPenal-confirmo-condena-a-Von-Wernich.html>. Acesso em: 03 jun. 2015.

PROGRAMA ALMORZANDO CON MIRTHA LEGRAND. Buenos Aires, Canal 9, 1997. Disponível em: <http://www.youtube.com/watch?v=4EJjDV8EXu8>. Acesso em: 21 jul. 2016. 
PROGRAMA HORA CLAVE. Entrevistador: Mariano Grondona. Buenos Aires: Canal 9, marzo 1995. Disponível em: 〈http://www.youtube.com/watch?v=SswwGCYC4GM>. Acesso em: 23 jul. 2016.

WALSH, Rodolfo. Carta Abierta a la Junta Militar. Buenos Aires: Espacio Memoria y Derechos Humanos, 2014.

\section{Paraguai}

COMISIÓN DE VERDAD Y JUSTICIA. Informe Final. Anive Haguã Oiko. Asunción: CVJ, 2008.

COMISIÓN INTERAMERICANA DE DERECHOS HUMANOS. Observaciones que la Comisión considera apropiadas respecto de las comunicaciones que ha recibido (1977). OEA, 1977.

COMISIÓN INTERAMERICANA DE DERECHOS HUMANOS. Informe sobre la Situación de los Derechos Humanos en Paraguay (1978). OEA, 31 enero 1978b.

CORTE INTERAMERICANA DE DERECHOS HUMANOS. Sentencia Comunidad Indígena Yake Axa Vs. Paraguay (2005). OEA, 17 jun. 2005.

CORTE INTERAMERICANA DE DERECHOS HUMANOS. Sentencia: Caso Goiburú y Otros versus Paraguay (2006). OEA, 22 sept. 2006a.

CORTE INTERAMERICANA DE DERECHOS HUMANOS. Sentencia Comunidad Indígena Sawhoyamaxa Vs. Paraguay (2006). OEA, 29 marzo 2006 b.

CORTE SUPREMA DE LA JUSTICIA; MUSEO DE LA JUSTICIA. Los Archivos del Terror del Paraguay. Patrimonio documental del mundo. Asunción: Centro de Documentación y Archivo para la Defensa de los Derechos Humanos, 2011.

MERCOSUR. Plan del Sector Educativo del Mercosur (2006-2010). Disponível em: $<$ http://www.edu.mercosur.int/pt-BR/documentos-categoria/finish/7-planos-planes/412-plano2006-2010.html>. Acesso em: 20 jul. 2017.

MERCOSUR. XIII Reunión de la Comisión Regional - Coordinadora de Educación Básica del Sector Educativo del MERCOSUR. Asunción, mayo 2007. Archivo personal de Albert Manke.

MERCOSUR. Sistema de Informação sobre Institucionalidade em Direitos Humanos. Disponível em: <http://sisur.ippdh.mercosur.int/si/web/pt/ficha/institucion/365>. Acesso em: 03 ago. 2017.

MESA MEMORIA HISTÓRICA. Boletín Oñondivepa, Paraguay, N.2, 20--.

MINISTERIO DE EDUCACIÓN Y CULTURA. Plan Optativo: Orientaciones para la gestión pedagógica. Paraguay: MEC, 2007. Disponível em: 
<http://www2.ohchr.org/english/issues/education/training/docs/PARAGUAYPlanoptativo.pdf >. Acesso em: 09 jul. 2017.

MUSEO DE LAS MEMORIAS. Folleto de Información. Asunción: Celestina Pérez de Almada, 2007.

PARAGUAY. Ley 631 (1995). Ley Orgánica de la Defensoría del Pueblo. Asunción: Congreso Nacional, 1995.

PARAGUAY. Ley N.838 - que indemniza a victimas de violaciones de derechos humanos durante la dictadura de 1954 a 1989 (1996). Paraguay: Congreso de la Nación Paraguaya, 12 sept. 1996.

PARAGUAY. Resolución 179 (2009). República del Paraguay, 23 enero 2009. Disponível em: <http://www.verdadyjusticia-dp.gov.py>. Acesso em: 20 ago. 2015.

PARAGUAY. III Censo Nacional de población y vivienda para pueblos indígenas (Censo 2012). Paraguay: Dirección General de Estadística, encuestas y censos del Gobierno Nacional, 2012.

PARAGUAY. Ley N.2225. Por la cual se crea la Comisión de Verdad y Justicia (2003). Paraguay: Presidencia de la República Paraguaya, 16 oct. 2003. Disponível em: $<$ https://www.usip.org/sites/default/files/file/resources/collections/commissions/ParaguayCharter.pdf >. Acesso em: 21 ago. 2015.

SENIOR EXPERTEN SERVICE. Informe sobre la visita de cooperación técnica del experto Albert Manke al Museo de la Memorias: Dictadura y Derechos Humanos. Asunción, 31 mayo 2007. Archivo personal de Albert Manke.

\section{Uruguai}

COMISIÓN INTERAMERICANA DE DERECHOS HUMANOS. Informe sobre la Situación de los Derechos Humanos en Uruguay (1978). OEA, 31 enero 1978c.

COMISIÓN INTERAMERICANA DE DERECHOS HUMANOS. Informe Anual de la CIDH (1977). OEA, 20 abr. 1978d.

COMISIÓN INTERAMERICANA DE DERECHOS HUMANOS. Caso N.1909 Jorge Mazzarovich (1979). OEA, 21 jun. 1978e.

COMISIÓN INTERAMERICANA DE DERECHOS HUMANOS. Resolución N.11. Relativa a casos individuales (1984). OEA, 3 oct. 1984.

COMISIÓN INTERAMERICANA DE DERECHOS HUMANOS. Informe N.29. Informe Anual de la CIDH (1992-1993). OEA, 12 marzo 1992.

COMISIÓN PARA LA PAZ. Informe Final. Uruguay: Presidencia de la República Oriental del Uruguay, 10 abr. 2003. Disponível em: 〈http://archivo.presidencia.gub.uy>. Acesso em: 03 jul. 2015. 
CORTE INTERAMERICANA DE DERECHOS HUMANOS. Sentencia: Caso Juan Gelman versus Uruguay (2011). OEA, 24 feb. 2011.

FERRARIO, Elbio. Informe General del Museo de la Memoria (MUME): Actividades 2005-2010. Montevideo: Departamento de Cultura, 2010.

GRUPO DE INVESTIGACIÓN EN ANTROPOLOGÍA FORENSE. Investigaciones antropológica sobre detenidos desaparecidos en la última dictadura cívico-militar. Uruguay: GIAF, 2012.

JUICIO DE LAS JUNTAS. Arquivo 2539, 1985. Disponível em: $<$ http://www.desaparecidos.org/nuncamas/web/testimon/rodlarre2.htm>. Acesso em: 09 mar. 2016.

LARRETA MARTÍNEZ, Enrique Rodríguez. Conferencia de prensa para la inauguración de la exposición EI Informe Orletti - Conexión Internacional. Montevideo: 14 mayo 2009. Disponível em: <http://elinforme.larreta.org/?q=node/37>. Acesso em: 25 abr. 2017.

LARRETA PIERA, Enrique Rodríguez. Testimonio, Londres, 18 marzo 1977. Disponível em: <http://elinforme.larreta.org>. Acesso em: 13 abr. 2017.

MADRES Y FAMILIARES DE URUGUAYOS DETENIDOS-DESAPARECIDOS. Comunicado de Prensa, Montevideo, 10 de agosto de 2005. Disponível em: $<$ https://desaparecidos.org.uy/wp-content/uploads/2015/06/2005.08.10-Sobre-informe-de-lasFFAA-al-Presidente.pdf $>$. Acesso em: julho 2015.

MERCOSUR. Primer Encuentro de Museos de la Memoria del Mercosur. Montevideo: Museo de la Memoria, 1 al 4 abr. 2008. Disponível em: <http://www.museovillagrimaldi.info/doc/1_6_4_33.pdf>. Acesso 05 abr. 2017.

MUSEO DE LA MEMORIA. Folleto de divulgación. Montevideo: MUME, 20--a.

MUSEO DE LA MEMORIA. Folleto Parque y ex-Casa Quinta de Máximo Santos. Montevideo: MUME, 20--b.

MUSEO DE LA MEMORIA. Propuesta de anteproyecto museográfico. Montevideo: MUME, 10 dic. 2007.

PROGRAMA DE DISEÑO DE COMUNICACIÓN VISUAL (UDELAR). Proyecto Lugares de la Memoria de la Resistencia. Montevideo: UDELAR, agosto 2006.

ROSENCOF, Mauricio. Conferencia de prensa para la inauguración de la exposición El Informe Orletti - Conexión Internacional. Montevideo: 14 mayo 2009. Disponível em: <http://elinforme.larreta.org/?q=node/37>. Acesso em: 27 abr. 2017.

UNIVERSIDAD DE LA REPÚBLICA. Investigación Histórica sobre la dictadura y el Terrorismo de Estado en el Uruguay (1973-1985). Montevideo: UDELAR, 2008.

URUGUAY. Ley N.14068 (1972). Uruguay: Cámara de Representantes, 5 jul. 1972. 
URUGUAY. Ley N.15848 (1986). Uruguay: Senado y Cámara de la República Oriental del Uruguay, 28 dic. 1986.

URUGUAY. Resolución 858 (2000). Uruguay: Presidencia de la República Oriental del Uruguay, 9 de agosto de 2000. Disponível em: <http://archivo.presidencia.gub.uy/noticias/archivo/2000/agosto/2000080912.htm>. Acesso em: julho 2015.

URUGUAY. Ley N.18596 (2009). Uruguay: Presidencia de la República Oriental del Uruguay 18 sept. 2009a. Disponível em: <http://tbinternet.ohchr.org/Treaties/CAT/Shared\%20Documents/URY/INT_CAT_ADR_UR Y_16779_S.pdf>. Acesso em: 25 set. 2016.

URUGUAY. Sentencia N.0157. Alvarez Armellino, Gregorio Conrado - Larcebeau Aguirregaray, Juan Carlos. Reiterados delitos de Homicidio Muy Especialmente Agravados (2009). Montevideo: Suprema Corte de Justicia, 21 oct. 2009 b.

URUGUAY. Fallo condenando a Juan María Bordaberry Arocena (2010). Montevideo: Suprema Corte de Justicia, 9 feb. 2010.

URUGUAY. Ley N.18831. Pretensión Punitiva del Estado (2011). Montevideo: Senado y Cámara de Representantes de la República Oriental del Uruguay, 27 oct. 2011. Disponível em: <https://parlamento.gub.uy/documentosyleyes/leyes/ley?page=13>. Acesso em: 26 set. 2016.

URUGUAY. Sentencia N.152 - Excepción de Inconstitucionalidad (2013). Montevideo: Corte Suprema de Justicia, 8 marzo 2013.

YAÑEZ, Antonia. Entrevista. Radio Espectador, Montevideo, 27 jun. 2013. Disponível em: $<$ http://www.espectador.com/sociedad/267939/recorrido-de-la-memoria-un-paseo-por-lahistoria-reciente-que-busca-reivindicar-el-movimiento-de-resistencia-a-la-dictadura>. Acesso em: 16 jun. 2017.

\section{Diversos internacionais}

COMISIÓN INTERAMERICANA DE DERECHOS HUMANOS. Sentencia: Caso Velásquez Rodriguez versus Honduras (1988). OEA, 29 jul. 1988.

CORTE INTERAMERICANA DE DERECHOS HUMANOS. Caso Barrio Alto versus Perú. Sentencia (2001). OEA, 14 marzo 2001.

ESTATUTOS do The International Council of Museums, Viena, 2007.

EUROPEAN PARLIAMENT. Interim Report on the alleged use of European countries by the CIA for transportation and illegal detention of prisoners (2006), 15 June 2006. Disponível em: <http://www.europarl.europa.eu/sides/getDoc.do?pubRef=//EP//NONSGML+REPORT+A6-2006-0213+0+DOC+PDF+V0//EN\&language=EN $>$. Acesso em: 03 ago. 2016. 
KÖHLER, Ernest. Speech A 'red-letter day'. Bundestag, Berlin, 12 June 2007. Disponível em:

<http://www.bundespraesident.de/SharedDocs/Reden/EN/HorstKoehler/Reden/2007/06/2007 0612_Rede.html>. Acesso em: 17 jul. 2017.

ORGANIZAÇÃO DAS NAÇÕES UNIDAS. Carta das Nações Unidas e Estatuto da Corte Internacional e Justiça (1945). São Francisco: ONU, 26 jun. 1945. Disponível em: <http://www.planalto.gov.br/ccivil_03/decreto/1930-1949/d19841.htm>. Acesso em: 04 maio 2017.

ORGANIZAÇÃO DOS ESTADOS AMERICANOS. Declaração Americana dos Direitos e Deveres do Homem (1948). Bogotá: OEA, 1948. Disponível em: <http://www.cidh.org/Basicos/Portugues/b.Declaracao_Americana.htm>. Acesso em: 24 out. 2016.

ORGANIZAÇÃO DAS NAÇÕES UNIDAS. Declaração e programa de ação de Viena. Conferência Mundial sobre os Direitos Humanos (1993). Viena: ONU, jun. 1993. Disponível em: <http://www.pge.sp.gov.br/centrodeestudos/bibliotecavirtual/instrumentos/viena.htm>. Acesso em: 07 maio 2017.

ORGANIZAÇÃO DAS NAÇÕES UNIDAS. Estatuto de Roma (1998). Roma: Corte Penal Internacional, 17 jul. $1998 . \quad$ Disponível <https://www.oas.org/36ag/espanol/doc_referencia/Estatuto_Roma.pdf>. Acesso em: 07 maio 2017.

ORGANIZACIÓN DE LOS ESTADOS AMERICANOS. Tratado Interamericano de Asistencia Recíproca (1947). Rio de Janeiro: OEA, 1947. Disponível em: <http://www.oas.org/juridico/spanish/tratados/b-29.html>. Acesso em: 13 out. 2016.

ORGANIZACIÓN DE LOS ESTADOS AMERICANOS. Carta de la Organización de los Estados Americanos (1948). Bogotá: OEA, 1948. Disponível em: $<$ http://www.oas.org/es/sla/ddi/tratados_multilaterales_interamericanos_A41_carta_OEA.asp>. Acesso em: 13 out. 2016.

ORGANIZACIÓN DE LAS NACIONES UNIDAS. Convención para la prevención y la sanción del delito de genocidio. ONU: 9 dic. 1948. Disponível em: <https://www.icrc.org/spa/resources/documents/misc/treaty-1948-conv-genocide-

5tdm6h.htm>. Acesso em: 14 maio 2017.

ORGANIZACIÓN DE LOS ESTADOS AMERICANOS. Quinta Reunión de Consulta de Ministros de Relaciones Exteriores: Acta final (1959). Santiago de Chile: OEA, 12-18 agosto 1959. Disponível em: <http://www.oas.org/es/cidh/mandato/Basicos/Acta-finalQuinta-reunion-Chile-1959.pdf>. Acesso em: 14 out. 2016.

ORGANIZACIÓN DE LOS ESTADOS AMERICANOS. El sistema interamericano: su evolución y función actual. Washington: Unión Panamericana, 1963. 
ORGANIZACIÓN DE LOS ESTADOS AMERICANOS. Convención Americana sobre Derechos Humanos (1969). San José: OEA, 1969. Disponível em: $<$ https://www.oas.org/dil/esp/tratados_b-

32_convencion_americana_sobre_derechos_humanos.htm>. Acesso em: 14 out. 2016.

ORGANIZACIÓN DE LOS ESTADOS AMERICANOS. Estatuto de la Comisión Interamericana de Derechos Humanos (1979). Bolivia: OEA, 1979. Disponível em: <http://www.oas.org/es/cidh/mandato/Basicos/estatutoCIDH.asp>. Acesso em: 15 out. 2016.

ORGANIZACIÓN DE LOS ESTADOS AMERICANOS. Convención Interamericana sobre Desaparición Forzada de Personas (1994). Brasil: OEA, 9 jun. 1994.

VON WEIZSÄCKER, Richard. Speech by President Richard von Weizsäcker during the Ceremony Commemorating the 40th Anniversary of the End of War in Europe and of National-Socialist Tyranny. Bundestag, Bonn, 8 May 1985. Disponível em: <https://www.bundespraesident.de/SharedDocs/Downloads/DE/Reden/2015/02/150202RvW-Rede-8-Mai-1985-englisch.pdf?_blob=publicationFile>. Acesso em: 10 maio 2017.

\section{Reportagens em Jornais e Revistas}

ABRAMOVICI, Pierre. "Operación Cóndor", pesadilla de América Latina. Le Monde Diplomatique, 19 enero 2005. Disponível em: <http://www.elcorreo.eu.org/OperacionCondor-pesadilla-de-America-Latina?lang=fr>. Acesso em: 03 mar. 2016.

A ARGENTINA PEDE EXTRADIÇÃO DE ENVOLVIDOS NO PLANO CONDOR. Estado de São Paulo, São Paulo, 14 de abril de 2001. Disponível em: $<$ http://politica.estadao.com.br/noticias/geral,argentina-pede-extradicao-de-envolvidos-noplano-condor,20010414p31591>. Acesso em: 14 jul. 2017.

A LA LUZ, LA FAMOSA LISTA NEGRA. HALLAN DOCUMENTOS DE LA REPRESIÓN STRONISTA. Ultima Hora, Asunción, Año XX, N.5652, p. 72, 22 dic. de 1992.

ALMORZANDO CON MÁXIMO SANTOS. El País, Montevideo, 7 oct. 2014. Disponível em: <http://viajes.elpais.com.uy/2014/10/07/almorzando-con-maximo-santos>. Acesso em: 03 fev. 2017.

BENEDETTI, Mario. No hay caducidad para la memoria. Brecha, Uruguay, 21 abr. 1989. Disponível em: <http://www.uc.org.uy/d04011.htm>. Acesso em: 21 set. 2016.

CANJE DE PRISIONEROS Y RESPECTO A LOS COMBATIENTES. Estrella Roja, Buenos Aires, N.31, p. 6-10, marzo 1974.

CAPELLI, Dino. Un recorrido por la memoria, 40 años después del golpe de Estado. El Mundo, Montevideo, 28 jun. 2013. Disponível em: <http://www.elmundo.es/america/2013/06/28/noticias/1372449320.html>. Acesso em: 28 abr. 2017. 
CENSURA Y PICANA ELÉCTRICA. Revista Militancia, Buenos Aires, N.23, 15 nov. 1973. Disponível em: <http://www.teaydeportea.edu.ar/archivos/prohiben-las-obras-made-inargentina-y-celda>. Acesso em: 06 jan. 2017.

CONNIO, Francisco. Reflotan ex-fabrica Camponar como proyecto cultural. República, Montevideo, 18 marzo 2014. Disponível em: <http://www.republica.com.uy/ex-fabricacampomar>. Acesso em: 15 mar. 2016.

CUÉ, Carlos E. Argentina, primer país que condena a los jerarcas del Plan Cóndor. El País, Madrid, 28 mayo 2016. Disponível em: <http://internacional.elpais.com/internacional/2016/05/27/argentina/1464377638_258435.htm 1>. Acesso em: 04 jan. 2017.

DANDAN, Alejandra. La Comisión Interamericana de Derechos Humanos Desclasificara Documentos de su Informe sobre la Dictadura. Página/12, Buenos Aires, 29 nov. de 2011. Disponível em: <http://www.pagina12.com.ar/diario/elpais/1-182293-2011-11-29.html>. Acesso em: 05 ago. 2016.

DARTON, Robert. As grossas camadas do tempo. Folha de São Paulo, São Paulo, 20 ago. 1995. Disponível em: <http://www1.folha.uol.com.br/fsp/1995/8/20/mais!/13.html>. Acesso em: 04 maio 2017.

DECEPCIÓN DE LA DELEGACIÓN URUGUAYA EN ROMA POR EL FALLO SOBRE EL PLAN CÓNDOR. El Observador, Montevideo, 18 enero 2017. Disponível em: $<$ http://www.elobservador.com.uy/decepcion-la-delegacion-uruguaya-roma-fallo-plancondor-n1021937>. Acesso em: 18 mar. 2017.

EL JUEZ SOLIMINE FUE DESTITUIDO POR UN JURADO DE ENJUICIAMIENTO. La Nación, Buenos Aires, 24 marzo 1998. Disponível em: <http://www.lanacion.com.ar/91401el-juez-solimine-fue-destituido-por-un-jurado-de-enjuiciamiento>. Acesso em: 14 jun. 2016.

EL MUSEO DEL NUNCA MÁS. Espectador, Montevideo, 25 enero 2008. Disponível em: <http://www.espectador.com/sociedad/113817/el-museo-del-nunca-mas >. Acesso em: 09 abr. 2017.

EL PRESIDENTE HORST KÖHLER VISITÓ AL MUSEO DE LA MEMORIA. Ultima Hora, Asunción, 06 marzo 2007. Disponível em: <http://www.ultimahora.com/el-presidentehorst-kohler-visito-el-museo-la-memoria-n25064.html>. Acesso em: 18 jul. 2017.

GALAK, Oliver. Controversia por el prológo agregado al "Nunca Más". La Nación, Buenos Aires, 19 mayo 2006. Disponível em: <https://www.lanacion.com.ar/807208-controversiapor-el-prologo-agregado-al-informe-nunca-mas>. Acesso em: 14 jun. 2016.

GAUTO, Dionísio. Qué entendemos cuando se habla de derechos humanos. Boletín Oñondivepa, Paraguai, N.3, p. 12, 20--.

GINZBERG, Victoria. El golpe no nos afectó la memoria. Terrorismo de Estado Nunca Más. Pagina/12, Buenos Aires, 1 de marzo de 2001. Disponível em: <www.pagina12.com.ar/2001/01-03/01-03-24/pag04.htm>. Acesso em: 10 fev. 2017. 
GINZBERG, Victoria. Un 24 de marzo diferente. Pagina/12, Buenos Aires, 24 marzo 2004. Disponível em: <www.pagina12.com.ar/diario/elpais/subnotas/1-11697-2004-03-24.html>. Acesso em: 10 fev. 2017.

'GOLI' STROESSNER Y SU RELACIÓN CON LA DICTADURA. Ultima Hora, Asunción, 13 oct. 2013. Disponível em: <http://www.ultimahora.com/goli-stroessner-y-su-relacion-ladictadura-n731631.html>. Acesso em: 17 jul. 2017.

GUIÑAZU, Magdalena Ruiz. Robar a los Muertos. La Nación, Buenos Aires, 29 de octubre de 2012. Disponível em: <http://www.lanacion.com.ar/1521586-robar-a-los-muertos>. Acesso em: 15 jun. 2015.

HALLAN EN LA TÉCNICA MÁS DATOS SOBRE PRESOS POLÍTICOS. Ultima Hora, Asunción, Año XX, N.5653, p. 11, 23 dic. 1992.

LA CIUDADANÍA REFLEXIONA. Memorias Hoy, Asunción, Año II, N.2, p. 20, feb. 2013.

LA JUSTICIA Y LA MEMORIA EN DEBATE. Memorias/Hoy, Asunción, Año II, N.2, p. 6-7, feb. 2013.

LANZAN CAMPAÑA PARA ROMPER EL SILENCIO EN MISIONES. ABC Color, Asunción, 18 de junio de 2006. Disponível em: <http://www.abc.com.py/edicionimpresa/politica/noticias-breves-911618.html>. Acesso: 04 ago. 2015.

LA OPERACIÓN ZANAHORIA NO EXISTIÓ. La República, Montevideo, 31 agosto 2014. Disponível em: <http://www.republica.com.uy/la-operacion-zanahoria-no-existio>. Acesso em: 03 jul. 2015.

LA PRESIDENTA INAUGURÓ EL SÍTIO DE MEMORIA EN LA EX ESMA. Educ.ar, Buenos Aires, 19 de mayo de 2015. Disponível em: <https://www.educ.ar/noticias/126477/lapresidenta-inauguro-el-sitio-de-memoria-en-la-ex-esma>. Acesso em: 07 fev. 2017.

LA POLICÍA MIENTE SOBRE LOS ARCHIVOS SECRETOS. Ultima Hora, Asunción, Año XX, N.5650, p. 29, 19 dic. 1992.

LA SOCIEDAD CIVIL SE MOVILIZA CONTRA LA REIVINDICACIÓN DEL TERRORISMO DE ESTADO. Memorias/Hoy, Asunción, Año II, N.2, p. 17, feb. 2013.

LA TÉCNICA, UN MUSEO. Ultima Hora, Asunción, Año XX, N.5656, p. 27, 26 dic. 1992.

LIBERTARON AL EXMARINO SCILINGO. Clarín, Buenos Aires, 18 jun. 1997. Disponível em: <http://edant.clarin.com/diario/1997/06/18/t-01504d.htm>. Acesso em: 01 fev. 2014.

LYNCH, Guido Carelli. Piden que el prólogo del "Nunca Más" lleve la firma de Sabato. Clarín, Buenos Aires, 13 nov. 2012. Disponível em: $<$ https://www.clarin.com/sociedad/Piden-prologo-lleve-firmaSabato_0_H1imQ3TivQe.html>. Acesso em: 04 jun. 2015. 
LYNCH, Guido Carelli; ROFFO, Julieta. Adhesiones y acusaciones cruzadas por el prólogo del "Nunca Más". Clarín, Buenos Aires, 14 de noviembre de 2012. Disponível em: $<$ https://www.clarin.com/sociedad/Adhesiones-acusaciones-cruzadasprologo_0_rks7qjTowQe.html>. Acesso em: 16 jun. 2015.

LÓPEZ, Miguel H. Aniversario y resignificación a partir de los lugares de memoria. Memorias/Hoy, Asunción, Año II, N.2, feb. 2013.

LOS DERECHOS HUMANOS EN UNA VISIÓN REGIONAL. Memorias/Hoy, Asunción, Año II, N.2, p. 2-9, feb. 2013.

MARTIN ALMADA EN EL CUARTEL CENTRAL. LA POLICÍA DEBERÁ ENTREGAR FICHA A EDUCADOR. Ultima Hora, Asunción, Año XX, N.5634, p. 72, 03 dic. 1992.

MICHELINI-BORDABARRY SIN TREGUA. El Observador, Montevideo, Ano XV, N.4965, p. 3, 05 oct. 2006.

MICRÓFONO ABIERTO VOLVERÁ EN MAYO. ABC Color, Asunción, 14 abr. 2013. Disponível em: <http://www.abc.com.py/nacionales/microfono-abierto-volvera-en-mayo560590.html>. Acesso em: 03 ago. 2015.

OVIEDO, Susana. La lucha por la memoria y los derechos unifica agenda de los organismos. Memorias/Hoy, Asunción, Año III, N.3, p. 6, marzo 2014.

PÁEZ MONGES, EL DEFENSOR DEL PUEBLO RESISTIDO POR LAS VÍCTMAS. Ultima Hora, Asunción, 3 feb. 2014. Disponível em: <http://www.ultimahora.com/paezmonges-el-defensor-del-pueblo-resistido-victimas-n764472.html>. Acesso em: 08 jul. 2017.

PARAGUAY: TRAS LA MASACRE DE CURUGUATY, TRES CAMPESINOS PARAGUAYOS SE REFUGIAN EN ARGENTINA. La Nación, Buenos Aires, 01 oct. 2013. Disponível em: <http://www.lanacion.com.ar/1624942>. Acesso em: 03 ago. 2015.

POR LA MUERTE DE UNA MAESTRA. EI Mundo, Montevidéo, 21 abr. 2010. Disponível em: <http://www.elmundo.es/america/2010/04/21/noticias/1271858336.html>. Acesso em: 03 mar. 2018.

PRESENTAN QUERELLA CRIMINAL CONTRA DICTADURA DE STROESSNER EN ARGENTINA. Abc Color, Asunción, 10 agosto 2013. Disponível em: $<$ http://www.abc.com.py/edicion-impresa/politica/presentan-querella-criminal-contradictadura-de-stroessner-en-argentina-605355.html>. Acesso em: 03 ago. 2015.

PRIETO, Martín. Alfonsín decreta el estado de sitio en Argentina por 60 días. El País, España, 6 oct. $61985 . \quad$ Disponível <https://elpais.com/diario/1985/10/26/internacional/499129210_850215.html>. Acesso em: 15 out. 2016.

REPATRIAN LOS RESTOS DE LA NIÑA KRYYGI DE LA COMUNIDAD ACHÉ. Gobierno de la Nación, Asunción, 2012. Disponível em: $<$ http://www.cultura.gov.py/2012/05/repatrian-restos-de-la-nina-kryygi-de-la-comunidadache>. Acesso em: 14 jan. 2017. 
REPUDIAN REIVINDICACIÓN DEL STRONISMO. ABC Paraguay, Asunción, 02 nov. 2013. Disponível em: <http://www.abc.com.py/nacionales/repudian-reivindicacion-delstronismo-635092.html>. Acesso em: 17 jul. 2017.

REVIVIR TODO ES VIVIR CON ELLOS. Pagina/12, Buenos Aires, Año 11, N.3309, p. 2-3, 12 feb. de 1998.

RODRÍGUEZ, Lourdes. El brillo de tu mirada. La Diaria, Montevideo, 18 jul. 2013. Disponível em: <http://revista.escaner.cl/node/6940>. Acesso em 09 jun. 2017.

RODRÍGUEZ, Roger. La casona de Punta Gorda: Los fusilados de Soca, la operación Morgan y los vuelos de Orletti. Caras \& Caretas, Montevideo, N.535, 16 dic. 2011.

SANGUINETTI: "HAY MILITARES NOSTÁLGICOS DE LA DICTADURA Y RADICALES DE IZQUIERDA NOSTÁLGICOS DE LA REVOLUCIÓN”. La República, Montevideo, 18 abr. 1989. Disponível em: 〈http://www.uc.org.uy/d0401n.htm>. Acesso em: 05 set. 2016.

TORRES, Gustavo. Paraguay: Treinta años de desaparición forzada de personas. Proyecto Desaparecidos, 17 mayo 2007.2 Disponível em: <http://www.desaparecidos.org/bbs/archives/003832.html>. Acesso em: 13 jan. 2017.

TRIBUNAL ARGENTINO CONDENA A 15 MILITARES POR CRÍMENES DEL PLAN CÓNDOR. La Nación, Buenos Aires, 27 mayo 2016. Disponível em: $<$ http://www.nacion.com/mundo/latinoamerica/Tribunal-argentino-militares-PlanCondor_0_1563243742.html>. Acesso em: 18 out. 2016.

URUGUAY: HISTÓRICO INFORME SOBRE LOS DESAPARECIDOS. La Nación, Buenos Aires, 9 agosto 2005. Disponível em: <http://www.lanacion.com.ar/728555-uruguayhistorico-informe-militar-sobre-los-desaparecidos>. Acesso em: 10 jul. 2015.

VERBITSKY, Horacio. La confesión de uno de los represores, el capitán Scilingo, reabrió en otro nivel toda la discusión sobre los crímenes dictatoriales y la impunidad que los cubría. Pagina/12, Buenos Aires, 3 marzo 1995b. Disponível em: <http://www.pagina12.com.ar/especiales/20aniversario/la_solucion_final.html>. Acesso em: 13 jul. 2014.

VIGLIONI, Daniel. Mauricio Rosencof: El pacto de resistir desde la Memoria. Clarín, Buenos Aires, 30 abr. 2014. Disponível em: <https://www.clarin.com/rn/literatura/MauricioRosencof-pacto-resistir-memoria_0_SJVzhaqP71.html>. Acesso em: 01 nov. 2017.

WEINRAUB, Bernard. Reagan Joins Kohl in Brief Memorial at Bitburg Graves. New York Times, New York, 6 May 1985. Disponível em: <http://www.nytimes.com/1985/05/06/international/europe/06REAG.html?pagewanted=all>. Acesso em: 03 maio 2017.

WIESEL, Elie. Art and the Holocaust: Trivializing memory. The New York Times, New York, 11 Jun. 1989. Disponível em: <http://www.nytimes.com/1989/06/11/movies/art-andthe-holocaust-trivializing-memory.html?pagewanted=all>. Acesso em: 17 maio 2017. 
YAÑEZ, Antonia. Marcas como abrazo. No te olvides, Montevideo, N.10, 2012.

YO SOBREVIVÍ A LA DICTADURA. El Colombiano, Colombia, 16 enero 2017. Disponível em: <http://m.elcolombiano.com/relato-de-sobreviviente-de-la-dictaduraargentina-DY5753371>. Acesso em: 04 fev. 2017.

2000 TESTIMONIOS PARA VERDAD Y JUSTICIA. ABC Color, Asunción, 9 jul. 2007. Disponível em: <http://www.abc.com.py/edicion-impresa/politica/2000-testimonios-paraverdad-y-justicia-994101.html>. Acesso em: 09 ago. 2015.

\section{Bibliografia}

ABRAMOVICH, Víctor. Das violações em massa aos padrões estruturais: Novos enfoques e clássicas tensões no Sistema Interamericano de Direitos Humanos. SUR - Revista Internacional de Direitos Humanos, São Paulo, Vol.6, N.11, dez. 2009.

ADORNO, Theodor; HORKHEIMER, Max. Dialética do esclarecimento: Fragmentos filosóficos. Rio de Janeiro: Zahar, 1985.

ADORNO, Theodor. Indústria cultural e sociedade. São Paulo: Paz e Terra, 2002.

ALMADA, Martin. Paraguay: La cárcel olvidada. Buenos Aires: Ediciones Antiquera, 1988.

La lucha es justa, necesaria y continua. In: Anales del III Seminario Latinoamericano de amnistía y derechos humanos. Brasilia: Comisión de derechos humanos de la Cámara de Diputados del Congreso Nacional, 22-24 nov. 2009.

ALFONSÍN, Raúl. Memoria política: transición a la democracia y derechos humanos. Buenos Aires: Fondo de Cultura Económica, 2013.

ANDERSON, Benedict. Comunidades imaginadas: Reflexiones sobre el origen y difusión del nacionalismo. México DF: Fondo de Cultura Económica, 1993.

ANSALDI, Waldo. La novia es excelente, solo un poco ciega, algo sorda y al hablar tartamudea. Logros, falencias y límites de las democracias de los países del Mercosur, 19822005. In: ANSALDI, Waldo (Org.). La democracia en América Latina, un barco a la deriva. Buenos Aires: Fondo de Cultura Económica, 2007.

Democracia de pobres, democracia pobre, pobres democracias. Temas y Debates, Rosario, Año 7, N.6 y 7, p. 27-43, nov. 2003.

APPLEBAUM, Anne. Gulag: Uma história dos campos de prisioneiros soviéticos. Rio de Janeiro: Ediouro, 2009.

ARAUJO, Maria Paula. Comissões de Verdade: um debate ético-político na contemporaneidade. In: FICO, Carlos. ARAUJO, Maria Paula. GRIN, Monica (Org.) Violência na história: memória, trauma e reparação. Rio de Janeiro: Ponteio, 2012. p. 145162. 
ARAUJO, Maria Paula; PINTO, António Costa (Org.). Democratização, Memória e Justiça de Transição nos Países Lusófonos. Rio de Janeiro: Autografia, 2017.

ARENDT, Hannah. Eichmann em Jerusalém: Um relato sobre a banalidade do mal. São Paulo: Companhia das Letras, 1999.

Homens em tempos sombrios. São Paulo: Companhia das Letras, 2008.

ARTEAGA, Juan José. Uruguay: Breve historia contemporánea. México DF: Fondo de Cultura Económica, 2000.

ASERETTO, Rodolfo Manuel. Ligas Agrarias: Reseña de los orígenes, persecución y extinción de las Ligas Agrarias. Asunción: CIPAE, 2001.

Caso Hermanos Ramírez Villalba. Paraguay: CIPAE, 2010.

ASOCIACIÓN DE FAMILIARES DE DETENIDOS DESAPARECIDOS Y MÁRTIRES POR LA LIBERACIÓN NACIONAL. Informe sobre las desapariciones forzadas en Bolivia. La Paz: Capítulo Boliviano de Derechos Humanos, dic. 2007.

BARREIRO, Line. Prólogo de la 5a Edición. La evidencia. In: BOCCIA PAZ, Alfredo; GONZÁLEZ, Myrian; PALAU, Rosa. Es mi informe: Los archivos secretos de la policía de Stroessner. Asunción: Servilibro, 2006. p. 5-21.

BASCH, Fernando et al. A eficácia do Sistema Interamericano de Proteção de Direitos Humanos: uma abordagem quantitativa sobre seu funcionamento e sobre o cumprimento de suas decisões. SUR - Revista Internacional de Direitos Humanos, São Paulo, Vol.7, N.12, 2010.

BAUER, Caroline Silveira. Brasil e Argentina: Ditaduras, desaparecimentos e políticas de memória. Porto Alegre: Medianiz, 2014.

BAUMGARTNER, José Luiz; MATOS, Jorge Duran; MAZZEO, Mario. Os desaparecidos: A história da repressão no Uruguai. Porto Alegre: tchê!, 1987.

BENJAMIN, Walter. Magia e técnica, arte e política: ensaios sobre literatura e história da cultura. São Paulo: Brasiliense, 2012.

BOCCIA PAZ, Alfredo. Operativo Cóndor: ¿un ancestro vergonzoso? Cuadernos para el debate, Instituto de Desarrollo Económico y Social (IDES), N.7, Buenos Aires, oct. de 1999.

La década inconclusa: Historia real de la OPM. Asunción: El Lector, 2006.

BOCCIA PAZ, Alfredo; GONZÁLEZ, Myrian; PALAU, Rosa. Es mi informe: Los archivos secretos de la policía de Stroessner. Asunción: Servilibro, 2006.

BOCCIA PAZ, Alfredo et al. En los sótanos de los generales: Los documentos ocultos del Operativo Cóndor. Asunción: Servilibro, 2008. 
BONASSO, Miguel. De los "desaparecidos" a los "chicos de la guerra". Nueva Sociedad, Buenos Aires, N.76, p. 52-61, marzo-abr. 1985.

BOSI, Ecléa. Memória e Sociedade: Lembranças de velhos. São Paulo: Companhia das Letras, 1994.

BRESCIANI, Stella; NAXARA, Márcia (Org.). Memória e (Res)sentimento: Indagações sobre uma questão sensível. Campinas: UNICAMP, 2004.

BRITO, Alexandra Barahona; SZNAJDER, Mario. A política do passado: América Latina e Europa do Sul em perspectiva comparada. In: PINTO, António Costa; MARTINHO, Francisco Carlos Palomanes (Org.). O passado que não passa: A sombra das ditaduras na Europa do Sul e na América Latina. Rio de Janeiro: Civilização Brasileira, 2013. p. 295-328.

BRESCIANI, Stella. NAXARA, Márcia (Org.). Memória e (res)sentimentos. Campinas: UNICAMP, 2004.

BRODSKY, Marcelo. Memory Works. Salamanca: Ediciones Universidad de Salamanca, 2001.

BRODSKY, Marcelo (Coord.). Memoria en construcción: el debate sobre la ESMA. Buenos Aires: la marca editora, 2005.

BUCK-MORSS, Susan. The Gift of the Past - Das Gift der Vergangenheit. In: JOZAMI, Eduardo; KAUFMAN, Alejandro; VEDDA, Migue (Comp.). Walter Benjamin en la ex ESMA: Justicia, Historia y Verdad. Escrituras de la memoria. Buenos Aires: Prometeo Libros, 2013. p. 75-89.

BUSTOS, Dalmiro. El otro frente a la Guerra: Los padres de las Malvinas. Buenos Aires: Ramos Americana Editora, 1982.

CÁCERES, María Stella. Las luchas por la memoria histórica en tiempos de golpe. Derechos Humanos en Paraguay, Asunción, 2012.

CALLONI, Stella. Las largas alas del Cóndor. Terrorismo sin fronteras. In: INSTITUTO ESPACIO PARA LA MEMORIA (Coord.). Un Espacio para la Memoria. Buenos Aires: Instituto Espacio para la Memoria, 2006. p. 72-74.

CALVEIRO, Pilar. Formas y sentidos de lo represivo entre dictadura y democracia. In: CENTRO DE ESTUDIOS LEGALES Y SOCIALES. Hacer Justicia: Nuevos debates sobre el juzgamiento de crímenes de lesa humanidad en Argentina. Buenos Aires: Siglo XXI, 2011. p. 112-142.

Poder e desaparecimento. São Paulo: Boitempo, 2013.

CANCLINI, Néstor García. El patrimonio cultural de México y la construcción imaginaria de lo nacional. In: FLORESCANO, Enrique. El patrimonio nacional de México. Ciudad de México: Fondo de Cultura Económica, 1997. p. 57-85. 
Museu para a globalização. Cadernos do CEOM, Santa Catarina, Ano 27, N.41, pp.37-46, dez. 2014.

Consumidores e cidadãos. Rio de Janeiro: Editora UFRJ, 2015.

CANTON, Santiago. Leis de anistia. In: REÁTEGUI, Félix (Coord.). Justiça de transição: manual para a América Latina. Brasília: Comissão de Anistia/Ministério da Justiça, 2011. p. 263-290.

CAPELATO, Maria Helena. O "gigante brasileiro"na América Latina: Ser ou não ser latinoamericano. In: MOTA, Carlos Guilherme (Org.). Viagem incompleta: A experiência brasileira (1500-2000). São Paulo: Senac, 2000. p. 286-316.

CASSEL, Douglass. La Corte Interamericana de Derechos Humanos. In: THE UNITED SPACE INSTITUT OF PEACE (Org.). Víctimas sin mordaza: El impacto del Sistema Interamericano en la justicia transicional en Latinoamérica. Los casos de Argentina, Guatemala, El Salvador y Perú. México DF: Comisión de Derechos Humanos del Distrito Federal. 2007. p. 197-217.

CATELA, Ludmila da Silva. Situação-limite e memória: A reconstrução do mundo dos familiares de desaparecidos da Argentina. São Paulo: Hucitec, 2001.

CELESIA, Felipe; WAISBERG, Pablo. Firmenich: La historia jamás contada. Buenos Aires: Aguilar, 2010.

CENTRO DE ESTUDIOS LEGALES Y SOCIALES. Hacer Justicia: Nuevos debates sobre el juzgamiento de crímenes de lesa humanidad en Argentina. Buenos Aires: Siglo XXI, 2011.

CERRUTI, Graciela. La historia de la memoria. Revista Puentes, Buenos Aires, p. 14-25, 2001.

CHAUVEAU, Agnès; TÉTART, Philippe (Org.). Questões para a história do presente. Bauru: EDUSC, 1999.

CHOAY, Françoise. A alegoria do patrimônio. São Paulo: Estação Liberdade, 2006.

CLAVERO, Bartolomé. Delito de genocidio y pueblos indígenas en el derecho internacional. In: CLAVERO, Bartolomé et al. Los Aché del Paraguay: Discusión de un genocidio. Copenhague: IWGIA, 2008. p. 23-42.

CLAVERO, Bartolomé et al. Los Aché del Paraguay: Discusión de un genocidio. Copenhague: IWGIA, 2008.

COLMÁN, Emilio Alapanian. Identidades em confronto: imagens do Brasil e do Paraguai nos jornais Estado de São Paulo e La Tribuna durante o caso dos Saltos Sete Quedas/Guairá (1963-1966). 2016. 182 f. Dissertação (Mestrado em História Social) - Faculdade de Filosofia, Letras e Ciências Humanas, Universidade de São Paulo, São Paulo, 2016.

COMITÉ DE DEFENSA DE LOS DERECHOS DEL PUEBLO. La gran mentira: el caso de las listas de los 119. Santiago: CODEPU, 2005. 
COUTO, Andréia Terzariol. O país das mil colinas: relatos sobre uma região marcada pelo ultimo genocídio do século XX. Curitiba: Appris, 2013.

CRENZEL, Emilio. La História Política del Nunca Más: la memoria de las desaparaciones en Argentina. Buenos Aires: Siglo XXI, 2008.

CRENZEL, Emilio (Coord.). Los desaparecidos en Argentina: Memorias, representaciones e ideas (1983-2008). Buenos Aires: Biblos, 2010.

CYTRYNOWICZ, Roney. O silêncio do sobrevivente: diálogo e rupturas entre memória e história do Holocausto. In: SELIGMANN-SILVA, Márcio (Org.). História, Memória, Literatura: O testemunho na Era das Catástrofes. Campinas: UNICAMP, 2013. p. 123-139.

DE LA VEGA, María José Hidalgo; SERNA, Jesús María Sanz; BRAVO, Mario Bedera. Presentación. In: BRODSKY, Marcelo. Memory Works. Salamanca: Ediciones Universidad de Salamanca, 2001. p. 3.

DEPRÁ, Giseli. O lago de Itaipu e a luta dos Avá-Guarani pela terra: representações na imprensa do Oeste do Paraná (1976-2000). 2006. 159 f. Dissertação (Mestrado em História) Faculdade de Ciências Humanas, Universidade Federal de Grande Dourados, Dourados, 2006.

DERRIDA, Jacques. Mal de arquivo: Uma impressão freudiana. Rio de Janeiro: Relume Dumará, 2001.

DINGES, John. Os anos do Condor: Uma década de terrorismo internacional no Cone Sul. São Paulo: Companhia das Letras, 2005.

DULITZKY, Ariel E. La Comisión Interamericana de Derechos Humanos. In: THE UNITED SPACE INSTITUT OF PEACE (Org.). Víctimas sin mordaza: El impacto del Sistema Interamericano en la justicia transicional en Latinoamérica. Los casos de Argentina, Guatemala, El Salvador y Perú. México DF: Comisión de Derechos Humanos del Distrito Federal. 2007. p. 171-195.

DUSSEL, Inés; FINOCCHIO, Silvia; GOJMAN, Silvia. Haciendo Memoria en el País de Nunca Más. Buenos Aires: EUDEBA, 2006.

ENDERS, Armelle. Les lieux de mémoire, dez anos depois. Estudos Históricos, São Paulo, N.11, p. 132-137, 1993.

FEIERSTEIN, Daniel. Memorias y representaciones: Sobre la elaboración del genocidio. Buenos Aires: Fondo de Cultura Económica, 2012.

El genocidio como práctica social: Entre el nazismo y la experiencia argentina. Buenos Aires: Fondo de Cultura Económica, 2014.

Juicios: Sobre la elaboración del genocidio. Buenos Aires: Fondo de Cultura Económica, 2015. 
FELD, Claudia. Estrategias de construcción de testimonios audiovisuales sobre la desaparición de personas en Argentina: el programa televisivo Nunca Más. Documentos Lingüísticos y literarios del Instituto de Desarrollo Económico y Social, Buenos Aires, 2007.

La representación en la prensa de la transición: "el show de horror". In: CRENZEL, Emilio (Coord.). Los desaparecidos en Argentina: Memorias, representaciones e ideas (1983-2008). Buenos Aires: Biblos, 2010. p. 25-42.

El imposible debate entre víctimas y victimarios: notas sobre las declaraciones televisivas de Miguel Etchecolatz (1997). Rubrica Contemporánea, Buenos Aires, Vo.5, N.9, p. 77-101, 2016.

FELD, Claudia; FRANCO, Marina (Org.). Democracia, hora cero: Actores, políticas y debates en los inicios de la posdictadura. Buenos Aires: Fondo de Cultura Económica, 2015.

FERES JR, João. A história do conceito de "Latin America" nos Estados Unidos. Bauru: EDUSC, 2005.

FERRO, Marc. O Ressentimento na História. Lisboa: Editorial Teorema, 2007.

FICO, Carlos. ARAUJO, Maria Paula. GRIN, Monica (Org.) Violência na história: memória, trauma e reparação. Rio de Janeiro: Ponteio, 2012.

FILIPPINI, Leonardo. La persecución penal en la búsqueda de justicia. In: CENTRO DE ESTUDIOS LEGALES Y SOCIALES. Hacer justicia: nuevos debates sobre el juzgamiento de crímenes de lesa humanidad en Argentina. Buenos Aires: Siglo XXI, 2011. p. 19-47.

FRANCO, Marina. La "teoría de los dos demonios": un símbolo de la post-dictadura argentina. Foros sobre Memoria Social y Historia Reciente, Instituto de Desarrollo Económico y Social, Buenos Aires, 2014.

FREUD, Sigmund. O mal-estar na civilização. São Paulo: Companhia das Letras, 2011.

GAGNEBIN, Jeanne Marie. Lembrar, escrever, esquecer. São Paulo: Editora 34, 2006.

Após Auschwitz. In: SELIGMANN-SILVA, Márcio (Org.). História, Memória, Literatura: O testemunho na Era das Catástrofes. Campinas: UNICAMP, 2013. p. 89-111.

GARRETÓN, Francisca; GONZÁLEZ, Marianne; LAUZÁN, Silvana. Estudio de Políticas Públicas de Verdad y Memoria en 7 países de América Latina. Santiago de Chile: Centro de Derechos Humanos, 2011.

GATTI, Gabriel. Identidades desaparecidas: Peleas por el sentido en los mundos de la desaparición forzada. Buenos Aires: Prometeo Libros, 2011(a).

De un continente al otro: el desaparecido transnacional, la cultura humanitaria y las víctimas totales en tiempos de guerra global. Política y Sociedad, España, Vol.48, N.3, pp.519-536, 2011(b). 
GATTO, Hebert. El cielo por asalto: El Movimiento de Liberación Nacional (Tupamaros) y la izquierda uruguaya (1963-1972). Montevideo: Editorial Santillana, 2004.

GAUDICHAUD, Frank. La sombra del Cóndor: Terrorismo de Estado Internacional y Contra-Revolución en el Cono Sur. 1994. Disponível em: <http://www.archivochile.com/Ideas_Autores/gaudif/gaudif0004.pdf>. Acesso em: 04 jan. 2016.

GINZBURG, Carlo. Nenhuma ilha é uma ilha: Quatro visões da literatura inglesa. São Paulo: Companhia das Letras, 2004.

GONZÁLEZ, Ana María Sosa. El museo de la memoria en Uruguay. Algunas reflexiones en torno a los processos de patrimonialización de memorias traumáticas. Clepsidra. Revista Interdisciplinaria de Estudios sobre memoria, Buenos Aires, N.2, p. 80-101, oct. 2014.

GÖRLING, Reinhold. Recordando a Walter Benjamin: justicia, historia y verdad. In: JOZAMI, Eduardo; KAUFMAN, Alejandro; VEDDA, Migue (Comp.). Walter Benjamin en la ESMA: Justicia, historia y verdad. Escrituras de la memoria. Buenos Aires: Prometeo, 2013. p. 195-205.

GRANDE, Alfredo. El genocidio llama dos veces. In: INSTITUTO ESPACIO PARA LA MEMORIA (Coord.). Un Espacio para la Memoria. Buenos Aires: Instituto Espacio para la Memoria, 2006. p. 46-47.

GROPPO, Bruno. Las políticas de la memoria. Sociohistórica, La Plata, N.11-12, p. 187-198, 2002.

GROSSMAN, Jonathan. Violência e silêncio: Reescrevendo o futuro. Revista História Oral, Brasil, N.3, p. 7-24, 2000.

GRUZINSKI, Serge. Que horas são... lá, no outro lado?: América e Islã no limiar da Época Moderna. Belo Horizonte: Autêntica Editora, 2012.

GUENA, Márcia. Arquivo do Horror: Documentos secretos da ditadura do Paraguai (19601980). São Paulo: Memorial da América Latina, 1996.

GUIGOU, L. Nicolás. La bifurcación del tempo en una história hecha pedazos: Vladimir Roslik y Basilio Lubkov. Los héroes y el tiempo de la muerte. Uruguay: Unesco, 2009. Disponível em: <http://www.unesco.org.uy/shs/fileadmin/templates/shs/archivos/anuario2009/Guigou.pdf>. Acesso em: 03 mar. 2018.

La bifurcación del tiempo en una historia hecha pedazos Vladimir Roslik y Basilio Lubkov. Los héroes y el tiempo de la muerte. L. Nicolás Guigou

HARFF, Barbara. The etiology of genocides. In: WALLIMANN, Isidor; DOBKOWSKI, Michel N. (Org.). Genocide and the Modern Age: Etiology and case studies of mass death. New York: Syracuse University Press, 2000. p. 41-59. 
HARRIS, Verne S. Taller: Rastros y pruebas. Gestión, accesibilidad y usos de los archivos del pasado en sudáfrica. Buenos Aires: Instituto de Desarollo Económico y Social, 14 out. 2014.

HEYMANN, Luciana Quillet. O devoir de mémoire na França contemporânea: entre memória, história, legislação e direitos. In: GOMES, Angela de Castro (Coord.). Direitos e cidadania: memória, política e cultura. Rio de Janeiro: FGV, 2007. p. 15-43.

HILB, Claudia. La Tablada: el último acto de la guerrilla setentista. Lucha Armada en la Argentina, Buenos Aires, N.9, septiembre 2007.

HOBSBAWM, Eric. Era dos extremos: O breve século XX (1914-1991). São Paulo: Companhia das Letras, 1995.

Barbárie: manual do usuário. In: Sobre História. São Paulo, Companhia das letras, 1997. p. 268-280.

HOBSBAWM, Eric; RANGER, Terence. A invenção das tradições. São Paulo: Paz e Terra, 2005.

HUNT, Lynn. A nova história cultural. São Paulo: Martins Fontes, 1992.

2009.

A invenção dos direitos humanos: Uma história. São Paulo: Companhia das Letras,

HUYSSEN, Andreas. Seduzidos pela memória: arquitetura, monumentos, mídia. Rio de Janeiro: Aeroplano, 2000.

El arte mnemónico de Marcelo Brodsky. In: BRODSKY, Marcelo. Memory Works. Salamanca: Ediciones Universidad de Salamanca, 2001. p. 7-11.

Culturas do passado-presente: modernismos, artes visuais, políticas da memória. Rio de Janeiro: Contraponto, 2014.

INSTITUTO ESPACIO PARA LA MEMORIA (Coord.). Un Espacio para la Memoria. Buenos Aires: Instituto Espacio para la Memoria, 2006.

JELIN, Elizabeth. Los trabajos de la memoria. Madrid: Siglo XXI, 2002.

Víctimas, familiares o ciudadanos/as? In: CRENZEL, Emilio (Coord.). Los desaparecidos en Argentina: Memorias, representaciones e ideas (1983-2008). Buenos Aires: Biblos, 2010. p. 227-249.

Memoria y democracia. Una relación incierta. Política. Revista de Ciencia Política. Santiago de Chile, Vol.51. N.2, pp.129-144, 2013.

JOZAMI, Eduardo; KAUFMAN, Alejandro; VEDDA, Migue (Comp.). Walter Benjamin en la ex ESMA: Justicia, Historia y Verdad. Escrituras de la memoria. Buenos Aires: Prometeo Libros, 2013. 
KAUFMAN, Ester. Un ritual jurídico. El juicio a las Juntas Militares. Buenos Aires: FLACSO, 1987.

KOSELLECK, Reinhard. Futuro passado: contribuição à semântica dos tempos históricos. Rio de Janeiro: Contraponto, 2006.

LACAPRA, Dominick. Historia y memoria después de Auschwitz. Buenos Aires: Prometeo Libros, 2009.

LANG, Berel. Post-Holocaust: Interpretation, misinterpretation and the claims of History. Bloomington: Indiana University Press, 2005.

LANUSSE, Lucas. Montoneros: El mito de sus 12 fundadores. Buenos Aires: Ediciones B Argentina S.A., 2005.

LAQUEUR, Thomas W. Corpos, detalhes e a narrativa humanitária. In: HUNT, Lynn. A nova história cultural. São Paulo: Martins Fontes, 1992. p. 239-275.

LE GOFF, Jacques. História e memória. Campinas: UNICAMP, 1990.

LEVÍN, Florencia Paula. Arqueología de la memoria. Algunas reflexiones a propósito de los vecinos del horror. Revista Entrepasados, Buenos Aires, N.28, 2005.

LORENZ, Federico. Testigos de la derrota. Malvinas: los soldados y la guerra durante la transición democrática argentina, 1982-1987. In: PÉROTIN-DUMON, Anne (Dir.). Historizar el pasado vivo en América Latina. Santiago de Chile: Universidad Alberto Hurtado, 2007.2 Disponível em: <http://etica.uahurtado.cl/historizarelpasadovivo/es_contenido.php>. Acesso em: 14 ago. 2017.

Las guerras por Malvinas (1982-2012). Buenos Aires: Edhasa, 2012.

LOWENTHAL, David. Como conhecemos o passado. Projeto História. São Paulo, N.17, p. 63-201, nov. 1998.

MADSEN, Jacob Westergaard. The vividness of the past: A retrospective on the West German Historikerstreit in the mid-1980s'. University of Sussex Journal of Contemporary History, Brighton, n.1, p. 1-9, 2000.

MANKE, Albert. El nacionalsocialismo en Colonia hasta 1945 y la recuperación de la memoria histórica hasta la actualidad. In: PINEDO, Aristarco Regalado. Violencias y medios: Una reflexión desde la historia, el cine y las migraciones contemporáneas. Guadalajara: Universidad de Guadalajara, 2014. p. 101-142.

MARCHESI, Aldo. Los límites legales de la memoria: la Ley de Caducidad en la Justicia Transicional uruguaya. In: FICO, Carlos. ARAUJO, Maria Paula. GRIN, Monica (Org.) Violência na história: memória, trauma e reparação. Rio de Janeiro: Ponteio, 2012. p. 217227. 
MARTÍN-BARBERO, Jesús. Dos meios às mediações: Comunicação, cultura e hegemonia. Rio de Janeiro: Editora UFRJ, 2013.

MATTINI, Luis. Hombres y mujeres del PRT-ERP de Tucumán a La Tablada. La Plata: De la Campana, 2007.

MELIÀ, Bartolomeu. Pueblos indígenas en Paraguay y violación de derechos humanos (1958-2003). In: CLAVERO, Bartolomé et al. Los Aché del Paraguay: Discusión de un genocidio. Copenhague: IWGIA, 2008. p. 135-146.

MENESES, Ulpiano T. Bezerra. Do teatro da memória ao laboratório da História: a exposição museológica e o conhecimento histórico. Anais do Museu Paulista, São Paulo, N.2, p. 9-42, jan.-dez. 1994.

MERCOSUR. A 40 años del Cóndor: De las coordinaciones represivas a la construcción de las políticas públicas regionales en derechos humanos. Mercosur, 2015.

MIGNONE, Emilio F. Igreja e Ditadura. Porto Alegre: Tchê!, 1987.

MORALES, Diego R. Limitaciones al aceso a cargos públicos para implicados en crímenes de lesa humanidad: La experiencia argentina. In: CENTRO DE ESTUDIOS LEGALES Y SOCIALES. Hacer Justicia: Nuevos debates sobre el juzgamiento de crímenes de lesa humanidad en Argentina. Buenos Aires: Siglo XXI, 2011. p. 79-110.

MUÑOZ, Heraldo. A sombra do ditador: Memórias políticas do Chile sob Pinochet. Rio de Janeiro: Jorge Zahar, 2010.

MUNZEL, Mark. Los indígenas Aché: genocidio en Paraguay. In: CLAVERO, Bartolomé et al. Los Aché del Paraguay: Discusión de un genocidio. Copenhague: IWGIA, 2008. p. 55105 .

Los Aché: El genocidio continua en Paraguay. In: CLAVERO, Bartolomé et al. Los Aché del Paraguay: Discusión de un genocidio. Copenhague: IWGIA, 2008. p. 107-133.

NEVES, Debora Regina Leal. A persistência do passado: patrimônio e memoriais da ditadura em São Paulo e Buenos Aires. 2014. 255 f. Dissertação (Mestrado em História Social) - Faculdade de Filosofia, Letras e Ciências Humanas, Universidade de São Paulo, São Paulo, 2014.

NICKSON, Andrew. El regimen de Stroessner. In: TELESCA, Ignacio (Org.). História del Paraguay. Assunção: Taurus, 2010. p. 265-314.

NOLTE, Ernest. "The past that will not pass: A speech that could be written but not delivered. In: Forever in the shadow of Hitler?: Original documents of the Historikerstreit controversy concerning the singularity of the Holocaust. New Jersey: Atlantic Heights, 1993. p. 18-23.

NORA, Pierre. Between Memory and History: Les lieux de Mémoire. Representations, California, N.26, p. 7-24, 1989. 
NOVARO, Marcos; PALERMO, Vicente. Historia Argentina. La ditadura militar 1976/1983. Del golpe de Estado a la restauración democrática. Buenos Aires: Paidós, 2003.

PADRÓS, Enrique Serra. Kosovo: a desintegração do mosaico iugoslavo. Indicadores Econômicos, Porto Alegre, Vol.22, N.2, 1999.

Como el Uruguay no hay... Terror de Estado e Segurança Nacional. Uruguai (1968-1985): do Pachecato à Ditadura Civil-Militar. 2005. 840f. Tese (Doutorado em História) - Instituto de Filosofia e Ciências Humanas, Universidade Federal do Rio Grande do Sul, Porto Alegre, 2005.

Repressão e violência: segurança nacional e terror de Estado nas ditaduras latinoamericanas. In: FICO, Carlos et al. (Org.). Ditadura e democracia na América Latina: Balanço histórico e perspectivas. Rio de Janeiro: Editora FGV, 2008. p. 143-178.

A Igreja Católica e as ditaduras no Cone Sul (1960-1980). Outros Tempos, Maranhão, Vol.12, N.20, p. 74-94, 2015.

PAREDES, Roberto. 25 años de democracia (1989-2014). Asunción: Caballo de Troya, 2014.

PÉROTIN-DUMON, Anne (Dir.). Historizar el pasado vivo en América Latina. Santiago de Chile: Universidad Alberto Hurtado, 2007. Disponível em: <http://etica.uahurtado.cl/historizarelpasadovivo/es_contenido.php>. Acesso em: 14 ago. 2017.

PINTO, António Costa; MARTINHO, Francisco Carlos Palomanes (Org.). O passado que não passa: A sombra das ditaduras na Europa do Sul e na América Latina. Rio de Janeiro: Civilização Brasileira, 2013.

POLLAK, Michael. Memória, Esquecimento, Silêncio. Estudos Históricos. Rio de Janeiro, Vol.2, N.3, p. 3-15, 1989.

PORTELLI, Alessandro. O massacre de Civitella Val di Chiana (Toscana, 29 de junho de 1944). In: FERREIRA, Marieta de Moraes; AMADO, Janaína (Org.). Usos e abusos da História Oral. Rio de Janeiro: FGV, 1998. p. 103-130.

POULOT, Dominique. Uma história do patrimônio no Ocidente. São Paulo: Estação Liberdade, 2009.

PRADO, Maria Ligia Coelho. Repensando a História Comparada da América Latina. Revista de História, São Paulo, N.153, p. 11-33, 2005.

PRADO, Maria Ligia; PELlEGRINO, Gabriela. História da América Latina. São Paulo: Contexto, 2014.

PURDY, Sean. A História Comparada e o desafio da Transnacionalidade. Revista de História Comparada, Rio de Janeiro, N.1, Vol.6, p. 64-84, 2012. 
QUADRAT, Samantha Viz. A emergência do tema dos direitos humanos na América Latina. In: FICO, Carlos et. al. Ditadura e democracia na América Latina: Balanço histórico e perspectivas. Rio de Janeiro: Editora FGV, 2008. p. 361-395.

REÁTEGUI, Félix (Coord.). Justiça de transição: manual para a América Latina. Brasília: Comissão de Anistia/Ministério da Justiça, 2011.

RICO, Álvaro (Coord.). Investigación histórica sobre la dictadura y el Terrorismo de Estado en el Uruguay (1973-1985). Montevideo: Universidad de la República, 2008.

ROA BASTOS, Augusto. Prólogo de la Primera Edición: El terror escrito por el mismo (1994). In: BOCCIA PAZ, Alfredo; GONZÁLEZ, Myrian; PALAU, Rosa. Es mi informe: Los archivos secretos de la policía de Stroessner. Asunción: Servilibro, 2006. p. 25-32.

ROCHA, Marina Maria de Lira. "Não são nada mais que bestas": Os debates sobre violência no governo de Isabelita Perón. Rio de Janeiro: Multifoco, 2015.

ROLLEMBERG, Denise. Resistência: Memória da ocupação nazista na França e Itália. São Paulo: Alameda, 2016.

ROLLEMBERG, Denise; QUADRAT, Samantha (Org.). A construção social dos regimes autoritários: Legitimidade, consenso e consentimento no século XX (Brasil e América Latina). Rio de Janeiro: Civilização Brasileira, 2010.

ROMANIN, Enrique Andriotti. Memorias en conflicto: El movimiento de Derechos Humanos y la construcción del Juicio por la Verdad de Mar del Plata. Mar del Plata: Editorial de la Universidad Nacional de Mar del Plata (EUDEM), 2013a.

Decir la verdad, hacer justicia: Los Juicios por la Verdad en Argentina. Revista Europea de Estudios Latinoamericanos y del Caribe, Amsterdam, N.94, p. 5-23, 2013 b.

SAID, Edward W. Cultura e imperialismo. São Paulo: Companhia das Letras, 2011.

SALAMA, Mauricio Cohen. Tumbas anónimas: Informe sobre la identificación de restos de víctimas de la represión ilegal. Buenos Aires: Catálogos Editora, 1992.

SANDOVAL, Carlos A. MIR: Una historia. Santiago de Chile: Sociedad Editorial Trabajadores, 1990.

SANTOS, Cecília Macdowell. Ativismo jurídico transnacional e o Estado: reflexões sobre os casos apresentados contra o Brasil na Comissão Interamericana de Direitos Humanos. SUR Revista Internacional de Direitos Humanos, São Paulo, Ano 4, N.7, 2007.

SCHELOTTO, Magdalena. La ditadura cívico-militar uruguaya (1973-1985): la construcción de la nocíon de víctima y la figura del exiliado en el Uruguay post-dictatorial. Nuevo Mundo, Mundos Nuevos, França, 2015. Disponível em: <https://journals.openedition.org/nuevomundo/67888>. Acesso em: 1 jul. 2018.

SELIGMANN-SILVA, Márcio (Org.). História, Memória, Literatura: O testemunho na Era das Catástrofes. Campinas: UNICAMP, 2013. 
SIKKINK, Kathryn; WALLING, Carrie Booth. La cascada de la justicia y el impacto de los juicios de derechos humanos en América Latina. Cuadernos del CLAEH, Montevidéo, Ano 31, N.96-97, p. 15-40, 2008.

SOUSA SANTOS, Boaventura de. (Org.). Another Knowledge is Possible: Beyond Northern Epistemologies. London: Verso, 2007.

Refundación del Estado en América Latina: Perspectiva desde una epistemología del sur. Lima: Instituto Internacional de Derecho y Sociedad, 2010a.

Se Deus fosse um ativista dos direitos humanos. Coimbra: Almedina, 2013.

SOUSA SANTOS, Boaventura de et al. (Org.). Repressão e memória política no contexto Ibero-Brasileiro: estudos sobre Brasil, Guatemala, Moçambique, Peru e Portugal. Coimbra: Universidade de Coimbra, 2010.

SCHWARTZ, Joan M.; COOK, Terry. Arquivos, documentos e poder: A construção da memória moderna. Revista Registro, Idaiatuba, Vol.3, N.3, p. 15-30, jul. 2004.

SELIGMANN-SILVA, Márcio (Org.). História, Memória, Literatura: O testemunho na Era das Catástrofes. Campinas: UNICAMP, 2013.

SKREPETZ, Inês. Nunca Más: Para que não se esqueça para que nunca mais aconteça. Extraprensa, São Paulo, Ano VI, N.10, jun. de 2012.

THE UNITED SPACE INSTITUT OF PEACE (Org.). Víctimas sin mordaza: El impacto del Sistema Interamericano en la justicia transicional en Latinoamérica. Los casos de Argentina, Guatemala, El Salvador y Perú. México DF: Comisión de Derechos Humanos del Distrito Federal. 2007.

TEITEL, Ruti G. Transitional justice genealogy. Harvard Human Rights Journal, Cambridge, Vol.16, p. 69-94, 2003.

TODOROV, Tzvetan. Los abusos de la memoria. Barcelona: Paidós, 2013.

VALLE, Mariano Fernández. La Corte Suprema Argentina frente al Legado de la Última Dictadura Militar: Reseña del Fallo "Simón”. Anuario de Derechos Humanos, 2006.

VAN ZYL, Paul. Promovendo a justiça transicional em sociedades pós-conflito. In: REÁTEGUI, Félix (Coord.). Justiça de transição: manual para a América Latina. Brasília: Comissão de Anistia/Ministério da Justiça, 2011. p. 47-72.

VARSKY, Carolina. El testimonio como prueba en procesos penales por delitos de lesa humanidad: Algunas reflexiones sobre su importancia en el proceso de justicia argentina. In: CENTRO DE ESTUDIOS LEGALES Y SOCIALES. Hacer Justicia: Nuevos debates sobre el juzgamiento de crímenes de lesa humanidad en Argentina. Buenos Aires: Siglo XXI, 2011. p. 49-74. 
VÁSQUEZ, Inés; DOWIE, Karina. Un país, 30 años: El pañuelo sigue haciendo historia. Buenos Aires: Asociación Madres de la Plaza de Mayo, 2006.

VERA, Myrian Gonzáles. "Fecha feliz" en Paraguay. Los festejos del 3 de noviembre, cumpleaños de Alfredo Stroessner. In: JELIN, Elizabeth (Comp.). Las Conmemoraciones: Las disputas en las fechas “in-felices”. Buenos Aires: Siglo XXI, 2002. p. 149-194.

VERBITSKY, Horacio. El vuelo. Buenos Aires: Editorial Planeta, 1995.

Sudamericana, 2005.

El Silencio: Relaciones secretas de la Iglesia con la ESMA. Buenos Aires:

La mano izquierda de Dios: La última dictadura (1976-1983). Buenos Aires:

Sudamericana, 2010.

VEZZETTI, Hugo. Pasado y Presente: Guerra, dictadura y sociedad en la Argentina. Buenos Aires: Siglo XXI, 2003. 2009.

Sobre la violencia revolucionaria: memorias y olvidos. Buenos Aires: Siglo XXI,

VILLAGRA, Luis Rojas (Comp.). La economía paraguaya bajo el orden neoliberal. Asunción: Base IS, 2011.

VINYES, Ricard. Un futuro para el pasado: Proyecto de creación del Memorial Democrático. Barcelona: Universitat Autónoma de Barcelona, 2004.

"Hacer las paces". Sobre símbolos y monumentos: La construcción del museo sincrético. Clepsidra. Revista Interdisciplinaria de Estudios sobre memoria, Buenos Aires, N.2, p. 12-27, oct. 2014.

\section{Obras Literárias e Musicais}

BENEDETTI, Mario. Cotidianas. Buenos Aires: Editorial Sudamericana, 1979.

CELAN, Paul. Obras completas. Madrid: Editorial Trotta, 1999.

CONTI, Haroldo. Sudeste-Ligados: Haroldo Conti. Edición crítica. Santiago de Chile: ALLCA XX, 1998.

ESPINOSA, María Fernanda. El pez dorado de Arizona (poema), Ecuador, 2013. Disponível em: <http://www.excentrica.com.ar/maria-fernanda-espinosa-poeta-ecuatoriana/>. Acesso em: 03 jul. 2017.

FOGWILL, Rodolfo. Los pichiciegos. Visiones de una batalla subterránea. Buenos Aires: De la Flor, 1983.

GIECO, León. La memoria (letra de música), Buenos Aires, 2001. 
LEVI, Primo. É isto um homem? Rio de Janeiro: Rocco, 1988.

LEVI, Primo. A trégua. São Paulo: Companhia das letras, 2010.

LEVI, Primo. Os afogados e os sobreviventes. Rio de Janeiro: Paz e Terra, 2016.

MARTÍNEZ, Tomás Eloy. La pasión según Trelew. Buenos Aires: Punto de Lectura, 2007.

ROA BASTOS, Augusto. Hijo de hombre. Asunción: El Lector, 1960.

SABATO, Ernesto. A resistência. São Paulo: Companhia das Letras, 2008.

WALSH, Rodolfo. Operación Masacre. Buenos Aires: Ediciones de la Flor, 2000.

WIESEL, Elie. Night. New York: Hill and Wang, 2006.

\section{Filmes e Documentários}

DEL SILENCIO AL NUNCA MÁS. Buenos Aires: Todo Noticias, Canal 13, 2004.

DOCUMENTAL COMISIÓN DE VERDAD Y JUSTICIA. Asunción: TV Pública Paraguay, 2008.

EL ALMA DE LOS VERDUGOS. Realização: Baltasar Garzón e Vicente Romero. Espanha: TVE, 2007. Disponível em: <www.rtve.es/alacarta/videos/informe-semanal/informe-semanalalma-verdugos/592458>. Acesso em: 5 jul. 2016.

GARAGE OLIMPO. Direção: Marco Bechis. Produção: Amadeo Pagani, Marco Bechis, Enrique Piñero, Eric Heumann. Buenos Aires: Instituto Luce, 1999.

HOLOCAUSTO. Direção: Marvin Chomski. Produção: Robert Berger. Estados Unidos da América: NBC, 1979.

MALAJUNTA. Dirección: Eduardo Aliverti, Pablo Milstein, Javier Rubel. Texto: Eduardo Aliverti. Buenos Aires: CREARS Producción, 1996.

NOITE E NEBLINA. Direção: Alain Resnais. Texto: Jean Cayrol. França: Comitê de História da Segunda Guerra Mundial, 1955.

NUNCA MÁS. Buenos Aires: Canal 13, 1984.

THE BERLIN WALL. Edition: Wieland Giebel. Production: Berlin Story. Berlin: 2013.

ZANAHORIA - DETRÁS DE LA VERDAD. Dirección: Enrique Buchichio. Uruguay; Argentina: Lavorágine Films, 2014.

35 AÑOS DE STRONISMO. Dirección: Leonardo Navaja. Producción: TV Pública Paraguay. Asunción: 2011. 
108 CUTILLO DE PALO. Dirección: Renate Costa. Producción: Carlos Vázquez. Asunción: 2010.

\section{Endereços eletrônicos}

ARCHIVO CHILE. Disponível em: <http://www.archivochile.com/Memorial/caidos_mov_popular/P/prats_gonzalez_carlos.pdf >. Acesso em: 06 jan. 2017.

ARCHIVO DE LA PRESIDENCIA DE LA REPÚBLICA ORIENTAL DEL URUGUAY. Disponível em: <http://archivo.presidencia.gub.uy/fotos/banco/2002/octubre/octubre2002.htm>. Acesso em: 16 jul. 2015.

ARCHIVO DE LEÓN FERRARI. Disponível em: <http://propuesta77.blogspot.com.br/2014/03/Leonferrari.html>. Acesso em: 13 nov. 2017.

ARCHIVO DE LEO VACA. Disponível $<$ http://www.infojusnoticias.gov.ar/especiales/la-esma-en-13-fotos-del-horror-a-la-memoria56.html>. Acesso em: 05 jul. 2017.

ARCHIVO DEL GOBIERNO DE ARGENTINA. Disponível em: $\langle$ https://www.argentina.gob.ar/derechoshumanos/sitio-de-memoria-esma.aspx>. Acesso em: 04 fev. 2017.

ARCHIVO DE PABLO NOGUEIRA. Disponível em: <http://revista.escaner.cl/node/6940>. Acesso em: 27 jun. 2017.

ARCHIVO EDUC.AR. Disponível em: <https://www.educ.ar/noticias/126477/la-presidentainauguro-el-sitio-de-memoria-en-la-ex-esma>. Acesso em: 04 fev. 2017.

ARCHIVO UNIVERSIDAD DE LA REPÚBLICA. Disponível em: $<$ http://concursos.fadu.edu.uy/index.php/concursos/memorial-en-recordacion-a-los-detenidosdesaparecidos>. Acesso em: 10 jan. 2017.

COMISIÓN DE VERDAD Y JUSTICIA. El autoritarismo en la História Reciente del Paraguay. Disponível em: 〈http://www.cipae.org.py/V2/biblioteca/CVJAutoritarismo.pdf>. Acesso em: 14 jul. 2017.

COMISIÓN INTERAMERICANA DE DERECHOS HUMANOS. Fotos de los vuelos de la muerte. Disponível em: <http://www.infojusnoticias.gov.ar/nacionales/vuelos-de-la-muertelas-fotos-del-horror-3618.html>. Acesso em: 09 jan. 2017.

COMISIÓN INTERAMERICANA DE DERCHOS HUMANOS. Visitas realizadas en los países. Disponível em: <http://www.oas.org/es/cidh/actividades/visitas_todas.asp>. Acesso em: 03 nov. 2016. 
COMISIÓN NACIONAL SOBRE LA DESAPARICIÓN DE PERSONAS. Entrega del Informe Final Nunca Más. Disponível em: <https://www.youtube.com/watch?v=eHn4wYeWuuY>. Acesso em: 01 fev. 2017.

CONFERENCE AMERICAN ARMIES. Disponível em: <https://www.redcea.com>. Acesso em: 04 jan. 2017.

CONSTITUTION HILL. Disponível em: <https://www.constitutionhill.org.za>. Acesso em: 6 jul. 2017.

CRYSOL. Disponível em: <http://crysol.blogspot.com.br/2011/12/la-casa-del-infierno.html>. Acesso em: 08 jul. 2017.

DESAPARECIDOS. Disponível em: <http://www.desaparecidos.org/arg/victimas/t/tatter/> . Acesso em: 04 jan. 2017.

DACHAU CONCENTRATION CAMP MEMORIAL SITE. Disponível em: <https://www.kz-gedenkstaette-dachau.de/>. Acesso em: 18 jul. 2017.

ESPACIO CARTA ABIERTA. Disponível em: <http://www.cartaabierta.org.ar>. Acesso em: 19 jan. 2017.

ESPACIO MEMORIA Y DERECHOS HUMANOS. Disponível em: <http://www.espaciomemoria.ar>. Acesso em: 03 fev. 2017.

EXPOSICIÓN INFORME LARRETA. Disponível em: <http://elinforme.larreta.org>. Acesso em: 10 jul. 2017.

FUNDACIÓN CELESTINA PÉREZ DE ALMADA. Disponível em: <http://www.fcpa.org.py>. Acesso em: 05 fev. 2017.

GOBIERNO DE BUENOS AIRES. Automotores Orletti. Disponível em: <http://www.buenosaires.gob.ar/MbdUp/contenido/automotores-orletti>. Acesso em: 09 ago. 2017.

HOLOCAUST MEMORIAL MUSEUM. Disponível em: 〈https://collections.ushmm.org>. Acesso em: 07 jul. 2017.

LATINOBARÓMETRO. Disponível em: <http://www.latinobarometro.org/latOnline.jsp>. Acesso em: 20 maio 2018.

MADE IN ARGENTINA. Disponível em: <http://www.teaydeportea.edu.ar/archivos/prohiben-las-obras-made-in-argentina-y-celda . Acesso em: 03 jul. 2017.

MEMORIA ABIERTA. Disponível em: <http://www.memoriaabierta.org.ar>. Acesso em: 8 fev. 2017.

MEMORIA ABIERTA. La ditadura en el cine. Disponível em: <http://www.memoriaabierta.org.ar/ladictaduraenelcine>. Acesso em: 10 abr. 2017. 
MUSEO DE LA MEMORIA (MUME). Disponível em: <http://mume.montevideo.gub.uy/museo/centro-cultural-museo-de-la-memoria>. Acesso em: 20 mar. 2017.

MEMORIA EN EL MERCOSUR. Disponível em: <http://www.memoriaenelmercosur.educ.ar>. Acesso em: 24 jul. 2017.

MUSEEN KOELN. Disponível em <https://museenkoeln.de/ns-dokumentationszentrum>. Acesso em: 25 out. 2017.

MUSEO DE LA PAZ DE GUERNIKA. Disponível em: <http://www.museodelapaz.org/es>. Acesso em: 17 jul. 2017.

MUSEO VIRTUAL MEMORIA Y VERDAD SOBRE EL STRONISMO. Disponível em: <www.meves.org.py>. Acesso em: 09 ago. 2015.

PARAGUAY RESISTE AL GOLPE. Disponível em: <http://paraguayresiste.com>. Acesso em: 11 nov. 2015.

PARQUE POR LA PAZ. Disponível em: 〈http://villagrimaldi.cl〉. Acesso em: 20 jul. 2017.

PEACE PALACE LIBRARY. Disponível em: $<$ https://www.peacepalacelibrary.nl/2012/05/the-body-counts-civilian-casualties-in-war/newwache-statue >. Acesso em: 06 mar. 2017.

SECRETARÍA DE DERECHOS HUMANOS PARA EL PASADO RECIENTE. Disponível em:

$<$ http://sdh.gub.uy/inicio/institucional/equipos/centro_de_documentacion_y_comunicacion/do cumentos_equipo_historia>. Acesso em: 23 jul. 2015.

TEREZÍN MEMORIAL. Disponível em: < http://www.pamatnik-terezin.cz>. Acesso em: 13 jul. 2017.

WALTER BENJAMIN PORTBOU. Disponível em: <http://walterbenjaminportbou.cat>. Acesso em: 19 jul. 2017.

WORLD MONUMENTS FOUND. Disponível em: <https://www.wmf.org>. Acesso em: 04 jul. 2017. 